specific solutions, respectively: "individual and societal changes of values and civation," "socialist revnlution, delinking fron the world market and thus self-reliant developnent," "regulation of international consodity narkets, dismantling of Northern inport restrictions for Southern products and resource transfer fron North to South," "stateplanning, state participation in production and state-provided infrastructures" and, finally, "rational, narket-oriented resource allocation and policy-naking by rational state to minimize rent-seeking and maximize production."

My own approach differs fros the first three in bestowing less eminence on factors residing in either the African psyche or in the international system (iuportant as they way be) than on the clear-cut constellation of interests and distribution of power within African polities. Consequently, ay disagreenent with neo-classical development econonics and the econonistic wing of the public choice school concerns neither their analytical focus nor the desirability of their prescriptions, only their practicability. As to the former, I cannot see how the North could be convinced to be 1 ess protectionist and more generous. Regarding the latter there is a similar element of wishful thinking: acroeconomists in particular tend to be fundanentally skeptical of government intervention in aarkets. They treat the state and politics as sources of econonic distortions and advocate mininizing state involvement in the econony and "less politics" (Lal:1983 1988). Yet, I think, it bespeaks of a certain naivete, especially in the distinctive situation of post-colonial Africa, to wish away politics - or to define away politics. Like the inatitutionallet branch of the public 
Otuwa. Caneda

KiA onis

\section{NOTICE}

The quality of this microform is heavily dependent upon the quality of the original thesis submitted for microfilming. Every effort has been made to ensure the highest quality of reproduction possible.

If pages are missing. contact the university which granted the degree.

Some pages may have indistinct print especially it the original pages were lyped with a poor typewriter ribbon or if the university sent us an inferior photocopy.

Reproduction in full or in part of this microlorm is governed by the Canadian Copyright ACt. R.S.C. 1970, C. C-30, and subsequent amendmenis.

\begin{abstract}
AVIS
La qualité de cette microlorme dépend grandement de la qualité de la thése soumise au microtilmage. Nous avons tout fait pour assurer une qualité supérieure de reproduc tion.

S'il manque des pages, veuillez communiquer avec runiversité qui a confére le grade.

La qualité d'impression de certaines pages peut laisser à désirer, surtout si les pages originales ont été dactylogra phiées à raide d'un nuban usé ou si l'universiné nous a latt parvenir une photocopie de qualité inférieure.

La reproduction, même partielle, de cette microlorme est soumise à la Loi canadienne sur le droit d'auteur, SRC 1970 , c. C-30, et ses amendements subsequents.
\end{abstract}


The Bureaucratic state and Economic Development in Nigeria by

Franz Baumann, Dipl. Verw. Wiss.

A thesis submitted to

the Faculty of Graduate Studies and Research

in partial fulfilment of

the requirements for the degree of

Doctor of Philosophy

Department of Politisal Science

Carleton University
Ottawa, Ontario
25 March 1992
C Copyright
1992 , Franz Baumann 
The suthor has granted an irevocable nonexclusive licence allowing the National Lubrary of Canada to reproduce, ben, cistrbute or sell copies of his/her thesis by any means and in any form or format, making this theets avalablo to interested persons.

The author retains ownership of the copyright in his/her thesis. Neither the thesis nor substantial extracts from it may be printed or otherwise reproduced without his/her per. mission.
L'auteur a acoordé une licence irtévocable et non exchusive permettant à la Bibfiotheque nationeie du Canada de reproduire, proter. detrbuver ou vendre des coples de sa thes." de quelque maniere et sous quelque formi que ce soit pour mettre des exemplaires de cette thèse à la disposition des personnes intéressées.

L'auteur conserve la propriété du droit d'auteur qui protège sa thèse. Ni la thése ni des extraits substantiels de celle-ci no doivent Atre imprimés ou autrement reproduits sans son autorisation. 
The undersigned hereby recommend to

the Faculty of Graduate studies and Research

acceptance of the thesis,

THE BUREAUCRATIC STATE AND ECONOMIC

DEVELOPMENT IN NIGERIA

submitted by

Franz Baumann, B.A., M.A.

in partial Eulfilment of the requirements

for the degree of Doctor of Philosophy
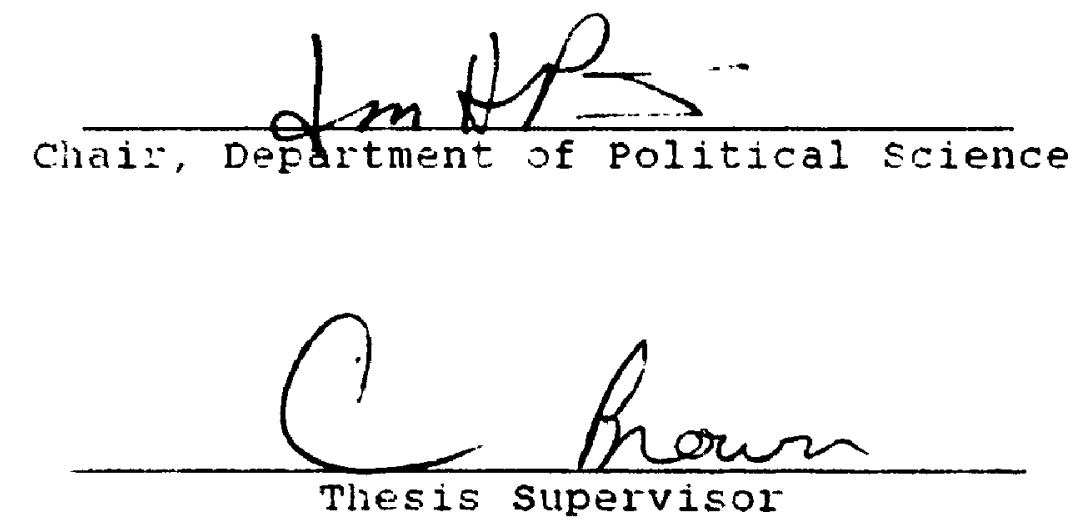

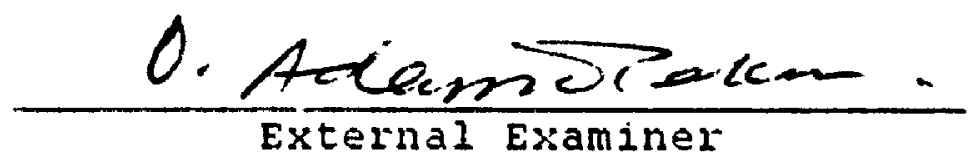

carleton University 
Preface ........................ . . . . . . . . . .

Abstract ....................... vii

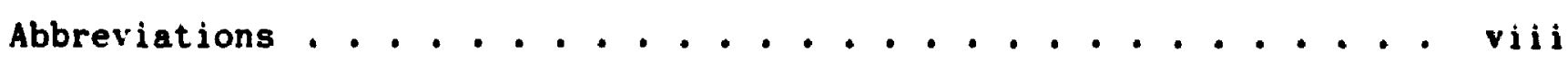

List of Tables ....................... ix

Introduction ....................... 1

Part I THEORETICAL CONSIDERATIONS ................. 31

1 On Social-Scientific Theorizing . . . . . . . . . . . . . . . 31

2 The Superiority of a State-centered Analysis of Nigeria's Development Problematique - snd the Inferiority of Perspectives focusing on Society or Global Constraints . . . . . . . . . . . . 43

3 The State as a Concept . . . . . . . . . . . . . . . . . 92

a) The Overdeveloped State . . . . . . . . . . . . . . . . 96

b) The Patrimonial State . . . . . . . . . . . . . . . 126

4 The Bureaucratic Nigerian state . . . . . . . . . . . . . . . 153

a) The Bureaucratic State as a distinct Order of Domination . . 153

b) The Bureaucratic Mode of Production . . . . . . . . . . . . 181

c) The Bureaucratic Mode of Production and Economic Development . 214

5 The Nigerian State Class . . . . . . . . . . . . . . . . . 238

6 why Nigeria is not Capitalist . . . . . . . . . . . . . . . 263

a) Capitalisa in the Conceptualization of Karl Marx
and Max Weber . . . . . . . . . . . . . . . 265

b) Nigeria is not a Capitalist Social Foration . . . . . . . . 290

c) The Developmental Efficacy of a Capitalist Market Economy
- and some Thoughts on its Ideological Unpalatability . . . . 298

7 Concluding sumary . . . . . . . . . . . . . . . . . . 321 
Part II EMPIRICal considerations . . . . . . . . . . . . . . . 330

1 The Genesis of the Bureaucratic Nigerian State . . . . . . . . . 330

a) Pre-Colonial Developaents . . . . . . . . . . . . . . . 334

b) Politics during the Colonial Period . . . . . . . . . . . 348

c) The Colonial Econony until 1945 . . . . . . . . . . . . . . 374

d) Politics before Independence . . . . . . . . . . . . . . . 395

e) Econonics before Independence . . . . . . . . . . . . . . . . . 414

f) Concluding Sunmary . . . . . . . . . . . . . . . . . . . . 439

2 The Bureaucratic Nigerian State in Action . . . . . . . . . . . . 448

a) The Macroeconomic Setting in the $1970 \mathrm{~s}$ and early $1980 \mathrm{~s}$. . . 451

b) Increasing State Autonony and maintaining State Legitinacy . • 481

c) The Bureaucratic State Transforned or Reformed? . . . . . . . 508

d) Concluding Sumeary . . . . . . . . . . . . . . . . . . 533

3 General Conclusion . . . . . . . . . . . . . . . . . . . 540

Patt II I supplement . . . . . . . . . . . . . . . . . . . . . . . 546

Selective Chronology of Nigeria . . . . . . . . . . . . . . . . 546

Appendix A: Statistical Tables . . . . . . . . . . . . . . . 555

Appendix B: Federal Parastatals in Nigeria . . . . . . . . . . . . 581

Appendix C: Indigenization Schedules . . . . . . . . . . . . . . . 586

Appendix D: The General Theory of Not-Gardening . . . . . . . . . . . 591

Bibl lography . . . . . . . . . . . . . . . . . . . . . . . 593 


\section{Preface}

In the early 1930s I was recruited by the United Nations Industrial Development Organization and sent to Nigeria on a two year contract to assist the resident UNIDO representative with the maliagement of the ongoing country programme of industrialization projects. The intensity of my desire to do something that was both "meaningful" and good was easily matched by the fervour of my belief in the correctness of the thesis, formulated by Walter Redney but held by practically everybody on the left, namely that Europe had underdeveloped Africa and, relatedly, that the North's realth was founded on the exploitation of the South. Specific circumstances prevented me from recognizing earlier than I did that my ideas about Africa or development, to the extent I had any, were more reflective of my at tempts to make sense of the world than of Africa's real problems: multilateral aid provided by a United Nations afency was nolitically correct long hefore the term was coined, and the fuct that my sillary has about filt: limes the il gerian per capita GNP only swelled my head. It did not occur to me that this money proved only the privileged condition into which I had been born, but not at all the value of my skills nor the pertinence of my Weltanschauung, as I flattered myself. With time I becane increasingly aware of, and embarrassed about, my ignorance, fer.. ly hoping that dentists at the beginning of their careers were mor a command of their field than I was in mine.

In the 1970s and 1980s, probably until the Berlin Wall crashed, and with it communist reality in Eastern Europe as well as Marxist theory world-wide (hopefully), the argumentation of Samir Amin, Andre Gunder Frank, Walter Rodney e tutti quanti, had tremendous emotional appeal not only for members of African establishments but also for members of Western anti-establishments. The reasoning, very roughly, ran as follows: the slave trade robbed Africa of the human resources for development. Thereafter the legitimate trade, by underpaying for agricultural commodities and by overcharging for manufactures, deprived the continent of the capital for development, while both derailed technological advances which in their absence would have taken place. By implication, African rulers received a general absolution for their policy blunders, and Western progressives one more confirmation of the evils of capitalism as well as for the imperative to build socialism. Socialism in this discourse had no empirical referent, even though, when pressed, its partisans could be relied on to defend Castro's Cuba with few qualifications, if any. As vaguely as romantically it referrod to a aystam in which pangln aro tmontod with dignity rathor thy.. exploited by profiteering capitalists, in which resources are rationally utilized in the general interest rather than privately appropriated by self-centered individuals, in which people cooperate rather than compete, and in which the state efficiently, selflessly and wisely pursues the common weal rather than the sectional interests of an oppressive plutocracy. To repeat, I found this diagnosis plausible and the vision appealing. The trouble was only that neither survived the onslaught of reality. 
Two observations in particular challenged my worldview: on the one hand the great dignity, energy, industriousness, imagination - and cheer - with which ordinary Nigerians went about their ways, even in lagos which must rank prominently among the world's most arduous spots; on the other hand, the arrogance, carelessness, inefficiency, officiousness and corruption of many, too many if by no means all, government officials. The bureaucracy, far from serving "development" or "the people," seemed an instrument entirely for the benefit of its own staff. Instead of facilitating economic growth and national development, I became to be overwhelmed by the evidence which virtually forced itself on me that it was obstructing both. The two hour trip by car from Lagos to Cotonou in neighbouring Benin provided a crash-course in reality: first there were the half dozen or so roadblocks on the Lagos - Badagry Expressway whose only purpose was to extort money from hapless travellers. The border itself had a bustling market atmosphere. All kinds of costly illegal goods were being carried openly across the frontier. Petrol by the bucket was hauled westward where it

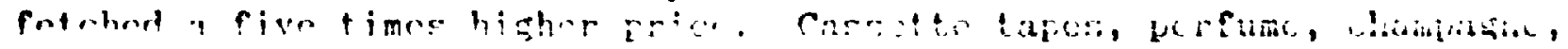
lace und whatever else a rell-stocked department store anywhere in the world would carry, made the reverse journey - all under the watchful eye of the law. Regulars could cross over and back at great ease, of course only after slipping the requisite amount of money over the counter. Irregulars and all expatriates were directed to another table where an officer with great seriousness entered one's "particulars" into a ledger: name, first name, birthdate, birthplace, passport number, issued when and where, expiration date, date of departure from the country, date of arrival in the country etc. ctc. were painstakingly recorded on huge horizontal sheets. I never found out what happened with these sheets or what their official purpose was. That they were an artificial obstacle which could be lowered if not circumvented entirely with money was obvious. Once I asked one of the border guards, yet instead of an answer my inquiry elicited looks as if I had, out of naivete or subversiveness, called into quesion the reason for their wearing uniforms or guns. Yet $I$ would have been most surprised if the data collection, or the toll collection, was put to any constructive public use.

Since my experiences with ordinary Nigerians and with government bureaucracies were, all in all, similar to the example of the border crossing, I began to doubt the plausibility of the standard "left" exegesis of the sluggish development: deteriorating terns of trade, scarcity of capital, manipulative multinational corporations in cahoots with a comprador bourgeoisie etc. Also, some hard facts seemed to suggest otherwise. Between 1970 and 1980 the price of Nigeria's major ex-

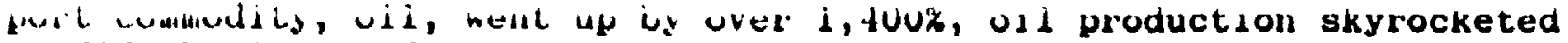
as did the income fron oil (by over $3,300 \%$ ) and government revenues (by over $2,500 x)$. The dominance of foreign capital in the econony was a thing of the past since foreign oil companies had been all but nationalized and manufacturing or service businesses, previously owned by expatriates, indigenized. Yet there were few traces of self-sustaining development, economic or social. Instead there was overwhelming evidence of entropy, fraud and waste, especially in the ever expanding 
public sector. My dissatisfaction with leftist explanations ( = the largely external determination of problems), and even more so solutions (= the naed for a strong, socialist state), grew. After having studied Nigeria's colonial history in considerable detail, I am now inclined to believe that the record of British colonialism, to put it starkly, was one of relative economic success and of relative political failure. The one-dimensional focus on econoinic exploitation, so characteristic: of much of radical analysis, began to strike me as utterly reductionist, the result of an urge to condemn much more than an interest to understand. Also, I began to wonder whether the implicit idealization of pre-colonial African societies, as if to make up for the colonizers" patronizing attitude towards the "primitive" natives, does not comait anothe: form of condescension - and one quite as egregious because it fails, on the one hand, to explore the relationship between ecology (e.8. overabundance of land, harsh $c l$ imate) and socio-econonic st.ructures (e.g. polygamy, slavery, military aristocracy, low propensity for technological change) and because, on the other, it robs traditional

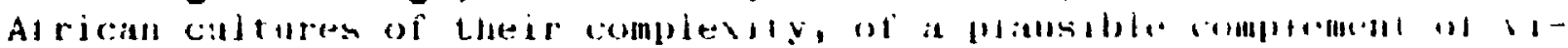
ces as well as virtues. Relatedly, to perceive the present Nigerian State as a catalytic agent in the development process, the role normatively assigned to it by both the neo-classical and the radical paradigm, began to appear as similarly voluntaristic and unsatisfactory. Instead, I began to think it more appropriate to view the state as part. of the problem, not the solution.

The present study, thus, is an attempt to come to terms not just with Nigeria's development problematique but just as importantly with the vexing puzzle of Marxist social theorizing. This excursion was particularly worthwhile since it enabled me to see why Marxism, dizzying in scope and depth but ultimately barren, could be so influential: as a multipurpose vehicle it combines a moral posture with an intellectual method and a political mission. Hence its immunity against scholarly or empirical criticism derives from the fact that it is an instrument not in the pursuit of knowledge but in the pursuit of power - either to attain it or to defend it. I am grateful to my supervisory committee, Professors Anglin, Brown and Subramaniam, to have nressed me to deal explicitly and extensively with this question of epistemology or, as I would call it, ideology. Given the resulting length of this dissertation, they have probably developed second thougrts about the wisdom of prompting me to foray into this vast, and as I now know, arid and chilling expanse. For the first tiwe in my life I read a great part of Karl Marx's works - in the origi.lal German, it should be added. The English translation of his collected works, bequn only in the mid-1970s, is still incomplete - and may well remain so: Progress Publishers and the Institute of Marxism-Leninism (both of Moscow) have gone out of business. The discovery that I aust have been the first to use many of the Marx volumes at Carleton library came as a startling revelation to me. Cracking open the virginal books was $\mathrm{A}$ forceful cue that left-wing radicalism - like most sectarianisas - is more a matter of attitude than the result of careful analysis. This, of course, puts a skeptic or critic at a disadvantage since it is difficult to argue with a state of mind: as Mark Twain observed wistfully, 
the trouble with the world is not ignorance - it's people knowing all them things that ain't so. Given the resounding implosion of the Soviet empire, I would like to think that my altercation with Marxism in all its permutations and derivations is an exercise of dead-horseflogging. Still, I an afraid that to pronounce the chapter closed might be premature. Utopian or mythological ideologies are startingly resilient. One only needs to look at the dismal examples of the governments of China, Cuba or Ethiopia, or of the communist movements in India, Kurdistan, Peru, South Africa and possibly Cambodia, for the frightening spectacle of utopias, ostensibly based on scientific truth, being peddled by reckless vanguards all too willing to sacrifice other people's lives and liberties on the altar of revolutionary bliss.

St. Bernard of Chartres or Sir Isaac Newton (or both) are reported to have said that we were like dwarfs seated on the shoulders of giants and that we saw more things than the ancients, yet that this was due neither to the sharpness of our sight nor to the greatness of our stalure; it was simply because they had lent us their own. I felt uplifted and supported by the humanity and lucidity of such giants as Chinua Achebe, Arthur Koestler, W. Arthur Lewis, Joseph Alois Schumpeter, Max Weber and many others whose influence resonates through this study. Obviously unable to reach their standards, I have nevertheless attempted to keep them in mind. Professor Subramaniam's theory of the derivative middle class proved an elementary insight when $I$ first began to grapple with organizing my thoughts. I acknowledge with thanks my temporary release from the United Nations Secretariat which permitted me to write this dissertation. As stipulated by United Nations Staff Rules, I declare that the views expressed are personal and do not reflect those of the United Nations. At a more practical level I am particularly grateful for the invaluable support I received fron everybody I dealt with at Carleton Library. The staff of the interlibrary loan section managed to procure even the most obscure publications, and there were many I requested, unfailingly, in almost no time at all, and always without waking me feel I was imposing on thea. Similarly helpful were the librarians at the reference and documents desks for whom neither my many queries nor my constant requests to trace yet another missing book seemed a burden. Also, not a single one of my many suggestions regarding book purchases was rejected. Having spent countless hours in the Carleton library during the past year, I have come to think of it a veritable model for a public service organization: quietly efficient, truly user-oriented and able to keep its staf under adverse circumstances. Finally, my greatest gratitude goes to $\mathrm{my}$ wife Barbara Gibson. Barbara, to whom this dissertation is dedicated,

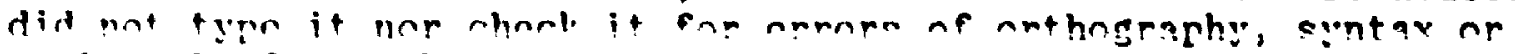
style. In fact, she has not even read it (yet). Her contribution was inaeasurably more consequential. Despite enormous work-pressures and a multitude of demands on her energies, she has been unfailingly goodhumoured and steadfastly supportive. Her integrity, love of life, optimism about the world and faith in me were the source of my recklessness to embark on this venture - and of my strength to complete it. I am grateful. 
Abatract .

This dissertation explores the reasons for Nigeria's lackluster developiental perfornance and rejects as too faclle anowers which concentrate on sarcities, unfavourable teras of trade or other exocenous factors. Pocusine instead on covernance as a central explanatory variable, the logic behind the state's actions (and inactions) is analyzed. The thesis puraued is that the state, staffed by officials wodelled neither in the lease of Platonic philosopher kings nor of Pabian adninistrators but by bureaucrats with their own intereste, is developnentally counterproductive. Consequently eaphasized is the necesaity to conplenent the state-oriented perspective of neo-claseical development econonics pointing to ubiquitous arket-failures with the equally likely syndrone of state-failure. Sopecially in a context of atate autonony, reasonably assuned for a nilitary regine with an independent resource base, there are few conatraints to arrest the wastage of acarce resources. Of equal or sreater ioportance is that nothing prevents such a state from pursuing regulatory policies which pre-enpt the nobilization of those potentialities which lie ungarnered in civil society.

To provide historical depth, the origins of the bureaucratic Nigerian state are traced to the colonial governnent's oulssions and comissions as well as to the specific foras of nationalist opposition these gave rise to. The colonial state failed to create private landownership, open the civil aervice to qualified Nigerians and abolish produce arketing boards after the energency situation of World War II. It used traditional chiefs as its extension agents which ensured ability, yet at the expense of development. Similarly, it prevented the eaergence of a manufacturing sector and of a productive bourteolisie. Then, in the twilight of its existence, and financed with ruinous agricultural taxes, it heavily intervened in the econony through the expansion of the state sector, unwieldy retulation of private activity and through direct participation in production. The nationalist opposition consisted ainly of westernized intellectuals, both a product of colonialian and dependent on the colonial econoay for their livelihood, yet who were also intensely frustrated because of the colonial sovernment's disinclination to involve the in political natters. The state becane a trophy as inportant as national sovereignty, or nore, and dirigiste policies the natural reflex of this etatiste fixation. The post-independence Nigerlan state, so ay contention, uncannily fits Weber's ideal type of a patriconial state. By applying this nodel to the 19708 and 19808 , the discrete logic of the Nigerian state's interventionist policies (to seek and distribute rents) cones into sharp relief as does the desirability of sreater arket-reliance and a respectively oriented state. 


\section{Abbrevintions}

AC Africa Confidential

AG Action Group

ACR Africa Contenporary Record

ADP Asricultural Developent Project

AED Africa Econonic Digest

AFRC Armed Forces Ruling Council

ARBe Africa Research Bulletin ("econonic, financial and technical serles" (ron 1964 to 1984; eince 1985 "econonic series")

ARBp Africa Research Bulletin ("political, social and cultural eeries" (ron 1964 to 1984 ; since 1985 "political series")

b barrel

BCCI Bank for Credit and Connerce

CFA

CPI

DF

Conounauté Financiere Africaine (previously: Colonies Françaises d'Afrique)

Consuner Price Index

DCA Development Forue (United Nations, New York)

EIU Econonist Intelligence Unit (refers to Country Report Niseris if year has a prefix indicating a quarterly report, e.s. 3/1990; otherwise it refers to the annual publication Country Profile Nireris)

ENI Ente Nazionale Idrocarburi

FAO Food and Agricultural Orcanization of the UN

Fos Federal office of statistics (Nigeria)

FT Financial Tines (London)

IHT International Herald Tribune (Paris)

ILt Inport Licencing Authority

IPE International Petroleue Encyclopedia

IQAC Import Quota Allocation Connittee

MVA Manufacturine Value Added

N Naira

NCNC National Council of Nigeria and the Caneroons

NEPB Nigerian Enterprises Pronotion Board

NET Nigerian External Teleconnunications Ltd.

NNOC Nigerian National Oil Corporation

NNPC Nigerian National Petroleun Corporation

NOM National Orientation Movenent

NPC Northern People's Congress

NSO National Security Organisation

NYT New York Tines

RBDA River Basin and Rural Developnent Authorities

SAP Structural Adjusteent Prosrane

SGS Societé Générale de Surveillance

SSS State Security Service

TCPP Technical Connittee on Product Prices

UNCTC United Natione Centre on Tranenational Corporations

UNDP United Nations Developaent Progranae

UNIDO United Nations Industrial Developent Orcanisation

WA West Africa nagasine (London)

WAI War Against Indiscipline 


\section{List of Trblere (pp. 561ff.)}

Table 1: Quantity of Principal Export Products (1900-1988)

Table 2: Value of Principal Export Products (1900-1988)

Table 3: Percentage Share (Value) of Principal Export Products (1900-1988

Table 4: Unit Value (World Market) of Principal Export Products (1900-1988)

Table 5: Producer Prices of Asricultural Export Products (1950-1986)

Table 6: Value of Trade and Governnent Finances (1900-1988)

Table 7: Exchange Rates (1900-1989)

Table 8: Sectoral Origins of GDP and Share of Employment (1950-1988)

Table 9: Enploynent by Sector (1935-1988)

Table 10: Foreign Investment (total assets), Foreign (public) debt (1960-1988)

Table 11: Performance Indicators for Agriculture (1955-1988)

Table 12: Food Inports (1960-1988)

Table 13: Food Production (1955-1988)

Table 14: Federal Civil Service (1960-1988)

Table 15: Structure of Manufacturing Value Added (1963-1984)

Table 16: Index of Manufacturing Production (1970-1988)

Table 17: The Significance of Oil for State and Econony (1960-1988)

Table 18: Nigerian Governuent Interests in 0il Conpanies

Table 19: Nigeria's Perfornance compared with other poor Countries 


\section{Introduction}

"The wain obstacle has now cone to be the predator atate itself, heightening the need for collective political reform." Editorial in Nest Africs (No. 3819,5 Novenber 1990 , p. 2773 ).

This dissertation is concerned with a crisis of singular proportions, nanely that of econonic developnent in Africa. There can be, of course, no clain to originality in this effort as explanations for the persistence of underdevesupnent proliferate as wuch as do recipes to overcome it. In the body of my study, I will refer to and discuss a great number of them. What they all have in concon is little nore than the time-honoured question "why sone countries should have developed while others remain more or less stagnant, or why sone countries renain econorically backward while others experience sustained secular advance" (Leibenstein:1957,4). The answers they give fall into five broad categories, according to which the tenacity of underdevelopeent is the result of:

- pre-modern culture, norns and values (modernization theories, cf. Bendix, Braibanti, Eisenstadt, Hoselitz, McClelland, Riggs, Nash);

- the Third World's position at the periphery of the capitalist world systee, that is, of inperialist exploitation or of the archetypal distortions of dependent capitalist development (neo-Marxist approaches generally and the sub-branches of world systea and dependency specifically, cf. Anin, Baran, Eananuel, Frank, Prebisch, Shivji, Wallerstein, ECLAC); 
- the falling terms-of-trade for the Third World's export products, the protectionism practiced by the developed North, and of the strangulating debt burden (social-denocratic or structuralist interdependence school, cf. Brandt, Helleiner, Pearson, Tinbergen, UNCTAD);

- scarcities especially of human and financial resources, a defective mix of production factors, lack of infrastructure and of technical know-how (neo-classical development economics, cf. Gerschenkron, Green, Hirschman, Lewis, Myrdal, Papanek, Rosenstein-Rodan, Rostow, UNDP, UNIDO);

- fallacious government policies (especially arket interventions such as price-fixing, exchange rate distortions, protective tariff barriers, state monopsonies for agricultural products, and state involvement in production through inefficient parastatals) which nurture rent-seeking and discourage pr.s.ction (public choice school, cf. Bates, Bhagwati, de Soto, Elsenhans, Hyden, Lal, Krueger, Rimmer, Tullock, World Bank).1

These paradigms operate with discrete epistenologies which not only diagnose the problems from anique perspective but also suggest

1 The stylization inherent in grouping developent writers into schools is particularly apparent in the case of the public choice faction because on the shared foundation of a fervent belief in the arket arise two sub-groups, warket purists and those who see the need for the state to create, maintain and regulate markets. The World Bank, for instance, has in recent years adopted the second position. S.ructural adjustnent programmes are no longer confined to macroecononic nodifications but complemented by capacity-building neasures (cf. World Bank:1984a,20). 
specific solutions, respectively: "individual and societal changes of values and wivation," "socialist revnlution, delinking fron the world market and thus self-reliant development," "regulation of international commodity markets, dismantling of Northern inport restrictions for Southern products and resource transfer fron North to South," "state. planning, state participation in production and state-provided infrastructures" and, finally, "rational, market-oriented resource allocation and policy-making by a rational State to minize rent-seeking and maximize production."

My own approach differs from the first three in bestowing less eminence on factors residing in either the African psyche or in the international system (important as they nay be) than on the clear-cut constellation of interests and distribution of power within African polities. Consequently, my disagreenent with neo-classical development economics and the economistic wing of the public choice school concerns neither their analytical focus nor the desirability of their prescriptions, only their practicability. As to the former, I cannot see how the North could be convinced to be less protectionist and more generous. Regarding the latter there is a similar element of wishful thinking: macroeconomists in particular tend to be fundamentally skeptical of government intervention in markets. They treat the State and politics as sources of economic distortions and advocate mininizing state involvement in the econony and "less politics" (Lal:1983 1988). Yet, I think, it bespeaks of a certain naivete, especially in the distinctive situation of post-colonial Africa, to wish away politics - or to define away politics. Like the institutionalist branch of the public 
choice school, I take politics to be central and, therefore, focus on the politically dominant actor in contemporary Africa, nanely the State. I assume the state, wore than any other internal or external factor, to hold the clues for the underdevelopment syndrone in Africa. Hence, the problem I will address is the role of the state, of the bureaucratic state to be precise, in the process of econonic developnent in contemporary Africa. Since my interest is not encyclopedic and aince there are enough important sivilarities between African states historical, sociological, ideological, economic - the nethod chosen is not a systematic survey of all fifty or so cases. Instead, ey analysis is limited to the detailed investigation of one prototype: Nigeria. What is unique and what is generalizable, so it is hoped, will becone apparent in the process.

The state's centrality, inherited from colonialisa and consequently consolidated, makes it a critically important elenent in Africa's economic performance. In a situation in which the probability of price increases for Africa's traditional export comodities is marginal and in which developments elsewhere render prospects for increased, let alone adequate, foreign assistance dimber than ever, national policies and inst \&tutional performance are key determinants for Africa's destiny. The picture is bleak: Over two thirds of the world's least developed countries (29 of 42) are in Africa, as are five of the seven candidates for that category (DF, \& July-August 1991, 9). Twenty (of 52 ) African countrieg had negative econosic growth rates in the 1980s (WA No 3804,23 July 1990, 2157). Sub-Saharan Africa's population has doubled since 1965 and grown five-fold since the turn of the 
century (World Bank:1989,25). Such population growth, the fastest in the world, by far outpaces any increases in food production and overwhelos treasuries, social services and job narkets; life expectancy, literacy rates and per capita incones are falling. Population pressure on the land accelerates desertification and deforestation, compounding an already massive rate of environnental destruc'ion and thus threatening long-term productive capacity. The continent can no longer feed itself, even though fertile land is not scarce and despite the fact that two thirds of its labour force is in agriculture. While in other regions of the world dependence on food imports can be a sign of development, of shifts in the economy away from activities with low value added, this is not so in Africa. Here decreasing food production is part of a general econouic decline: "low incone Africa is poorer today than in 1960. ... For the first time since World War II, a whole region has suffered retrogression over a generation" (World Bank:1986,9). Without generating perceptible development, sub-Saharan Africa today receives $35 x$ of the world's official developnent assistance (up from $10 \%$ in 1960), even though its share of developing countries' population is only about $12 x$ (Helleiner: 1991,1).

From 1980 to 1987 sub-Saharan Africa's output grew a neager 0.4x, compared with an average annual leap of $8 x$ in East Asia (NYT editorial, 5 June 1990, A23). Its 450 aillior people produce a GDP of about US $\$ 135$ billion which equals that of Belgium - population 10 aillion (World Bank: 1989,2 ). Its share of world trade which stood at $3 x$ in 1960 has fallen to under $1.5 x$ (ibid:37). Its share in global wanufacturing value added in 1989 was around $0.5 \%$, tendency falling (UNIDO: 
1989,61). Oversupply and substitution through synthetic products will continue to depress world narket prices for its main export connodities, raw materials and minerals, while its attraction as a Cold War battlefield, redeenable in cash and kind, began to recede in the late 1980s. Now it is too poor and unstable to attract nuch foreign investment while, through interest payments and by flights of capital, a net transfer of funds out of Africa takes place. By the end of 1989, Africa's foreign debt totaled $\$ 143$ billion. This is more than its total gross dowestic product, and over three times its foreign exchange export earnings (Die Zeit, 22 June 1990, C28). The extent of the crisis can be glanced from calculating what would be needed to achieve nodest per capita gains over the next ten years: a sharp drop in African fertility levels, a doubling of the growth rate of agricultural production, a major increase of investment levels and of the rate of return on investment, as well as real growth in foreign aid of $4 x$ annually. All this would produce only 1-2\% annual increase in per capita incone. At that rate, it would take Africa ten years just to recover the level of per capita income of 1980 (Brent:1990,130-131).

Obviously, these predicaments cannot be blaned in their entirety on inadequate policies or on mismanagement, nor would it be plausible to suggest that it was in the realm of public policy to avert then altogether. It would be equally facile to clain that there were any easy, let alone authoritative or conprehensive answers. These are in principle inpossible and what can be achieved, at nost, is to identify consequential factors and catalysts, expose relationships between then and explain resulting dynanics. This requires an analysis which reac- 
hes into the past, because any vision of "African developnent that we may aspire to will evaporate if we remain anchored in scientific present that resenbles nothing so wuch as child's-eye-view of the world" (Hart:1982,4). Inportant explanatory factors for the conteaporary quandary ust be traced back to the dislocations preserved or generated, enforced or cenented by colonialise, such as Africa's role in the international division of labour as a producer of raw naterials, its pervasive poverty, its largely pre-capitalist node of production and its only rudientary industrial sector, the randonness of its borders, the formation of a disaffected intellectual elite, and the legacy of central but frail politico-administrative structures.

Nevertheless, a question, as pertinent as puzaling, is whether these birth defects alone suffice to explain Africa's present quandary. Marx suggests in the 18th Brunaire of Louis Bonaparte that nen "make their own history, yet not just as they pleage, not under self-chosen [circumstances], but under conditions directly encountered, given and [historically] transaitted" (Marx:1975,226)..$^{2}$ Accordingly, the assunptions guiding my inquiry of the specific Nigerian situation are that:

- the contemporary Nigerian State can only be understood before the background of its colonial incarnation;

- at independence the Nigerian State was, netaphorically speaking, the synthesis of a dialectical process in which the colonial State was the thesis and the nationalists' strugsle

2 This quotation and all subsequent ones fron the works of Karl Marx and Friedrich Engels are ay translation. 
against it the antithesis.

My study's central hypotheses, which will be theoretically argued and enpirically substantiated, are that:

- in the years since independence, and facilitated by the rent income from mineral oil, the state has consolidated both its econonic and political centrality as well as its autonony visà-vis society;

- it was the State's autononously designed and implenented regulatory and allocative policies which were of critical inport for the persistence of underdevelopwent.

It follows that external factors (e.g. higher connodity prices, more favourable terms of trade, debt rescheduling or forgiveness, inproved and expanded technical assistance) will be less important for future development prospects than internal adjustment strategies. Without the latter, even the unlikely repeat of an unexpected windfall in revenue, such as the one caused by the doubling of oil prices and by increased production in the aftermath of Iraq's occupation of Kuwait, will not affect the fundanentals.3 "If for internal reasons [Nigeria] does not make sensible use of its resources, if investments yield lit-

3 Based on estinates by World Bank econonists of sales figures and narket prices, Nigeria's windfall has been calculated at about 85 billion. Reporting this, as well as the contenticn that at least $\$ 3$ billion were not accounted for in Central Bank data for the period between July 1990 and May 1991 (Keeling:1991,4), led to the deportation within 48 hours of William Keeling, the Financial Tines' Lagos Correspondent (FT, 1 July $1991,4)$. For the governnent, Vice-President A. Aikhonu specified the extra revenue to be $\$ 2.3$ billion (WA No. 3856,5 August 1991,1287 ). 
tle increage in output and if it iaplenents 'developnent' in ways that allow capital to deteriorate aleost as fast as new capital is created then further increaents of anpower and finance will only reinforce present distortions" (Moris: 1981,134).

Although other African countries night be equally appropriate to test my hypotheses, Nigeria seeas particularly interesting as an object of study for several reasons. Unlike many other newly independent African countries, Nigeria throughout its history has renained integrated in the capitalist world econony and has never pursued a socialist path to development; instead private capital - whether national or international - was permitted to play a proninent role in the econony. I will argue, however, that it would be seriously nisleading to consider Nigeria a "capitalist" social foraation or even a "dependent capitalist economy", if these concepts are to be taken seriously rather than as mere beacons in a largely ideological discourse. Nigeria's additional attractions are her inherent importance as sub-Saharan Africa's most populous country and, conceptually fascinating, her wil-wealth which would, after about 1970, have peraitted a path to developnent in which capital formation was not realized through the extraction of surplus from the agricultural sector.

Unlike most other African regines, the Nigerian one thus enjoyed considerable resources, significant degree of internal and external autonomy and, at least theoretically, sone elasticity in policy naking. 
Yet, despite oil revenues of nearly $\$ 200$ bn between 1970 and 1988, neither an internal nass narket nor viable structures - private or public - for the accumulation of capital have been created. It is now widely accepted, even in Nigeria, that the oil fortunes were not nerely squandered but that the anner in which they were used caused severe internal dislocations and atifling external liabilities (Achebe:1983,23; Obasanjo:1990,762ff). The challenges facing the Nigerian State are, in a nutshell, the diversification of the country's econonic base ${ }^{5}$ under conditions of serious population pressures, increasing environnental degradation and a heavy external debt burden 1833 billion at the end of 1989; AED 428 February 1991, 13). Nigeria's history wight provide pertinent lessons for the future.

The present study will provide the conceptual franework, the basic facts and the historical perspective which, in oy view, are essential to an understanding of the development problematique in Nigeria. It is intended to serve two purposes, one theoretical and one explanatory. The theoretical purpose is to denonstrate the pertinence for the analysis of Nigeria's political economy of a state-centered approach, that is, of an analytical franework in which the State is treated as an independent actor rather than as a variable entirely dependent on society, on relations of production or on the international syatea. To

4 see table 1; sone estinates put then considerably higher, cf. Central Bank of Nigeria, Annual Report 1987, p. 86 and WA No 3811,10 Septenber 1990, 2431.

5 At present output levels of about 2 million barrels per day, the country's known oil reserves of 16 billion barrels (IPE:1989,79) will be exhausted in about 22 years. For a elightly wore sanguine ecenario - 25 to 30 years - see WA No. 3836, 11 March 1991, 345; also Pinto:1987,435. 
this end an ideal type of the bureaucratic state will be constructed in an attenpt to distill its inner losic and thus to render coherent ite actions and inactions. The explanntory purpose is to denonatrate the eapirical validity of this nodel, that is, to show that the Nigerian State's econonic policies Bince independence were eignificantly deterained by endogenous rather than exogenous factors and that they had the effect to retard as well as to distort econonic developnent. Underlying both the theoretical and the explanatory project is the question why significant econonic development has not taken place in Nigeria. Assuaing the bureaucratic State to be the political and econonic hegemon, the question will be tackled fron two distinct yet conplenentary perspectives: how does the state act and why, and what are the resulting effects on econony and society.

The first, which focuses on the logic of state behaviour, requires a review of economic policies (allocative and regulative) and suggests their interpretation as closely related to the interest position of the state class. This "class project" will be conceptualized as the pursuit of legitinacy, autonony and property. To achieve explanatory significance, a number of policies will be exanined in order to establish to what extent they serve one, two or even all three interests. To cover the full span of independent Nigeria and, additionally, to include the last fifteen years of colonial rule would be ideal if impractical. Instead, I will concentrate on the 19708 (after the civil war consolidation) and the 1980s. Skinning over the Second Republic, the policies of Nigeria's previous and present military regines will be considered. This tinefrane was chosen firstly because it enconpasses 
an extengive enough period to detect patterns, secondly because of the prina facie case for state autonony of a vilitary resine whose eandate is not subject to periodic renewal throush popular elections and, thirdly, because it covers monentous developents such as the srowing importance of aineral oil, the nationalization of the oil industry, the business indigenization decrees (and their slow erosion), the increasing use of inport licencing (and its scaling down), the srowth in parastatals (and the announcenent of their conercialization and privatization), the regulation of currency markets (and their deregulation). It is mostly for reasons of econony that the Second Republic (1979-1983) is not considered in any great detail. There is little doubt that the civilian regine was not different in kind fron its predecessors and successors, only different in degree: less efficient, wore wasteful and more corrupt.

The second and complementary perspective adopted is the one Theda Skocpol calls the Tocquevillian perspective in which "states satter not siaply because of the goal-oriented activities of state officials. They atter because their organizational configurations, along with their overall patterns of activity, affect political culture" (Skocpol: 1985,21). Of interest here are the ways in which the logic and actions of the bureaucratic state shape the econony, influence the behaviour of econonic and social actors and thus prevent the eaergence of capitalisa, defined in accordance with Max Weber's ideal type, navely as "the rational (deliberate and systenatic) pursuit of profit through the rational (systenatic and calculable) organization of forally free labour and through rational (iapersonal, purely inetrunental) exchange on the 
market, guided by rational (exact, purely quantitative) procedures and guaranteed by rational (rule-governed, predictable) legal and political systens" (Brubaker: 1984, 1-2).

Both perspectives augsest a focus on policies, rather than on policy-raking. Consequently, I will try to infer policy deterainante not fron individual reaults but fron broad patterns eatablished over tine. The questions guiding ay analysis are why Nigeria's bureaucratic State acted the way it did, why it aade costly choices and why it did not adopt policies that would have achieved desired objectives nore cheaply. In other words, I an exploring whether policies represented the purposive actions of a state nore concerned with its hegenony and with the material interests of the state class than with broad econonic development, and to what extent these policies obstructed capitalist development. My study is squarely placed in a political econony framework which means that a close, causal relationship between politics and the econony is accepted as given and that saterial factors or social conditions are accorded primary, yet not exclusive, significance to explain human action. 6 Implicit in ay approach is a disaiseal of cultural factors ("traditional values" in the Modernization paradiga) and an emphasis on aterial determinants to account for development. A case for such a materialist approach was advanced by Max Neber when he

- Political econony has been defined as "the science of the conditions and forns under which the various hunan societies have produced and exchanged products and under which products were distributed ..." (Engels:1968,139). Max Weber who, in 1895, assuned a chair in Political Economy in Freiburg, considered it more broadly as the science that investigates the econonic and social conditions of existence which shape the quality of societies and of human beings (cf. Scaff:1989,28-33). As will becose clear, this study is nore confortable with Weber's concept. 
contended that "[i]ndustrialization was not impeded by Islaw as the religion of individuals .. the Tartars in the Russian Caucasus are often very 'modern' entrepreneurs - but by the religiously detereined structure of the Islanic states, their officialdon and their jurisprudence" (Weber:1978,1095). Analogously, and unlike the nainstrean of political economy analyses - especially those by Marxists of advanced capitalist. societies - which assume that econonic forces are fundanental to polltical life, I hold the reverse to be true in the Nigerian case, namely that politics, the politics of the bureaucratic state, are decisive in shaping the national economy. State power is, of course, naterially based, yet not in the process of societal production and reproduction processes; its rent-incone from mineral oil effectively de-links the State from society. The bureaucratic Nigerian state constitutes an independent variable while the operations of other relevant actors (e.g. foreign interests, the indigenous bourgeoisie or the class of peasant farmers) are dependent variables.

It is my contention that economic actors rationally adapt to their environment and that, therefore, the policies of a preponderant State are decisive in conditioning the reactions of non-state actors. State policies can, for example, reinforce non-capitalist social groups or classes, encourage rent-geeking rather than productive investnent, skew accumulation and capital formation as well as "inpose a clinate of arbitrariness und unpredictability which weakens the calculability nexus" indispensable for productive activity (Callaghy:1988a,73). Declining gricultural production in response to the nonopsonies of state earketing boards and to adninistratively established low prices cone to 
mind. Other examples are rural-urban migration as a result of policies favouring urban gettlers and penalizing rural producers, the creation of an import-licencing regime and the emergence of a black market as the result of an overvalued currency, the sluggishness of dosestic industries as the result of tariff protection, or the energence of a small class of wealthy businessmen, entirely dependent on the state from which it obtains contracts or inport licences, both of which guarantee monopoly rents. Therefore, the conclusions about the relationstip between the state and economic development are derived from a nacroscopic, Tocquevillian perspective.

Guenther Roth in his introduction to Max Weber's Economy and Society contends that "[m]ost books have a foil as well as a model. They are written to criticize some books and emulate others" (Roth in Weber: 1978, LXVII). This fittingly characterizes ay approach. Very broadly speaking, the foils for wy project are, on the one hand, behavioural Modernization perspectives with their insistence on traditional vs. modern cultures as well as types of social organization and, on the other, neo-Marxist Dependency approaches and related outlooks which explain the underdevelopment of the Third World as functionally linked to the development of the First World, and which enphasize the integrality of a predatory capitalist world systen, articulation, class struggle and the like. Both positions share a structural-functional framework of analysis and consequently emphasize, in my view overemphasize, the prominence of socio-cultural factors (e.g. Mcclelland's achievenent motivation) in one case, and of the international environment (e.g. Hallerstein's world system) in the other. It follows that both detect 
little room for autonomous a-tion of endogenous institutions in developing countries and, instead, expect predominantly exogenous impulses to determine policies. Moreover, neo-Marxist approaches, implicitly if not explicitly, suggest that the responsibility for the state of affairs in developing countries is the product of the international system rather than of local circumstances. 7

While there is widespread agreement that econonic development today is more difficult for the "latecomers" than it was for the European early developers, dependency approaches, in my view, systematically underestimate the influence Third World states can exercise over their own affairs; concomitantly, they overestimate the importance of the Third horld as loci for production and even as markets for international capital. ${ }^{\text {s }}$ From a practice-oriented point of view, dependency approaches' teleological finality which, in strict logic, can detect a

i In a seminal study by a number of prominent practitioners of the dependency approach, these cogently summarized its underlying heltanschauung, spelled out the problem it addresses and identified the latter's putative causes: "the label [dependency] signifies a broad set of contemporary discussions about imperialism, global inequality, and underdevelopment that focus on the economic, social and political 'distortions' of 'peripheral' societies which result from their incorporation into the slobal capitalist system" (Duvall et al.:1981,312).

5 In his discussion of "development dichotomies," Paul streeten deplores the widespread tendency for development analysts to think in specific, absolute categories with no inclination to consider others. An expmple is the neo-classical proposition that development is accelerateu by integration into the international system vs. the dependency assertion that underdevelopment is caused and perpetuated by it. To avoid the sterile stalemate implied in such a "rhetoric of intansigence" (Hirschman: 1991,168 ), Streeten wisely advocates exploring the possibility that the industrialized countries "enit a large number of impulses of two kinds: those that present opportunities for faster and better development than would otherwise be possible, and those that present obstacles to development, those that stunt growth" (Streeten:1983,883). 
solution only in a socialist path to development, de-linked frow the international system, are frustrating and ultimately paralyzing. Albert Schweitzer melancholically contended that the "independence of the primitive is lost at the ooment when the first white nan's boat arrives with powder or rum, salt or fabrics" (cited in Perhan:1962, 169). Dependency writers, mirroring this lament and radicalizing it, elevate to a political programe the illusory return to a stage of innocence. Yet, it has not been lost on Africans that "[a]nyone who wishes in the name of independence to become free, may do so, providing he considers suicide as the supreme act of independence" (Marchés Tropicaux, cited in Bretton: 1973,17 ). It should be borne in aind that all my references to the inappropriateness of dependency and other neoMarxist approaches refer to Nigeria. Whereas I strongly suspect that much of my critique could be generalized, the inaediate purpose of the present study is to understand the Nigerian political economy and not t.o debunk dependency as a paradigm.

My instinctive dissatisfaction with Modernization theories does not quite match the intensity of my aversion of neo-Marxist approaches. While their generally ahistorical and apolitical analyses have gurely undermined their validity, I take issue sostly with the insistence on modern values as a precondition of progress which disregards entirely the influence of indigenous institutions (e.g. the State), and which implicitly neglects the possibility that the very attitudes alleged to be the pre-requisites of economic development can, in fact, be only its natural side-effects, "generated on the job and 'on the way,' by certain characteristics of the industrialization process" (Hirschnan: 
$1986 \mathrm{~b}, 20)$.

The prototype I an trying to enulate is Göran Hyden's No Shortcuts to Progress (1983). His study goes againgt the grain of both Dependency and Modernization theories in that it eclectically coabines the consideration of cultural factors with naterial ones. Hyden suggests that African countries reflect socio-econonic characteristics prevalent in pre-industrial Europe wore than those of a "periphery capitalist" type. Underlining the inportance of institutional arrangements, Hyden views Africa's curse as the absence of a secular, rational and effective bureaucratic state achinery, determined to "capture" the pre-capitalist peasantry and to accelerate broadly based capital accumulation. This lacuna seriously retards the energence of an indigenous, productive bourgeoisie. While he endorses the notion that aaterial production conditions social and political behaviour, Hyden rejects Marxist interpretations which conclude that in the wake of ieperialism, Africa has been unconditionally subjugated by international capital. He predicates Africa's future on economic and political decentralization, i.e. on the strengthening of warket forces at the expense of the incapacitated state bureaucracy, and on the emergence of more open and pluralistic politics.

While I find Hyden's approach pertinent and his exegesis plausible, the Nigerian case shows momentous idiosyncracies which call for some adaptation of his arguents. For example, unlike in East Africa, the peasant farmers' exiting out of the systea did not existentially threaten the State since oil revenues have replaced agricultural surpluses as the najor source of governsent revenues. The "uncaptured 
peasantry" operating in the "peasant mode of production" with the resulting "economy of affection" permeating every nooli and cranny of society may well explain that the Tanzanian State is suspended in "midair" and unable to extract surplus from a peasantry which does not depend on the state for its own reproduction. However, to understand the Nigerian situation, Hyden has to be turned on his head as it were: here it is the state which does not need the peasantry for its reproduction. Enjoying its own resource base, the State is autononous from at least three quarters of the population, namely the peasantry. Therefore, its driving force is not the need to extract surplus frov obstreperous agriculturalists, but the necessity, or luxury, to manage the rent gained from one treacherous mineral. Paradoxically, Hyden's description of the modi operandi of African States perfectly fits the Nigerian case, even though his pan-societal explanation does not. The Nigerian State is what John Hall evocatively calls a "capstone" State in contrast to an "organic" state. The former sits on top of societies and blocks alternative sources of power. It reasins static and ossifies while the latter allows and encourages the co-operation of diffarent power sources, which is held to be characteristic of European development. The broadly capitalist dynamic over the past several centuries and "the organic quality of the European state arose from its having to accept and co-operate with other elenents in civil soniety" (Hall:1985,190). The Nigerian State did not evolve slowly and doggedly in the idst of a pre-existent civil society, firstly because it atarted out as a conquest State and secondly because of its independent resource base. Nordlinger plausibly suggests that the "autonony of any 
social unit is very wuch a function of its dependence upon actors in its environment" (Nordlinger:1987,376) and that autonony means the State's ability to turn "its own policy preferences into authoritative actions, and markedly so ... even when these conflict with the preferences of the politically best-endowed private actors" (ibid.,355). Thus, differing from Hyden's assessent, I contend firstly that the macro-level structure of the Nigerian social fornation (the "capstone" State) is not linked to the organization of production at the micro-level and that, secondly, the actions of the Nigerian state are not in any way reflective of society, only of the concrete interests of the state class. My argument thus follows Weberian reasoning which deems implausible the existence of laws of class struggle and, instead, sees conflicts being acted out under created laws and within an established institutional order. Prominent beneficiaries and defenders of this order are the employees of its apparatuses. These develop an acute sense of vested interests which invariably results in the tendency to perpetuate but also to transfore these apparatuses bejond their original purpose. If social and economic development was the declared goal of the Nigerian State at independence, its actions soon betrayed a different agenda, even if the developmentalist rhetoric continued to be invoked.9 My central proposition is thus that the bureaucratic state,

9 Skillfully enploying the nethods of fiction - to overdraw, sinplify, satirize and thus to clarify complex reality - T.M. Aluko's novel Chief the Honourable Minister vividly portrays the constraints, and the temptations, facing public "servants" in a newly independent African country. All pervasive and overwhelains as these opportunities are, even those who at the outget are paragons of correctness, decency and hunility capitulate eventually. 
in order to preserve the state class's aterial base, has been the deterwining influence frustrating Nigeria's developwent. This line of thought shows considerable affinity also to the public choice perspective which focusses attention on the behaviour (econonic and political) of individuals and groups which, though rational from a self-centered position in that it yields tangible returns, produces no socially valuable goods or services and thus destroys rather than enhances the resources available to society. In case studies of specific Third horld experiences, such arguments are developed by Robert Bates, Hartmut Elsenhans and, specifically for Nigeria, by Douglas Rimer. Their work serves as a major inspiration for this study. They share the premise that Third World States are purposive rational actors whose policies, geared towards the interests of the state class (Elsenhans's term), are developmentally dysfunctional and economically wasteful. Unquestionably, Nigeria has, since independence, witnessed considerable economic growth (at least in teras of Gross Donestic Product, if not in terms of broadly distributed welfare gains), life expectancy at birth has increased, illiteracy decreased, a systen of modern highways, airports and seaports has beer built and a sall manufacturing sector has ewerged. It is not my intention to belittle these achievements (nor to place too wuch store in the fact that in recent years previously positive indicators have turned negative), only to suggest that they are prime examples for growth without developnent, economic or human. This distinction is not sophistry but points to the need for definitional precision. "Development" for too long has been a catchall phrase which, because it weant everything, weant nothing. Only if 
it is clear what precisely "developsent" is, does it make sense to devise or criticise specific strategies, is it possible to debate their respective merits and drawbacks, and can one see who stands to gain and who to lose in the various phases of what is unavoidably a long tere process. Development, as Dudley Seers reainded us, is inevitably a normative term (Seers:1972,123). This neans that, whichever concept of "development" is embraced, its highly political nature is obvious, as is the reluctance of technocrats of all stripes to adnit this out of fear to get drawn into an inescapably value-laden, acrimonious debate. It is not surprising that the Chairaan of the 1969 World Conference of the Society for International Development "expressed considerable doubt about either the desirability or the necessity of defining developsent" (Blaisdell:1970,39). Unconstrained by such burdens of office, I can be explicit about the present study's operative definition of development. To begin with and in the interest of conceptual clarity, it is important to distinguish between econowic growth (which is concerned with realized output) and economic development (which is concerned with productivity). "The one concerns actual production, the other potential production or capacity for production" (Uphoff \& Ilchaan:1972,88). Development, as I will use the concept, is thus more than economic growth and also more than the realization of checklist of investment projects in infrastructure, agriculture or industry, especially if these icons of progress are paid for from rent-incone and acquired abroad without spawning any internal linkages or raising general living standards; it is also more than higher living standards, as desirable and important as they may be. 
National developeent. as a comprehensive concept refers to hunan development on the one hand and econonic developnent on the other. The basic objective of human development "is to enlarge the range of people's choices" (UNDP:1991,1 and 13-21) while econonic developnent is the process of creating the capacity to generate wealth. Successful national development is the creation of broadly based welfare in a process which raises individual and social productivity. History has shown that this is best achieved if it is participatory, equitable and sustainable. In other words, development in the present context refers to increasing the options available to people. This, as a prerequisite, necessitates economic development: the production of a given output with fewer inputs, and the introduction of new products and services. Economic development ioplies and engenders rising nass incones and nass consumption based on expanding output which, indispensably, has to be the consequence of greater efficiency rather than greater effort: the difference between relative and absolute surplus value on which Marx elaborated (Marx:1983,260ff). Increasing productivity, or augeenting the ability to add value, requires new conbinations of existing natural risources, capital, labour, and ingenuity - the productive forces in Marxist terminology - to produce needed goods and services (Jacobs: 1984,119). Needed is, therefore, a successful transformation of an economy's structure through the "calling forth and enlisting ... of resources and abilities that are hidden, scattered, or badly utilized" (Hirschman:1986c,56). In an econony characterized by subsistence agriculture, measures to increase societal productivity, perforce, hinge on transforming agriculture and on initiating an industrialization pro- 
cess whose inputs and outputs are closely related to agriculture (cf. Kuznets:1966).10 The challenge of developnent policies is thus to optimize the combination of given resources and to engage people's creativity, initiative and energy as widely as possible.

This emphasis on econonic developnent is not to discount husan development but to suggest that, for all practical purposes, the forner is a necessary if insufficient condition of the latter. If people's energy is monopolized with basic survival strategies, to procure food, clothing and shelter, they have precious few options to exercise. The advantage of econonic growth, as Arthur Lewis pointed out, is not "that wealth increases happiness, but that it increases the range of human choice, ... that it gives nan greater control over his environment and, thereby, increases his freedon" (Lewis:1965a,421). Once the imediate necessities of 1 ife are secured and even sore so once people have attained a certain level of material welfare, they will denand and struggle for civil, economic and political rights. As the experiences of all OECD countries, but also of Taiwan or South Korea, demonstrate, highly industrialized countries are the ones where pressures for positive human choice issues, such as access to education, ecological sanity, gender and racial equality, human rights, social security and the State's public accountability, are the strongest and the wost successfully pursued. Conversely, the countries in which econonic developnent as defined above is deficient are also as a rule the ones in which hu-

20 "Historically, the rise in the share of anufacturing in output and employment as per capita income increases, and the corresponding decline in agriculture, are anong the best docunented generalizations about development" (Chenery, Robinson and Syrquin:1986,1). 
an developaent is severely circunscribed. Finally, while the first steps in the process of transforming an agricultural econony into an industrial one are anenable to coneand style, a highly differentiated economy requires a sophisticated mix of decentralization and selective, finely tuned public interventions; it also requires educated, eotivated and skilled people whose initiative is not regarded with suspicion or just tolerated, but encouraged.

Capitalism is a singularly effective econonic arrangenent for the task of econonic development because in "part it appeals to, and in part it creates, a schena of motives that is unsurpassed in simplicity and force. The promises of wealth and the threats of destitution that it holds out, it redeens with ruthless promptitude" (Schunpeter:1962, 73). Not surprisingly, developnent in theory and practice has always been conceptualized as capitalist developent (Ruescheneyer and Evans: 1985,44; Cohen:1978,180-181; Phillips:1977), the Marxist-Leninist approach being only a nore complex and less successful version of capitalisa.

Marx throughout his oeuvre was unequivocal about the progressive nature of capitalism, and about the dependence of econonic and social progress on capitalism. He considered capital the driving force of development. More specifically, it is the systen of connodity production for profit which, according to Marx, realizes the naxinun development of the forces of production. Leninisn attenpted, unsuccessfully, to duplicate the process, indeed to rationalize it, with comprehensive central planning and public ownership of the means of production. It failed for many obvious reasons, nost inportant of which must be the 
suspension of the market to establish factor prices and opportunity costs, but also because connunian had neither a theory nor was it in practice successful at creating persuasive incentives; its substitutes were either bizarre or sinister: ideological exhortations and eeasures to "educate the nasses," inducenents such as nedals honouring "activists of socialist labour," or just crude force. Nevertheless, the bottom line was not any different fron capitalisn, only auch less effective econonically. As early as 1930, Karl Kautsky, Marxist, former teacher of Lenin as well as Trotgky, and grand old ean of European Social Democracy wrote: "What the capitalists of Europe and Anerica are doing under the pressure of the present crisis, i.e. reducing wages in order to increase profits and accunulate more capital, the Soviet rulers are doing systematically on the basis of their Five Year Plan, thanks to their excessive power over the workers" (Kautsky:1931,12; see also Gide: 1950,187 and Koestler:1946a).

Albeit with different connotations, both Marxist and liberal theories of growth assume that capitalistic/narket economies energe quasi automatically in developing countries because of low labour costs and correspondingly high profits, that is, because of the necessity to launch and/or accelerate industrialization (Brenner:1977; Lewis:1954; Shivji:1976; Warren:1973). Therefore, to put ay leading question differently and polenically, I an asking why a capitalist econony did not emerge in Nigeria or, nore specifically, why, in the absence of an indigenous bourgeoisie, the Nigerian state failed to perforn the bourgeoisie's historic role. As in all analyses of modes of production, the critically important questions are who appropriates surplus and who 
deterwines its use (Marx:1968,884-885).

Ideal-typically in a capitalist narket econony, enterprises appropriate surplus as profit and - aseuning sufficient demand for their products - will reinvest it, lest they be crowded out of the aarket by cospetitors. The state in this nodel, "is the specific organization which the bourgeois society gives itself in order to alintain the general conditions of the capitalist mode of production and to defend thew against encroachaents by workers as well as by individual capitalists. The modern State ... is the notional collective capitalist" (Engels:1977,133). In this view, the state is neither an instrunent nor a servant of the capitalist class, even though it "seeks to implement and guarantee the collective interests of a class society doninated by capital" (Offe:1984,121) by creating a requisite norative order as well as by protecting and sanctioning set of institutions and social relationships which are essential for waintaining the capitalist ande of production. One does not have to subscribe to the inplied insinuations of sinister and conspiratorial manipulations to see the validity of the observation that the state's general perfornance is indeed crucial to the success, or otherwise, of a national econony. The overwhelming material accomplishnents of modern welfare capitalisa, so my contention, are precisely the result of the specific societal division of labour between the econonic and the political spheres: the econony, itself composed of conpeting vicro-units, is prinarily responsible for the material reproduction of society, while the state not only authoritatively ensures the capitalist order, which includes the prevention of capitalist monopolies as well as the creation and the defen- 
ce of markets, but also provides inportant econonic support services in the widest sense. The two spheres are nutually dependent on the other's effectiveness and efficiency, and it is this tension which, if productively used, is a pre-requisite for developnent, econonic and human.

In Nigeria, in contrast to this ideal-type of a capitalist narket economy, the State combines the two discrete functions of econonic and political reproduction. It eaploys the great majority of modern sector workers while public consunption has massively increased at the expense of private consumption. The State centrally appropriates society's economic surplus and deteraines its use. In this undertaking it is not compelled by potentially threatening political forces to adopt macroeconomic policies conducive to capitalist development, nor to avert developmentally retarding ones. The same immunity, or autonouy, also means that the Nigerian State is not forcer by narket presgures to usefully invest surplus. Optimally, the State would do so regardless or, not being bound by a strict calculus of profitability, funds would be used at least "constructively." Yet in actual fact, because of the absence of effective countervailing pressures frov outside groups or classes, it does not have to and - more of ten than not - it will not. The reasons for this delinquency have been tersely sumaed up as the circumstance that in "African countries governance is more atter of seamanship and less one of navigation - that is, staying afloat rather going somewhere" (Jackson and Rosberg: 1982,18 ). Put differently, the Nigerian State nay lack, on the one hand, the capacity to establish the crucial conditions for capital accumulation or, on the other, it nay 
lack the necessary conviction. In the latter case, its economically irrational policies would point to tangible non-developmental or even anti-developmental interests which dictate apecific economic policies, not as tools of development, but as weapons of political survival (Roemer: 1982,134$)$. It is in this light that the Nigerian State's policies and their effects on economy and society will be considered.

The dissertation is structured in two parts:

- A theoretical discussion firstly of the suitability of a statecentered perspective; secondly of an appropriate theory of the post-independence Nigeriar State; thirdly of the cardinal determinants of state behaviour, viz. the interests of the state class (i.e. state legitimacy, autonomy and personal enrichment) and, fourthly, of the discrete economic system (mode of production) germane to a political system (order of domination) characterized by a central, autonomous and economically interventionist bureaucratic state.

- An empirical investigation of the genesis of the bureaucratic Nigerian State. This is followed by a -eview of Nigeria's political economy of the 1970 s and early $1980 \mathrm{~s}$ in order to provide the material support for wy theses, namely that the State is the nodal point in the Nigerian development scenario, that the interests of the state class are in conflict with the requirements of development, that the policies pursued will mostly (yet do not necessarily have to) be dictated by the 
state class's interests, and that a devolution of State pomer and greater reliance on market aechanisas will be necessary (yet by no means sufficient) preconditions for econonic development, that is, for the esergence of capitalism. 


\section{Part I THEORETICAL CONSIDERATIONS}

\section{On Social-scientific Theorising}

Economic development is studied in many acadeaic diaciplines: anthropology, economics, econonic history, ethnography, geography, history, political science, public administration and sociology. Each of these disciplines concentrates on but one aspect of what is, in fact, a dynamic, interactive and altidiaensional process, thus running the risk of missing "much of the texture of this essentially holistic activity" (Siddle and Swindell:1990,89). Operating within strict boundaries, all disciplines are involved in discrete processes of evolution and, hence, are far from agreeing on conpatible, let alone common, epistemologies, methodologies or paradiges. Cunulative growth of knowledge and a convergence of views concerning the development problematique seem a long way off, and the iapression of the field is that of a cacophonous choir made up of autistic soloists. Efforts to identify, for example, the principal factors causing economic growth (or its absence) in each of these disciplines invariably leads critics to point out the failure of each theory to explain particular instances of growth or stagnation (Papanek:1977,27). Serious barriers for the convergence of theory seen to lie in inconpatible ideological predispositions $c .1$ the one hand and, on the other, in the reluctance of practitioners of one discipline to consider variables, insights or findings of a competing academic discipline. The ideological dispute will be brought up throughout this study; the technical probleas of interdisciplinary comunication are more straightforward and ignored only at 
one's own peril.

Many econonists, for example, habitually abstracting fron politics, tend to view developnent issues in acroecononic categories like money supply, exchange rate and trade regiwes, savings/investment ratios etc. or aicro-economically in teras of production factors, inputoutput ratios, capital coefficients or cost-benefit calculations. Working within conceptually rather narrow boundaries and, in particular, ignoring politics, they essentially fail to produce theories which explain what is actually happening in specific societies. The policy proposals or national development plans which are based on such analyses very rarely achieve the expected benefits and not, as is frequently suggested, because they are technically flawed, inconsistent or not comprehensive (Killick:1976); nor do they fail only because of inexperienced politicians (cf. Wallis:1989,23) or incompetent administrators (World Bank:1984b). A major reason for the disappointing performance of many narrowly econonistic plans is their digregard of the fact that development policy, like any other policy, is politics.1

The challenge for a successful politological analysis is thus to avoid the pitfalls of paradigmatic rigidity and, instead, to use "Erkenntnisse" from other disciplines, to strive for historical depth and not to shy away from ventures into seemingly alien territories such as

1 "Only in a very special sense can we speak of a nation's policy or policies. In general declared policies are nothing but verbalizations of group interests and atti-tudes ... though every group exalts the policies that suit it into eternal principles of a 'comon good' that is to be safeguarded by an inaginary kind of state. Nobody has attained political maturity who does not understand that policy is politics" (Joseph Alois Schunpeter, cited in Snithies:1950,427). 
literature and folklore. The purpose of this expansive search, of course, is to complement an argument, give it colour and texture, or simply to test it. There are sone interesting cases of interdisciplinary borrowing in the developnent debate where insights acquired significance not only in their original field but also in their application in political analysis, or where theories frov one discipline fertilized conceptual development in political science.

Cardoso and Faletto, for example, adopted a concept developed by economic geographers, namely the grouping of staples into various categories, as a basis for identifying differences in countries' economic and sociopolitical destinies (Cardoso and Faletto:1978,xix). Sinilarly, it was an econowist who introduced the distinction between "leftwing-crops" and "right-wing-crops," pointing out that products requiring individual attention by skilled labour (e.g. wine grapes, certain fruits and vegetables), are particularly unsuitable for collectivized agriculture, while "left-wing" crops (e.g. grain and most livestock, except sheep) flourish equally well in large-scale arrangements and under standardized procedures (Wiles:1977,102).

Hyden's concept of the "peasant mode of production" draws heavily on anthropological and sociological insights, such as Goody's argument that the virtual absence of land alienation and social stratification has its origin in the failure of African societies to acquire the technological means (e.g. irrigation systens, the wheel, the plow and other applications of "internediary technology") which are instrunental to the unfolding of productivity, skills and specialization and which initiated the sweeping development processes in Asia and Europe (Goody: 
1971,76). With the hoe as the main agricultural tool (cf. Morgan and Pugh: 1973,67-68), that is, on "highly restricted energy base, African polities remained weak, less centralized and nore egalitarian than in other parts of the world" (Hyden:1986,681). Rather than utilizing the land and advancing agriculture, African rulers sustained their regines by appropriating surpluses fron long-distance trade which they could control and on which their fortunes and influence was based. This trade of mostly gold and slaves was founded on a systen of coercive internal or external extraction and so "contributed to the oanipresent brutality and wars characteristic of pre-colonial Africa" (Sender and Smith:1986,7). In the absence of any productivity gains, agricultural output was/ is a linear function of factor inputs, especially labour and land. However, land in Africa generally, and in Nigeria specifically, has historically been and still is today relatively abundant. With labour thus being the most highly valued asset in Africa, sidilarly to land or money in Europe or Asia, Hyden explains the Eurasian dowry system as an attempt to "prevent property passing out of privileged strata into less privileged strata ... and to compensate husbands for the responsibility of supporting wonen whose productive and reproductive potentials are held in low esteem ... while bride-price is a sympton of the ability of society to absorb nore labour" (Hyden:1986,681-682). Another example of cross-disciplinary fertilization, highly controversial three decades ago but long since passed into oblivion, concerns the role of investment in development. What had been originally a concept created by general macroeconomists became extraordinarily influential in development studies at large: the Harrod-Dosar nodel 
which postulated that growth depended only on the capital-output ratio and on the availability of capital as deternined by the propensity to save and/or the inflow of capital from abroad. During the $1950 \mathrm{~s}$ and beyond, the received truth held econonic growth to be investnent driven (Ranis:1977,261). For a generation of planners and aid officials this concept was essential to their status as experts - "it was the only game in town" (Hirschman:1977a,68). The contrary notion, nanely that egalitarian income distribution would much faster create the requisite market size and so lead to the emergence of a manufacturing sector and balanced growth (Baldwin:1956; Elsenhans:1983 1986; Lewis:1953; Murphy, Shleifer and Vishny:1989 1989a; Weber:1966), has not had much influence on development theory and practice.

A final illustration for epistemological and nethodological borrowing, by now equally historic, was the importation into political science of the Parsonian evolutionary universals and their operationalization into a specified list of functional requisites, i.e. tasks that all political systems had to perform if they were to survive (Alnond and Coleman:1960). This structure-functional approach was then applied to political institutions in order to assess actual compared with normatively dictated performance (Hoselitz:1963; Braibanti:1969; Riggs: 1969). These analyses were highly abstract, general and theoretical and thus altogether too accomodating. In analogy to Lowi's verdict on systew's theory, one could say that structure-functionalisa was everything, therefore it was nothing (Lowi:1988,888). It has been argued that the institutionalist revival in political science was, to sone extent, a reaction to the eapirical migmatches between the grand theo- 
ries of socio-economic differentiation and political development on the one hand, and specific case studies and comparative-historical evidence on the other (Skocpol:1985,5). Such at tempts to operationalize structure-functionalist developmentalism were/are studies in management and organization theory which explore "appropriate" ways for transferring Western concepts to African settings (Blunt:1983; Moris:1981; Reilly: 1987). Their pervasive exasperation, warranted by presuned cultural incompatibilities, seems as misplaced as the econonists' aloofness. Again, a case could be made that the root problem which prevents the emergence of a rational legal order in Africa is not cultural but political (cf. Leonard:198i).

These examples of more or less fruitful transcendence of narrow disciplinary boundaries are, despite their varying rates of success, encouraging and enriching. They all underline the challenges for theory-building in the social sciences, in particular the necessity to carefully choose appropriate levels of abstraction and generality as well as to consider all relevant variables, whatever their "proper" discipline of study. Of course, they also show the limitations of theorizing as that method of understanding empirical reality by means of abstract constructs. As the objects of social scientific inquiry are normally fluid and not objectively bounded, almost any theory can be applied and any anticipated finding can be generated. ${ }^{2}$ This is be-

2 The resulting paralysis, and cynicism, has been acutely diagnosed in Arthur Koestler's novel The Call-Girls. Siailarly, Leszek Kolakowski (1990:240-241) satirically explains the proliferation of theories with the predicament that a theory must be convincing and scientific, but that to different people different theories are convincing and scientific. His General Theory of Not-Gardening (reproduced in Appendix D) is conclusively supported by a great number of self-contained doctrines: Marxist, psycho- 
cause theories are tools and as such finely attuned to the specific task their user wishes to undertake, such as to explain certain phenomena and/or, possibly, to guide action. Epistenologically, theories have a dual role: as prerequisites for cognition, they precede and aake possible systematic perception while, as the product of cugnition, they pernit the interpretation of inforation, the relating of one observation to others, and the identification of regularities (Brecht:1976, 15ff). In other words, theories reduce complexity of enpirical reality, order and explain it; however, they can also distort it. In order to minimize overly tactical theorizing, Sweezy proposes three questions to gauge appropriate abstraction:

- are the simplifying assuaptions (or abstractions) framed with a proper regard for the problem under investigation?

- do they eliminate the non-essential elements of the problem?

- do they stop short of eliminating the essential elements? (Sweezy: 1946,20 )

The desired result is a coherent framework - a theory - which, although abstract, has an identifiable eapirical referent. Inevitably, social scientific theories simplify complex reality, not only because of the natural limitations of human cognition but also because of the objects of study. The phenonena which form the subject natter of the social sciences are not physical facts but abstract constructs. Each theoretical framework, perforce, delineates the bolndaries within which 
its findings will be placed and so exact a price: "for every insight that is won, certain other insights are foregone, left out, undereaphasized, or whatever the appropriate expression aay be. Kenneth Burke once wrote that every way of seeing is a way of not seeing, and that the poor pedestrian capacities of the fish are best accounted for by his excellence as a swiner" (Bendix:1984,21). Given this intrinsic handicap of social theorizing, the quest for general theories ${ }^{3}$ but also the positivist requirenents - intended as danage-liniting devices that a theory be generalizable, testable and interpersonally verifiable, are unduly restrictive. They reduce the scope of inquiry to measurable "facts" or quantifiable trivia, at the expense of the essential, the intangible or the unique. The shop-worn but plausible objection to the positivist requirement of testability is that whatever is generalizable or measurable is probably trivial and whatever is interesting is very likely idiosyncratic or non-quantifiable. One consequence to be drawn from this dilema is to consider it sufficient if it can be demonstrated that particular theory is not excluded by enpirical evidence.

Arguing in this vein, that is, in the Weberian tradition, Friedrich August von Hayek contends that "[t]heories of the social sciences

3 Tocqueville gave eloquent expression to the dubious merit of general theories: "When one studies the history of our revolution, one sees that it was conducted in the sane spirit that preaides over nany abstract books on the principles of government. Sane attraction toward general theories, complete systen of legislation, and exact synetry of laws; sane contempt for existing facts; sane trust in theory; same taste for what is original, ingenious and novel in designing institutions; sane bent for remaking simultaneous the entire constitution, following the rules of logic and anique plan, instead of attenpting to anend its parts. A frightening spectacle!" (cited in Hawthorn:1991,43). 
do not consist of 'laws' in the sense of expirical rules about the behaviour of objects definable in physical terms: [what they do is to provide] a technique of reasoning which assists us in connecting individual facts, but which, like the logic of nathenatics, is not about the facts, and can never be verified or falsified by reference to facts. ... All that we can and must verify is the presence of our assumptions in the particular case. ... The theory itself can only be tested for consistency" (cited in Dobb:1981,27). This, adnittedly second-best, concept of theoretical approximation of complex reality, suggests the application of Occan's razor (pluralitas non est ponenda sine necessitate) in the selection of variables: as it is inpossible to consider everything, even everything that is important, unnecessary aspects will have to be disregarded and the analysis focused on the essential. Given the unavoidability of reductionisa, what can be dewanded and expected of a theory is not that it be general but that it be helpful for the interpretation and understanding of sone complex socjal phenomenon "by seizing on some crucial aspect of it and enabling us to think more clearly and systematically about it than we would have been able to do without the theory" (Barry:1977,237).

What is being invoked here is Weber's concept of an "ideal type," that is, the heuristic device intended to render coherent and intelligible a particular social reality. An ideal type too is created in the two stage process of firstly abstracting pertinent features of a phenosenon and secondly reconstructing thes as coherent whole. "Ideal-types are, Weber eaphasized, deliberately constructed to be 'one-sided;' they are aeant ... to accentuate the phenonena under 
study" (Wolin:1981,415). Ideal types are not axionatic or doctrinaire but rather attempts to reasonably delineate a phenonenon; they are products of an analyst's inagination rather than conprehensive or concretist descriptions of real chains of causation, in Weber's words, illuminations of reality without being able to exhaust its infinite richness. "They are all attempts ... to bring order into the chaos of those facts which we have drawn into the field circuescribed by our interest" (Weber:1964,105; emphasis in original). An ideal type as a model of reality offers insights nuch like a focused strobe light in a large, darkened roon: the detail is sharp, but the resulting view nay well be partial. The only way to ainimize these inherent linitations is to broaden the eapirical scope and to deepen the historical range; in other words, to marshal evidence for the plausibility of the nodel by supplying, as richly detailed as possible, background, texture, context and colour. Nevertheless, as Max Weber denonstrated so consunmately, ideal-typical analysis is by necessity anecdotal rather than systematic. It also intertwines theoretical reasoning with enpirical evidence and empirical analysis with theoretical argunents. The strict separation between a first stage of abstract nodel-building and a second stage of their application and testing "in reality," so cherished by positivists and other linear thinkers, is therefore excluded on principle.

The concept of theory which I will apply to the specific case of Nigeria, namely a Weber-inspired ideal type, is about perception, description, interpretation and reasoned argunent. It is not inforwed by any Promethean streak - to inport into the world the one element lack- 
ing for its perfection - and is devoid of intellectual extravagance: there is no clais to either prove an entirely counter-intuitive hypothesis, or to have developed a ceneral theory of universal validity; in fact, there is no attenpt to justify or prove anything. Its self-conscious restraint, rather than liniting such a theory's force, to the contrary entajis the potential to widen the scope of inquiry, to generate new insights and to enhance our understanding. The cross-disciplinary fertilization referred to earlier becones possible. Thus, limited as the formal aspirations of this kind of theorizing are, to refute an ideal type it would be insufficient to show that its applicability is limited in scope, that it is less than absolutely certain, that sove of the support marshalled is open to different interpretation, and that it faces difficulties as well as sone contrary evidence. What would have to be established is that it is less incigive and less plausible than alternative theories about the sane subject natter and "that there are in its case nore difficulties, nore negative evidence than in the case of at least sone one alternative theory" (Burnhan: 1960,274; emphases in original).

In this spirit, I will construct an ideal-type of the bureaucratic Nigerian State. The net will be cast as widely as I can, theoretically, historically, eapirically, to support ny contention that there is a better way to account for Nigerian politics and econonics than has been done by neo-Marxist theories generally and of the dependency/ underdevelopment/world system varieties specifically. It is well posgible, albeit not the aspiration of the present study, that the ideal type of the bureaucratic Nigerian state has validity for other case 
42

studies; its proper test, however, has to be how well it explains $\mathrm{Ni}-$ Beria. This caution, or humility, does not result from doubts about. the soundness of ny theory but from the desire to avoid getting sidetracked into establishing, and then finding myself obliged to defend counter-orthodoxy. Dreading the prospect of biting off more than can be chewed, I feel more comfortable heeding Paul Streeten's advice: "Know the limits of your methods and do not apply them beyond their scope. Otherwise you run the danger of Samuelson's man who knew how to spell 'banana' but did not know when to stop" (Streeten:1991,422). 


\section{The Superiority of a State-centered Analysis of Nikeris's}

\section{Develowent Problenatioue - and the Inferiority of Perspectives}

\section{focusing on Societs or Global Constraints}

Development as the process of changing the structure of an econowy an be analyzed ex ante and operationally (before it has taken place), or ex post facto and critically (if indeed it has happened). However, the tools of normative or historical analysis are much less useful to decode why something has not happened than to explain why something has happened, or should happen, and to identify the relevant process determinants. Hirschman's linkage concept illustrates the former case in viewing the "developwent story [... as] essentially the record of how one thing leads to another, and the linkages are that record" (Hirschman:1977a,80). As for the second case, conclusive, empirically testable and interpersonally verifiable answers are impossible in what must by necessity be a counterfactual explanation. It may be possible to "explain (or at least seek to explain) how what did happen could have happened. ... We cannot explain why it did happen. The key truth about politics - arally, practically, theoretically - is always that matters could have been different" (Dunn:1978,214; emphases in original). This predicament cardinally accounts for the plethora of approaches, schools or theories, all of which atteapt to authoritativeIy account for the persistence of underdevelopment - or for the distorted nature of development of the Third World. These diverse paradigas identify and isolate one salient feature around which they then organize their respective interpretation of, and suggested renedy for, the 
problem of underdevelopment. To illustrate this process with reference

to three of the five broad schools of development .udies mentioned

earlier:

Dependency analysts view the persistence of underdevelopnent in structural terms as the consequence of Third World countries' location at the periphery of the capitalist world systen. Since neither their position in the systen nor the systen itself can be changed by the dependent capitalist countries, their deliverance is seen - despite Albania as a thoroughly disheartening prototype - in a socialist path to developnent and in opting out of the systea (Dos Santos:1970,236; Lubeck: 1987,9; Nigeria:1987; Trimberger:1978,174; Wallerstein:1976, 133). Failure to do so is evidence for the conprador nature of the indigenous governing class (Shivji:1976) or, which is a mirror image, for the enduring donination of international capitalism despite fornal independence (Frank:1972).

- Modernization theorists study underdevelopment (backwardness in their concept) behaviourally. Enphasizing cultural, social and psychological factors, their level of analysis is societal; the global context in which the pre-sodern society is enbedded is the cradle of nodernizing impulses. Earlier beliefs in the inevitability of progress have, under the impression of the past three decades' sobering experience, been nodified; sophisticated writers within the Modernization school no longer adhere to the mechanistic view of a uniform process of developwent leading to a convergence of societies. The original assuaption of a strict dichotomy between modern and traditional societies has been modified and the co-existence of traditional patterns with modern ones seems no longer a logical impossibility. Also, not just any change, even if far-reaching, is now equalled with modernization and the danger is recognized that tradition can be destroyed without by necessity leading to the crystallization of viable modern societies (Nash:1984).

- Neo-classical developsent econonists (and international or bilateral development agencies, not including the World Bank group) assume, unlike the other two approaches, that Third World governments are composed of altruistic policy-nakers maximizing some social utility function subject to given resource and technological constraints, that they are comnitted to broad-based or even to socially equitable developnent. The major obstacles for such development are located both internally and externally. At the international level, factors retarding development are identified to be the unfavourable teras of trade, wildly fluctuating revenues for Third World countries' largely agricultural exports, and the OECD bloc's tariff barriers which prevent the Third World from pursuing export-led industrialization strategies. Internally, the persistence of 
underdevelopment is seen as resulting from the scarcity of human and material resources which is to be alleviated with international assistance (Brandt Connission Reports).

If the Dependency School is stridently materialist and revolutionary, Modernization theories ultinately idealist and evolutionary, neoclassical development economics is thoroughly realist and refornist (even if the assistance agencies, the school's operational arw, of ten have to be quite idealistic sinply to keep going). The latter shares with the Modernization approach two cors assumptions: firstly that the developnent process in Third World countries should or will be a variation of the Western experience and, secondly, that the impulses, knowhow and resources, whether to accelerate or even to initiate the process of development, will have to be supplied externally. Yet, "states way have leaders who have ... little interest in building reliable infrastructures that would support capital accualation. ... the state may still aid its favourites, but they will be unproductive, plundering the businesses they are awarded instead of improving them" (Kasfir: $1983,12)$. In other words, the possibility that Third Norld States "public officials writ large" (Nordlinger:1987,353) - realizing their weakness and/or their interest position, in their own calculus rationally decide not to unleash a comprehensive development effort - and that they have the wherewithal to prevent it - cannot be accomodated very easily by these three schools, ${ }^{1}$

1 It is in my view a reasonable supposition that "there are a good many cases where one cannot even assume that the elites in charge of government have any interest whatever in the development of their respective societies. A good nany ei ites have discovered that poor peasants tend to be less troublesone politically than people in the throes of successful development: peasants with refrigerators have disconcerting 
Dependency writers would hold that international capital, not any national government, is the econonically and politically crucial determinant; underdevelopment persists because it suits international capital. The state as an institution and a purposive agent who, as a gatekeeper, selectively admits modernizing influences and instrunentalizes them for its own purposes, can only very strenuously be acconnodated in the Modernization school's structure-functional framework. If faced with obstruction fron certain elenents in the State, neo-classical economists tend to view this as a syopton of underdevelopment, or of the growing pains of development. Their advice would be the nobilization of other state-factions (Lancaster:1988,32; iden:1990,121; Streeten: $1987,1480)$, and if this was unsuccessful, to shift attention and resources to less controversial areas and to wait for another opportunity to launch the contentious programe or project. 2

propensity to becoming 'uppity'" (Berger:1986,242). In a siailar vein it has been suggested that "the rulers of West African states both are rational in their approach to agriculture and possibly pose the gravest obstacle to its further development" (Hart:1982,14).

2 As far as development agencies - the functional arm of neoclassical development economics - are concerned, recent trends indicate that with the deepening crisis, their traditionally rather technocratic stance will be given up in favour of an attitude which holds aid to be a privilege not a right, and which will advocate the direct political involvement of donors. An aid official, giving expression to this growing sense of exasperation declared that the "donor community has becone the loyal opposition in [one-party] Tanzania and all donors here are hardening their positions." A Western diplomat added that the "power of the money we're spending gives us influence, and we can't not use it" (cited in Valpy: $1985,1)$. After Western donors in November 1991 decided to delay aid to Kenya pending economic and social reforas, Mr. Martin Shikuku, former member of parliament and a founder of the opposition group "Forun for the Restoration of Democracy" said that his movenent was very pleased about the decision. "It is not fair for the donors to give funds that in the end are stashed in individuals' pockets. ... Until the Government is able to show transparency and accountability and respect for its citizens, no funds should be allotted to it" (cited in the NYT, 29 Noveaber 1991, A3). 
These three approaches, to repeat, operate within different theoretical frameworks; consequently they ask different questions and give different answers. In the present study, I will atteopt yet another cut at the problem. It is ny enpirically based prejudice that the State's centrality - the origins of which 1 will trace back to colonialigm and the struggle against it - nugt go a long way in explaining the persistence of pre-capitalist relations of production and thus of underdevelopment. Being concerned with the macro-context in which Nigerian economic development is being managed, ay analysis firstly seeks to identify the political arena and the key actors, their behaviour patterns and the resulting systemic dynamics. It secondly examines how the institutional arrangements and the interests of the dominant actors shape, distort or prevent the development of capitalisw. Under normal circumstances, the analysis of societal determinants and constraints on the one hand and of international ones on the other would reconmend itself. I will argue that the Nigerian case is rather special in that it is characterized by a State whose resource base is independent from society and whose decisional autonony vis-à-vis external actors is real, rather than merely formal.

Such a concretist line of investigation would, until very recently, have had difficulties being accommodated in the mainstrean of North Anerican social sciences, where the behavioural revolution had displaced the concept of the "State" in favour of the "political systen," had replaced "institution" by "stable valued, recurring patterns of beha-

Shortly thereafter the government noved to legalize opposition parties. 
viour [and had defined the] level of institutionalization of any political system ... by the adaptability, conplexity, autonony and coherence of its organizations and procedures" (Huntington:1968,12-13).3

Especially for analyses of Africa, one "of the nost curious paradoxes in recent intellectual history was the sinultaneous vast increase in the scope and impact of the state and its virtual eclipse as an issue in all major theoretical paradigms" (Young:1982,72). Thus, just as the African State ascended, "many political scientists were abandoning the theoretical tools necessary to perceive it" (Jackson and Rosberg:1986, 31). In sum, the vision which dominated North American political science in the past decades - whether structure-functionalist or Marxist would have been inclined to focus on society rather than on the State, and to treat the State not as an actor sui generis, but as an arena within which political behavior, driven by various interests and different capabilities, occurs. Such society-centered perspectives view political phenomena as the "aggregate consequences of individual behavior [and do not] ascribe the outcomes of politics to organizational structures" (March and Olsen:1984,734-735).

Development policies in the classical systems theoretical flow models of the behavioural-pluralist school (e.g. Easton:1957 1965) would originate in society and be inplenented in the following nanner: problems arise in society and are transmitted to the decision units as information and/or political pressures (inputs); policies are fornula-

3 Having done his share to send the "State" into the acadenic wilderness, it is rather ironical that only a few yearg later Huntington finds it necessary to deplore the "virtual absence of the concept of "the state" in American thought" (Huntington: 1981,34). 
ted (policy-making) and then executed (outputs); the impact of policy (outcome) is experienced by society and, possibly, transforned into fresh inputs. Public policy, in this conceptualization, represents the decision-making systea's responses to the inputs fron the environment. The system itself is seen as a completely neutral structure, as facilitative and value-free, rather than as causative (Cortes et.al:1974, $11 \mathrm{ff})$. To the extent that the inputs are conflictual, the policy outputs are the aggregate of dissenting positions and thus correspond to the "national interest". On account of their failure to look inside the "black box", the value of these society-centered input-output models has been questioned even for their prinary referent, nanely advanced societies with pluralist, ass-participatory polities. Ignoring the decision-making system generally and in particular the considerable potential which individual policy-aakers have for directly influencing the environment within which they operate, these models are too simplistic to serve as useful tools for understanding the policy process anywhere, but especially in developing countries. Here, so ay contention, Easton et al. have to be turned on their respective heads: public policy cannot be understood in terms of environeental or societal variables but only as reflecting the interests and structural properties, (including the resource base) of the political decision unit, the State.

Neo-Marxigt theories, for entirely different reasons, are equally uneasy about the concept of the State as an autononous, purposive and effective decision-making unit in developing countries. If considered at all, the state is viewed as hardly core than a residual variable 
which facilitates the interest-realization of the accunulative process generally or of specific, national or foreign, capitals or classes (cf. Cardoso and Faletto:1978,passim; or Evans:1979,39ff). "The dependency framework, in other words, explicitly rejects the unified state as actor as a useful conceptual building block of theory" (Caporaso:1978, 2). This verdict is categorically supported by world systen theorists who discount "states [...as] created institutions reflecting the needs of class forces operating in the world econony" (Wallerstein:1986,150), and who, therefore, consider as "clearly naive" to treat developing societies or states as units of analysis. "Actually, the econonies of the system's periphery have no real conjunctural phenomena of their own, even transmitted from the outside, because they are without any internal dynamism of their own" (Amin:1976,279), which is why "external determination remains the dominant perspective anong Africa's nationalist, radical, and progressive theorists" (Lubeck:1987,7).4 It is declared that the

economies, states, and cultural systens of almost all national societies are historical creatures of the European political economy [and ....] the current evolution of most national societies is greatly affected by the economic, political, and cultural events which occur entirely outside their boundaries. Econonic developnents in Africa ... are clearly resultants, for better or for worse, of doninant world warkets and technologies. Sivilarly, political events in such areas (e.g. the Nigerian civil war ...) are also creations of the world systen" (Meyer and Hannan:1979, 11-12).

- The Review of African Political Econony (RAPE) is an important forum of this position. The editorial in its maiden issue declares that RAPE "is published with the express intent of providing a counter-weight to that ass of literature on Africa which holds: that Africa's continuing chronic poverty is priasrily an internal problen and not a product of her colonial history and her present dependence" (RAPE No.1, August-Novenber 1974 , p. 1$)$. 
At the heart of all these predicanents, in the world system perspective, is the circumstance that the "periphery is dominated by the capitalist node of production and class relation" (Kazancigil:1986, 118). As far as I an concerned, the problen with these approaches and their error - is not that they draw attention to the global interconnectedness of econonic and political processes and events, but that they refuse "to grant the part any autonony, any specificity, any particularity independent of its membership in the whole" (Saith:1979,252).

For Nigeria, the international environment is certainly important, yet not so much because it determines the behaviour of Nigerian actors, especially the state, but rather because it limits it. As a market for Nigerian exports and as a source of her imports it is the only marginally manipulable - environment in which the Nigerian State can seek to optimize its position. While the value of Nigeria's exports and the prices of her imports are deterained outside the Nigerian State's purview, it would be difficult to seriously question its sovereignty concerning the implementation of internal policies. This is, of course, precisely what dependency theorists do by declaring incompatible economic dependence, economic development and political autonomy. Dependence, the independent variable in this equation, has been defined with various degrees of specificity. A rather general meaning refers to "a situation in which the econony of certain countries is conditioned by the development and expansion of another econony to which the former is [sic] subjected" (Dos Suntos:1970,231). Nore concretely it is argued that "three neasures are connon to nost attempts to operationally define African econouic dependence ... [nanely] 
the percentage of total official bilateral aid coning fron the najor donor country, ... the percentage of exports going to the most important trading partner, ... and the three leading connodity exports as a percentage of total exports" (McGowan:1976,26). Unquestionably, this represents a welcome effort to operationalize "dependency" because, in most instances, dependency writers have only an attitude or, as they invariably protest, an approach rather than theory. Even so, a laundry-list of attributes is hardly a substitute for substantive argumentation of how, exactly, they translate into losses of welfare or the exogenously imposed restriction of political choice. The twin fallacy which is as central as debilitating in the dependency paradigm is the denial of any State autonomy on the one hand and, on the other, the failure to distinguish between the fact of some kind of econonic dependence and the allegedly fiendish consequences of this condition.

Ekekwe makes the argument concisely and comprehensively:

In the event, the national economy is more and more exposed to the whims and caprices of international capital. ... This is the situation of typical post-colonial (neo-colonial) states, of which Nigeria is one, notwithstanding its huge resources. Short of extricating itself decisively from the stranglehold of international capital, such a state appears dooned to crest one crisis only to fall into the trough of another (Ekekwe:1985,68).

Another twist has been added by those, mostly African acadeaics and diplomats, who deplore Africa's marginalization and who recoumend a "strategy of collective self-reliance involving political and econonic cooperation [... which] requires a carefully planned prograne of gone deliberate delinkase fron the rest of the world" (Ndegwa:1991,20-21; 
emphasis in original). The UN's Econonic Comission for Africa develops this theme by also lamenting African countries' "excessive outward orientation and dependence" (E/ECA/CM.15/6/Rev.3,p.1) and then declaring that "the negative effects of the openness of African econonies should be seen only in the context of the region as a whole vis-d-vis the outside rather than in the context of individual Airican countries among thenselves" (ibid.,5). Nationalist, if not to say racist aythology informs this definitional sleight of hand which decrees that dependence is not dependence and outward orientation is not excessive, so far as they are confined within Africa.

Reasoning such as this is sonewhat unsatisfactory because the mere correlation of epiphenomena does not, in strict logic, permit the draving of conclusions concerning any possible econonic dislocations/disadvantages or of any infringenents of the dependent country's political autonomy and sovereignty. Dependency becomes "the residual variable that explains anything and everything, nuch the same as the role played by the term 'traditional' in earlier nodels of development. The temptation of making international inequality a deus ex nachina, which explains the true causes of all poverty, can lead to a neglect of the complex linkages between outside pressures and internal mechanisns" (Mi gdal: 1983, 324-325).

I consider as plausible the proposition that dependence on the exportation of primary comodities, or the preponderance of foreign capital investment and foreign trade in a national econowy can, as Marx himself was concerned to enphasize and as the cases of, anong others, Canada, Finland or Sweden denonstrate clearly enough, have their eco- 
nowically productive and even progressive functions. In those instances, rapidly rising living standards were quite conpatible with both, a continued dependence on exports of priaary products into a very narrow range of arkets, and with continued donination of foreign direct capital investment in donestic industries, because they were conplenented by effective state policies. One can, of course, explain away state autonomy or re-interpret all state policies as having been in the interest of foreign capital, if not directly engineered by it. It is also possible to object to any such kind of dependence even if it were coincident with domestic prosperity. 5 However, gentidents like this have more to do with xenophobic paranoia or "nationalist netaphysics" (Kitching:1987,56) than with science or, one could add, with Marxiso (for a valiant if futile attempt to salvage Marxism fron such pitfalls see Booth: 1985).

Concerning the historical case for external deteraination, dependency, world system and some other neo-Marxist analysts argue that capitalism was always an international system, characterized by exchange between technically advanced and backward economies through the world market. "The rule of nonopoly capitalism and imperialisa in the advanced countries and social and econonic backwardness in the underdeveloped countries are intimately related, representing nerely different aspects of what is in reality a global problem" (Baran:1962, 250). Specifically, it is the econonic, technical and ailitary super-

5 Shivji makes this point when he declares that revolutionary "victories would mean nothing if our econony reatins the appendage of iaperialism" (Shivji:1976,4). 
iority of center states which resulted in the domination and distortion

and thus in the underdevelopment of the periphery (Duval1:1981, 317).

This is a view, or naybe better a sentinent, which can view poverty only as the result of outside interference - particularly the development of market relations and colonial doninance - without according adequate weight to diverse indigenous factors and their autually conditioniry relationship such as the developmentally retarding effects of certain forms of political organization, the difficulties of the environment, the low level of technology, and the obstacles of anall-scale subsistence farming for the development of the forces of production. From the lofty heights of a characteristically acrosociological perspective, the persistence of underdevelopment (which in this discourse means non-industrialization) is explained through the logic of capitalism, of colonialisa, of dependency and of exploitation. 6 Underdeve-

6 The following quotes are to illustrate the various charges: Underdevelopment "was and still is generated by the very sane historical process which also generated economic developnent: the development of capitalism itself" (Frank:1972b,9).

"Responsibility for [the tragedy of underdevelopment] undoubtedly goes back to the brutal and primitive forns of colonial pillage, which was satisfied to have Africa produce and then crean off an agricultural surplus without technological and social transfornation that would nake it possible to move from extensive to intensive forms of faraing the land" (Am in: 1987,1).

Underdevelopment is the result of the distinctive defornation of dependent economies in which "capitalist accumulation ... does not conplete its cycle. Lacking 'autonomous technology' .... and conpelled therefore to utilize imported technology, dependent capitalisn is crippled l... and therefore] must insert itself into the circuit of international capitalism" (Cardoso: 1973,163).

Underdevelopment "expresses a particular relationship of explc itation: namely the exploitation of one country by another. All the countries named as 'underdeveloped' in the world are exploited by others and the undercievelopment with which the world is now preoccupied is a product of capitalist, imperialist and colonial ist exploitation" (Rodney:1981, 14). 
lopment here is an expressly transitive concept: sone countries "underdevelop" others. This is a dramatic charge going far beyond the arguable accusation that colonialisa historically dislocated and distorted the economies of "backward" countries, or that the structure of today's world economy has the same effect; it also goes much further than the lament that colonialism (the developed North) did not do more than it did to assist their development, or did less than it did to obstruct it.

A quick aside: Popper points out that towards the end of their lives "Marx himself and Engels, began with the elaboration of an auxi1.jary hypothesis designed to explain why the law of increasing misery does not work as they expected it to do. According to this hypothesis, the tendency towards the falling rate of profit, and with it increasing misery, is counteracted by the effects of colonial exploitation" (Popper:1971,187; emphasis in original). This revision of one of its fundamental tenets is noteworthy because it reveals Marxisw's ideological or quasi-religious, in any event, non-scientific nature; ${ }^{7}$ in its cosmo-

Commenting on such like analyses (or rather tautologies), Joan Robinson proposed that "the misery of being exploited by capitalists is nothing compared to the misery of not being exploited at all" (Robinson:1962,45).

7 It is as breathtaking as symptomatic that Marx, at the 18 international's Governing Council in June 1865, moved the adoption of a resolution, not on point of moral values or of political strategy, but on a matter of observable fact, nanely that the "seneral tendency of capitalist production is not to raise average wages, but to lower then" (Marx:1968b, 151). Reality turned out differently which is why the adage, attributed to Herbert Marcuse, applies: if reality and theory fail to correspond, too bad for reality. That this is not joke is nicely illustrated, for example, by Bienefeld's admission that real wages increased dranatically in industrialized capitalism combined with his insistence that "the fundamental logic of ... capitalism continues to imply" a wage reduction (Bienefeld: 1982,30$)$. 
logy, empirical facts are verely a facade for "deep," morally engaged revelations which can always be placed on some new footing if their original claims become untenable. Accordingly it should be considered, not as a question of development economics, but of the sociology of knowledge (or of the psychological phenomenon of cognitive consistency . whether the concepts of "underdevelopwent" and "unequal exchange" do not, in fact, correspond to "proletarianization" and "exploitation" of classical Mar.ism. As such, they are but attempts to salvage Marx's immiseration theory by transposing it from the national level (where it clearly did not materialize) to the global one. The people of the Third horld can be perceived as an "external proletariat" which is subjected to the immiseration prcsess Marx postulated as sharacteristically inherent in capitalism (Marx:1969a,641-649). The class struggle brtween capitalists and proletariat which for a variety of reasons did nol unfold as envisaged in the capitalist core, can now be reinterpreted as a struggle between metropole and periphery or between (neo-)colonizers and (neo-)colonized, with the proletariat of the North having heell co-opted by the bourgeoisie. Thus the "immiseration thesis, so central to the Marxian drama of revolutionary redemption, is saved by being globalized" (Berger:1986 21).

Analogously to "exploitation" whinh, in the context of a Marxist analysis of industrial capitalism was/is a central explanatory variab-

5 Keynes made the point in 1926 that "Marxian socialiso must a!ways remain a portent to the historian of opinion - how a doctrine so illogical and so dull can have exercised so powerful and enduring an influence over the minds of men and, through them, the events of history" (Keynes:1972, 285; for all in-depth analysis of this puzzling phenomenon see Koestler: 1950 and 1968; Revel:1991). 
le, the equally essential variable in the dependency/underdevelopent/world system framework is the process of unequal exchange - the "exchange of products whose production involves wage differentials greater than those of productivity" (Amin:1977,211; see also Amin:1972 and 1973) - through which economic surplus was/is extracted from the periphery in a variety of ways, such as

- the payment of lower wages for equal work under conditions which are identical to those in the center ${ }^{9}$ and resultingly

- the secular deterioration of the terms of trade under conditions of extreme price volatility for primary exports; ${ }^{10}$

9 The notion of unequal exchange commonly invoked by writers such as Amin or Wallerstein goes back to Hans Singer, Raúl Prebisch and Arghiri Emmanuel. Especially Emmanuel's is a static and highly stylized concept with a number of essential assumptions: unequal exchange, accordingly, takes place when commodity production is carried out in disparate areas at dissimilar wage rates, but with identical tools (i.e. the "organic composition of capital" is the same as is the rate of profi.). It is possible because the capital factor is acille but the labour factor is immobile on the international plane (Emanuel:1972,264- 267). Given "the premise that there is equalization of profit rates in all regions and lines of production - as is indeed the tendency under capitalism - part of the surplus appears to be lost frow the lower wage region to the higher wage region" (Brenner:1977,63) because industrialized countries appropriate productivity gains as higher wages, while developing countries pass on productivity gains as lower prices (Singer:1950,478; Prebisch: 1962,5$)$. This circumstance is thought to account for the secular trend of deteriorating terms of trade. However, despite the appeal of this hypothesis, "the evidence over the longer term has not been supportive of the basic idea of a consistent secular deterioration of either primary product prices as a whole or of low-income countries as a group" (Lewis: 1989, 1548).

10 An extensive empirical study of primary conmodity prices between 1900 and 1982, undertaken expressly to test this hypothesis, did indeed find some corroborating evidence. The authors, however, caution that, as a general conclusion, it "would be highly misleading if read without a number of qualifications: the neasured tendency to decline, in fact, is (i) suall in size; (ii) statistically significant at the lowest confidence level; and (iii) in most cases reversing itself given a sufficiently long 
- the direct transfer of capital from periphery to the center and the implied denial of investment resources to the former;

- the periphery's enduring dependence on the iarortation of manufactured goods which follows from the first three argunents and, effectively, forecloses the establishnent of anufacturing base in the periphery.

The extensive pilfering of resources to the advantage of the advanced industrial countries which is part and parcel of free trade, so the argument goes, deprives the periphery of the economic surplis necessary for autonomous national development. At the same time it results in a structurally distorted economy, lopsided in favour of primary agricultural products (with litile scope to add value) and deprived of a dynamic, modern, industrial sector. "The satellites reain underdeveloped for lack of access to their own surplus and as a consequence of the same polarization and exploitative contradictions which the metropolis introduces and maintains in the satellite's donestic structure" (Frank:196i,9; emphases in original). Peripheral backwardness, in the theoretical edifice of Amin, Baran, Frank, Shivji, Wallerstein et al, is not, not even to some extent, the result of "international differences in the endowment of productive assets" (Evans:1989, 1244). It is, instead, the inevitable result of the workings of predafory capitalisw: development and underdevelopaent are the opposite sides of the same coin. Turning on its head Adam Saith's optimism

time horizon" (Diakosavvas and Scandizzo:1991,250). 
about the developmentally progressiveness of trade and the division of labour (Smith:1974,479), two interrelated implications of this reasoning energe: the first holds that underdevelopment is the result of "lack of capital" (which, were it available, would be nanaged wisely), and the second that, in the absence of capitalisa cun foreign trade, a path of econoric evolution centering on manufacturing for the hone markets would have been followed.

At least as $f a r$ as $N$ igeria is concerned, these contentions are quite implausible. Even if, during pre-colonial, colonial and postcolonial times, the prices for Nigeria's agricultural connodities were "low" (there is no such thing as a "fair" price in an unregulated arket), they were higher than the farmers could have obtained elsewhere or for growing and or doing something else with their time. Also, it is quite unclear whether higher prices - like higher oil prices today hould have resulted in an accumulation of capital and productive investment rather than in extra consumer spending on imports. Parenthetically the paradox should be noted that higher prices, to the extent that they create the possibilities to diversify and develop the economies of primary exporters, they also reduce the incentives for decision makers to do so (Singer: 1950,482). In any event, it is fairly straightforward to say, in hindsight, that foreign trade was a necessa$r y$, even if not a sufficient factor in the process of industrializing Nigeria's economy, rudimentary as it is.

Mass-produced manufactures require narkets, which are provided by rising incone. Incone has been raised in west Africa mainly by exports of priaary products, fron pala oil to crude petroleum. So far as creation of deand is concerned, the export trade has been the path to industriali- 
zation rather than a diversion fros it; thus, foreign investment in manufacturing in Nigeria has been chiefly notivated by the growth of the narket. ... Counterfactualisn is pushed to the extrene by the belief that the path of growth through hone-narket manufacturing was available in West Africa as an alternative to growth through exports (Rinner: $1984,231-232$ ).

Nigeria's iapressive econonic growth during the colonial period was based on an immense increase in the production (alas, not in the productivity) of agricultural comodities for export. This achievenent was braced by the concomitant expansion of food crops for local consumption which, despite considerable population growth, obviated the need to import food staples (Duignan:1986,14; Forde:1946,83-84 \& 102; Helleiner:1966,10ff) and, instead, peraitted the inportation of luxuries (Pim:1948,236). Because of favourable world narket prices, Nigeria's agricultural exports increased draatically in the 1950s (see tables 1, 2 and 5). During the same time, food production also grew by about 50x (cf. Okigbo:1962,37; World Bank:1955,397). Although referring to the Ghanaian experience, the following conmentary applies to Nigeria equally well: "Contrary to some interpretations, there was nothing especially 'distorting' about this pattern. Such agricultural production was the natural growth pole for Ghana's econony, given the relative factor endownent and low level of technological developent, quite apart from prevailing arket conditions" (Jeffries:1982, 309). A contrary interpretation seems to be at odds not only with common sense, but also with classical Marxisn which considered technology and productive forces (available equipment, technical ability and division of Iabour) the ultimate motive of historical change (Marx:1969,130). 
There is no precedent in history for the energence of aanufacturing $!=i$ alone industrial capitalism in an econony of subsistence agriculture. Everywhere it has been an advanced phase in a process which begins with swall-scale production and exchange of connodities. In Hest Africa, before its contacts with the outside world intensified, there was no commodity economy nor were there any traces that would have justified any respective expectation. As was entioned earlier (5. 33), the division of labour and the development of a market was obilously restricted by several adverse factors, such as

- the abundance and easy availability of land in combination with the absence of transportation networks;

- the demographic constraints of low population density;

- the easy availability of slaves, especially after the abolition of the slave trade;

- the low level of technology (irrigation, the plow and the wheel were unknown) and the resulting low productivity of labour;

- the wealiness and extreme decentralization of the existing polities which were materially supported through warfare rather than through taxation of trade or production.

The scenario was indeed disheartening and not because of any involvement in the capitalist world econony, nor because by "coercion, indirect pressures and material inducenents [the colonial state had] smashed the self-sufficiency of indigenous pre-capitalist societies and 
managed their subordinate linkages to metropolitan capital" (Berman: 1984,161). Contrary to such polenics which inplicitly idealize precolonial circumstances, the prevailing, inordinately hostile "conditions must have been roughly the sane for several millennia. ... a sparse population, disease ridden and poor, farming at low levels of productivity, limited by transport facilities, organized in weak polities, and exposed to the vagaries of climate" (Hart:1982,27).

Attempting to avoid the pitfalls of either an apologetic or a moralistic treatment of Africa's relationship with Europe and the former's colonization by the latter, I will try to show that tracing Nigeria's contemporary problems in a linear fashion to economic exploitation generally or to capitalism specifically is a sowewhat artless claim. For one, Nigeria was not looted as for example Peru had been, nor was the element of coercion present (e.g. induced drug addiction and direct military intervention) which made China involuntarily import opium in large quantities from the specially grown poppies in Bengal in exchange for tea which had become a highly valued comodity in Britain. Instead, Nigeria's trade was not only voluntary but also obviously worthwhile for the great number of smallholder peasant farmers who engaged in it. Also, the creation of commications and transportation infrastructures was of unquestionable benefit. 11 More ambiguous in that it arguably had the effect of avoiding short-term suffering but

11 A road network was created absolutely from scratch. By the nid$1950 \mathrm{~s}$ it had reached well over 35,000 ailes which led the World Bank to conclude that Nigeria's systee of main roads was "practically complete" (horld Bank:1955,501). The same goes for the railway system. Construction of its present, rapidly deteriorating systen of over 20,000 wiles was completed by 1927 (Burns:1972,282ff; World Bank:1974,88). 
ensured long-term suffering, was the colonial government's protective conservationism - the refusal "to expose West Africans to the soap boilers of the world" (Hart:1982,85; see also Hailey:1938,768-774). The colonial government, as Governor sir Bernard Bourdillon declared, had no intention of turning Nigerians from race of farsers "into a race of labourers" (cited in Udo:1967,299). At considerable loss in productivity and thus exploitability, capitalist agriculture generally and the establishment of plantations specifically was prevented $(\mathrm{c} f$. Siddle and Swindell:1990,82). "West African land policy ... had as its goal apparently the confirmation of the natives in their possession of the land, the erection of a virtual system of peasant proprietorship and conversely the exclusion of foreign capitalist planters; in a word, the establishment of the econonic autonony of the natives of West Africa" (McPhee: 1971,196$) .12$

Other acts of omission (and comission) caused serious political dislocations whose ramifications are felt still today:

- the failures to organize the colony as a unitary polity, to avoid the monopolies and monopsonies of expatriate trading conglomerates, to encourage the emergence of a protuctive bourgeoisie and to employ and share political responsibility with the intellectual widdle class of its own aaking; and

- the policies of collaboration with expatriate trading compa-

12 There is not a little irony in the fac that this conservationist approach was given up in the twilight of colonial rule. It was demanded and implemented "by indigenous politicians and can be seen as one of the signs of the approaching political independence. The change was made possible following the constitutional arrangeants which established a cabinet consisting largely of Nigerian ainisters" (Udo:1967,311). 
nies, of heavy intervention in the econony after the second World War, and of the expansion of the State's scope and size well beyond what was adninistratively and financially supportable.

These points will be developed in sone detail below and are brought up in this connection only to underline ay contention that $\mathrm{Ni}$ geria's current political pathologies are indeed traceable to historical colonialism but emphatically not to the kind of economic exploitation invoked by neo-Marxist analysts, nor to any continuing outside interference, that is, to lacking substantive sovereignty. But, as Schumpeter suggested in a similar context, "it is perhaps superfluous to insist on the shortcomings of a theory which not even in the most favorable instances goes anywhere near the heart of the phenomenon it undertakes to explain, and which never should have been taken seriously" (Schumpeter: 1962,18 ). As will be elaborated below, ay point is that, whereas economic dependence on foreign aarkets and suppliers has not in the past and does not now per se exclude econonic developent and domestic prosperity, the bureaucratic State's patrimonial intervention in the economy, as well as its kleptocracy, are wholly regressive in their effects.

For contemporary Nigeria - like for Saudi Arabia - the critical external constraints boil down to the worldarket price of crude oil. Her dangerous dependence is thus wuch more on one treacherous aineral than on conspiratorial international system. 0il revenues, unlike surplus extracted from agricultural production or taxes levied on in- 
dustries are rent-incone derived fron off-shore operations with hardly any linkages to the donestic econony. Maximizing these windfall profits and spending them efficiently entails opportunities to be realized (or aissed) at the level of the international systen. In other words, the Nigerian State cannot alter the actual teras of exchange between its national econony and the international econony. But it can determine how to use the fortuitous and externally generated rent:

- whether to spend it on the protection of an inefficient, import dependent manufacturing sector as well as directly on inported goods, including food, all of which aight increase the welfare of sowe, not however the economy's productive capacity; or

- whether to use it to purchase domestic goods and services as well as to invest it in infrastructures ${ }^{13}$ (again using donestic factor inputs), and to do so slowly so as not to ignite inflation and put too heavy pressures on existing production capacities. This, admittedly, is a much slower process but one which would hold the promise to create economic linkages and raise effective mass demand.

The challenge for Nigeria, as for all developing countries, thus is to "establish a flexible, responsive econony that can take advantage of opportunities generated in the world at large and, wore inportantly,

13 The term infrastructure as it will be used throughout this study encompasses "the totality of the material, institutional and personnel facilities and conditions at the disposal of the econony" (Jochingen and Gustaffson, cited in Schätzl:1973,88). 
that can generate its own opportunities" (Bruton:1989,1637). Nigeria, more than most other sub-Saharan countries, has the resources, naybe not to buy its way out of its backwardness, but to give decisive inpulses in that direction. To pre-enpt argunents about donestic supply inelasticities, I wish to point to their siailarity with the concerns raised by white South Africans, nanely that the low educational levels of Blacks stand against their being given greater political and economic responsibilities. Contentions such as these, ostensibly supportive of second steps but opposed to the necessary initial leap, follow the logic of the Irishman's direction: "If you want to get there you should not start from here" (Hunter:1975,42). Choosing the second broad alternative would pronise to affect positively the capacity of citizens and enterprises, private and public, to take appropriate measures to improve their productivity and production. By creating conditions conducive to constructive economic activity within Nigeria, the State would in fact be instrumental in inproving Nigeria's position in the norld division of labour. Placing the burden on the Nigerian State ls not, of course, to belittle the difficulties lateconers face in their attempts to develop. It is only to suggest that the "international environment can raise or lower the potential for growth, but it always leaves substantial roon for nations to deternine their own perforance, in Africa as elsewhere" (Roemer:1982,131; see also Riedel:1987,88-95).

Even the influence of altinational corporations does not significuntly reduce the Nigerian State's freedon of manoeuvre and aight in fact increase it. Multinationals, the concretization of foreign investment, have for decades enjoyed the pride of place as dependency/ 
underdevelopment/world systee theorists' favourite bête noire, cast in the "United Fruit" inage of ruthless octopuses which run whole countries like private concerns. This prejudice should be reviewed for empirical accuracy because their considerable power today is exercised "above all, to choose the kind of state they need to cooperate with and the kind of labor force they will have. ... Capital's greater intensity and mobility allow it greater selectivity in concentrating on islands of production" (Cooper:1981,51). Africa generally and Nigeria specifically are unlikely to be among the chosen few sites. British conpanies, traditionally the most prominent foreign investors in Africa, and even more so in Nigeria, are withdrawing. According to the UK Department of Trade and Industry, by the mid-1980s, Africa has become of minor interest if not to say inconsequential, accounting for only $0.5 x$ of British overseas investment (cf. Bennell:1990,159). The stark truth is that Nigeria, Africa or even nost of the Third World are increasingly being marginalized in the world economy. If, as I believe, the extraordinary economic development, growth and prosperity of OECD countries has in the past been determined largely internally (cf. Rosenberg and Birdzell:1986; Chandler:1990), this is still and increasingly so today, as even an unsyepathetic observer concedes: the "external relations of the advanced regions taken as whole with the periphery of the world system, are quantitatively arginal in conparison with the flows that take place within the center" (Anin:1976,75). Third World governments, individually and collectively, can ignore this fact only at their peril or, rather, at the expense of their people, During the past three decades in the advanced capitalist coun- 
tries, a technologically induced explosion in productivity - entirely centered around the electronic processing of infornation ${ }^{14}$ - was the reason for a secular shift in production from high-volune to high-value goods and production processes. Industrial profit no longer depends on the exploitation of econonies of scale, of producing ever larger numbers of all-black nodel Ts to keep unit costs down. Flexible manufacturing systems open up economies of scope, that is, the ability to profitably produce with existing machinery a wide range of goods, even in small quantities. Such a system "reacts quickly to a custoner's request, pulling goods through the factory on demand. Inventories are minimized; in its ultimate fora, it can produce batches of one at no extra cost" (Main:1990,58). The flexible manufacturing system consists of

computer-controlled machining centers that sculpt complicated metal parts at high speed and with great reliability, robots that handle the parts, and remotely guided carts that deliver waterials. The components are linked by electronic controls that dictate what will happen at each stage of the manufacturing sequence, even automatically replacing worn-out or broken drill bits and other implements (Bylins$k y: 1983,53)$.

In its Neckarsulm factory, for instance, Volkswagen produces si-

14 In 1946 only one conputer existed in the world, the ENIAC at the University of Pennsylvania. "It weighed 30 tons, utilized 18,000 vacuum tubes, stood two stories high and covered 15,000 square feet. It cost many aillions. ... Within less than three decades of the birth of the computer age, the industry was producing, for a few hundred dollars, a microcomputer that was 20 times faster than the ENIAC, ten times more reliable, required 3,600 times less power and took up 300,000 times less space. ... In the seventeenth century it took Johannes Kepler four years to calculate the orbit of Mars. Today a microprocessor can do it in four seconds flat" (Blumenthal: 1988,534). 
multaneously Audi 100s, Audi $80 \mathrm{~s}$ and Porsche 944s. All three entirely different cars undergo, together, a fully autonated production process in which one supervising engineer replaces several hundred workers. Further, the highly capital-intensive storage of large quantities of a myriad of different spare parts before production and of thousands of completeri cars afterwards has been obviated. All cars now are custombuilt with an endless variety of colours, features and accessories, the latter delivered by suppliers directly to the assembly line and only when ordered.

These rationalization processes, still ongoing, greatly diminish the importance of the traditional production factors raw aterial and (unskilled) labour. This decrease is evidenced by the dramatic drop of labour's share in total manufacturing costs; in the United state their share stood at 25-30x during the 1960 s and 1970 s but had fallen to 1015x by the mid 1980s (Nasar:1984,43). Today in the United States, $75 x$ of the work force is employed in the service sector and even "in automobiles, the most labor intensive of the aajor industries, direct labor costs ... are down to $18 x$. And $8 x$ to $12 x$ is fast becoming the industrial norm. One large nanufacturing company with a labor-intensive process, Beckman Instruments, now considers labor costs 'miscellaneous"" (Drucker:1990,97). According to the Chief Executive officer of the American Computer Firm "Unysis" states his conpany

can assemble computer terainals in the United States at a cost roughly equivalent to the Far East, even though wage rates differ substantially between our plant in Fleaington, New Jersey, and those in South Korea or Taiwan. For a company like ours, the location of manufacturing and service facilities for our worldwide operations can now be determined more by market and customer considerations than pro- 
ximity to needed raw materials or areas with low labor rates (Blumenthal: 1988,537).

In Japan, Toyota, one of the automotive industry's productivity leaders, requires 13 man-hours to complete its Camry while at Volkswagery 20 are needed for a Golf; employing 91,800 workers, Toyota's annual output is a stunning $4,400,000$ cars (48 per worker) compared with $3,000,000$ vehicles at Volkswagen which has 250,000 workers and thus averages 12 cars pt: employee (Oppermann:1991,56\&66).15 In this new situation, Third World countries (even those with much lower labour costs than Nigurial with their perhaps extensive but shallow markets, fore all their luster as production sites. W. A. Tewis in his study on thr. jndustrialization prospects of the Gold Coast contended incisively that lih hages are not the same as low labour cost. Labour cost is lowir "only if the difference in wages is great enough to of set the difference in productivity" (Lewis:1953,2). This was not the case then and is eved less so today. The argument which explains Third horld countries' attraction for international capital with cheap labour is latwd on the realities of the 1960s, if not the "1920s, when direct, hlus-collar labor accounted for $80 \%$ of all manufacturing costs oththan ran materials" (Drucker:1990,97). Today, a manufacturer's primary intri:st is not cheap labour but a highly skilled and motivated work forre (cf. Schmitz \& Carvalho:1989). In its absence, few multinationais nill remain in Third World locations, let alone assume or expand

15 Similar inefficiencies, 13 cars per worker per year, led General Muturs in late 1391 to anrounce the elimination of 74,000 jobs (Levin: 1991,051 . 
operations, unless of course extensive state-guaranteed subsidies can be counted on. 16

In sum, my argument is that in terms of constraints or deterainants, the international syst $\mathrm{m}$ does not hold the clues to the Nigerian economy's performance, nor to the Nigerian State's econouic policiea (cf. Teal:1988; Schatz:1984). The contrary position, in my view inplausibly, is held by neo-Marxist analysts who contend

- that the "root cause [for persisting underdevelopment] lies in Nigeria's mode of incorporation, economically, politically, ideologically, in a subordinated position, into a world econom: dominated by transnational corporations" (Beckman: 1985,74);

- that "the internal and external production relations ensure the reproduction of underdevelopment in the African countries"

16 of the $\$ 196$ billion of foreign direct investment in 1990 , only $\$ 30$ billion were invested in developing countries, over $\$ 23$ billion of which were concentrated in ten newly-industrializing countries, such as Singapore, Hong Kong, Thailand, China, Malaysia and Mexico (DF 5 (September-October 1991,4; for 1980-1989 data, see UNCTC:1991,10-11). In $1970 \mathrm{Nigeria}$ accounted for over half of total net foreign investment in Africa; in 1982 still for $47.5 \%$, but by 1985 its share had fallen to just over 20\% (UNIDO:1988,4). To illustrate this exodus, between 1979 and 1989 no less than one third of British companies $(25$ of 68$)$ withdrew from Nigeria, citing the generally hostile investment climate and a rate on return "two to three times less than in Europe and North America and considerably lower than from similar types of investments in developing countries in other regions of the world" (Bennell:1990,166 170). A particularly grim example for the de-industrialization taking place is the reduction of vehicle manufacturing in Nigeria. From an index base of 100 in $1977(40,223$ vehicles), production increased to 208 in $1980(83,984)$, but fell to 88.3 in $1985(35,517)$ and to a stunningly low level of 14.6 $(5,873$ ) in 1987 (Nigeria, FOS, Economic and Social Statigtics Bulletin 1988, 40; see also table 16). Nevertheless, the State protects a captive market (cf. Fajana: 1977,518) and so permits unit prices of locally assembled Volkswagen and Peugeot cars to be $30 x$ higher than imports (WA No 3758,19 August 1991, 1380). 
(Shivji:1976a,17);

- that so "long as the underdeveloped country continues to be integrated in the world market, it reains helpless" (Anin: $1973,131)$; and

- that the state "acts fundamentally as a collaborator on a project led by international capital [so that its] weakneas derives from its subordination to stronger external institutions" (Bratton: 1989,418).

I submit that the pattern of divestment and the resulting deindustrialization of the past decade painfully underline the fact that international capitalism does not depend on Third World countries, either as suppliers nor as markets nor as production sites or, polemical15, on exploiting them. ${ }^{17}$ while the absence of significant foreign interests in Nigeria might have a retarding effect on development, the concomitant absence of external pressures and constraints strengthens the theoretical possibilities for internal reforms managed by the St at...

17 The stark truth about the Third World generally is its increasing marginalization. Even its most conspicuous power instrument, its debt oned to the developed North, is, on closer inspection rather blunt: "The combined gross national products of all troubled debtors amount to less that is of world output. The total face value of all loans to troubled debtors comes to less than 17 of the wealth of the creditor nations (and its market value to much less). Moreover, the debt service on those loans is less than one third of $1 x$ of the creditor's national incomes. Terrible as it is to say, advanced nations in general and the United States in particular do not have a strong financial interest in what happens to Third horld debtors" (Krugman: 1990,143). The South's minimal economic attractivelless ras hell illustrated in the Spring of 1991 when all Canadian trade und inestment officer positions in sub-Saharan Africa fell victim to gorerument ausierity measures. 
If the international system is of only limited value as a determinant of Nigerian public policies, how about indigenous society? It is my contention that a society-centered analysis of Nigeria's postindependence development policies would be as seriously misleading as it would have been during colonial times. The Nigerian State's organization and activities have traditionally had a far-reaching influence on society: under colonial rule they facilitated the growth of an agricultural export sector whereas; after independence, they arguably precipitated its decline and prevented the growth of a viable manufacturing sector. A state-centered analysis, therefore, would seem appropriate in view of ligeria's specific history and, with added urgency, also because of the remaining tenuous relationship between the State and civil society. Under colonialism, the State's power base was in London. After independence, it shifted to Lagos, iiterally. The switch of the State's economic base from surplus extracted from agriculture to rent captured from mineral oil obviated the need for any meaningful devolution of power within Nigeria.

The Nigerian State since about 1970 does not depend on society to provide the funds for its activities. By the same token the peasantry, that is, the majority of the population can meet its productive and reproductive needs without the support of the State or of other classes. Development of the agricultural sector through the State's concentrated effort to raise the productivity of land and labour, falls victim to this stalemate because "relations between those who rule and those who till the land are not firmly rooted in the production system as such. ... African countries are societies without a state. The lat- 
tor sits suspended in 'wid-air' over society and is not an integral mrchanism of the day-to-day productive activities of society" (Hyden: 1983,7). Hyden draws the conclusion that the peasants' autonony from the State (because of their secure access to land and the "exit option" which is hence open to them) creates a basic impediment for state-led transformation. He contends further that the existing pre-rational State, weak, soft and corrupt as it is, cannot initiate any change and, to be able to do so, has to begin by developing its own capacity to "rapture" the peasantry in order to extract surplus from it and secondly to defend itself against their "excessive demands [which result iII indiscriminate and wasteful consumption of scarce resources" (ibid.,19). In short, Hyden suggests that where the State fails to mert its developmental abjectives, the cause may be that it is overWhelmed by strong pressures from the economy of affection or because of the- self-sufficiency of the peasants.

Hyden might be guilty of over-generalization from the (narrow and for the whole of Africa non-representative) East African situation which leads him to percejve the State as being besieged by society. Th. Nigerian case is quite different, the reverse actually: here it is the State which does not need society for its reproduction. The State's relative autonomy which ensues from this tenuous relationship between society and the "uncaptured state" (as it could be called analogously) would, theoretically at least, permit a wide spectrum of policy options: pictured as a continuum, one extreme would be occupied by imaginative development policies, especially of the agricultural sector, aimed at raising productivity (the state as prime mover of deve- 
lopment); the other extreme represents the unconstrained pursuit of worthless or even harmful policies which de-link the agricultural sector and cause it to regress (the State as developent's main obstacle). of course, where exactly the Nigerian state must be placed cannot be postulated abstractly but has to be established eapirically. Nevertheless, a strong theoretical case can be made in support of Lord Acton's universal rule that all power corrupts and that the reasons for the Nigerian State's wastefulness lie within itself, not in society. By implication, this means also that it is not "objective" developmental needs which motivate state behaviour: the fact that something should be done is no guarantee that it will be done. It is thus an altogether implausible argument for far-reaching state involvement in the econom?, especially through parastatals, that this would promote

social equity through the goods and services that the enterprises will make available for the entire population [and that the] policy option that asserts the desirability of state control of the commanding heights of the economy is a formal rejection of the two available alternatives of foreign control (exploitation) and control by indigenous entrepreneurs (serious inequality) (Adamolekun and Ayeni: $1990,276)$.

The nationalist mythology informing reasoning such as this, touches on - yet does not seriously raise - the important question at what cost the public is serviced and to whose benefit. Its answers are predetermined and, in my view, erroneous: public enterprises, normally shielded from competition and therefore immune against pressures to increase their productive and allocative efficiencies, tend to waste resources and disregard consumer interests in exactly the way left-wing 
critics of capitalist monopolies disparagingly note. In the case of

Nigeria, for instance, a government-owned company produces steel local-

ly at costs about three times the import price (Rinmer:1984,267). Con-

versely, if steel were bought abroad, the resulting savings could po-

tentially do more for social equity than a deficit-generating steel

plant. ${ }^{15}$ Also, capital is not nationalistic but profit-oriented which

is why it is hard to see why foreign control should be associated with

exploitation while local control should not. ${ }^{19}$ Exploitation however

defined, whether as the insufficient remuneration of labour, the exces-

sive repatriation of profits, the degradation of the environment or

whatever, is something governments can address through regulative le-

15 "One of Africa's grandest white elephants is taking shape in Nigerja's kivara State. The Ajaokuta steel plant... has so far cost $\$ 3$ billion. It is still incomplete and a further $\$ 1$ billion is needed to finish the first phase, now years behind schedule. If and when it is ever completed, the scheme will, in the words of a confidential government repurt drawn up in 1984, be 'uneconomic and will incur recurrent losses to the end of the century'" (Holman:1989,22). By 1991 and already nine rears behind schedule, $\$ 4-\$ 5$ billion had been spent and a further $\$ 2$ billion were required before the plant could be operational (Keeling: $1991 \mathrm{a}, 5)$. The project, beset with financial and technical problems - iron ore is planned to come from the Itakpe reserves, where production has not itt started, while up to $1.4 \mathrm{million}$ tons of coking coal will have to be imported annually and for this the rail link from the coastal ports to Ajaokuta requires rehabilitatin $(E I U: 3 / 1990,18)$ - has been hampered in addition by "gross mismanagemen, as well as the theft of equipment and machinery" (EIl::1/1990,20). These crises meant that by March 1991, employees were still waiting for their January and February salaries and that the project's completion would be delayed far beyond 1992 (WA No. 3836,11 March 1991, 366).

19 Xenophobic arguments about foreigners' involvewent in the national economy are as irrational as international, vide the uproar in Germany when the appliance company Braun was taken over by the American Gilette corporation, the outcry in Great Britain when General Motors purchased Lotus and Vauxhall, Ford Aston Martin and Jaguar, and Honda a sizeable chunk of Rover. It was hardly less of a scandal in Sweden when General Motors' swallowed Saab, or in the United States when the Japanese Mitsubishi concern acquired a mere $15 x$ of New York's Rockefeller Centre. 
gislation - if equity is considered more important than growth - no matter what a company's legal ownership structure is.

Evidence (also but not only) from Nigeria suggests that publicly owned businesses place the burden of their inefficiency (which is sure1y a form of exploitation) not onto their enployees but onto society as a whole. Put differently, their deficits add to the already exorbitant State expenditures and thus represent high opportunity costs for society a, large: on the one hand, parastatals are usually endowed with monopolistic rights and immune against competitive pressures as the treasury will make up for deficits which cannot be translated into higher prices; on the other hand, making them publicly accountable is exceedingly difficult, especially when they have been created as the fiefs of influential politicians. In other words, since parastatals are not normally subject to profitability criteria and since surpluses usually have to be passed on to a supervising institution, a strong structural efficiency-disincentive exists. As public bureaucracies, their interest is in perpetuating their raison d'ètre, to grow and to acquire economic clout. They become ossified and politicized - if they are not directly instruments of organized political interests, as they were and still are in Nigeria - too handicapped to perform the role of disinterested promoters of development. Their vandate to either stinulate wider devel, pment or to provide socially valued goods and services for at least t. of itablel, is seldom realized and their actual function whatever their official charge - becomes distributive rather than productive. This is because their operative principles are ideological and political, rather than informed by the imperatives of development 
or, if that would be asking too wuch, at least by the rules of supply and demand.

The employment of scarce resources in a less than optimal wanner brings into sharp relief a classical pattern of bureaucratic behaviour:

- firstly the tendency to view developmental problens narrowly in terms of investment, as if money spent would directly translate into productivity or welfare gains; and

- secondly to spend resources without regard for efficiency, rather than to save or return them to the treasury.

In a situation in which the state bureaucracy is not merely the dominant but the sole economic actor of note, the course into economic disicter is chartered. This points to the crucial mode of production quest ion, that is, the question of which group or class appropriates sucietal surplus and which societal mechanisms determine its use (Mar: 1968,884-885). What makes it virulent in the Nigerian case is mi so much the obvious answer, namely that it was and still is the slate class which appropriates and allocates societal surplus. More impurtant is the developmental effectiveness of this allocation. State centrality and economic interventionism do not ipso facto entail inefficiency and waste, but can in propitious circumstances lead to broad basid development. Taiwan's case amply illustrates the success of a state-led strategy which transformed an ethnically divided, export oriented, agricultural colony into a modern industrial economy and welfare society (cf. Amsden: $1988,57 \mathrm{ff}$ ). In Taiwan as in the other "little 
tigers" Hong Kong, Singapore and South Korea, technically solid policies found strong political support (cf. Wade:1990) while in Nigeria, technically dubious policies were instrunents first in sectarian political conflicts and later in the hands of an incoherent state. The State in the former cases was/is the motor of development while its Nigerian counterpart was/is so much less effective: it was/is too politicised and too segmented, too wealthy and too frail to agree on a any - development strategy and to implement it.

The Nigerian State's involvement in the economy is thus damaging not only because of the inefficiency of parastatals, because of the suboptimal allocation or even the direct waste of resources for certain costly projects which turn out to be unproductive white elephants, and because of developmentally retarding macroeconomic policies. Of equal1y critical importance are the considerable powers of patronage - and the displacement of entrepreneurial by political skills as a strategy of economic surrival - which result from the State's extensive participation in the use of resources and from its strategic location as the dispenser of concessions, contracts, licences, permits, tax breaks and regulations.

A logical consequence of a preponderant yet unchecked state is corruption because of the multifarious temptations open to officials who, for example, are in positions to administer import duties, allot import licences for restricted comodities, exchange worthless local money into hard foreign currency at the "official" or subsidized rate, give permits for land-use and construction projects, grant dispensation from confining legal stipulations, bar certain market participants to 
oblige others, and who can award contracts for goods and services - all in return for cash or other favours. Trotsky's observation, whether authentic or apocryphal, is pertinent: whenever someone has sonething to distribute, he will not forget hinself. More seriously than the direct economic losses caused by corruption (bribery, aisappropriation, nepotism), however, is the aisdirection of creative energies which, in the absence of a calculable legal framework, are reoriented from producing wealth to buying favours. The result, devastating for poor societies, is this particularly unwarranted, appalling waste which lies in freventing the mobilization of a hidden resource for economic development, namely the great potential which resides, largely unrealized, in civil society.

This leads to the (ideological?) core of $m$ argument, namely the contention that the lack of developmental progress in Nigeria is not the result of resource shortages - as will be shown in Part II, the Nigerian State has been most successful in capturing the oil rent. Nor is it the result of factors residing in the international system or in the national society which are, at most, of secondary relevance to the develupment problew in Nigeria. At its heart is poor governance as evemplified by the bureaucratic State's inability, or unwillingness, to appropriately manage the oil rent. It is a pathology which goes beyond weat public administration, bureaucratic incompetence or petty corruption, and which cannot be remedied by technical fixes or additional resources. The state is not doing what it should (according to neoclassical development economists, liberals, Marxists or whoever), nor what it pretends to do. Its actions and inactions reflect a profound 
misuse of political power for the benefit of a ruling elite, the state class, and a lack of comitaent to pursue development objectives in an honest and forthright manner.

Through a variety of measures, ostensibly all in the interest of development, such as the utilization of the oil rent (and more) to finance the expansion of the state in size and scope, inefficient inportsubstitution industrialization, and the assive inportation of food, serious damage has been inflicted on agriculture, the country's real economic base, yet without creating a viable new one. The oil rent sustained the illusion that the flourishing agricultural sector could be ignored, or worse, and development instead bought from abroad or furthered by State investment in manufacturing, as well as by pervasive state direction and protection; it also subsidized disregard for the truism that the creation of wealth, as one astute observer noted almost a century ago, "lends itself ill to bureaucratic regulation, individual profit being a far more effective spur to the classes engaged in production than any government salary could be" (Mosca:1939,86). Looking for developmental obstacles in the international system or in a society which has withdrawn under the onslaught of misplaced state policies is like not seeing the forest for trees. I am suggesting, instead, to give the pride of place in the drama of Nigeria's distorted and retarded development to the invidious anti-aarket policies implemented by the bureaucratic state largely for its own sectional benefit. The market, as will be explained, is not only a most useful heuristic device to evaluate the bureaucratic State's policies and to decipher why they are being pursued; it is also the mechanism which, theoretically, 
could chart the course out of the present morass.

The argument which I will more fully develop in the course of this study is that the market is a most viable indicator to guide the State's macroeconomic policies as well as its resource allocation. The market, in addition to the obvious efficiencies implied, would also reduce the opportunity for pervasive rent-seeking (and rent-distribution). Since the present over-reliance on controls uses too many of the fer shilled people available to perform functions which the price mechanism could perform with greater efficiency, a reorientation towards the market would open up the possibility, indeed create the necessity, to contract the State's scope (and size). This reorientation towards the market would presuppose a major change in the style of political management to firstly establish institutional effectiveness and accountability and to ensure the rule of law as well as the pursuit of efficiency. Secondly, and substantively, having taken the clues from the market, the State's economic policy would have to be oriented towards raising the productivity of the agricultural sector and of the nascent manufacturing industry. This presupposes not a weak, but a strong and purposeful State which "must have a system of policy management that recognizes the effects of interactions among its own activities, and must be able to insure that desired responses are forthcoming from the commitment of public resources used as side-paynents to those who would otherwise block market processes" (Wade:1990,380). The results of relinquishing the bureaucratic State's largely ineffectual, if not outrightly counterproductive economic policies, would most certainly be to liberate human and material resources for private spending 
and investment. Also, if historical experience is anything to go by, statism reoriented and curtailed would ignite a process of class formation based on genuinely productive acconplishnents rather than on political power and through it on privilege, as has been the case in post-independence Nigeria.

The free market is far more likely than the state to induce entrepreneurship, hard work, thrift, and other economic virtues. ... Historically, the middle class has been far more creative and progressive than have socialist, mercantilist, or other classes whose existence is dependent on statism. An entrepreneurial class might emerge to pronote the w-qlth of nations - as has often happened when the state has reduced its involvement in the market place. A more prosperous ... peasantry could develop in circumstances in which a free market price, rather than a state monopolized price, was allowed to determine the allocation of agricultural commodities - a peasantry that could produce in expectation of a fair market return and could avoid resorting to smuggling or curtailing production under an artificially depressed state monopolized price (Jackson: 1986,427 ).

Warnings against state dirigisme have a long tradition, and a long tradition of being ignored. Writing in 1917, that is, before the Russian Revolution and thus still in the subjunctive, Max Weber cautioned that "[s]tate bureaucracy would rule alone if private capitalism were eliminated. The private and public bureaucracies, which now work next to, and potentially against, each other and hence check one another to a degree, would be merged into a single hierarchy. ... [This] rould simply mean that also the top management of the nationalized or socialized enterprises would become bureaucratic. [The result would be economic waste and] less freedom, since every power struggle with a state bureaucracy is hopeless and since there is no appeal to an agency 


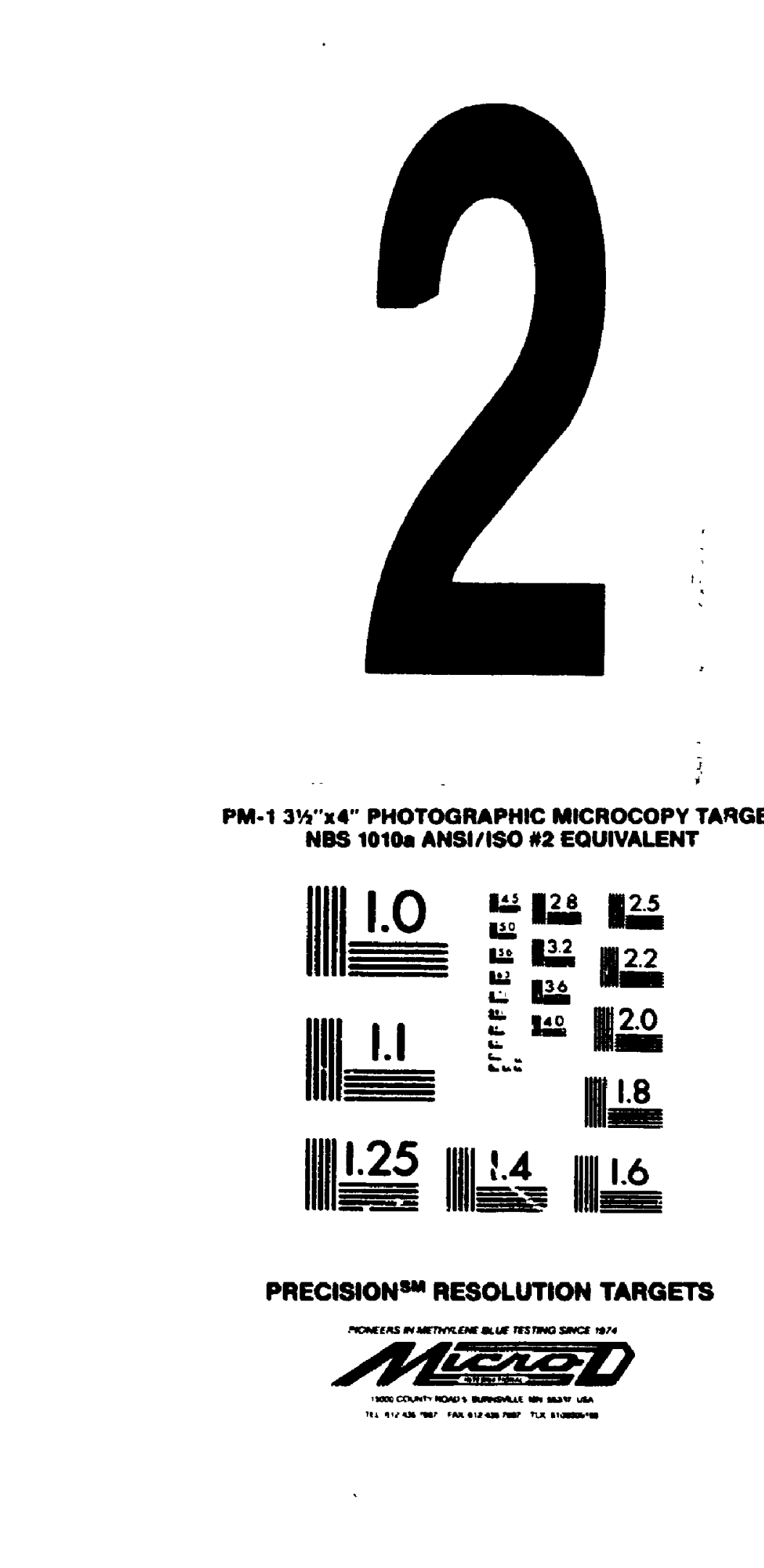


which as a matter of principle would be interested in limiting the emfloyers' power, such as there is in the case of private enterprise. That would be the whole difference" (Weber:1978,1402). Despite admonitions such as Weber's and those of other liberals, the pro-market bias has not been, with predictable exceptions, an a priori position, but one which slowly jelled after patterns emerged in the specific experiences during the past quarter century of many developing countries (cf. de Soto: 1989).

In the case of Nigeria there are specific historical factors which explain the genesis and the nature of the state as well as its pivotal role in the economy. But in addition, and not to be underestimated, are the theoretical reasons for heavy state-involvement in the process of economic development which were advanced by the field of development economics which emerged as a discipline just as the release into independence of most colonies became inevitable. At its core lay the two conspicuous defects of backward countries, namely "rural underdevelopment" and "late industrialization," both of which called for an activist state and for planning to overcome the disadvantages of lateness through "a deliberate, intensive, guided effort [and through] protection, planning and industrialization" (H1rschman:1981,10-11). Two additional themes were rapid capital accumulation and the mobilization of underemployed human resources (Galenson and Leibenstein:1955). To achieve the postulated goal, namely an escape from the poverty trap, desirable strategies evolved around arguments of balanced, w uth and critical minimum inputs of capital end technology, all of which called for a massive effort at planning and coordination by the sole agent 
sufficiently endowed with power and resources, the State. This was, notabene, in addition to the classical public responsibilities such as the provision of infrastructure, the maintenance of law and order and, most importantly, the creation of calculable law in both adjudication and state administration. other, more specialized, arguments concerned the "technical indivisibilities in sociai overhead capital" (Myint: 1973,116) which required public utilities and facilities to precede private investment. While necessary, such advance work was/is not sufficient to overcome objective developmental obstacles.

In the absence of a viable market, investment decisions by one, or only a fer, enterprises are not profitable since they will not create sufficient purchasing power to make them so. To overcome the simultaneous problems of inadequate savings, inadequate incentives to invest and the need for large-scale units to obtain economies of scale, a critical minimum of investment capital is required to escape the lowlevel equilibrium trap (Papanek:1977,272). In the place of reluctant indigenous private investors, the state through public enterprises (or through negotiations with foreign private investors or public aid donors) has to generate the capital required for investment in the directly productive sector of the economy (Green:1974,30ff). A related argument for the necessity of industrialization to proceed on a broad front centers on the demand-linkages of individual enterprises. Only if the input-requirements of one firm can be met from the outputs of another will their individ. - activities add up to dynamic macroeconomic growth (Hirschman:1977a,77ff). Finally, "latecoeers" in industrialization will have to compete against their advanced Northern counter- 
parts. These, whether companies or countries, show little inclination to raise their own competitors by selflegsly sharing technology, as was sanguinely assumed during the first "International Development Decade" (Rosenstein-Rodan: $1966,276 \mathrm{ff}$ ).

All of these reasons do suggest that a rational, strong and efficient state is necessary for development: internally it has to maintain sound macroeconomic policies as well as to plan, finance and organize development at the technical level; politically it has to mediate allocational disputes without sacrificing economic efficiency and growth objectives; externally it has to successfully negotiate in a highly competitive environment to secure, for example, technology, capital and markets (Gerschenkron: $1962,44 \mathrm{ff}$ ). Yet, what is a priori logical and desirable is not, by necessity, also feasible. "In our time, when faith in the manipulative omipotence of the state has all but displaced analysis of its social structure and understanding of its political and economic functions, the tendency is obviously to answer these questions [about the State's capability to do what has to be done] in the affirmative" (Baran:1952,78). It has been called a "functionalist trap" to assume that "because the state is 'necessary' it will therefore have the inclination and capacity to fill the required role" (Rueschemeyer Evans:1985,46). The argument for a strong State - shared right across the ideological spectrum, at least until very recently - is reminiscent of the reasoning behind orthodox liberal comparative advantage arguments.

Both dogmas overlook the long-term effect of their prescription. For countries whcse saleable commodities are mainly unprocessed agri- 
cultural products, adherence to comparative advantage - that is the maximization of their economic potential by specializing in the production of commodities at which they are nost efficient in terms of such inputs as capital and labour - wight provide considerable welfare benefits in the short term and up to a point. Yet attempts to raise revenues through greater output tend to $r \geq s u l t$ in oversupply since demand is usually inelastic and thus depresses unit prices. Also, unless primary production is intensified, that is, productivity raised, it does not result in economic diversification or development (Lewis: 1978, 191). Both are ultimately linked to industrialization which, unlike traditional agriculture, 20 can "provide the growing points for increased technical knowledgo, urban education, the dynamism and resiiience that goes with urbar civilization" (Singer:1950,476). It is thus not primarily the immediate products of industry nor its direct welfare benefits which make an important contribution to development, but its catalytic effects on general economic and social transforation. The importance of learning by doing - of the "dynamic economies of scale" (Kaldor:1972,1243) - was enphasized already by Adam Smith.

The call for a state-led development strategy seems, like economic strategies following the comparative advantage, easier and tidier than relying on the mobilization of diverse social forces. However, it is equally abstract, general and static and ignores inportant concrete

20 The emphasis is on "traditional" since its uodern variant is a most powerful engine of growth. Traditional agriculture is defined as one in which there is little or no technological change, in which there is little or no change regarding the notives underlying incone generation, and in which there is hardly any saving (cf. Schultz:1967,30). 
interests, specific capabilities and dynanic elenents. In particular, it treats state action axionatically as a constructive, value-neutral variable and disregards the anti-efficiency biases of public institutions and the personal or class interests of those who staff state institutions.21 The Nigerian experience of the past decades has been that étatiste or dirigiste prescriptions have been tried and found wanting, either because they were econowically aisconceived or because the State was incapable of executing them efficiently and with probity. Apart from missed economic opportunities, the risks associated with a preponderant state which prevents the formation of other economic and political hubs is that it will ossify and collapse under its own weight, as has happened so dramatically in Eastern Europe. Naturally, this is not a deterministic prediction but a probabilistic one becauge preponderant states have a vast array of repressive and co-optive instruments at their disposal. From the narrow perspective of economic development, the real peril epitomized by such a state is not that it can be ineffective, but that it can be counterproductive.

21 Modern welfare theory (derived from a Walrasian general equilibrium system), a very prominent strand of econonic thought, deals with public goods and externalities. These are at the heart of explanations of market failure and, therefore, of arguments for governmental intervention. However, while it is plausible that unregulated markets perform suboptimally under both growth and distribution considerations, it does not follow that governments can supply the affected goods and services at marginal cost, as many economists axionatically assume (cf. Cowen:1988, 4). In reality, governments, especially in the Third World, way tend to act like monopolists, that is, overcharge a hostage public for substandard products. It is interesting in this connection that one of the nost articulate advocates of state intervention, John Kenneth Galbraith, now contends that the "myth that it [great organization] serves social purpose is deep in our faith and in our scholarly instruction. This must not continue" (cited in the NYT, 8 May 1991, A23). 
The dilemma at issue is thus the tension between the historically as well as normatively grounded imperative for a strong state, and the inability - or unwillingness - of a preponderant state such as the $\mathrm{Ni}$ gerian one to constructively employ its economic centrality and to effectively use the resources at its disposal. Concentrating on the State as the crucial variable in economic growth and attenpting "to account for the authoritative, highly consequential actions of the State" (Nordlinger:1988,881), implicitly relegates to less prominent positions other perspectives such as the ones emphasizing as paramount factors the politico-economic world system, cultural and human factors, or certain econowetric approaches (investment-growth or capital-savings models). A State-centered approach, in contrast, takes seriously the growing sense of impatience, eloquently articulated by Richard Rathbone in his condemnation of Western scholars for their "long and decent tradition of relative flummery in which a post-colonial liberal conscience has hindered attempts at objectivity, a position that neither adds understanding nor in the long term helps [any African] country and its inhabitants" (cited in Kirk-Greene: 1986,76).

Weber suggests that in the social sciences "concept-construction depends on the setting of the problea, and the latter varies with the content of culture itself" (Weber:1964,105). The particular perspective in which the state is more a problea than a solution in the development process, for a variety of reasons, has been gaining currency only in the last years. The culture and the perception of probleas in the decades after World har II favoured different propositions. In the social sciences - as in the military field with its tradition of prepa- 
ring for the last war - theory construction is hardly ever ahead of events and more of ten grappling to catch up with then. This quandary is not new and Hegel, in the preface to his Elenents of the Philogophy of Right, illustrates it with the allegory of Minerva's owl which waits until dusk before commencing its flight (Hegel:1981,28). 


\section{The State as a Concept}

The centerpiece of ay analysis is thus the State, that "naster noun' of political discourse" (Geertz:1980,121) which, at least in North America for the past thirty years or so, has been besieged by the "political system" or other structure-functional concepts such as classes, political culture or policy-outputs. "Bringing the State back in" is the declared ain of the neo-institutionalists, a recently energed school within American political science. ${ }^{2}$ In Germany, in contrast, the State never experienced a comparable relegation to oblivion. Indeed there, the "State" denotes the politically organized public sphere (symptomatically, the category "Nationality/Nationalité" in Geraan Passports is translated as "staatsangehörigkeit" which literally aeans "membership of state") and the "science of the State" (Staatswissenschaft) is synonymous with "political science" (Politikwissenschaft). At German universities, politological departments are called either the one or the other without intention to denote any substantive distinction, much as in the realm of music there is no difference between "sinfonic" or "philharmonic" orchestras.

"States are not standardized comodities. They come in a wide array of sizes, shapes, and styles" (Evans:1989,561) which is one important reason why, like in the case of other core concepts of the

1 It is an acute observation that "the word l'Etat in French should be the only one normally beginning with a capital letter" (Nett):1968, 567 .

2 The following works give a good tour d'horizon of the debate: Almond:1988; Easton:1981; Evans et al.:1985; Krasner:1984; March and Olsen:1984; Nordlinger:1987 and 1988; Skocpol:1985. 
political science (e.g. class, democracy, development or power), no generally agreed upon definition of the "State" exists. The notion is usually translated into the language of the paradign eaployed by any particular writer and then iabued with a specific and unique connotation. To illustrate, but by far not exhaust this conceptual proliferation: the State is,

- in Weberian teras, "a human conmunity that (successfully) claims the monopoly of the lexitinate use of physical force within a given territory" (Weber:1946,78; enphasis in original);

- for some functionalists, "the institutionalization of euthori$t y$, which is a special form of power. ... Since occasionally there will be 'deflations' in the power system, sinilar to monetary deflations, society needs institutions authorized to exercise force in order to reestablish confidence. The most typical form of these institutions is the state" (Johnson: 1966,30 ; emphasis in original);

- for a liberal neo-institutionalist, "all those individuals who occupy offices that authorize them, and the alone, to make and apply decisions that are binding upon any and all segments of society" (Nordlinger:1981,11);

- for Marxist neo-institutionalists, "the public adninistrative apparatus as a coherent totality. It is different from the government, which is the set of persons who collectively occupy the highest positions of central decisional authority in the polity. The government is a decision unit, an actor. By contrast, the state is the organized asgregate of relatively permanent institutions of governance. It is the institutional ab gregate of public bureaucracy and administrative apparatus as a coherent whole" (Duvall and Freeman:1981,106; emphases in original);

- for Marxist instrumentalists, the "instrument lof the capitalist class] for the donination of society. ... In the Marxist scheme, the 'ruling class' of capitalist society is that class which owns and controls the means of production and which is able, by virtue of the econonic power thuz conferred upon it, to use the state as its instrunent" (Miliband:1969,22). This position, goes back to the classical statenent in the Conaunist Manifesto that the executive of the modern state is but a conaittee which manages the common affairs of the whole bourgeois class (Marx and Engels: 1975,28 ); 
- in its postcolonial manifestation (for some neo-Marxist analysts), "the state of the international bourgeoisie [which] continues to function in the interest of capitalist imperial ism" (Gana:1985,127). The Nigerian State, specifically, is. termed a "comprador state: state institutions and state officials operate as agents of inperialise. The real ruling class is the bourgeoisie of the netropolitan countries. It is not the indigenous businessmen and bureaucrats, who nerely aasquerade as a 'national bourgeoisie'" (Becknan: 1983, 39);

- in Marxist structuralist terns, the superstructural expression of the econonic base, i.e. the "specific econonic form in which unpaid surplus labour is punped out of direct producers. [These production relations reveal] the innernost secret, the hidden basis of the entire social structure, and therefore also ... the corresponding specific form of the state" (Marx:1968, 799-800). Neo-Marxist structuraligts arguing in this tradition consider the State "not an 'entity' with an intrinsic instrumental essence, but itself a relation, nore precisely the condensation of a class relation" (Poulantzas:1975,26). The state apparatuses, in this view, do not have power of their own because they "are never anything other than the materialization and condensation of class relations" (ibid.,25). Applied to Africa, the structuralist contention is that the "state is a specific modality of class donination. This modality is one in which class domination is nediated by comodity exchange 80 that the system of institutional nechanises of donination is differentiated and dissociated fron the ruling class and even the society, and appears as an objective force standing alongside society. ... The state is essentially a capitalist pheno-

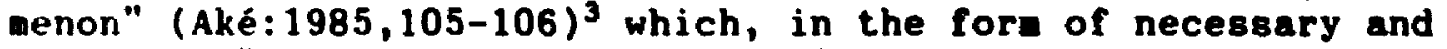
purposely "created institutions [is] reflecting the needs of class forces operating in the world econony" (Wallerstein: $1986,150\}$.

These conceptualizations of the State differ in their focus (geographic, historic), and/or level of atstraction, and/or in their enphasis on functional, organizational or structural properties of the political/public as opposed to the social/private sphere in a polity. To

3 Aké, without attribution and in an entirely different context, borrovs Friedrich Engels" argunent that in capitalign, the "state, whatever jts form, is an essentially capitalist achine, the state of the capitalists, the notional collective capitalist [der ideelle Gesantkapitalist]" (Engels:1977,133). 
sumarize: the State is viewed firstly as a normative order and as the institution of supreae authority within society (Weber, nore abstractly also Johnson), secondly as governeent (narrowly defined: Nordlinger, broadly defined: Duvall a Freenan), thirdly as an instrument of the dominant class, rational or international (Becknan, Gana, Miliband), and fourthly as an expression of class relations in society or in the world system, i.e. also not an autononous actor (Aké, Gana, Poulantzay, Wallerstein). Tris altitude of conceptualizations suggests not on? a certain elusiveness of the phenomenon "State" but also its cuntextual contingency. Their wide range and diffuse foci $2 ! s o$ underline the preference of most political analysts to investigate the State's behavioural determinants and their effect on society, rather than its institutional structure which could be defined auch more easily. Closer inspection corroborates the impression that none of these concepts could, rithout substantial expansion or adaptation, satisfactorily illuainate the specificities of the Nigerian State.

The Weberian, functionalist and neo-institutionalist definitions do, at their high level of generality, of course, apply to Nigeria. My conceptualization of the bureaucratic Nigerian State will include then as necessary components. It would not be sufficient, however, to limit the concept to its top-level decision akers and to just one aspect of the State's relationship with society (donination) while disregarding significant others. Also, ny interest is not taxononical but behavioural, namely to anaiyze why the bureaucratic Nigerian State acts the way it does and how this affects the country's developmental prospects. For the reasons which have been mentioned earlier and will be elaborat- 
ed throughout this dissertation, neo-Marxist notions, whether of an instruaentalist or a structuralist variety, are considered unsuitable tools. With regard to the instrumentalist perspective of the State, it is difficult to see how the couplex yet badly organized, central yet anarchic Nigeriar. State can be understood adequately through a nodel which views state behaviour in teras of class-conscious anipulation by a capitalist class (Gold et al:1975,36), especially if such a class does not exist locally and, at the international level, is as diffuse as disinterested in Nigeria. At botton rejecting state autonon, the struccuraiist perspective cannot and does not explain the "nechanisas through which intra-system tensions are resolved" (Lee:1988,10); nor can it account for specific state policies, except with the insunizing argument that they do serve the purpose of systen maintenance, if not in the short term then over time, and if not firmy denonstrable then in their intangible, structural essence. Structuralists inplausibly deny that the State and its officials possess their own reality, logic and driving force as well as differentiated and autonomous interests.

Before outlining my own concept of the bureaucratic Nigerian State, I will review two other theories which have been applied to postcolonial Africa and which, at first sight, seen to correspond to ay own concern: the Overdeveloped state and the Patrimonial State.

\section{a) The overdeveloped state}

The concept of the overdeveloped State superficially appears to be, at first glance, closely related to ay interest in fashioning an 
explanatory framework with "development" as a dependent variable and the "State" as an independent variable. Closer inspection reveals quickly some fundamental inconpatibilities. These are founded in different ideological predispositions and, consequently, in different theories, each of which wight well be coherent in itgelf but plaugible only to symathizers who share its underlying premises (see the argument above, p. 38). The following discussion of the "overdeveloped State" concept is thus to illuminate the reasons why I consider it not germane to my own argument.

The debate about the overdeveloped state took place in the 1970 s. The original geographic referent was the Indian subcontinent, although it gained greatest currency among writers on Tanzania. One of the expectations was for the debate to result in a "general theory of the State in post-colonial societies" (Alavi:1972,60). By and large it was a rather arcane, intra-mural neo-Marxist affair involving gcholars who worked within the dependency, underdevelopment as well as world system paradigms, and who attempted to adapt to post-colonial social formations classical Marxist axioms of the State such as, for example, the nature of the state being deterained by the nature of the governing class; the state being the instrument of specific classes to realize their interests; and the State being an agency to transmutate the economically dominant into the politically ruling class. Obvious problens were not only the prima facie eapirical wisfit between observed reality

4 The principal contributions to this debate are: Alavi:1972; Beckman:1982; v. Freyhold:1976; Leys:1976; Petras:1977; Saul:1974; Shivji:1976; Ziemann and Lanzendörfer:1977. 
and these theoretical requirements, but also Marx's onission to develop a coherent and comprehensive theory of the state. The debate was thus both an exegesis of Marx's writings in search of a correct understanding of the state and its subsequent application to post-colonial countries. It took place between supporters of Marx's structuralist notions of the State (as developed in the Critique of Hegel's Philosophy of Law; Marx:1969b[1843] and in the Capital; Marx:1968[1880s]), of his inst.rumentalist ones (of the German Ideology - Marx \& Engels:1968 [1845], 62 and of the $\mathrm{CO}_{4}$ unici lanifesto - Marx and Engels:1975[1848], 28 ), and of a position which seems to straddle the two earlier ones (as developed in the 18th Brumaire of Louis Bonaps-te - Marx: 1975[1852], 250f(). Although the interest in this particular version of the overdeveloped State has since waned and the debate fizzled inconclusively, for the sake of convenience, my discussion will continue in the present tense as if it were still ongoing. I should emphasize that the whole debate is interesting, if this is an appropriate description, not for the insights it generated but for exemplifying the dreary scholasticism so characteristic of wuch of neo-Marxist analysis. Therefore, the following brief outline is intended as much to point out the need to rescue Marxian method from its vulgar practitioners as it is to argue that, and why, the Nigerian state is indeed overdeveloped.

Possibly because capitalism is more a phenomenon of the global economy than observable reality on the ground in the former colonies and, consequently, because of the uncertain progress of class formation there, the basic referent for the overdeveloped state is not indigenous society but the international capitalist system. In fact, the capita- 
list nature of post-colonial societies is simply declared but never supported argumentatively, let alone empirically. I will discuss this lacuna below. Applying a distinction introduced by Poulantzas, the ruling class is taken to be the metropolitan bourgeoisie while its local agent, the "economic bureaucracy" (Shivji:1976,4) is merely the "governing class" ( $v$. Freyhold:1977,85). It is held that the State in post-colonial countries is an essential instrument for the regulation of the dependent role of their economies in the international capitalist division of labour and in the global process of capital accumulation. "The existence of the process of capital accumulation and the international division of labor, world-wide and in the underdeveloped countries themselves, thus become the principal determinants of the role and the form of the state in the Third World" (Frank, cited in Carnoy: 1984,188$)$.

What precisely this role and form are lies at the core of the debate. Except for a dissenting vote basec on empirical-comparative considerations (Leys:1976,41ff), and a second one based on a theoretical argument which amounts to considering any State's size "adeduate" (Ziemann \& Lanzendörfer:1977,145), there seems to be agreement that the State (i.e. the superstructure) is "overdeveloped" in a very specific sense, namely "in relation to the 'structure' in the colony, for its basis lies in the metropolitan structure itself [which had to be replicated. Any colonial power] has to create state apparatus (sic) through which it can exercise dominion over alt the indigenous social classes in the colony" (Alavi:1972,61; emphasis in original). The contemporary expression of this overdevelopment is the State's "relative autonomous 
economic role... The state appropriates a very large part of the economic surplus and deploys it in bureaucratically directed economic activity in the namr of promoting econowic development" (Alavi:1972,62). It tears emphasizing that Alavi's postulate about the overdeveloped state and its autonomy is based exclusively on the argunent of the State's class hegemony which arises out of its "nediatory role between the competing interests of the three propertied classes, namely the domestic bourgeoisie, the metropolitan bourgeoisie and the landowning classes" (Alavi:1972,63; emphasis in original). Both Leys and Saul point out that, at least in East Africa, there were no sizeable indigenous classes to begin with (Leys:1976,41; Saul:1974,352). One could add that, in West Africa, there were/are no landowning classes since 1 and was (cf. Forde:1946,46-47,88-91 \& 121) and to a great extent stil: is held communally.5 After suggesting that Alavi asks the wrong question because "in order to understand the significance of any state for the class struggle, we must start out from the class struggle, not the state" (Leys:1976,43), Leys concludes that "in post-colonial societies in Africa there can be little doubt that the dominant class is still the foreign bourgeoisie; and the question then is whether or not

5 Land is also abundant. FAO estimates suggest that Nigeria's current area of medium-and high productivity soils is around 84 milliona cres, of which only between 21 million and 29 million acres are cultivated (cf. Collier: 1983,194); the Nigerian government assumes that $50 x$ of cultivable land is put to use (Nigeria:1970,103) while a World Bank study contends that the "area presently cropped represents ... only 11-16 percent of the land potentially suitable for agriculture" (World Bank:1974,78). It hould appear that these discrepancies originate in varying definitions of "reasonable suitability of land for agriculture." In any event, the fact of land surplus energes clearly and with it an explanation why land has not been alienated or commodified, and why there is no significant group of landless labourers in Nigeria. 
the Tanzanian state serves its interests, not whether the Tanzanian state bureaucracy has 'become a bureaucratic bourgeoisie' by virtue of its control over state-owned capital" (Leys:1976,44-45; eaphasis in original). In contrast to Leys, Saul supports the notion of an overdeveloped State, yet he takes issue with Alavi's explanation of its origins and contends that, historically, "the state in East Africa became 'overdeveloped' not so much in response to a need to 'subordinate the native social classes' as a need to subordinate pre-capitalist, generally non-feudal, social formations to the imperatives of colonial capitalism" (Saul:1974,353). Nevertheless, he refutes Alavi's postulate concerning the overdeveloped State's relative autonomy and, instead, cautiously endorses Leys' view which is also v. Freyhold's, Ziemann and Lanzendörfer's and Shivji's, namely that "the real 'socio-economic base' of those elements who directly control the state lies 'in the international bourgeoisie' [and that therefore the local] oligarchy falls much more directly under the thumb of the 'Metropolitan neo-colonialist bourgeoisie' - the transnational corporations" (Saul:1974,353). It might be too empiricist an interjection, but it would appear that the decidedly independent actions as well as the extraordinary expansion of the Nigerian State, both in size and economic activity, which took place in the 1970s (see Part II, chapter 2), can only with great difficulty be interpreted as a reaction to pressures exerted by the metropolitan bourgeoisie or as serving the latter's interests.

$Z$ iemann and Lanzendörfer lift the argument to a more structural plane and declare that with "their integration in the world market the indevendent development of the peripheral societies is blocked and 
their inner structure is adapted to the reproductive needs of the metropolis ... So one condition for structural dependence is a functional subordination to the needs structure and reproduction dynamic of the metropolis, or in other words, that the peripheral reproduction is overlaid by the international production relation derived from the metropolitan reproduction; on the other hand, structural dependence denotes the inner aspect of articulation" (2ienann and Lanzendörfer: 1977,157). They consequently decree that for "so long as a state is fitted for its main function, to secure the societal reproduction, the extent of its influence on society is neither too great or too small, but adequate" (Ziemann and Lanzendörfer:1977,145).

This esoteric debate is somewhat exasperating in its seminal disregard for the empirical richness of complex historical processes which, instead, are forced into theoretical straightjackets in an attempt to respectably clothe the analysts' dissatisfaction with the status quo: ${ }^{6}$ an omnipresent if unaccountable and impotent State, a

6 I an conscious that this charge might be disqualified as an argument ad hominem and my surnising about the debaters' putative psychology as unscientific. However, given their messianic pretensions and aggressive cocksureness, such restraint is not easy. For my exoneration 1 wish to produce an attestant who considers the "New Left explosion of academic youth ... an aggressive movement borne of frustration, which easily created a vocabulary for itself out of Marxist slogans, or rather some expressions from the Marxist store: liberation, revolution, alienation, etc. Apart from this, its ideology really has little in comon with Marxism. It consists of "revolution" without a working class, hatred of modern technology as such (Marx glorified technical progress) ..." etc. (holakowski:1987a,490-491). To the extent that capitalise is the ofject of their abhorrence, non-existent as it is as yet in nost of post-colonial Africa, they represent "the type of radical whose adverse verdict about capitalist civilization rests on nothing except stupidity, ignorance or irresponsibility, who is unable or unwilling to grasp the nost obvious facts, let alone their wider implications" (Schumpeter:1962,129). 
venal and oversized bureaucracy, continued econoaic dependence despite

political sovereignty, and a slow pace of developnent with growth only in general pauperization levels and incone disparities. It remains unclear if the debaters' primary motivation is acadewic - that is, to demonstrate the applicability of neo-Marxist theory to Third World reality - or political, - that is, to contribute to the socialist struggle by "guiding revolutionary practice" (Shivji:1976a,4). In case it is the former, it exquisitely represents what has been called the "tendency toward compulsive and windless theorizing" as a hindrance to understanding (Hirschman:1970,329).

In case it is the latter, it illustrates well the self-delusion of those" shrewd neo Marxists who imagine (and propagate) that they are still involved in the struggle. Finely chiseled words are the last resort of those doggedly dying myths which in forwer times primed whole battalions for battle" (Marcuse:1966,2; my translation). Most probab$1 y$, not only the verdict of non-Marxists would be this negative. It is more certainty than conjecture that Karl Marx would have chided Alavi et al. as illusionists for not realistically analyzing the "objective" material conditions of their societies which made them singularly unprepared for socialism. His materialism was entirely economic, if not economistic and, correspondingly disaissive of politics and political action. He never ceased to emphasize that political fantasy is no substitute for economic necessity and that socialism can only emerge from the economic maturity of capitalism and the resulting polarization of classes. This idiosyncratic perspective also explains the peripheral 
treatment given to the concept of the state or to political action; both are seen as mere superstructural reflections of an economic mode of production, not as agents sui generis. All this would not natter, of course, if only the proponents of the overdeveloped state would not consider themselves Marxists, and not renegade ones. Marx was clear enough in viewing the conditions for socialism or, as he put it, for the "cooperation and the comunal ownership of the earth and the means of production created by labour itself" (Marx:1969a,791) to arise only aiter capitalism has reached its terminal crisis, that is when "the centralization of the means of production and the socialization of labour reach a point at which they become incompatible with their capitalist mantle. It will be burst asunder. Time is up for private property. The expropriators will be expropriated" (loc. cit.).

The overthrow of capitalism, for Marx, is not a voluntaristic act but the consequent outcome of contradictions in material reality, to be specific, of the contradictions inherent in the capitalist relations of production which, "with the blind impulse of a natural process begets its own negation. It is the negation of the negation" (loc. cit.). These contradictions culminate only at "a certain level of development [and then] capitalism gives birth to the material means for its own destruction. From that moment on, forces and passions which feel constrained by it, begin to stir in its womb. It has to be destroyed, it will be destroyed" (Marx:1969a,789). Marx, throughout his oeuvre is unequivocal about the automatism of historical progress which runs its course following the iron laws of dialectical and historical naterialism. "No social order ever disappears before all the productive forces 
for which there is room in it have been developed; and new higher relations of production never appear before the material conditions of their existence have matured in the woob of the old society itself" (Marx:1969c,9). Overzealous partisans are cautioned that "one cannot solve an equation which does not include the elesents of its solution in its givens ... One thing you car be sure of, a socialist government does not come to power in a country unless conditions are so developed that it can, above all, take the necessary steps to browbeat the bourgeoisie sufficiently to gain time for decisive action" (Marx:1967,160). An equally categorical dismissal of voluntaristic political activism and an archetypal statement of the economistic determinism so characteristic of classical Marxism is Engels" dictum that wherever "the internal state formation of a country stood in opposition to its economic development, the struggle in all instances ended with the overthrow of the political orjer of domination. Inexorably and without exception, the economic evolution has forced its way through" (Engels:1968,170). of cou'se, the debaters' epistemological interest is quite irrelevant. Thoir analytical flaws, however, are not: the mere correlation of epiphenomena makes for a rather assailable aetiology, that is, the monocausal genesis of the overdeveloped state is insufficiently substantiated as is the insistence on the constraints emanating from the international system as singular determinants of the actions of post-colonial states; also, the concept of the overdeveloped state is rather underdeveloped. In short, "[ $[$ ]ediocre theory leads to a bad analysis" (Hoffmann:1990,192) and blaming the imperialists, past and present, for all the ills may be ideologically rewarding if intellec- 
tually flimsy and politically imature. ${ }^{7}$ The early nationalists used similar arguments, with much more reason, in the $1940 \mathrm{~s}$ and $1950 \mathrm{~s}$ in their bid for power. Yet they soon realized that the real challenge had not been to gain independence but to use it. This they have not done very well and the temptation to declare sovereignty a vere formality is understandable. However, it is just as inappropriate as the vien of independence as a veritable caesura and the tine thereafter as a clean slate. Yet, instead of analysing the complex web of econonic, social, psychological and political aspects of colonialism and decolonization, the "overdeveloped state" debate is a collective flogging of dead horses or, put differently, a continuacion of the anticolonial struggle after the fact and by other means.

It matters little then that even the concept's major props are rather rickety. For example, what evidence is there to suggest that the overdeveloped State was the result of colonial domination? Ziemann and Lanzendörfer point out that even those Third World countries which had not been colonized have equally "overdevelopec" state formations (2iemann and Lanzendürfer:1977,145). This is, of course, as much a non

7 A related theoretical inconsistency characterizes the position of at least some of the proponents of the overdeveloped state: the involvement generally of multinational corporations in Third World countries incurs censure on the one hand, while their failure to develop a modern industrial sector is, on the other, just as harshly criticized. Explains Ernest Mandel: "It is industrial underdevelopnent that is the basic flaw in the econony of the underdeveloped countries. [One of its roots is] the fact that foreign capital invests nothing ... in the development of manufacturing ..." (cited in Shivji:1976,4). Such arguments which damn the foreign companies if they do and dann then if they don' $t$, must he accepted for what they are - bastions to defend a position taken up in adrance for political or ethical reasons, rather than as the result of strict analytical deduction. 
sequitur as would be a statenent to the opposite effect. Theoretical$1 y$, overdeveloped states can have many origins, including colonialism. What would make the observation interesting would be the distillation of aspects which are unique to ex-colonies, if the research interest is in the latter. Alternatively, if one were interested in the origins of the "overdeveloped state," a number of then should be subjected to conparative analysis in an attempt to identify the range and wix of causes for the observible phenomenon of a swollen state. The proponents of tha "overdeveloped State" do neither.

Their second major omission is to make a strong case, empirical or theoretical, for the continued dowinance of the "metropolitan bourgeoisie" which, throughout the debate is being treated as an axiom rather than something to be clarified and verified. It is taken for a fact that the indigenous state class aay govern, but that it does not rule; likewise it is insinuated that independence was aerely foraal and that the successor states are, in fact, not more than "colonialisa under new management" (Hart:1982,46). The apriorism which informs the whole debate is at its most extreme here, because everything the state does - even 'correct' policies such as the socialization of foreign assets - is considered supporting evidence because "international capitalism can make adjustments and begin to shape to its own purposes the fact of nationalization" (Saul:1974,366). Thus, what superficially appears as an autonomous act and in direct contravention of the interests of international capital - for example the establiahnent of socialism - turns out to be to its advantage after all because the socialist state class emerges as "a viable partner of the netropolitan bourgeoi- 
gie" (v. Freyhold:1977,88). Taking issue with what I consider facile argumentation, I submit that the policies of the Tanzanian, or any other government should not be dismissed so easily as a result of such self-absorbed theorizing. It is baseless if not irresponsible to argue that a government (progressive or otherwise) in a peripheral country cannot do anything to alter the economy or the conditions of life of the population. One of Chinua Achebe's heroes castigates such facile and self-serving displacement of responsibility in an address to "revolutionary" university students: "First and forenost, this [new] radicalism must be clear-eyed enough to see beyond the present claptrap that will heap all our problems on the doorstep of capitalism and imperialism" (Achebe: 1987, 146).

Another point of explanatory logic: the mere presence of foreign enterprises does not, by any necessity, inply that alien forces doninate internal politics, nor the perpetuation of underdevelopment (see the argument made earlier, p. 54, about Canada, Finland and Sweden). The power of foreign enterprises is not an "attribute" of theirs, but the property of their relationship with the "recipient" state (cf. Emerson: 1962,32). Since it is not a one-dimensional, fungible category which could easily be generalized, the ability of a nultinational corporation to realize its interests in a conflictual situation is sonething to be analyzed in concrete circumstances, not just asserted as if self-evident. Important aspects to be considered in such an analysis rould be a company's significance for and integration into the local economy, its size, market, product-range, capital-endownent and capital-intensity, labour utilization, technological aturity, ownership 
and managenent structures, investaent and profit-transfer performance etc. The state's position vis-d-vis aultinational corporations equally depends on a whole range of factors, the nost inportant of which are the country's attractiveness as a production site and the asfresate of concessions it is willing to nake for a multinational company to invest in production facilities, to aintain then and not to exercise its exit option (cf. Kasfir:1983,11). This just touches on what is a conplex issue to illustrate that a satisfactory treateent would require a specific and thorough empirical investigation which the "overdeveloped State" debate has not generated. What it has done instead is in typically populist fashion to "foster cultural and national antagonisa instead of serious criticism of class domination" (Sklar:1979,551), that is, of the domination of the indigenous state class which is firmly grounded in indigenous political organization.

To conclude, it is important to eaphasize that 1 consider inappropriate, not only politically but also theoretically, both the instrumentalist view that the state is dominated by the interests of the metropolitan bourgeoisie, and the violent solution derived from it, namely to "smash the inherited state machinery [and to] ... build social power among the people ... and create a state controlled by the popular forces and accountable to them. ... Such a state can only be born as a result of a popular denocratic revolution" (Nyong'o:1987,23; emphasis in original). "Sash the post-colonial state or use it?" (Saul:1974,367) is a question posed in siailar vein - as is the conclusion that "we have to get critically inserted anong the masses of our people and be willing to learn fron their rich practical experience 
of life as well as inpart to then our own theoretical knowledge so that together we can create a people's revolutionary novenent" (Osoba:1978, 77) and carry out such popular struggles which wight lead "to the transcendence of the dependent capitalist structure of srowth through the inauguration, after an appropriate class reconstitution of the state, of a socialist transformation of the development process. It is only through such socialist transformation that the self-reliant and egalitarian developnent process ... would begin to be realized" (Obadan and Ekuerhare:1989,220-221). A notch more militant is the opinion that "socialist reconstruction requires workers' control over the state machinery [which can] physically and in practice, be only expressed through a comnitted revolutionary vanguard party. The supremacy of the Party ... is therefore a prerequisite for destroying the old social order and building of socialism" (Shivji:1976,37).

Ritualistic incantations such as these are the politological equivalent of a gordian knot solution; they are synptonatic for analyses at a dead end. A gloonier interpretation takes them as expressions of the chilling pragmatism which follows so logically from Marx's philosophy that the proletariat is involved in a life and death struggle with the capitalist class which is not nerely its adversary, but its enemy, and that the proletariat, progressive by definition, can becone free only by conquering and suppressing these enemies who represent a mortal danger to its very existence and who, in the interest of hunan progress, have to be relegated to the rubbish heap of history. It follows naturally, as herleau-Ponty notes approvingly, that "[c]unning, deception, bloodshed, and dictatorship are justified if they bring the 
proletariat into power" (Merleau-Ponty:1969,XVIII-XIX). Notwithstanding the dubious philosophical, let alone woral, basis of such prescription, and quite apart from the debatable isgue of desirability Cambodia's tragic experience with the Khmer Rouge or Ethiopia's with the Mengistu regime stand as a fierce reminders - it is the utterly doubtful question of practicability which gives analyses such as these an air of phantasmagoria. It is, as Colin Leys adaits

\begin{abstract}
no less utopian to appeal to 'revolution' and 'socialism' to solve the problem .... than to the existing third world governments or the USAID, since a structuralist analysis doesn't disclose the potential class forces on which a revolutionary struggle can be based, ... or a strategy or organizational forms of struggle, or - a fortiori - a'socialist' solution, since a socialist solution must itself be disclosed by the interests and capacities of the revolutionary forces and their strategy, which have not been identified at all (Leys:1977,98).
\end{abstract}

It is tempting to relegate the whole debate to "the class of spurious problems that always result from attempts to work an unsound theory, and the solution to the class of counsels of despair" (Schumpeter:1962,29). In light of the manifold risservations about the central propositions of the debate, it might seem paradoxical that I actually support the hypothesis that colonialism did indeed establish a dynamic which, in many cases, lead to a central and preponderant State after independence. But this is not the linear, one-dimensional, cause and effect relationship which formed the axiomatic core of the "overdeveloped State" debate.

With reference to Nigeria, I will try to show in chapter 1 of Part Il that colonial rule was neither exercised by "a powerful bureau- 
cratic-military apparatus ... to subordinate the native social classes" (Alavi:1972,61), nor "to subordinate pre-capitalist social formations ... to the imperative of colonial capitalism" (Saul:1977,353). In fact, in the case of Nigeria as possibly in most other African ones, it is nonsense to talk of colonial capitalism. Ideologically rewarding as this invective might be, no serious claim can be made that capitalism, metropclitan or otherwise, captures the essence of British colonialism. Moreover, in Nigeria as anywhere in Africa a substantial army was not even necessary for purposes of imperial conquest, ${ }^{8}$ nor a substantial government for purposes of colonial control, a point made most succinctl:- by Hilaire Belloc in his contemporary satire The Modern Traveller:

We shot and hanged a few, and then The rest became devoted men (Belloc: 1898,42$)$.

"The colonial governments ... were comparable not to states but, rather, to small provincial, county, or municipal governments in European countries - except that they were overseas and accompanied by tiny military establishments - backed up by much larger imperial forces" (Jackson \& Rosberg:1986,7). The very facility of conquest and, thereafter, of preserving the colonial State's uncontested hegemony over native socjety, obviated the need to actually employ the empire's over-

5 The fiercest resistance experienced was in 1903 during the carpaign against Sokoto when a British force of 650 Yoruba soldiers and their 25 British officers were confronted by some 15,000 horsemen and 3,000 footmen. The battle, ending in Sokoto's total defeat claived about 100 casualties, of whom only one, a carrier wounded by a stray shot, on the British side (Lugard's 1902/1903 reports to the Colonial office, cited in Perham: 1960,127). 
whelming power resources. It was possible to rely not on the actual use of force but on its implicit threat. Hilaire Belloc again:

Whatever happr ss we have got

The Maxim Gun, and they have not

(Belloc: 1898,41 ).

Even though it might appear notably different in hindsight, the establishment of African colonies in the late 19th century in reality involved a great deal less purposive design and much more increnental improvisation than one would think probable. The conservatism of the colonial State in Nigeria thus can be seen not as the operationalization of a coherent imperialist ideology but as the result of a pervasive role-insecurity. Politically it aimed in the first instance to he a State in the Weberian sense of an institution which could claim the monopoly of the legitimate use of physical force within its territory. Not genuine strength but the actual tenuousness of its position made it. a priority for the colonial state to equip itself with a mythology of irresistible power and to leave behind "crucial aspects of European state theory [such as the] state-limiting doctrines that had grown in tandem with the jural philosophy of the state - constitutionalism, civil liberties, liberalism" (Young:1982,75). Authoritarianism in matters of sovereignty and legitimacy found its correspondence in the economic policies of laissez faire and in "ecological" conservatism: preserving the pristine Muslim North, preventing land alienation and the establishment of plantations, maintaining or even creating indigenous political structures for local self-government, and in viewing with considerable contempt the hustling of traders and with moderate 
suspicion the activities of Christian missionaries. Easy trade relations required minimal active state involvement in the economy, and "Indirect Rule" perwitted government on a shoe-string budget. Both were not only, but also, a function of the colonial State's weakness. Its minimalism moreover immunized the colonial state against the vulnerability inherent in being an alien entity. Paradoxically, its viability was negatively affected only after its end was decided and when the political co-determination of the indigenous population as well as the economic development of the colony were no longer anathema. Nevertheless, the coloniel State's unconnectedness to society must be considered a grievous birth defect of the post-independence state and a major factor in its consequential deformations. Of particular import were the colonial State's personnel policies.

First its haughty disinclination to train and admit to its senior ranks indigenous stafi led to a quite unnecessary alienation of an important segment of the local population. Frustration was especially widespread among the literate salariat, itself a product of colonialism, namely of missionary education and of the employment opportunities for clerical staff within the colonial administration. A second cardinal sin was the colonial State's prevention, by omission and commission, of the emergence of an indigenous business class which would have provided an outlet for the aspirations of ambitious and enterprising Nigerians. By forestalling both avenues, the colonial state deprived itself of legitimacy while, at the same time, elevating the conquest of State positions to a priority in the anticolonial struggle. In a sadly ironic twist, the colonial government's about turn after World War II 
only aggravated the damage of its earlier racist and exclusionary staffing policies. By now, with a severity of fervour intensified by forced abstine:ıce, no holds were barred in the pursuance of state positions which represented the pinnacle of power and prestige.

In its final years, the colonial state lacked the resolve and the commitment to maintain the professional standards and fiscally conservative recruitment practices of earlier times. Realizing that their days were numbered and that it was no longer their show, the British colonial of icials put up very little resistance when the store was given away, especially as any counsels of caution wight have been interpreted as revealing the old hidden agenda of racism. The State, at the same time bête noire and model to be emulated, began to swell in size, weight and cost well before independence and, thereafter, at an even faster pace. The financial implications of this expansion were as predictable as unavoidable since it was a matter of principle and pride that black officials, once permitted to move into "white" positicns, would enjoy the same benefits and conditions as their expatriate colleagues or predecessors. In the terminal phase of colonialism, their emoluments had shifted upward considerably to reflect postwar improvewents in European living standards and also because "metropolitan governments were anxious that salaries, pensions, and other forms of compensation for European administrators be set sufficiently high to induce these individuals either to stay on ... or to return to the metropole in a reasonable financial state" (Abernethy:1988a,9;. Quite inescapably, the nationalist sentiment legitimating this take-over produced the egalitarian side-effect of closing the gap in reauneration 
between the different levels of the administrative hierarchy, especialIy between the former "white" (or senior) and the former "black" (or junior) positions. Naturally, pressures to reduce the incone disparities could be accommodated more easily by raising the pay scales at the bottom so that, as a result intra-bureaucratic pay differentials were narrowed considerably even if at a high price for the economy: general administrative costs increased substantially and, equally if not more imporiantly, the income differential between bureaucratic and other forms of employment widened. Maintaining, in the name of egalitarianism, the pay packages for senior civil servants whose original comparator had been European rather than African circusstances, institutionalized "within the independent polity the powerful inegalitarian legacy of European rule" (Abernethy: 1988,198). An overstaffed, overpaid state sector became a heavy burden on the economy's narrow resource base while not contributing to - or even hindering - its development. Rather than displaying any sense of mission - ascetic, technocratic, capitalist, socialist or whatever - the "political class that took over the colonial administrative state of ten assumed primarily the status elements of these positions and neglected (or was unable) to fulfill many of the role functions" (Callaghy:1987,92).

The same changed and changing outlook which countenanced the recruitment of local staff for senior positions also subscribed to a more activist, development and welfare oriented, role for the state. This was facilitated by the fact that for the first time in colonial history, financial resources were rather plentiful, owing to the wartime surpluses accumulated by the marketing boards. At a much higher 
level, yet importantly reverberating throughout the transition frou colony to independent statehood, was the universally high expectation for State activism.

The American experience with the Great Depression and the New Deal as well as the Soviet Union's dramatic rise from backward peasant society to industrialized superpower not only thoroughly discredited laissez faire capitalism but also legitinated the state's role in effecting social change. Karl Polanyi's Great Transformation was a cri de coeur against the inhumanity and ultimate self-destructiveness of a market economy. "Only resignation to the inevitable laws of the arket could explain the proud acquiescence with which the cross was borne" (Polanyi:1944,215). Writing in the 1930s and 1940s under the impression of the global economic crisis triggered by the 1929 Wall street crash, Polanyi contends that through the system-inherent, inevitable failures of the market "a civilization was being disrupted by the blind action of soulless institutions the only purpose of which was the automatic increase of material welfare" (ibid, 219). Polanyi's views about the seeming superiority of a socially directed economy seemed supported by the truly spectacular mobilization and focusing of energies - everywhere - during the second World War. Indeed, the "war provided an actual demonstration, unique in the social sciences, of the efficacy of wholesale government intervention. Massive military spending quickly converted depression into prosperity and deep unemployment into severe labor shortages" (Schatz:1988,64). After the cataclysn of the second World War, these unexpected successes of étatisae were, not surprisingly, codified in legal norms, at least at the international level. The 
charter of the United Nations - itself an interestingly deceptive misnomer because it is in reality an agglomeration not of nations but of states - obligates its meabers "to promote social progress and better standards of life in larger freedom." The eninent success of etatisme was finally confirmed by the miraculous performance of the Marshall Plan for Europe: postwar reconstruction on a massive scale was mastered smoothly and speedily through inter-state economic aid, economic planning and state-led investment (cf. Baumann:1976). Universally during the 1950 s and 1960 s there "was stark confidence ... that the chaos of the moment would pass as new and renewed states would pull themselves together and create 'modern' national societies. It was eagerly anticipated that the new states could lay the way for directing the economic and social changes already engulfing their societies" (Migdal: $1988,11)$.

It was thus the unfortunate combination of weakness and guilt, of a fiscal windfall and of ideology, which formed the basis for Nigeria's fateful étatisme and thus lead to the "erection of complex state bureaucracies well ahead of the development of adequate canons of public accountability and of professional competence [which] have proved a continuing liability" (Elliott:1983,2). This constituted a sea-cinange because the colonial state before the war, reined in by the seiffinancing imperative and so constrained to rely on a system of "indirect rule" was, if anything, under-administered. Rather than intervening to change or to develop the country's economic structure - a simple dual economy, with a wide subsistence agricultural sector and a narron monetary sector consisting of maybe four cash crops for export - 
the colonial State limited itself to an enabling role. This laissez faireism benefitted the stronger expatriate trading houses over the fledgling indigenous entrepreneurs who joined the salaried niddle class as a second pillar of the anti-colonial movement. Not coincidentally, the focal complaints of this emerging nationalist opposition were precisely the absence of state-led developent and welfare neasures. Intimately related to this delinquency was the exclusion of Nigerians from the hub of the colonial economy and polity, in other words, their relegation to the subordinate roles of farmers and clerical gtaff.

Articulating these grievances enhanced the nationalists' legitimacy before independence. At the same time it invariably led to an inflation of expectations and to a "consumptionist approach to public services ... with major post-colonial consequences" (Acharya:1981,116). One prominent effect was that it justified the expansion in size and function of the past-independence state.9 "The inheritors encouraged the growth of public spending by emphasizing the benefits, rather than the costs, of the welfare state as if benefits are costless. ... African politicians have behaved as if they do not understand that no goverument can legislate to meet infinite wants with a finite national product" (Ayoade:1988,104-105). Putting a heavy mortgage on Nigeria's developmental prospects, it was overlooked or discounted that growing

9 For instance village roads before independence were built and maintained by the native authorities. The necessary funds cane from locally raised taxes and, in turn, were spent to pay the labourers who usually came from the village too. "But," lanents a character in Aluko's novel, "in the last few months the people appear to have stopped doing anything for themselves. They now say that as their own son is Minister of Works, Government must look after all the work of construction in their community" (Aluko:1977,151). 
output of goods and gervices can only be the result of efforts by the direct producers which $m$ ight be stimulated or focussed by state action, but which cannot be replaced by it. As a World Bank survey tean noted i'1 1955:

No progress can be ade unless the people thenselves are willing to assume the main burden of the development effort. The mission found this not fully appreciated in Nigeria. Nigerians of all walks of life tend to look too much to the government, more specifically to the British colonial officials for the fulfillnent of their aspirations. The heavy reliance on government is frequently coupled with a strong distrust of its actions and wotives (World Bank: 1955, 20).

Pushed by vocal demands, but also pulled by a tacit recognition of past omissions las exemplified by the absence of a productive aiddle class and a modern economic sector), the State became the natural agent for the realization of developmental aspirations. Thus, by default as much as by design, the colonial state, during the twilight of its existence, acquired the economic centrality which it bequeathed on its successor. What initially wight have appeared as blessing quickly turned sour because of the independent State's thorough failure to find an economic strategy compatible with the scale of public finances on which it initially had based its clain for legitimacy.

Thus, the post-independence State's "overdevelopment" or, better, its pre-eminence cum weakness can be traced back to its artificiality and arbitrariness. Created by foreign conquest and domination rather than through a gradual process of development, aggregation or expansion of indigenous polities, its relative effectiveness, before the withdrawal of the colonial sovereign, was deceptive. With the benefit of 
hindsight, the regional organization of the colony eaerges as another egregious design flaw. Nigeria's internal weakness and low level of organization obviated the need for the erection of a unitary colonial State to contain centrifugal forces. These did not becone virulent as long as they were potentially threatened by the wight of the British Empire which also provided thea with a focal point for their political action. This unity of purpose dissolved with a vengeance once decolonization was set in train and resulted in the painful dialectic that the organizational set-up which was conducive to governability under colonialism now unleashed forces which jeopardized the governability of the successor State. Regionalism provided the disparate power bases which, in the post war era of developmentalism and welfareism and, even more significantly, after independence, put tremendous pressures on the treasury for expenditures whose developmental merit was less obvious than their potential for patronage. It also amplified bureaucratic expansion with the creation of full-fledged civil services in the three regions (later four; then twelve, later nineteen, eventually twenty-one and finally (?) thirty states) and with the introduction of the principle of equitable regional representation in the federal civil gervice soon eroding the remnants of a merit system or of the self-restraint to tie bureaucratic growth to technical necessity or fiscal feasibility. The result was a state, greatly expanded in size as well as scope and an increasingly unequal relationship between neabers of the state apparatus and those outside it.

The causes of the overextended (swollen) and preponderant (central) post-colonial state are thus rooted in the colony's exclusionary 
principles and the specific policies based on thes, on the resulting grievances, real and inagined of the local population; inportant was also the spirit of the age of decolonization and, last but not least, the colony's regional organization. Developental aspirations conbined with the weakened resolve of a departing colonial service formed the most conspicuous "pull factor" for the State's expansion, while the most portentous "push factor" was the material interests of the educated elite who, humiliated under colonialise, sought to inherit fron the colonial administrators their positions, power, privileges and investible funds. These two quite distinct clusters of factors initially operated rather independently from each other, even though both resulted from attempts to provide redress for earlier delinquencies. Their fusion in the innediate pre- and post-independence eras "thrust the state into a role it had yet to earn" (Glickman:1987,39). They laid the foundation for a state whose primary rationale, in light of its inability to get anywhere near to fulfilling the aspirations itself had kindled, rather quickly became to serve the interests of the state class and which, as a result, becane oversized, underperforming and weak.

Concentrating on the state as hegemonic institution and on the state class as a purposive actor, my position is at variance with the pan-societal perspectives as exemplified by Hyden who suggests that, because "capitalist or socialist institutions have failed to penetrate the peasant economy and have instead become influenced by the social logic of the peasant mode itself, the state in Africa has becone increasingly weak and vulnerable" (Hyden:1987,663). My disagreenent with 
the "overdeveloped state" debaters and sone other neo-Marxists concerns the explication of both the origins and the behavioural deterainants of the overdeveloped State, the Nigerian phenotype of which they like to label the "state of internationally subordinated state nonopoly capitalism" (Beckman:1983,50). They assume that "the state and the ruling class are objectively serving the jnternational capitalist eystea" (Shivji:1976a,16-17), that is, that a peripheral state within a world capitalist economy performs principally as an instrument of adjustaent to the changing demands of global accumulation so that its "purpose is to subordinate its development to the deands of the redeployment of globalized capital" (Amin:1987,1). If, as this perspective maintains, the state is entirely externally determined then it follows that "the state's weakness in Africa derives from its subordination to stronger external institutions" (Bratton: 1989,418-419).

Sharply differing with such views, I believe the contenporary Nigerian State to be deterwined not externally but largely internally and, to be even more specific, by interests and dynamics internal to the State itself. This line of thought will be elaborated below. As to its origin, I propose that the growth of the colonial state apparatus after the war - and of the successor State's after independence can be seen as a reaction to:

- the colonial government's pre-war personnel policies which preserved senior positions for white expatriates and relegated Nigerians to junior positions. This led to the emergence of an alienated and frustrated widdle class; 
- the reorientation of British trusteeship fron econonic laissez faire to paternalist developnentalisa. Econoaic planning and intervention followed as did affirmative action in personnel recruitment;

- the considerable financial resources available to the colonial government (surpluses accrued to the aarketing boards as well as price hikes generated by the Korean war);

- the reakness (not the strength, as Alavi et al, would have it) of the indigenous business class. This weakness, of course, was closely related to colonial policy which had done little to support the emergence of local entrepreneurs and auch to prevent it;

- pressures (for control, development and enployment) exerted by the Nigerian opposition. These pressures were anplified, far beyond technical necessity or budgetary viability, by centrifugal forces unleashed by the colonial state's organization along federal, rather than unitary lines;

- the federal colonial structure. It encouraged the survival of ethnic loyalties, most particularly and ironically during the dying days of colonialige. Moreover, it enkindled the view of the State not as an instrument for national development, but as a receptacle of spoils. Access to and distribution of these spoils became the rationale of politics. 
With formal independence, even the vestigial constraints exercised by the colonial government disappeared and the new state developed a dynamic of its own. The former opposition had replaced the rulers without itself being succeeded by another opposition. There were conflicts, to be sure, but they were between nembers of the ruling elite who, for their partisan interests, nobilized popular support. Since the external enemy had departed, appeals to Nigerian nationalisn would have been futile and it was only logical in the now existing zero-sun situation to stir up, and then to appeal to, ethnic loyalties, aspirations and envies. The political elite shrewdly instrumentalized ethnic sentiments in the competition for the spoils of the State - posts and public funds. Patronage coalesced with ethnicity and the struggle for State resources unleashed violence. After only six years, the new country had reached the verge of self-immolation and the politicians were replaced by the military which, in a coalition with civilian bureaucrats, have governed $\mathrm{Nigeria}$ ever since, excepting the interlude of the Shagari regime. Even though it seriously overstretched the organizational strength of the State, the étatiste and dirigiste ideology of State omnicompetence was maintained and even fortified, as is not surprising under military tutelage. The State's doninant position in the economy provided opportunities for personal enrichnent to those groups and individuals who acquired access or position. Not dependent on popular confirmation through periodic elections, unconstrained by an independent judiciary and blessed with the bountiful rent-income from oil, the military/bureaucratic coalition which controlled the State was free to pursue its project of class entrenchment and class donination. 
The Niger: n State, consequently, acquired distinctly patrimonial traits. In urder to identify and assess them I will now turn to the eminently incisive concept of patrimonialism.

\section{b) The Patrinonial State}

Cunsiderably deeper insights than those generated by the arid polemics of the "overdeveloped State" debate are emerging from the recent rediscovery, and application to various African countries, of Weber's concept of "patrimonialism" which is one of his ideal types of domination. ${ }^{10}$ As an ideal type, patrimonialism is not the analysis of an authentic entity but a basic her istic tool employed by weber to scrutinize a specific reality. His focus is on institutional and beha$v$ oural attributes of the patrimonial order, rather than on its origins or on its external relations, which is why, prima facie, it fits own hypothesis about the internal determinacy of the Nigerian State. I will begin by briefly outlining those aspects of Weber's extensive treatment of natrimonialism which are germane to Nigeria - there al none which are entirely incompatible - and then explain why, after all, characterizing the Nigerian State as a patrimonial one tout court would be to do violence to the theory, to reality, or to both.

$$
\text { Like "gerontocracy" and "patriarchalism," patrimonialism is a }
$$
"most elementary type of traditional domination" (Weber:1978,231).

10 Examples are: Callaghy: 1987; idem:1988a; Hyden:1983; Kasfir: 1983; Nedard:1982; Theobald:1982. 
While weber does not make the deterministic argument that patrimonialism will eventually and as a matter of course develop into rationallegal authority, he considers patrimonialisw "the nost inportant kind of administration before the emergence of modern bureaucracy" (Roth: $1978, \mathrm{XCV}$ ) and points to significant dynarics which could, though do not perforce have to, lead to a rational-legal order with modern bureaucracy as its organic institutional expression. The increasing volume and complexity of administrative work as well as the requirement for continuity, which are corollaries of a patrimonial state's economically interventionist policies, require "the growing rationalization of finance [which means that] the clerical and accounting officials begin to play an increasingly important role" (Weber:1978,1089).

Weber's yardstick for evaluating patrimonialism - indeed all economic, political and social phenomena - is rationality. In this perspective, development processes become rationalization processes ${ }^{11}$ and, conversely, their absence signifies stasis, even if there is accumulation or growth. Rationalization as a process refers in general terms to dimystification, calculability, predictability, quantifiability, reliability, universality etc., in other words to the intensification of formal reason in economic, political and social organization and pro-

11 In analyzing these, Weber eschews ex ante determinism in favour of ex post explication as, for exanple, in the quite characteristic suggestion that "the bureaucratic structure is everywhere a late product of development. The further back we trace our steps, the more typical is the absence of bureaucracy and officialdom in the structure of donination. Bureaucracy has a 'rational' character: rules, means, ends, and matterof-factness dowinate its bearing. Everywhere its origin and its diffusion have therefore had 'revolutionary' results ... The march of bureaucracy has destroyed structures of doaination which had no rational character in the special sense of the word" (Weber:1946,244). 
cesses as well as in human action and thought. This points to, but does not untangle, the concept of rationality and notwithstanding the fact that rationality is acknowledged to be his idée mait $t_{1}$ sse, scholars are still occupied to decipher its "polymorphous character ... in Weber's oeuvre" (Kalberg:1980,1151). Rather than recounting the still ongoing, inordinately intricate debate in any detail, it should suffice to isolate and delineate the three types or aspects of rationality which are pertinent to understanding the nexus of political domination and economic development, viz. practical, formal and substantive rationality:

- Practical (or instrumental or technical) rationality refers to the efficiency of actions, procedures or systems. It is "the type of attitude which sees and judges the world consciously in terms of worldly interests of the individual ego" (Weber:1958, 77). It informs means-ends calculations and considerations of optimization and maximization.

- Formal rationality refers to laws, regulations, rules and to the strictly procedural accuracy, calculability, predictability, reliability and universality with which they are applied. For example, to be formally rational, public administration needs to be carried out on the basis of transparent and general rules: "'Sine ira et studio,' without hatred or passion, and hence without affection or enthusiasm" (Weber:1978,225); conflicts have to be adjudicated without any kind of arbitrariness and with the application of law in anner "which can be counted upon, like a machine" (Weber:1966,252); econonic action will have to be calculable, "capable of being expressed in numerical terms" (Weber:1978,85). Like practical rationality, formal rationality alludes to means; unlike practical rationality, however, it does not refer to ends and emphatically not to anv means-ends relationship. In most instances when Weber refe' $s$ to rationality without qualifying it, he means formal rationality.

- Substantive rationality refers to values, that is, to the ade quacy of actions for meeting "ultimate ends, whether they be ethical, political, utilitarian, hedonistic, feudal, egalitarian or whatever" (Weber:1978,85). These ends or values themselves are a priori, not accessible through the canons of logic or science and thus outside of any rationality considerations (Weber:1946,150f $f$ ). "A thing is never irrational in itself, 
but only from a particular rational point of view. For the unbeliever every religious way of life is irrational, for the hedonist every ascetic standard ... If this essay [The Protesttant Ethic] makes any contribution at all, may it be to bring out the complexity of the only superficially simple concept of rationality" (Weber: 1958,194 ).

Weber was well, almost tragically, aware of the hiatus between formal and substantive rationality. He considered it the great dilema of modern life. The conflict between the two was one of his central preoccupations, especially as he could not bring himself to reduce the complexity of life to any particular monocausality, as for example Marx did in postulating private property as the Fall of Man and its abolition as his salvation. Weber was torn between recognizing both the inexorability and technical desirability of formal rationalization processes, and their costs in terms of human freedom and cultural richness. The irreconcilability of the two forms of rationality is addressed on many occasions throughout his work, so for example in his forceful assertion that "the fact that the maximum of formal rationality [in capitalistic efficiency] is possible only where the workers are subjected to domination by entrepreneurs, is a further specific element of substantive irrationality in the modern economic order" (Weber:1978,138, emphases in original; for other examples see ibid., pp. $635 \mathrm{ff}, 812$ \& $918 \mathrm{ff})$. Elsewhere he explains that no "matter what the standards of value by which they are measured, the requirements of formal and of substantive rationality are always in principle in conflict, no matter how numerous the individual cases in which they way coincide empirically. It is true that they may be made to coincide theoretically in all cases, but only under assumptions which are wholly 
unrealistic" (Weber:1947,212). This incompatibility is exemplified by capitalism as an economic order. The formal rationality of unadulterated capitalism promises the efficient production of goods and thus increases the range of human choice. It cannot, however, guarantee the equitable distribution of these goods, their social utility, their ecological soundness or, for that matter, their contribution to human haf. piness. His conviction - starkly resembling Marx's - that capitalism is uitimately inhumane is powerfully expressed in the last pages of the Protestant Ethic. "The Puritan wanted to work in a calling; we are forced to do so. ... This order is now bound to the technical and economic conditions of machine production which today determine the lives of all individuals ... with irresistible force" (Weber:1958,181). None the less, for heber as for many others, capitalism is unsurpassed as an example of a dramatic and pervasive rationalization process. Its practices, for example, change the role of money from a simple medium of exchange

into a tool of rational cost-profit calculations, of which the towering monument is double-entry bookkeeping. ... primarily a product of the evolution of economic rationality, the cost-profit calculus in turn reacts upon that rationality; by crystallizing and defining numerically, it powerfully propels the logic of enterprise. And thus defined and quantified for the economic sector, this type of logic or attitude or method then starts upon its conqueror's career subjugating - rationalizing - man's tools and philosophies, his medical practice, his picture of the cosmos, his outlook on life, everything in fact including his concepts of beauty and justice and his spiritual anbitions (Schumpeter: $1962,123-124)$.

Such enthusiastic commentaries on capitalism's formal rationality have been misinterpreted, sometimes with reason, as arguments for its 
substantive rationality of crass, soul-destroying materialigm, of institutionalized avarice or of anti-human exploitativeness, etc. In the process of such confusion, the validity of the distinction between formal and substantive rationality has been challenged, in ny view erroneously, on the grounds that foraality "can never escape substance; its formality is relative; it is always most efficient for gone end Eisen: 1978,67; emphasis in original). Even though Weber himgelf is quite categorical in stating that "the highest degree of formal rationality ... is absolutely indifferent to all the substantive considerations involved" (Weber:1947,212), Eisen's contention is typical for an easy trap to fall into, and one Weber tried to cover precisely by differentiating the concept of rationality. Eisen and others arguing siailarly, plainly confuse practical and formal rationality. 12 Their claims are correct with reference to the former - which is not at all what they intend - but fallacious with regard to the latter. Formal rationality

12 "Substantively rational ends may contradict formal rationality (e.g. safety standards in the work area may slow production and reduce profit" (Antonio:1984,171). Protective measures, of course, do not frustrate calculability - they may in fact increase it by reducing accidentinflicted down times. What they may affect negatively is short-run efficiency and profitability, both of which are covered by the means-ends nexus of practical rationality.

"Formal rationality orders actions purely on the basis of meansends calculus with regard to universally applied abstract principles, laws and rules" (Callaghy:1988,70-71). Here, practical and formal rationality are being collapsed, or the distinction muddled: formal rationality does not refer to ends, nor to efficiency.

"Administration would, to the extent it is truly [formally] rational, tend towards the dissolution (Aufhebung) of donination (Herrschaft)" (Marcuse:1977,122; my translation). Weber's point is, of course, just the opposite: a technically perfect bureaucratic machine, because of its formal rationality (i.e. calculability, dependability, predictability etc.), is a formidable power instrument for whoever controls it; a rational adainistration does not dissolve domination but makes it nore effective. 
refers solely to the calculable, methodical, reliable and systematic nature of a process - as opposed to one which is haphazard, random, unreliable and unsystematic - and enphatically not to its efficiency. Efficiency is not part of the definition of formal rationality; it is arguably the effect of a formally rational operation.

As modern capitalisw (Heber:1978,161ff) and modern bureaucracy (Weber: $1978,217 \mathrm{ff}$ ) are held to represent the highest levels of formal rationality, Weber's presentation of patrimonialisw emphasizes its nonrational (formally) and non-capitalist features (Weber:1978,238ff and 1028 $(\mathrm{f})$. Defining patrimonialism as the political domination of a ruler with the help of his personal apparatus, the "person exercising authority is not a 'superior,' but a personal 'chief.' His administrative staff does not consist primarily of officials, but of personal retainers. ... What determines the relations of the administrative staff to the chief is not the impersonal obligation of office, but personal loyalt: to the chief. Obedience is not owed to enacted rules, but to the person who occupies a position of authority" (Weber:1947,341). Given the emphasis on personal loyalty, it is only consistent that patrimonial officials are neither professionally specialized and hierarchically or systematically organized, nor paid a fixed money salary and that they, instead, are deployed at the discretion of the ruler. They also depend on the ruler for their livelihood which normally takes the form of ad hoc awards of benefits in cash, in kind or in entitlements (Weber:1947,351). Even so, patrimonial officials, "just like bureaucratic officials, ... usually develop into a status group set off from the ruled" (Weber:1978,1026). 
Patrimonial domination is formally non-rational in that it is maintained by personal power in a conbination of traditional and arbitrary decisions, that is, not by laws or rules, but by a person who holds a position of authority, who issues laws but is not bound by them, and who runs the affairs of state like a patriarch runs his household. The patrimonial ruler is a definitely aster, perhaps a provider, not however a public servant. In such a situation of absolute, personalized and thus ultimately arbitrary rule, the modern concept of corruption - the infraction of rules for personal benefit does not, strictly speaking, apply. ${ }^{13}$ The behaviour which in a rational system would immediately be identified as corrupt, namely bribery, nepotism or misappropriation of funds, is in patrimonialism not deviant but standard operating procedure as long as practiced within accepted boundaries. In patrimonialism, formal rules concerning duties, rights and expected conduct of officials do not exist and positions of authority are quite naturally used to further the incumbents' private material interests.

One of the fundamental differences between patrimonial and rational-legal domination is thus that the latter is characterized by the codification of officials' duties, rights and discretionary scope. A logical extension of this rule-bound conduct is the strict separation between the public domain and the private affairs of an officeholder

13 Corruption is a pathology of a formally rational system of administration. It denotes the conduct of a public official who "accepts money or money's worth for doing something that he is under duty to do anyway, that he is under duty not to do, or to exercise a legitinate discretion for improper reasons" (McMullan:1978,319). It will be more fully discussed below, p. 146. 
(and between office and incumbent). In a patrimonial order, the office may, as a matter of course, be appropriated for personal wealth because "all governmental authority and the corresponding economic rights tend to be treated as privately appropriated economic advantages" (Weber: 1947,352). Indeed, the patrimonial state "offers the whole reald of the ruler's discretion as a hunting ground for accumulating wealth" (Weber: 1978,1099 ). It follows that political authority, instead of having the impersonal and abstract character of the legal-rational type of domination associated with the modern state is, on the contrary, a personal prerogative which is respected only as long as the traditional order as such is sanctified. Modernization generally and the devolution of political and economic prerogatives specifically are threatening to erode the traditional, unquestioned monopoly of power. It folJows with great stringency that "in the interest of his domination, the patrimonial ruler must oppose ... the economic independence of the bourgeoisie" (Weber:1978,1107). Correspondingly, policies which increase public choice will be anathema.

Capitalist development (or economic rationality) is thwarted by the arbitrariness which characterizes law-making and adjudication as well as by the pervading uncertainty regarding an economic actor's obligations towards the State. This means that two "fundamental bases of the rationalization of economic activity are entirely lacking; namely, a basis for the calculability of obligations and of the extent of freedom which will be allowed to private acquisitive activity" (Weber: 1947,355). Stlinied or distorted economic growth follows from the absence of "formally rational regulations, which can be depended upon to 
remain stable and hence are calculable in their economic implications and exploitability" (Weber:1947,356). A further developmental obstacle is the patrimonial state's proclivity to directly participate in the economy through the establishment of production wonopolies, or to intervene by means of "fee-taking or taxation. In this case, the development of markets is ... more or less seriously limited by irrational factors. The important openings for profit are in the hands of the ruler and of his administrative staff. Capitalism is thereby either directly obstructed, ... or is diverted into political capitalism, if there is tax farming, leasing or sale of offices" (Weber:1978,238). Patrimonialism's inherent tendency to substantive regulation of economic activity follows from the ruler's and his retainers' complementary interests in perpetuating both their political monopoly and their material privileges. The ruler's additional and much less suspect motive - if in its impact on the economy equally counterproductive - "is derived from the character of the claim to legitimacy and the corresponding interest in the contentment of the subjects. Its effect is to breal down the type of formal rationality which is oriented to a formally technical legal order" (Weber:1947,357). The picture of economic irrationality is rounded out by the "wide scope for actual arbitrariness and the expression of purely personal whins on the part of the ruler and the members of his administrative staff. The opening for bribery and corruption ... would be the least serious effect of this if it remained a constant quantity, because then it would become calculable in practice. But it tends to be a watter which is settled from case to case with every individual official and thus highly variable" 
(Weber:1978,239-240). In sum, the

patrimonial state lacks the political and procedural predictability, indispensable for capitalist development, which is provided by the rational rules of modern bureaucratic administration. Instead, we find unpredictability and inconsistency on the part of court and local officials, and variously benevolence and disfavor on the part of the ruler and his servants. ... But a capitalist economic systen is obviously greatly handicapped by these factors, for the individual variants of capitalism have a differential sensitivity toward such unpredictable factors. Industrial capitalism ... requires an organization of labor that ains at a mass market and depends upon the possibility of correct calculations. [... it] must be able to count on the continuity, trustworthiness and objectivity of the legal order, and on the rational, predictable functioning of legal and administrative agencies (Weber:1978,1095; emphasis in original).

The Nigerian State's congeniality with the patrimonial order of domination will be illuminated in subsequent sections. Its broad outlines should have become apparent: the Nigerian State's undemocratic claim to power, its anticapitalist nodus operandi and, if viewed from a developmental perspective, its economicaliy dislocating effect. The specific extent to which Nigeria's system of governance fits the patrimonial ideal type can be synthesized as follows:

\section{Patrinonialist Features in Niserio}

Patrieonialisn

1) The ruler's (or the State's) legitimacy is based in tradition
Nigeria

The State's legitinacy

is generally based on

its status as successor of an alien colonial regime; the militarybureaucratic State's legitiaacy specifically 
2) Political domination is exercised by a ruler with his personal apparatus

3) Administrative staff are personal retainers without professional training and with no fixed salary paid in money

4) Administrative staff not organized hierarchically and without clearly defined spheres of competence

5) Personal loyalty defines relationship of staff to ruler

6) Ruler makes law while himself being above it

7) Domination maintained by personal power through arbitrary decisions based on ethical common sense, justice or on utilitarian expediency. Absence of formal rules in the context of absolute political power and heavy regulation of econony leads to widespread corruption is based on its status as successor of a corrupt and inept predecessor regine (both are non-renewable and fast dwindling assets)

Political domination is exercised by the state class consisting of appointed officials

Adninistrative staff are trained government officials with fixed money salary but with ample opportunities to illicitly supplement their legitimate income

Formally, administrative staff organized hierarchically with explicitly defined spheres of competence. In practice, there is duplication and overlap but little coordination or supervision

State class is de facto sovereign. Leadership positions filled as result of intra-class bargaining

State class aakes law and is de jure, much less de facto, bound by it

Domination maintained by power of state class. Decisions are, de jure, rule bound within the context of impersonal obligations of office. De facto the rules are of ten violated through corrupt practices such as bribery, patronage and isappropriation 
8) Ruler is autonomous frow society by virtue of tradition

9) To stabilize and enhance the ruler's central power, development of clerical accounting systems strongly supported

10) The raison d'être of public office is to benefit the incumbent, not to serve the public

11) Officials develop into a status group set of from the ruled

12) Office is (ab)used to acquire personal wealth

13) Substantive regulation of economic activity which increases opportunity for bribery and corruption

14) Widespread corruption reduces calculability nexus for private entrepreneurs and thus productive economic activity

15) In the interest of power consolidation, ruler opposes economic independence of the bourgeoisie and, instead, tries to tie it to the state in a clientelist relationship

16) Since extraction is relatively easy and production relatively difficult (or potentially threatening if independently organized), state relies heavily on extraction
State class is autonomous from society by virtue of resource independence and lack of constraints by significant dosestic classes

To stabilize and enhance their individual discretion and privileges, nenbers of state class resist bureaucratic rationalization

ditto

ditto

ditto

ditto

ditto

ditto

ditto 
The behavioural features of Weber's patrinonialist order of domination do indeed apply to Nigeria - as do the resulting inpediments for economic development. Nevertheless, there are two institutional attributes, both militating against the State's legitinacy, which do not. The compelling and interconnected reasons why it would be istaken to consider the Nigerian State a patrimonial one tout court are firstly the absence of a personal ruler and secondly the fact that it is not rooted in tradition.

The Nigerian State, as opposed to its counterpart in the Côte d' Iroire, henya, zaire or other countries - the list is very much in flux these days - is not presided over by a dowinant personal ruler or a patron, but by a class whose power derives from occupying state offices. Formally, it is organized along bureaucratic lines with a strict internal hierarchy, clearly defined spheres of competence, regular systems of appointment (requiring technical training) and promotion, as well as quite adequate money salaries. De facto, however, the state class is the collective sovereign, relatively immune from societal pressures generally, and willing to arrange itself with those groups whose conflict potential could become irritating or even threatening (e.g. those public employees who do not belong to the state class, urban dwellers, regional elites, businessmen, university students etc.). ${ }^{14}$ The state

14 Machiavelli says about the Prince, whose motives and interest position the state class shares, that as "long as he does not rob the great majority of their property or their honour, they reasin content. He then has to contend only with the restlessness of a few, and that can 
class's main preoccupation is the balancing act of containing threats to its position by sharing some of the spoils of office and of pursuing its own uaterial interests. "Self-aggrandizement combined with enough redistritution so maintain its tenuous and vital hold on the state" (Cooper:1981,46) has been suggested as the project of the class which, evocatively, has been labelled a "political aristocracy ... because its basic viues, its power, and its economic base result from its relationsilp to the state" (Callaghy:1987,92)15. In Nigeria, the retainers have replaced the absolute ruler but have, with uncanny consequence, introduced the full complement of the behavioural features of a patrimonial State.

\begin{abstract}
Personifying the state, ministers dress thenselves up in uniforms, build themselves palaces, bring all other traffic to a standstill when they drive, hold fancy parades and generally demand to be treated like Egyptian pharaohs. ... There are also vast opportunities for pickings in bribes, state contracts, diversion of public funds to private uses, and commissions of various sorts. To be a minirter is to have a lifetime's chance to make a fortune (Lewis:1965,3132 ).
\end{abstract}

It is noteworthy that in one crucial instance, the bureaucratic State has regressed to a proto-patrimonial stage. Weber argued that patrimonialism had an inherent tendency to develop in the direction of a rational-legal order. The demands on the system for administrative efficiency - e.g. to keep track of obligations, decisions and benefi-

be dealt with easily and in a variety of ways" (Machiavelli:1978,102).

15 Aristide Zolbcrg, in a similar vein, argues that the state class has "begun to constitute a genuine bureaucratic gentry, a class based not on their relation to property, but on their relation to the state apparatus" (2olberg: 1966, 141). 
ciaries - quite naturally introduced standards of continuity, equity and rationality which, initia'ly strengthened the ruler's central authority but which, aventually, undermined the patrinonial order. The bureaucratic Nigerian State, in contrast, resists simelar pressures and actually exhibits the reverse trend, informal and substantive incapacitation ompanying formal and substantive centralization. Its predecessor, the colonial state, provided a setting of predictability, "of protection for person and property, and of development of the vital infrastructure of transport and communications" (Abernethy:1988a,7). The bureaucratic Nigerian State, although greatly expanded, comparatively abundantly endowed with resources, and supplied with well educated staff is, by all accounts, chaotically organized, inefficient and corrupt. A Nigerian historian contrasts the colonial of ficers' "patriotism and probity, ... self-discipline and other remarkable ideals of public responsibility with the bad and dishonest example, ... the criminal wastage, the fraudulent and selfish mismanagement of the continent's resources practiced by the new 'predatory elites' in post-colonial Africa" (Asiegbu: $1984, X X I X){ }^{16}$ This regression is not mysterious.

16 To give but two illustrations of the colonial administration's standards of integrity Asiegbu is referring to. Sir Frederick Lugard, High Commissioner in Northern Nigeria and a 44 year old bachelor was getting married to Flora Shaw, the Colonial Correspondent of the Times (London). Having served almost a quarter century in various colonies and not availed himself of any vacation for several years, Lugard requested several days of special leave on full pay for the occasion. Sir Reginald Antrobus, Assistant Under-Secretary for the Colonies "put the conclusive official case against such an irregularity but ended with the remark that as the leave was for marriage it might be granted. Chamberlain [the Colonial Secretary] minuted his agreement with the case against the grant, noted the inconsistent decision and then benignly permitted the union of his two friends with the question 'who will say after this that Downing street is bound by red tape" (Perham: 1960,70). An example from the lower end of the colonial service was the con- 
The power of individual officials correlates inversely to bureaucratic rationalization. If spheres of competence and rules of conduct are clearly established, if the discretion of officials is circuascribed and the rights of the public are precisely defined, if decisions are recorded and subject to appeal, then the influence of individual office holders and their possibility for self-enrichment is severely constrained. ${ }^{17}$ Also, and in an interesting inversion of the adage that

siderable excitement generated by the unwarranted squandering of funds: one man was paid twice. "As a result of a query raised in Lagos in connection with the double payment to a reservist an investigation was made into the system of control exercised by the Records office of the Royal West African Frontier Force at Kaduna over such payments. It was disclosed that there was no regular recording the names of reservists or pensioners, nor were the cards held by the latter properly numbered and controlled" (Report on the Audit of the Accounts of Nigeria for the vear ended 31 March 1938 (Lagos: Government Printer, 1939), p. 25.

17 This point is well illustrated by four of a virtually limitless number of publicized cases. In 1979 it was alleged that N2.841 billion (about $\$ 4.4$ billion) were missing from the NNPC accounts because of a collusion of NNPC and Nigerian customs officials with foreign buyers concerning actual amounts of oil sold. Lacking documentary evidence, itself the result of NNPC's deficient monitoring and bookkeeping systems, prevented the presidential "Crude 0il Sales Tribunal" to settle the matter. It was established that large amounts of money had been stolen not, however, how much and by whom (cf. Onoh:1983,36-38). In the early 1980s, the whally government owned Nigerian External Telecommunications Ltd. was losing money despite flourishing business. An independent audit of the period August 1980-September 1981 established that at least N25 mn (over $\$ 40 \mathrm{mn}$ ) had been culpably lost "due to lapses in procedures and the inefficiencies and malpractices of its staff" (Daily Times (Lagos) editorial, 2 June 1982, 3; the auditors' report was reprinted in installaents in the National Concord (Lagos), 12-14 May 1982). A decade later, a Debt Verif ication Committee set up by President Babangida established that about "N6bn out of an estimated N9bn debt by the Ministry of Defence has been certified as false" (WA No 3827,7 January 1991, 3158). In accepting the Comittee's report, the Minister of Defence and Chief of Defence Staff, General Sanni Abacha, "acceded to the connittee's finding that technical problems relating to ineffective financial management at the ministry contributed immensely to the accumulation of the debts" (loc. cit.). Final$1 y$, in September 1991, the promotion of some 50,000 federal government empiuyees had to be suspended since "most of those lined up for elevation had bribed their way through ... others simply knew they did not nerit promotion and rould not be given any unless they did sonething about it" 
knowledge is power, obliviousness in a patrimonial-bureaucratic setting strengthens office holders. The paucity of statistical data, let alone reliable data, and the indifference with which this lacuna is treated in Nigeria might be understood as a reaction to the explosive nature of information. If the truth were known about population size and geographic distribution, labour productivity, the cause and the rate of inflation, government spending patterns, the rate of return on public investment, the size and cost of state apparatuses, general housing and health conditions, rural-urban, gender and intersectoral income differentials, disparities in access to health, sanitation and education facilities etc., the necessity to maintain state legitimacy and the aspiration to maintain state autonomy, would become incomparably more difficult tasks. Administrative reform programmes and other efforts to strengthen state officials' iccountability and to enhance process transparency will not be supported. The explanation, in the World Bank's delicate phrasing, is "that the process of institutional reform may be threatening and is therefore resisted, both by the decisionmakers at the political level and by the institutions whose own interests may be on the line. As a result, the initiative for much [institutional development work] tends to come from the Bank or other donor agencies" (World Bank:1984b,32). If the process of institutiona) entropy remains unchecked, the effectiveness of the state will decline and the calculability nexus, essential for broadly based development, is unfermined by state officials who act capriciously and who can do so

(WA No. 3863, 23 September 1991, 1604). 
with impunity. I will argue below that institutional ineffectiveness is not the cause of counterproductive policy choices, but that both are epiphenomena, indeed integral conponents, of the bureaucratic mode of production.

Patrimonialism, as Weber emphasizes, is a traditional order of domination which weans that "legitimacy is claimed for it ... on the basis of the sanctity of the order and the attendant powers of control as they have been handed down from the past, 'have always existed"" (heber: 1947,341 ). The Nigerian State is not a traditional one, its routs being not only alien but also rather shallow. As its status is not sanctified by tradition and thus beyond popular challenge, the Nigerian State's legitimacy is not a permanent quantity but a property which has to be carefully tended, lest it sinks below a critical threshold. At independence, the new State's legitimacy was at a peak because it had replaced alien rule by home rule and, of course, because of the widespread expectation that this changing of the guard would herald the advent of a state of general welfare which had remained elusive under foreign domination. Inspiring exuberance and lofty expectations marked the changeover from colonial to post-colonial state, lacking were only the resources - human, material and organizational to overcome backwardness. To what extent its foreign origins act like an albatross for the post-independence State is impossible to prove. What can be said is that the institutions of the inherited state, rudimentary though they were, were not consciously reorganized in an effort to adapt them either to local conditions or to the greatly enhanced role of the new State. Rather, the colonial state's institutional fra- 
mework was maintained in theory but over time eroded in practice. It was finally discarded in the convulsions of military coups and a civil war.

To explain this degeneration or patrimonialization, one of whose telling symptoms is pervasive corruption, 18 it has been guggested that the State is still considered an alien entity and that "he is considered a hero who can successfully defraud and appropriate public service resources. This notion of white man's job has gained wide currency even among the bureaucrats themselves. Sacrifice and diligence are not necessary because the job is no man's" (Okoli:1980,12; similarly Ayoade: 1988,104 ; Leys: 1978,$341 ; 0$ lowu: 1983,292$)$. This is an interesting if somewhat psychologizing hypothesis and therefore one quite difficult to substantiate. Not entirely convinced by it, I tend to be-

is In the 1970s, the Permanent Secretary of the Nigerian Federal Ministry of Establishments, Mr. M.A. Tokunboh, stated that it "is not an exaggeration of the tragic events of the years since independence to say that all efforts to establish a just and efficient administration have been frustrated by corruption. The evil exists in every facet of our society. You bribe to get your child into a school; you pay to secure a job and you also continue to pay in some cases to retain it; you dash the tax officer to avoid paying taxes; you pay the hospital doctor and nurse to get proper attention; you pay the policeman to evade arrest. This catalog of shame can continue without end. Against his background, administration at national, state and local levels has been adversely affected. ... This sordid state of affairs has virtually developed into a conspiracy against the people" (cited in Aina:1982, 71). Because of the very nature of corruption, hard and especially conprehensive evidence is difficult to come by. However, even the uncovered incidents are breathtaking. In most years, the Africa Contenporary Record carries a subsection entitled "Corruption" in its Nigeria chapter in which the year's nost brazen instances are recounted (ACR: 1973,B653-654; 1974,B687 694-695; 1975, B731; 1976,B742-743; 1977, B786; 1976,B669-670; 1979,B737-740; $1987, B 129-130 ; 1988, B 117 ; 1989, B 115-116)$. See also Nigeria:1987,212215; Schatz:1977,243-250; WA No, 3415, 24 January 1983, 190-192; AC No 14, 13 July 1990, 4-7; AC No 6, 22 March 1991, 4-5; WA No. 3861, 9 Septenber 1991, 1494-1495; AC No. 9, 27 Septenber 1991, 3-5. 
lieve that the opportunity structure provided by the bureaucratic state more plausibly explains Nigeria's rampant corruption. ${ }^{19}$ Its temptations triumph over all but the saintly, and set in train a vicious, self-reinforcing and accelerating circle. If all civil servants are considered corrupt, an atmosphere of suspicious certainty ensues in which the honest ones are suspected of exacting a higher price. Corruption functions like a virus. Once

it enters the blood of a public organization, it spreads quickly to all parts. If it is not diagnosed and treated it will eventually destroy public credibility and organizational effectiveness. Even if treated, there is no guarantee that it will be eliminated or that all infected areas will be reached. The possibilities of stamping it out altogether are remote as long as the machinery responsible for eliminating it is also corrupt" (Caiden, cited in Hope: $1985,2-3)$.

In a patrimonial order, the abuse of office by individual retainers will be curbed by the patron whose own power and income is threatened by his subalterns' excesses. However, no such corrective exists in a socially detached and uncontrolled State, bureaucratized in form vet not in substance, ${ }^{20}$ Unchecked self-seeking by officials is an ele-

19 defined succinctly and comprehensively as the "behaviour which deviates from the formal duties of a public role because of private regarding (personal, close family, private clique) pecuniary or status gains; or violates rules against the exercise of certain types of private-regarding influence. This includes such behaviour as bribery (use of a reward to pervert the judgement of a person in a position of trust); nepotism (bestowal of patronage by reason of ascriptive relationship rather than merit); and misappropriation (illegal appropriation of public resources for private-regarding uses)" (Nye:1967,419).

20 Focusing on the political macro-context, ny reading of the syndrome deviates from others which either take the analytical hign road, e.g. modernization theories' vjewing of corruption "as a phase, a transitional condition ... growing pains rather than malignant disease" (hilliams: 1986,25 ), or which look for aberrant attitudinal catalysts such 
ment, indeed a logical consequence, of an autonomous State, such as Nigeria's, whose rationale is decidedly not to serve the public. It appears if there are formal and material opportunities. Formal opportunities are the effect (and, one could uncharitably surmise, the purpose) of the State's heavy regulatory intervention in the economy. In Nigeria, the multitude of visa, nationality and quota stipulations as well as the wide range of licencing requirements from a variety of local, state and federal authorities, erect formidable thresholds of entry into the formal economy. Because it lacks economic logic and coherence and also because it can be bypassed, with money, the State's gatekeeper role has little developmental merit. To the contrary, because it is so lucrative for the officials behind the ubiquitous roadblocks, it has seriously retarding and dislocating consequences for the national economy; it keeps out all but the most determined, the affluent and the well-connected. The problem is not that the doors are locked completely against commercial enterprise - this would be self-defeating; the trouble is that there are so many doors which can (or have to) be

as its being: an integral part of "the present accept-ed value system of Nigerian society" (Legum:1972,B653); the result of "greed or love of ostentation, either in the culture at large, or only anong an élite or clique" (Brownsberger:1983,216); the "general absence of a civil service work ethic" (Hope:1985,3); the surrender to "strong obligations of family, tribe, and district" (Leys:1978,341); the lack of discipline of the Nigerian people generally as suggested by General Obasanjo (Ayoade: 1988, 109), or of the State class which aakes corruption "siaply and squarely a failure of leadership" (Achebe:1983,1). Without atteapting to assess the validity of these explanations, ay point is that they are at best partial. I contend that corruption is not just a carbuncle on the body politic but the life blood of a patrimonialized bureaucratic state which, therefore, cannot be fully understood by concentrating on isola ved epiphenomena while disregarding the systemic context which nurtures this particularly marasmic behaviour. 
knocked on (Rimmer:1978,159). The material opportunities of corruption are summed up in the truism that the "greater the proportion of material resources controlled by the state, and the wore extensive the stata's regulation of the private economy and social life, the greater will be the level of corruption" (Diauond, cjted in Ergas: 1987,12). While tempting material circumstances might explain the occurrence of corruption, they cannot interpret the phenomenon.

Corruption hinges on the existence of prescribed rules of conduct which car be illicitly transgressed. If there are no rules, corruption ill its modern connotation does not exist. As was suggested earlier, patrimonialism, from a legal-rational perspective is virtually synonymous with corruption which, provided it is practiced in moderation, is not at all deviant bellaviour. The same holds true for the bureaucratic Vis.?ian State where officials relish their freedom to allocate resourifs irrespretive of rules concerning the dispersal of funds by impersonal, formalls rational, that is, bureaucratic criteria. Again, it is II 1 corrurtion per se which threatens the State's legitimacy. As Climua trhebe ubserves in his compelling novel about the political procoss in Nigeria, the people "were not only ignorant but cynical. Tell them that this man had used his position to enrich himself and they nould ask you ... if you thought that a sensible man would spit out the juicy morsel that good fortune placed in his mouth" (Achebe: 1966,2). What threatens the State's legitimacy are either excesses or the unwillingness to share the ill-gotten gains. In such cases the tension betheell rhetoric and reality escalates temporaril: and redress is sought in courses of action escalating in approxinately the following 
sequence: ethics codes (Aina:1982,73), ad hoc comissions of investigation (Eker:1981,178-182), permanent institutions such as the Public Complaints Commission or the Corrupt Practices Bureau (Olowu:1983,293), purges (Chiedo:1979,89-91) and, finally, military coups. So far, all military take-overs and palace coups have been justified with the need to eradicate corruption, and chances are, the next ones will be too. In sum, corruption in a patrimonial or in a bureacratic state (as defined in the subsequent section) is not so much a character-defect of individual officials as system-conforming behaviour. While it does not threaten a patrimonial order, mostly because of the patron's selfinterest in containing it, it seriously weakens a pseudo-modern State like Nigeria's. Here, there are no institutionalized self-correcting and self-limiting mechanisms, and the only response the system regular15 generates in order to arrest a seemingly unstoppable process of entrops, is military intervention. The difference between the causes for mjlitary coups in Latin America and in Africa are noteworthy. In the latter the military typically steps in to prevent the state from selfdestructing, that is, to decisively settle intra-state conflicts. In Latin America, in contrast, the military intervenes in order to redress the ungovernability brought about by multifarious social pressures on the state (cf. Nef:1990). Here it is, in effect, an act of social containment while in Africa it is the decisive settlement of intraelite conflicts.

In Nigeria the pattern of military interventions was established not long after the British withdrawal. The great hopes which had surrounded independence were dashed soon enough. Even so, the ensuing 
frustrations did not result in any significant threat to the State as such which, as a military one, no longer depended (or depends) on popular support to the same extend as a civilian regime. Yet even a military-bureaucratic regime requires a minimum amount of popular support (or a maximum of public acquiescence) because the "pressures arising from the discontent of the masses who are governed, frow the passions by which they are swayed, exert a certain amount of influence on the pulicies of the ruling, the political class" (Mosca:1939,51). More important, however, is the somewhat more heartfelt backing of important groups which have the capability to disrupt or threaten the state more immediately. A tro-tier strategy follows. The general population is plased to with policies such as the introduction of an universal primary education policy - which, after a splendid inauguration very quickly disintegrates hecause of inadequate financial commitment ${ }^{21}$ - or with publicity stunts such as the mass-expulsion of aliens or the clamor for reparations from the riest for the damage done by the slave trade. More tangible and more serious are the policies of coopting critically impertant groups.

The rational-legal principles which characterized the colonial State were never officially relinquished, only emptied of their con-

2) The diversion of resources is another if intimately related syndrome. During the Third Development Plan (1975-1980) and in support of the universal primary education scheme, N636 aillion (about \$1bn) was allocated for the construction of 150,000 classrooms. This proved insufficjent and had to be supplemented by another N126 million, yet only 63,000 classrooms were completed at unit costs of about $\$ 18,000$. "This is despite the very poor quality of work done. ... much of what is ostensibly spent on education is not wholly used for education but also diverted ... as commissions, fees, kickbacks, bribes and other earnings for those who control this very lucrative industry" (Nigeria:1987,60). 
tents. In what amounts to an inversion of Weber's chronology, the Nigerian State reverted from a rational-legal to a pre-sodern modus operandi and acquired distinctly patrimonial features in its behaviour (synopsis above, Nos 9-17) while aintaining bureaucratic traits in its organization (Nos 3-4) and substituting class doaination for the domination by a traditional ruler (Nos 2 and 5-8). Therefore, if the cogency of heber's ideal type is to be maintained, the Nigerian State cannot unequirocally be called patrimonialist, despite the wide range of patrimonial traits in evidence. Nor is it truly satisfactory to "modernize" the concept by introducing the notion "neo-patrimonialism" in an effort to cover those former colonies where "the bureaucratic logic was applied to the patrimonial logic" (Medard:1982,179). This example of concept-stretching misses the point of both patrimonialism as a unique order of domination and of the reality in present-day Africa. The misfit is not due to diverging operating logics but because of a different category of cast. My point is that there is a fundamental dissimilarity between an order of domination in which Herrschaft ${ }^{22}$ is exercised by

22 Translating Herrschaft into English is problematic and has generated a veritable debate. Talcott Parsons, one of Weber's main translators into English, seems to have been concerned less with a faithful rendering of Weber than with fitting him into his own theoretical edifice. He translates (or better interprets) Herrschaft as "imperative control" (heber:1947,152). In his own work he explicates Herrschaft as "leadership" or "authority" and suggests a "societal interest in leadership. This is essentially what Max Weber meant" (Parsons:1960,150). Parsons criticizes Bendix who, in my view correctly, interprets the concept as "domination" because, for Parsons, this translation implies "that a leader has power over his followers [whereas] the critical factor from Weber's point of view [... was] the integration of the collectivity in the interest of effective functioning" (Parsons: 1960a,752; emphasis in original). By insinuating that the latter is crucial in Weber's thinking, he downplays domination, coercion and power which are not only the correct deno- 
- a single patron who is legitimated by tradition, who governs with a personal staff beholden to him, and who is unconstrained by rules which can be sued for; or by

- a class which has neither traditional nor popular legitimacy, which governs by virtue of its occupation of state offices, which treats the State and its resources like private assets without being seriously constrained by external forces, and which is ostensibly, though not actually, bound by rules.

It is this latter complex of class domination through the bureauCrat ic apparatuses of the state which, in my opinion, characterizes Nigeriata.

tat ions of the German terms Herrschaft and Herrschaftsform, but also very clearly the connotations of Weber's usage. Roth and wittich in their edition of Economs and Socjety, translate Herrschaft as domination (Weber: 1978,53 ) and explain their reasoning in considerable detail (ib: 1.,616.2). For a systematic analysis of Parsons' misrepresentations of Weber sec Antonio: 1984 and Scaf : 1989. 


\section{a) The Bureaucratic State as a distinct Order of Donination}

Before proceeding to a review of its behavioural properties, the bureaucratic Nigerian State will be delineated briefly in structural terms. A serviceable conrept must take account of four essential features:

- the existence of a system of hierarchically structured institutions (buroaurracy), staffed by tonured and - rhon appliablin elected officials (the state class) who are directed by a frequently changing group of leaders; these leaders are recruited either straight from within the state class or from closely associated groups;

- the State's resource independence from society. Its control of the oil revenue endows it with a rent income and obviates the need to finance itself by extracting surplus from the production of civil society i.e. through taxes imposed on its citizens

- the State's economic centrality. This implies the State's claimed monopoly over economic regulation, its extensive participation through parastatals in the production process itself, considerable control through equity holdings of private industry, and a de facto preponderance in societal resource allocation. One of several significant effects of this economic centrality is that the state becomes the principal force in the 
formation of that class which is dominant in society;

- the State's territorial scope and integrity. The latter is not threatened externally but entirely internally, namely by the centrifugal forces of the country's ethnic diversity. This diversity is the zesult of the arbitrariness of the country's creation by the British colonizers, and it is exacerbated by intense competition for state resources. Preservini unity depends on successfully maintaining the State's monopoly of the legitimate use of force. It is a prominent state goal as well as all important terrain on which to acquire or to lose legitimacy.

The bureaucratic Nigerian State, in my conceptualization, denotes a generic order of domination as well as a concrice organization, a decision unit, an actor, rather than, for example, an arena for class striggle or a neutral processor of societal pressures. This organizafion claims control over in territory and its people. It consists of the governaent in the widest sense (i.e. including federal, state and local authorities as well as parastatals) and is staffed by the state lass which I take to consist of the set of persons who collectively o:cupy the positions of decisional authority in the Nigerian polity or whu command over sizeabl public resources. Naturally, the "state" is a reifying shorthand for the more complex reality that institutions and apparatuses as such do not behave in this way or that, but that only state officials, that is, the members of the state class do. "For sociological purposes, there is no such thing as a collective personality 
which 'acts.' When reference is made in a sociological context to a 'state' ... or similar collectivities, what is meant is ... certain kinds of ... social actions of individual persons" (Weber: 1947,102). It is not its juridical rule-making function through which the Nigerian State conditions and orders social iffe, but through its economic centrality, that is, through its role as framer of the macroeconomic context, as gatekeeper at various junctures in economic processes, as supplier of inputs, as at least the nominal guarantor of legal rationality, as direct producer or as controlling share-holder in many private enterprises, and as distributor of economic benefits and costs. In other words, the state is not limited to regulating and maintaining a rramenork within which private activity takes place; its direct participation in the production process and its command over resources make it the most salient actor in the national economy. The Nigerian State, more than any other identifiable unit, is in a position to, and actually does, alter not only the country's social and economic structure but also the behaviour of many Nigerians.

The adjective "bureaucratic" is to qualify the nature of the Nigerian state as an order of domination and to distinguish it from other possible manifestations of stateness such as "aristocratic," "democratic," "monarchic," "one-party," "patrimonial, " theocratic" etc. In all these instances, the qualifier indicates the locus of the State's power base and its ruling element. It also allows some inferences concerning its recruitment practices and possibly even its operation, although it is understood that these attributes are not exclusive and that any given state can combine several. The bureaucratic 
State is a State controlled by bureaucrats. In analogy to James Burnham's characterization of the bourgeois State this means "fundamentally a state which, by and large, most of the time and on the most important occasions, upholds those rights, those ways of acting and thinking, which are such as to permit the continued social donination of thelbureaucracy]" (Burnham:1960,69). Designating the Nigerian State "bureaucratic" thus is to specify a form of government and a distinctive order of domination, not a manner of administration. The Nigerian bureaucra$c y$, needless to say, bears little resemblance to Weber's ideal type of a modern bureaucracy which, as an instrument of policy execution for a legal-rational authority, he considered the epitome of (formal) rationality. Indeed, for weber, the

development of modern forms of organization in all fields is nothing less than identical with the development and continual spread of bureaucratic administration. ... Experience tends universally to show that the purely bureaucratic type of administrative organization ... is, from a purely technical point of viek, capable of attaining the highest degree of efficiency and is in this sense formally the must rational known means of exercising authority over luman beings. ... The choice is only that between bureaucracy and dilettantism in the field of administration (heber: 1978,223).

heber's conceptualization of modern bureaucracy as virtually synonsmous with efficiency dominates in the social sciences and leads (1) assertions like: "the problem of African administration is ... that it is 'underbureaucratized" (Hyden: 1983,78 ) or that "African s ates do not have true bureaucracies" (Callaghy:1987,91). Paradoxically and in shary intrast to such implicitly positive assessments, bureaucracy and more pronouncedly still the adjective "bureaucratic" have, in collo- 
quial usage, manifestly negative connotation and not, as could be expected, because of any inherent, Huxleyan and Orwellian tendencies

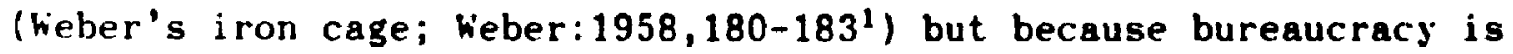
seen as the embodiment of inefficiency, as "the giant power wielded by pıgmies ... [displaying] a natural kindness for vediocrity, a predilection for categorical statements and reports" (Honoré de Balzac, cited in Smith:1988,5). It is the bureaucratic method of transacting business and the moral atmosphere it spreads which "often exert a depressing influence on the most active minds. Mainly this is due to the difficulty, inherent in the bureaucratic machine, of reconciling individual initiative with the mechanics of its working" (Schumpeter:1962, 207). Rather than representing "domination through knowlecige" (Weber: 1978,225 ), bureaucracy here is associated with, at a minimum: officious arrogance, formalism and pedantry; long-winded, paper-intensive procedures, paralyzing red tape; unresponsiveness to the needs of the public and immunity against consequences of errors; inconsiderate, unimaginative, routinized operation; a wasteful system, overstaffed, overpaid and possibly corrupt. Even though the Nigerian State's operations can be aptly described in these terms (cf. Obasanjo's annual public service

1 The iron cage is the image of the constraints on human action imposed by the success of rationalization processes. "The cage is iron because the main forces of modern life, science, capitalism, and bureaucratic organization are triumphs of rationality and so the and has no purchase point to attack them. They are ind incarnated into legal codes and administrative organizations that pronise order, predictable decisions, regularity of procedures, and responsible, objective, and qualified officials; into economies that operate according to principles of calculated adrantage, efficiency, and means-ends strategies; and into technologies that promote standardization, mechanical behaviour, and uniform tastes" (wolin:1981,415). 
Jecture, reported in WA No 3824,10 December 1990,3017 ), this is not th:e reason for calling it "bureaucratic."

Two more disclainers: despite some phenomenological parallels, the Nigerian bureaucratic State does not either deserve its designation because of any relation to Guillermo O'Donnell's model of a "bureaucratic authoritarian" state or to Gaetano Mosca's prototype of a "bureaucratic" state. A brief digression is in order to establish the gerire-difference between the Nigerian phenotype of a bureaucraticmilitary regime and its contemporary Latin American or historical Euroletan equivalents. To begin with Mosca's bureaucratic state: it is

just a feudal state that has advanced and developed in or-
ganization and so grown more complex. ... The main charac-
teristic of this type of social organization lies, we be-
lifie, in the fact that, wherever it exists, the central
power conscripts a considerable portion of the social
health by taxation and uses it. . . to support a more or
less extensive number of public services. The greater the
number of officials who perform public duties and receive
their salaries from the central government ..., the more
bureaucratic a society becomes (Mosca: $1939,81-85$ ).

Firstly, the genesis of the Nigerian State was not an evolutiona$r$ : process but an alien creation, bequeathed to Nigeria at independence and transformed thereafter. Secondly, welfareism might well be the $\mathrm{Ni}$ gerian State's self-image, even if it has no basis in reality. Third$1 y$, and in line with Mosca's argument, the growth of the public service does indeed bureaucratize the Nigerian State, however only in the specific sense outlined below. The contemporary Nigerian State does not display any of the key features of rational legal authority such as the methodical separation of office and incumbent, the systematic rule- 
bound conduct of office, specified and precisely delineated spheres of competence in an organizational set-up in which each office is endowed with all the functionally indispensable yet clearly defined and circumscribed powers, the necessity to formulate and record decisions in rriting and the possibility to appeal decisions or to register grievances to a hierarchically superior office (Weber:1978,217ff). In the absence of institutionalized accountability, discipline, hierarchy, inpartiality, specialization, transparency and responsibility, the bureaucratic Nigerian State takes its designation emphatically not from ans substantive aspect of its manner of operation, but from the fact that the decisional center of the polity is the bureaucracy (rather than a personal ruler, a parliament or a party). Whereas legal-rational bureaucracy is orjented towards and strictly bound by rules, the iigerian state bureaucracy is thoroughly patrimonialized and driven by power considerations. Therefore, the concept of the bureaucratic Nigerian State implies a dissolution of the time-honoured dichotomy betheer politics and administration, between the superior responsibility of goal setting and the subordinate duty of policy execution, by collapsing the tho functions into the competence of the bureaucracy. A (senior) Nigerian bureaucrat is not in authority, merely occupying an office and being subject to an impersonal order (cf. Smith:1988,2). His power derives from his personal standing within his peer group and from the degree of leadership support he enjoys. It is thus the conspicuous circumstance of the bureaucracy's role as the politically dominant actor - instead of being a subsidiary instrument of administration - which harrants the qualifier "bureaucratic" as the wost essential 
characteristic of the Nigerian State.

The bureaucratic authoritarian (BA) States of Argentina, Brazil, Chile and Argentina of wuch of the past quarter century were similarly characterized by a bureaucracy whose political hegemony and unaccountable rule was guaranteed through the military. However, despite this phenomenological similarity, few insights would be gained from crafting O'Donnell's BA model onto Nigerian reality. For one, O'Donnell is emphat ic that the "BA is a type of capitalist state, and should therefore be understood in the light of the distinctive attributes of capitalist states in general" (0'Donnell:1988,2). As will be argued below in considerable detail (pp. $290 \mathrm{ff}$ ), it would be seriously aisleading to perceive Nigeria to be capitalist. Secondly, the BA was inposed because its predecessor displayed an "extremely low level of aut.onomy with respect to all sectors and classes [and] had become a battleground for social forces whose micro-rationalities it could not reconcile with the normal functioning of the economy" (O'Donnell:1988,24). The emergence (If an authoritarian (BA) State, thus, was the reaction to a serious socio-economic crisis which had resulted in massive social upheavals. Earlier in the century, and facilitated by extremely favourable conditions for Latin American exports, something akin to a welfare state was instituted in an attempt by the elites to prevent social explosions. Once unfavourable developments of export and import prices rendered this inclusionist strategy less and less viable, the military intervened, essentially acting in the interest of the haute bourgeoisie whose living standards were endangered by the demands of the working and middle classes (Nef: 1990,374$)$. 
In Nigeria, in contrast, the wilitary has always intervened on its own behalf rather than vicariously for some other class whose existence was threatened by competing social forcas. Here the overwhelaing majority of the population, the peasantry, had no politiral voice under colonialism and did not gain one after independence. The British colonial regime was replaced seamlessly by a government which represented, and consisted of, the derivative widdle class (see below pp. $254 \mathrm{ff}$ ), largely an urban-based elite which transformed itself at independence into the state class. Conflicts within this class, that is, an intransigent struggle for state power in which popular sentiments wight have been much more instrumentalized than represented, threatened the very survival of the State and prompted the intervention of the only existing national (rather than regional or sectional) force, namely the military. However, since the successive military regimes were equally unable to preserve the State's managerial competence and, instead, regularly degenerated into corruption and ineffectiveness, they were in turn toppled by palace coups: only two of the six successful military interventions replaced civilian regimes. Therefore, while the BA's foremost purpose was the exclusion of the "popular sector" (O'Donnell: $1988,96)$, the Nigeria. military intervened to decisively settle conflicts within the State. This also explains why the declared policies of the various military regimes differed only marginally from their respective predecessors, and why each regime's claims to legitimacy here/are based on a promise of higher quality governance but not on any meaningful programmatic difference. In sum, whereas the $B A$ is indeed an arena for class struggles, the bureaucratic Nigerian State, for 
raasons which will be explained throughout this study, is highly autonomrus and not subject to social pressures. Also, in the former, political power is a function of economic success, whereas in the latter, economic success is "the fruit of political power rather than the seed from which it springs" (Mazrui: 1977,474).

Still, given that the wilitary rules the country at present and that it has done so for over twenty of Nigeria's thirty-odd years as an independent country, decision to label the state "bureaucratic" with no reference to the military, might seem to call for an explanation. I submit that the main reason why it would be misplaced to perceive and analyze Nigeria as a military and not as a bureaucratic state is the virtual consensus among analysts concerning the pre-erinent role in policy making consistently played by the civil service (cf. Adamolekun: 1986; Ahinyele:1979; Koehn:1983; Olugbemi:1979; Ostheimer:1973; Othman: 1989; Otobo:1986). Nigeria takes after the prototype of "military regimes iustalled by coup d'état, [with] a civil service-military axis in which armies have the physical power to conserve he regime, while the "ivil service rields effective executive power in the state" (First: $1970,432)$. As could be expected from intra-state bargaining and coalition-building, the weight of various segments varies over time. After the 1966 military coup, for example, senior civil servants successfully resisted the plan of military leaders "to appoint them to the political headship of their winistries. They preferred to remain civil servants as before" (Asiodu:1979,82). This reluctance did not last and under the Gowon regime the species of the super permanent secrelaries ("super perm secs") emerged. These were "not only partici- 
pating in important decisions, they [were] also arrogating auch more political power than the ministers during the civilian regime" (Akinsanya:1976,75). The pendulue gwung back under the Murtala Mohamed regime when the civil service was purged and permanent secretaries banished from active participation in the deliberations of the highest policy-making body, the federal executive council (Adanolekun:1986, 126). This relegation did not last and the civilian bureaucrats' influence under the subsequent regimes - excepting the Second Republic when power and spoils had to be shared with politicians - has been decisive. Empirical studies have invariably confirmed the comon sense expectation that a military regime which is not deliberately destructive, firstly does depend on civilian bureaucrats for policy preparation and implementation as well as for general administration and, secondly, that the civil service as a whole and/or some of its individual members consistently emerge among the principal beneficiaries of government policies.

A second reason for de-emphasizing the military aspect of the bureaucratic Nigerian state is that, in contrast to for example, the distinct and energetic developmentalist reforms undertaken by Praetorian Taikanese (Amsden:1988) and Peruvian (Trimberger:1978) military regimes, or the equally energetic if reactionary efforts at social engineering by their Burmese (Feit:1973), Argentinian, Brazilian, Chilean (Nef:1990) or Sudanese counterparts, the Nigerian military has never displayed a comparable unity of purpose. One notable exception was the conduct of the Civil War and, even more remarkable, the achieveaent of national reconciliation after its successful suppression of the seces- 
sionist revolt. Nevertheless, the role of the ailitary will be left unconsidered mainly because, for present purposes, it can be subsuned as a branch under the umbrella of bureaucracy. Nigeria has no traditional warrior class and the alitary establishment was created at independence, drawing its nembers from a wide ethnic, regional and social spectrum. At the outbreak of the Civil War, the military consisted of only 518 officers and 10,500 men (Ostheiner:1973,114) which grew to over 250,000 by 1970 and has since 1989 been reduced to about 95,000 (IISS:1990,139). This war-related, massive expansion led to a socially highly diverse membership which supports the contention that the military is not the tool of any discernible class or ethnic group. It is chiefly distinguished from the social mainstream by a comparatively authoritarian empathy for virile values such as austerity, discipline, probity and national unity, especially upon assuming power or in autobiographical retrospectives after having surrendered it. ${ }^{2}$ To illustrate: ten years after leaving office, General Obasanjo described the civil service as "inefficient, corrupt, ineffective and unreliable" and, to remedy the situation, he called for an attitude change which,

2 The Buhari regime launched a War Against Indiscipline (WAI) which, for instance, was intended to implant the merits of queueing in the Nigeri un population. In this context, 4 August 1985 was proclained "National Sanitation Day." Male employees were instructed to report to their workplaces with brooms, shovels and rakes where they were organized in groups to clean the cities, while women and children were expected to clean homes. Policemen at roadblocks loaded garbage into private notorists boots and forced them to take it to rubbish dumps (ARBe:7/1985,7843). After WAI had run out of steam, it was succeeded by NON which "continued its prederessors goals of attempting to instil discipline, patriotise, nationalism, altruism and cleanliness. The final Saturday in each month was proclained as 'sanitation day,' when no cars would be allowed on the roads between $7 \mathrm{a.m}$. and noon to force people to remain at home to clean their houses. It also became an offence to fly a torn national flag" (ACR:1988,B111). 
he said, could be achieved "through a conbination of weans such as training, motivation and leadership by example" ficited in WA No 3824 , 10 December 1990,3017$)$.

In the more than twenty years of ailitary rule, the actual running of the affairs of state had, with a few notorious exceptions, no discernible military quality but exhibited the bureaucratic-patrimonial traits which are presently being discussed. General Murtala Mohanmed, who became Head of State after the third coup d'état and who was assassinated in another coup attempt a mere six months later, declared about his comrades in the previous regime that the ilitary governors were "running their fiefs like private estates" (cited in Turner:1976,74). Indeed, a commission of inquiry established by General Mohanmed found ten of the twelve military state governors guilty of corruption and misuse of funds totalling over 16 million naira (Nigeria:1976e; Olorunsola: 1977,127; Othman:1989,121). A similar ratio obtained after the Buhari coup on New Year's eve 1983. The "Recovery of Public Property Tribunals," established to investigate and punish the corruption of the overthrown Shagari regime's politicians found guilty - and convicted to serve between ten and twenty-three years - not less than fifteen of the nineteen ousted governors (ACR:1986,B546-547). The present Babangida regime which toppled and succeeded Buhari's did not engage in comparable investigations and, in fact, released many of those convicted under Buhari. This is not surprising, given that the two regimes, except for a handful of changes at the very top, are virtually identical, and that Buhari's ouster was explained as a reaction to the latter's relentless authoritarianism. There is not a little irony in the fact that General 
Buhari himself came under a dark cloud of suspicion of having engaged in corrupt practices while pontificating on the virtues of discipline, honesty and service (ACR:1987,B124-125). As has been suggested earlier (pp. 146ff), rather than viewing corruption principally as indicative of sharacter defects of individual officials, civilian or military, it wight be more appropriate to perceive it as system-conforming behaviour in a bureaucratic-patrimonial state. ${ }^{3}$ The important question is, then, who are the key-players in the bureaucratic Nigerian State, and what are their motives?

Following Weberian reasoning, I assume state policies to reflect the vested interests of the burenucracy which constitutes an identifiable status group, aptly characterized as the state class. A quick aside: the issue of class analysis and its pertinence for the Nigerian situation will be addressed in considerable detail below (see pp. $237 \mathrm{ff})$. For now I wish to limit my justification for choosing "class," rather than "elite" or "group" or "stratua" etc. to the bureaucrats"

3 Gunnar Myrdal made this point when he suggested that corruption was "one of the forces that help to preserve the 'soft state' with its low degree of social discipline" (Myrdal:1968,952). As a matter of fact, the bureaucratic Nigerian state displays great resenblance to the "soft state" which, in the $1960 \mathrm{~s}$, was but an innovative and astute label for the anachronistic phenomenon of patrimonial substance in legal-rational guise. The "soft state" is characterized by, inter alia, the following truits:

- heary state intervention in the economy through developnent plans, general regulating and direct investment (ibid.,709ff);

- a seneral absence of the rule of law. The "overgrowth of aduinistrative discretionary controls" (ibid.,926) peans that even where laws exist they are of ten circumvented or unevenly applied (ibid., 933);

- governments expect extraordinarily little of their citizens and there are few obligations either to do things in the interest of the community of to avoid actions opposed to that interest (ibid.,896);

- widespread corruption (ibid.,937ff). 
strategic position in the economy (Marxian criterion; cf. Marx and Engels:1975,26ff) as well as to their socially privileged status based on income, wealth and power (Weberian criterion, cf. Weber:1947,424). The interests of the state class are considered central to any analysis of the behavioural dynamics of the bureaucratic Nigerian State. In analogy to Machiavelli's Prince, the state class is considered a selfinterested, (practically) rational actor desirous to hold on to power and to maximize its personal returns. It is not primarily concerned with promoting the welfare of society at large which, in any event, has found ways to cope, "to reproduce itself" in the Marxist argot, without significant support from the State.

Since politics involves both spoils and policies, the quest for state office or simply political power may be looked on as means of private gratification, but it may also be looked on as a means to getting things done. Since it is also quite normal in the social sciences to find what one is looking for, special care is necessary to avoid the

4 The state class's paramount ambition is to remain in power in order to safeguard its material privileges. The resulting behavioural dynamics form a coherent ensemble ard are substantially those of a patrimonial state as outlined above, namely the tendency of office (ab) use to acquire personal wealth, substantive regulation of the economy and, as a result, the development of bureaucrats into a status group independent from and above the population. Extensive economic control, whatever the resulting opportunity costs, is in the interest of the state class, because it a) permits the selective focussing of benefits and costs; it b) creates clientelist relationships of dependency between outsiders and officials and thus is a tool to generate legitimacy; and it c) creates opportunities for corruption; this reason aight also inform the State's considerable participation in the economy through parastatals. The state class's reluctance to deveiop rational accounting systens (as this would reduce personal discretion) and the opposition to the emergence of an independent bourgeoisie (as this might threaten its political and economic power basel, are in keeping with the logic of its class position. 
fallars of the pars pro toto, that is, to concentrate on a partial aspect of a phenomenon and to extrapolate the findings with the attendant (-laim that doing so explains the whole. One example for this fallacy is the aseptically abstract and static - and therefore apolitical analysis of current Third forld States' intervention in the economy (usually taken to be the modern sector) which fails to distinguish form from function while implicitly assuming the State's comonweal orientatiun. Such studies commonly identify (and reconmend) a more or less d.tailed and comprehensive laundry list of economic polycy measures 5 without sering them as part of a larger whole. Questions not addressed al thether these discrete policies cohere to a larger, integrated patt'rn an! are being pursued consistently over time; who rules and who liruefits; why certain policies are implemented but. ot others; or how and why the State prevents the emergence of a different economy? ObViulal!, the State's influence on the economy is greater but also different that the sum of its individual policies vis-à-vis modern industr. hlich, at least in Nigeria to which Biersteker refers inter alia, is but a small enclave in the economy. More important is the degree of lationplit! the State can infuse in the economy: "how conducive is the political and administrative framework to econonic development irres-

5 Good examples are the following, all taken from Biersteker's articie: attempt to influence the behaviour of private entrepreneurs positivily through fiscal, moneta"y, investment, and trade policies; at 1 (mpt to regulate their behaviour and direct their activity into soially acceptable production through consumer or environmental protection, wrher safety programs, and wages legislation; attempt to mediate conflicts betheen capital and labour; distribute the social and private protuct of (apital; produce goods and services itself; plan and therefore rittionalize the entire process (Biersteker:19>0,480). 
pective of particular policies?" (Sandbrook:1986,319). Prominent are such factors as political stability, legal predictability, adwinistrative efficiency and financial rentability. In other words, what matters in addition to the market size is the general economic climate created and sustained by the State - primarily its formal but also its substantive rationality - as exemplified by the quality and probity of policy implementation in related fields such as education, infrastructure, administrative, monetary and legal systems.

The structure-functionalist public administration literature of the 1960 s addresses the issue cluster of a Third World State's general level of performance (its responsiveness to the needs of development, its efficiency, probity and its self-restraint) rather naively, statically, ahistorically and also quite unpolitically, by analysing the balance of porer betreen a developing country's political institutions and its administrative institutions. It treats them like black boxes on a pair of scales and posits as the "correct" balance (to ensure policies broadly representative of the public interest) a preponderance of the former over the latter (Riggs:1963,122ff). Given that "certuin actions of bureaucracies in economically little developed countries are often directed, not towards the fulfillment of systemic goals, but rather of private or sectional goals" (Hoselitz:1963,171) the probability is feared that bureaucratic overparticipation will stunt the growth of viable representative institutions (Sigelman:1972,525). The suggested solution is to slow down the development of administrative institutions and to accelerate the development of political institutions (Riggs: 
$1963,166 \mathrm{ff}) .6$ Disagreeing with the focus and level of analysis of this prorspective, 1 contend that the crucial issue is less that of a balance within the State as that of a balance between the state and society and, crucially, between the respective shares and roles in the economy played by the private and the public sector.

In the Nigerian experience, the political parties of the First and Second Republics were vehicles to gain access to the State and as silit they were far frum representative of any societal interests, excroting those of the party activists themselves. Their legitimacy was basind on claims to represent distinctive regional or ethnic interests asininst other resional or ethnic interests. Compared with class-based rartius, whicl by necessity involve the state in concerns of societal frodurtivity, regional parties have a tendency to reduce politics to dictributional matters in a static zero-sum situation. They weaken the Stat. rurther by enlarging the bargaining coalition and by placing additjulal burdens on it. ' horkable political institutions which, ideal-

6 lnterestingly, Ralph Braibanti, working within the same paradigm comen to exactly the opposite conclusion, namely "that the strengthening of administratjon must proceed irrespective of the rate of maturation of lle pulitical process" (Braibanti:1969,3). The tangible advantages for the development process would be that an "administrative system much more highly developed than other parts of the social order" could function as a ruservoir of talent which, ideally, would be diffused to the political and ot heer spheres (idem: 1970,238).

'In the 1970 s when the creation of additional states was discussed, the ferling of inequitable provision with amenities, infrastructural facilities and employment opportunities was at the core of most demands for ne'h subdivisions. For instance, the spokesmen for a Niger state complain$e d$ "ahout the discriminatory manner ir which the 1970-74 Development Plan hal hen implemented, particularly with respect to the location of indust$\because \because$. lectrification, water supply and education. The only three indusIries to be established, a tannery, a furniture factory and an oil mill, hat all been located in Sokoto Division, although Minna or Abuja would hale been a better choice for the furniture factory because of the local 
$1 y$, are constructive and democratic, representative and responsible and which can meaningfully control the state, cannot be voluntaristic constructs but will take shape quasi automatically once the state creates the material preconditions for the emergence of classes or groups. It seems that a good starting point would be to cut the scope (and size) of the preponderant bureaucratic state in whose present expansive shador not much independent activity can thrive.

Thus, these administrative/political imbalance assumptions are plausible as far as they go which, however, is not far enough. By Jorating conflict within the state and by counselling adjustment of the internal porer distribution, it is overlooked that the real imbalance. of power is between the state and civil society. The paradoxical realits of the Nigerian situation is that both the political institutions (of the First and Second Republics) and the administrative institutions (throughout) were/are fundamentally weak (Adamolekun:1986,168ff). This neakness does not, however, preclude the State's successfully pursuing the interests of the dominant class (i.e. the state class), namely to perpetuate its hegemony through patronage-oriented policies. The eccnomically central Nigerian State, despite its internal brittleness, is able to create divisible belefits for specific target groups (and impose precisely targeted costs on others) because it has the decisional monopoly concerning the national economy's macro-framework (investment codes, labour legislation, monetary policy, tariffs and taxes ete. $)$

supply of wood. Other projects listed in the Plan for which Niger Province could supply the raw material, such as starch processing, fibre firoduction and rice milling, were simply not started" (Yahaya:1978,213-214). 
and, it addition, it enjoys discretionary power over the major proportion of socifty's economic resources. Popper reminds us "that in th." long run, all political problems are institutional problems ... rathur than of persons, and that progress towards more equality can be safroguarded only by institutional control of power" (Popper:1971,162). The pathologies of the bureaucratic State, accordingly, can be viewed as llis result of an absence of control. Naturally, the significance for ecummir detelopment of controlling the State decreases with the reduriton in the latter's scope.

Another and final example of the fallacy of the pars pro toto, artually a variant of the previous two examples, is the charitable mitruretation of politicians and bureaucrats as modernizing elites who wuld substitute for an absent entrepreneurial class. Also assuming swil will all around, this particular strand of the literature exudes aplualing compassion for the plight of development planners in Third hilld countries who are perceived to valiantly soldier on against all odis and despite scarcities in material, human and information resourw. Puliticians and bureaucrats here are typically viewed as benevolunt if impotent in light of the overwhelming nature of the problems ahitiling solution.

Guernment is part of the environment of uncertainty and werty. It also acts on that environment. But governments have not achieved mastery yet; that is part of what it meins to be poor. ... Rulers may be firmly entrenched but they lack the ability either to mobilize sufficient resources or to allocate them productively, or both (Caiden and kildavsk: 1974, XVII).

11 thugh one can sympathize with this expressly practice-oriented 
outlook, because of its somewhat naive abstraction from politics it cannot provide an appropriate theoretical framework for understanding the larger picture of the Nigerian political economy.

Greater suitability must plainly be attested to a more suspicious approach, especially after the experience of three decades of independence. As time rent by, the widespread optimism about the prospects of the soon to be independent African colonies which marked the 1950s, gave way to successive stages of disappointment. If, initially, the successor states were given the benefit of the doubt, they have by now squandered this intangible credit - externally as well as internally and jaded sentiments of cynicism, disappointment and doubt have taken hold. In Nigeria, the unpublished Report of the Presidential Transition Committee of 1983 explains matter-of-factly that the "'new morality' wich has emerged from the military era is such that there is general acceptance among most members of the power elite that power is for profit rather than for responsible exercise of its privileges or for service. This philosophy has resulted ... in the privileges of power being used for pillage" (cited in Dthman:1989,113). Yet, quite apart from any concrete historical experience, the prima facie case for conjecturing about the abuse of unchecked power has been a standard concern of political literature. Juvenal's question "quis custodiet ipsos custodes?" (who controls the controllers?) found one of its most compelling answers in the Federalist Papers with their emphasis on the need for checks and balances, not only to ensure general liberty by thwarting the concentration of political power, but also to prevent political leaders from engaging in personal excesses. Warned James 
Madison:

Ambition must be made to counteract ambition. ... It may be a reflection on human nature that such devices should be necessary to control the abuses of government. ... In framing a government which is to be administered by men over men, the great difficulty lies in [... obliging] it to control itself. ... the constant aim is to divide and arrange the several offices in such a manner as that each may be a check on the other - that the private interest of every individual may be a sentinel over the public rights (Hamilton, Madison and Jay:1961,322).

liderlining the hazards inherent in public monopolies, he held that the "accumulation of all powers, legislative, executive, and judi'ials, in the same hands, whether of one, a few, or many, and whether lirroditary, self-appointed, or elective, may justly be pronounced the wry definition of tyrany" (ibid.,301).

In Nigeria, systemic internal or external controls of the State (l) mol fist. The bureaucracy comines legislative, executive and economiralls allocative and regulative functions. The markets for capital, gurds and labour, because of multifarious state interventions, are litilils distorted if not essentially suspended. The judiciary, besides being part of the state class, is too weak and, not surprisingly for a military regime, too impotent to constitute a meaningful check on the hurcaucracy, Broadcast media are a state monopoly and even the unuhually (for African standards) free press is less effective than it could be in a system with broader participatory possibilities. ${ }^{8}$ Never-

"Ill appreciation of the potential subversiveness of information, the Armed Forces Ruling Council in March 1988 banned the use of satellite dishes to receive fureign broadcasts. "The Government also declared that in future radios would be imported which could pick up only domestic stations" (ACR: 1989,B118). 
theless, the bureaucratic Nigerian state is not totally immune to popular pressures, especially those for public services. The accomodation of demands emanating from groups with at least some conflict potential (e.g. those public employees not belonging to the state class, urban dwellers, regional elites, businessmen, university students etc.), afford the State a critically important element of legitimacy without which it would have to resort to outright repression. A case in point were the notorious salary increases between $70 x$ and $130 x$, including mine months in arrears, for over 750,000 public servants in 1974 which were the attempt to encourage the acquiescence of a pivotal section of the population (ef. Campbell:1978,73ff; Dudley:1982,247; Joseph:1978, $237 ;$ Olugbemi : 1979,107).

It is worth emphasizing that the relationship of these pressure. groups to the State is non-antagonistic and, in parts, even complementar?. Their interest is not to capture but to benefit from the state, to secure for themselves "some piece of government largesse - licences, scholarships, jobs, grants, loans, equipment, and so on" (Glickman: 1988,33). In other words, their preoccupation is to increase their shart of the State's resources and not to take over the state or to modify its role in the econowy as this might threaten their own, rather privileged position. It would be mistaken to assume, for instance, that private businessmen were lobbying for less state intervention in the econom:, for mrre calculability and for greater reliance on the market. The dom. .usrgeoisie is not (yet) autonomous or in an antagonistic position vis-ì-vis the state. Its material base is not marlet success, but access to the State, which is why it is a derivative 
(asss which "has arisen ia lít context of state protection - not, as so often in historical Europe, in opposition to interventionist policies" (Eates:1987b,259). This domestic bourgeoisie which, for reasons of conceptual precision, will be called the business class, together with the state class, is the beneficiary and defender of both the restriction of market frecdom and of the state-sponsorship of monopolies. 9 As it has managed to secure its access to the State, the latter's irratiollal modus operandi protects it from undesirable intruders. While this might contradict the long term and objective class interests of capitalists, the thus revealed false consciousness serves very well indeed the immediate interests of those who have found their niche in the jung] of arbitrary regulations. State autonomy in this context, it

9 ('util the mid-1980s, Nigeria's highly inefficient industrial sector, despite its access to subsidized foreign exchange, coulds urvive only in a captive market, protected against international competition by high tar iff barriers. Industrialists used newspaper ads to put pressure on the gow rument to strengthen its market interventions. The Industrial Group of the Lagos Chamber of Commerce and Industry and the Manufacturers Asso( $i$ at $i$ on of Nigeria publicly urged the government "to introduce positive madsules that hill effectively curb the unpatriotic activities of smugglers and unscrupulous businessmen who have turned $\mathrm{Nigeria}$ into a dumpins ground for products imported from other parts of the world" (Nen Nig(rian (Kallo), 19 February, 1981, 14). The Nigerian Battery Industry demalided that the government "police our borders with armed custom officjals 1...and] prohibit importation of R20 batteries" (New Nigerian, 17 July $1981,22)$. The Nigerian Shoe Industry published an obituary in which it furecast the sector's demise because of "Murderous and unsyapathetic tradurs who cont inue to enjoy their illegal business of SMLGGLING footwear." "II I NIGERI A.NS" were reminded to 'keep in wind that smuggling is a crime which affects the progress of the country more than even armed robbery"

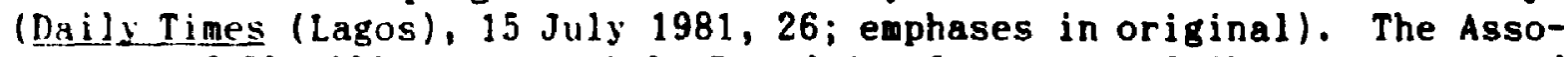
ciation of Flymillers \& Particle Board Manufacturers of Nigeria requested the surernment to "protect the industry against foreign unfair competition [becallse] the Nigerian products which are of the best quality in the world ure being driven out of the market by cheap, inferior but low priced 'im"werted' wood products which have now flooded the Nigerian market" (Daily Times, 10 April 1981,11 . 
should be understood, does not imply actions which hurt potential antagonists or run counter to their fundamental interests. It means accommodating them in a controlled fashion.

The pressure groups confronting it are either in a bargaining or in a clientelist relationship with the state as a wole or with certain segments such as ministries, offices, parastatals etc. whose interest it is at least to defend and possibly to expand their quota of state resources. The concern of individual players in the patrimonialized bureaucratic State cannot be its overall efficiency or the attainment of sump developmental gaol, but must be the magnification of their own unit. It follows that the growth of the State's size, weight ${ }^{10}$ and scope should not be interpreted as the result of purposive endeavours of the state as a homogeneous and rational actor, nor as a reasonable reaction to increased societal demand for specific state services, nor as its passive surrender to societal pressures, but as the cumulative effect of uncoordinated, politically motivated or patronage-driven recruitment actions of individual bureaucrats at various levels in the hierarchy.ll These bureaucrats or managers of state-owned enterprises can always resort to the legitimating claim that their recruiiment action serves the regional balance - or redresses perceived imbalances -

10 Public sector staffing has $r$ isen from some 200,000 in 1960 to 3.7 million in 1983, an almost twentyfold increase and figure which represents $65 \%$ of the total number of modern sector workers (Olowu:1987,29).

11 A small news item nicely illustrates this dynamic: "Governor Raji Rasati has approved the promotion of 40,000 civil servants, wore than half the state's 73,000 work force. ... Financially, the upliftments ... arr expected to cost some N100m annually" (WA No. 3802, 9 July 1990, 2075). Shortly thereafter, Rasaix announced the promotion of 8,000 primary school teachers (WA No. 3805, 30 July 1990, 2207 ). 
in the public sector; a recruitment freeze can be resisted with precisely the same reasoning.

Intra-state bargaining does not amount to effective internal controls because it is, in fact, only a competitive tussle for resources il a zero-sum situation. Indeed, the compromises and quid pro quos obtained through bureaucratic politics might well be a major factor in the incessant growth of the state sector and in turning a zero-sum into n posilive-gain situation: private consumption stood at $87 x$ of GDP in 1960 but fell to $58 x$ by 1979 (Korld Bank:1981,147). Since there is no discrinible conceyt concerning the limits of government action, the rivalrs over resources of the different segments of the State tends to ensure that all of the available financial resources will be disbursed. oftell even more than is available is being spent. The Third National p*a (10pment Plan (1975-1980) contained the startling declaration that "ther. will be no salings and foreign exchange constraints during the Third Plan period and beyond" (Nigeria:1975,48). As could be expected, in the 1970s, both Nigeria's foreign debt and government budget defi-ith gren dramatically, even though state revenue had increased eightfold and GDF threefold within half a decade: in 1970 state revenue stoud at $\$ 758$ million (i.e. $14 x$ of GDP of N5,290 million), in 1976 at NG, 766 million ( $38 \%$ of GDP of $\mathrm{N} 17,785)$; State budget deficits in 1970 amounted to Ntit million (external balance of paynents: + N43 willion) while in 1976 they were N1,091 million (- N340 million). (Central Bank of Nigeria, Annual Reports and Statement of Accounts and Economic and Fintucial Revien, various issues; see also tables 6 and 10$).$ 
while the patrimonial State will strive for a maximug of autonomy, the bureaucratic state has to temper this pursuit with measures to sustain its legitimacy. Not being legitimated by tradition and increasingly losing its lustre as an anti-colonial institution, the bureaucratic Nigerian State, naturally, claims to be a machinery for the implementation of the general will, a public trust being used for the common good and not for the benefit of particular sectional interests. In reality, however, its patterned behaviour reveals different driving forces. It is hypothesized that, in the absence of, firstly, openness and accountability in the State's institutional infrastructure and, secondly, systemic external and internal controls, the Nigerian state's policies will oscillate between two contradictory imperatives, both of which are instruments to realize the state class's overall objective, namely "property" (which is but a shorthand for privileges, both material and participatory). On the one hand there is the state class's interest in preserving its autonony. On the other hand there is the imperative to sustain the loyalty of significant, that is potentially perilous segments of society in order to prevent the State's legitimac? from sinking below a critical threshold; legitimacy-enhancing measures usually involve the transfer of state resources to non-state actors. These goals, for logical reasons clash with each other and can be implemented only tilrough mutua! limitation. Nonetheless, they can be pursued simultaneously as long as a rertain balance is maintained (cf. E]senhans:1981,145-146). "The ex-policeman put it very well. 'We knon they are eating,' he said, 'but we are eating too. They are bringing us water and they promise to bring us electricity. He did not have 
thrse things before; that is why I say we are eating too"" (Achebe:

1966,1391. Policies in support of autonomy on tise one hand and legitimacy on the other are bounded only at the margins which means that there is a trade-off relationship solely if one or the other is pursued in extremis: if the state class were to exclusively expand its own privileges, legitimacy would erode; if it were to increase its legitimacy through the provision of public goods, its goal of self-gratification wald be compromised. The policy-mix will be determined politically within the state: the controllers are controlling themselves. ${ }^{12}$

The bureaucratic state is thus intent on preserving this autonomy ull which the state class's material and social privileges depend. Auluromis indicates the degree of independence an actor enjoys from "thers. State autonomy, specifically, connotes the situation in which, as: "all independent actor, the state's agenda of preferences is very much its onn. Public officials are minimally malleable - susceptible and receptive to societal preferences - in forming and altering their ows" (Nordlinger:1988,881). This means that the State's actions are, in a cunflict, not reflective of the interests of society as a whole, or of an identifiable group or class outside the State. International (apital generally and muitinational corporations in particular are, af-

12 This control works poorly not only in a substantive sense, but even formally. The half-heartedness of internal checks is startling, if little surprising. "Thus, when the reforming zeal of the military rulers led them to establish a corrupt practices investigation bureau to help fight corruption, the civil servants ensured that there was an accompanying Public Officers (Frotection Against False Accusation) Decree.... On the whol the bureau achieved very little, and ... the wilitary leadership decided to abolish it, effective from 30 September 1979 [the day before poner was returned to a civilian government]" (Adamolekun:1986,128). 
ter their establishment in Nigeria, in their clientelist relationship to the state not fundamentally different from indigenous pressure groups. Short of exercising their exit option (as, for example, the Chase Manhattan Bank did in 1986, and as the First National Bank of Chicago announced in 1990), they can extract concessions from the state (tariff protection, tax holidays, wage policies etc) or they can offer benefits, tangible (bribes) and intangible (employment, economic growth etc). They cannot, however, force the bureaucratic Nigerian state to do their bidding. Nigeria's failure in recent years to attract interrational capital, not to mention the wave of divestment, does not fit easily into a neo-Marxist conception of the metropolitan bourgeoisie as the ruling class. In fact, it has been a distinctive characteristic of the bureaucratic Nigerian State that it has not only hindered rather that aided international capitalist expansion, but, partly in consequence, has held back the development of its society and inflicted crippling damage on its own productive base.

\section{b) The Bureaucratic Mode of Production}

In support of its quest for autonomy, the bureaucratic state will act, under normal circumstances, to consolidate its control over the economy. Control, the ability to influence or even set the agenda and to determine results, is the linchpin of the bureaucratic mode of pro- 


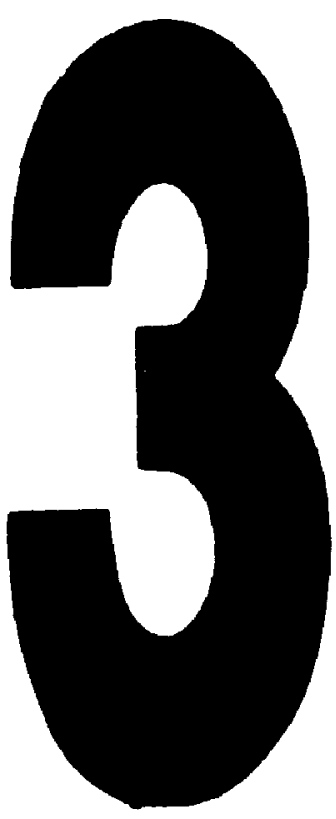

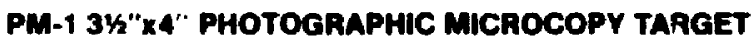
NBS 1010a ANSI/ISO "2 EQUIVALENT

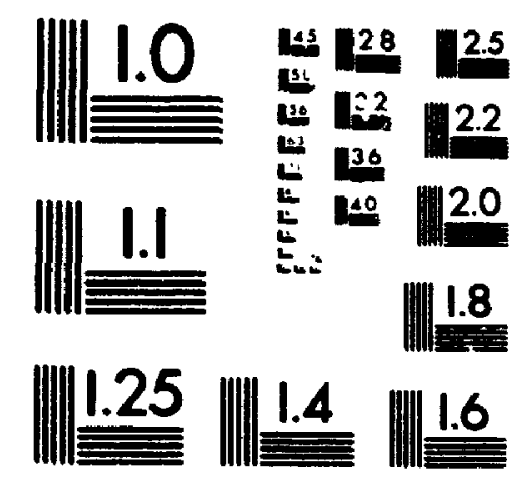

PRECISION ${ }^{\text {EM }}$ RESOLUTION TARGETS

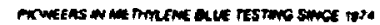

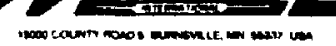

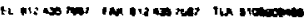


duction. ${ }^{13}$ This mode of production differs significantly from capita-

lism (private ownership of the means of production, free labour and market exchange) and to a lesser extent from socialism (State ownership of the means of production, regulated labour, central planning) or from patrimonialism (mixed ownership of the means of production, heavy state regulation of private economic activity). While in a capitalist system, authority resides in two realms, state and market, socialism, pa-

13 In much of the social science discourse, Marx's concepts of "mode of production" (Produktionsweise) and of "relations of production" (Produktionsverhältnisse) are used interchangeably or, more precisely, "mode of production" is used to cover both concepts. The distinction is admittedly arcane and makes sense only in the dialectical-materialist, teleological Marxist conceptualization of history which posits a progression from lower to higher modes of production. A mode of production is the dynamic unity of the "forces of production" (the combination of tools - at whatever level of technological development - acquired technical ability plus technical division of labour) and the "relations of production" (the orgarization of societal production and the determination of who works, who appropriates surplus and what mechanisms decide the allocation of surplus). To illustrate this point, Marx states that the "social relations are intimately connected with the forces of production. With the acquisition of new forces of production, men change their manner of production and ... all their social relations. The handmill results in a society with feudal lords, the steam-mill in a society with industrial capital. ists" (Marx:1969,130). Modes of production emerge incrementally; in the form of modernized tools, better trained labour and more differentiated production processes which lead to changing patterns of ownership and organization of labour, a new mode of production exists, in embryo, during the twilight of its predecessor ( $\mathrm{cf}$. Marx and Engels:1975,31). This ineluctable process encapsulates the principal tenet of historical materialism, namely that a particular technological level calls for particular relations of production and causes them to come about historically in the course of time to form a new mode of production (cf. Engels:157,,122128). I submit that the concept "mode of production" is useful even when shorn of the rigidities of an internal dialectic and of historical determinism. It is more comprehensive and multidimensional than "economic system" and I will use it in my concept of the "bureaucratic mode of production" to denote the discrete organizing logic of the Nigerian social order. It is not as exclusive or totalizing as "capitalist" or "socialism" and can well coexist with the "peasant mode of production" which provides all independent resource base for three quarters of Nigeria's population. Because of its integration of economic and political power, the bureaucratic mode of production is the leitmotif of the Nigerian social formation. 
trimcmialism and the bureaucratic mode of production are characterized b) the marginalization of the market and by their state-centeredness: wirste economic activity is highly regulated, or at leas', decisively conlitioned by the State, and the predominant share of the national roonomy's resources is bureaucratically appropriated and allocated. Thus by virtue of its regulatory authority and because of the resource colume arailable to the bureaucratic state - in absolute terms but even nrorr so relative to the rest of the economy's output - it is the most prominfut actor in the economy; this is what is meant by the state's toumomic centrality.

Social conservatism, whatever the of ficial rhetoric, and an aversion to the marhet in favour of administrative control are, for the burefucratic as for the patrimonial or the socialist State, self-interested refleves in the service of their respective substantive rationalities. The market is a highly effective mechanism to diffuse power and decicion making which means that to the extent the market is constrained, poner accrues to the political realm: administrative control permits centralization of power and resources while the market invariably leads to pressures for a reduction in the State's autonomy, an increase in its efficiency and for its greater accountability. It might also lead to demands for personal freedom and to pressures for democracy, understood as a system in which r.lers are accountable to the ruled (cf. Shlar:1983,11). In this sense patrimonial, socialist and bureaucratic States are undemocratic and prone to repress personal freedom. The relationship between market and democracy is direct only in one sthste. As Lindblom points out, not all market systems are democratic, 
but all democratic systems are market systems (Lindblom:1977,162). Yet it would appear, theoretically as well as by all historical accounts, the market is where the slippery slope towards individual freedom and democracy begins. This is not to say that the idea of freedom and the concept of democracy are direct products of the market, or that they did not exist before the advent of capitalist market economies. "It seems beyond doubt, however, that in recent history political and economic liberalism nourished and supported each other" (Kolakowski:1990, 164). People who are free from traditional or political constraints to do what they want or to go where they want, and who are constrained onl! by economic scarcities and personal limitations, will very likely be economically successful and sooner or later become politically assertive and demanding. Individual rights vis-à-vis the state and freedoms from the State, increasing people's space and defending it against encroachments by the State, came before demands concerning participatory rights in its affairs. This has been the order of priority and the sequence of events in the American and French revolutions (Lindblom: 1977,163 ) and in $18 \mathrm{th} / 19 \mathrm{th}$ century Europe (Hirschman:1991,1-5). Accordingly, for the socialist or the bureaucratic state, containment of the market is warranted as a central element of its survival strategy; what gives it additional luster is that it is highly lucrative.

A range of typical interventions follows from the bureaucratic State's market-aversion and control-preference. Yet their individual presence or absence is not constitutive of the bureaucratic mode of production, just indicative; indeed, some may be dropped, others added and yet others modified. What matters is the control-oriented logic 
which is applied to further the State's particular interests and which make it the most prominent factor in the economy. Quite irrelevant are thus the bureaucratic State's rationalizations which are advanced to support the necessity of its economic interventi sns, such as for instance the ostensible exploitativeness of foreigners or the inability of non-state actors to rapidly and equitably develop the economy as well as to ensure food security and to erase poverty. While the private sector's inadequacy may be true enough, the State's performance may be worse and the "activities of public sector institutions ... could well constitute a sufficient condition for failure to develop" (Abernethy:1988,181; emphasis in original; see also Wolf:1979). Typically, the State's economic interventions in the bureaucratic mode of productjon are:

- comprehensive controls over international transactions which, logically, lead to extensive controls also over the national economy's formal sector and to the development of clientelist relationships between the state class (= patron) and the business class (= client);

- ethnic quota and indigenization policies, which not only benefit the state class directly but also confirm its role as patron and regulator of the economy;

- an expansive and usually loss-making parastatal sector;

- massive investment in non-productive prestige projects;

- heary reliance on contractors, local and expatriate, to carry 
out public sector investment;

- to make food in urban areas both cheap and abundant, the importation and subsidization of foodstuffs is complemented by agricultural policies which attempt to increase production through the bureaucratic allocation of subsidized inputs in the context of capital-intensive and high-technology programmes;

- an inflated public payroll (in terms of numbers and relative cost per capital compared with the rest of the formal economy.

The bureaucratic State is rommitted to modernize which means to industrialize. Beginning in the 1950s, Nigeria's agricultural sector was increasingly heavily taxed, that is, the differential between world market prices and prices paid to Nigerian farmers widened (see table 5). Booming world market prices (see table 4) afforded the state a very high rent without depressing agricultural production, and thus the resources to finance an expanding state and an import-substitution industrialization programme. The ease with which these resources were obtained did not enhance the soundness of their utilization. Tariff protection against foreign competition in combination with concessionary loans and grants as well as tax breaks extended to state-owned and private ventures alike, created an inefficient and sluggish manufacturing sector. Unable to compete abroad or to mature from light consumer goods to capital equipment, its survival depended on aptive home-market, and on imported technology, machinery and even seni.-

finished components. The advent of oil-rents in the 1970s obriated the 
nord to tax agriculture and permitted even more lavish subsidies for the urban economy which was not only considered "modern," but also more critical for political stability than the "backward" rural areas. This did not contribute as much to an improvement of the former's productivity as to the latter's general decline.

Because of their positive impact or Nigeria's balance of payments, oil revenues amplified the bureaucratic state's natural instincts which favour not only protecting local industry, but also a "strong" national currency because it means that one naira buys more dollars (and thus affords more imports) than if it were "weaker." The benefits of a strong naira are of course an illusion because to the extent it cheapens imports it increases the costs of domestic products and exports and so undermines their competitiveness. This loss obtains for Nigeria's exports since a given dollar worldmarket price translates into ferer naira, while all local prices, whether for accommodation, food, hages and of course for local manufactures are, if calculated in dollars, high. Depending on the extent of the naira's overvaluation, the are extraordinarily high. In sum, an exchange rate manipulation cannot, in itself, create values. It can only alter opportunity structures and incentives.

The naira's overvaluation benefitted the state and urban areas and harmed agriculture, both export and food producers. The export sector first stagnated, then regressed and finally collapsed during the 1970 s and 1980 s lexcept for cocoa which only regressed; for data see table 1), not only because the state-determined producer prices increased considerably slower than domestic inflation (see tables 5 and 
7), but also because farming became ever more unattractive, especially in view of better paid urban employment opportunities. Food prices, kept low by subsidized imports failed to induce the great majority of smal tholder farmers to produce for urban markets. They were discouraged further by poor infrastructural conditions and by the State's inputoriented agricultural policies (subsidized fertilizers, irrigation and mechanization) which reached only a few privileged farwers and thus negatively affected the relative position of the great majority.

The bureaucratjc State, as a consumer, producer and employer, but also as the patron of local industry, is interested in low prices for imports, lon rages and low food costs. An overvalued exchange rate does indeed make all imports appear cheap, and it becomes tempting to compensate the national economy's inability to produce capital goods with imports from Europe, and the farming sector's unwillingness to supply food in sufficient quantities with imports from America and 4sia. Hohever, if the naira were not only overvalued but also convertible, and if access to the Nigerian market were unrestricted, the country rould be flooded overnight with imports. The local economy would collapse under this onslaught (this is what happened in former East Germany when the D-Mark was introduced in July 1990), and the oil revenues rould leak abroad without stimulating local production. An overvalued exchange rate, therefore, requires strict and comprehensive controls. To maintain a modicum of balance in the paradoxical disequilibrium situation in which foreign exchange is both cheap and scarce, foreign exchange has to be rationed, imports restricted and local industry protected and subsidized. Economically, in principle and prac- 
tice, this stimulates consumption and penalizes production. Political$1:$, it. stimulates corruption, patronage and clientelisw. In Nigeria in the 1970s and early 1980s, this entirely unproductive system was powered by oil revenues. These were used to plug those holes which the bureaucratic State's policies had created in the first place. In the process, more holes opened up. The remedial action at every turn involved more resources, more state control or state intervention, and mure opportunities for patronage and self-aggrandizement. An overialued exchange rate implies state regulation of international transactions and of access to "hard" currencies. Yet administrative measures such as rationing, licencing or sealing of the counIry's burders are attempts, not to alter but to ccntrol the fact that foreign rxchange is subsidized and sold below its value (Bates:1981;9799). F(conomic distortions result and new beneficiaries emerge from the modifed incentive structures. In the words of Kwesi Botchwey, the Ghanaian Secretary of Finance and Economic Planning: "A grossly overvalued currency confers unjustified wealth to those who have access to it" (1) ited in fit lo 3518,28 January 1985, 146). The greater the market distortion, that is, the "cheaper" foreign exchange is, the greater the disjunction between its supply and the demand for it; the more difficult cheap foreign exchange is to obtain, the more energy has to be expended gaining access to $i t$, and the more lucrative is the position of gatekeepers. As is usual when a good is priced below its market value but rationed, black markets or dual price structures emerge and with it the practice that busers in the official market will sell in the free marhet and thus cash in the subsidy. 
Beneficiaries of an overvalued exchange rate are generally the members of the urban salariat including the state class, but especially individual bureaucrats who are positioned to grant, deny or delay applications for foreign currencies. Immediate victims are all agricultural producers: their exports are no longer competitive because an adequate internal price makes their produce prohibitively expensive abroad; imports of food staples like rice or wheat are by the sane token rather cheap, forcing internal producers out of the market. Developmental prospects are a less tangible victim: agricultural production is discouraged and a trend-reversion to subsistence farming ellsues. Manufacturing industry is equally uncompetitive, requiring permanent state protection against cheaper imports, state-ensured access to foreign exchange for imported production factors, and off $\mathrm{i}$ cial market guarantees. A stultifying dependency relationship develops which might benefit those involved in negotiating these artificial obstacles. However, economic rationality and developmental prospects suffer if energies are better utilized if focused on politically brokered dea's rather than on issues of efficiency, marketability and productivity.

Import restrictions and import licencing are a coro!lary of an artificially overvalued, non-convertible currency. Foreign exchange authorizations and import permits for specified goods and quantities are administratively allocated, ostensibly to save foreign exchange and to protect indigenous industries. The latter aight be true enough, benefitting shareholder, managers and workers alike, but at the expense of consumers who have to pay higher than necessary prices for shoddier 
than necessary goods. The former argument, saving foreign exchange, is implausible in the Nigerian practice. The whole revenue from oil, and more, is spent - much of it abroad. As a result Nigeria's external debt began to outweigh the country's foreign reserves after the windfall gains from oil materialized (see table 10). State regulation influences what is being bought and by whow, yet only a weak case can be mad- that it does so with more wisdon or to greater developmental effect than private consumers would. Since the imposition of quantitative import restrictions raise the prices of imports, a rent accrues to the importer who is able to secure a licence for the linited quantity of imports. There is a redistribution of welfare from the consueers to the importer in the anount of the preaium (which is in fact a monopoly rent) betheen the lower world market price and the higher domestic pric*. Hence, beneficiaries in import licencing regiees are those private businesswen who obtain licences and those bureaucrats who award them (cf. Krueger:1974,292-293). Innediate victins, as was suggested earlier, are consumers who pay monopoly prices for inported goods and for inferior local products sheltered from competition. However, the genera! developmentally counterproductive effects are as obvious as their benefits for the state class. Firstly,

rent-seeking activity - the use of time and resources to secure the import license - has no social value. In the importer's attempt to capture the restriction-created rents, there is an opportunity cost as real resources are used in lobbying or other rent-seeking activities. As importers engage in activities to receive the favor of government, resources that go into the rent-geeking activities are diverted from other productive activities. Although the rent-seeking activity is rational in teras of self-interest, it is socially wasteful (Meier:1989,273). 
Therefore, productive econonic activity, that is, the creation of real income and wealth, fades in appeal if more money can be made easier as well as faster through trade or through conpetition for unearned profits.

Secondly, quantitative import regtrictions and high import tariffs shield existing industries behind protective walls. They are an integral part of an inport-substitution regine, and a major factor in its fajlure to succeed. In Nigeria prior to the structural adjustment reforms of the mid-1980s, textiles, food processing, metal and plastic fabrication and related industries all enjoyed rates of effective protection in excess of 10\% (Collier:1983,192). Under such conditions, cost efficiency and market success are far less important factors in a firm's profitability than conducive relations with the state. Since there are no incentives to improve productivity, uncompetitive infant industries seldom grow up and, unable to sell abroad, remain limited to the captive national narket which has to absorb not only shoddy goods but also high production costs, either through higher than necessary sales prices or through state transfers. In either case the protection represents a subsidy to industries which buyers' demand alone would not support. Profits in such a state-created sellers' arket, then, stea from martiet control rather than frow value-added in the production process which is marginal in any event in the assembly and processing of imported inputs. ${ }^{14}$ The combination of tariff protection and dependence

14 UNIDO studies found that in the early 1980s, $60 \%$ of the raw ante$r i a l$ consumed in the nanufacturing sector was inported (UNIDO:1985, 27) and that the "most striking aspect of the pre-recession period (19701978) was the relatively high level of the gross profit to value added ratio. [It] was as high as 80 per cent [... declining only] to 75 per 
on imported inputs also prevents the backward linkages which would result from the establishment of local capital goods industries. The latter is avoided because these would most likely produce nore expensively, at least in the beginning, than the present foreign suppliers (cf. Roemer: 1982,132). The classical argunent in favour of infant industry protection hinges on the necessity to pernit learning, but enphasizes the time-limited nature of protection to ensure that learning does indeed take place (cf. Lewis:1953,18-21). John Stuart Mill nade this point clearly but guardedly in his Principles:

[I]t cannot be expected that individuals should, at their own risk, or rather to their certain loss, introduce a new manufacture, and bear the burthen of carrying it on until the producers have been educated up to the level of those with whom the processes are traditional. A protecting duty, continued for a reasonable tine, night gonetimes be the least inconvenient mode in which the nation can tax itself for the support of such an experiment. But it is essential that the protection should be confined to cases in which there is good ground of assurances that the industry which it fosters will after a time be able to dispose with it; nor should the domestic producers ever be allowed to expect that it will be continued to them beyond the time necessary for a fair trial of what they are capable of accomplishing (Mill:1965,918-919; enphasis added).

If this learning argument is accepted, rational import substitution, ostensibly the Nigerian government's objective, would involve two transitions.

cent during the recession of the 1980s. Profit levels have risen even in years when industrial output has fallen drastically (such as 1983).... The decline in factor productivity aust therefore be attributed to a high level of monopolization of the Nigerian manufacturing sector. This monopolization inhibits the growth of investment, codernization and upgrading of the productive equipaent in most manufacturing enterprises. ... Up to 1986 it was possible to discern a relationship between the level of protection and the level of industrial efficiency" (UNIDO: 1988, 19-22). 
The first is that from a system characterized by lack of growth to a flexible, responsive system in which social welfare is continually rising. This takes place behind some form of protection. The second is the transition from protection to participation on a more equal footing in the world economy. Between these two transitions lies the process by which the economy achieves its netamorphosis (Bruton: 1989,1603 ).

The bureaucratic state allows a semblance of the first step but is unable, or more likely unwilling, to complete the process. Since it is the controller, gatekeeper, insurance broker, protector and provider for the business class, indigenous as well as expatriate, and since the members of the state class derive tangible benefits from their position as patrons in these multifarious clientelist relationships, little speaks for transforming the status quo by inducing the second transition. Political pressures from industrialists as well as from labour are exerted to maintain existing production and employment levels, even though this is predominantly in inefficient and highly import-dependent consumer gouds industries. "As a consequence, scarce foreign exchange is allocated to maintaining consumption instead of being allocated to high-priority investments" (World Bank:1981,27; see also Stolper:1966, 228-233). Finally, the national manufacturing sector is incapable to adapt to new consumer demands which, then, can only be met through additional imports of either the product or the machines with which to assemble it locally. In either case, wuch of the multiplier effect of demand seeps out. The manufacturing sector's transformatory scope is thus highly constrained, and its adaptive ability limited to adjusting the degree of capacity utilization. 
Independent of the specific objectives for establishing parastatals - over twenty five have been identified (cf. Chosky:1979,8) $\checkmark$ iewed from the interest position of the state class, they serve similar purposes as those of economic regulation. They provide the opporturity to dispense patronage either directly (employment, contracts, procurement of inputs) or indirectly (subsidized products). ${ }^{15}$ This is what accounts for the ubiquity . : parastatals even if, on grounds of efficiency, productivity or rationality, they make no sense at all: be(aust profit-making is only a stipulated not, however, an enforced objective, parastatals typically operate at a loss, despite "higher capital/output rations relative to private-sector investment in the same economy" (Gillis:1980,274).16 Nigeria's Second National Develop-

15 In the run-up to the 1983 elections, the federal government announced the setting up of 58 new breweries, even though the existing brewing capacity of 13.1 million hectoliters was already in excess of demand (11.5 million hectoliters) (ACR:1984,B531). The Babangida regime in late 1989 established a "People's Bank" with much fanfare as a means of directing lending to Nigeria's poor (ARBe:9/1989,9709). Not even two years later, the organization was "faced with many of the problems traditionally associated with government agencies. Despite the widespread ac-claim that the project initially received, ... the bank has experienced difficulty in building up business and ... is characterised by problems of ethnicity, profligacy, inefficiency, maladministration, fraud and greed" (EIU:3/91,17).

16 The number of public enterprises (utilities, banks, commercial and industrial operations) grew, between 1966 and 1977, from about 70 to 300 (Adamolekun:1978,316-317) and to over 500 in the 1980s (Adamolekun and Aseni:1990,275). In 1981 parastatals employed 949,000 staff (Lincauer: $1991,832)$, i.e. almost twice as many as the private manufacturing sector (see table 9). A list of the over 160 federal parastatals which existed in the early 1980s is reproduced in Appendix B. Of these in excess of 100 were of a purely commercial nature. However, none except the Nigerian Ports Authority was earning positive returns. The verdict which obtained for the state-run agricultural food production companies, established in response to the increasing demand for food, had universal character. They "have not been an unqualified success. High overhead costs have made them tuo dependent on government subsidies" (Nigeria:1979,24). Detailed figures on the finances of most of the parastatals either do not exist or are 
ment attributes the poor performance of public enterprises to their "heavy, sometimes fraudulent, over-capitalisation, [to] wrong decisions on the location of industrial plants, motivated by political advantage" (Nigeria:1970,76). However, instead of properly identifying the root. causes of these pitfalls, the plan suggests that "all these [problems] can be traced ultimately to the nature and character of management, especially with respect to the process of selection, appointment, promotion, incentive and discipline in the leadership hierarchy" (loc. cit.).

It rould appear that a more realistic assessment would show that the real problem lies in exactly the dilemma parastatals are intended to overcome, that is, in the private sector's assumed failure to perform and in its feared lack of responsiveness to political guidance. However, and this is no paradox, parastatals are more oblivious to market signals and more immune to regulation than private firms, because price and incentive mechanisms have even less leverage. Therefore, "direct controls via budgeting, expenditure controls, personnel action and policy guidance are of ten much less effective in practice than in principle" (Nelson:1984,991). For example and contrary to superficial expectation, equity-capital is not considered scarce but dependent only on any manager's negotiating skill. If capital is ap-

not public. "The sketchy data that does exist points to massive trangfers from government to support the parastatals. Federal government loans to public corporations totalled N5.75bn during the 1980-86 period, though this was only the tip of the iceberg since, in 1986, government transfers to parastatals amounted to N830m of which only N450 was accounied for by loans" (Tony Hawkins, "The Privatisation Programme: Thorny Issues raised by Policy Reversal," FT, 8 March 1988, p. V Nigeria supplement). 
proved at all, the Stata does not place a price on it upon transfer to parastatals (cf. Shir_ y: $_{1983,13-29)}$. Similar considerations, entirely disregarding actual opportunity costs of capital, lead to economically wasteful and politically determined investments. Conspicuous if by no means isolated examples are the $\$ 5$ billion investment in a telecommunications system "which has yet to produce an efficient domestic or international service" (Holman:1989,22), a chronically deficitary state airline, ${ }^{17}$ luxury hotels (e.g. the four new foreign built and managed hotels in Abuja), ${ }^{18}$ steel plants (e.g. Ajaokuta and Aladja), expressways to the capitals of newly created states (Nigeria:1981a,5) or even a new federal capital city built from scratch in the wilderness. Fortunately, economic reality intervened and put a stop to the megalomaniac: ambition for Nigeria to pursue civilian and military nuclear projects. 19

17 In mid-1991, Nigeria Airways was unable to pay the $\$ 21$ million it oved to three airlines (Aer Lingus, KLM and Sabena) which maintain $\mathrm{NA}$ 's planes. At the same time there were allegations of impropriety in the vay in which "the hush-kitting and sale of three Boeing 707s from the airline's fleet" was handled (EIU:3/91,19). Yet, rather than streamline operations, properly manage resources and compete through performance, Nigeria Airways in a manner typical for parastatals, calls for state protection. In late 1990 it appealed "to the government to limit the flights of the 25 foreign airlines operating in Nigeria to once a week as well as forbidding them from transporting more than 100 passengers per flight. The director general of Nigeria Airways said that in commercial affairs 'you must first of all protect yourself. There is no other mfans" (cited in WA No. 3821, 19 November 1990, 2869).

15 The Golden Tulip Hotel, costing \$29.4 willion and opened in May 1986 is managed by a KLM subsidiary. The three other hotels are a Hilton, a Regency Hyatt and a Sheraton (ARBe:4/1986,8210).

19 In an interview, the Defence Minister Professor Iya Abubakar outlined three major reasons why his government pursued the acquisition of nuclear heapons: as a scientist he had always hoped that Nigeria should acquire nuclear technology for peaceful purposes and develop intoanuclear power; Nigeria as a strong country needed an unassailable defence capabi- 
Commonly, public investment funds, whether for construction projects, equipment for military and civilian use, the provision of services or the importation of agricultural implements or even for food such as in the case of the Presidential Task Force on Rice, are disbursed through contracts which are awarded with little regard for transparancy and competitive bidding yrocedures ( $c f$. Gunn:1982; Nigeria:1976a;

Nigeria:1976d; Schatz:1977; Turner:1978).20 Most projects are deened urgent which exerts an upward pressure on prices. 21 It also overwhelms the capacity of local suppliers. Given their inability, in the demand-

lity and it was only after becoming a nuclear power that she could boast of that status; since South Africa had nuclear weapons, Nigeria should obtain them also at any price to qualify for membership in the superpower club (hA No. 3278, 19 May 1980, 872-874). President Shagari echoed these sentiments (cf. Daily Times (Lagos), 5 March 1981, 3 and 17 December 1980, 3 ; KA No. 3353, 2 November 1981, 2604), as did Vice President Ekwueme

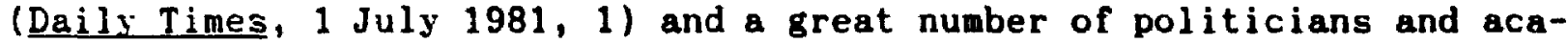
demics (cf. Dails Times 10 August 1982, 3; Sunday Times (Lagos), 16 May 1982; National Concord (Lagos), 16 June 1982, 3; New Nigerian (Kano), 3 July 1982, 9). In March 1981 the Senate Comittee on Finance and Appropriation approved $\mathbf{N} 10$ million ( $\$ 16$ million) for a nuclear research programme (Dailv Times 24 March 1981, 1; New Nigerian, 24 March 1981, 1 ).

20 It was reported that much of the $\$ 5$ bn windfall after Iraq's invasion of Kuwait was spent by President Babangida's government, ostensibly committed to austerity, on a number of dubious contracts: a $\$ 1.4$ billion aluminum smelter estimated to be 60-100x above comparable project costs elsewhere; the acquisition of 150 Vickers tanks; to host the OAU summit in Abuja at costs of $\$ 150$, a great part of which was due to prices inflated by the short time in which the facilities were built, but also because of the purchase of a fleet of Mercedes stretch limousines alone worth more than the level of the 1991 contributions to the OAU by member governmants (AC No. 25, 20 December 1991, 2; Keeling: 1991,4 1991a,5).

21 For instance, during the Second National Development Plan (19701975), EN33 million (about $\$ 92$ million) was initially allocated for the federal road rehabilitation programme. Within one year, the programme had to be revalued to \&N64 (\$180) only because construction prices had risen sharply. The same held true for the Western State's construction programme (50x price increase), for Lagos State (100x increase) and for others (World Bank: 1974,38). 
ed short time frame, to supply the required items from indigenous sources, contracts are typically awarded to Nigerian middlemen who then sub-contract foreign suppliers "while the 'commission' is disgorged in a paroxysm of self-indulgence" (Joseph:1978,235).22 A winisterial commitiee, established to study the "causes of the excessively high cost of government contracts" confirmed these practices and pitfa_ls. It found that

Whereas the total value of Federal Highway Contracts awarded in 1973 was under N100 million [\$152 $\mathrm{mn}]$, the values in $1974,1975,1976,1977$ and 1978 were N811,402 [\$1.3 bn], $\mathrm{N} 982,073[\$ 1.6 \mathrm{bn}], \mathrm{N} 847.516[\$ 1.4 \mathrm{bn}], \mathrm{N} 515.432[\$ 800 \mathrm{mn}]$ and $\mathrm{N} 113.743[\$ 180 \mathrm{mn}] \mathrm{million}$ respectively. ... Nigeria turned out to be a country in a hurry. Consequently, in most cases no feasibility studies to establish the aggregate social national benefit of schemes marked for develop-

22 The examples of expensive white elephants created by these practices are legion. One of the most notorious cases was the importation of over $16 \mathrm{million}$ tonnes of cement between December 1974 and June 1975 by various branches of the ministry of defence. This was over ten times the amount scheduled and required (Ohiorhenuan:1989,197). More importantly, the number of cement ships awaiting unloading in Lagos harbour - 142 on 4 August 1975,242 on 26 September, 180 on 17 October, 170 on 14 November and 148 on 20 December 1975 etc. - stretched its handling capacity beyond its limit. The volume of cement contracted to be supplied in one year would have taken nearly four years to handle, even if the shipment of all other exports and imports had been halted (Ogundana: 1978,73-79). The government tribunal established to investigate this scandal implicated many government officials: the defence ministry official in charge of army development projects, the ministry's accountant, the head of army engineers, the Central Bank chief of banking operations, the Central Bank's officerin-charge of the bills office and the Nigerian ambassador to the Netherlands. It also revealed that none of the 69 cement contracts considered was awarded by the Ministry's Tender's Board in spite of the fact that most of the contracts were for a sum of $\$ 14$ million (Nigeria:1979a,19). The method used merely encouraged a free-for-all bargain by the "scavengers known as local agents. ... The selection of suppliers depended on his [Mr. Larkin Soith, Deputy Secretary in the Defence Ministry] whins and caprices. ... If one were to read in a fiction some stories told to us as to hoh some suppliers were selected, one would accuse the author of being too ethereal. ... a lady just passing by, saw a crowd and on enquiring and being told that the crowd were waiting for cement contracts, she got in and won a contract of 14 million dollars" (Nigeria:1976a,19-20). 
ment were carried out. The options open to governments for achieving a singular objective were not exhausted prior to the decision to award contracts (Nigeria:1981a,5).

The committee determined that the costs in Nigeria were about trice those of comparable projects in Kenya and a third higher than in Algeria (ibid.,37). The reasons, in addition to the inflationary demand-push, were thought to be the murky contract procedures (ibid., 11-17), the predominance of expatriate-dowinated executing agents (ibid., 18-22) and the monopoly position of construction materials' importers (ibid.,24-25). The reward-structure of these arrangements for the state class and its client, the business class (or individual members of either class) is the same as with import licencing: use of public office (or access to it) for private advantage and at society's expense; this is facilitated by a self-created regulatory system which, intransparent though it is, gives wide discretional scope to individual bureaucrats. ${ }^{23}$ A similar developmentally counterproductive effect also obtains because societal surplus is used to promote highly inefficiert investments or conspicuous public consumption which on the one hand limits the growth of private consumption and, on the other, eliminates the possibility of growth in the economy.

In Nigeria, unprecedented increases in income have accrued to the State and have been spent without leading to more than moderate in-

23 After the Second Republic's fall, the former governor of Anabbra state, Jim Nwobodo, was accused of abuse of office for awarding several contracts to a construction company "in conplete disregard of the tenders board" (WA, No. 3507, 5 November 1984, 2238-2239). Surprisingly, after "months of investigation the Panel has come to the conclusion that Jim Nwobodo is actually the owner of the mysterious Greenfield company" (loc. cit.). 
creases in private consumption. Since only statistical aggregates

matter (and income distribution is not considered), Nigeria has long been considered a "middle income country." In the late 1980s, because of a dramatic drop in oil revenues - to under $\$ 7 \mathrm{bn}$ in 1988 from a high of over $\$ 24 b n$ in 1980 (see table 2) - the country became eligible for concessionary aid and found itself anong the world's least developed countries. 24

Even though the bureaucratic State's agricultural policies are very differently motivated than its industrial policies - to increase output, rather than to modernize the economy or to exert control - they display the same reflexes and follow the same logic: direct government

24 In late 1988, the World Bank accepted Nigeria as eligible to benefit from the resources of the soft-loan International Development Agency (IDA) which lends to the poorest countries (ARBe:9/1988,9299). The LDC status is officially conferred only if a country applies for it and if its yer capita GDP has been below $\$ 600$ for the last three years (cf. DF 4 July-August 1991, 9). What the chances are for the former is harder to asse'ss than to predict that the second criterion will be met. From 1978 when the World Bank's World Development Report was first published until 1988, Nigeria was classified as a middle income country, since 1989 as a lok income country. In 1991, only Mozambique, Ethiopia, Tanzania, Somalia, Bangladesh, Laos, Malawi, Nepal, Chad, Burundi, Sierra Leone and Madagascar were ranked lower.

1978 p. 76 ; rank: 42; cat: mid income; per cap GNP \$ 380

1979 p. 126 ; rank: 44 ; cat: mid income; per cap GNP $\$ 420$

1980 p. 110 ; rank: 52; cat: mid income; per cap GNP \$ 560

1981 p. 134 ; rank: 56 ; cat: aid income; per cap GNP \$ 670

1982 p. 110 ; rank: 60; cat: mid income; per cap GNP $\$ 1,010$

1983 p. 148; rank: 54; cat: wid income; per cap GNP \$ 870

1984 p. 218 ; rank: 52 ; cat: mid incone; per cap GNP $\$ 860$

1985 p. 174 ; rank: 53 ; cat: wid income; per cap GNP \& 770

1986 p. 180 ; rank: 52; cat: mid income; per cap GNP \$ 730

1987 p. 202 ; rank: 54 ; cat: nid income; per cap GNP \$800

1988 p. 222; rank: 48; cat: mid income; per cap GNP \$ 640

1989 p. 164 ; rank: 31 ; cat: low income; per cap GNP $\$ 370$

1990 p. 178; rank: 17; cat; low incowe; per cap GNP \$ 290

1991 p. 204; rank: 13; cat: low income; per cap GNP \$ 250 
participation in production in a context of input-orientation and overregulation, seemingly based on the assumption that progress can be bought and that its attainment depends mostly on the state-directed deployment of massive resources. The effects are very similar, namely the "trading up" of dependence. To obviate the importation of food and manufactured goods, local production is initiated, subsidized and protected from foreign competition. Yet the production relies heavily on foreign inputs (know-how, machine tools, semi-finished components in the case of manufacturing or chemicals in the case of agriculture) which, because of the urge to acquire state-of-the-art technology and to achieve results quickly, is not a temporary phenomenon but a permanent feature. Import-substitution production, if it is protected and subsidized, has a tendency to become entrenched, to remain uncompetitive and not to spann significant economic linkage effects. Its adaptability is limited co variations in the degree of capacity utilization and hardly ever ex 'ends to the abiiity to substitute local for imported inputs or to generate innovations in product design and processing method.

Whereas in the case of industrialization, a charitable interpretation could ascribe the strategies of the 1950 s and 1960 s to misplaced notions of development and to strategies inappropriately derived from thew, the specific policy choices vis-à-vis agriculture are clearly the result of a different calculus. Here, control- and input oriented measures are undertaken because they promise the lesser goal of increasing food production and, importantly, because they directly further the state class's legitimacy, autonomy and property interests. Legitimacy 
and autonomy are best ensured by measures guaranteeing cheap food in urban areas on the one hand without, on the other, creating a querulous farming population or, better still, by tieing some farmers' interests to the State. Importing food is attractive because it is relatively cheap under conditions of windfall gains from oil exports and of an overvalued national currency, because it helps to check inflationary pressures as well as to contain wage demands. Sponsoring selected farmers splits the camp and demonstrates the advantages of conducive relationships with the State. Both measures entail the possibility to anard lucrative import contracts, whether for foods or for agricultural implements such as fertilizers or equipment. However, ignoring the requirements of development, that is, the necessity to extend the scope of the exchange economy and to increase the productivity of all sectors, the best that can be achieved is incremental gains in output. And even that is possible only as long as the state can afford to be unconcerned about opportunity custs of capital and about efficiency of production. This input-orientation thus serves only a small, precisely 
targetable group of beneficiaries ${ }^{25}$ without realizing the larger economy's inherent potential or comparative advantage, and with only slight promise for structural transformation and the creation of mass income.

The fundamental fallacy of inputism or input-fetishisa as a developmental perspective is its exclusive focus on the conditions of production. Ignoring effective dewand (purchasing power conbined with rillingness to buy) leads to the misplaced conviction that agricultural outpit is low because productivity is low whereas, in fact, productivity is low because effective demand is sluggish, not only for its output. but also for its production factors 1 and and labour. The market demand for food which exceeds the level satisfied by subsidized imports is too heak to lead to an intensification of production. Increased effective demand as expressed in markedly higher prices for food lor for export crops) hould at first lead to an extensification of production and only subsequently to an intensification. Putting the horse (productivity) before the cart (effective demand), the bureaucratic state attempts to shortcut this natural progression. Especially since productivity is

25 The manager of the World Bank supported "Gombe" project in Bauchi state called the distribution of fertilizer "the single biggest identifiable item in the program." Inported and subsidized by the federal government, a bag's market value was N14 but a farmer paid only N2 and could obtain $\mathrm{N} 8$ on the black market. "Last year fertilizer went out in an abominable way, and there was a ripoff all the way along the line." It was impossible to introduce accountability because "fertilizer here is a political matter, particularly in marginal areas between the NPP and the ruling NPX. So if you sell to the wrong person, or don't sell enough of it, it has political consequences" (cited in the IHT, 18 June 1982, 78 ). In connection with the Structural Adjustment Progranme of the id 1980s, the World Bank advised against continuing the importation and subsidization of fertilizer, firstly because it accounted for $70 x$ of the Ministry of Agriculture's budget, but also because smuggling and storage losses amounted to $50 x$ of distributed fertilizer (FT, B March 1988, X). 
being raised only in enclaves, rather than across the whole agricultura) board, the massive infusions of resources have little developmental impact. This disappointment is attributable not so euch to insufficiently "progressive" farmers or to excessively corrupt extension agents. "A more fundamental reason is to be found in the ultinate objective of most agricultural development projects, notably the increase of the marketed output to the benefit of the state, rather than the improvement of rural living conditions on the basis of an active participation of the farmers concerned" (Hinderink and Sterkenburg: 1987,2701 .

Favoured strategies in Nigeria were/are river basin development schemes (irrigated farming of rice and wheat), integrated rural develupment projects (promotion of high-yield seeds, chemicals and fertilizers plus the provision of extension services) and agricultural credit prugrams. They all share a propensity to be capital-intensive, dependent on government subsidies or on imported inputs such as fertilizer and machinery. The prccise number of beneficiaries of these projects is hard to determine, yet there can be no doubt that they are below one million or vell below $5 \%$ of Nigeria's rural population. Thus, while the vast majority of small peasant farmers is largely ignored if not jenalized (cf. Koehn:1990,89-91; Wallace:1980,60-65), irrigated land, fertilizer and machinery is made available at subsidized rates to a small group of wealthy farmers (Sano:1983,57-60) who produce food crops for an upscale urban market. The State chooses to increase food output - agricultural policy since the 1970 s has been largely unconcerned with Nigeria's traditional export crops - through well-targeted subsidies 
which are intended to neutralize the conditions which are generally adverse for the production of export crops and food crops alike.

Production is discouraged in particular by the overvalued currency, by the rising urban wage levels which feed back to rural areas, but also by the monopsonic state-operated arketing boards which take a rent in paying the farmers less than their products' world market prices (see table 5). Before the advent of oil, this rent provided the greatest share of state revenue. Since about 1970 , the incone from crude oil has been essentially a fortuitous and externally generated windfall which provides the material basis for the bureaucratic Nigerian State's relative autonomy from the majority of its citizens. As long as it is cheaper (and more profitable) to import food, rural development entails more dangers than benefits for the bureaucratic State: a restive and demanding new clientele might exert pressures for change, power and a sizeable share of the oil wealth. Therefore, rather than building on what exists in terms of inputs and production techniques, and instead of improving the rural-urban terms of trade and the rural infrastructural conditions, the Nigerian State attempts to circumvent the market equilibrium by deploying scarce resources in unsustainable, capital-intensive and high-technology endeavours.

The market is balanced at a low level of agricultural output because of a variety of state interventions in separate but related areas: wage policies favour urban over rural activities, subsidized food imports prevent a balance between national supply and denand at 
higher price and output levels, ${ }^{26}$ finally the tariff policies increase the price or lower the quality of sanufactured incentive goods. Subsidized inputs such as irrigated land, wechanical and chenical inplements, even if they reach the aajority of the smallholder farmers (which they don't in Nigeria), affect only one elenent of a farmer's incentive structure. If product prices are low, manufactured goods expensive and prospects insecure, reducing some factor prices will not very likely provide sufficient incentives for the vast majority of small-scale producers who are responsible for cultivating over $90 x$ of the country's food crops. In agriculture, as in other sectors of the economy, the problem "is more the anti-market and control orientation of the state than its presence. The objective is to move it from a control to a service role which pronotes a highly conpetitive private and cooperative sector" (Leonard: 1986,188).

26 In the 1970s, the government supported the development of highyiflding variety of maize as a feed for the urban poultry industry. The I badan based International Institute of Tropical Agriculture (IITA) developed a promising new variety of aize which was widely accepted by local rarmers in over 2,500 villages. "Then the government reversed itself. In April 1977, in an effort to lower urban food prices by cutting the production costs of poultry, it removed all barriers to the importation of yellow maize. With protection renoved, the overvaluation of the Nigeria's currency neant that U.S. number one corn could be imported at 150 naira a ton, over 100 naira ton below the local costs of productjon. Local farmers who had adopted the IITA package found that they could no longer sell their maize at a profit, given prevailing price in the Nigerian market. As a result, the experinent was devastated (Bates:1981,3738). A similar fate awaited those farmers who had increased their production in the framework of World Bank supported developnent projects (cf. hallace:1980,69). In the early 1980s, a highly instructive policy reversal took place: the subsidization of inports was complemented with the subsidization of domestic produce. "The special maize programme, aimed at helping the poultry farners, purchased maize at $N 325$ and sold it to feed millers at $N 240$. With total purchases of 500,000 tonnes, the subsidy amounted to N16,575 million" (Idachaba:1985,163). 
It is in agriculture that the bureaucratic State's anti-developmental conservatism, tutelar veness come into sharp relıef: on the one hand is its signal failure to move decisivel: on a broad front towards the commodification of rural life while, at the same time - which means prematurely - insisting on economies of scale. Concentrating lavish resources on enclaves wight succeed, at high cost, to increase overall output. Yet it does not address the basic reality, namely that the cash economy remains rudimentary, the peasantry largely in a subsistence mode and thus "uncaptured" (Hyden), property relations vague, agricultural returns insufficient and productivity low. The bureaucratic state effectively frustrates the emergence of a dynamic private sector of smallholder peasant farmers. Prominent factors are the dislocations resulting from the subsidized imports of food on the demand side and the above mentioned capital-intensive implants on the supply side,

of great importance is also the State's reluctance to grant land titles to small farmers. Yet, what might pass as concerned conservationism, namely the reluctance to alienate land, does not prevent the State to use its authority to privatize attractive parcels for the personal benefit of members of the state class and of their clients. As both history and theory show, economic development requires the treatment of land as a commodity which must be able to be owned, mortgaged, rented and sold by everyone. Such individualization "will cause a land market to emerge. Land will be transferred to those who are able to extract 2 higher value of product from the land as more productive users bid land away from less productive users" (Barrows and 
Roth:1990,269). Schultz in his seminal stidy states categorically that rent, that is, the price of land (analogously to interest as the price of (apital),

perforas a necessary economic function in the allocation of resources in farming. Thus any suppression of rent impairs the signals and incentives that are necessary to guide and induce farmers to 'se farm land efficiently. ... The allocative function of product and factor prices cannot be dispensed with in transforming traditional agriculture. There is no efficient alternative (Schultz:1967,125-127; see also Cohan:1980,354-356; Dorner:1972,44; Johnston \& Mellor:1961, 582; Siddle Swindell:1990,82; Stolper:1966,305-308; for the anti-developmental effects of non-individualistic land tenure see Smock: 1969,123$) .27$

$2 T$ This point will be elaborated below (pp. $265 \mathrm{ff}$ ). To summarize hriafly: land as a major factor of production - in fact, Marx called earth "the mother of material wealth" (Marx:1969a,58) - cannot remain outside the general commodification of life which both Marx and Weber considered the conditio sine qua non of economic development. Also, land as an ownable and tradeable commodity improves the productivity of both Jand and labour, a point made already by Adam Smith: "A person who can acquire no property can have no other interest but to eat as much, and to lahour as little as possible. Whatever work he does beyond what is sufficifnt to purchase his own maintenance can be squeezed out of him by violence only, and not by an interest of his own" (Smith: 1974,488-489). hitll hautsk! developed this argument: "Security of tenure is necessary even hith farming in a very primitive state, for the peasant does not immediately harvest what he has sown. It is many months before he reaps the fruit of his labour, and the rencfits to be derived from improvements are often not visible for years. Unless he is certain that his farm and crous will remain his property, he will avoid all improvements and will reduce his soving to a minimum" (Kautsky:1931,61). Moreover, the separation of the direct producers from the means of production is imperative fur the creation of a proletariat forced to sell its labour on the marhet (cf.Marx:1969a,742-743). For historical evidence see Braudel:1982; Dobb:1981; Elsenhans: 1983; also Moore who contends "that when the common fields disappeared and a new economic system began to win out in the [English] ccintryside, the old peasant comunity finally gave way and disintegrated" (Moore:1966,28). Economically, the case for enclosure was that it "enabled uncultivated land to be brought into use and made the commercially minded' improving' farmer independent of his more custombound and oldfashionsd neighbours. This was undoubtedly so" (Hobsbawm: $1990,101)$. 
Even if initially equally d; tributed, the wholesale comodification of land would mark the separation of the direct producers from their means of production, thus altering the relations of production and marking the beginning of capitalist agriculture. The problem was recognized by the Nigerian State, if misinterpreted in its exclusive emphasis on large-scale application:

The land tenure system has long been a bottle-neck in the establishment of large-scale farms by private operators. With the implementation of the recent Land Use Decree ... private sector involvement in large scale agricultural activities should receive a boost during the next Plan period. ... The reform should promote better security of tenure and also encourage consolidation of holdings and large-scale operations (Nigeria:1979,29).

While the bureaucratic state in 1978 , by promulgating the Land Use Act and resting the state governors as land trustees, has created the legal conditions for expropriating land, these have so far not been used in any systematic fashion for constructive deveiopmental purposes; as has been argued above, the attempts to achieve economies of scale by means of giant irrigation projects hardly qualify as such. The decree's significance lies in its broadening of the State's power base. In resting all the land in the State (state governors for rural land and local councils for local land) and thus reducing the possessor's interest to a revocable right of occupancy, almost feudal power relations were created, even if the rhetoric accompanying the decree's promulgation resonated with public trusteeship and the need to prevent capitalist exploitation.

Thus, drawing somewhat indiscriminately upon ideologies of developmentalism, egalitarianism and socialism, the Decree 
enacted a statign which operates beyond the rule of law. It converts erstwhile property rights to privileges held at the pleasure of executive and bureaucratic powers. [... moreover, the] placing of enorwous discretionary powers over land in the hands of local bureaucracies present great potential for patronage (Francis:1984,14; see also Uchendu: 1979,72 ).

Obviously, the decree served the state class's pecuniary interests also in more direct ways. One of the few empirical studies of the effects of the Land Use Act of 1978, concluded that "the vast majority of the population are denied even admission to the land-allocation process [...hhich] is structured, both formally and informally, in a fashion that is biased in favour of the wealthy and the well-connected" (hoehn: $1983,467-468$ ). Another study corroborated this assessment as did the official haduna State Land Investigation Commission which declared that the "system of administration in this state is both inefficient and corrupt. ... Allocation of plots is not based on application or on the real needs of the applicant but on the basis of who he is or hliom he knows" (cited in Famoriyo:1986,135 \& 139). It was moreover established that records were not properly kept and that the "majority of beneficiaries of statutory grants in Kaduna state ... was made up of public servants" (loc. cit; see also Koehn:1983,464). Given their ease of access to bureaucratic decision makers and their relative affluence, "many government employees have used surplus income and loans to speculate in land and enter the private housing market by building houses for rent ... Fjelds have been taken over for housing and institutional use at a sometimes staggering rate symptowatic of the way in which the interests of peasants have been gratuitously over-ridden in favour of 
those of the military and educated bourgeoisie" (Swindell and Mamman: 1990,1751 .

The bureaucratic State as Nigeria's singularly most infiuential and important economic actor is also highly attractive as an enployer. ${ }^{28}$ This has not changed since pre-independence days and its growth in size and cost has been enormous enough to justify considering it as an intervention in the economy at large. As their pay originates in the oil-rent, it is not so much the public employees' cost to the treasury which matters. More important is their level of remuneration relative to per capita GDP which creates equalization pressures for the small manufacturing sector and so renders it internationally uncompetitive, which feeds back to increase protective tendencies; by the same token it. undermines the already low pi ductivity and production of agriculture, accelerates rural-urban migration and amplifies the inclination to import food for subsidized distribution in urban areas. As long as the bureaucratic state is open for recruitment, which it must be for a number of reascns - historical, distributional, ideological, legitimatory, patronage - it will have an anti-production effect for the economy at large. Formal education being an entry-requirement, popular pressures for schooling at all levels result. Even for peasant farmers, sending a child to school and possibly to university with the

25 Data for the staffing levels of the states of the federation are notoriously hard to come by. Nevertheless, it is estiated that the number of staff on the public payrolls lexcluding the military and parastatals) rose from 63,000 in 1950 to 213,000 in 1960 , to over 1 million in 1975 and to 3.7 million in 1983 (see table 9). The federal civil service grew from about 35,000 staff in 1960 to over 100,000 by 1973, to over 225,000 by 1980 and to over 300,000 by 1984 , before revenue crises forced the $f$ igures down again (see table 14). 
prospect of government employment is a more rational investment than technical improvements of their farming methods. 29 The demorratization of education leads to demands for additional white collar jobs which, under the circumstances, ainly the state can provide. Further, the State's employees who, together with the non-state urban salariat, are a relatively privileged and affluent segment of society, will want to travel abroad, send their children to foreign schools and acquire consumer goods which the national economy does not produce and which have to be imported. ${ }^{30}$ They will bring their influence to bear to maintain or improve their income levels, to hold food prices low and to keep the exchange rate overvalued. In short, the "expansion of the state apparatus provides the fundamental opportunity both to maintain political cont rol and to achieve remarkable wealth amidst great and growing po-

29 The marked rural-urban income differential will be discussed in Part II, chapter 1. The key role of education (rather than class, ethnicity or genderl in social mobility cannot be overemphasized. "For the individual child the horizon opened up by schooling is a ride one. For example, the chojces open to the child for earning a livelihood in wag? employment are extremely limited. With four years' schoolins ivis earnin, capacity rises to roughly 250 per cent of the earnings of undif ierentiatec' labor. A further $f$ ive years of postsecondary schooling puts his earnings at 412 per cent of the earnings of his counterpart without this additional training" (Okigbo:1965,171).

30 During the oil boom of the 1970s and early 1980s, every Nigerian was entitled to an annual basic travel allowance (BTA) of N1,000. Upon presentation of airline tickets, any bank would exchange the $N 1,600$ into, say, US\$ at the official exchange rate which, in 1980 , yielded $\$ 1,830$. It is obvious that only those involved in the cash economy benefitted from this policy and that extensive abuse was possible. With the help of fake tickets, BTAs could be sold to the highest bidder; or the $\$ 1,830$ could be changed back into Naira in the parallel market where they fetched N3,000 or more. The sums involved in this subsidy programe in favour of the urball salariat were considerable, amounting to over N300 aillion (nearly $\$ 500 \mathrm{million}$ ), for instance, for the first 8 ix months of 1981 (WA No 3353 , 2 lovember 1981,2604 ). 
verty" (hasfir:1987,45). Obviously, these trends are not unique to the bureaucratic State, but are symptomatic for all developing countries. Nonetheless, in the absence of countervailing economic or political pressures, they are particularly virulent here, reinforced by the bureaucratic State's distinctive interest position and policies.

\section{c) The Bureaucratic Mode of Production and Econonic Developnent}

In the bureaucratic mode of production, there is a conspicuous conflict of interest for a preponderant State between its hegemonic self-interest (i.e. its substantive rationality) and capitalist development. The latter requires a different kind of rational calculus, one in which regulatory and allocative decisions are taken in accordance with strictly economic standards, while the former recommends pulitical, control and patronage-oriented criteria. Patronage-driven allocative decisions cannot be assumed to coincide with economically optimal uses of scarce resources. Unfortunately, it cannot be assumed either that socially beneficial investments will be made or sponsored whose returns will accrue in the medium- or long-term to a diffuse group of beneficiaries. More typical are:

- inflated public payrolls, loss-making parastatals, infant industries which refuse to grow up (and don't have to) behind protective barriers, highly visible, prestige-enhancing in- 
vestment projects (e.g. university campuses, highways or steel plants), for which a one-time capital outlay is made and which can be inaugurated in splendid ceremony. More typical is a) so

- the failure to budget in advance and to supply the necessary resources to cover the recurrent costs for these facilities;

- the delinquency to create integrated systems of maintenance and supiort; and

- the omission to provide skillful and patient management over an extended period of time.

"Postrolonial African politicians have not been content to act as custodiaus of established programmes; they want to preside over new ohos" (Ayoade: 1988, 105).

The bureaucratic State, ostensibly the central agent of developmall has, on closer inspection, interests which are less altruistic and mis.. pyuitucal." In the words of the economist who headed the team f tacnsible for Vigeria's first National Development flan: "It may held b. that economic development has not, in fact, the high priority in the thinling and aspirations of ... the leaders of underdeveloped countries as the'se leaders pretend" (Stolper:1966,16). For the state class as

31 This has not gone unnoticed. A survey of three Nigerian universities concerning attitudes about public servant integrity found that over $30 \%$ of respondents believed that relatively few civil servants in most African countries are capable of putting national interests ahead of their onll interests (Beckett and $O^{\prime}$ Connell:1977,148). 
such, the long-term gains of broadly based econonic development would by far be outweighed by short-term costs. The inevitable emergence of an independent, productive bourgeoisie would be a nost effective check on the excesses of an uncontrolled state. High standards of calculability, efficiency, probity and responsiveness to the needs of economic enterprise or, at least, non-interference, would be deaanded fros the State. The State's autonomy and the possibilities for the self-enrichment of the state class would be much reduced and the State's legitimacy more closely tied to its general performance. This does not wean that individuals or whole segments of the state class would not genuinely pursi'e economic development, regardless of its costs in class terms. It also does not, on principle, exclude a strong leader or a determined coalition from initiating and executing forceful, reformist actions; General Murtala Mohammed rather successfully did as much in the fer months before his assassination (which, naturally, is not much of encouragement for anyone to emulate him!), as did President Gorbacher during the initial years of his government. What it does wean, however, is that such efforts are either the noble acts of individuals, rather than the bureaucracy's standard aode of operation, or that they are more likely to be undertaken in times of crisis or under the force of external pressures such as IMF imposed conditionalities. ${ }^{32}$ Normal-

32 The present Nigerian military government has, precisely to avoid succumbing to an IMF octroi, implemented a structural adjustment programme intended to end high budget and balance of payments deficits, to reduce nonproductive public sector investaents and to stiaulate private sector activity. The naira was devalued at first and later allowed to float freely (with the effect that its value dropped from about $\$ 1.30$ in 1984 to about $\$ 0.14$ in 1989 ; see table 7 ); ioport licencing was abolished, price controls were reduced, narketing boards were abolished and most parastatals were scheduled for commercialization or even privatization. 
$1 y$, however, the kind snd degree of control exercised by the bureaucratic Nigerian State, as well as the manner of its intervention in the economy, are developmentally counterproductive because of the two different substantive rationalities involved.

This goes against the grain not only of dependency and related approaches but also of a large chunk of more orthodox development thinking, most of which is based on the visceral prejudice that control is better than laissez faire and that state control is better than control by private, national or international actors. However, treating state control over the economy axiomatically as beneficial, invariably leads to the resurrection of the state as a black box and also to a selective blindness concerning the motives of State officials as individuals and as a class. The stance taken is often rather binary and absolute, leaving little room for differentiating arguments concerning either contextual contingencies or about the optimal scope, range and nature of control in relation to a specified objective. In a characteristic sample it is for instance asserted that the "issue of control is (entral to an understanding of the economic and political conflict that separates North from South, rich from poor, the haves from the havenots in the contemporary world economy. It is related to ... the issue of improving the material well-being of the South" (Biersteker:1987,3). Although Biersteker's analysis is considerably more sophisticated than

These reforms, all intended to reduce state control of and interference in the economy in favour of the warket as a mechanism for economic resource allocation, seem to undermine the validity of arguments concerning the dynamics of the bureaucratic State. These ostensible contradictions will he discussed in some detail in Part II. 
this quote would suggest, it is fair to say that he views synpathetically the Nigerian State's increased control of the econony which resulted from its indigenization policies.

I consider the opposite to be true, namely that Nigeria is overcontrolled, if badly administered, and that this conbination has created many of the severe problems which controls ostensibly were introduced to address in the first place. Controls in Nigeria typically tackle symptoms not causes and, in the process, lead to further deterioration of both, and to the need for wore controls. ${ }^{33}$ For instance, the controls and market interventions accompanying the post-independence expansion of the state sector and import-substitution industrialization were a major cause of declining agricultural output. Unattractive producer prices in a context of subsidized food inports and expensive manufactures had a dampening effect on output but also precipitated the smuggling out to neighbouring Benin, Niger and Cameroun of a sizeable

33 of course, there also controls which are entirely ineffective, mere Pavlovian reflexes of an interventionist state. The elaborate and futile price-setting mechanism for agricultural comodities, in place from 1973 until 1986, is a case in point. The Technical Comaitee on Product Prices (TCPP) consisted of representatives of the Central Bank, the Ministries of Finance; Agriculture, Water Resources and Rural Development; Co-operatives and Supply; Trade; Economic Development; Comerce; National Planning; the state Agricultural Ministries; the Productivity, Prices and Incomes Board; the Operation Feed the Nation Comnittee and the Farmers' Union. The terms of reference were as vague and unwieldy as the Committee's membership. Rather than having clear guidelines (such as to minimize food prices or to maximize agricultural output, the earning of foreign exchange or farmers' incone), the TCPP was to consider more than twenty factors, nost of them obscure or impossible to operationalize or both ("the need to check sauggling" or the "prevailing situation in the country"). Until its abolition in 1986, the TCPP's intricate nachinery had tied down valuable adainistrative and financial resources - the commodity boards had run up debts of over N1 billion - without perceptively stimulating production or safeguarding farners' incones (cf. Idachaba and Ayoola:1991). 
share of the country's cocoa, cotton and groundnut crop. State controls, such as the closing and sealing of borders between 1984 and 1986 (ARBe:2/1986,8108), or the imposition of 21 -year jail terns for the unlawful exportation of foodstuffs (WA No. 3493, $30 \mathrm{July} 1984,1551$ ), did not induce farmers to sell in the hone-market, but to withdraw until prices improved. The pull of world market prices in the adjacent cfa zone (higher for agricultural products and lower for manufactured goods which, moreover, were of higher quality than those available in Nigeria) could not be neutralized by police methods. These, at nost, increased transaction costs somewhat because the border patrols had to be paid off.$^{34}$ With the SAP-related reduction of state intervention in the economy generally, and the abolition of state controls over agriculture specifically, a sense of equilibrium was restored. Higher prices managed automatically what had eluded the state for two decades, namely to increase output.

This should not be surprising since it is a common sense observation and has been empirically substantiated that, other things being equal, people as producers and as consumers are responsive to price incentives. All respective studies from Nigeria as from other parts of Africa emphasize this point (cf. Askari and Cumings:1976; Lancaster: 1988,34; Lipton: 1987,202\& 204; Klitgaard:1990,166; Ruthenberg:1968,

34 After the Buhari regime sealed the borders in 1984 , a thriving market in the commodity "border crossing" energed. "Touts suspected to be agents of the security guards collect N2 per head at the Nigerian end of the border while another N2 per head is paid to such agents at the Benin Republic end. Motorists pay about N2O and up to N200 to the agents if they carry contrabands" (report in the National Concord (Lagos), cited in WA No. 3504, 15 October 1984, 2100). 
B48; Schultz:1967,50; Stock:1969,119; Stolper:1966,143; Woodsworth:-

$1988, X()$. The author of a study entitled Africen Farner Response to Price: A Survey of Eppirical Evidence observes exasperatedly that "one gets very tired of reading through elaborate formulations and estimations, study after study, only to come to the sane conclusions: 'Therefore growers respond to price incentives.' As this survey has shown, there is enough evidence to make this conclusion a truisa" (cited in Kasfir:1986,348). This conclusion will be corroborated for Nigeria in Part II: the absolutely phenomenal growth of agricultural production before independence was as much a reaction to realized prices as was its equally astounding decline thereafter.

In general terms, the state controls and interventions associated with the bureaucratic mode of production lead to low productivity and stagnant or even falling output - which wight temporarily and at great expense to the treasury be reversible through heavily subsidized inputs directed at isolated enclaves. Input-subsidies, however, even if higher and more evenly distributed than they are, will not be able to overcome all the adverse market conditions created by state intervention, such as relatively high urban wage levels and resulting pressures on rural economies, massive food imports and overvalued currencies. Similarly, the main problem of manufacturing industry in Nigeria is not unfair foreign competition or ownership, but inefficiency, a foible not at all addressed by influencing the nationality of owners and anagers, or by perpetual subsidization through open-ended and unconditional protection. The vicious circle of interventions, controls and subsidies 
is not static; inescapably distortions accelerate and ultimately, at the latest when resources dry up, they lead to paralysis or break down. In Ghana but also in Tanzania this happened when the agricultural sector withdrew to escape penalizing taxation and when the state's revenues had been reduced to a trickle. Even though its wechanisas and motives are siailar, oil has enabled the bureaucratic Nigerian State to avoid comparable consequences until very recently. Oil rents, because they were immediately monetized in the national economy rather than used to build up foreign reserves, translated into increased state expenditure (out of step with national productive capacity) which lead to inflation and/or imports in ace to balance effective deaand and available supply. An overvalued national currency cheapened imports and, in a largely agricultural economy with underdeveloped possibilities to meet urban demands, helped to keep inflation down. Yet, to manage the thusly induced resource outflows, foreign exchange and inport controls became imperative. The more successful these were:

- the more infiation soared and the more intensive pressures became for urban wage increases;

- the less (internationally) competitive indigenous industries and agricultural exports became;

- the more the gap between urban and rural wage levels widened which, then, induced the regression of agriculture to a subsistence level.

Inflation, in turn, was attempted to be contained through price 
controls, smuggling lof agricultural produce out and of manufactures in) through border controls, and black currency markets through police action. Of course, these enforcenent actions were not too seriously pursued since some movement of goods lowered popular discontent and raised the possibility for inspectors of all types to share in the rents. ${ }^{35}$

To summarize, I propose to interpret the extensive regulation of foreign trade, just as the indigenization of the economy's formal sector, the nationalization of the oil industry or other interventionist policies as but elements of a larger project in which enhanced controls strengthen the state and, at the same time, enable it to satisfy the material vants of the members of the state class as well as of those groups which are organically linked to it. Economic control, more generally, not only ensures the State's resource base and thus enhances its autonomy. It also gives it the financial wherewithal for patronage and thus to procure state legitimacy. Control, as is nicely illustrated by the ubiquitous roadblocks in Africa, is not an efficiencyenhancing steering mechanism but a power instrument which can be used to raise funds, to build loyalties by rewarding followers and to deter or punish dissenters. In Aluko's fictitious "Newtown," the

Local Authority staff under the very able leadership of the \$360 year Clerk had become an arm of the Government party

35 The guidebook, Doing Business in Nigeria, advises delicately that "various problems could arise when clearing goods if the inporter is not used to the procedure and is not aware of the documents required by the Customs and Excise Department. In such circumstances, it is advisable to use local clearing agents who already have an ongoing relationship with the officials of the Custons and Excise Departeent" (Price Waterhouse: 1987,34 ). 
in their official activities. Market stalls, permits to operate taxi cabs, petty contract awards - all these essentials to keep body and soul together in the fierce struggle for existence went to men and women known to hold government party cards. The local government police and the sanitary inspectors were most ruthless in thir prosecution of cases of minor offences against public health by-laws involving members of the Opposition party ... (Aluko:1977, $187)$.

Last but not least, controls further the State class's immediate interests in self-aggrandizement ( 1 use the shorthand "property" for this particular preoccupation which refers mainly to material privileges but also to political power and to social status).

I have argued that the bureaucratic mode of production is a distinct economic system, with its own laws of notion, and ruled by a domingnt class rooted in the state bureaucracy. The concentration of eccnomic and political power in one class makes it, in appearance and performance, rather similar to the former East Bloc states. As early as 1939, the unorthodox Marxist Bruno Rizzi spoke of "bureaucratic collectivism" when discussing Stalin's Soviet Union, where

the bureaucratic state channels surplus value in various ways to its functionaries, forming a privileged class installed within the state. We too had never seen a ruling class without a bureaucracy directly under the control of the state, nor had we seen a bureaucracy which was also the ruling class. But there is no doubt that today that is what we are seeing, and moreover we are quite sure that we are not fooling ourselves (Rizzi:1985,73; also Gide:1950).

This train of thought was taken up by the dissident Yugoslav communist, Milovan Djilas, who contended that, under socialism, "power and government are identical with the use, enjoyment, and disposition of almost all the nation's goods [... and that the] ownership privi- 
leges of the new class and membrship in that class are the privileges of administration" (Djilas:1962,46; for a congenial, more recent appraisal of the Soviet state class see Bialer:1991,168-170). Such proprietorial sentiments are not alien for the state class. Unaccountable to other societal forces, the economic policies of the autonomous bureaucratic State are power instruments at the service of the state class, rather than essential components of a coherent economic growth strategy; they might turn out as developmental non-starters but they seldom fail to tangibly benefit members of the state class. Also, they are rarely well focused, one-time, tactical interventions to solve a specific technical problem, but usually operations which are wide in scope, open-ended and bereft of any mechanism for self-evaluation, self-correction or self-termination. "There is circular causation with cumulative effects in the sense that a corrupt body of administrators ... will have an interest in preserving and building up discretionary controls that give them the opportunity to enrich themselves" (Myrdal: 1968,933). The developmentally retarding effect of the state class's gateleeper position is not primarily the resulting denial of economic resources to the productive sector. Much more seriously obstructive for a take-off are the secondary consequences of the state class's actions or inactions, namely its failure to perform the historical rule of the bourgeoisie or, realizing its respective weakness, to reverse its practice of obstructing the emergence of a dynamic entrepreneurial class.

Even though it considers itself Western, perhaps even capitalist, the bureaucratic state's economic role is, in reality, quite similar to 
that of the former East Bloc regimes toppled in the memorable Fall of 1989. Their disastrous and ultimately terminal defect was not their leaders' venality which denied welfare to their people and led to social injustices, but something nore debilitating. The apparatchic system prevented the creation of any wealth at all which, then, could have been distributed, fairly or unfairly. This point was made eloquently and presciently as early as 1930 by Karl Kautsky who criticized the Bolsheviks for failing

to realise that the vital problem is to raise the efficiency of labour, and that the products of labour would then yield a surplus automatically ... The Bolsheviks would not profit by recognising this, for this method of increasing the productive capacity of the workers presupposes a high degree of freedom and this requires a far-reaching democracy. ... The attempt, by means of centralised bureaucratic and police intimidation, to evolve a socialist system of production superior to that of the capitalist system in a most backward people was, from the outset, doomed to end in bankruptcy. The latter is approaching with sinister speed (Kautsky:1931,13-14\&45; see also Gide: 1950 and koestler: 1946 a).

Even though the requisite economic factors (huge markets, capital, skilled labour and technology) were available, they could not make use of them. The communist states' ineptitude at organizing production (and thus at generating any extractable surplus to speak of) was an indication not only of their general economic inadequacy, but also of their failure as "exploiters."36 since economic development depends on

36 Exploitation, for Marxists, is very narrowly and precisely defined: it refers to the extraction of surplus from direct producers, i.e. to the circumstance that the worker's labour is not fully compensated because the employer's benefit exceeds what he pays out as salary. On this definition, as will be explained below (p. 269), hinges Marx's concept and critique of capitalism. In contrast, Weber's and Schumpeter's far more incisive analyses suggest that capitalism is so successful in generating wealth, not because of any 'orm of exploitation, but because capitalism's 
the generation of surplus and of its productive investment, it "only happens when the surplus gets into the hands of those who will use it productively, that is, to finance industrial investaent" (Sutcliffe: 1972,175-176). In the former communist countries, as in Nigeria, the surplus did precisely not get into the hands of those who did or would use it productively. The bureaucratic Nigerian State is sisilarly regressive in preventing, not perpetual and pervasive drudgery, aisery and poverty, but capitalist exploitation which, if temporarily perhaps even worse in terms of human suffering, at least is time-limited.

It bears pointing out in this connection that capitalism is indeed, as even Marx and Lenin recognized, an eminently dynamic and progressive system, better suited than any other to develop the forces of production and, conseguently, the productivity of labour. Marx spoke about the "civilisatory mission of capital that it conpels ... additional labour to be performed in a manner and under conditions which are more favourable for the development of the forces of production, for the social relations and for social progress than earlier forms such as slavery, serfdom etc." (Marx:1968,827). He also emphasized the revolutionary role of the bourgeoisie which, "wherever it came to power, has destroyed all feudal, patriarchal, idyllic bonds and relationships. ... Only it has proved what human uction can achieve. It has performed completely unique miracles, unlike the egyptian pyramides, roman aqueducts, it has performed totally different marches as mass migrations or crusades. ... Through the rapid improvenent of the neans

systemic logic induces both capitalists and workers to act in ways which make both of them better off (see bolow pp. $279 \mathrm{ff}$ ). 
of production ... it yanks all, even the most barbarian nation into civilization. ...[it has] rescued a considerable part of the population from the idiocy of rural life" (Marx and Engels:1975,28-30). Marx considered it pitifully "sentimental to upbraid capitalism in the hope of stopping or diverting its victorious advance" (Kolakowski:1988,413), while Lenin chided the Narodniks for doubting "the progressiveness of capjtalism [which consists in the] increase in the productive forces of social labour and the socialisation of that labour" (Lenin:1956,602603). Yet capitalism's revolutionary impact is not limited to the suhere of material production; it equally transforms culture and society.

The capitalist process rationalizes behavior and ideas and by so doing chases frow our winds, along with metaphysical belief, mystic and romantic ideas of all sorts. Thus it reshapes not only our aethods of attaining our ends but also these ultimate ends themselves. ... [The] rationalization of the soul rubs off all the glanour of super-empirical sanction from every species of classwise rights. This then, together with the typically capitalist enthusiasm for Efficiency and Service - so completely different from the body of ideas which would have been associated with those terms by the typical knight of old - breeds that 'will' within the bourgeoisie itself. Feminism, an essentially capitalist phenomenon, illustrates the point still more clearly (Schumpeter:1962,127).

Capitalist development seriously pursued would be for the state class far more taxing and far less rewarding than tinkering with the bureaucratic mode of production. This accounts for the latter's resilience to an equal or greater extent than such factors as poverty, scarcity and the general problen-overload facing fledgling governments which are sometimes charitably assuned to be the main obstacles for 
economic development. Without totally discounting these constraints, the point is that the Nigerian state class is doing quite well for itself regardless, and that its policies, norally, are nowhere near the optimum which could be expected, even considering the arduous conditions it is compelled to operate in. In a classical case of goal-displacement, the State is pursuing objectives which are only distantly related to its ostensible developmental purpose. ${ }^{37}$ Suffering from the serious design defect that the substantive purpose of its economic policies is often not only incongruous but also incompatible with their rhetorical rationale, it cannot surprise that they should cause dislocations and negatively affect developmental prospects. In the absence of serious constraints imposed by actors outside the State, that is, in view of the latter's relative autonomy (compromised mostly by organizational and technical inefficiencies), its action and nonactions are the significant variables to account for developmental progress or lack thereof. The potential for decisive, coherent and constructive State operation was demoristrated, for example, by the effectiveness of economic control policies (on both sides!) during the emergency of the Civil War when reserves were mobilized, energies focused and egotisms temporarily subordinated to a larger cause. Capital formation proceeded apace, capacity utilization rose significantly and existing "assets were stretched to their limits as many factories pro-

37 Commenting on the Algerian State's performance, Nellis argues along the same lines: "it is quite clear that the ... administrative systen exists mainly for the benefit of those who have succeeded in enfolding themselves within it, rather than for the benefit of the public it supposedly serves" (Nellis:1979,421). 
duced non-stop in three shifts ... there were booming records in industrial turnover, employment, capital expenditure and profit" (Nigeria: 1970,24). Development for the bureaucratic State, unfortunately, does not qualify as a similar emergency, whatever the official rhetoric. ${ }^{38}$ Without the discipline enforced by a disaster, recognized as such by the bureaucratic State, its behaviour will revert to its normal, that is degenerate and patrimonialized patterns.

The models of the bureaucratic mode of production and of the bureaucratic State reveal a systemic logic behind the Nigerian State's policies. These are developmentally counterproductive, not so much because they are incoherent, poorly implemented and wasteful, which they are, but because they contradict capitalist rationality. The concept of capitalism referred to is Max reber's. For reasons to be pointed out below (pp. 275ff), Weber considered capitalism the most successful framework for economic development. If the heuristic nature of the three concepts - bureaucratic mode of production, bureaucratic State, capitalism - is accepted, a vista opens for a normative discussion of the State's role in economic development. Even though prescription is not the purpose of this study, it might be useful to briefly sketch out what the State should do, and how, and what it should not do, and why. It should be emphasized that the following outline is stronger on desirability than on probability. It is also

36 Nigeria's Second National Development Plan acknowledged that a "developing country in the context of 20 th century Africa and of changing world technology is really in a state of permanent crisis hardly distinguishable in its essence from war-time mobilization" (Nigeria: 1970,31). This recognition, however, was never translated into coherent state policy. 
fairly sweeping because technical subtleties can be dealt with fruitfully only once fundamental issues are settled.

If the model of the bureaucratic mode of production captures the essence of Nigerian reality, economic development will remain elusive, unless economic and political power is devolved from the state, and unless the State undergoes a fundawental reorientation and transformation. The State would have to become differently rational in substance and, consequently, more formally and practically rational. Substantively, the emphasis of its role in economic development would have to shift from that of hub, key actor and provider, to that of guarantor of the capitalist order, of catalyst to stimulate private responses, and of regulator of temporary imbalances. By implication, the state class's project of autonomy and property would have to be subordinated to capitalist development. Formal rationality ensured by the state lan economic environment of calculability, predictability and stability) would have to be complemented by practically rational economic policies (by the most efficient means to reach the goal of capitalist development).

At a minimum, the State would need to establish and maintain the legal and political framework in which productive investment can flourish, because an "environment of security and property and predictability is basic to encourage investment ... Otherwise, investors cannot calculate that an investment today will bear fruit tomorrow" (Sandbrook: 1986,320$)$. Relatedly, the state would have to create an incentive system to induce private initiatives in priority areas such as agriculture and manufacturing industry. The state, any state, has at 
its disposal a number of policy tools which, if enployed in concert, non-discriminatorily and consistently, can create an environment favourable to production. Macroecononic stability with calculable inflation and exchange rates, both as low as possible, are non-negotiable. Production incentives could be provided by uniform import duties; by relatively egalitarian income structures (obtainable through progressive taxation), by measures to maintain existing aarkets (through the stimulation of competition), and by those which create new markets.

In addition to regulating the economic environment, the state would have to mold the physical environment. It would have to act on the core prescription: of classical development economics which went out of fashion not because of their recently discovered undesirability, but because time showed that many states did not play the parts assigned to them by the literature. In particular, the state should generate the physical conditions conducive for productive investment by private actors. This would presuppose a high level of executive capacity and entail undertaking those large investments which are imperative for development yet unattractive for private business because benefits are not precisely targetable to paying customers and prone to be utilized by "free riders." These "positive externalities" refer to a specific form of market imperfection whish, in the interest of macroeconomic efficiency, have to be overcome by publicly provided pacing devices and pressure mechanisms (Hirschman:1981b,9). Outside the scope of private suppliers, such critically needed intermediate production factors are primarily infrastructures (communications, irrigation, power and transportation), but also the mobilization of indigenous surplus (through 
support for or organization of a rational banking system), the inprovement of mass education systems, the controlled inportation of expatriate expertise, and the creation of an indigenous productive bourgeoisie (Gerschenkron:1963; Lewis:1953). As important as doing all these things is that the state does them efficiently, that is, as cheaply as possible, at the right time, and with enough flexibility to avoid the minimize the opportunity for rent-seeking.

Since Nigeria is a predominantly agricultural economy, and since development implies transforming the econony's structure, agriculture must be the linchpin of any development strategy. To raise agricultural productivity, an immediate priority would be to eliminate the incentive bias against agriculture, mostly through the restoration of macroeconomic conditions in which normal market incentives can take hold to establish scarcities and prices and so guide the allocation of resources. ${ }^{39}$ As was argued before, the fallacious yet preventable and reversible policies penalizing agriculture (and industry) in the postindependence era were artificially overvalued exchange rate cum import

39 In March 1990, to cite a most instructive example of the benefits of state-withdrawal, the Ethiopian government lifted price and state marketing controls; it also allowed farmers to vote on the dissolution of compulsory cooperatives, which they did with overwhelaing majority. The result by year's end, in the words of an OXFAM correspondent, has been "greater motivation, a resurgence of traditional forms of co-operative working, better use of land, and cultivation on new land. ... There are five farmers in this area now and they are doing more and growing more than 30 used to" (McGrath:1990,9). One farmer who has dug new irrigation channels around his three trees and interplanted then with lines of sweet potato comments: "Look at these trees. People are looking after then now. When they were commonly owned and the oranges were ready, everyone rushed to eat them before their neighbour. Now even if I lose one fruit, I will pursue the person who has stolen it" (loc. cit.; for a nore systematic analysis see $A C$ No, 2, 25 January 1991, 3-4). 
regimes which, sending distorted price signals, drove farmers out of production and kept donestic industry inefficient. Policy responses such as importing food and exhorting industry to increase its productivity were not exactly appropriate answers for a dileama created by aisconceived policies in the fist place. ${ }^{10}$ An unregulated price system is internally consistent, and one "ignores the warning which prices give on profitability or the lack thereof, and on how to allcoate resources rationally, only at the grave risk that priorities get distorted in unexpected places and that the problems are simply shifted to the budget or the balance of payments" (Stolper:1966,89). Thus, "getting prices right is not the end of economic development, but getting prices wrong frequently is" (Peter Timmer, cited in Killick:1980,375). "Right" does not by any means equal "high;" it suggests much rather domestic prices in line with international prices (cf. Wade:1990,29; Stolper:1966,138-

40 Throughout the 1980 s, despite the fact that two out of three workers were in agriculture, per capita food intake was lower than in 1961 (FAO:1987,21 \& 106; see also table 11) and over 20\% of Nigeria's imports were food stuffs (World Bank:1989,242; see also tables 6,11 and 12). Agriculture's poor record, unfortunately, is matched by very poor productivity gains in Nigeria's manufacturing industry. Even in the boom years 1973-1983, labour productivity grew in only 13 of 26 branches. "Productivity growth in the case of three of these sectors (electrical machinery, chemicals and leather products) was not significantly greater than zero. The productivity growth performance of the intermediate and capital goods industries was particularly disappointing" (UNIDO:1988,18). According to official Nigerian figures, the average Nigerian worker's productivity has increased by only $8 \%$ in the 1980s (WA No 3833, 18 February 1991, 232). The Nigerian government's response, incongruously, was to designate February 21 as national "Productivity Day" (loc. cit.). By comparison and indicative for the marginalization of Nigeria (indeed auch of the Third horld) as a production site, productivity growth between 1973 and 1990 was $50 x$ in the US, 60x in Germany and 130x in Japan (Main:1990,56). More detailed data on productivity gains in these and other industrialized countries are provided in the World Economic Survey 1990 (United Nations:1990, $172)$. 
218; for a thorough discussion see Streeten:1987,1473-1475).

In this connection, the great attraction of the market lies in the anonymous and thus non-arbitrary process of establishing scarcities and commodity values through the expression of consumer preferences on the one hand and of factor demands on the other. Consumers put their money where their mouth is and so signal their preference unequivocal$1 y$; workers tend to move into the areas, functional and physical, of highest wages, and capitalists strive to optimize their return on investment. ${ }^{41}$ of course, this means that industries, ad infinitum dependent on trade barriers and producing at higher than world market costs, especially if they are net losers of foreign exchange because of their heavy dependence on subsidies to import machinery, raw materials and intermediate inputs, are not viable in the long run and should not survive. On the other hand, agriculture which in a distorted environment is doubly penalized by overpriced domestic manufactures and an overvalued home-currency, cannot compete internationally. Any given world market price translates into fewer than necessary local currency units so that, depending on the extent of overvaluation, it might not even be competitive with imports, because the magnitude of its penalty is equal to its foreign competitors' subsidy. Removing these distort-

41 The flexibility induced by the market is well illustrated by the manner of information transmission in New York City. During the 1980s, with the US Postal Service slow and unreliable, and with the established private mailing companies too inflexible, thousands of saall fires sprung up, employing bicycle couriers who picked up and delivered mail in under two hours throughout Manhattan. After less than a decade of booming business, this industry, in its heyday possibly employing over 50000 bikers, has all but disappeared because facsimile transmissions are much cheaper, even faster and more reliable still (cf. R.E. Tomasson, "Fax Displacing Manhattan Bike Couriers," NYT, 19 March 1991, pp. A1 B3). 
ions would level the playing field.

In the absence of government officials with the competence, wisdom and public-mindedness of a Platonic philosopher king (or of Fabian bureaucrats), the proper role of the state cannot be to administrative1) substitute the pricing decisions of markets, either directly through public sector wage policies way out of line with incomes in agriculture or industry, through artificially high exchange rates or indirectly through import and export regimes. The State should intervene at most e. post facto (in a logical, not in a temporal sense) to correct market imperfections such as monopolies, and to alter distributive imbalances. Thr. Lurenucratic State's interventions typically are ex ante and quite differently motivated: the consistent preference given to discretionary rathor than automatic allocation of costs and benefits reflects the State's pursuit of legitimacy and the state class's interest in prowerty. Eronomic stagnation is the not unexpected consequence.

The State, to summarize, must play a crucial role in ideal typical capitalist development and the quality of its policies is an absolutely decisive factor. ${ }^{22}$ To fulfill this historic mission, the bureaucratic Nigerian State would have to mutate from a control-oriented micru-manager to a macroeconomic facilitator whose role it would be to "'plan' the physical, social and psychological environment of private

42 The historical experience of all OECD (i.e. of industrialized capitalist) countries shows the indispensability for successful capitalist development of effective leadership provided by a strong State. Only the State could unify domestic markets, if necessary defend the national econumy and control its links with the outside world, create favourable investment conditions and ensure the availability of qualified and free labour ( $\mathrm{c} f$. Bienefeld: 1982,31). 
agents rather than to plan what these agents are supposed to do" (Lindbeck, cited in Hade: 1990,13$)$. Put differently, what is required is not necessarily "less government but better government - government that concentrates its efforts less on direct [economic] interventions and more on enabling others to be productive" (World Bank:1989.5).43 The framework within which the development process takes place will have to be the market. Not the market tout court, but one organized by the State to ensure that it works efficiently. The market's centrality in capitalism and thus also in the wider context of economic development will be explored in greater detail below (pp. $298 \mathrm{ff}$ ).

I have argued and will empirically validate in Part II that the bureaucratic Nigerian State is economically central, financially selfsufficient and, as a result, relatively autonomous from society. These attributes are integral elements of a distinctive political system for order of domination) whose power base is the bureaucracy, which is controlled by bureaucrats and in which state action can be expected to aim at consolidating precisely these elements. As a generic economic formation, the bureaucratic mode of production derives from the operation of the hegemonic bureaucratic State whose overriding goals (its substantive rationality) are autonomy and property. Economic development, in particular capitalist development, is incompatible with the bureau-

43 It is heartening that the African voices demanding this are turning up the volume. In 1990 ECA convened a conference in Arusha/ Tanzania which then issued the "African Charter for Popular Participation in Development and Transformation." It calls on African governments to "yield space to the people" and criticizes much of Africa's post-independence history as marked by "an over-centralization of power and impediaents to the effective participation of the overwhelming majority of the people" ! oited in DF, 4 July-August 1991, 12). 
crat:c mode of production on which the State's fortune depends and which it w11, therc'ore, not transform voluntarily. As was mentioned earlier (p. 154), the state as such does not act, just as an orchestra does not, glay music. Both notions are merely descriptive shorthands for institutional frameworks which influence or shape the behaviour of the membe:s of the state class (the orchestra), and within which they, individually and collectively, act. Understanding the dynamics of State behaviour presupposes an analysis not only of the historical origins and the organizational scope of the state, of its relationship to societs, and of its role in the economy. What is required in addition is a consideration of the State's human agency, namely the state class. 


\section{The Nigerian Staice Class}

In view of the peculiarities of the Nigerian political economy and, as a consequence, because of the uncertain progress of class formation (in the Marxist sense), the kind of class analysis requires here is of a different variety than that normally covered by this term. In Nigeria:

- about 70\% of the labour force is in agriculture (World Bank: $1989,277)$; $95 \%$ of these agriculturalists are subsistence or small scale cultivators (peasant farmers'), growing both cash and subsistence food crops on parcels of two hectares or less (hoodshorth:1988, XI; World Bank:1974,78), with secured access to land (Tomori:1979,20; Harman: 1986,35), either for free or at nominal cost (about $\mathrm{N} 10$ or under $\$ 2$ per hectare year); they account for over $90 \%$ of total agricultural output (Bolsover: $1982,18)$. As will be explained, they are not a class but the amorphous mass which Marx, rather uncharitably, compared to a bag of potatoes (Marx:1975,307);

- there is neither a capitalist class (in 1980, the Manufacturers' Association of Nigeria had 500 individual members, cf. AED, May 1982, 68) nor an industrial proletariat to speak of (there are under five million wage labourers, the majority of which employed by the State or by businesses with less than ten workers; $c f$. World Bank:1982). It is telling that the Nigerian Federal Ministry of Industries or the Federal office of Statistics consider as "large scale enterprises" all establishments employing more than ten staff;

- after agriculture and, depending on the world market price of oil, sometimes before, the largest single share of gross domestic product is not "produced" but "won" by an identifiable group (the state class). In 1980 [1986], oil accounted for: 27\% [12x] of GDP (agriculture 21x [36x], manufacturing $9 x$ [11\%]); for $84 x$ [64x] of government revenue and for $97 x$ [93x] of exports (see tables 2, $3,6,8 \& 17$ ). The state class, although not owning the wealth it appropriates, still comands

1 "Peasant farming is taken ... to mean farming with hoes and animaldrawn ploughs or other simple equipment, using mainly family labour, producing a significant proportion of the basic consumption need sof the local community, while purchasing some cunsumption goods and some agricultural inputs, and selling some local products, outside the community" (Barker: 1989, 38). 
over it without, and this is significant, having to employ/ exploit human labour;

- the greatest disparity in Nigeria is not between labour and capital but between rural and urban dwellers; the operative catalyst for this division is not ownership of the means of production but the ease of access to the State or to the statedependent formal sector of the economy. Marx assunes that in capitalism "distribution relations are generally identical with production relations, the former being the reverse side of the latter" (Marx:1968,885) while in Nigeria the two are entirely unconnected. This supports my contention that Nigeria is not capitalist.

rlass, in the Marxist discourse, is a precisely defined, dialectical and dynamic concept rather than merely the label for a layer in a system of social stratification or for one social aggregate among others. Marx could only write two pages of the 52nd chapter of Das Kapital, entitled "The Classes," in which he began with setting out a categorization of social groups according to the ownership of the means of production. "The owners of nothing but labour power, the owners of capital and the owners of land, whose respective sources of income are wages, profit and ground-rent, in other words, wage labourers, capitalists and landowners constitute the three big classes of the kind of moderu society which is based on the capitalist mode of production" (Marx:1968,892-893). Building on Marx's taxonomy and extending it to the resulting social relations, Lenin's definition is the most cogent and comprehensive of Marxist orthodoxy:

Classes are large groups of people, differing from each other by the places they occupy in a historically determined system of social production, by their relation ... to the means of production, by their role in the social organization of labour, and consequently, by the dimensions of the share of social wealth of which they dispose and the mode of acquiring it. Classes are groups of people one of which can appropriate the labour of another owing to the 
different places they occupy in a definite system of social economy (Lenin: 1967,213-214).

Classes are thus objectively definable groups of people (not voluntary associations) with definite and antagonistic relationships to other classes. One class is described in terms of another one, and neither class can exist without the other, even though "their interests remain fundamentally antagonistic" (Meillassoux:1969,103). Non-Marxist analysts, Weber and Schumpeter for example, have questioned whether class antagonism is indeed constitutive of capitalism or whether this is not only a requirement of a theoretical edifice which, without it, hould crumble. "To any mind not warped by the habit of fingering the Marxian rosary it should be obvious that their [capitalists and workersl relation is, in normal times, primarily one of couperation and that any theory to the contrary must draw largely on pathological cases for verification" (Schumpeter:1962,19).

Analysis based on Marx's concept of class, partisans claim, is more than just one of many investigative tools. Instead, it is supposed to represent the supreme method of social investigation. Marxist class analysis, it is argued, permits the penetration of mere surface appearances and exposes the essence of concealed reality which, essentially, lies in the mode of production, that is, in the manner in which in a society the production and distribution of goods is organized. Understanding a particular mode of production, in this perspective, requires identifying any particular class's relationship to the social production process and hence to other classes. Betraying the 19 th century eurocentric perspective, it is contended, firstly, that as long 
as there exists private ownership of the means of production, classes are the fundamental element of the social structure; and, secondly, that the division of society into classes represents the deepest, most essential and most decisive social contradiction.

The specific economic form in which unpaid surplus labour is pumped out of the direct producers, determines the relationship between rulers and ruled ... It is always the direct relationship of the owners of the means of production [Marx here says "conditions of production" - Produktionsbedingungen] to the direct producers ... in which we can find the innermost secret, the hidden basis of the entire social construct and therefore also of the political form of sovereignty and dependency, in short, the corresponding specific form of the state (Marx:1968,799-800).

As each mode of production serves the interests of one group or class - which then dominates and strives to perpetuate it - other classes are exploited by it, irredeemably opposed to it and naturally intent on overthrowing it. The antagonism between those classes benefiting from any mode of production and those others which are exploited by it is the "primary contradiction" and thus the key to social development. Going back to the Comounist Manifesto's categorical declaration that the "history of all societies to date is the history of class struggles" (Marx and Engels:1975,26) and that all pre-communist societies "rest on the contradiction between oppressing and oppressed classes" (ibid, 36), Marxist social analysis evolves around class struggle as the mechanism through which societies unfold, in teleological fashion, frow lower to ever higher modes of production, culminating in communism. Especially in its more vulgar exemplars, Marxist analysis of- 
ten displays sn unsettling determinism ${ }^{2}$ as well as an equally disconcerting Manichaean tendency to axionatically assert conflict within simplistic pairings such as capitalist-worker, centre-periphery, developed-underdeveloped, dominant-dependent etc., all in an effort "to locate the 'primary contradiction' of a given political situation at a given time" (Wallerstein:1973,380). Such "objective reality" - the dreaded formulation of Marxist discourse and Stalinist politics ${ }^{3}$ - is

2 While their epigones perfected the technique - cf. Khrushchev's assertion that "the ultimate triumph of communisa is scientifically inevitable" (cited in the Bulletin of the Atonic Scientists No. 3 (1962), p. 48) - there can be no doubt that unflinching deterainism characterizes the writings of Karl Marx and Friedrich Engels themselves. The following statements are quite typical: "The natural laws of capitalist production [... are] the tendencies working themselves out with an iron necessity. The industrially more developed country siaply shows to the less developed one a plcture of its own future" (Marx:1969a,12). The accumulation of capital by necessity implies an equivalent accumulation of misery. "The accumulation of wealth on the one side is thus at the same time the accumulation of misery, slavery, ignorance, bestialization and moral degradation on the other" (Marx:1969a,671). "What I did ... was to prove: 1) that the existence of classes is definitely tied to specific historical phases in the development of production; 2) that the class struggle necessarily leads to the dictatorship of the proletariat; 3 ) that his dictatorship itself only constitutes the transition to the abolition of all classes and to a classless society" (Marx:1963, 508; emphases in original). "Wherever ... the internal state formation of a country stands in opposition to its economic development, the struggle in all instances ended with the overthrow of the political order of domination. Inexorably and without exception, the economic evolution has forced its way through" (Engels:1968,170; see also Engels:1977,129).

3 Darkness at Noon, Arthur Koestler's outcry against Stalin's show trials provoked the wost ruthless and - emerging from Marx's theoretical/ideological framework with chilling consequence - the most stringent justification of the necessity of terror: Maurice Merleau-Ponty propounded in $194 i$ that "Marxism is not just any hypothesis that aight be replaced tomorrow by some other. ... Marxism is not a philosophy of history; it is the philosophy of history, and to renounce it is to dig the grave of Reason in history" (Merleau-Ponty:1969,153; enphasis in original). This revolution, too, ate its own children: of the 700 writers who participated in the first Soviet writers' congress in 1934, only 50 were left over to attend the second in 1954. Over 600 had been detained in prisons and concentration canps where the majority of them was killed (Die Zeit No. 5 (24 January 1992), 1). Such brutal absolutisa has a nubber of progenitors - 
considered sufficient to explain human behaviour, even if plainly it cannot. For instance, the independence struggle in Nigeria and elsewhere, I contend, cannot be captured in class-terms with the attendant concept of "objective" exploitation (i.e. surplus extraction in the production process). Viewing it as a revolt against foreign control, motivated by experiences not of oppression or robbery, but of domination, humiliation, exclusion and racism seems more plausible. Any analysis of group action which excludes such subjective factors, and which remains mired in the binary mode of Marxist class analysis wust be considered heuristically inadequate in the specific Nigerian circumstancrs.

Nigeria is not (yet) an integrated society in which "either one class, or else a coalition of classes with some common interest, constitutes the dominant class, and stands in partial or complete antagonism to another class or classes" (Dobb:1981,13). The classes here are

one is nicely revealed by Lenin's definition of the dictatorship of the proletariat as "a rule based directly upon force and unrestricted by any laws" (Lenin:1965,236) - all of which, however, are rooted in Marx's ideological edifice. Marxism as a self-proclaimed philosophy of libera$t$ ion, reveals itself in such statements, let alone in the deeds these refer to, as "the dark angel of Utopia" (Cruise O'Brien:1991,54). It combines the fervent belief in the life-and-death nature of class struggles with the certainty that all means are justified by the end, that a Utopia (an be constructed on earth, and that the proletariat, led by the communist party, will do it. It was not in a Monty Python skit but in the 1969 constitution of the Chinese Communist Party in which the party was proclaimed "great, glorious and correct" (cited in Lindblom:1977,250). Yet Marxist dogma begot more than aggressive cocksureness in epistemological matters. Its urge to speed up a historic mission led to a suspension of moral standards and the nonchalant readiness to shed blood in the inevitable crushing the buureoisie have multiplied human aisery on a colossal scale during the present century. It is extraordinarily remarkable that communism was nct defeated ideologically, but that its apologists and propagandists kept singing its praises right up the system's econonic implosion, and beyond. 
not organically linked in the production process. On the one hand, much of the peasant farmers' activities is subsistence farming on land which they do not own in the legal sense but for which they have tenure on the basis of customary usufruct. Unlike proletarians, forced to sell their labour to capitalists who explojt them by appropriating surplus value - the value generated by workers in the productive process over and above their wages - and to whom they therefore stand in an antagonistic class relationship, these farmers choose to sell the fruits of their labour in the amorphous market. They are not compelled to do so in order to escape starvation as they can always grow and eat their own produce. The distinction between proletarian and saallholder peasant farmer is significant, not as far as the level of remuneration is concerned, but much more crucially because of the fundamentally different relations of production both are involved in. While alienated and exploited, workers are part of a dynamic system whereas peasant farmers, self-determined but isolated from their peers, are part of a static system in which the probability for broadly based development is slim. Smallholder peasant farmers are not a class (in the Marxist sense). Instead, they

form a huge mass whose members live in similar conditions but without entering into manifold relations with each other. Their mode of production isolates them from one another instead of bringing them into wutual intercourse. ... Each single peasant family is almost self-sufficient, directly producing the major share of its consumption and thus gaining their provisions through an exchange with nature rather than with society. ... In so far as there is merely a local interconnection anong these peasants, and the identity of their interests does not create a comon purpose, no national union and no political organization, they do not form a class (Marx:1975, 307). 
The state class, on the other hand, while clearly dominant, is so through its access to the State and its resources, rather than by virtue of owning any neans of production and, consequently, by extracting surplus from a proletariat in the process of production. The state class is a close relative to the "new class" in communist states whose "ownership privilege ... manifests itself as an exclusive right ... to distribute the national income, to set wages, direct economic development, and dispose of nationalized and other property" (Djilas:1962,4445). The state class's domination is of a different quality than that of the capitalist over the worker or of the feudal lord over the serf or the villein. To be sure, its actions affect the conditions under which the peasant farmers work, their earnings potential, living conditions and chances to escape from their downtrodden existence; but the basis of the state class's domination is not the exploitation of the peasant farmers. Its material base is the rent-income from off-shore oil wells. The class nature (in the Marxist sense) of the state class is therefore in question: constituting an "association for the organized pursuit of their common aims" (Bendix and Lipset:1966,9), it might meet the necessary conditions of constituting a class. However, it fails the sufficiency requirement according to which "individuals form a class only in so far as they have to carry on connon battle against another class" (Marx and Engels:1969,54). The state class "confronts no other trans-national class adversary against whom it must define its ideology and with whom it must compete. Divided as it usually is, among narroter elites and factions ...., the [state] class remains a class only by dint of its common recognition as a superior stratum 
throughout the country" (Jackson:1973,400). Controlling the national economy's most attractive resources, the state class is interested in its autonomy and privileges which means that, ideologically, its class consciousness is not a progressive sentiment, but basically the shared aversion to all non-state actors. It is not concerned with exploiting (extracting surplus from) another class, but in not being interfered with in its exploitation of the country's natural treasure. It shares the benefits, and thus compromises its autonomy and property interests, only to the extent necessary to maintain its legitimacy.

The organic if antagonistic relationship of classes in the process of production does not, therefore, exist in Nigeria, and what Myrdal said about South Asia equally applies, namely that "there has beell almost nothing in the pattern of political development ... corresponding to Marx's model of the class struggle. For the most part the lower classes have remained apathetic and disunited" (Myrdal:1968,780). Marxist class analyses of Nigeria are, not surprisingly, rather tortured examples of concept stretching. The existence of the "bourgeoisie" or the "capitalist class", let alone its size, significance and patterned behaviour, is never empirically analyzed but, just as its dominance, apodictically stated as given. As is usual once a case is treated as axiomatic, empirical evidence becomes irrelevant (cf. Beckman: 1985,97; Williams \& Turner:1978,163; Nolutshungu:1990,100ff $)$. Alternatively and nore comsonly, the arena is expanded fron production to trade and then the dominance of the metropolitan bourgeoisie is asserted, again without ewpirical substantiation (cf. Aké:1985,112; Anise:1980,25; Beckman:1982,39; Gana:1985,127; Osoba:1978,67; similarly 
for Tanzania Shivji:1976,4 and for Africa as a whole Shivji:1976a,17). In the process, the coherence of Marx's analysis is sacrificed and no attempt is made to provide serious evidence for the putative class nature of the relationship between the wetropolitan North and peripheral Nigeria. For some observers (Ayoade:1988; Kaplan:1986; Lenarchand:1988), Marxists included (Brenner:1977; Kasfir:1987), analyses like these are unsatisfactory attenpts to save the class analytical approach by fiat.

What I propose instead is an analysis which

- outlines the State's catalytic effect on the formation of this class and locates its power base in the economic sphere of rent-appropriation and allocation rather than in the sphere of production;

- traces the socio-historical origins of the state class; and which

- discusses how the state class instrumentalizes the State for its class purposes and how this affects economic development.

Before proceeding, wy choice of terminology, class instead of group, elite, stratum or state/administrative/ managerial bourgeoisie etc., should be justified. As explained above, because it is outside the social production process and thus not in a dialectically antagonistic relationship with another class, the state class is not a class in the Marxist sense. Because it does not own the means of production - the hallmark of the bourgeoisie - any combination of "bourgeoi- 
sie" with an epithet such as "administrative," "auxiliary," "bureaucratic," "managerial," "organizational" or "state" is, if used in a Marxist analysis of non-communist states, a muddle-headed oxymoron, just like "conventional atom bomb" would be.

For all the reasons given earlier, my class analysis cannot be Marxist, but also because I am primarily concerned with the state class's relationship to the State and with the affinity of the country's political organization (which results from being dominated by the state class) to its social and economic structure. The State is considered the decisive element in the formation of the state class and also in shaping its relationship to other actors such as foreign capital or groups within the Nigerian society. Paradigmatically, my approach to class does not $f$ it either into the broader frame of elite studies whose epistemological interest it is to examine power structures in a polity and to analyze whether power is held by a cohesive, self-conscious minority (Michels:1962; Mosca:1939; Pareto:1968). Their concern is with the changing composition of leadership personnel, but neither with substantive policies nor with state structures and their relation to society and economy. Elite rule, the domination of a minority orer a majority, is seen as inevitable, if not desirable, and their analyses focuses on the relationship between leaders and masses. This is perceived to be a power relationship, whose base however is not located in the economy but in the character and abilities of the political leadership.

The state class, to conclude, does not correspond to Marx's 
ruling class whose power base is the ownership of the means of productjon (Marx and Engels:1975,26), nor to Burnhan's managerial class whose base is in the centrol of the means of production (Burnham:1960,72), nor to Mosca's political class whose power base is strictly political (Mosca:1939,50). The state class is a synthesis of the three. Its class nature emerges above all in its control over the national economy and in its surplus extraction from the national treasure of natural resources; its r lass project is the quest to maintain state power and thus to ensure its continued material and political privileges.

The concept of the state class is further inspired by Karl Kautsky who, in 1930, wrote: "In Soviet Russia [the high noble] is represented by the Communist Party, which rules the State. ... The Communists are the ruling class and they dispose as they please of the rest of the population, of which they form but a small percentage" (Kautsky:1931,9i), and by Bruno Rizzi who added the spin of a "bureaucracy which [is] also the ruling class" (Rizzi:1985,73). Some decades later, Milovan Djilas argued in a similar vein when, referring to Yugoslavia, he designated as the "new class" this "special stratum of bureaucracs, [who] make up the core of the governing bureaucracy" (Djilas: 1962,43$)$. Other ancestors of the state class are Wittfogel's "ranking officials" who "include civil and military functionaires of recognized status. They do not include the bureaucratic underlings" (Wittfogel:1967,306), or Burnhan's "managerial class" which, through the state, "will control the distribution of products ... so that they will themselves receive the privileged share" (Burnhan:1960,122-123). In the Nigerian state-dominated social formation, like in communism ( $D j i-$ 
las:1962,35; Gide:1950,187; Kautsky:loc. cit.; Koestler:1946; Rizzi: 1985,87 ) or in the hydraulic society, "state power, nore than any other factor, shapes the fate of both the members of the ruliug class and the commoners" (Wittfogel:1967,327).

Conceptually, the state class is a hybrid: too sizeable to be called a "group" or an "elite" and too purposeful and cohesive to be called a "stratum." Designating it a class is an act of definitional volition, yet not a random one but one informed by the considerations that this specific social aggregate is formed through and based upon economic autonomy and dominance as well as monopoly control over the instruments of power. The state class is not merely a descriptive category - denoting its membership as well as its role and status within economy, society and polity - but also an analytical category which indicates a circurscribed and identifiable set of behavioural patterns.

The state class consists of "all those persons who hold public and parastatal posts which confer upon occupants a measure of authority or discretion" (Jackson:1973,393), that is, all public sector employees who are involved in policy-making or who command over public resources. The state class is functionally defined in that it comprises all those decision-makers who participate in the appropriation and allocation of public monjes. Their executive status is manifested by above-average (legitimate) material benefits, by their position-inherent opportunities for illegitimate self-enrichment, and by a high degree of social prestige. A precise delineation of the state class is less important than the recognition that it is internally segmented into branches such 
at the military, the federal government, state governments, managers in parastatals etc. The civilian politicians during the First and Second Republics were temporarily incorporated and promptly expelled when they threatened, through excessive waste and corruption, whe interests of the class as a whole. Military coups in Nigeria have never been popular insurections; they were always intra-class conflicts.

Even if composed exclusively of appointed officials, the state class is not homogenous and, as in the case of capitalists or workers, its "class interest" is an abstraction at a high level of generality which should not be allowed to obscure the intense competition within the state class as well as the confluence of interests, in specific jssue areas, of individual members of the state class with those of m+mbirs of outsider,. The preferences of the state class, or of indivicual members of the state class, cannot be realized in any pure form because distributional and other conflicts take place within it. To permit intra-class bargaining and coalition-building, formal internal contruls are neak. Policies and allocative decisions will be the result of internal bargaining, rivalries and coalitions between the various segments of the stace class as complemented by the interests and cunflict potentials of exter : clients. State action (and inaction) normally reflects a political balance of powar within the state class rather than between antagonistic classes as mediated by the state; it

4 "Thus, when the reforming zeal of the military rulers led them to establish a corrupt practices investigation bureau to help fight corruption, the civil servants ensured that there was an accompanying Public Officers (Protection Against False Accusation) Decree.... On the whole, the bureau achieved very little, and ... the military leadership decided is abolish it, effective from 30 September 1979" (Adamolekun:1986,128). 
also is unrelated to broad societal preferences as expressed, for example, in a pluralist political process. In the absence of effective internal and external controls and because of its inherent dynamic, the Nigerian state class tends to be economically wasteful. It can be expected to pursue as its highest goal the strengthening of its position and to design economic policies from this partisan perspective.

As explained earlier (pp. 179ff), I suggest the state class's fundamental interests, its "class project," to be the perpetuation of its hold on state power and of the material privileges this entails: "self-aggrandizement combined with redistribution to mantain its teruous and vital hold on the state" (Cooper:1981,46). Short of resorting to outright repression, this class project requires a modicum of state legitimacy. Popular legitimacy, periodically confirmed and renewed in democratic elections is not essential in a military regime; here legitimacy is provided by those specific groups whose conflict potentias could pose a serious threat to the state. In fact, legitimac? (or these groups' acquiescence which is pretty much the same thing) is bought with public funds. Under these circumstances, legitimacy is inversely related to the state class's autonomy (that is, its ability to implement its own preferences) and to its property interest: the more it needs to spend and to compromise its interests in order to acquire legitimacy, the less autonomous and the less able to pursue its self-aggrandizement. The one policy instrument which is singularly rell-suited to the state class's power interest is economic control, the extensive bureaucratic regulation of and intervention in the economy. Economic control: 
- permits the focusing of legitimacy-generating largesse;

- allows the creation of dependencies and thus, conversely, of power and finally of autonomy;

- directly serves the state class's property interest.

Development in this matrix of interests and instruments is goal only to the extent that it coincides with, or is a side-effect of che pursuit of these interests which is not the case in any systematic fashion. In fact, development and, more precisely, capitalist development, conflicts with the state class's interests.

The state class is not a homogenous, unified, purposive actor. It is much rather internally segmented, afflicted by intense intrarast conpletition, bargaining and coalition building between its varivil constituent factions. Its cohesion and unity of purpose, to the extent the! exist, derive from its collective control over the means of sucietal surplus appropriation and from the resulting prerogative to allocat" this surplus. This allocation of resources to agencies and bramches of the State itself, but also to non-state recipients, takes place - perfunctorily through the nedium of development plans - according to political criteria which are informed by intra-class bargaining As well as by the necessity to satisfy external demands. The results are predictable because the "injection of planning into a society liing in the trilight between feudalism and capitalism cannot but result it additiunal corruption, larger and more artful evasions of the law, all mor brazen ahuses of authority" (Baran:1952,81). Of course, plan- 
ning in Nigeria is not as rigid and comprehensive as, say, that of the pre-perestroika Soviet Union. It is the expression much more of the State's desire to make the disbursal of funds appear coherent, to provide a rationalizing narrative for the allocation of funds to the various projects, government branches and budget titles. State planning is not congruous economic management or a strategy to achieve useful economies of scale.

The centralized appropriation and allocation of massive economic resources concentrates power in the State and, as an inevitable corollary, leads to the formation of the state class as a privileged class. State intervention in and regulation of the economy pre-empt the controlling mechanism of the market which, in a capitalist economy, has the thin function to reduce the income of privileged groups as well as to guide investment decisions. Incomes are, then, not distributed according to economic criteria (scarcity, supply and demand or rentability) because there are no economic or political constraints which would prevent the politically dominant class to (mis)appropriate surplus. The allocation of resources will therefore ultimately be done in the consumptive interests of the state class or of individual members. This does not benefit national development nor does it lead to the transformation of the state class into a productive bourgeoisie. The very "difficulties of transforming privileged access to resources into accumulation of productive capital have often fostered the tendency of this class project to take the easier forms of urban real estate speculation and compradorism" (Cooper:1981,20-21). What hampers economic development, thus, is not the emergence of the state class as domiriant, 
but its often "parasitic character as a political class feeding of the revenues of a swollen state" (Dianond:1987b,592).

Sociologically, the Nigerian state class's origins lie in the intellectual elite which emerged in the 1940s. It was relatively sall ill size, not economically powerful yet vocal and hostile in its opposition to colonialism and able to nobilize other disaffected groups. 5 This intellectual elite was not a social class sui generis, nor was it the antithesis to the colonizers in a dialectical struggle, but itself a product of colonialism. Frantz Fanon scathingly characterized it as "i sort of greedy caste, avid and voracious with the nind of a huckster, only too glad to accept the dividends that the former colonial porier hands out to it ... it becomes not even the replica of Europe, but its caricature" (Fanon: 1968,175).

l. Subramaniam, in more measured and analytical treatment of Fanor's theme, designates the intellectual elite a "derivative middle class." He explains that the bourgeoisie in western countries was the product of a natural evolution of these societies, created by internal factors. It was creative of its own standards, balanced in its economic and professional wings and expanding aggressively. It grew in strength over a long period of time under such influences as the Pro-

5 0'Connell called it the "Nigerian political class" and suggested that it consisted of four main groups: "the first-on-the-scene nationalist leaders - Nnandi Azikiwe and Obafemi Awolowo [... and] the leaders from the North ... Aharadu Bello and Abubakar Tafawa Balewa ... The second here the professionals and businessmen who joined early on with the first sroup ... [the] 'communal champions' ... formed the third group. ... Finally there was a large group of political activists made up of the 'opinion leaders' in the various communities. These were the new men teachers, clerks, traders ..." (0'Connell:1967,159-160). 
testant Reformation and the Industrial Revolution. A aiddle class of langers, docturs, teachers etc. existed before the rise of capitalism but with its ievelopment there was more need for the services of these professionals. The availability of such skills indirectly released capital and energy that could be used to create new jobs in comerce and industry. Thus, the development of the economy and the rise of the bourgeoisie (constituted in two "wings": a comercial/industrial and a professional one) reinforced and complemented each other. The bourgeoisie in Africa or in other areas subjected to Western colonialisa, by contrast, was the product of colonial rule, that is, it was derived from the particular circumstances of colonization. The colonial governments' practice of minimum contact between conquerors and conquered and its economic poljcies (export of unprocessed agricultural products, prevention of industrialization) resulted in the middle class's lopsidedness: with economic activities increasingly reserved for expatriates, the emerging local bourgeoisie was confined to the roles of professionals and salary earners such as junior clerks and teachers; the rise of a local bourgeojsie engaged in economic and productive activities was blocked. As a result of being so constituted, the new class lached the capacity for social invention and adaptation; it became an imitative bourgeoisie. Lastly, the policies of the colonial governments created humiliating dependencies among the emerging bourgeoisie demand for its services never reached the available supply - and led to dissatisfaction and frustration, economic as well as psychological. In summary, Subramaniam contends that in every colonial situation involving the conquering west, aiddle class arose with the four attributes 
of being derivative, lopsided, initative and frustrated (Subramanian: $1990,405-406)$.

The sociology of the derivative widdle class provides the key to understanding the developments in Nigeria during the 1950s and beyond. As "rlass for itself," its first goal was to conquer the state apparatuses, to replace the British at every level of government including the commanding heights of government. Nkrunah's of ten quoted credo "suek ye first the political kingdom, and all shall be added unto you" concisely captures the sentiments of a intensely frustrated westernized elite which hitherto had been relegated to the political off-side. The sluw pace of economic development, from their perspective, was not a matter of hard choices under circumstances of scarce resources, but conclusive proof of a racist conspiracy. The solution, entirely voluntaristicully, lay in gaining control, in their gaining control. They, "the ellightened few, were not only destined by right to rule, but by an act of will they could create an independent Nigerian nation which nould allon them, in the words of their prophet Nnandi Azikiwe, to walk 'majestically with the other races of mankind'" (Coleman:1958,410). Having begun in the late 1940s, "Nigerianization," the affirmative action programe in public service recruitaent giving Nigerian candidates preference over expatriates, was almost completed at independence in 1960. The derivative widdle class, its overriding objective of gaining state employment and state power achieved, transmutated into the state class. It, of course, quickly discovered new interests and developed new ambitions. Its status as dominant class was the consequence of exercising state power on which, in turn, its 
reproduction henceforth depended. Having "turned against the colonial power to become the mouthpiece of the exploited ..., the bureaucracy fias gaining some of the characteristics of a social class: control of the economic infrastructure and use of it as a means of exploitation, control of the means of repression involving resort to various devices to maintain dominance" (Meillassoux:1969,107).

Inheriting the State uncontestedly and in the absence of potentially competitive classes, the derivative oiddle class became the dominant and ruling class by default. The State it took over had become, in the previous fifteen years, economically interventionist. Buoyed by massive surpluses which high commodity prices had let accrue to the state-run marketing boards, ambitious development and investment plans had been embarked upon. In keeping with the spirit of the age, development was equated with "a vigorous process of capital formation, that is, a high rate of successful investmert" (Schatz:1988,67). Under the circumstances, only the State could meet this challenge and the state class's rested interests seemed to coincide with the requirements of development. In the absence of competing social classes such as capitalist farmers (like in the Côte a'Ivoire), industrialists (like in 2 imbabre) or expatriate settlers (like in Kenya), the state class became the ruling class; its policies ever since have been aimed, before anything else, at perpetuating this hegemony. Direct ownership of the means of production has become secondary to access to and control of the State, the real locus of power and wealth. The siate class acts, mutat is mutandis, like Burnham's managerial class:

Those who control the state, those whose interests are 
primarily served by the state, are the ruling class under the structure of state-owned economy. Through the state, they will control access to the instruments of production. Through the state they will control the distribution of products of those instruments so that they will themselves receive the privileged share (Burnham:1960,122-123).

The state class is the dominant class in Nigeria, if only be default since there is no other class, group or stratum with the declared objective and the means to dislodge it from the state. It has th. pumer to appropriate the largest single portion of the national eccilomy's surplus, oil revenues today and the withholdings of marketing loards before. Its inordinate economic preponderance permits the tying to the state, in a corporatist fashion, of other groups such as traditional rulers or businessmen. The respectful treatment and symbolic iuclusion into the state of traditional rulers conveys legitimacy to the mudern state without, however, implying meaningful power sharing. The relationship between the State and the business class does not have The overtones of guilt and usurpation - which is typical for the relationship between the state and the traditional rulers - but is clearly olle of patron and client. In sum, in the Nigerian situation, "class relutions, at bottom, are determined by relations of power, not production" (Sklar: 1979,537).

The State's economic interventionism was initially rationalized with the dearth, inherited from colonialism, of indigenous entreprenaurs. The eventual emergence and expansion of the business class (most!y traders and contractors as well as, with some qualifications, medium-scale entrepreneurs), was the result of State policies and patronage which, in effect, aakes the small stratum of businessmen a new 
derivative class. They are prime beneficiaries of the naze of regulative economic policies such as import licencing, tariff protection, investment registration requirements or support measures, indigenization, contracting and the importation of food and agricultural implements. 6 They owe their existence and their fortunes to the state. In a symbiotic relationship with the state class, they are the dependent and weaker element, if only because as individuals they are replaceable and abundant. Just as the colonial state needed the services of the professional middle class - it could perform clerical and other support functions much cheaper than expatriate labour - the state class needs the business class. It can complement state policies such as, for example, ensuring low food prices in urban areas by executing the importaticin and distribution of foodstuffs or by increasing food production through their middleman functions between international financiers and the state in agro-industrial complexes.

6 To qualify for government contracts, a veritable obstacle course must be negotiated, an all but impossible task without the assistance of a hell-connected Nigerian contact: first the company must be registered with the Federal Works Registration Board (or the equivalent state body) which involves passing an interview and/or an inspection as well as the submission of detailed information concerning staff, equipment, tax record, completed projects; this process takes many months. Thereafter, the company must pre-qualify with the respective federal winistry in a similar procedure as the initial registration. In the case of the Nigerian Posts \& Telecommunications Agency and the Nigerian Electric Power Authority, a third layer of pre-qualification requirenents has to be scaled. The next hurdle is that tenders are often inadequately publicized, submission deadlines mostly only days later, and the selection process shrouded in secrecy and usually drawn out over many months. Receipt of payment after contract completion involves a further round of lobbying. The logic behind the granting of investment approval is similar, involving a variety of government departments with incommensurable rules. Stepby-step descriptions of the various process stages are provided by Gunn:1982 \& 1982a; Price Waterhouse:1987. 
In addition to strengthening the State's executive capacity, businessmen are, for individual government officials, a convenient conduit to aterial gain and security outside the state sector. While in office, civil servants or politicians can act as silent partners in cummercial ventures which, of course, can also receive official business. As all activity on the side, after retirement or after a purge, such partnerships are lucrative safety nets which, in a systematic fashion, permit the privatizeiion of benefits and the socialization of risks. Even if individual businessmen can acquire phenonenal wealth and influence, collectively the businessmen are dependent-subordinate to the state class. ${ }^{7}$ The same is true for international capital, especially since the early 1970s which sak the nationalization of the oil industry and the indigenization of foreign companies. If before, the balance of power between the state and expatriate capital might have

i The President's legitimate income in the 1990s would, if saved in its ent irety, within four years pay for one Nigerian-assembled Volkswagen "Santana." However, if President Babangida can serve as a yardstick, mobility might not come at the price of frugality and deferred gratificatioll. On the Occasion of his 50 th birthday, President Babangida was presented by his brother in law, Chief Sonny Odogwu, a businessman, with an 18-seater executive jet. "Mrs. Babangida was promised a 10-bedroom house with a nuclear shelter as well as a car" (WA No. 3859, 26 August 1991, 1420). It is probably more accurate to interpret this generosity more as a sign of the business class's subsidiarity to the state class, than as a token of brotherly affection. Nevertheless, individuals can cross the burders between the two classes which are anything but herwetic. While civil servants or military of ficers aight cross them more surreptitiously, poli. i ans do so openly. The Second Republic's President, Alhaji Shehu Shagari, was not only Commissioner of Finance in the Gowon government but, just before becoming President, Chairman of the Board of Peugeot (Nigeria) Ltd., whose giant and loss-making assembly plant was/is in Kaduna, his native region. With some hyperbole it has been suggested that the "ethics of business penetrated politics, the ethics of politics penetrated business, the ethics of gangster penetrated both" (Williams:1976,43). 
been subject to argument, the matter seems decisively settled since. ${ }^{8}$ This is not to suggest that the state is omnipotent and absolutely dominant, only that it is omnipresent and relatively dominant vis-à-vis other internal and external actors; by implication, this also means that external controls of the state are rather unsubstantial.

I have argued that the bureaucratic Nigerian state is a generic political system or order of domination. This reasoning, extended into the socio-economic realm suggests that the Nigerian social formation, duminated by the state class is an equally generic economic system or mode of production, just as capitalism (or feudalism) is an economic system or mode of production with the bourgeoisie (the aristocracy) as tlat duminalit class. The "logic of the class situation" (Popper:1971, 117) is thus useful in explainjug the rorking of the institutions of the bureaucratic Migerian state. Assuming that ecomomic development is symbimmis with caritalist development, the problematique of the Nigerian situation is thus the extent to - and manner in - which the existins mode of production constrains the emergence of capitalist relations 1f production.

s This does not deter a number of self-styled radicals to argue a revisionist case and to charge that the members of the state class "became imperialism's faithful allies who betrayed the anticolonial struggle and here rewarded with state power at flag independence, while Britain and other imperialists retained economic power in Nigeria. Subsequently, inperialism has been strengthening this class of petty-bourgeois civil and military collaborators who impose reactionary policies of underdevelopment on the country in a mutually beneficial adventure of neocolonial entrenchment." (Onimode: 1983,236-237). 


\section{Why Nigeria is not Capjtalist}

Nigeria is almost universally considered a capitalist country, whether this characterization is intended as a slur (Beckman:1985; Forrest:1987; Graf:1988; Hoogvelt: 1976; Nigeria:1987; Oculi:1987; Ohiorhenuan:1989; Williams:1976), as a value-neutral description (Biersteker:1987 and 1990; Schatz:1977; Young:1982) or, more infrequent ly, as an accolade (Diamond:1985; Glickman:1987; Kirk-Greene:1986; Mummery:1968). Analysts operating within a Marxian theoretical framenork are most emphatic about Nigeria's capitalist nature, Others, not hound ly the conceptual strictures of Marxist theory, apply the label as a descriptive shorthand; little in terms of epistemology, ideolog: or explanation is tied up for them in this designation. The present Puprition, therefore, is to take Marx seriuusly and to examine whether, oll his terms, Nigeria can be considered capitalist. It is also intended to point out the counterscientific spirit of much of Marxistinspirtl theorizing whose moralizing outrage (at the state of the enVirunment, the collapse of the education system, the Gulf war, Africa's quagmire, the pervasiveness of racism, sexism or whatever) only ever identifies capitalism as the culprit. Quasi-religious by nature and temperament, much of contemporary Marxist theorizing (including dependency/underdevelopment/uorld system and related approaches) is immune to arguments that its founding claims are poorly substantiated. Mariist discourse can always be shifted to a different plane and its "deep" 
revelations placed on some new footing. ${ }^{1}$ Upon encountering similar dodges in his studies of the history of astronomy, Adam Smith observed exasperatedly "how easily the learned give up the evidence of their senses to preserve the coherence of the ideas of their iagination" (Smith:1980,77; for a thorough treatment of this puzzling phenomenon of selective perception in the service of cognitive consistency see hoestler: 1950 and Revel:1991).

$M y$ contention is that it is not only wrong but seriously misleading to consider Nigeria a capitalist social formation and that its development problems are precisely its non-capitalist nature. In the interest of theoretical clarity, the notion of capitalism will first be clarified on the basis of Marx's and Weber's conceptualizations.

1 Marxists argue that each mode of production has its own logic, its own way of unfolding over time. To explain Africa's non-adherence to its pre-determined trajectory, given that it is supposedly capitalist, requires a number of revisions which all but refine away the coherence of Marx's theories. For instance, a number of auxiliary hypotheses are introduced, the focus is shifted from production to trade and from smaller units to the world systen, or a theoretical mainstay is unceremoniously given up altogether, such as in the following contention: "the single major theoretical impediment to the effective analysis of actual production in the Third World is the concept of 'mode of production'" (Kitching: 1980,4-5). Even cruder is the technique to concede one's theory's enpirical falsification and still insist on its validity: "striking though [capitalism's] material success has been in the industrialized world, where real wages increased steadily and by more than 500 per cent between 1860 and 1960, this does not alter the fact that the fundamental logic of competitive capitalism continues to imply that under conditions of excess labour supply, the wage will tend to be reduced progressively until full emplovment is achieved..." (Bienefeld:1982,30). A final example for logical bankruptcy is "post-Marxism" whose proponents, under duress, have removed one structural support after the other from Marx's theoretical edifice - exploitation, class struggle and the inevitable collapse of capitalism - but who continue to assert its enduring integrity, stabiliiy and vitality. To dissolve this contradiction, it is suggested limply, that "the political agenda for progressives will continue to vary with respect to time and place" (Corbridge: 1990,634). 
Emphasis will be laid on capitalism's constitutive elements and their wsitive relation to economic development. Since Nigeria's problems are the labour pains of development rather than the crises of mature (alitalism, Marx's deterministic and Weber's probabilistic arguments concerning the collapse of capitalism will not be considered. Subsrofurntly, the Nigerian situaiion will be assessed against the background of the preceding arguments. Finally, the market's developmental merits and the ideological controversy surrounding it will be discusser.

\section{a) Capitalisn in the Conceptualization of Karl Mar: ad Max Weber}

hall Mars himself did not speak of "capitalism" - the notion was crimel bs herney Sombart whose magisterial study Der moderne Kapitalismus wic puhlished in 1902 (Braudel:1982,237) - and referred instead to Ilie apitalist mode of production as distinct from other modes of produclion. Production is the cornerstone of Marx's oeuvre just as ratiolial its ic at the heart of heber's on human happiness at that of Bentham 11. Mill. For Marx, everything - political conflict and organization, sucial stratification and ideology, economic efficiency and technologial frugress - is subsidiary to production, that is, to the manner in hlich a human group as a group provides for its subsistence, for Rulinson Crusoe existences are the rare exception. Production is the creaiton of "use values, of material wealth. Labour is its father... and the earth its mother" (Marx:1969a,58). The fruits of all forms of Iroduction are divided into three components: one part consumed by the 
producers themselves, one part ised up in the future production process and a third part "which is always surplus labour, whose product serves general social needs, no matter how this surplus is being distributed and whoever acts as a representative of these social needs" (Marx:1968, $884-885)$.

The capitalist mode of production is a type in which the production process is organized in a specific way with definite consequences for eccnomic, social and political organization.

There are two traits which, before anything else, characterize the capitalist mode of production: First, it produces its products as commodities. ... The second special characteristic of the capitalist mode of production is the production of surplus as direct reason and determining motive of production (Marx:1968,886-887).

Commodity production means that a plethora of diverse goods is createl in innumerable processes of production,

diverse in their nature and suited to the fulfillment of thousands of different human needs ... all of these diverse goods can be directly compared with each other in terms of an abstract property ... their monetary price [or exchang. value]. Products looked at from the point of vien, not of those qualities whereby they can satisfy specific needs, but of the exchange value, in which respect all products are the same in kind and differ only in quantity, are what is meant by 'commodities' (Burnham:1960,11; emphasis in originall.

of course, commodities are produced in all modes of production, yet only under capitalism do "all or even a majority of the products take the form of commodities" (Marx:1969a,183-184). This includes labour, or rather labour power. As long as the direct producer can accumulate for himself, "which he can as long as he owns his mears of 
moduction, capitalist accumulation and the capitalist mode of production is impossible. The indispensable, absolutely necessary class of nitgw-labrurers is missing" (Marx:1969a,794). In other words, as long as peasants have access to land (their means of production or means of subsistence), they are self-sufficient and not forced, in order to survive, to offer their labour power as a commodity on the market. Only after a peasant is liberated (or expelled) from the land or from his hondage to a feudal lord (or to guilds and other restrictive regulatums), can he be the "free agent of labour power who carries his commilits whereser it finds a market" (Marx:1969a,743). Labour-power, in capitalism, has itself become a commodity and is bought and sold in the marhet like any other object of exchange.

The sale and purchase of labour power ,.. forms the absolu1t foundation of capitalist production and is an integral moment within it. Material wealth transforms itself into cilital simply and solely because the worker sells his lalwur-power in order to live. The articles which are the material conditions of labour, i.e. the means of production, and the articles which are the precondition for the suri ival of the worker himself, i.e. the means of subsisteme, both become capital only because of the phenomenon of nugp labour. Capital is not a thing ... Without a class dependent on riages, the moment individuals confront each other as free persons, there can be no production of surplus value, without the production of surplus-value there can be no capitalist production, and hence no capital and no capitalist: Capital and wage labour ... only express tho aspects of the same relationship (Marx:1969a,611; emphases in original).

In short, "the buying and selling of labor power is the differentia specifica of capitalism" (Sweezy:1946,56; emphasis in original) ${ }^{2}$

2 Sheezy, without attribution, uses Marx's own formulation: "the main fenture ... the differentia specifica of capitalist production lis that] labour power is being bought. Labour power is being bought here, 
and the epitome of human self-alienation since all human qualities are reduced to quantitative values of exchange: the providers of labour power, individually and as a class, are forced to sell it, in order to survive, to the owners of the means of production, individually and as a class. The ensuing relationship is a priori an antagonistic one which, in Marx's conception, ensures the speedy development of the capitalist mode of production but also its eventual, unavoidable overthroh (Marx:1969a, i89ff).

Marr's second characteristic of capitalism - production of for the purpase of surplus creation - is a specific extension of commodit? puduction. "Capitalist production is not merely the production of commorities, it is, by its very essence, the production of surplus valuf. The worher produces not for himself, but for capital. It is wo lotget sufficient for him simply to produce, He must produce surplus value" (Marl:1969a,532). This surplus value, that is, the "unpaid surlulus labour pumped out of the direct producers" (Marx:1968,699) is identical with the profit accruing to capitalists. It follows that profit is the rationale of economic activity, not the satisfurtion of human needs - the baker is in the business of making money, not of feeding the hungry. It follows further that the use-value of goods is entirely subordinated to their exchange-value: "capitalist production is basically irdifferent as far as any use-value or in fact any commo-

not to satisfy the buyer's personal needs through its services or its product. His purpose is the utilization of capital, the production of commodities which contain more labour than he pays for which, therefore, contain an portion of value which he does not pay for and which is being realized when he sells the commodities. Production of surplus value ... is the absolute law of this mode of production" (Marx:1969a,647). 
dity's peculiarity is concerned" (Marx:1968,205).

This "output fanaticism" is exactly what kicks off and drives ecoworic development processes, yet it also entails a particularly nasteful bias in production for, if "the aim of production were use-valur, much less use-value would be sought, produced, and consumed than is in fact produced and consumed" (Cohen:1978,303). Shifting the purpost of economic activity from want satisfaction to profit-making inpios a changed role also for money. Money in many societies and modes of production is used as a medium of exchange; the more prevalent money js, and the smaller the role of subsistence or barter, the greater the ophortunities for exchange and finally for commodity production. let, only in cautalism is money transformed into capital whose purpose it ic to mahe mole money, not to meet any direct needs. To illustrate the differance, Marr calls "simple commodity circulation" the process of a I"isint wh, sells grain and buys clothes (Marx:1968,162). "The simple commonily circulation - to sell in order to buy - serves a purpose outMd. of the sphere of circulation such as the acquisition of utensils ur the fulfillm+rit of needs. The circulation of money as capital, in Cuntrast, is an end in itself, because the realization of value exists onl? withut this constantly renewed movement. The movement of capital is therefore Iimitless (Marx:1968,167). It is activated by the profit motive which implies intense competition between capitalists - "each capitalist wipes out many others" (Marx:1969a,790) - and the systemic imperat ive to accumulate. Unprofitable businesses, even if they produce sucially most highly valued goods or even if they are monopolies fince the danger of bankruptcy. 
Profit-seeking is not optional behaviour; for capitalists as capitalists it is existentially important. "This absolute drive for enrichment, this passionate chase after value is common to the capitalist and the miser, but whereas the miser is only a capitalist gone mad, the capitalist is a rational miser" (Marx:1969a,168). The capitalist will not consume his accumulated wealth but transform it into capital (that is, productive investment) which in turn will create more wealth and re-investable capital and so on ad infinitum. For a capitalist, not consumption is the rationale of his activities but "accumulate, accumulate! ... is Moses and the prophets" (Marx:1969a,621). Mars's insistence on accumulation (the creation of productive capacity) as capitalism's inner drive and secret, exposes the role of profits which are created, and this is of the highest significance, in the process uf production, rather than through misuse of monopoly or monopsony positions, overcharging, cheating, "plunder, sharp trading with foreigners, or feudal exactions" (Heilbroner:1980,100). Marx's insistence on production ${ }^{3}$ is required in order to defend the key tentets of his universe, such as, on the one hand, the labour theory of value with its iuiosyncratic notion of exploitation and the prognosed immiseration of the masses or, on the other hand, the contemptible nature of privats property which causes class struggles but also the ineluctable victory of communism. Against all tenets of common sense or logic, Marx thus has to insist that "on average, commodities are sold at their real va-

3 To preempt doubts or alternative views about the primacy of production, Marx categorically asserts that the "real science of andern economy begins only when the theoretical consideration passes from the process of circulation to the process of production" (Marx:1968,349). 
luas and that profits are derived from selling commodities at their balurs, i.t. in relation to the quantity of labour incorporated in them" (Marx:1968b,129).

Profits, translated into productive commodities such as labour, marhines and raw materials, create new saleable commodities and ner profits, and so on in ever accelerating circles. The success of capitalism is not, therefore, a function of abundant resources and no am.unt of arcumulated money wealth can, alone, ignite a process of rocouml, development. For this, wealth needs to be transformed into apital. "This transformation itself can take place only under certain rifrumstalices ...: tho different kinds of commodity owners must face wh hther and get into contact. On the one hand owners of money [and] nown- of probution ... which thes want to employ through the purchase "f lalwur; on the other hand there must be free labourers" (Marx:1969a, TI:-1.

Prenduct jon and exchange processes in capitalism are unregulated; the' are goserned by the market, that is, the anonymous forces of supils alm demand. The logic of private ownership, of commodity productinn and of production for profit demands the unobstructed market (the "sphere of circulation") as the medium through which exchanges take llace, hlich regulates scarcities, assigns factors of production and which enforces system-conforming behaviour such as the continuous accumulation by capitalists or the need for workers to offer themselves for hire. In fact, it is only in the market that the profit, generated in the process of production, is realized (Marx:1968,836). For "free labour" the anonymity of the market replaces kinship or ascriptive 
ties, and the existential uncertainty it entails replaces the security of subsistence farming or the self-sufficiency of artisans. Individuals emerge who are severed from communal moorings, thrown upon thenselves, existentially insecure and forced to sell their labour in order to survive. Not at least because of the human misery it causes, the market's inherent dynamics make the capitalist mode of production both ecollomically efficient and socially progressive. "The pressure to reduce production costs to a minimum becomes the most important lever to erhane the social productivity of labour" (Marx:1968,888). The dyliamics interent in capitalism, for capitalists the imperative to accupulate, expand, innouate - or perish, 4 and for workers the imperative to sell their labour at the going market rate - or perish, distinguish it from ither social formations. These system-determined behavioural propensities, if viened from a dialectical perspective, permit a capita-

4 Tho telling examples of this dynamic: In the United States, by "the turn of the century, there were not a dozen men on the rloor of a mill rolling 3,000 tons a day, or as much as a pittsburgh rolling mill of 1880 rolled in a year" (Temin:1964,165). As a consequence, the price of sterl in Fittsburgh fell from $\$ 67.50$ per ton in 1880 to $\$ 29.95$ sinc years later; and by the late 1890 s the costs had dropped to $\$ 11.25$. Aggressive industrial pioneers were able to cut prices so dramatically that less well-equipped competitors were forced out of business. "Ry the mid-1880s British steelmakers could no longer compete in the American market" (Chandler:1990,129). In Nigeria, cloth manufacturing in Kano followed a similar pattern. During the early 19 th century, merchants started to buy cloth frow weavers and to put it out for processing by dyers in return for whit wr in effect a wage. As the market grew, larger and more expensive $\lambda^{-} t$ same into use. Owing to reduced production costs, the price of. J's cloth fell throughout the second half of the 19 th century and its market expanded considerably. By 1890 Kano cloth could undersell locally woven textiles in distant Northern Ghana, i.e. about $1,000 \mathrm{~km}$ akay from its place of origin (Iliffe: 1983,10ff). Weber describes the historical genesis of capitalism in Europe as a process of improving the quality and range of wares, of price competition and of high turnover in wich "those who would not follow suit had to go out of business" (heber: 1958,68). 
list societ? to be enrisaged as a "system in motion whose trajectory and destination can be deduced from its expansive tendencies and its (halneling institutions" (Heilbroner:1980,119).5

Marx's and his followers' tendencies to make deductions about sorial developments from abstract and a priori dialectical schemata, with insufficient regard to actual facts, is the result of the paradigm's pseudo-objectivity, moralizing vision of reality, economic rulutiunism, historical determinism and ineradicable utopianism; it Alst urforlits, of course, its fanaticism and sectarianism. Marx did wint, within his theoretical framework could not anticipate,

- in the ohe hand, capitalism's adaptabllity, resilience and breathtaking economic: success and,

- on thw other, the elusiveness of his predictions of immiseratiun, of falling profit rates, of the proletariat as revolutionary subject and of the inevitable collapse of capitalism.

Volite the less, ever when shorn of all prophetic and some thenreIical elements, ${ }^{6}$ Marx's concept of the capitalist mode of production is

5 Marx indeed claimed to have revealed "the economic law of motion of modern society" (Marx:1969a,15), thereby, as one commentator observed, "all but designating himself the Newton of the social sciences" (Hirschmall : 1991,156 ).

6 To explain social change and historic transformation, I deem of little use - theoretical, analytical, political and predictive - and hill therefore not consider: Marx's labour theory of value (Marx: $1969 \mathrm{a}, 54$ ), the "lah of the tendency of the falling rate of profit" (Marx:1968,221-279), the theory of immiseration (Marx:1969a,641-649), the centrality of class struggle (Marx \& Engels:1975,26) - and the implied rejection of gender, race, religion, nationalism etc. - or, finally, the 
robust and instructive: it identifies capitalism's institutional framehork (market-regulated comodity production by private or at least profit-seeking enterprise and free labour), the resulting behaviour of human actors (accumulation, profit and income maximization), and the vigorous consequences of both for economic growth and jevelopment.

In contrast to Marx's dialectic and deterministic theory, Neber's concept of capitalism is, again, an ideal type which attempts to identify characteristics and to clarify and systematize their connections. heber's main preoccupation, however, was with the origins and the historical developmert of capitalism, rather than with its dynamics which has Marx's interest. Putting history and typology over teleology, heber aroided Marx's error of hypostatizing that economic systems have purposes, trajectories or, indeed, goals. Instead of perceiving histor? as a marche générale toward a telos, propelled by an underton that. could not be resisted, for heber history is open, diverse, relative and often contingent. His analyses are based on the premise that institutions - economic, political, social and religious - provide a framework within which human beings pursue their aspirations and that, at most, tendencies and probabilities of systemic development can be recognized.

premise of the inevitability of capitalism to collapse (Marx:1969a,789791 and 1963,508$)$. The problem at hand is the initiation of capitalist. development, not the intricacies of a mature industrial economy. Besides, the expectation of capitalism's inevitable demise, shared by a rather catholic group of analysts including Marx, Weber, Schumpeter and Burnham, all advancing different arguments, has so far not been borne out. Although it might still happen, the persisting lack of a more propitious alternative should encourage research to be concentrated on improving capitalism rather than on forecasting its ruin or on denunciating capitalism's ever receding wirage of material bliss, that is, to decry it. as a particular, system-inherent turpitude that capitalism brings society to the threshold of abundance and locks the door" (Cohen:1978,307). 
Institutions (in the larger sense of modes of production, orders of domination and social formations, but also in the more immediate sense of bureaucracies or business enterprises etc.) provide the incentives, the opportunities and constraints that structure human behaviour, but institutions do not possess goals of their own.

of interest for Weber is how institutions or structures are relatod to outputs, and which institutions or structures are better suited than others to maximize outputs. Capitalism's immense success (measuralle for examile by the number of hours any category of worker must work in order to acquire the purchasing price of any commodity) is attributed to the high degree of rationality ${ }^{7}$ on which it is premised and which rharacterizes its operation, whereas capitalist rationality, for Yary, is a catalyst for the collapse of the capitalist mode of production. Also, while Weber's richer concept can accommodate Marx's - only the. lattre's inherent determinism is incompatible - the opposite is obIousl: nut the case. In the subsequent discussion of heber's concept uf cafitalism, its parallels with Marx's (cf. Giddens:1970; Mommen: 1971; Turner:1985) - as far as disparate elements are concerned, yet Minusly not their interpretation - will be obvious and not pointed out un erer! occasion.

heluer defines "capitalistic economic action as one which rests on the expectation of profit by the utilization of opportunities for exchalı', that is on (formally) peaceful changes of profit" (Weber:1958, 17) and suggests this action to be "present wherever the ... provision

i On the important distinction, even conflict, between practical, formal and substantive rationality see above, pp. $128 \mathrm{ff}$. 
for the needs of a human group is carried out by the method of enterprise [i.e. profit-seeking business], irrespective of what need is involved" (Weber:1966,207). Six distinctive factors are constitutive of capitalism as an economic order:

- Freedom of the market, that is, the absence of irrational limitations on trading in the warket.

- Private appropriation by entrepreneurs of all the means of production and separation of the workers from the means of production.

- horkers who are formally free but economically compelled to selI their labour.

- Calculable lak in both adjudication and state administration.

- A rational monetary system and the general commercialization of economic life.

- Rational capital accounting [double entry bookkeeping] and rational technology based on calculation and knowledge, especially mechanization (Weber:1966, 207-209).

As an ensemble these factors corstitute capitalisa as the most comprehensively rational organization for susial want satisfuction. However, Weber does not assume a harmonic or static uni-linearity towards rationality in capitalism. Instead, the possibility of derationalization exists. Market freedom or calculable administration 
and conflict adjudication, for example, are threatened once monopolies emerge and might well entropy if the resulting economic or political power is brought to bear. The conflictual and dynamic nature of Weber's ideal-type of capitalism, much more diffuse and complex that Marx's model centered on class struggle and accumulation, cannot be overemphasized. As heuristic devices, the six factors represent the various fora in which rationalization processes take place, namely "the ratiunal (deliberate and systematic) pursuit of profit through the raIional (systematic and calculable) organization of formally free labour and through rational (impersonal, purely instrumental) exchange on the marhet, suided by rational (exact, purely quantitative) accounting procrolures and guaranteed by ratjonal (rule-governed, predictable) legal and political systems" (Brubaker:1984,1-2). The essence of these nulti-fuceted rationalization processes, or the "spirit of capitalism", helur explains, is "that attitude which seeks profit rationally and sistenatically" (heber: 1958,64).

The play of market forces, unobstructed by non-economic interfer'lle', it necessary and sufficient for capitalism's continuance, provided the. State can ensure the calculability nexus which, in addition to rational law making and application, includes the maintenance of law and urder. As his purpose is analysis rather than policy prescription, heber does not diell on the issue of private or public provision of phisical and human infrastructures nor, with one exception to be discussed helow, on the preferred role of the state in a capitalist ecoIIIm: Whether the State, through parastatals, participates directly in the productive sector or whether and to what extent communications fa- 
cilities, roads and ports, or education, health care and social insurance are supplied by the public or the private sector, is not constitutive of capitalism, although weber in passing mentions the state's supportive role in the "development of the intellectual disciplines, notably science and technology" (Weber:1978,200). Whichever mix is chosen is immaterial as long as none of the above six elements is decisively contradicted, that is, as long as the state itself behaves in a rational or market-conforming manner. The burdens it imposes on the economy must be limited to calculable and predictable tax payments; excluded are ad hoc levies, bribes, enforced discounts or purchases. "A state based exclusively on money contributions, conducting the collection of taves (but no other economic activity) through its own staff, and calling on personal service contributions only for poljtical and judicial purposes, provides an optimal environment for a rational market-oriented capitalism" (Weber:1978,199).

For heber, the feasibility for a state-dominated economy, incontrast, is not so much a problem of theoretical design than of practical implementation, evolving around the twin predicament of information arid motivation, or lack thereof. In a planned economy, goods are distributed on the basis of planned, rationed needs and goods are produced according to a plan (Weber:1978,203). In a market economy, production and distribution of goods take place according to effective demand. Here, the "striving for income is necessarily the ultimate driving force of all economic activity" (loc. cit.). In a planned economy, the State is the principal method employed to allocate scarce resources to human needs and wants; prices will not, therefore, reflect the real 


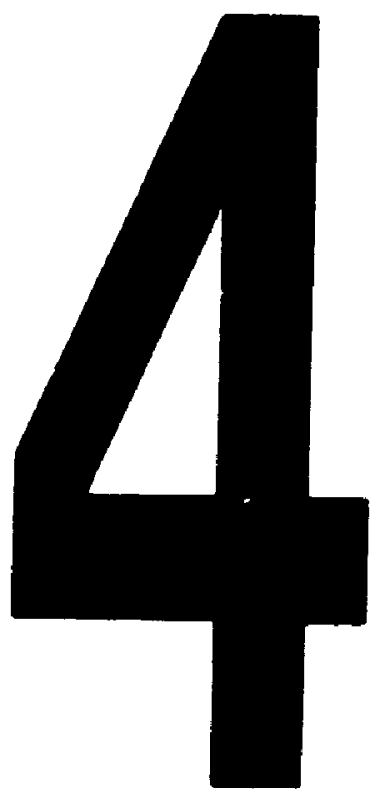

PM-1 3\%"X4" PHOTOCRAPHIC MICROCOPY TARGET MES 10100 ANSI/ISO *2 EOUIVALENT

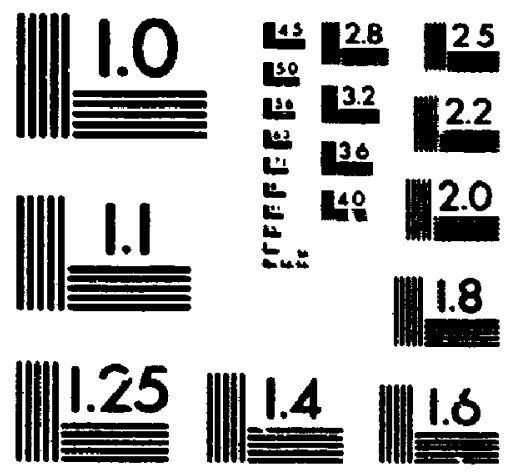

PRECISION RE RESOLUTION TARGETS

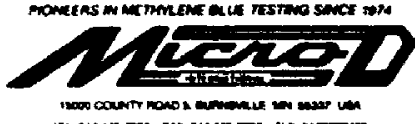

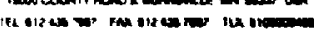


costs of production nor the real demand for a product. In capitalism, decision-making is decentralized and takes place in the market; prices, as a rule, do reflect production costs (no conmodity can be sold in the long run below its costs) but also consumer demand (high demand may raise the price, low demand will force it down to cost level). Prices in capitalism are crucial signalling devices for the efficient allocation of resources.

Whereas not all market economies are capitalist, capitalism cannot be other than a market economy. Market exchange is one of the defining characteristics of capitalism: it is a socio-economic system in which "it must be possible to conduct the provision for needs exclusively on the basis of market opportunities and the calculation of net income" (Weber:1966,209). Business does neither rely nor depend on any kind of force, fraud, bribery, protection or cartelization. Irrational interventions are, for example, protective tariff barriers, artificial exchange rates, the state-regulated assignment or withholding of production factors, price controls, monopolies and monopsonies, in short, all those disturbances that invariably lead to the emergence of black markets. "The modern rational organization of the capitalist enterprise [... is] attuned to a regular market, and neither to political nor irrationally speculative opportunities for profit" (Weber:1958,21). In this respect, as in many others, Weber's concept of capitalism corresponds to Marx's, and both their views of the narket resemble inse of neoclassical economics: scarcities direct the flow of capital, labour and goods to the areas of maximal return, while competition increases choice, reduces consumer prices and forces producers to invest, 
inrovate and improve. Unlike laissez faire advocates, Weber does not assume the market's formal rationality to be its natural state of equilibrium. The unicnization of labour may introduce an element of nonopoly formation just as capitalists favour the

extension of the free market, but only up to the point at which some of them succeed, through the purchase of privileges from the political authority or simply through the power of capital, in obtaining for themselves a monopoly for the sale of their products or the acquisition of their means of production, and in thus closing the market on their own part (Weber:1978,638).

The market, to remain rational, thus depends on certain specific substantive conditions such as "thorough market freedom, that is, the ahsence of monopolies, both of the imposed and economically irrational and of the voluntary and economically rational (i.e. market-oriented) variety" (Weber:1978,108), Weber does not say so explicitly, but this regulation of the market, preserving its rationality through the safeguarding of the rules of competitions (prevention of cartellization and ensuring access to the market), wust be part of the State's portfolio of maintaining law and order, and of ensuring the economy's calculability nexus.

In a formally rational or free market, exchange "is a compromise of interests on the part of the parties in the course of which goods or other advantages are passed as reciprocal compromises" (Weber:1978,72). Impicitly expanding on Adam Smith's idea (cf. Smith:1974,126-127), Weber thus assumes that, on cercan assumptions, "market exchanges approximate a certain kind of optimality or efficiency simply because people will have entered into an exchange when they gain from it and 
othertise not" (Lindblom:1977,40). Market freedom is the "degree of autonomy enjoyed by the parties to market relationships in the price struggle and in competition (Weber:1978,82). Its logic explains Weber's insistence on privately owned means of production (including autonomy in the selection of management by the owners), and on free labour (including freedom of the labour market and freedom in the selection of workers) as defining characteristics of capitalism (Weber: 1978.161-162). The dynanic of capitalism, and its superiority compared with a planned economy derives from the pervasive, market-engendered competition. It is not Marx's antagonistic class struggle between capitalists and workers which drives capitalism, but its all-encompassing and comprehensive rationalization pressures. Workers, in contrast to Marx's assumption, are not only victims of capitalism but also beneficjaries and their relationship to capitalists is not, per definitionem and absolutely, antagonistic. In other words, capitalism is not a zero-sum game in which class struggles determine the distribution of welfare and power, but a system with a variety of possible outcomes, including Pareto-optimal ones and positive-sum ones in which everybody rins.

Capitalists realize that low "wages are by no means identical with cheap labour" (Weber:1958,61) and workers benefit not only because with mechanization their skill requirements increase and therefore their wages, but because as consumers they provide the market for the goods produced. The increase in purchasing power in capitalist economies ( $i . e$. in the countries belonging to the OECD and in some Asian ones) during the past half century, even of most of the poor, has been 
dramatic by all accounts:

There are no doubt some things available to the nodern workman that Louis XIV himself would have been delighted to have yet was unable to have - modern dentistry for instance. ... Queen Elizabeth owned silk stockings. The capitalist achievement does not typically consist in providing more siik stockings for queens but in hringing them within the reach of factory girls in return for steadily decreasing amounts of effort (Schumpeter: 1962,67).

Rationalization pressures tend to reduce production costs, improve production processes and increase the range of goods available. Science and technology are systematically employed to increase labour productivity (electrification and mechanization), to expand the range and reduce the cost of raw materials by substituting synthetic substances for organic matter and to develop new saleable goods (Weber: 1966,227). The calculating practices of the capitalist market economy make technological innovation predictable, rather than, as previously, an accidental factor in economic life (Weber:1966,231). Capitalism, Schumpeter argues, taking up Weber's theme,

is by nature a form or method of economic change and not only never is but never can be stationary. ... The fundamental impulse that sets and keeps the capitalist engine in motion comes from the new consumers' goods, the new methods of production or transportation, the new markets, the new forms of industrial organization that capitalist enterprise creates. ... The opening up of new markets, foreign or domestic, and the organizational development from the craft shop and factory to such concerns as U.S. Steel illustrate the same process of industrial mutation ... that incessantly revolutionizes the economic structure from within, incessantly destroying the old one, incessantly creating a new one. This process of Creative Destruction is the essential fact about capitalism (Schumpeter:1962,8283 ; emphasis in originall. 
Like Marx (1969a,742), Weber considers the contribution of wealth brought about by colonial trade or plunder insignificant for the development of capitalism (Weber:1966,223). Its success is due to the unique social and economic arrangements of a market economy in which want satisfaction "results from action oriented to advantages in exchange on the basis of self-interest and where cooperation takes place only through the exchange process" (Weber:1978,109). To be socially relevant, capitalism needs large markets, not in the sense of a great number of people, of pervasive needs or of widespread wants, but effective demand for goods. Anticipating Keynes' doctrine of effective demand, Reber contends that a clientele with sufficient purchasing power "in a substantive respect, regulates ihe production of goods by profit-making enterprises" (heber:1978,108). Only on the basis of extensive effective demand can capitalism benefit from economies of scale and, in its early stage, provide the economic prerequisite for the appearance and existence of factories. The market on which the factory owner, the capitalist entrepreneur "reckons must be sufficiently large and also relatively constant; hence a certain mass of pecuniary purchasing power is necessary, and the development of money economy must have reached the corresponding stage, so that a certain demand can be depended upon" (heber:1966,129). In view of the input fetishism (emphasizing low rates of saving, the scarcity of capital, skilled labour, agricultural tools, implements extension services etc. and their putative essentiality) of much of the development discourse and practice, it is an interesting contrast that, for Weber as for Marx, the decisive impetus toward capitalist development could come "only from one source, namely 
mass market demand, which again could arise only in a small proportion of the luxury industries through the democratization of the deaand, especially along the line of production of substitutes for the luxury goods of the upper classes. This phenomenon is characterized by prize competition, while the luxury industries working for the court could follow the handicraft principle of competition in quality" (Weber:1966, 230). The mass market creates a self-reinforcing dynamic: consumptive possibilities serve as an inducement for higher economic performance, especially in a subsistence economy. If the availability of goods in the market increases in terms of range and price, agricultural production for the market will be stimulated as will, eventually, investment in agriculture which means demand for additional market inputs, and so on.

Implied is the argument that growth without equity is inherently self-limiting because inequality reduces mass demand which, in turn, retards the development of backward and forward linkages among the product ive sectors and maintains the disjunction between production and consumption: the wealthy elite consumes imported commodities while the majority of the population either remains mired in a subsistenre economy or/and produces for external markets. It is important to note that the case for a reasonably equitable distribution of income is not made in humanitarian or social but in strictly functional terms; it is the rising tide of mass demand that lifts all boats. According to heber, the historically observed development from a subsistence to a commercial economy implies that rational capitalisa "is organized with a view to market opportunities, hence to economic objectives in the 
real sense of the word, and the more rational it is the more closely it relates to mass demand and the provision for mass demand" (Weber:1966, 247).

The remaining elements of Heber's typology of capitalisw general commercialization of economic life, rational capital accounting and a rational monetary systen - follow logically from what was said earlier and are largely self evident prerequisites for, and consequences of, a capitalist economy. Under capitalism "man is dominated by the making of money, by acquisition as the ultimate purpose of life. Economic acguisition is no longer subordinated to man as the means for the satisfaction of his material needs. This reversal of what we should call the natural relationship, so irrational from a nave j. int of bien, is definiteiy the leading principle of capitalism as it is foreign to all peoples not under capitalistic influence" (Weber:1958, 53). The commercialization of life corresponds to Marx's concept of commodification as differentiated into its technical components. It refers to the social environment, in particular to the destruction of all obstacles - political, social, moral or whatever - to the free morement or economic transferability of labour, land, and products. The capitalist market in its rationality and efficiency

is the most impersonal relationship of practical life into which humans can enter with one another. ... The reason for the impersonality of the market is its matter-of-factness, its orientation to the commodity and only to that. Where the market is allowed to follow its own autonomous tendencies, its participants do not look toward the persons of each other but only toward the commodity; there are no obligations of brotherliness or reverence, and none of those sfontaneous human relations that are sustained by personal unions. They all would just obstruct the free developaent of the bare market relationship, and its specific interests 
serve, in their turn, to weaken the sentivent on which these obstructions rest. Market behaviour is influenced by rational, purposeful pursuit of interests. The partner to a transaction is expected to behave according to rational legality and, quite particularly, to respect the formal inviolability of a promise once given. These are the qualities which form the content of market ethics (Weber:1978, $6.3(i)$.

This capitalist market economy depends on such institutional supforts as formally rational administration and application of law in a mannir "which can be counted upon, like a machine" (Weber: 1966,252), that is, legally guaranteed private property, the ability of anybody to enter into contracts with anybody else, and the ensured and impartial enforcement of the law. Furthermore required is a rational monetary syitem, without which exchange is limited to barter and the economy shackled because of the immense complication of atching suppliers and husers as well as quantities of produce and tining of exchanges. Entirely impossible on any significant scale without money is capital formation, banting, share-holding, insurance or wage labour (Weber: 1978,80-82). These practices, constitutive of capitalism, turn "money into a too! of rational cost-profit calculations, of which the towering monument is double-entry bookkeeping" (Schumpeter:1962,123), that is, the method applied by enterprise to determine "its income yielding power by calculation according to the methods of modern bookkeeping and the striking of a balance" (Weber:1966,207).8 This technique is the

S A Nigerian historian points out that the value of book-keeping was well appreciated by the traditional rulers in the Niger delta who, in the first half of the nineteenth century, welconed the establishment of a mission by the United Presbyterian Church of Scotland. "The early desire of the chiefs of Calabar to naster the secrets of the white nan's language and his method of keeping accounts was motivated by a desire to make commercial transactions with Europeans nore profitable" (Nduka: 
ultimate expression of the commercialization/rationalization of life (Weber) or of its conmodification and the resulting hunan self-alienation (Marx). A capitaligt economy is "rationalized on the basis of $r i-$ gorous calculation, directed with foresight and caution toward the economic success which is sought in sharp contrast to the hand-to-auth existence of the peasant, and to the privileged traditionalism of the guild craftsman, and to the adventurers' capitalisa, oriented to the exploitation of political opportunities and irrational speculation" (Weber: 1958,76). In rational capitalism, everything "is done in teras of balances: at the beginning of the enterprise an initial balance, hefore every individual decision a calculation to ascertain its probable profitableness, and at the end a final balance to ascertain how wuch profit has been wade" (Keber:1958,18). Everything can be calculated and everything has a price; "expression in money terms yields the highest degree of formal calculability" (Weber:1978,85). Those facets of life that cannot be quantified - externalities in the language of noderu economics or immaterial values - will literally be discounted. hipher, in contrast to Marx, had no masses to mobilize and therefore no need to offer a soteriology; nor had he allowances to make for the practicability of his analysis for political action. His study of capitalism is therefore more sober than Marx's yet no less cutting. "Each individual operation undertaken by a rational profit-aaking enterprise is orienced to estinated profitability by means of calculation. Capital accounting in its formally most rational shape presup- 
poses the battle of man with man" (Weber:1978,91-93; eaphasis in original). Moreover, "the 'free' warket, that is the arket which is not bound by ethical norms, with its exploitation of constellations of interests and monopoly positions and its dickering, is an abomination to every system of fraternal ethics. In sharp contrast to all other groups which always presuppose some measure of personal fraternization or even blood kinship, the arket is fundanentally alien to any type of fraternal relationship" (Weber:1978,637). The previously nentioned conflict between the different categories of rationality is in evidence h.r.r, yet heber had no answer to the perplexing question of how to reconcile efficient production with a bearable sciety: the formal rationality of capitalism is substantively irrational in that it undermines dist inctively laudable human values and social wores; besides, it threatens to engulf human autonomy and individuality within ever more perfect systems. However, his assumption of history's indeterminacy Jed him to formulate his proposition, not as a statement of fact, but as a consideration: do "the technical and economic conditions of machine production ... determine the lives of all the individuals who are burn into this mechanism ... with irresistible force?" (Weber:1958, $181 ;$

Given the low level of development and the dearth of alternatives in Nigeria - as in much of the Third World - such anxieties about possible, if uncertain, long-term repercussions should not obscure the inst ructive lessons and developmental merit of capitalisa. On the basis of Mary's and Veber's concepts of capitalisw: as outlined in the preIous pages, the ground is now prepared to answer the questions whether 
Nigeria is capitalist and how or why the bureaucratic state prevents capitalist development. To sumarize the two positions briefly:

Marx's notion of capitalisa centres on the production process and the, in his view, inherent exploitation of workers. He writes from What he perceives to be the workers' perspective which is why he entirely ignores the calculability nexus so important for Weber. For him, the relationship between capitalist and wage-labourer determines the entire character of any mode of production. The capitalist mode of production refers to the separation of labour from the means of production, to the production of commodities for exchange (rather than gnods for use) by capitalists who combine capital which they own with labour power which they buy from propertyless workers. Horkers are formally free but compelled to sell their labour power as a conmodity in order to survive; their pay covers only part of the value they produce and the capitalists invest, rather than consume, this surplus. Value is created and surplus extracted in the process of production and not in sphere of exchange (where it is realized). The whole purpose of lroduction is production on an expanded scale, not the satisfaction of luma: needs. Capitalism is revolutionary and universalizing in character; it destroys all traditional ties and behavioural patterns and replaces them with the alienating conformity conditioned by omripresent commodit: production, but also with greatly enhanced productivity of labour which, at least theoretically, allows the sphere of necessity to be shrunk and the sphere of freedom to be expanded,

heber's notion of capitalism centers on its formal rationality as a system of hant satisfaction. His perspective is very much that of a 
bitician ellireprenfur who appr ziates the importance of an effectiv aul ('Alculable but non-intrusive state as well as of a free market. For him, capitalism is the symbiotic process in which free and selfinterested actors (owners of capital and workers; sellers and buyers) associate in the market according to strictly economic criteria. Cawitalism's regulating principle is the invisible hand of the free markift which has to encompass all elements of the economy (capital, land, labull, goods and services). It firstly directs these elements to areas of maximal return. It secondly enforces efficiency by compelling the onllers of capital to produce as advantageously as possible and thus to support their competitiveness; this requires them to invest in, expand, rationalize and modernize the production process; expand the rangit of goods, innovate them, improve their quality and reduce their (usts. The market thirdly depersonalizes human relations by replacing truditional forms of association or those based on morals or values with purely contractual ones based on constellations of interests and lower. All three aspects of the market point in the direction of ecoImic rationaljty and efficiency which, however, depend on the state to lroide the necessary calculability nexus, that is, to maintain market freedom, law and order as well as to enact laws and adjudicate conflicts promptly, reliably and impartially.

\section{b) Nigeris is not a Capitalist Social Pornation}

Nigeria, applying Marx's criteria, despite a small industrial ellclate, a rudimentary working class and an even smaller indigenous 
bourgeoisie, is not a capitalist social formation. The majority of Nigeria's population are peasant farmers who own their own land and who are engaged not in commodity but in subsistence production. They are not a propertyless class for whom the sale of labour-powe: is the only source of sustenance. Controlling their own means of production and more particularly their means of subsistence most Nigerians are not compelled to "exchange in order to reproduce, [they are under] no pressure/necessity to comnete, thus no requirement to accumulate, especially by way of innovating in order to survive" (Brenner:1977,49). This fundamental reality is not affected by the temporary or even permanent migration of peasant farmers to cities in search of salaried employment because they always can (and mostly do) go back. This reality is not affected either by the farmers' integration into a market which is strictly limited to isolated contacts rather than a totalizing immersion: instead of depending on the market to sall all their produce and to buy everything they need, Nigeria's swallholder peasant farmers are normally self-sufficient food producers who sell some portion of their harvest in the market to obtain the money with which they then buy those necessities or luxuries which they cannot produce themselves (cf. Barker: 1989,7; World Bank:1974,78).

The peasant hinself, when he regularly sells a part of his harvest and buys tools and clothing, is already a part of the market. But if he comes to the market town to sell a few items - eggs or a chicken - in order to obtain a fer coins with which to pay his taxes or buy a plowshare, he is merely pressing his nose against the shopwindow of the aarketplace. He remains within the vast world of self-sufficiency (Braudel:1977,20). 
Braudel, of course, merely illustrates Marx's emphasis of the non-capitailst nature of simple commodity circulation (to sell in order (c) buy) which "serves a purpose outside of the sphere of circulation suc', as the acquisition of utensils or the fulfillment of needs. The circulation of money as capital, in contrast, is an end in itself, because the realization of value exists only within this constantly reneved movement. The movement of capital is therefore limitless" (Marx: $1968,167 !$ A capitalist usi mono: not to buy something in response to a rifed, but to generate more money. The peasant farmer, on the other hind, might save but he does not accumulate and, as long as land is not a saluable commodity, there is little chance for him to become either a (itpitalist farmer (kulak) or a landless labourer. The relations of a Nigtriar peasant farmer to people outside his kinship group, like those of subsistence farmers elsewhere, are governed by three primary needs: "tu dispust of accidental or deliberate surplus production, to make guod a temporary deficiency in the production system, to acquire spatially discrete essential resources (e.g. salt)" (Siddle and Swindell: $1990,90)$

There might be some growth - increased output as a result of more inputs of land or labour - but the chances for development (rising produrtivity of labour and increased output at given levels of inputs of land or labour) are seriously circumscribed. Self-provisioning shields the peasant farmers from the full force of market relationships and, so one argument goes, only when they are fully captured by market forces will they begin to implement their capacity to improve the productivity of land and labour (cf. Hyden: 1980 \& 1983). The presence of an uncap- 
tured peasantry, constituting the majority of the population, implies the absence of a proletariat.

Lacking in Nigeria is not only a class of free labourers, but also a dominant, accumulating, profit-maximizing and production-oriented bourgeoisie, engaged in fierce competition in the marketplace with other capitalists. The clientelist relationship of businessmen, even capitalists, whether as individuals or as a class, with the state effectively replaces the competitive dynamism which, normally, would force each entrepreneur to accumulate and to adopt an aggressive, expansive and innovative business strategy to defend himself against the threats posed by other capitalists. Value in Nigeria, as has been pointed out repeatedly, is not, at least not predominantly, created in a process of production, but is won as a rent from oil, centrally appropriated and allocated by the state. Accordingly, the competitive accumulation of capital in the extensive parastatal sector is replaced by transfer payments from the State treasury. In the industrial sector as a whole, the heavy dependence on imported technology as well as .. terial inputs, mostly "ckd" (completely knocked down) parts which are only assembled locally, leaves precious little room for locally added value. Therefore, as long as capitalist relations of production are confined to the small (in terms of employment and contribution to GDP) enclave of the industrial sector, one cannot, from a Marxist perspective, apply the totalizing label of a "capitalist mode of production" to the Nigerian economy.

From a heberian perspective, a similar verdict obtains because a "whole epoch can be designated as typically capitalistic only as the 
provision for wants is capjtalistically organized to such a predominant degree that if we imagine this form of organization taken away, the whole economic syste .ust collapse" (Weber:1966,207). In Nigeria, capitalist enterprise, whether in agriculture, manufacturing or services, is not a substantial factor and it would bear no relationship to reality to suggest that business corstituted of capitalistic entrepreneurs and free labourers were the basic unit of the Nigerian national economy. Subsistence farming on the one hand and State allocation of funds, determilled politically rather than economically, are the two mainstays of the economy. The opportunity structure created by a patrimonialized State with ample investible funds at its disposal, calls for agile brohers, contractors or traders, not for risk-taking entrepreneurs content to see their return on investment materialize, if at all, in the long run. Investing in real estate and rental property for expatriates, arranging deals with foreign companies or acting as a front for them so as help them evade indigenization policies, performing widdleman functions in contracts with foreign suppliers or importing restricted foreigu commodities as a monopolist through a State-issued import licence - all these are more lucrative endeavours than performing the histori(al rolt of the bourgeoisie. In Marxist terms, though equally representative of Weber's ideas, this role consists in ensuring the expanded reproduction of capital and the development of the productive forces, that is, to accumulate capital and to invest it in productive enterprise. The largely speculative role of the Nigerian business class is possible because market mechanisms govern only very few exchange relat ionships. 
Especially the vast agricultural sector which still employs three out of four Nigerians of working age has, under the force of state policies been marginalized and has largely regressed to an unproductive subsistence econony, unable not only to produce exportable cash crops but also to feed the country. It would be entirely erroneous, however, to censure the smallholder peasant farmers for limiting themselves to self-provisioning. For a fieberian it is evident that all they do is to act rationally within the framework of constraints erected by the State. This enforced faralysis is, of course, a form of exploitation, even if of an entirely different kind than the one postulated for the capitalist mode of production by Marx. Their exploitation, and oppression, is rooted in the bureaucratic mode of production which operates to berefit the state class and its clientele. Ikem Osodi, the main character in an Achebe novel addresses a radical student crowd which has just demanded to put the nation under the dictatorship of the proletariat:

When your fat civil servants and urban employees of public corporations march on May Day, wearing ridiculously undersize T-shirts and school-boy caps and spouting clichés from other people's histories and struggles, hardly do they realize that in the real context of Africa today they are not the party of the oppressed but of the oppressor. For they are the very comrades who preside over the sabotage of the nation by their unproductivity and fraud, and that way ensure that the benefits of modern life will ever remain outside the dreams of the real victims of exploitation in rural villages (Achebe: 1987,146).

The basis of this exploitation and, which is the same, of the non-capitalist nature of the economy and of the prevailing developmental paralysis, is that many transactions take place outside of war- 
kets or are decided politically. The farmers' subsistence activities are not only caused but also mirrored by the State's self-interested manipulation of existing markets through tariffs, subsidies, price controls, hiring directives or ethnic quotas. Thus, the market is not, as it is in capitalism, a significant regulating mechanism to establish scarcities and to allocate resources. Viewed from a developmental perspective, the fact that economic actors are not subjected', the full discipline of unregulated markets implies that there are few incentives to improve productivity and that the market's efficiency-enhancing, rationalizing and developmental impetus is not utilized.

Finally, the bureaucratic Nigerian State's interests (its substantive rationality) and, therefrom derived, its policies (practically rational in relation to the State's interests) are decidedly averse to capitalist development. It appropriates and allocates, according to luljtical, not economic criteria, the greatest share of the socially arailable surplus. Inconstrained by political or economic countervailing pressures, this money is largely sunk into conspicuous consumption, uuprofitalule investment or the extension of the state itself; it is neither, however, used to raise broadly based private consumption nor io create viable structures for the accumulation of productive capital. The bureaucratic Nigerian State's market interventions lead to the substitution of a political calculus for an economic one. For economic actors, whether managers of parastatals or of private enterprises, efficiency and profitability is less important than staying in the good graces of individual officials or of the State as a whole. An overvalued, non-convertible currency and its corollary, an import licencing 
regime amplify the politicization of economic life because economic success depends on using, or gaining access to state office: with foreign currencies rationed and subsidized, and with the privilege to inport goods administratively regulated, the gatekeeper's position becomes as crucial as lucrative; secondly, since buying and selling are easier and more profitable than building, they exert an anti-production (i.e. anti-accumulation or anti-capitalist) pressure. Political instability and patrimonialized administration - pervasive corruption, general inefficiency and doubtful legal protection - wilitate against the calculability nexus on which a capitalist economy depends.

To summarize, if a serious argument instead of merely a polemic is intended, and even if Marx's or Weber's concepts are only very loosely applied, Nigeria cannot be considered capitalist. To be sure, there are some capitalist features or relations of production in Nigeria, but they are rather marginal and do not determine the character of the social formation as a whole. I have discussed capitalism as a concept in some detail precisely to evince the misleading character of all these instances of loose terminology about Nigeria's capitalism: for neo-Marxists it serves as a straw-man to properly focus revolutionary zeal while for neo-liberals/conservatives it radiates some of the hope entirely missing in countries like, say, Tanzania or Uganda. Both perspectives, for their own partisan reasons, wight be blinded by the sheen radiating from oil revenues and therefore detect only what they wish to see: neo-Marxists, some islands of ostentatious affluence and rapacious decadence in an ocean of poverty and backwardness as is typical, in this outlook, for a capitalist model of accumulation (cf. Oba- 
dan and Ekuerhare:1989); neo-liberals/ conservatives, a gold-rush situation in which a professed non-socialist government of dynamic pragmatists, although not altogether immune to the temptations of personal gain, struggles to modernize the country following a nodel of "nurture capitalism" (Schatz:1977 \& 1984). So, if Nigeria is not capitalist (yet), what would be required for Nigeria to make it so and thus enhance its chances for economic development.

\section{c) The Developental Efficacy of a Capitalist Market Bconosy - and sone Thoughts on its Ideolorical Unpalatability}

Given the unfortunate combination of the Nigerian State's distinctive interest position, its limited managerial capabilities, its extensive intervention in the economy and the wide scope of the public sector, the state-led path to capitalist development (à la singapore, South Korea or Taiwan) seems unpromising. It has, arguably, been tried - and failed - in the past four decades and one conclusion to be drawn from this experience is that state hegemony itself is, under the circumstances, incompatible with economic development. "Like other preindustrial and essentially patrimonial governments, those of tropical Africa are often deficient in public purpose and collective resolve but open to private, parochial and personal interests. This is often a source of frustration to those - often intellectuals, planners and socialists - who believe in strong, public government" (Jackson:1973, 396). The costs, priorities and policies of the bureaucratic state 
themselves constitute serious problems for development and do, actual1y, reduce the nation's socio-economic capacity for problem solving. Given that in macroeconomic matters only two mechanisms for the allocation of value exist, the State and the market, and given the serious shortcomings of the "really existing" bureaucratic Nigerian state, greater reliance on the market is then not a matter of ideological choice but of practical necessity.

In light of the bureaucratic Nigerian State's system-inherent indiscipline, it might not be an optimal solution but a realistic secondbest one. If history is anything to go by, a capitalist market economy because of its devolution of power from a molithic political center to a private sector and to budding classes, is essential also to the emergence of a plural society: "No bourgeois, no democracy," as Barrington Moore sums it up (Moore:1966,418). Since the bureaucratic Nigerian state cannot engineer it, capitalist development necessitates the readiness of the state to subordinate its own interests to this goal and to surrender power either to a competing class (possibly of its onll making) or, initially, to the market. In view of the present stalemate there is

an urgent need to strengthen those forces in society that enable the development of a ruling class who is free from the constraints imposed by the present pre-capitalist formations. ... the only force capable of addressing this issue in a relatively short perspective is the market. The latter promotes the rise of a local bourgeoisie, encourages greater effectiveness in the public sector through diversification of structural mechanisms for development, and promotes behavioural changes throughout society, leaving people of different backgrounds wore ready for alternative social action (Hyden:1983,197-198). 
Hyden, obviously following Weber's argumentation lcf. Weber:1978, 103-113), seems to suggest that the market is beneficial in eroding the concentration of power, economic and political, and thus in releasing hitherto muzzled productive forces. It is in this sense that the Pope in his otherwise almost anti-capitalist encyclical "Centesimus Annus" derlares "that, on the level of individual nations and of international relations, the free market is the most efficient instrument for utilizing resources and effectively responding to needs" (cited in the NYT, 3 Mat 1991, Pl. Al \& A10).9

The market is superior, compared with other conceivable economic steering mechanisms of the administrative-regulative or the politicala) lucative variety, in generating economic growth or even development (creative or productive function), and in solving the competition betheell alternative uses for scarce resources (allocative function). 10

9 It is more than delicious irony that the kremlin before its demise should have been applying for membership in this (un)holy alliance; see belon, frotnote No. 19, p. 320 ).

10 Nicholas kaldor introduced the distinction between "allocative" and "creative" functions of markets (Kaldor:1972,1240). The former refers to the market mechanism's propensity to move an economy towards the ontimum point on a given production possibility curve; the latter refers to the tendency of market economies to generate growth, i.e. to move the pruduction curve outiard ( $\mathrm{c} f$. Arndt:1988,219). It is important to realize that creative efficiency and allocative efficiency are enhanced by competition in different markets. Creative or productive "efficiency requires that whatever is done should be achieved at aininum cost, allocative efficiellcy implies that what is done meets consumer needs at prices which reflect the costs of provision. Encouragement to achieve efficiency may come from the product market, or the capital narket, or both. The product marhet may be one in which consumers can transfer their custon to other firms, the capital market can impose the threat of barkruptcy or of takeover. ... It is competitive, privately owned firms which have incentives to achieve both productive and allocative efficiency. Privatisation tends to promote productive efficiency, competition allocative efficiency" (Kay and Thompson: $1986,20 \& 22$ ). 
Its respective strengths derive from two distinct competencies, namely its inherent effectiveness to simultaneously generate information and to focus motivation. This means that the market is notably useful to:

- orient economic decision-naking. In a functioning market mechanism, prices rather than plans or adninistratively, demoscopically or politically derived information, are the signals that tell the economy how its resources can best be used and thus provide the incentives for the decisions of economic actors who, entirely independently, decide the nature of their purchases as well as the division of their incone into consunption and savings. The sovereignty of consumers is mirrored in the producers' unrestricted planning competence as regards the level of investment, the manner of production, its structure and volume. By rewarding efficient factor use - and by sanctioning waste - market mechanisms lead to optimal utilization of scarce resources (which does not mean to an income distribu$t$ ion perceived as fair or just) and are, in this respect, superior to administrative controls. Yet the information provided by market prices is only necessary not however a sufficient pre-requisite of a working economy: unless resources, especially productive assets, are privately owned, the danger remains that price signals will simply be ignored. This leads to the second strength of the market, which is

- to harness private initiative and instrunentalize it for developmental goals. By making economic success contingent on purely economic efficiency and customer approval, rather than on ideological, political or power factors, private individuals and enterprises, reacting to the system-inherent principle of competition, can be expected to achieve national developmental goals more effectively than can government officials and agencies, even if these are guided by market considerations. Government investments and parastatals are normally shielded, to a greater or lesser extent, from competition and thus from efficiency considerations or rationalizing pressures. Yet, if economic performance is the issue, whether in analysis or in policy prescription, to onit competition from any theory, "even if correct in logic as well as in fact, is like Hamlet without the Danish prince" (Schumpeter:1962,86).

Competition could be introduced into the Nigerian economy only if the State's economic centrality would be replaced by plethora of freely interacting decision-makers: producers and consumers, capital- 
ists and workers, debtors and creditors, all of whose individual decisinns would be coordinated in the various markets by the impersonal rules of supply and demand. State policy would have to be oriented at macroeconomic profitability criteria and its economic interventions at correcting market imperfections, instead of attenpting to distort, subdue or replace markets. This recomendation reflects an iaportant lesson of the past decades, namely that direct state intervention in production or to correct market failures often makes matters worse by inhititing whatever private responses would have been forthcoming, while neither increasing output (production) nor improving factor utilization (fruductivity) levels. "Put simply, governments need to do less in thuse areas where markets work, or can be made to work, reasonably will. In many countries, it would help to privatize any of the stateohned enterprises. Governments need to let domestic and international competition flourish. At the same time, governments need to do more in thuse areas where markets alone cannot be relied upon" (World Bank: 1991,9; see also keynes:1972,291 and Lewis:1953). Reducing the State hould, potentially, have the additional advantage of diminishing administrative weaknesses by focusing governmental institutions better and thereby cutting down the strain on them.

My argument, it should be stressed, does not anount to an advocacy of orthodox liberal laissez faireism; in fact, aarket advocacy is not the primary purpose of the present study. Rather, the market is employed as a heuristic device to illuainate the economic irrationalities of the bureaucratic Nigerian State and its developmental counterproductiveness. Underlying this approach is the conviction that "re- 
source management rather than resource constraints per se is the primary bottleneck to econonic growth" (Timmer:1991,320). The market as a formally rational mechanisa of resource allocation, in this context, acts as a yardstick against which the state's actions are to be measured. By so doing I also hope to transcend, rather than get aired on (as many analysts seem to, $c f$. Hettne:1990,43 or Sandbrook:1990) the axis of whether the state should be "nore" or "less" involved in the development process. 11

Instead, what comes into relief is what the State is actually doing and why and how this affects Nigeria's economic performance alid development prospects; what the State should be doing can then be inferred deductively. Thus, even a less intrusive State, as I have argued earlier ( $p .230$ ), would have to play a decisive, if different, role in the economy, Unfortunately, the rationality and, from developmental point of view, desirability of these market-oriented reforms say nothing about their practicability which must be considered low. "The ruling coalition of interests does not abdicate of its own valition, nor does it change its character in response to incantation"

11 Although markets and states are often thought to be incompatible and mutually exclusive economic steering aechanisms - with the public choice economists of the Chicago variety assuming that government can do no right and traditional development econonists a la Gerschenkron or Tinbergen exhibiting considerable weariness of the market - this strikes me as an unjustifiable and unsatisfactory dichotony. The success story, for example, of Asia's "four little dragons" Hong Kong, Singapore, South Korea and Taiwan is, contrary to popular myth, not so much an argunent in favour of free markets as it is proof that sone governments intervene wore effectively than others. "Effective industrial policies in East Asia are characterized by four key features which contrast sharply to the situation in Latin America [or Africa]: flexibility, selectivity, coherence and an emphasis on promotion rather than regulation (Jenkins:1991,199; see also Wade: 1990 ). 
(Baran:1952,81-82). The benefits of aarket-oriented reforms would be indivisible and collective while the costs for the state class and its clients would be direct and tangible. A hegenony-oriented state class naturally prefers policies which enhance its econonic control, which engender direct, rather than diffuse, loyalties and which, therefore, generate concrete benefits for itself in terms of atonony, legitieacy and wealth. The state class will yield, wisely, only to the nost threatening, not necessarily however to the most deserving, nor to the must developmentally progressive claimants.

The matter is confused, however, since it is not just a question of priner, but also one of ideology. The goal of a market-oriented capitalism, is an ideologically charged subject, almost a shibboleth to identify the ideological Left and Right. For the academic and political Right it is the economical deus ex machina whose wonders would only lin spilt by the interference of the state (in this discourse it is alvags "big government"): "From the experience of a large number of developing countries in the postwar period, it would be a fair professional judgement that most of the more serious distortions are due not to the inherent imperfections of the warket-mechanism but to irrational government interventions" (Lal:1988,36; see also Cosse:1988). The State's intervention in the econory is regarded with suspicion because of a prejudicial pessinism about politicians' and bureaucrats' faculty to resist the temptation to ill-use economic powers, and because of an emphatic skepticism that governments could "detect opportunities which private entrepreneurs have missed" (Wade:1990,13). Market-oriented capitalism in this view cannot be, or only very little, improved upon. 
Until the last decade of the twentieth century, the reality of capitalism in the developed North alone sufficed to provoke anti-capitalist sentiments amonit nationalists throughout the Third World, and among festern intellectuals. In either case, counter-hegemonic impulses were as strong as positive arguments for socialism or against capitalism. For Third vorld nationalists during the 1940s and 1950s, the liberals' assurances concerning the emancipatory elements of capitalism rang hollow enough as it was. They had to be anti-capitalist, at least in rhetoric, simply because their oppressor was a capitalist, even if only at home and barely so in his colonies. Western intellectuals arrived at their anti-capitalist convictions at least as much through similar contrarian impulses, ${ }^{12}$ even if it meant, in Third World contexts, implicitly taking the sides of cliques which abused the state for narrowly selfish reasons. Deriding Mobutu but exculpating Kaunda, the Left (especially the academic Left) has had serious problems to perceive the abuse of power as anything else than a quandary germane only to capitalism.

More generally and theoretically, a capitalist market economy is, for the Left, a system which perforce increases inequality by preventing the fruits of development to trickle down or spread to the poor. Even more contemptible is its all-corrosive power whith is the root cause for the alienation, cultural degeneration, exploitation and ma-

12 Koestler suggests that the intelligentsia in the modern sense constitutes that part of a sociecy which is driven to independent thought, that is, to a type of group-behaviour which debunks the existing hierarchy of values (from which it is excluded) and at the same time tries to replace it with new values of its own" (Koestler:1946,62-63). 
turialization of life, a fate that should be spared the Third forld. In this perspective for rather in this state of mind which Ernst Jünger described as "that anti-capitalist nostalgia"), a capitalist market economy would be anathema, even if its effectiveness were demonstrated beyond all doubt. Viscerally distrustful of the common man's common sense and of his mundane-materialist interests, capitalism, the system in which values are allacated through the market rather than through some political agency - axiomatically assumed to be both benevolent and omniscient - is either a sham or evil incarnate. "We criticize capitalism not because it causes desires which might otherwise not have arisell, but because it causes desires the fulfilment of which does not afford an appropriate degree of satisfaction" (Cohen:1978, 319-320). Also, what are considered the superstructural expressions of capitalism, such as liberalism, pluralism or bourgeois demccracy, in this view turn out to be but post-fascist makeshifts or crypto-fascist compromises, merely a phony

coated with a moral veneer, hypocritical about human rights, as if the capitalist whore could once wore become a virgin ... freedom as the utopia of western capitalism is chloroform, nothing else. ... The worker in a capitalist class-state has only ever had the freedom to starve [... whereas] the land where socialism is being built [the Soviet Union] has employed its stupendous power, and has had to without fail, to end all power over people" (Bloch: 1979,682 \& 1061 ; my translation).

Such discourse is oblivious to the dangers emanating from an uncontrolled State; it is equally oblivious to the essence of communist systems. The latter are, or better vere, a special form of social despotism, combining the crude authoritarianism of Taylorite factory dis- 
cipline with the brutal authoritarianism of a police state. Blind to the empirical reality as well as the fevelopmental potential of either communist or capitalist systems, much of Marxist inspired analysis is, instead, informed by a messianic utopianism oddly conjoined with a romantic anti-mudernism, by an unwarranted idealization of the past and, possibly, by a good deal of condescending paternalism which wants to spare the witless proletariat in the North and the Third World asses (today's equivalent of the erstwhile image of the "noble savage") the banal consumerist existence of an industrial society.

It is singularly" ironical that "the author of the firsi and still one of the grandest and most sophisticated conceptions of economic development" (Arndt:1987,38) inspired some of the crudest forms of antidevelopment thinking. What for Marx was the ideal endpoint of a process of economic development which, in his view, had to run its often cruel and inhuman course, became for many of his epigones an utopia, instantaneously attainable through shortcuts to be revealed by correct. plijlosophical reasoning, suitable social engineering or through appropriate political action. Moreover, everything is to be achieved without destroying any of the healthy traditions, mores and kinship ties of traditional society so much admired and envied by alienated Western so cial scientists. Parodying this sentiment so evocatively expressed by Rousseau's "Man is born free, but everywhere is found enslaved and in chains," Emile Faguet offers a parallel observation about sheep: "Dire: 1 . : moutons sont nés carnivores, et partout ils mangent de l'herbe, serait aussi juste" (To say that sheep are born carnivorous and everywhere eat grass would be equally correct; cited in Berlin: 1990,125). 
Thus, while dissatisfaction with the shortcomings of apitalist system might well be virtuous, two points should be kept in mind: firstly, impatience with the status quo loses some legitimacy if an -lite is required - progressive cadres as the avantgarde of the unwitting proletariat for example - not only to fight for the "masses" or to avert mischief from them, but also to formulate their interests. Secondly, the human desire for certainty, for system, for unshakable beliefs is understandable. More, it is possibly unavoidable, incorrigible and even noble, but it is also highly dangerous. On the one hand it can be hijacked, as Georges Sorel showed with his wedding of Marxism and Fascism. "Marxism for him and his followers, was a sociology of violence, and it amounted to class struggle. Marxism, they believed, was never anything except an instrumert of combat" (Sternhell:1991,79801. On the other hand and emphasizing more the economic and moral asprects of Marx's apodictic critique of capitalism, pragmatically reformist policies for Third World development are discounted without, however, being suhstituted by palatable and workable alternatives.

We, who retain in our language and sentiments the ideology without the substance of a society organized through kinship, project our own romantic nostalgia onto the factionridden and anxiety-prone family life of African villages. Then, in the name of this fictitious utopia, we declaim against developments that shift the focus of social life akay from that narrow-minded sphere, or invent nonexistent social forces of external oppression to explain why West Africans, like countless millions elsewhere, yearly vote with their feet on the relative attractions of town and country life (Hart:1982,40).

The Left's quite undialectical and idealistic anti-market utopianism, in which the holy "once upon a time" has been replaced by the 
holy "one day" and in which the "pure futurum tries in vain to fill the empty heaven" (Marcuse:1966,4; my translation), goes back to what is but one element of Karl Marx's philosophical edifice, namely the ideal of a truly humane, post-capitalist society which would no longer be tyrannized by the system-inherent dominance of production for exchange but which could concentrate its creative energies on production for use. ${ }^{13}$ In this respect, Marx truly was "a nineteenth century romantic. He looked to men, having overcome scarcity, permitting their better natures to flower; to work for the joy of personal expression in a setting where affluence had removed the need and teaptation for avarice" (Roston:1968,156). Analogously to the kind of historiography which focusses on kings, commanders-in-chief, discoveries and other such landmarks, and which either ignores everyday life altogether or insinuates that it is derivative, shaped. stly by the actions of leaders, Marx's materialist analysis of capitalism focusses on the systemdetermined behaviour of capitalists and the resulting macro-dynamics. The proletariat is treated as a residual category with its roles of

13 of course, Marx's sentiments can be traced back to more ancient roots, namely to the early Christian teachings (e.g. St. Augustine's) against mammonism, a sin condemned for turning men away fron their search for God. Wealth as such was castigated as evil, a sentiment concigely expressed by Saint Jerome who judged that a "rich nan is either a thief or the son of a thief" (cited in Dillard:1988,89). Other towering representatives of this anti-materialist credo were thinkers like Rousseau, Nietzsche or Tolstoy and, of course, the great political activist Mahatma Ghandi who held that civilization "is not an incurable disease, but ... the English people are at present afflicted by it.... Its true test lies in the fact that people living in it make bodily welfare the object of life. ... This civilization is irreligion" (cited in Arndt:1987,19). Capitalism, the incarnation of this despised modernity, despite its productive success does not inspire much idealism. "The stock exchange is a poor substitute for the Holy Grail" (Schumpeter:1962,137). 
victim and eventual saviour deduced from capitalism's systemic dynamism. Its historical mission - and here Marx's materialigm reaches its limit, in fact overshoots into soteriological idealism - ¿s not explained by reference to the proletariat itself, but assigned to it because it is the one untainted force in an otherwise despicable system (cf. Engels:1977,139-140). Marx's humanist epigones for whom the practicability of the proletariat's emancipatory assignment, under the overwhelming force of empirical reality, had lost plausibility, concentrated instead on its other role, that of victim.

This utopian leitmotif is present throughout Marx's oeurre. Already in his Economic-Philosophical Manuscripts of 1844 he explains communism as the "positive abolition of private property ... It is the solved puzzle of history and knows it is such" (Marx:1968a,536); in the Grundrisse of 1857 he censures the alienation experienced by workers in the process of capitalist production (Marx:1983,601); in his Critique of the Gotha Programme of 1875 he prognosticates that only in a "higher phase of communist society ... can the narrow horizon of the bourgeois lar lie fully left behind and society inscribe on its banners: from each according to his ability, to each according to hi= neads" (Marx:1969e, 21); and at the end of the third volume of Das Kapital which remained unfinished on his death in 1883, he alludes to his vision of the rein of liberty to be built on a rationally and communally organized rein of necessity (Marx:1968,828). Similarly Friedrich Engels who, in his Socialism: ltopian and Scientific, contends that the forces of production, ararchic, destructive and demonic under capitalism, will be tamed by the 
socially planned regulation of production, oriented at the needs of society and of the individual. ... As soon as no social class needs to be oppressed any longer, as soon as class domination is abolished and thus the collisions and excesses which before followed from the existential struggle for survival in anarchic production processes, nothing remains to be oppressed and nothing remains which previous$1 y$ necessitated a repressive force, a State. ... The State will not be abolished, it will wither away (Engels:1977, 134-135; emphasis in original).

This credo in an eventual, ineluctable state of salvation in which alienation, contradiction and conflict would be finally "aufgehoben" gives Marxism an air of secular religion or, more charitably, of compassion and humanism. Marxism presents itself as a morally more exacting and thus superior alternative to capitalism. It equates socialism or communism with the "recovery by man of his lost humanity, the reconciliation of his species-essence with his empirical existence, the restoration to man's being of his 'alienated' nature" (Kolakowski: 1987,41). In more irreverent terms:

socialism aims at higher goals than full bellies, exactly as Christianity means more than the somewhat hedonistic values of heaven and hell. First and foremost, socialism means a new cultural world. ... the material seems to be abundant. Some socialists are ready enough, with folded hands and the smile of the blessed on their lips, to chant the canticle of justice, equality, freedom in general and freedom from 'the exploitation of man' in particular, of peace and love, if fetters broken and cultural energies unchained, of new horizons opened, of new dignities revealed. But that is Rousseau adulterated with some Bentham (Schumpeter: 1962,170$) .14$

14 Keynes' verdict was similarly caustic: "I criticise doctrinaire State Socialism, not because it seeks to engage men's altruistic impulses in the service of society, or because it departs from laissez-faire, or because it takes away from man's natural liberty to make a million, or because it has courage for bold experiments. All these things I applaud. I criticise it because it misces the significance of what is actually happening; because it is, in fact, little better than a dusty survival of 
Prominent representatives of this humanistic or idealistic, as opposed to economistic or materialistic strand of Marxism, united in their opposition to the vulgarity of a comodified and thus alienated life were thinkers like, for instance, Ernst Bloch, Jean Jaurès, JeanPaul Sartre or the members of the Frankfurt school. For them, Marxism was above all a moral notion, a value-concept, the highest expression of man's external longing for freedom and justice. Capitalisa's negat ive utopia was castigated by Herbert Marcuse ${ }^{15}$ in his famous OneDimensional Man (Marcuse:1967), by Ernst Bloch in his monumental Principle of Hope (Bloch:1979) or by Erich Fromm's stereotypical "marketing character" (Fromm:1976,144ff). Underlying their approach, and those of some other Marxists whose outlook is psychological rather than materialist, is the contention that "Marx's entire critique of capitalism and his vision of socialism has its roots in the conviction that human self-realization is paralyzed in the capitalist system and that it must be the goal to return to man his humanity by recreating this self-realization in all spheres of life" (Fromm:1976,97; my translation). While I manage to muster a modicum of admiration for this "keltanschauung" (i.e. ideology and attitude) of idealistic humanısm,

a plan to meet the problems of fifty years ago, based on a misunderstanding of what someone said a hundred years ago" (Keynes:1972,290-291).

15 It should be emphasized that Herbert Marcuse is neither identical nor related, especially not in spirit, with the above cited Ludwig Marcuse. Ludrig Marcuse, much closer intellectually to Karl Popper, was the other Marcuse's intellectual antipode. He chided Herbert $M$. and other Mariists as "those pragmatists who despise eternal truth and at the same time proclaim it" (Marcuse:1966,145; ny translation). 
it is confined to the narrowest of margins because of the attendant melange of attributes such as naivete, wishful thinking and even crypto-totalitarianism. In the present context, these traits all too easily transcend the fine line to a somewhat patronizing anti-developmenta$\operatorname{lism:16}$

It is the absence of the threat of individual starvation which makes primitive society, in a sense, more human than market economy, and at the same time less economic. Ironically, the white man's initial contribution to the black man's world mainly consisted in introducing him to the uses of the scourges of hunger. To separate labor from other activities of life and to subject it to the laws of the market was to annihilate all organic forms of existence and to replace them by a different type of organization, an atomistic and individualistic one. ... the noncontractual organizations of kinship, neighborhood, profession, and creed were to be liquidated since they claimed the allegiance of the individual and thus restrained his freedom (Polanyi : 1957, 163-164).

16 Even less sympathetic is the virulent anti-semitism which permeates this idealistic humanism's genealogy. 19th century radicals in some sense precisely mirrored the reactionary ideology they fought against. Equally caught in anti-material romanticism, their similarity in outlook to the increasingly influential and militant religious-mythological Jeh-haters was remarkable. "On the political left, and at a certain distance (though not far enough by half) from such fanaticism, blood became a metaphor" (Alter:1991,38; see also Langmuir:1990). Moses Hess (1812-1875), the Rabbi and revolutionary friend of Marx emphasized (as Marx did too) an intrinsic bond between capitalism and the Jews. His tract of 1843, Uber das Geldwesen (The Essence of Money), is filled with images of cannibalism and bloodsucking. Hess suggests that the "invention of money [... is] ascribed to the same people who also invented the Jewish god." Speaking of money as "coagulated blood," he imagines capitalist exploitation as a secular reenactwent of the crucifixion (cited in Rose:1990,314-316). Marx elaborated his own views on the matter in 1844 in the essay "On the Jewish Question," a quite shocking outburst. In it he asks "What is the Jewry's secular basis? The practical need, selfishness. Which is the worldly cult of the Jew? Hagaling. Which is his worldly god? Money. ... We thus recognize Jewry as an omnioresent antisocial element ... The enancipation of the Jews is, in the final analysis, the emancipation of humanity frow the Jewg" (Marx:1969d, 373-373; emphases in originall. 
Polanyi's reproach, and congenial critiques of the West, seen to be informed by the concept of the noble savage,

the myth of the unsullied purity of human nature, innocent, at peace with its surroundings and itself, ruined only by contact with the vices of the corrupt culture of western cities. The notion that somewhere, whether in a real or imagined society, man dwells in his natural state, to which all men should return, is at the heart of primitivist theories; it is found in various guises in every anarchist and populist programme of the last hundred years, and has deeply affected Marxism and the vast variety of youth movements with radical or revolutionary goals (Berlin:1990,30).

Whether or not the rural iffe of a subsistence economy, today or in the past, was as harmonic and idyllic as we would like to think is an empirical, not an ideological question. But it could well be a serious illusion to consider virtuous what may have existed only for lack of alternatives.

Peasants who had little or nothing to eat are assumed to have had a rich spiritual life. Some who may have stayed with their fathers only in order to survive are credited with filial piety. What may have been the absence of incentives to change becomes a resistance to innovation and a defense of traditional ways. The rich who hid their wealth are perceived as having shown great modesty, and hostility among villages is converted to village solidarity. Somehow what might only have been the necessities or oppressions of one era come to be interpreted as traditional values during the next (Popkin:1979,3).

The picture emerging from Nigerian literature ${ }^{17}$ hardly conforms

17 See for example: C. Achebe, Things Fall Apart (London: Heinemann, $197 i$ [1958]). E. Amadi, The Concubine (London: Heinemann, 1978 [1966]). Idem, The Great Ponds (London: Heinemann, 1975 [1969]). B. Emecheta, The Bride Price (Douglas: Fontana, 1976). V.C. Ike, Toads for Supper (Douglas: Fontana, 1979 [1965]). W. Soyinka, Aké: The Years of Childhood (New lork: Aventura, 1983). 
to the ideal of villages as mcdels of social equality or of harmonious or warm family life (see also Guyer:1981). Domination resembling slavery, especially by the man over his wives and children, rather than consensus is the standard. A married woman can walk out on her husband only with the greatest of difficulties and has no say if he decides to marry another wife (cf. Achebe:1966,110). She carries the back-breaking burden of agricultural production while the man is in charge, sells the surplus, if any, controls the money and purchases what he deems fit. One exasperated observer suggests that

Africa's deepest ills are the ills of the African males. ... Men monopolize formal organizations from village councils to government ministries. Men are the forces of control but also of a lack control, of dissipation. Women are the creators, the sinews of both home and economy. It is the men who are wasting Africa's money on armaments and corruption and luxuries, the women who nurture the young, grow the subsistence crops, tend the houses, and make marhets work (filitgaard: 1990,166 ; see also Barker:1989,58).

Lnder such circumstances, the market - the forum where individuals take decisions for themselves as opposed to being taken for others by a patriarch in the family or by an autonomous state in the polity - can have profoundly liberating consequences. In a society in which status rests not on individual merit but on one's sex firstly and on one's place in a rigid matrix of privilege and patronage secondly, the market is in fact a significant democratic innovation which empowers the hitherto poverless. There is something positively egalitarian about the way money in a market society can erase other social distinctions, about a system in which anybody with cash can pur ihase in the market whatever goods he or she pleases without incurring personal 
obligations. Markets are about economic power and their abolition or retrenchment aggregates the power of numerous individual actors in the hands of only a fek. But markets are also about development. The stages of development processes are quite clear; what is open is only hon fast and how smoothly they are scaled, at what human and ecological cost, and at whose behest. The first stage covers the distance from a subsistence economy to a commodity economy or from production for the use of thr direct producer to production for the market. The evolution of a commolity economy is virtually synonymous with the expansion of Ihe markret and, indeed, "economic history can be boiled dorn to the mislete ecortoms, from its origins to its possible end" (Braudel:197i, 17). Thus, in al underdeveloped country where most of the resources, luman anl material, are still engaged in subsistence production, "even the nust plaming-minded government must start by encouraging the deveL.i mir.11l of all exchange economy as the chief method of mobilizing the resiure of the subsistence economy" (Myint:1973,143).

The marhet is both a mirror and a catalyst in the accelerating divicion of labour, the increasing specialization and differentiation of producers and their enhanced productivity. These interrelated rationalization processes are fuelled by escalating inputs of capital and accompanied by technological innovations which, historically, have culminated in industrialization. Industrial capitalism is thus an advanced phase of a process of economic development beginning with selfprovisioning before moving to small-scale production and exchange of commodities (cf. Chenery:1979). Unable or unwilling to see the market's catalytic and channeling role in economic development, the in- 
tuitively anti-capitalist Left usually decries the concentration of economic power in the hands of monopolies and the miserable working and living conditions of the exploited asses. As to the former (cartelization), this represents an instance of market-fajlure which can/should be redressed by the State; this market-intervention, to be sure, is to enforce market principles, not to overrule them. To argue in favour of state-ownership of enterprises, let alone outright socialism, out of fear of private monopolies is a classic case of throwing out the baby with the bathwater. As to the second point (immiseration), it is not only theoretically plausible but also empirically substantiated that market-oriented economies are more successful than étatiste or central1y planned ones in generating development, welfare (for all strata of society) and respect for human rights and civil freedoms. 18

Possibly because of an instinctive suspicion of the people's political maturity, powerful states are viewed benevolently, against overwhelming empirical evidence which would counsel caution. Max Weber in 1917 disparagingly commented about the trepidations of intellectuals

16 Not surprisingly, UNDP's Human Development Report which ranks countries on a "human freedom index" according to the degree of freedom their citizens enjoy, regularly provokes a storm of outrage anong any Third World governments (see Paul Lewis, "UN Index on Freedoa Enrages Third World," NYT, 23 June 1991, 11). This year's report indicates once more that all of the world's poorest countries have little freedon and that all the economically successful ones have high degree of individual freedom. The two notable exceptions are Costa Rica and Singapore, while the grey area in the middle is sizeable (UNDP:1991,20). The report concludes that "there seens to be a high correlation between hunan development and human freedom" (ibid.,21). The report's data also show, even though this is not made explicit, that high levels of huaan and economic development as well as of human freedom also positively correlate with capitalism. This is not to say that all capitalist countries do well in these aspects, only that all countries which do well are capitalist. 
concerning the freedoms involved in the developnent of private capitalista, namely

the fear of our literati that the political and social development wight bring us too much 'individualism' or 'denocracy' or other such-like things, and about their anticipation that 'true freedon' will light up only when the present 'anarchy' of economic production and the 'party machinations' of our parlianents will be abolished in favour of the pacifism of social impotence under the tutelage of the only really inescapable power: the bureaucracy in state and economy (Weber: 1978, 1403).

There is a fine irony in the fact that Weber's contempt was directed at the intellectual Right, clearly dominant in the first two decades of this century, while today it fits better the (far and especially academic) Left. Just as remarkable as this ideological groundshifting is the Left's selective blindness: the presumption of inevitalle market failure rarely extends to the potentiality of state failure which, in reality, is equally likely. The point is that the market and the state are bounded by each other and require each other's corrective influence to prevent an otherwise inevitable process of entrom. horthilile illustrations of this symbiotic relationship are the Asian success stories Singapore, South Korea and Taiwan whose energies, it should not be overlooked, were properly focussed by foreign menaces. It is rell possible that only existential external threats have the catalytic effect to temporarily suspend Lord Acton's rule of unchecked power concentration leading to corruption and wastefulness. The normal case, that is, state behaviour in the absence of foreign aggression is What the bureaucratic State is all about. 
Nigeria, thus, is not a capitalist, market-oriented but a bureaucratic, control-oriented mode of production. It, too, has an internal dynamic of its own which, however, is not as linear and directed as that of an ideal-typical capitalist system. I have argued that the disposition of the bureaucratic Nigerian State was determined by the distinctive historical experience of colonialism on the one hand and, on the other, by the internal dynamics of the post-independence institutional structures. My reasoning thus follows Weber in finding implausible the existence of laws of class strugg.e and, instead, viewing conflicts as being acted out under created laws and within the established institutional order of social domination. It follows that the fate of a state-dominated developing society is not preordained, even if confined to a rather narrow range of possibilities. While it might be able to grow before reaching a ceiling, sustained economic development seems beyond its scope. Politically, the bureaucratic Nigerian State is inherently unstable, in constant danger of being hijacked by an element of the state class which, if necessary by force, will assert its hegemony. This precariousness normally, not necessarily, prevents reforms since incumbents have, out of a sense of realism honed by experience, short-term agendas and a great reluctance to offend powerful groups, most of which are able to form hardy coalitions with other victims of reforms. Of course, the exact opposite is also possible, namely that incumbents use their pivotal power position to neutralize potential opponents and to transform the state and the economy. This is what General Murtala Mohamed started before his assassination and what General Ibrahim Babangida began with his structural adjustment program- 
mo. There are no clues in the bureaucratic mode of production regarding the direction of radical reforms: if they do take place, or the chances for their success. In a way, Babangida's reforms would have been more puzzling than the behaviour of his predecessors, had they been sustained and had their implementation lived up to their theoretical promise. Why would he, given the short-term conflict between developmental requirements and the political indigestibility of these requirements, refuse the easy way out and opt for the perilous path of reform? ${ }^{19}$ As it happens, he did not. Forced by a cash-flow crisis, his revisions were more in the category of dumping ballast, trimming sails and perhaps tacking. They did not amount to steering towards Soals different from those of his predec ssors.

19 This dilemma was suspensefully acted out also in the former Soviet lnion. Initially, Soriet President (then communist party leader) Gurbacher's spectacular reforms were an extraordinary example of farsighted policies, initiated and carried out by a member of a hegemcuic state class and directed primarily against itself. His backtracking in the autumn of 1990 must be viewed as the consequence of growing politi(a) opposition, mainly from the reactionary pillars of the bankrupt old order. Gorbachev's unceremonious dismissal in late 1991 could, possib$l y$, have been avoided had he acted more forcefully on the vision contained in his Economic Programme of 1990, astutely prefaced by the statement that there "is no alternative to the market. The whole world experience proved the vitality and efficiency of the market economy" (cited in the NYT, 17 Octoher 1990, A8). Having retreated from a market-oriented reform course fur a couple of months, President Gorbachev in June 1991 changed course once more, too late for him as it happened, and announced his commitment to more swiftly to a market economy. Valentin Falin, Director of Foreign iffairs in the Central Committee of the Soviet Communist Party and member of the Supreme Soviet, in a desperate rear-guard action, confirmed the new line: "The market existed before feudalism, and before capitalism, and it'1! survive after Communism, since man has thought up no better mechanism for the exchange of goods" (cited in the NYT, 16 June 1991, 8). 


\section{Concluding Sunnary}

In contradistinction to dependency, underdevelopment and world system analysts who locate development problems at the global level, that is, in the dynamics of internationally operating, predatory capitalism, I contend that a more appropriate focus is the State, the bureaucratic Nigerian state to be precise. For contemporary Nigeria, the international environment is certainly important, yet not so much because it determines the behaviour of the Nigerian State but rather because it limits it. The world market price for crude oil is beyond the influence of individual producing countries, yet without foreign customers and irrespective of their on socio-economic system, countries like Nigeria or most other OPEC members could not make any profitable use of their natural resource. In other words, there is no trade-off betheen selling abroad or using at home and whatever revenue is realized is net rent-income. Similar arguments obtain for the historical case of rigeria's trade in agricultural commodities. They did not divert resources from other, more profitable or developmentally more promising ventures, nor was there any coerced extraction. Qujte the opposite, the beginning of the colonial trade saw a dramatic increase in general production (including food crops), as well as in trade and welfare Which was slowed down only by the reduced demand as a result of the 1930 s depression.

Superficially, the colonial trade met the criterion of Paretooptimality: some were better off while nobody was worse off than before. What made colonialism, in hindsight, an economic albatross, ras 
not exploitation or piunder, but precisely the lack of exploitation. The colonial government protected the existing relations of production, especially the traditional land tenure system which ensured universal access to land and prevented its commodification and sale. Capitalist development which requires the separation of the direct producers from their means of production and, more significantly, their means of subsistence, was effectively forestalled. Economic expansion thus was limited to an extensification of production, rather than being the result of its intensification. What under colonialism might have been the result of a conservationist ideology (especially as the economy "worked" well enough for the purposes of the colonial government), after independrence turned into a policy of benign neglect. With oil-revenues replacing levies on agricultural exports as a government funding source, rural development lost all urgency, if indeed it ever had any. It was chealer land for those government officials directly involved more lucrative), more trouble-free and also beneficial for the State's legitimacy to import luxury food crops (North-American wheat and Asian ri(e) for urban consumption, rather than paying adequate prices to stimulate local production. In short, these and other purposive policies reflect concrete, identifiable interests, namely those of the Nigerian State. In or' $r$ of priority, therefore, the analytical focus properly has to be on it, rather than on such vague concepts as international capital, the metropolitan bourgeoisie or the capitalist world system. The bureaucratic Nigerian State is a specific order of domination and a concrete organization. It is not an arena for class struggle nor an impartial processor of societal demands. Its power base and its 
ruling element is the bureaucracy. Unlike the institutional form of legal-rational bureaucracy which is strictly rule-oriented, the bureaucratic Nigerian State is thoroughly patrimonialized and driven by power. The bureaucratic Nigerian State conditions and orders social life much more through its economic centrality than through its juridical rule-making function: it is the framer of the macroeconomic context, the most significant distributor of economic benefits and costs, the gatekeeper at various junctures in economic processes and the nominal guarantor of legal rationality; it is important as a supplier of inputs, as a direct producer and as controlling share-holder in many private enterprises. In other words, the state is not limited to regulating and maintaining a framework within which private activity takes place; its direct participation in the production process and its command over resources make it the most salient actor in the national economy.

The bureaucratic Nigerian state is the product of its historical genesis. It is a distinctive blend of, on the one hand, colonial paternalism, welfareism and mercantilism and, on the other, of the anticolonial agitation of the derivative middle class for whom the State, almost more than national sovereignty, was the prized trophy, the holy grail of its struggle. As such it was treated like a magic device with the inherent capacity to generate development, to employ everybody and to create wealth for all, once it had been conquered from the colonialists. The rent-income from oil which began to accrue in the mid-1960s and which increased dramatically in the 1970s did little to dispel this misconception. The British colonial government, by omission and com- 
mission, prevented the develcpment of a competent civil service as well as of an independent Nigerian business class. The notionalist niddle class which did materialize was itself the product of colonialism. Because of the preponderance of professional or clerical elements and the absence of a productive or comercial component, it was 10;sided and naturally interested in a state-led path to development. Its natural, temperamentally predetermined inclinations were soon amplified by tangible material interests. These, closely related to the state's monopoly over the instruments of economic extraction and those of political power, were vital in the transformation of the derivative middle class into the state class. This state class is not a class in the Marxist sense, or one half of a dialectical relationship of two antagonistic groups who are defined in terms of each other. Much rather, the state class is a status group, formed and socially dominant through its access to the State, and capable as well as intent on preserving its vested interests.

The bureaucratic Nigerian State's actions (and inactions) follow an identifiable political logic, namely that of a patrimonial ruler whose primary interest is the maintenance of his autonomy as well as of lis material base. With the state class substituting for a traditional ruler and the bureaucratic state neithe: legitimated by convention, nor endowed with a periodically renewed popular mandate, the bureaucratic State requires the support (or at least the acquiescence) of critically important groups and actors whose conflict potential is significant enough to either threaten the State's operation or to bestow legitimacy on it. Since legitimacy is thus very narrowly based, its pursuance and 
attainment is fully compatible with the state's being arbitrary, inefficient, wasteful and developmentally retarding.

The bureaucratic Nigerian State's political autonomy which to some extent is a function of its legitimacy, as well as the state class's property interests are best served by the economically interventionist and control-oriented policies of the patrimonial state which create dependencies and clientelist relationships between economic actors and the State. Control assumes the macro-management forms of politically determined exchange rates and tariffs or of property and managenent stipulations for private industry (indigenization, nationalization and Nigerianization). It can also assume the micro-management forms of direct participation in production and of administratively regulated access to foreign exchange and to import licences, both of which suggest that economic activity is seen more as a sinecure than as a way to create realth. Consequently, the State is neither very effective nor predictable but much more typically corrupt, erratic, spendthrift, overstaffed and intent on preventing the emergence of potentially threatening classes such as an autunomous bourgeoisie or capitalist farmers.

Nigeria is not capitalist. Commodity production and the antagonistic classes of accumulating capitalists on the one hand and of formally free labourers on the other are, if not marginal, then by no means dominant phenomena. The organizing logic of the Nigerian social order is the bureaucratic state and the bureaucratic node of production. The latter is a generic economic system just as the former is a generic order of domination. It refers to the state's resource in- 
dependence and the thus possible generic patterns of political organization and economic arrangements; having captured the oil rent in the 1970s, both evolve around managing it. The bureaucratic State does so with policies which follow its interests in legitimacy, autonony and property. Thus, the bureaucratic Nigerian State centrally appropriates the greatest share of the national economic surplus and allocates it, not according to market-derived rentability criteria, but politically. Rather than creating a macroeconomic framework conducive to general productivity improvements, guaranteeing the calculability nexus for private economic actors and utilizing the market's inherent developmental potential, ${ }^{20}$ the bureaucratic Nigerian State typically operates in a control and supply oriented fashion with artificially low consumer prices and subsidized factor inputs. Both varieties of actions permit the targeting of benefits and thus the strengthening of clientelist ties. While the market establishes costs according to criteria of scarcity, the bureaucratic State will price (and allocate) resources according to political criteria. Economic development and the bureaucratic mode of production are incompatible largely because actions determined by the bureaucratic Nigerian State's hegemonic self-interest are not only wasteful of resources but dislocating of productive incentive structures and paralyzing of individual initiative.

At the heart of the development problem in the bureaucratic mode

20 for instance to provide reliable information concerning consumer preferences and thus to permit the accurate costing of production factors and the optimal allocation of scarce resources; or to motivate econonic actors by rewarding the satisfaction of effective consumer demand and efficient production as well as, conversely, by sanctioning unappealing products and waste. 
of production is thus misplaced substantive rationality (i.e. the pursuit of state autonomy and legitimacy not as means to a socially useful end, but as ends in themselves, or rather, as stratagems in the service of the state class's property interests) which leads to poor governance. To be sure, poor governance here denotes sonething rather sore serious than flawed policy design, policy inconsistencies or substandard policy implementation owing to a poorly endowed state apparatus, bureaucratic incompetence or petty corruption. It is a profound misuse of public office for sectional benefits, the absence of a serious commonkeal orientation and, therefore, an egregious lack of commitment to pursue economic and human development honestly, energetically and patiently. Imperiled by this affliction of poor governance might be more than the chances of development. It bears the seeds of societal selfdestruction because the forces of redistribution (the gate-leepers, rent-seekers, profiteers and speculators) are threatening to overwhelm the forces of production, especially in agriculture, and to pre-empt the emergence of a worthwhile manufacturing sector. In contrast, capitalist economic development implies a different substantive rationality which requires public accountability, the rule of law, freedom of information as well as expression and the pursuit of efficiency; it reguires, in other words, a formally rational state which calculably administers public affairs and adjudicates conflicts, which is answerable to the public and which predictably takes regulatory and allocative decisions according to strictly economic standards. The bureaucratic mode of production is typified by economic decisions taken on the basis of political, patronage-oriented criteria which benefit not only the 
state class directly but also external loyalists while penalizing critics; for economic actors, staying in the good graces of the authorities is a more rewarding ambition than efficient production or consumer support. Official rhetoric notwithstanding, development is neither the primary goal of State policy, nor its effect. State power and the interests of the state class, not mass welfare or social change, constitute the central foci of state policy.

$A$ powerful instrument in the hands of the bureaucratic State is the regulation of domestic prices. Exchange and trade controls are, fur an oil exporting country with a narrow industrial base, particularly attractive - and dangerous, since the temptation of an overvalued f'change rate is hard to resist. An overvalued exchange rate is consumpr oriented (it increases the domestic currency's purchasing porer) aud, in effect, makes foreign goods - whether agricultural or manufactured - appear cheaper than they would be at a lower rate of exchange. As a result of this artificially created and maintained disequilibrium, domstic producers are disadvantaged by the subsidies implicitly conferred on foreign supplies. The State, as a consumer (and as an employer and a producer in its own right) is vitally interested in keeping factor prices low which suggests the desirability to import ostensibly cheap goods. Yet as a guardian of the nation's foreign reserves and of the emerging manufacturing sector, it must prevent the outward leakage of resources and provide protection against the harsh winds of foreign competition. Administrative trade regulations, as well as currency and price controls, seemingly allow the state to eat the cake and have it, too. 
By executive fiat, the bureaucratic State allocates foreign exchange, grants import licences and imposes tariffs; food prices (and rage levels) are contained through imports. In all these transactions, the State is the gatekeeper and provider, a role with its obvious attractions for the state class. The distortions resulting frow these types of state intervention lead, not to time-limited subsidies, but to permanent debilities: agriculture stagnates because subsidized imports keep domestic prices for both food crops and the traditional export crops low, and because inflation-protected urban wages exacerbate the rural-urban wage differential and render agricultural work unusually unattractive. Industry's stranglehold over a captive home-market shields it forever from the need to take on the challenges of international competition. The more entrenched it gets, the greater the difficulties become to withdraw the subsidies implied in protection. The playing field is not level, tilted against agriculture in favour of a hypertrophic public and a phlegmatic industrial sector (with capitalists, managers and workers sharing in the benefits).

The plausible argument that the inefficiencies of protection and subsidization constitute necessary and unavoidable tuition outlays during a finite start-up period, loses its conviction if it continues indefinitely and converts a learning fee into a rent and an acquired right. The bureaucratic State's direct participation in the economy, its overprotection and overregulation, all militate against the attainment of national productivity gains, the creation (as opposed to the mere distribution) of wealth, and therefore obstruct economic development. 
The Bureaucratic state and Economic Development in Nigeria by

Franz gaumann, Dip1. Verw. Wiss.

\author{
A thesis submitted to \\ the Faculty of Graduate Studies and Research \\ in partial fulfilment of \\ the requirements for the degree of \\ Doctor of Philosophy \\ Department of Political Science \\ Carleton University \\ Ottawa, Ontario \\ 25 March 1992 \\ c Copyright \\ 1992, Franz Baumann
}




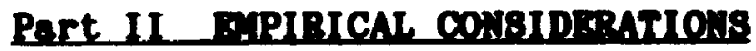

\section{The Genesin of the Burenucratic Nirerien state}

Nigeria's integration into the international econony had profound econonic, political and social consequences - as it did in other countries, whether colonizing or colonized ones. Contacts with the outside world, mostly Europe, grew over the centuries in scope and intensity, finally culminating in formal colonial rule. Independence, obtained after about half a century could not and did not provide a clean slate. Instead, the changes wrought and the structures created by colonialism as well as, very iuportantly, the aanner in which $\mathrm{Ni}-$ gerians reacted and adapted to these transfornations, together forned the building blocs for the edifice of the post-cnlonial state. Socioeconomic and political developments since independence can only be understood against this historical background. However, the purpose of this chapter, it should be emphasized, is not to provide a conprehensive or in depth historical analysis, but to present a backdrop painted with a broad brush - for the theory of the bureaucratic Nigerian state. What is attenpted, thus, is what could be called an ex post projection, that is, a process of reasoning backwards fron today, of distilling with hindsight out of a whole ocean of influences those factors which nost decisively determined the status quo.

Mostiy for reasons of econony, the pre-colonial period will be touched on only in the nost superficial nanner. This can be justified also on substantive grounds: the post-colonial state is the direct successor of the colonial state, not only chronologically but geographi- 
cally, politically, structurally and, arguably also to a considerable extent as far as its adninistrative and political leadership is concerned; no claim can or has been aade to trace it back to the precolonial polities of the territory of what is today Nigeria. While colonialism represented a significant political caseura, this was not the case in the econosic sphere. To the contrary, I will argue that under colonialise and because of its trade and infrastructural investment policies, the subsistence-oriented pre-colonial econony exparded along its natural growth pole. Without changing the existing forces or relations of production, output grew in reaction to external stinuli and contracted in response to external constraints. Production was inordinately diversified, the nornal unit of production beins not a plantation with wage or slave labour but individual sallholder peasants and their households. Revenue obtained fron the export of cash crops was largely spent on inported consuner goods which was not only the fastest, but under the circunstances also the natural way to satisfy consumer demands while serving the interest of the colonial government and the expatriate trading houses. These inports (as well as the exports which generated purchasing power) could be taxed with aininal adainistrative effort to raise government revenues since transfers fron the British treasury were anathena; at the sane time they were a neans to optimize capacity utilization for traders and shippers. The colonial government's main goal, besides keeping law and order, was to facilitate and increase the outflow of pribary products and the inflow of nanufactured products. This is to say that colonialise did not forcibly impose a certain econonic structure on Nigeria, yet it also did very 
little to encourage the country's econonic developent. ${ }^{1}$ Growth was achieved through additional inputs of labour and land rather than through modern tools, fertilizer and farming nethods (forces of production), or through the connercialization of land which would have created a landowning and a landless class and thus changed the relations of production. In short, the colonial Nigerian econong until the 1940 s corresponded to the ideal type of an "open econony" (cf. Hopkins: $1973,168 \mathrm{ff})$,

- as one with miniaal government intervention in the econony, except for the provision of infrastructures;

- in which the narket was the nechanisn to allocate resources, deternine scarcities and establish prices;

- whose growth potential was deterained by external denand for its primary products (and the prices they fetched); yet

- whose potential to diversify and industrialize was severely constrained by the easy availability of inported nanufactures.

I will briefly review Nigeria's recent past with the intention to point out her century-long voluntary involvenent in international trade and the resulting effects on her econonic structure. In an attenpt to refute the nyth of conservative and irrational peasants unwilling to

1 The concept of econonic development used here, it will be recalled, refers to the process of changing the structure of an econony, in particular to increasing per capita productivity so that ereater output is the result of greater efficiency rather than greater effort. 
change, attention will be drawn to the responsiveness and innovativeness of African cultivators faced with new narket opportunities and the phenomenal increase in agricultural production. Then I will denonstrate that in the econoni. sphere, the British colonial governnent initially played an 'enabling" role, trying to perpetuate, albeit at higher production levels, the existing trading relations. Politically, this minima: is was reflected in the systen of "indirect rule" which, given the management requiresents of an open econony as well as the human and financial resources available to the colonial government, was a singularly efficient institution even if, in the long tera, it seriously retarded economic and political development. Only in the afternath of the 1930s depression and, more vigorously after World War II, did the colonial state becone economically interventionist while, throughout, its policies, especially in the social and political spheres, were either regressive or defensive. My final point will be that the exergence of an internal opposition and the progranatic denands it adopted, strikingly reflected the colonial government's policies and prejudiced the nature of the post-colonial state. It is a painful irony that the economically interventionist policies introduced by the colonial government after the gecond World War by far exceeded its adainistrative capacity, taxed already to its linit by the highly politicized vent es of regionalization and Nigerianization. They were vigorously continued after independence, yet resulted wore in overextending the State and in entrenching its centrality in the econony (in purguance of the state class's vested interests) than in the latter's diversification or growth. 


\section{a) Pre-Colonial Developents}

The establishnent of Nigeria as a British colony in .14 did not by any means dearcate the beginning of relations between the people inhabiting I territory and the outside world. While the Northern parts of what is today Nigeria had carried on an intensive transSaharan trade with the Arab and the Old World as early as the twelfth century, the Southern parts of the territory had trans-atlantic trade relations with Europe since the fifteenth century (Niane:1984). In both cases a whole range of products was sold (nostly gold but also ivory, timber, gum, leather, spices and, of course, slaves) and bought (cloth, liquor, some manufactured utensilg including firearns, and salt). "Legitimate" comerce, although always confined to nonessentials and thus not a defining characteristic of African econonies, was never entirely replaced by the slave trade, even before it was officially banned in 1833. These pre-colonial contacts, devoid of any element of force (as far as trade was concerned) and exclusively comercial in nature, showed a considerable capacity on the parts of the indigenous producers to adapt to changes in denand in a aanner reseabling the classical econonists" concept of "Econonic Man".

It is significant that European traders did not until the late nineteenth century penetrate the interior but exchanged goods at coastal trading posts. In the case of both najor export products - gold first ${ }^{2}$ and slaves thereafter - Europeans were discouraged to cone on

2 Around the year 1500, Hest Africa was the source of about half of Europe's supply of $801 d$ (over 2 tons), three quarters of which was exported through the Sahara and the renainder by Portuguese traders via the Atlantic 
shore to protect trade secrets. As in East Africa where "African niners had long taken pains to ensure that Arab traders could never visit the aines, [in the West ...] they kept the Portuguese at a distance also" (Pacey:1990,70). The European traders' counterparts were African niddlenen who in turn bought export comodities fron primary producers (or warlords in the case of slaves) and sold to then European goods such as firearns, cloth, spirits and manufactured utensils. The principle guiding the relationship between European and African traders was the "credit" or "trust" systen (cf. Dike:1956, 103ff) which meant that they did not meet like enployer or enployee but, instead, as "two complenentary and more or less equal trading partners, whose nutual business interests were cenented by a nixture of goodwill and extensive credit obligations ... It was connon practice for Europeans to advance goods against deliveries either if [slaves or other comodities] were unavailable immediately, or to book supplies for the following season" (Hopkins:1973,108-109). Econouically, the slave trade did not differ fron that of other conmodities. It was ade possible by an alliance of two groups, European buyers and African suppliers, who colluded in the exploitation of the continent's weaker people. It lay in the nature of this trade that the distribution of benefits was a minus-sum gane. Although obviously benefitting sone Africans, the costs, not only in human suffering but also in terns of econoric and political dislocations were egregious.

sea route (Bovill:1968,106ff). 
Given the nature of the political systens in west Africa, it is not surprising that slave raiding - rather than the organization of a conercial sphere - was the preferred nethod to earn "foreign exchange."3 They were essentially nilitary aristocracies and as such oriented towards econonic extraction, not production; the dearth of products which could be traded for attractive European wares was inevitable. Under the circunstances, slaves becane the natural saleable conodity, also because they "had the additional advantage, in a land beset with transportation difficulties, of being the only connodity capable both of walking to the point of sale and of conveying sone other valuable commodity along the way" (Hart:1982,34). As to the nunbers of people taken from West Africa between the fifteenth and the nineteenth century, there is no consensus in the literature. Estinates range fron 5 or 6 million (Diké:1956,3) to 11 aillion (Lovejoy:1983,19) and finally to 30 million, of whon 15 million supposedly survived the passage across the Atlantic while another 15 nillion aight have perished in the process of capture and transfer (Hallett:1970,167). It bears enphasizing that the traditions of glavery and of gignificant intra-African slave trade preceded the advent on the scene of European buyers, nor did their disappearance lead to an end of slavery. Also, there is a strong current of opinion which considers it as inappropriate to view West African slavery as the coercive, oppressive and exploitative social institution which is commonly associated with the concept in wo-

3 Early in the nineteenth century, an African Chief described the trading systen succinctly: "We want three things, powder, ball and brandy, and we have three things to sell, cen, wonen and children" (cited in Burns:1972,230). 
dern Western discourse. Instead, it is sugsested that slavery hould be viewed as part of the "kinship idion" which neans "that slaves were in some sense fanily vembers, that their differentiation often was wuch or wore social as econonic [... and that they were] not working much harder or at tasks nuch different fron those of nonslaves" (Northrup: 1981,103-104; see also Law:1977,206ff). In this perspective both kinship and its variant slavery are symptons of a mode a production in which labour is the scarcest factor of production and as such is prone to be secured by means of coercion. Thus, in the traditional peasant economy of West Africa,

kinsmen, especially junior males and wonen, were often treated like slaves. The point is that social organization based on kinship does not conform to the ideal of warn family love that for many modern Americans is the standard. It can be consensual, if weaker nembers of the donestic group can walk out; and it can be a form of domination, in varying degree. Nor is slavery its antithesis, but rather a natural outgrowth of the expansion and developnent of kinship organization (Hart:1982,39).

Domestic slavery was geriously eroded only once the naterial base of a slaving econony was underained through innovations associated with colonialism: the expansion of trade and modern money as well as of western education. These had a liberating iapact on the lives of the weaker comunity members and conconitantly undernined the traditional order of domination. "The old men who had ruled in nost of these gerontocratic little societies were often left to sit outside their huts in otiose bewilderment" (Perham:1962,37).

The external aspect of slave trading is aignificant because, like with legitinate trade, assive deaand induced not only quantitative 
changes but qualitative ones (cf. Siddle and Swindell:1990,125). The conditions of "disunion, warfare and raiding in the interior at once facilitated the [slave] trade and were aggravated by it" (Perhan:1946, 2). Relevant for present purposes is the realization of an active adaptation to changing opportunities. In the case of the slave trade, an increase in the denand for slaves resulted in the reorientation of polities and econonies towards staging - or defending against - arauding canpaigns. The organizational requirenents of slave raiding and trading gave an outward orientation to what were previously largely subsistence econonies. It encouraged the expansion of sone states auch as Oyo or its tributary Dahoney and led to political and social changes. The hitherto rather diffuse power structure (cf. Lloyd:1954) of these and other slaving states becane concentrated: in Yoruba states, a patrimonial order of donination energed with an absolute ruler exercising power through personal retainers.

The case of Dahoney is quite representative. Here, a rather elaborate and hierarchical state organization developed, and degenerated, in tandew with the slave trade. "The King controlled appointments to office throughout his domain and could promote, dismiss or transfer officials. ... The standing arny and the ailitia were officered by men appointed by the ruler and dependent upon hiv for advancenent" (Colson: 1969,39). Since slaving became the deterninant of the prevailing node of production, raids through neighbouring territories were part of society's routines: "Annual wars were carried on as a national institution: first, for the supply of foreign trade; to analler extent for the refilling of royal plantations; last, but not least for the regular 
upkeep of half the nale population engaged in the canpaigns" (Polanyi: 1966,23). The King, through his retainers, intervened extensively in the econony. Slave trading was a state bonopoly, and a governor was installed at Whydah to ensure conpliance with state policies regarding prices and taxation (Hopkins:1973,107). Agrisultural production was regulated, taxes were collected fron all citizens, and sone redistribution of wealth in the interest of social equality was carried out (Polany i : 1966, 33-59).

In the coastal regions of the East, not patrimonial states doninated by an absolute nonarch, but a systen of "houses" energed. It consisted of a great number of horizontally unconnected units, headed by a wealthy merchant who enjoyed undisputed powers within his house and who was not foraally subordinate to a political overlord. In its full development the "House" becane at once a co-operative trading unit and a local government institution. As a rule, every trader of any inportance owned any slaves which had been bought or captured fron various tribes. These, along with the trader's fanily forned the nucleus of a "House" (Diké: 1956,34).

In both instances, (i.e. in Nigeria's Eastern and Western parts) econonic and political power rested in the hands of a relatively snall group of rulers or entrepreneurs. This engendered a trend towards social differentiation and increased econonic inequalities. Yet the slaving states' and entrepreneurs' political position was precarious. The nore lucrative the slave trade becane, the more the centralized Yoruba states were weakened by internecine struggles and external slaving raids. There is no question that the Oyo eopire's break-up - 
before the collapse of Dahoney's political order for lack of clients was principally caused by the desire of its provincial and tributary rulers to share in the profits of the slave trade (cf. Crowder:1980, 89). After the trans-Atlantic slave trade had finally ceased, the various warlords continued their arauding canpaigns for sone tine. The conversion fron slave trade to legitinate trade aight have reduced the denard for slaves as internationally tradeable connodities not, however, for their labour force as a donestic factor of production. Also, no one could be sure whether the Europeans' change of heart would last. Slaves were required not only to produce legitimate comodities, that is, to collect the wild paln fruits or to work the plantations, but also to carry then to the cosst (Lovejoy:1983,140ff). Yet, the nature of the legitianate trade, and of its produce increasingly weakened the traditional political organizations and widened the social base of external trade. Obviously, the slave trade had not occasioned the development of the wider West African econonies, even if the economic fallout proved far less damaging than the political one.

At the end of the slave trade in the aiddle of the nineteenth century, legitimate exports, besides being comparatively insignificant, were limited to unprocessed natural produce. Increased deand could be net by extending existing methods of production while leaving intact existing relations of production (i.e. slave labour and smallholder farming). Inports consisted of consuner goods (mostly liquor, dried and sacked fish, salt and textiles) which provided only few opportunities for investaent and econonic diversification in the local econouy. Finally, the lopsided distribution of incones, conbined with the rela- 
tively high costs of inports, prevented the energence of a nass narket based on cheap nanufactures. The developmental potential was thus rather slim; not that development in today's mense was on anybody's nind. None the less, a new era, lasting until the discovery of aineral oil in the 19508, began in the aid-nineteenth century. Legitinate connerce expanded rapidly. It entirely replaced slave trading and released anpower fros unproductive ailitary employent; it also set in train a process of intiately involving West Africa's econony in the expansion and trade cycles of Europe's new and industrial econony, flourishing in tiwes of its growth and contracting during recessions. The Nigerian economy's centre of gravity shifted to palv oil. Producing and selling palm oil, like the subsequently introduced staples groundnuts and cocoa, did not require investment capital since land was not scarce; it was communally owned and thus readily available for individual use (Forde:1946,46-47). "All the oil cane fron wild palns or gemi-cultivated trees growing in farmlands, in fallow bush or in conpoundlands in Southern Nigeria." Throughout this period [the nineteenth century], Nigeria was the sole exporter of pala oil and although a considerable proportion of the oil produced by the people was used for food, the country was able to neet the denand for pala oil by the industrial countries of Western Europe" (Udo: 1967,302).

The fact that pale oil could be produced on anall scale by households eaploying fanily labour and using traditional tools, anoun-

4 This has not changed in the century which followed and which saw Nigeria becone the world's largest exporter oil paln products: 90\% of the output of oil paln still cones fron sall seei-wild groves (World Bank: 1974, 77-78). 
ted to an effective absence of barriers of entry and, over time, awitched econonic power away from an oligarchy of powerful warlords and entrepreneurs who had benefitted fron the slave trade (and the enploynent of slaves) towards a broad base of snall scale farners and traders (Crowder: 1981,7ff). These did not produce inpassively, or in reaponse to benevolent advice, let alone coercion, by colonial officials. Quite the opposite, they displayed a considerable responsiveness to monetary incentives, nade use of new opportunities and in sone areas achieved astonishing progress (Green and Hyeer:1966). Iupressive examples are the introduction fron Central Anerica in the late nineteenth century of cocoa by West Coast faraers (Hill:1963,170ff; Gann and Duignan:1970a, 308 ) and of groundnuts by Hausa traders (Hogendorn:1970,30ff; Wilson: 1977, 207). Maize and cassava had been introduced fron the Anericas by the Portuguese in the 16th century; they were adapted very quickly and became essential staples (Law:1977,203). Existing econonic and political structures were reshaped from below and with sone outside assistance: the actual abolition of slavery in Nigeria occurred gradually up to 1921 (Agiri:1981,142ff), having begun with the establiahnent of Lagos Colony in 1861 which becane a safe haven for eacaped slaves. The general ostracisa of slavery then moved in tanden with the gradual establishment of effective colonial rule after 1900; the earlier key date, the 1885 Berlin Conference, had only instituted formal diplonatic rule over auch of the continent and not led to significant politico-adninistrative action. The socio-econonic consequence of this nove was well appreciated by the colonial governnent, as was confirned by Sir Ralph Moor, the High Connissioner for Southern Nigeria (1900-1904) who wrote 
to the Colonial Office in 1901: "Doing away with slavery is revolutionising the entire econonic conditions of the country" (cited in Saith: $1979,44) .^{5}$ As could be expected, with the expandins trade traditional power bases were further underwined, a procese sreatly accelerated by two consequential innovations in the econonic sphere, both of which assioted in the expansion and differentiation of the arket: the steanship and wodern money.

The steanship, introduced in the 18508 , was cheaper per ton/aile than sailing ships and could carry nore cargo. As it was also faster reducing the voyage fron thirty-five to under twenty-one days - as well as more reliable, it pernitted the introduction of scheduled services between Europe and West Africa (De Gregori:1969,161ff; Headrick:1981, 129ff). This upgrade in technology led to a wider range of traded conaodities, to diversification and to increased competition at both the European and the African end of business (McPhee:1971,72-73). According to a director of the African Steanship Company, after the introduction of regular service in 1852 the number of firms in the West African trade increased from "very few [to] upwards of 200 in 1856" (cited in Diké:1956,115). Shipping and trading - differentiated again between import and export operations - becane separate activities and established firas were less able than before, when they also monopoli-

5 Sir Ralph Moore's insight reflected, of course, Adan Snith's counterintujtive and therefore revolutionary contention that "the work done by slaves, though it appears to cost only their naintenance, is in the end the dearest of any [... because a slave] can have no other intereat but to eat as auch, and to labour as little as possible" (Seith:1974,488). Sigilarly Karl Kautsky who contended that the slave or serf "are the nost inefficient of all the possible forms of production. The alave ill-treats his anter's cattle and can only be entrusted with the clunsiest of tools" (Kautsky:1931,37). 
zed shipping space, to saintain control over access to the narket by other Derchants, European and African. Occurring at a tiae of general trade expansion, "the newconers tended to ewanp the nonopolistic firas and the result was a savage trade war" (Dike:loc. cit.).

European silver coins appeared in Hausaland in the second quarter of the eighteenth and in Accra and Lagos in the first half of the nineteenth century (Johnson:1970,335), despite the fact that, Initially, neither the wetropolitan or colonial governments, nor the large trading houses had any interest in the proliferation of noney. The former because of the "dislike of the British Treasury of this large drain of British currency to West Africa" (Hawkins:1958,345). The latter because it was nore expensive for then to introduce official British currency rather than the special coins ainted in Birwinghan (Ofonagoro: 1976,8; Smith:1979,47). "Real" money as a mediun of exchange was also much less advantageous than barter trade with wares which were cheaply manufactured especially for the Weat African market.

The logic behind the inforaal sector's initial and spontaneous importation of money becomes clear if the various parties' interests are considered. Money, in contrast to barter trade or personalized voucher systems, helped to increase the number and variety of possible transactions and thus strengthened the position of African producers and traders vis-a-vis European nerchants and African rulers alike. By expanding the exchange econony, woney dissolved the ties which had traditionally linked African producers and traders to, on the one hand, the foreign firv which previously had exchanged African produce for European wares and, on the other, to the traditional chief who, as the 
Europeans' counterparts, had exercised control over export sales and over the distribution of foreign trade earnings. It is rearkable that this innovation, which benefitted a large nuaber of traders and faraers, was introduced against an unholy alliance coneisting of all powerful interests: British traders, Colonial governeent and local rulers." As a result of fiscal constraints inposed by the netropolitan sovernment, its colonial sub-branch was the first to break ranks and to recognize the instrunental value of money for its own purposes, nanely as a source of revenue to offset its adsinistrative costs. In 1887, custons duties - half payable in cash, half in kind - were inposed in Lagos Crown Colony (Hawkins: 1958,346).?

These innovations triggered considerable econonic srowth, yet until 1886 - the year the Royal Niger Company was chartered and proceeded to penetrate the hinterland - the export and inport aarkets were still

6 Poly Hill reports that in February 1888, one of the spokesen for Ghanaian export farners asked Governor sir Willia Brandford Griffith if he could "instruct the aerchants of Adda to pay in cash instead of in $g$ in for palm-oil." The Governor apparently replied that "the natter was one between the buyer and the seller and that they had the reaedy in their own hands" (cited in Hill:1963,166).

7 The gradual adoption of the colonial currency was obviously facilitated by the development of trade, taxation and wase labour. In 1917 the Native Currency Repeal Ordinance was passed, finally denonetising brass rods, cowrie shells and aanillas (McPhee:1971,238). In sone parts of Igboland, cowries were used until the $1950 \mathrm{~s}$ to pay the bride-price, a custon that eventually fell victiv to two aspects of nodernity: the expanded product range available in a cash econony and thus the devaluation of sall-denonination units of account, as well as price rises as a reflection of excess denand: "In the late forties, it was no longer possible to find a wife for less than a bride-price of $£ 15(432,000$ cowries), and there were nuwerous cases where parents insisted on $\$ 20$ (576,000 cowries), and even $\$ 25(700,000$ cowries), for the han 1 of daughter in marriage. These staggering suns required the services of 15 porters, and the customary unpaid labour of kinswen was no longer as readily available as it had once been" (Ofonagoro:1976,16-17). 
confined to a few cosstal enclaves in the Niger Delta and at Lagos. Additional cost-reducing or efficiency enhancing neasures were not possible within the existing geographic and, inportantly, political franework. A range of obstacles, fron the European nerchants' permpective, had to be overcome and the metropolitan State was the natural agent of change. Market expansion required the inposition of law and order, that is, the ternination of internecine struggles, mostly in Yorubaland (Robinson et al:1968,387ff) which threatened the supply of produce and the distribution of manufactured goods. Related inpedinents, again from a European point of view, were the untrameled competition by African middlemen which had developed in the paln oil trades fron the 1870s as a result of declining commodity prices (Munro:1984,16), the internal tolls levied by African states (Ekundare:1973,53-54), and the underdeveloped internal transport systes.

As there was no wheeled traffic [this transportation aystea consisted of] canels and donkeys [in the North], but further south, owing to the prevalence of the tsetse fly, aninal transport was out of the question, and where canoes could not be used, everything had to be carried on the heads of wen [... over] narrow tracks which did not pernit of two men walking abreast were a sufficient substitute for roads (Burns:1972,282; see also Law: 1977, 208).

Internal free trade with aininal unproductive overhead costs was important for the classical reasons of increasing the volune of produce on of fer and of ensuring that export crops were delivered to the coast as cheaply as possible. It was a necessary condition, yet not a sufficient one. The latter was the construction of railways, the "White Hope of the nineteenth century [which] was thought to be capable of 
transforming the economies of West Africa, just as it had those of Europe" (Hopkins:1973,156). ${ }^{8}$

It is not crucial in the present context whether the European, especially British, colonial activism in the $1880 \mathrm{~s}$ was deterained primarily by

- intra-European balance of power considerations (Gall:1990, $019 f f)$;

- purely economic reasons internal to the metropolis, such as the search for raw naterials (Wells:1923,989ff), the inperative necessity of outside arkets for the realization of surplus value (Luxemburg: $1963,350-367$ ), or the tendentially falling rate of profit (Lenin: $1964,213 \mathrm{ff}$ );

- conomic in arests in conbination with econosically irrational notives of national power and national myth (Schumpeter:1969,22 and 65; Perham: 1962,136$)$;

or predominantly by

- factors on the ground in (West) Africa (Flint:1969,224ff; Robinson: $1972,117 \mathrm{f})$.

Of greater iaport than the reason why Britain intervened is the manner how colonial rule was exercised and what effect this had on

8 Reviewing the dranatic econonic developents in nineteenth century Europe, Max Weber contended that the "railway is the nost revolutionary instrumentality known to history, for econonic life in general and not nerely for comerce" (Weber: 1966,221). 
Nigeria.

\section{b) Politice during the Coloniel Period}

Actual British rule was established either by ailitary defeat of African states (e.g. Egbaland a.k.a. Abeokuta, Ilorin, Oyo and the Sokoto Caliphate with its various tributaries) or by treaties (e.g. Bonny, Gandu Emirate, Lagos, Oil Rivers, Opobo), in which the African rulers, recognising the superiority of British ailitary power, consented to the imposition of British authority (Flint:1969; Snith:1979). This rather undranatic process began in 1861 when the island of Lagos was declared a Crown Colony. In 1885, following the aigning of a nunber of treaties between local rulers and British officers, the Niger Delta area was proclained the 0il Rivers Protectorate. It was extended inland in 1893 when it.s nane was changed to Niger Coast Protectorate. The Berlin Conference of 1885 had acknowledged British clains to the Niger Basin, and Britain in 1886 oave the Royal Niger Conpany power "to administer, ake treaties, levy custons and trade in all territories in the tasin of the Niger and its affluents" (Coleaan:1965,41). Until 1900, thus, the territory of what is today Nigeria was adainistered by three different authorities: the British Foreign office (Niger Coast Protectorate), the British Colonial Office (Lagos Crown Colony) and the Royal Niger Company (Niger Territories). ${ }^{9}$ On 1 January 1900, the Bri-

9 These, in reality, did not extent far beyond the banks of the River Niger. The depth of the Northern region, in particular the enirates Bornu, Kano, Katsina, Maiduguri, Sokoto, Zaria, etc. were penetrated and brought 
tish government consolidated these rather anarchic arrangenents by transferring all responsibilities to the Colonial Office: the Foreign Office's mandate over Southern Nigeria was ended, the Royal Niger Conpany's charter was revoked and, in its place, the Protectorate of Northern Nigeria was proclained (Jeffries:1938,10 15).10 Stil:, froa 1900 to 1914, there were de facto three (after 1906 two) Nigerias, "each dealing directly with London and each, because of difficulties of comunication, acting as independently as its respective chief administrator saw fit" (Okigbo:1989,5). In 1906, Lagos colony was nerged with the Protectorate of Southern Nigeria to forn the Colony and Protectorate of Southern Nigeria; this reduced Nigeria fron three to two adninistrative zones. Finally in 1914 and under the force of econonic circumstances - the North was running chronic budgetary deficit which the British government had to cover while the South was running a surplus the two administrations were aerged to form a single territorial unit known as Nigeria (Lugard:1968; see also Adedeji:1969,27).

The ex post ideological justification for British colonialisa in Africa was the "oission civilatrice" as expressed in Lord Lugard's Dual Mandate in British Tropical Africa, published in 1922, shortly after

under British control only through the ailitary canpaigns conducted by Sir Frederick Lugard in the subsequent years.

10 The parlianentary vote on the acquisition of Northern Nigeria in ,uly 1899 was carried by a solid yet not overwheluing margin: 181 to 81 votes. "These debates show Britain in the act of adding a great new province to her empire at a cost ... of less than three-quarters of aillion pounds, and yet aany of the country's representatives passed the neasure grubbling and grudging every penny. ... Although this is generally characterized as a tine when the imperialist spirit was at its height, we find throughout the debates hardly one word of satisfaction and not one of enthusiass for this large act of imperial expansion" (Perhan: 1960,14). 
his retirenent as governor of Nigeria. The dual nandate consisted of the twin responsibilities which an ieperial power had - to the African peoples it ruled on the one hand, and to the outside world on the other. The colonial power was to suide its African subjects toward material and moral progress (Lugard:1965,613) and to ensure, for the benefit of the rest of the world, that the natural resources of the colonies were exploited, instead of laying "wasted and ungarnered in Africa because the natives did not know their value" (ibid.,615). Of course, all of this was to be achieved without burdening the British treasury, a maxin spelled out by Earl Grey, the aid-nineteenth century Secretary of state for the Colonial Departaent:

the surest test of the soundness of measures for the inprovenent of an uncivilized people, is that they should be self-supporting; and great advantage arises from throwing those who are to carry plans of this kind into effect upon their own resources. The people also, for whose binefit such measures are attempted, are rendered more sensible of their value when the pecuniary neans required for their adoption are furnished by themselves (Grey:1853, vol2, 281).

This meant that governeent expenditures were covered by direct or indirect taxes and, later but only to cover capital expenditures, by loans subscribed to by investors overseas. Not even the colonial sovernment and its expatriate officers were innune. In the depression of the 1920 s and 19308 , recruitment was severely curtailed, a pay cut introduced and salaries frozen fron 1923 until 1936 (Jeffries:1938,34).

In practice the colonial government's policies were rather pragnatic - one connentator speaks of the "essentially nakeshift character of West African colonialise" (Phillips:1989,156): they ained at ba- 
lance between the need to raise enough revenue to keep the colony selffinancing and the overriding goal of maintaining law and order while nininally interfering with the natives' life except, perhaps, to heed Governor Cameron's counsel that "no opportunity should be lost for gentle instruction of the native, whether he be chief or peasant" (Caneron: 1965,218 ). However, his advice was more a conponent of the law and order strategy than signalling the colonial government's intent to pursue forceful education policies. Hampered by financial constraints, by an anti-interventionist ideology and by the cultural differences between the Muslia North which had remained untouched by Western influences and the South where aissionaries had been active for decades, it would not be before the $1930 \mathrm{~s}$, and then only spuriously, that energies and funds would be devoted to education. ${ }^{11}$ In keeping with its conservationist (rather than developmentalist) cun laissez faire (rather than interventionist) econonic policies, the colonial governnent did not object to missionaries providing the bulk of the education services; by 1920, for every one of the 160 government operated schools, there were 10 aission schools (Colonial office, Annual Report 1920, cited in Taylor: 1984,194$)$.

The de facto purpose (and effect) of British occupation was econouic expansion, both to of fset the cost of the newly established colonial governnent structure as well as to ensure the provision of primary

11 In 1935, total governuent expenditure was $85,757,180$ of which 8229,057 or under 4x were for education (Hailey:1938,1309). With a poplation of about 19 aillion (ibid.,108), School enrolnent was 416,184 pupils, of whon 80,511 were in government schools, compared with 199,374 in Koran schools and 136,299 in Christian nissionary schools, both unassisted by the governaent (ibid., $1309)$. 
produce needed in Britain and, to a lesser extent, the srowth of narkets for her sanufactured goods. Sone policies were, almost inadvertently, positive stinuli to econonic srowth. The search for government revenue, for exanple, led to an enlargement of the exchange econony, thus creating one of the indispensable preconditions for econonic growth. Yet, as conscientious policy, at least until the 1940s, the colonial governeent enphatically did not pursue the development of the Nigerian econony, if developnent is understood to inply changes in the forces and relations of production as opposed to purely quantitative growth. The positive relationship between political stability and economic development was well appreciated, and the forner clearly enjoyed higher priority. In this connection, it should be borne in aind that development as a transitive and conprehensive concept applied to the Third World is a rather recent phenonenon, not just in Africa but anywhere: "As a major interest of Western governments, of econonists, and of public opinion generally, [it] was born during World War II" (Arndt: $1987,43)$.

The first Colonial Development Act, passed by the Labour Government in 1929 was sonewhat of a visnoner. It established a fund of $\& 1$ allion for all colonies which could apply for grants and loans for assistance which involved expenditures in the United Kingdon, rather than in the colonies (Okigbo:1989,15). The 1940 "Developnent and Helfare Act" whose purpose was to pronote "the social betternent of the colonies" did, because of the war, never get off the ground. Yet, the trusteeship concept it expressed, was in the next few years nodified into "connitaent to the modernisation of colcnial society achieved 
through 'partnership' and resulting in self-government" (Lee Petter: 1982,149). Thus, al ready the Conservative governnent, in the waning months of the Second World War, issued a statenent which confiraed that, after "the war is over, one of our first duties will be to fulfil our pronise to guide the sixty aillion inhabitants of our colonial territories - now at the nost critical stage of their history - along the road to self-government within the British Empire" (cited in Jeffries: $1972,34)$. Shortly thereafter, with Labour once more in power, the British governuent's colonial policy was decisively reversed: selfgovernment was confirmed and a welfare component added to the State's responsibility. Its new purpose, as outlined by the Labour Secretary of State for the Colonies, Arthur Creech-Jones, was "to suide the colonial territories to responsible self-government within the connonwealth in conditions that ensure to the people both a fair standard of living and freedom from oppression from any quarter" (cited in Kinble:1960a, 233).

Originally, the colonial governnent's intervention in the Nigerian econony was linited and tightly focused on the key rationale of colonization, the exportation of pripary produce. A subsidiary consideration was the dual mandate's conservationist undercurrent, nanely the conaitment to protect the natives and their land fron inappropriate modern influences, be they British interference in local courts, ${ }^{12}$ in-

12 For instance, inediately after colonisation, aative courts, presided over by British political officer, were set up in Nigeria's East and Nest. After analganation, Lugard "and his 'northern officers' fulninated against the southern Nigeria courts systen. They condeaned the subjection of the native courts to the suprene court on the grounds that it tended to introduce into the former European legal procedure. They condenned the sitting of Europeans in the native courts as destructive of the true native nature of these courts. 
dustrialization or capitalist exploitation (cf. McPhee:1971,196; Udo: 1964,301). The sase concern prevented the colonial government fron using conpulsory labour; this, however, did not inply preventing the Native Authorities fron resorting to it - only to insist that all labour rendered had to be duly paid - at least until 1933 when the Forced Labour Ordinance Act was pronulgated which banned it altogether (Crowder:1970,45; Hailey:1938,619). Governor Lugard's concern was not that of a naverick but, on the contrary, epitonized the spirit of the age. It was in full accordance with the ideological predisposition of the British colonial officers who, because of their "noral or religious criticism of materialisn, and upper niddle class snobbery towards trade and manufactures" (Wilson:1965,196), viewed econonic development with ambivalence, and traders, European or otherwise, with condescension. To generate revenue, trade was welconed, yet not enthusiastically and only within strict linits: "it should not be allowed to harn the natives, should be carried on by 'reputable' traders, and nust above all conform to administrative norms of tidiness" (Ehrlich:1973,651). Consequently, colonial rule was not to be a political enterprise in the sense of authoritative value-allocation as the result of negotiated conpromises between organized groups. The colonial adninistration initially pursued ainiaalist goals (revenue and stability), so that governeent, as far as it involved the native population, to a large extent meant local adoinistration. Therefore, the politicoadeinistrative systen created in the colony, "indirect rule," was

Consequently the Native Courts Ordinance of 1914 established a unifora systea for Nigeria based on the northern pattern" (Ikine:1968,423). 
conservative in intent and oriented predowinantly towards the maintenance of law and order. Indeed, a case can be aade that the colonial government, possibly reflecting the then current Darwinian notions of racial and cultural superiority or inferiority, fell victio to ragreasive tendencies which conpared nost unfavourably with the nodus vivendi as it had developed between Europeans and Africans in the nineteenth century. Unthinkable severs.l decades later, the Reverend sanuel Crowther, a freed slave, was, in 1864, consecrated Anglican "Bishop in charge of the Niger Diocese - in charge, that is, of both black and white aissionaries in the area" (Ndoku:1976,99; on a related point see Kaplow: 1977,323 ). Also, one of the prominent and successful Yoruba farmers, an Angljcan layman, was "narried to Queen Victoria's godchild" (Webster: 1963,421).

After colonialisa had been formally imposed, the westernized indigenous elite, a product of aissionary education and the nore liberal policies of the nineteenth century, was systeatically disinherited and preference was given to local rulers who nore readily corresponded to the colonial officers' normative image. Tellingly, they were neither encouraged to speak English nor to assigilate in other ways (Crowder: 1981,198ff). Thus, whereas in 1875 in Lagos, "the head of police, the head of the posts and telegraphs, head of custons, and the regisirar of the Supreae Court were all Nigerians" (Ajayi:1962,24), until the last decade or so of colonial rule, Nigerians were relegated to subordinate positions. This turn of event is a particularly sad irony because "the only people who on the eve of the scramble for Africa possessed a sense of a British 'inperial nission' were the educated or seni-educated 
Africans" (Flint:1969,222) who hoped for their society to be rescued from stultifying backwardness by outside intervention.

Governor Lugard, the archetypal representative of the "new" thinking of benevolent if condescending paternalisa, contended that "the African Negro lacks power of organization and is conspicuously deficient in the managenent and control alike of wen or of business" (Lugard:1965,69-70). He was particularly weary of educated Nigerians, troublemakers who, entirely unacceptably, demanded equality of treatment from the British adninistrators with whon they of ten clashed. ${ }^{13}$ Naturally, natives' assertively voicing their own demands, rather than meekly waiting for whatever the colonial government deemed fit to grant, went against the grain of the whole (British) spirit of colonization, that is, the White Man's Burden and, by inplication, undisputed British superiority. ${ }^{14}$ In practical terms it entailed the obligation

13 In 1912 , in a letter to his wife, written within days of his assuning the combined governorship of Northern and Southern Nigeria - fron 1900-1906 he had been High Commissioner in Northern Nigeria and from 1907-1912 Governor of Hong Kong - Lugard confessed to be "sonewhat baffled as to how to get into touch with the educated native. ... To start with, I an not in synpathy with him. His loud and arrogant conceit are distasteful to ne, the lack of natural dignity and courtesy antagonize me" (cited in Perhan:1960,586). What follows is equally instructive: "Nor do $I$ find it any easier to get on with the European agents of Liverpool merchants" (loc. cit.). Lugard went as far as to suggest that the "Europeanized African differs not merely in mental outlook from the other groups, but also in physique. Doctors and dentists tell us that he has becone less fertile, nore susceptible to lung-trouble and to other diseases, and to defective dentition - disabilities which have probably arisen from inbreeding among a very linited class, and to the adoption of European dress, which writers in the native press say is enervating and ininical to the health of the African" (Lugard: 1965, 79-80).

14 The French had a rather different idea, far less patronizing and eager to share France's cultural achievenent with its citizens who happened to live overseas and be black. It was not an isclated or outrageous incident, nor a denonstrative act for public consunption when, in 1945, a thirty-nine year old African and elected representative to the French Constituent, Léopold Sédar Senghor, was chosen to oversee the gramar and style of the newly drafted Con- 
to defend the natives' interests - even against thenselves - and therefore to maintain the colonial government's political monopoly and benevolent authoritarianisn. A symptonatic example for the irritations generated by inpetuous westernized intellectuals was the denand in 1936 of a group calling itself the Society of Union and Progress to fill a vacant chieftainship in Yorubaland's Egba Division (Abeokuta) with an educated man. The British Resident addressed the Native Authority Council:

Now I ask those gentlemen who, in this connection style themselves 'literate' what they nean. A literate person is one who knows to read and write; he nay not be a man of high character, he nay be, and often is, the grestest scoundrel inaginable, he nay be feeble ainded and utterly useless. Anyone can learn to drive a lorry or a train, there is no special virtue in the mere fact that he can drive a pen, a motor or a train. ... If this [the literates" snobbish feeling of superiority] is 80 , it is an insult to the large and inarticulate ass of illiterate people ... which they may quite justifiably resent (cited in Post:1970,3738 ).

Lugard's overbearing authoritarianisa was neither reserved for the black intelligentsia, nor was it typical for his successors, sone of whon were remarkably liberal and farsighted. Value judgenents about historical figures are inordinately tricky and, even though $I$ an aking one, I an fully aware of its tenuousness. Also borne in aind has to be the differences between the several governors who served during the distinctive phases of Nigeria's history as a colony; obviously, their tasks of consolidation and development denanded different qualities

stitution of the Fourth Republic (cf. Vaillant:1990,204). 
than were initially required. ${ }^{15}$ Governors' personalities eattered greatly because their "authority under the Queen and her Secretary of State to make and execute laws was cooplete, untranneled by even so wuch as the aininum control of an executive council of officials" (Perhan: 1960,23) and circunscribed only by the pervasive scarcity of funds. Internal political control was entirely absent, as the traditional chiefs had only local executive functions and no national decisionmaking let alone legislative authority. External political control by the British Parliament was not gore than rudinentary.

Debates on the colonies were interesting only to those who took the trouble to keep thenselves inforned ... Until 1950 when the Conservative opposition changed the day, the annual debate on the colonial estimates in the Comittee of Supply tended to coincide with the rival attraction of the Buckinghan Palace Garden Party, but even after the war nenbers continued to remark on the poor attendance when colonial questions were up for debate (Lee:1967,60).

Under the circunstances, each gubernatorial incunbent could inpress his personal style on his tenure. Significantly depending on his preference and style, British colonialisa in Nigeria was far from an innutable phenonenon with no variations over tiae and of ten enough, projects "were a response not to a global assessnent of the needs of

15 Sir (later Lord) Frederick Lugard served as Governor of the two not yet amalganated Protectorates of Northern and Southern Nigeria fron 1912-1914 and as Governor of Nigeria fron 1914-1919. His successors were Sir Hugh clifford (1919-1925), Sir Graene Thongen (1925-1931), Sir Donald Caneron (1931-1935), Sir Bernard Bourdillon (1935-1943), Sir Arthur Richarde (19431948), Sir John Macpherson (1948-1954). In 1954 the title changed to Governor-General; the two pre-independence incuabents were Sir John Macpherson (1954) and Sir Jases Robertson (1954-1960). Dr. Nnandi Azikiwe becase the first and only post-independence Governor-General (1960-1963). After Niseria's constitutional forn was changed to a Republic, he becane the country's first President. 
the country but to ... particular whins and predilections of the Governor on the spot" (Okigbo:1989,11).16 Politically, the most significant atations took place in the sanner in which the principle of "indirect rule" was carried out or, nore generally, in which the conflict between two contradictory nodes of governance was resolved: between the rather static mode of indirect rule through the chiefs on the one hand and, one the other, the vision of ultinate control held out to the westernized elite by the pronise of eventual self-government (cf. Colenan:1965, $160 \mathrm{ff})$. Until after the Second World War, all governors' nolens volens gave priority to indirect rule, a static and increasingly anachronistic concept. In 1936, an insider turned critic charged that it was "not possible to put one's finger on a single contribution or new idea or new development in the adninistration of the policy of Indirect Rule in Nigeria since Lugard's time" (Crocker: 1936,216).

Politically, law, order and stability were the colonial government's central concerns and the traditional chiefs for, if not traditional, then at least native) seened, given the prevailing financial

16 For exanple, Lugard held that "the native is core profitably enployed in growing and collecting raw naterials for export" (cited in Saith:1979,46) than in processing thea. He sought to reinforce this ostensible econonic advantage by imposing tolls on native nanufactures and by exenpting inports; this policy was reversed by his successor. Other, nore whinsical idiosyncracies of his led Lugard's adninistration to pursue sone rather wild fancies such as an ostrich culture, beekeeping, the donestication of zebras and the breeding of zebroid aules (Nicolson:1969,195-196). Colonial practice was both nore bizarre and mundane than inaginable to self-stgled radicals who eschew historical analysis in favour of enpty rhetoric. A typical exanple is the trite non sequitur that in "the absence of a coherent, progressive colonial policy, colonial rule cannot be said to have had a unifora iapact on Nigeria" (Graf:1988,8). As if "progressiveness," however this enpty formula is defined, would have anything to do, logically, with the uniforaity of colonialisa's iepact. 
constraints, the natural executive agents. They "took the strain of indirect rule, breaking down, like hunan transforners, the powerful current from above and distributing it in voltages that their own people could take" (Perhan:1962,143). Indirect Rule was, then, "the practice of accepting the local governing situation upon condition that local rulers in turn accepted British overlordship" (Davidson:1981,93). Turning weakness into virtue, it was claised that the British were not so much ruling, directly or indirtetly; the situation, in the words of Lord Harlech (earlier W. Orasby Gore), Secretary of State for the Colonies from 1936-1938, "should nore properly be described as native local self-government" (cited in Jeffries:1938,133). It neant that Nigerians were, as before, governed through their traditional for, in any event, indigenous) political institutions, although these were revised to exclude all incongruities with British concepts of civiliged behaviour (in the North) and to permit the introduction of direct taxes (in the East and West). Of course, the Chiefs had no policy-aaking function, even if care was taken to prevent the (largely accurate) iapression that they were incorporated as subalterns into the colonial adainistrative hierarchy. Lugard explained with more than a touch of windowdressing: "the essential feature of the gysten is that the native chiefs are constituted as an integral part of the machinery of adainistration. There are not two sets of rulers - Britigh and native - working either separately or in co-operation, but aingle Governnent in which the native chiefs have well defined duties and an acknowledged status equal with the British officials" (Lugard:1965,198).

In this division of labour, the probleas of local governaent (and 
only they) fell to the native chiefs, even if the official and oft repeated position was that "the ultinate future of the Colonial connunities lies less with the adoinistrator, however efficient and well disposed, than with those comunities thenselves. $1 .$. Therefore, the coIonial government adheres to] the dictum that 'good governnent is not a substitute for self-government" (Jeffries:1938,236). Thus mininizing the officially admitted role and function of the colonial government had an invaluably immunizing quality since it pernitted the easy deflection of claims for participation and of criticisms of overall performance. In the context of tìe colonial government's raison d'être, indirect Rule was thus a pragmatic solution recomended by the specific mission to be accomplished, by lack of staff, and by a shortage of funds (cf. Cameron:1965,197). Indeed, the scarcity of resources, itself to a considerable extent the result of the self-financing imperative tying the government's cash-flow to the trade revenues generated by the economy, was the central characteristic of British colonial rule. It kept state activities constantly restricted but it also prevented the flowering of a hypertrophic public sector engaged in selfaggrandi zement.

Lack of resources, financial and human, ${ }^{17}$ meant the thinnest pos-

17 The acquisition of the West African colonies seriously delayed the unification (in taras of remuneration, conditions cf service as well as rotationality) and professionalization (in terms of recruituent criteria as well as compotitive entry examination) of the whola Colonial Service. Until the 1930 s, terss were established and officers hired, not by the Crown, but by each colony separately. Sir Charles Jeffries described the dilema, namely that " $\mathrm{jt}$ was unlikely that recruitment for West Africa by competitive exanina. $t$ ion wold be successful. Candidates were already difficult enough to secure, and the difficulties would only be increased if they were to be asked to face the immediate horrors of an examination as well as the prospective rigours of the African climate. At the sane tine, it was not felt that sufficient justi- 
sible spread of colonial officers in the provinces. One poorly paid officer - the "adainistrative spinal colunn" of British Africa (Young: 1988,38) - assisted by Nigerian auxiliaries, looked after a huge population and a vast territory. In 1900, for instance, Northern Nigeria had a cadre of only nine political offi ers (Perhan:1960,145). Sone forty years into the colonial adventure, the Assistant Secretary in the Colonial office proudly recounted the personnel increases in the early days: "In 1901 the administrative staffs of Northern and Southern Nigeria together amounted to about 50 officers. By 1910 they had increased to over 150 , and by 1909 to over $250^{\circ \prime}$ (Jeffries:1938,188). let, what to the insider might be proof of a massive deployment of human resources, cannot veil to the nore detached observer that the inperial enterprise in West Africa was hardly more than "a gimcrack effort run by two men and a dog" (Ronald Robinson, cited in Austin:1977, 246). In 1921, still only 300 administrators - less than 200 on duty at any one time - served in Nigeria with an estimated population of then 20 million (Nicolson:1969,231); by 1938, their number had increased to 386 - complemented by 1,662 expatriate staff in service departwents (Hailey:1938,226); finally, by 1947, there were 468 administrators and three years before independence, 521 (Jeffries: 1972, 108). As to the law enforcement (or "repressive") apparatus, in the late $1920 \mathrm{~s}$, there were only 233 European officers and nonconsissioned officers among the 4,000 wen of the Nigerian regiment of the Royal West

fication existed for expecting the Eastern Colonies to sacrifice, for the problematic benefit of association with the unpopular Tropical African Bervices, the advantages which they had secured by associating their recruitnent with that for the Hone and Indian Civil Services" (Jeffries:1938,12). 
African Frontier Force, and 75 European officers in a police force also numbering 4,000 men (Hallett:1974,307). By 1939, the number of British of ficers in the Nigerian nilitary and police forces had dropped to 188 (Kirk-Greene: 1980,39 ).

Indirect rule was eventually adopted for the whole territory after it had been successful in the North. There the enirates had been centralized states with well defined procedures and institutions for the assessment of taxes and the collection of revenues. British Residents were added as divisional heads ${ }^{18}$ and a number of basic legal changes instituted, such as the abolition of slavery, of physical autilation and of inhuman prison conditions; also, sone aspects of British law were introduced to supplement the Muslim codes (July:1970,365). This apart, British policy aimed at preserving the Muslim North in its pristine Islamic purity by excluding Christian aissionaries, by liniting Western education and by denying Northern leaders representation in the central Nigerian Legislative Council, in short, by protecting the North from "the forces of the twentieth century" (Hanilton:1962,32).19 The British administrators' role was emphatically not a formally execu-

18 At its peak in 1955 there were 9 Senior Residents, 12 Residents and 28 Senior District officers in Northern Nigeria (Kirk-Greene:1980,34).

19 Lugard thought that "Islan carries with it its own religious sanctions, while the Animism and Fetish of the pagan represents no systea of ethics and no principles of conduct" (Lugard: 1965,437). Reasoning like this strove to minimize Western education - despite the 1914 analganation, separate education ordinances continued to be proaulgated for the Southern and Northern Regions until 1948; (cf. Ndoku:1976,94) - and even Western conerce. For example, despite obvious connercial advantages, the London t Kano Trading Company which had been founded by two forwer British administrators was, in 1910, not permitted to extend its lease in the old city of Kano because the colonial government feared that its presence night be a socially disruptive influence on the local population (Hove:1976,66). 
tive, but an advisory one, a point underlined by Lugard's choice of nomenclature. "Fron the first he decided that his chief adainistrative officers should be called Residents to indicate that they were advisers rather than executives ..." (Perhan:1960,40). Their "prinary function was that of watchdog for the central adainistration; to see that the Native Authorities were running snoothly, that there were no abuses of the system and to give advice either where it was sought or when he considered it necessary" (Crowder:1970,339). Indirect rule worked less well in the Eastern part of the colony, where a hieraichical political system presided over by a chief did not exist - and had to be created (Cameron:1965,222; Hailey:1938,423) and in the West, where chiefs traditionally were no autocrats but had acted within a complex systee of customary law (Lloyd:1954). Of ten probleas engued because the colonial government's intervention upset the traditional, delicate balance of power. In 1924, to illustrate, the Alafin or King of Oyo, the formerly dominant kingdom in Western Nigeria, had been appointed, contrary to traditional usage, sole Native Authority with power to designate subordinate native authorities. "The Alafin's 'paranountcy' becane arbitrary and he himself grew into an over-mighty personage relieved of all traditional checks and endowed with new powers" (Ikime: 1968,427-428). Since indirect rule through single, responsible chiefs and fiscal restraint were integral components of British colonial policy, a sall excursus on taxes is in order.

Direct taxes were unknown in both southern regions not, however, in the North were the Emirs, for lack of taxable trade, had traditionally depended on then. In the Southeast and Southwest, levies in sup- 
port of the slight political superstructures had consisted mainly in forced labour. After formal colonization, indirect taxation proved easy and worthwhile in the coastal regions of the East and South which were engaged in overseas trade, while in the autarkic North revenue could not be raised in this nanner. Therefore, until the analganation of North and South, the introduction of direct taxes in the coastal belt was, on purely figcal grounds, also less pressing as the required revenues had been generated by custons duties, levied predoninantly on exports. In 1900, customs revenues accounted for $94 x$ of the colonial government's gross income. During the 1930s, their share dropped to around $40 x$ before growing steadily to over $60 x$ at independence (see table 6). The difference, in typical zero-sun fashion, was ade up by direct taxes. The fluctuations which did occur are explicable by the various advantages (for the colonial government) attending to the different methods of taxation, as well as to the success with which the Colonial office or the Governors, respectively, nanaged to have their ways. The Colonial office consistently favoured indirect taxation, mostly because it dreaded tax riots which were occurring repeatedly in the country's Western region and in the Eastern region where, as a result, direct taxation was not introduced until 1921 and 1928 respectively (Pim:1948,228-229).

Governors, on the other hand, were obligated to raise the necessary revenues for their operation. For them, indirect taxation (inport, export and, since 1939, excise duties), while easier to collect, conflicted with the objectives of encouraging the importation of British manufactures and the production of export crops; in theory at 
least they also afforded unwelcone protection to African manufactures. For all three reasons, the British trading companies objected to trade taxes (Smith:1979,49). Yet it would be facile to suggest that their preferences swayed the Governors or the Colonial office. While not oblivious to econonic (or even noral) argunents, as will be explained below, Governors, especially Lugard who had established the systen in the North and who fought. for its adoption in the South, favoured direct taxes primarily for political reasons. They were the cornerstone of the indirect rule system, even if their introduction initially led to social unrest. Eventually, so it was hoped, direct taxation as an integral part of the local self-government regine would strengthen the position of native rulers since raising and disbursing of "revenue was and is an essential aspect of any form of rule or authority and if the non-European agency was to be respected by his people, as the exponents of Indirect Rule thought that it should be, then he could not be denied such a vital attribute" (Ikiee:1968,433). With the local chiefs visible not only as tax collectors, but as executives to organize public works projects such as the building of local roads, sewer systens, hospitals or even electricity systens, the connection between taxes and the provisions of public goods was hoped to becone obvious for all. Another, equally practical consideration informed by the inperative of administrative tidiness was Governor Lugard's argueent that "it is obvious that the native rulers aust have sone means of livelihood and of aintaining their position. If there be no legal and recognized tax, the necessary incore nust be obtained by arbitrary levies on the peasantry, subject to no control by the Government. In the Moslem 
Btates the tax is the corollary of the abolition of slavery" (Lugard: 1965,231). Moreover, by neans of official (and regulated) taxation, "the upper classes can be paid salaries for public works; slavery, forced labour, and all other foras of exactions fron the peasantry can be declared illegal without reducing the ruling classes to poverty" (ibid.,233). Finally and in addition to their fiscal value as revenue generators, direct taxes were considered pedagogically useful, "a aoral benefit to the people by stiwulating their industry and production" (Lugard: 1970,166$)$.

The economic, if not developnental, advantage of direct taxation was obvious: it forced Nigerians, in order to pay their taxes. either to work for wages or to produce cash crops. In contrast, as lugard recognized, indirect taxes had an anti-production bias. Referring to what wern economics calls "incentive goods", Lugard wrote that "[e]xcessive import duties will result in a dininution of the stimulus to production ... since the wants of the African are rarely necessities, and he can leave then ungratified" (Lugard:1965,266).20 Lugard was particularly incensed that between 1908 and 1915 well over half of all import duties derived from liquor, German liquor at that, which "pro tanto decreased British iaports of a more useful character" (Lugard: 1968,55). Yet, he did not clain that British substitutes belonged in this category and therefore rejected it "as a coral and legitinate ar-

20 In the 1930s, the nost significant inports for general consuaption were "cotton piece-goods, salt, and dried, salted, and snoked fish, with the luxury or semi-luxury imports of spirits, cigarettes and tobacco. ... The import duties levied on these commodities [in $1937 \ldots$ were] $17.6 x$ of the value of the cotton piece goods ... $59.3 x$ for salt and ... 8.0x for iish" ( in: 1948,236). 
gueent, that if they [the natives] nust have liquor we should supply and make a profit out of it" (Lugard in a letter to his wife, cited in Perhas: 1960,561$)$. Thus agreeing on principle also with the missionaries who "considered it ineoral that the Government ... should be financed by revenues froe gin" (Okigbo:1989,13), Lugard skillfully used this readily available noral high-ground to force direct taxation; resultingly, the proportion of government revenues derived from spirits fell to $1.23 x$ in 1918 (Lugard: 1968,141).

To return to Indirect Rule. The extent to which chiefs willingly accepted their role or subaitted out of fear, resignation or rational calculation of possible rewards is difficult to deteraine, as evidence for all motives have been cited (cf.Berman:1984,183; Fitzpatrick:1970, $118 \mathrm{f})$. Yet, wuch to the chagrin of the colonial government, chiefs of ten becane sources of disruption rather than agents of good goverrment. They frequentiy abused their power in ways they could rarely have done in traditional society without deposition. Tendencies to extort money from the populace were conmon enough, which was a temptation hard to rexist (Sharwood-Saith: $1969,252 \mathrm{ff}$ ). Since the chiefs were responsible for the collection of taxes and officially received a cut not only as part of their rewards but also to tie the to the colonial gystea, abuges were very difficuli to contain (Crocker:1936,216-218). Yet as the colonial state depend. 1 on tha native outhcrities 35 pillars of its law and order polecy id as executors of its incal development measures (rudimentary o. - haphazard though they were;, this authority colild nut be unduly eroded. This, on the part of the colonial government, necessitated a certain tolerance of irrational behaviour. In 
order to libit their decisional scope and so to check their tendency towards self-aggrandizement, however, even a most gignificant developmental tool was sacrificed.

It had been recognized that the connercialization (connodification) of land was necessary to raise the productivity of land and labour (cf. Forde: 1946,212 ). Yet it was also recognized that his inplied unacceptable dangers because of

- the inherent temptations for chiefs to use their traditional control of the land to their own benefit;

- the likelihood of protracted litigations between subjects and chiefs, but also between chiefs with conpeting land clains; and finally because of

- the resulting mobility of people who would nove voluntarily in search of more lucrative, more fertile or less costly land, or involuntarily after being expelled from their traditional land and thus deprive the chiefs of their subjects (West African Lands Comittee, Draft Report of 1916; referred to in Phillips: $1989,76)$

At botton, the fear was that the dislocations resulting from the commercialization of land would undermine the native chiefs' authority. By according stability priority over developnent, it has been plausibly argued, the colonial government's conservatisn "wight have actually retarded the development of capitalist production relations by supporting the concept of comunal tenures and the transference of traditional au- 
thority to the colonial state [which .... put a brake on land sales and retarded the emergence of a dispossessed labour force" (Siddle and Swindell:1990,81-82).

Not surprigingly, the educated elite which forned the core of the emergent nationalist oovenent, resented the way the colonial governuent obstructed progress, strengthened the powers of the chiefs at the expense of other political forces, and restricted the permissible discourse to local matters. With considerable justification, indirect rule as an unholy alliance between imperial and tribal authority to them "seemed designed to exclude the educated elite from an effective national role, and was therefore seen as an agency of reaction against the forces of modernization which colonial exploitation had stinulated" (Crowder:1981,213). It was thus against the colonial government's policy to exclusively deal with, and act through, (traditional) native rulers that the emergent political movenents directed their energies. Their grievance was that the indirect rule system

could not possibly be for the progress of the territories concerned, since it. merely favoured, sheltered and strengthened illiterate, conservative, unprogressive and sonetimes autocratic chiefs at the expense of younger educated elements who, adaitted into the Native Adninistration Councils, would be better able to understand and follow what was going on in the councils as well as be able to take bold initiative in atters with which the councils aight be concerned (Akpan:1956,28).

This critique was most acute, even if narrowly focused on personnel rather than structure or content (that is, on who the executives of British policy should be), while not questioning either the policy or the overall framework of policy-aaking. The fallacy of mere personnel 
exchanges would be revealed after the $1950 \mathrm{~s}$ when the educated elite noved into positions of authority and when the native rulera were successively being disenpowered. Two of colonialise's lasting legacies, both rooted in its "autocratic paternalis"" (McPhee:1971,310), were to prevent the energence of capitalist relations of production (and thus of genuine classes), and to establigh a powerful yet unaccountable political center. This combination of social atonization and political concentration was most propitious for the formation of a patrinonial bureaucratic State with its tendencies of abuse, centralization, instability and waste. However, the determinants of these onissions and commissions were, as I have tried to point out, rather nore complex as could be gathered fron the kind of conspiratorial flunery which suggests that the "fundamental defect in British colonial policy in Nigeria [was that] it was founded in order to serve and pronote the capitalist interests of the nother country ..." (Graf:1988,8). But this is getting ahead of the story.

The most important of the early oppositional organizations, the Nigeria National Denocratic Party (NNDP), was formed in 1923. It represented the South's educated elite (and the seni-educated sub-elite) and dewanded, inter alia, the nomination and election of the Lagos nenbers of the Legislative Council, ${ }^{21}$ the development of higher education

21 The Legislative Council was the only body for elected representation created by the 1922 [Clifford] Constitution; its authority was strictly advisory and its scope local because, in an indirect rule systen "it would be unjust to place under their control the interior tribes, who thenselves have a right to a neasure of self-rule" (Lugard:1965,90). The Council's total of up to forty-nine consisted of up to thirty official neabers (27 of whon were ex officio and 3 nowinated) and up to fifteen unofficial neabers noninated by the Governor. The noninated neabers included nowinees of the four Chanbers of Comerce and the banking and shipping interests, who were European; of the 
and the introduction of compulsory education throughout Nigeria, Africanization of the civil service, free and fair trade, equal treatnent for Nigerian traders and producers as well as the econonic developnent of Nigeria's natural resources (Boshen:1985,631). These denands sun up very concisely the legitinate grievances of a derivative aiddle class which, a quarter century later, led the vovenent for independence and which provided the pool fron which eventually the state bureaucracy would be recruited. They point to several aspects of the structure and process of the colonial State which are innediately relevant to the understanding of both, the nature of 1 ts post-colonial manifestation as well as the policies adopted:

- the alienation of political authority from society;

- the exclusion of an important social stratum fron the political process, frow the public service and, even, fron any areas of the econony; and

- the failure to provide education and to improve the economic: situation anywhere near the level of public expectation.

The conflict, unavoidable though it seened, involved a heavy price in terns of impaired realism for both parties. On the part of

African noeinated neabers one represented the Niger African traders and the others were selected as representatives of districts of the Colony and Southern Provinces which had not received the franchise (Hailey:1938,172). Finally, there were four elected nebers, one fron Calabar and three fron Lagos - elected by all adult males resident over one year and with an annual income of $\& 100$ (Crowder: 1980,210); under these restrictive circunstances, only 3,000 voters qualified (Kilson:1970,382), figure which in 1924 grew to 4,000 in Lagos and 453 in Calabar (Post:1970,40). 
the population, especially its educated elite, $i c$ fostered animosity towards the State combined with unrealistic expectations concerning it. abilities which, so the suspicion, were conspiratorially not nobilized by the oppressive colonial regine. On the part of the state, the slow$1 y$ growing hostility towards it, that is, its lack of popular legitiacy and support, led to defensively undertaken attenpts at coalition building with conservative forces. While conducive for stability, it proved ultimately very costly because it strengthened the colonial State's immunity from pressures to transform society. After the collapse of comodity prices as a result of the world econowic crisis, beginning with the Wall Street crash of 1929, and until their eventual recovery after World War II, the scope for stateinduced economic development would have been quite narrow in any event. In the context of a seeningly onnipotent, yet econonically passive colonjal State, it led to widespread resentment born of frustration and provided fertile soil for anti-colonial agitation - with particular inpetus in the $1930 \mathrm{~s}$ and 1940 s when the ooderate NNDP was overtaken by more radical movements - as well as for an unrealistic inflation of expectations concerning the aterial changes independence would bring. The spread of education, cash-cropping and wage enploynent - mainly clerical staff, unskilled construction workers and other subaltern positions in the colonial government ${ }^{22}$ - but also isproved comunications

22 In 1936 there were 227,451 wage earners in Nigeria (Hailey:1938,607). Yet $g$ iven that they were concentrated in the few urban areas, enployed in the econowy's modern sector and relatively well educated and well paid, their significance by far exceeded their saall proportion (about 1X) of the total population. 
as an effect of increasing popularity of notor transport and the spread of newspapers, had created a large and rather wilitant group of people, responsive to issues wider than those of traditional conanity. This modernization-induced nobilization changed the political discourse and put the stability-oriented colonial governnent increasingly on the defensive. With the country pacified and the econony passable, the originally nothing less than revolutionary impact of colonialism gave way to staid conservatisn while the educated elite, taking the status quo for granted or considering it not more than winimally acceptable, wanted to take over and push forward. For, while the NNDP during the $1920 \mathrm{~s}$ and the early 1930s would have been content with its clientele being listened to and treated respectfully, the aore radical and nationalist groupings emerging in the late 1930s, such as the Nigerian Youth Murament (NYM), demanded in its nanifesto "a complete taking over of the Government of Nigeria into the hands of the indigenous people of our country [... and] a reversal of the existing condition so that Nigerians will run the Adwinistrative Machinery of their own fatherland" (cited in Post:1970,49). Decisively underlining its popular appeal and support, the NYM in 1938 won all three Lagos seats on the Legislative Council, thus ending the supremacy of the NNDP which had lasted fifteen years.

\section{c) The Colonial Bconory until 1945}

Econoaically, the colonial period can be divided into three distinct stages with different iaplications each for independent Nigeria: 


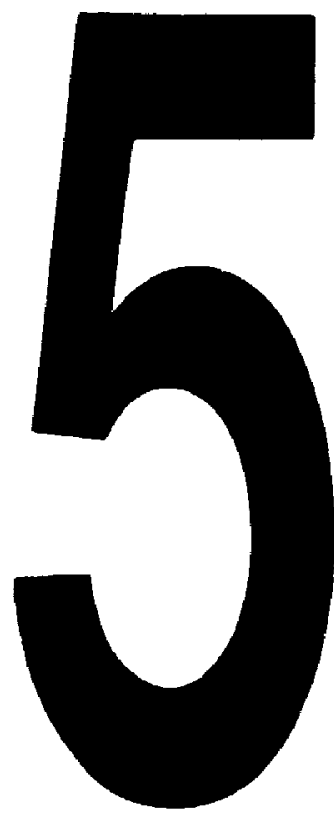

PM-1 31/2"X4" PHOTOGRAPHIC MICROCOPY TARGET MBS 1010a ANSI/ISO *2 EOUIVALENT

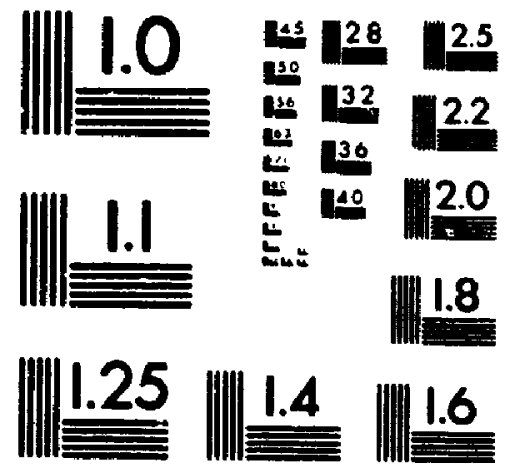

PRECISION ${ }^{2 m}$ RESOLUTION TARGETS

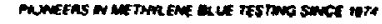

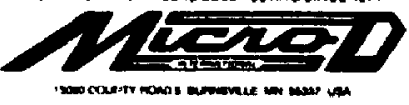

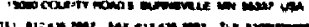


the first, ending in 1950, is characterized by the overall effect of consolidated colonial rule, by the creation of physical infrastructures and by the nassive expansion of exports. The second stage, ending in 1945, is characterized by a dramatic downturn of export revenues and by the beginning of governnent intervention in the econony. The third stage, ending in 1966, is characterized by an unprecedented boon in export sales, by the State's expanding economic intervention, and by the Nigerianization and Regionalization of the colonial government including the Public Service. What econonic progress had been achieved through the 1950 s - even if this was nostly in teras of growth, rather than development - began to erode in the political turaoil which continued and worsened after Nigeria's formal independence in 1960 . This period ends with the landwark of the 1966 ailitary coup which not only suspended parliamentary rule for the next thirteen years but coincidentally also marked the end of agriculture as the mainstay of Nigeria'a export economy and its role as revenue generator for the state.

It bears repeating that colonial rule did not initiate the phenomenal economic expansion of the first half of the twentieth century, that is, it cannot be ascribed to colonialism to have created "nodernity out of backwardness by suddenly disrupting a traditional atate of low-level equilibriua" (Hopkins:1973,235). On the contrary, the colonial government's assistance, creating political stability and a transport infrastructure, only accelerated a process which was already under way. What happened, thus, was the induced explosion of latent economic forces, not an "Econonic Revolution in British West Africa," as was suggested by the title and argunent of aesinal study in the 19208 
(McPhee:1971). The flag, for its very own reasons, had followed trade (in a chronological sense), had instrumentalized it and, in turn, had had a catalytic effect on both, African agricultural export production and the importation of European eanufactures.

When world trade first ade its in:luence strongly felt in Nigeria in this century it did so by reaching directly into the very nidst of the traditional peasant econony, offering rewards directly to the peasant producer. ... It was thus not through foreign exploitation of aining and plantation enclaves, but rather through indigenous peasant response to ordinary economic incentives that Nigeria entered upon the world econony (Helleiner: 1966, 48-49).

Especially the initial period of British rule (1900-1930) gave considerable, indeed absolutely astounding, boost to a snallholderbased export-econony which had begun to expand in the nineteenth century but which had reached a ceiling. Responding to effective external demand through the introduction of new crops, the export sector developed a phenomenal dynamism. Fortunately, it was also regionally balanced, consisting of the traditional forest staples paln oil and pald kernels (in the East), of the more recent agricultural comodities cocoa (in the West) and groundnuts (in the North). Cotton (North), rubber (South) and tin (Middle Belt) were of lesser significance (for the percentage share of the various export connodities' values, see table 3).

Palw oil, a traditional staple in West Africa, is an essential item of the local diet. Dairy products are virtually unknown because the tsetse fly prevents cattle keeping. Paln oil is the basis of nost African dishes, "being used both as a cooking naterial and as an ingre- 
dient in sauces, soups etc. The 'chop' oil produced for this purpose is despatched on a considerable scale fron the paln belt to other parts of Nigeria" (Scott:1946,231). Paln oil, in ninute quantities, was exported to Britain as early as 1772, yet only after the initial, still tentative, abolition of the slave trade in 1807 , did pala oil sales grow exponentially. "The 1,000 ton nark was surnounted in 1810 , the 2,00 ton nark in 1815 , the 5,000 ton mark in 1821 , the 10,000 ton mark in 1830 , the 20,000 vark in 1842 and the 30,000 ton aark in 1851" (McPhee:1971,32). Fron the beginning of the 20th century until the 1960s, Nigeria was the world's largest exporter of pale oil and pale kernels, accounting for about one quarter of total world supply (World Bank:1982,i). Reaarkably, this was not the result of a state-organized effort, but of the initiative of individual "peasant faraers who obtained the fruits from palm trees growing wild in their farm land" (Udo:1967,305). For reasons to be discussed below, Nigeria's production collapsed dramatically after independence. Exports fell on average by $23.6 x$ annually between 1961 and 1984 and Nigeria's world narket share of over 23x in 1961-1963 was reduced to $0.2 x$ in 1982-1984 (World Bank: $1986 \mathrm{~b}, 73),{ }^{23}$ before being wiped out altogether. Between 1983 and 1986, over 400,000 tons of paln oil had to be imported to neet donestic requirenents (FAO Trade Yearbook 1985,283; for trends see also table 1).

23 Malaysia, in contrast, increased exports of paln oil on average by $18 x$ between 1961 and 1984 ; likewise her world earket share fron 17.9x in 1961-1963 to 70.67 in 1982-1984 (World Bank: 1986b,73). 
As was mentioned earlier, cocoa is not indigenous to West Africa. Originating in the forest of the Amaron basin in tropical South Anerica, it was introduced via Fernando Póo (the island off the Niger delta in the gulf of Biafra, today called Bioko and belonging to Bquatorial Guinea), by a Gold Cosst labourer on his own initiative in 1879 (Hill: 1963,172). Appreciative of its connercial potential, the governuent of Lagos Crown colony, as early as 1887, wade cocos seedlings available from its botanical garden near Lagos (Udo:1967,303). Cocoa spread through much of West Africa, not only because the requisite seeds and know-how were ncw available, but because it was lucrative. As in the case of palm oil and later groundnuts, cultivation was in peasant farms. An enpirical study of cocoa farners in Yorubaland found that "farmers almost invariably mentioned money or profit in explaining why they or their fathers first planted cocoa. Either they had seen people getting rich from cocos, or they had heard it from a reliable source. By contrast, no one mentioned having been shown or taught how to grow cocoa" (Berry:1968,445). This rational pursuit of profit cones into even sharper relief if it is considered that cocua is not consuned in West Africa in any for and was from the beginning a purely connercial crop; also, it involved a longer gestation period - seven years - than any crop previously grown there. In $1899 / 1900$, under $1 x$ of the world's cocoa supplies cane from West Africa ( $80 x$ cane from the Caribbean and Latin America), yet by 1936 , "the centre of production had shifted so completely that West Africa was producing 67.7 per cent of the world's supply, the Gold Coast and Nigeria alone accounting for 59.5 per cent of total world exports" (Scott:1946,247). In Nigeria, cocoa growing 
had a conparatively late start but then her growth rates were truly astounding. Before 1900 , production was insignificant, the "annual output averaging only 32 tons fron the quinquiennial period 1892-1897 and 144 tons from 1897-1901" (Udo:1967,303). In 1911 when South Acerica and the West Indies were producing 150,000 tons, San Thone over 30,000 and the Gold Coast about 40,000 tons, Nigerian production was only 4,000 tons (Galletti et al.:1972,1). By 1925, production had grown to 45,000 tons, by 1950 to ove- 100,000 tons and by 1960 to over 150,000 tons (see table 1 ).

Groundnuts, like cocoa, are not indigenous to West Africa. They were imported to the region's coastal parts during the slave trade to supplement the diet of slaves during their passage to Anerica (Hailey: 1957,822). After methods had been developed for the industrial processing of margarine - a revolutionary invention of the early twentieth century - European demand for groundnuts skyrocketed between 1906 and 1914 (McPhee:1971,35). In Northern Nigeria, where snall quantities for local consumption had been grown for over a century, it was the "Hausa traders of Kano ... whose quick appreciation of profit opportunities [had] most to do with the establishnent of the groundnut industry" (Hogendorn:1970,38). It became a nost successful export oriented endeavour. In 1900 about 600 tons of groundnuts were exported, in 1935 already 186,000 tons. Between 1940 and 1960, Nigeria was the world's largest exporter of groundnuts. Production peaked before the civil war, reaching 573,000 tons in 1966 (World Bank:1974,77), and then declined dramatically. Exports ceased in the early 1970s. In fact, Nigeria's classical exporter position changed to that of inporter in 
the mid-1980s when thousands of tons of groundnuts had to be imported to neet donestic denand (see table 1 ).

Cotton has been grown in Nigeria since tines imeenorial in order to supply the demands of indigenous spinners and weavers. It is for this reason that export volunes fluctuated wildly, that the local prices for cotton were often higher than the export price and that often Anerican cotton had to be inported to neet local denand (Hailey:1957, 839). Sizeable quantities of cotton were inported particularly in the mid-1980s after the naira-devaluation inproved the conpetitiveness of the donestic textile industry and increased the prices of finished products (see table 1 ).

Growing in the tropical forests of the Niger delta, rubber, after palm oil, was Nigeria's second "legitimate" export connodity, both chronologically and regarding its sales values (see table 2 and 3 ). Like paln oil, rubber was not cultivated but gathered fron wild forest vines. Cultivated rubber, both from snallholdings and from foreignowned estates, becane important after the 1940s (Morgan and Pugh:1973, 481). Mining, particularly for tin, was the only econonic sector in which European involvenent squeezed native industry out of production. "In 1884 it was found that the tin used by the Hausa for tinning their brassware was mined by Nigerians in the Naraguta district, and anelted in priaitive furnaces, but by 1923 this indigenous industry had conpletely disappeared" (Bower:1948,4). In the 19308, Nigeria stipplied approxinately $5 \%$ of the world's tin production (League of Nations:1936, 152), even if its share in Nigeria's export basket never was of najor significance. It reasined in the low teens, except for the interlude 
of World War II (see table 3). Nonetheless, in the 1950s, with over 50,000 workers, the tin aines were the largest comercial enployer of wage labour (Hailey:1957,1509).

The national econony's regional balance peraitted, during the run-up to independence, the reconstitution of the wartime connodity boards for palm products, cocoa and groundnuts as regional arketing boards (see below, pp. 422ff). As such they generated the funds, withheld fron the direct producers, to consolidate the power base of regional elites with costly if dubious and ineffective developnent projects. Yet prior to the closing of the Nigerian econony in the 1950s, it had proved a textbook case of Hla Myint's adaptation of Adan Saith's implicit "vent-for-surplus" theory. In the chapter entitled "Of the Natural Progress of Opulence" Snith explains that wa

country supplies the town with the means of subsistence and the aterials of anufacture. The town repays this supply by sending back a part of the manufactured produce to the inhabitants of the country. ... We must not, however, upon this account, inagine that the gain of the town is the 1088 of the country. ... The town affords a market for the surplus produce of the country, or what is over and above the aintenance of the cultivators, and it is these that the inhabitants of the country exchange for sonething else which is in denand anong then (Snith:1974,479).

Referring to sone South-East Asian and African countries, Myint argued that the opening up of trade through inproved transport and conmunications as well as through the creation of political stability and judicial calculability provided an opportunity for the profitable enployment of the hitherto idle resources labour and land, namely a "vent" for the econony's potential surplus production. In the pre- 
export era, so his thesis, donestic denand was unable to absorb the potential output of available resources, sone of which were thus not eaployed. International trade, then, created the effective deand which stinulated the econon's latent productive capacity while, at the same time, offering the opportunity to acquire a whole range of new conodities fron abroad. Provided the inported goods were affordable and attractive, the national econony produced additional output. As long as there were reserves of underutilized resources, output could expand without changes in traditional modes and techniques of production (Myint: $1973,30-40$ and iden: $1971,124-137$ ).

Unfortunately however, such a vent-for-surplus econony can grow without developing - as Marxists would say, without involving a change in the relations or mode of production - a point ade by many analysts and, with particular cogency, by a World Bank tean:

Growth was provided nainly by the enploynent of surplus land and labour, and by the substitution of higher value export crops for subsistence crops, without significant reorganization of the society or the introduction of new production techniques. Technological changes were introduced in the fora of new crops and in the conconitant developent of modern transport and processing facilities. Economic growth thus took place within a fairly atac franework with little intervention by the colonial adninistration before 1960 or the independent government thereafter (World Bank:1974,1).

The Nigerian econony's (that is, the Nigerian sallholder peasants') response in terms of production increases to the denand enanating frow the world narket was truly phenonenal. Between 1900 and 1915 the volune of exports alnost doubled; between 1915 and 1925 it nore than doubled again and between 1925 and 1935 it grew by another 
25x, despite the considerable disruption caused by the 1929 depression. In thirty-five years, therefore, exported output had risen sore than fivefold (see table 1). Infortunately, however, the growth was sore in terns of volume rather then in terns of value. Export revenues rose only until 1920, and even then not keeping pace with volune. By 1930 , export volune having quintupled since 1900 , export revenue was up by only 50x (see table 2); it. then took until after World War II for export prices to recover to their post-World War I level (see table 4 ). The often self-defeating effect of expanding production in situations of inelastic deaand, namely to depress prices, proved itself in Nigeris. Conpounding this misfortune also the volune of inports stagnated in the same period, nostly because of increases in the price of inports (Helleiner:1966,494-495). In other words, in the absence of technical advances in agriculture - and hardly any productivity gains were achieved prior to 1945 - the capacity to inport was naintained only by increased inputs of land and labour. Thus, while not translating into economic development (increased productivity of labour) or into econoaic diversification (creation of an indigenous base for sustained welfare generation), the export-led growth raised hopes for future economic inprovenent and induced nore Nigerians to enter the export narket; this, in turn, fueled the further volune growth of exports.

It is beyond doubt that the unprecedented period of peace and of economic growth initially reconciled the majority of Nigerians with colonial rule. Yet after the aid-1920s, frustraticn set in, reaching crisis proportions when export values, despite rising volunes, consistently declined. This trend continued until after the second World 
War: their 1940 level was about half that of 1925 (see table 6).24 However, deteriorating terns of trade alone cannot account for the sluggish growth of export value and thus producer incone. Two other important factors were the escalating revenue extraction by the colonial government and the increasing concentration in the trading sector. The highly aggregated econonic data of export volune and export value conceal an important correlation: even if the incone or welfare effects of higher output were only marginal for Nigerian producers, macro-econonic growth did perait the state-led infrastructural expansion, especially the construction of roads and railways. This was essential if the econony was to expand further through the export of commodities from the country's interior; also, given the thin spread of British officers over such a vast territory, the possibility to swiftly mobilize troops to preent or quell any disorder was certainly a najor consideration. Between 1896 and 1925, over 1,200 ailes of railway tracks were conpleted; another 700 ailes were added until 1932 (Nigeria: 1934,8$) .25$ Yet the railway enthusiase of the last quarter of the nineteenth century had largely evaporated after the first quarter of the twentieth. Harsh econonic reality in the guise of the conpetitive

24 Most drabatic was the virtual cutting in half of Nigeria's export values between 1929 when they stood at $\$ 17,581,115$ (or $\$ 85,391,147$ ) and 1931 when they stood at only $88,553,353$ (or $\$ 41,560,747$ ) (Nigeria, Trade Report $1931,8)$.

25 The network has not been expanded in subsequent years. On the contrary, since independence the systen has deteriorated considerably. 1963 was the Nigerian Railways' last profitable year. Ten years later, the World Bank noted tersely that the Nigerian Railway Corporation "Is operatine inefficient$1 y$, and is consistently in deficit. These deficits are frowing and traffic denands are not being net" (World Bank:1974,88). 
superiority of lorries intruded, forcing the colonial government to review the progranne. Pragnatic considerations of strategic needs and econonic trends began to replace the earlier belief that the nere exiatence of a railroad line would generate its own traffic for anortization of capital costs and that "it sufficed to run iron tracks across any stretch of territory to fructify inpoverished lands, to anke deserts bloos" (Young: 1988,46 ). Great uncertainties had surrounded the earlier construction of railways and, reflecting a certain speculative enthusiasn on the colonial government's part, sone lines were built in anticipation of demand, not simply in response to it. ${ }^{24}$ Private investors were reluctant to get involved so that the entire systen had to be financed by the colonial government with public capital and through loans raised on the London money sarket (Ekundare:1973,137). At a rate of interest of $3 x$ (Hailey: 1938,1585), this was not too expensive. Neither was it too difficult: the colony's creditworthiness was a telling indicator of its macroecononic success.

In roughly the same period, that is, between 1900 when roads were nonexistent and 1926, nore than 6,000 wiles were constructed (Colenan: $1965,56)$, nostly as feeders for the railway. ${ }^{27}$ Yet nany roads, parti-

26 The railway fron Lagos to Kano, covering a distance of $1,140 \mathrm{~km}$, was completed in 1911. It had been built in the expectation that it would secure cotton supplies for Lancashire yet, in fact, becane an outlet principally for sroundnuts (Hogendorn:1970,31-37). Within ten years, exports aultiplied fifty-fold and within twenty years by a factor of 150 (see table 1 ).

27 In the aid-19508, the road network had reached well over 35,000 ailea which led the World Bank to conclude that Nigeria's aystes of nain roads was "practically conplete" (World Bank:1955,501); sill, another 20,000 wilea were added in the next two decades (World Bank:1974,88). The nubber of vehicles grew at an equally astounding rate: in 1907 there were only two in Lagos, by 1923 there were 675 (Okigbo:1989,10). By 1950 the nunber had reached 14,200, of which 6,900 were passenger cars (Kinble:1960,466). A veritable explosion 
cularly in the country'south-western region, were built parallel to the railway. The lucrative opportunities thus created led to the energence, in the 1930s, of a flourishing private industry and proved once more the Nigerians' enterprising spirit which, given conducive conditions will, with sheer energy and business acumen and altogether without requiring public assistance or prodding, create flourishing enterprises. In fact, the private transportation industry was so successful in challenging the railway's sonopoly that a bitter price-war ensued in which the railway used unecononical dunping prices to squeeze the private freight-haulers out of business (Nigeria, Railway:1938,10). ${ }^{28}$ To force the success which on purely econonic grounds it could not achieve, the government issued a licencing ordinance with the express goal "to enable unecononic competition to be controlled, [and to] assist and confirm the adoption of appropriate rates" (F.D. Evans, the Director of Transport, cited in Hays:1970,102). This intervention provoked opposition and led to the Nigerian Motor Transport Union strike of 1937 which was spearheaded by the nascent nationalist opposition. Chief Awolowo

occurred in the $1970 \mathrm{~s}$. The number of vehicles had reached 633,268 by 1980 , 215,436 of whi hh were passenger cars (Hackett:1989,789).

28 The Nigerian Railway's annual reports of the early 1930s make fascinating reading. Their bristling indignation is dirented both at the colonial government for underaining the railway's profitability by the wasteful construction of parallel roads, and of course at those natives who would neither recognize their own best interest nor the wisdon of a publicly provided rood. "It is interesting to speculate just how low the price of road tranuport can be reduced in an African country. The indigenous population is large, the standard of living low for a great nany, and it is easy to drive a lorry. ... assuning a driver or owner-driver willing to work long hours and setting low value on his personal services, it would appear possible to produce road transport at a cost which would practically anount to an exploitation of labour" (Nigeria, Railway:1938,11). 
emerged as a leading figure in this dispute, which clearly assuned nore than just an econonic dieension. He advised the strikers to 'refuse to obtain licences for that year, and that we should go on strike in order to iapress upon the government that we were in earnest in our agitation, and that we were not going to allow our business to be sacrificed on the altar of a grossly vismanaged railway systea" (Awolowo:1960, $126)$.

As suggested earlier, the trading conditions in the second half of the nineteenth century gave no advantage to large enterprises and a great number of seall European and African trading firas were able to flourish. This began to change already before the formal inposition of colonialism, especially in the territory controlled by the Royal Niger Company where prospective traders had to obtain a retail licence costing $£ 100$, a regine "created with the deliberate intention of excluding the African traders ..." (Flint:1960,97). In the 1920s, business concentration had largely elininated analler firms and trading witnessed the re-emergence of few but powerful companies which handled the whole spectrum of activities: shipping, and inport-export as well as wholesale and retail trading. The number of European firas engaged in trade only, that is, nainly the sealler businesses, dropped fron 88 in 1921 to 59 in 1929. The vast United Africa Conpany (UAC) energed over the sane period. It was a giant enterprise which handled about half of Nigeria's external conmerce (Mars:1948,58-59), collected half of the governaent's revenues fros tin-mining and, as a subsidiary, belonged to Europe's foreeost aultinational concern, the Anglo-Dutch Unilever soap and margarine manufacturing organization (Munro:1976,131). The shift 
towards fewer but larger firms strengthened oligopolistic trends in the export trade and put mounting pressure on the Nigerian internediaries who had bought and bulked up conoodities from local narkets. Now, actively supported by the colonial government, the larger companies relied on trading posts staffed by their own agents as well as on buying agreements with other companies to force down prices paid to the intermediaries, and through them to producers (cf. Hopkins:1973,205-206). Nigerian businessmen, increasingly dislodged by expatriate cartcis, had few viable outlets in other areas of the econony, a predicanent not at all ameliora. - iy the colonial government's active opposition against the establishment of an indigenous manufacturing industry.

The government's position, unchanged since Governor Lugard's times, was differently motivated yet in fact partially coincided with the trading companies' interests. On the one hand, these naturally preferred to monopolize the market for consumer goods, rather than sharing it with local products while, on the other, they resented import duties for their dampening effect on sales. Lugard for one did not feel that the development of manufacturing in Africa would reduce the Africans' demand for British-made goods; instead, he held the rather sophisticated view that it would "nerely change the nature nf their demands" (Lugard:1965,512). Nevertheless, three nutually reinforcing arguments spoke against industrialization: public revenue, public order and paternalisa. Public revenue was the least inportant and more a matter of administrative convenience than of political expedience. After the initial phase of the colony's establishnent had been concluded, and the government was beginning to lift its sight from 
the level of local government towards national development, relying too much on native rulers to collect taxes proved cunbersone and inpractical, especially as the populace was still poor and physically dispersed, engaged in a self reliant, pre-capitalist node of production. To stimulate the existing import-export econony, rather than encourage the creation of a more autarkic one, was thus very auch in the colonial government's own interest. On a practical level, the Colonial office's view began to prevail, namely that the collection of taxes and duties could easily be concentrated at the few points of entry or exit through which all trade had to pass; this obviously also reduced the political risks involved in direct taxation. Thus, the colonial government's "policies encouraging local people to purchase inported consumer goods - and discouraging then from producing their own - made fiscal sense because of the ease with which the imported goods could be taxed. That such taxes were indirect also greatly reduced the political sensitivity of the operation" (Abernethy:1988a,13).

The other two arguments against encouraging industrialization, paternalism and public order, were more ideologica' and nore serious. Attention has been drawn repeatedly to paternalist conservationisa as the colonial government's ideological predisposition regarding the economic, social and political affairs of the indigenous population. In keeping with these convictions, plantations, despite their denonstrated productive superiority, ${ }^{29}$ had been consistently and actively discoura-

29 In 1923, Sunatra with its plantation econony exported 7,000 tons of palm oil, compared with Nigeria's 128,000 tons. By 1937, Sunatra's export had grown to 194,000 tons while Nigeria's stood at 146,000 (Conoonwealth Econonic Comnittee, cited in Kilby:1969,141). 
ged; instead, saallholder peasant farmers were upheld as the country's econonic backbone. Concerning the still more revolutionary nanufacturing industries, nost Governors followed the tradition established by Lug who had shown great concern for the disruptive social effects which invariably accorpany the industriaization of econonies whose population is almost entirely agricultural. Specifically, he was apprehensive about the possibility of instability which would present a conflict with the government's primary objective of naintaining law and order because, "when trade is slack, with consequent unemployment, discontent will be rife and there will be no lack of labour leaders eager to organize agitation on the worst models of the West" (Lugard:1965, 515). The objective to prevent the energence of a manufacturing sector, which was more or less actively pursued by all colonial governments, was thus achieved. By 1950, the first year national incone data became available for Nigeria, manufacturing still anounted to only $0.5 x$ of her Gross Domestic Product which, in fact, was lower than that of any country publishing national account statistics (Liedhola:1970,54). The price of this "success," political and econonic was steep. In the second half of Britain's tenure in Nigeria, it consolidated the energing societal division of labour which left British colonial officials in charge of macroeconomic and political decision-naking, expatriate corporate merchants in charge of trading and banking, and Nigerians in the role of agricultural producers as well as, in sone very linited numbers, as teachers, clerical support staff and free lance profession- 
als. ${ }^{30}$ Lord Lugard's fears became true after all, although the agents of social unrest turned out to be not proletarians but frustrated professionals who wanaged to harness, verbalize and organize the grievances of others: traders, peasants, junior civil servants and teachers. With the benefit of hindsight it seens clear that the colonial government's political conservatisn, in conjunction with its econonic shortsightedness, created the pressures for state-led industrialization which, in the decade before independence and even nore so thereafter, particularly since it was not very successful, was instrunental

- in perpetuating Nigeria's dependence on the vagaries of the woild market;

- in preventing the energence of a viable internal nass narket based on cheap manufactures and the rise of a productive, accumulating bourgeoisie; and, finally,

- at least partially in the emergence of the bureaucratic state.

Between 1930 and 1945 external conmerce, under the circumstances the engine for economic change, stuttered through depression, recession and war. The volume of Nigeria's exports increased considerably (ex-

30 If only in minuscule numbers, it is significant that professional $\mathrm{Ni}-$ gerians had already been recruited into the colonial government before the war. By 1938 there were thirty-seven "higher appointaents" (auxinun salaries of $\$ 400-\$ 720$ ), including fourteen medical officers, one police magistrate, four assistant secretaries and three technical officers (Hailey:1938,235). While this represented under $2 x$ of the senior establishment, their responsibility as well as their pay was identical with that of their British colleagues (Jeffries:

$1938,138)$. 
cept for palm products and cotton), yet their values declined steadily. In 1940 they had fallen well below their level of 1920, re-reaching similar revenues, despite considerable higher volune levels only after the war (see tables 1 and 2 ). The colonial governeent's budget contracted in tandea; its 1935 outlays were only slightly higher than those of 1920 (see table 4). Severe austerity measures were taken. Infrastructural investments were delayed, gtaff were laid-off, salaries (including for British staff) first cut then frozen, and long-overdue educational programes were postponed (Jeffries:1938,34; Nicolson: $1969,242 \mathrm{ff}$ ), with the result that even as late as 1939 only $12 x$ of the Nigerian children of school age were receiving instruction (Colenan: $1965,126)$.

What makes this period significant for post-colonial Nigeria is not that it was an unfortunate interlude in economic history but that it marked the beginning of state intervention in the economy. The outbreak of the second horld War proved to be the catalyst for action. The colonial government shed its role of provider of infrastructure and arbiter between conflicting private interests. Even though it continued to dispense active, albeit modest, support to agriculture through technical extension services, its assunption of responsibilities for the overall managenent of the econony was of greater significance. Comodity exporting was transformed froe a private oligopoly into a public monopoly. The dearth of inportable consuner goods led to enforced savings which, however, did not accrue to producers who received prices well below those of the world arket, but to the government agencies which managed the export trade. After the war, these savings 
would form the naterial basis of abitious developnent projects: between 1946 and 1962 an altogether stunning $72 \%$ of the funds of Nigerian Development Institutions cane from connodity and regional narketing boards (Helleiner:1966,249), that is, fron surplus withheld from prisary producers.

With the outbreak of the war, the colonial governnent had to mobilize resources and to rationalize policies. Within weeks it began to assert control over the whole econosic structure, including wage ceilings, price and import controls and the marketing of exporc crops (Ekundare:1973,122). To ensure Britain's raw material requirenents as well as to avoid inflationary pressures resulting from increased demand, a produce control board was set up to operate the entire export system. Cocoa was the first connodity subjected to statutory narketing; cotton, groundnuts, and palm products were included in 1942 with the creation of the West African Produce Control Board. Opting for a path of least resistance, the board designated only established expatriate firms as its buying agents. Each firm's share of trade was determined on a quota basis according to past perforance which effectively excluded the small group of African exporters (Colean: 1965,84). The main beneficiaries of the statutory nonopolies were thus the large expatriate firms because official patronage - tellingly exemplified by the fact that no company income tax existed until 1939 (Liedhola:1970, 56) - very openly confirmed and extended the pooling arrangenents which they had operated previously.

Yet not only Nigerian traders were negatively affected. Producer revenues were low too: in 1940 the prices for the key connodities cocoa 
were pushed - and for paln products they fell - far below their 1900 level, while groundnuts barely canaged to saintain it (see table 4). As a consequence, imports in 1940 were only half those of even the crisis year 1930 and barely $40 \%$ of the level achieved in 1920 (see table 6). Moreover, what little Nigerians earned during the war could no longer be used to purchase inported consuner goods. On the one hand, alternative supply sources were blocked by currency restrictions while, on the other, British industry had been entirely redirected towards the war effort and could not therefore neet whatever effective demand there remained in Nigeria (Hopkins:1973,266). Indeed, the low prices fixed by the boards and the unavailability of imports anounted, in effect, to a forced loan in support of the British war econony. Policies such as these engendered ill will anong a wide spectrun of $\mathrm{Ni}-$ gerians - farmers, traders, salaried employees and professionals - all of whom depended on the export econony. The wartine change from economic neutrality to statism brought into ever sharper relief the institutional focus for their grievances, whether real or inaginary. For instance, one side-effect of the wartine developments was the emergence of a minuscule yet symbolically significant inport-8ubstituting industrial sector which appeared to be the conclusive proof of the colonial government's conspiracy against the Nigerian population. In short, the colonial governaent cane to be seen as an obstacle to developaent because of its failure to decisively nove in three ajor areas - education, Nigerianization and industrialization. It was these denands which fundamentally shaped the nature not only of the opposition to British rule but eventually the nature of the post-colonial state. 


\section{d) Politice before Independence}

The end of the second World War narked the beginning of an era of momentous changes for Nigeria: unprecedented econonic expansion, the Nigerianization of the colonial government culminating in political independence, and the collapse only six years later of the parliamentary systen of governzent in a military coup which was followed six months later by a counter-coup. Moreover, wineral oil had, by 1965 , becone the most prominent export connodity, thus decisively shifting the State's resource base fron ag:icultural surplus to mineral rent. It was these latter events, not the earlier attainuent of sovereignty which proved to be a caesura in an otherwise continuous, if knotty, phase of developnent. In 1945, an unprecedented export/inport boon set in. Until 1960, for a change, prices developed in Nigeria's favour, at least doubling (for rubber), wore typically tripling (pala products and gr sundnuts) and, in the case of cocoa, going up almost sixfold (see table 4); thus, the value of Nigeria's exports between 1945 and 1960 increased by over $650 x$ while their volune not even had to double (see tables 1 and 6 ). Aided by unusually favourable teras of trade, $31 \mathrm{Ni}$ geria managed to aintain her traditionally positive balance of trade until the aid-fifties. On the down side, this boon fuelled a dangerous

31 "By the vid-fifties the connodity teras of trade (ratio of export and import price indices) had shifted sone 60 per cent in Nigeria's favour conpared with the inmediate prewar years; even when the trend was broken at the beginning of the 'sixties, these terms renained better than at any tine in the 35 -year period between 1915 and 1950 . ... by the early 'sixties Nigerian purchasing power over inports was about three tines what it had been both innediately before and after the second world war" (Rimer:1978,146). 
illusion about iminent mass welfare and supported conspiratorial notions of previous colonial exploitation.

The Marketing Board systen, retained after the war, ostensibly to stabilize the incomes of export-crop producers by disconnecting conmodity prices from the world narket, became a revenue-generating instrument to fund public policy. Prices paid to producers during the 1950 s and 1960 s were between one third (for cocos and groundnuts) and two thirds (for palm products and cotton) below the world aarket prices (see table 5). Government budgets swelled accordingly: revenues increased six-fold between 1945 and 1960 and spending by factor of ten (see table 6). In theory at least, the problens for policy making were thus no longer the oppressive scarcity of funds which had been typical for the previous decades. The handicaps now were two intense political conflicts: on the one hand, the colonial government and the nationalist politicians negotiated the modalities and the timetable for independence; on the other hand, the various factions of the nationalist novement quarrelled over the distribution of political power inside the Nigerian Federation and, intimately related, over the regional allocation of resources.

After the British Labour government, incidentally with some reluctance, had accepted as inevitable the eventual dissolution of the British colonial eapire, ${ }^{32}$ the years prior to 1960 were characterized

32 Unsurprisingly, it received little recognition for this change of course. Instead, the post-independence Minister for Econonic Developnent, Waziri Ibrahia, declared to a cheering House that "God has now brought about an era when even we in Nigeria who are so weak, can talk and do what we like. Credit should not be given to anybody in world for the preaent state of things in this country, or for our freedon. It is an act of God for, left with the imperialists, they would never have allowed us to be free. There is no doubt 
by the defensively undertaken rear-guard operations on the part of the colonial government and by increasingly energetic camaitus on the part of the nationalist novenent - itself breaking up into various refional components - for Nigerianization, self-government and independence. Amidst political tureoil, exenplified by three constitutions in the short time-span of twelve years, the colonial governnent took charge of the domestic econony. Progress in econonic and social developent cane to we seen as a precondition for political freedon. Yet as the colonial government could not or would not identify viable internal forces to carry out this crash prograne, the bureaucratically obvious solution was to have the State engineer it. It was of course a paradox, both curious and eninently consequential, that Britain, a liberal capitalist society, should have done everything to discourage the energence of an indigenous comercial niddle class, and then would establish a quite formidable bureaucratic machinery to nake up for past onissions. As will be shown, this therapy was not any better for Nigeria's econoaic well-being, and probably worse, than the ills it was neant to cure. Centre stage in the post-war years was accorded to political issues in a process which avalanche-like thundered towards independence. Adversaries were the colonial government on the one aide and Nigerian nationalists, nostly Southern urban professionals, on the other. This European or American educated ninority had absorbed western ideas such as democracy, national self-determination and state-driven econonic development. Under the Indirect Rule systen they had largely been ex-

about that" (Hansard:1961,79). 
cluded from any meaningful role in the government of the country. By default, they had been relegated to organizing extra-parliamentary political novenents and to publishing newspapers

ten times nore scurrilous, more seditious, and sore extrene than the sober and more dignified weeklies which had aroused Lugard's wrath during the first World War. The British official took pride of place in the denonology of this press, as a vicious oppressor, a racialist, living a life of ease and luxury, an eneny of freedon, a ruthless inperialist exploiter, and worse (Nicolson: 1969,247 ).

Nnandi Azikiwe, an Anerican educated Ibo and Obafeni Awolowo, a British educated Yoruba, were leading nenbers of the Nigerian Youth Movement, the radical nationalist organization which had been founded in 1936. In 1937, Azikiwe had been jailed, though not finally been convicted of sedition, for his writings as the editor of the "African Morning Post" in Accra. After his release in 1938 and unbowed, he began publishing the West African Pilot in Lagos, a paper which was soon to become "the bane of the colonial adainistration" (Crowder:1981,472). The anti-colonial nationalise was populist and socialist in outlook. The movement's leaders identified thenselves with the masses and claimed to represent their interests against the foreign rulers, political and commercial. Socialisn was the natural ideology under the circunstances: combining the advocacy of governmental initiative with the desire for social equality it was the precise antidote to a laissez faire expatriate government under whose protection big foreign business could siphon off huge profits and discrininate against indigenous businessnen, just as the colonial government discrininated against indigenous professionals. Beyond representing a reflexive opposition to eve- 
rything Britain stood for, socialisa was not a coherently franed political philosophy. 33 Nevertheless, in strict losical deduction fros the prenises of populisa/socialise, the key to solving the problens afflicting Nigeria, was for the nationalists to take over sovernment, "the one powerful society-changing organizational device that [they] knew" (0'Connell:1966,132). After independence, anti-capitalist agitation, the continuation of the anti-colonial strugsle by other neana as it were, served to energize the parlianentary opposition. Itg leader, Chief Awolowo, called for

the nationalisation of basic industries and commercial undertakings of vital inportance to the econony of Nigeria.

33 At a 1962 conference on African Socialisa, held in Senegal, the Nigerian representative suggested that "Socialisn has been called a return to African-ness, but we would prefer to call it the essence of African-ness" (Dr. Biobaku, Pro Vice-Chancellor of the University of Ife, cited in WA No. 2378, 29 Decenber 1962, 1449). A greater degree of philosophical prasnatisn was revealed by members of a 1962 NCNC convention who defined "Socialisn [as] the right of everyone to start his own business" (reported by Proehl:1965,231). Aluko synthesizes the two positions with the quite hardy undercurrent of xenophobia in post-independence Nigeria. An indigenous businesanan, portrayed as ruthless, crooked and incompetent, converses with a cabinet ninister: "I won this contract, beating fourteen other bidders in the contest. Your European friends failed woefully this time.' 'They too conpeted?' 'Ask your colleagues in the Cabinet in the North. The Ministers up there are now seeing what we've been telling the all these years. The days of the white capitalist are numbered, Minister'" (Aluko:1977,100). The tradition of progranatic eclecticisa, populisn and voluntarisn was continued by the "New Nigerian Socialist Party" launched in April 1982. Its ail was "to propagate and execute socialist ideology in all its forns; to cure with absolute finality and with perannence all the fundamental ills or diseases of our Nigerian aciety [... auch as] 1. The Ban of Bribery, Corruption and Nepotisa; 2. The Problen of Deatitutes and of Lunatics who roan about our streets sonetines in absolute nudity; 3. The Problea of Environnental Beauty and Sanitation, and of Maintenance; 4. The General Break Down of Public Utilities particularly of NEPA lieht and pipe borne water; 5. The General Break Down of Religious and Moral Education; 6 . Indiscipline and Inefficiency particularly in civil service" (Advertisenent published in Daily Tines (Lagos), 23 April 1982, 23). The "Political Bureau," an official connission established by President Babangida in 1986, presented a like analysis and reconnended socialisn as a cure for Nigeria's llls (Nigeria: $1987,67-68$ ). 
... Nationalian is the cornerstone of the politico-econonic systea called socialisa. We are advocatins nationalisation, therefore, because we are convinced that, in contenporary Nigerian circunstances, its adoption is both prageatic and in the best interest of our people and Nation. [In particular he denanded that the federal soverneent] step in ... and national ise any businese undertakins which Nigerian entrepreneurs are unable to buy out" (Hanard: 1961,348 ).

Even a decade after independence, Chief Awolowo, as Chancellor of the University of Ife and as Federal Conalasioner of Finance, advocated socialism

as the only policy suitable for the advancenent of the econonic prosperity and social well being of Nicerians, without exception or discrinination. Socialisn can elininate inter-state inequality as well as inter-personal inequality in Nigeria by giving the people equal access to gain full eaployaent, education and health (cited in ARBp:3/1970, 1649 ; other illustrations are provided below, p. 421 ).

Capitalisn generally and foreign conpanies specifically were to remain for quite sone time the whipping boys, or rather the straw nen, conveniently at the service of the state class. They were useful to deflect criticisa, to justify state intervention or to reward clients as well as nenbers of the state class itself. The advice given by $H . A$. Lewis to the Ghanaian government was of equal pertinence for its Nigerian counterpart. It was ignored by both.

Whatever the foreigner's faults may be, the fact renains that the Gold Coast needs hin nore than he the Gold Coast. Foreign capital does not need the Gold coast. If all the foreign capital now in the Gold coast were driven out, it would have little difficulty in being absorbed elsewhere, for the sieple reason that the Gold Coast is a very snall place relatively to the world as a whole. ... The Gold Coast cannot gain by creating an atmosphere towards foreign capital which nakes foreigners reluctant to inveat in the Gold Coast (Lewis: 1953,9). 
Beginning in 1948, the Awolowo/Asikiwe generation, that is, the radicalized, westernized, intellectual elite, increasingly noved into State positions (political as well as bureaucratic), and its notives and policies began decisively to shape the transition to independence and, later, the post-colonial state. It was relatively snall in size, not econonically powerful, yet as vocal as hostile in its opposition to colonialise and therefore well placed to nobilize other disaffected groups. The class nature of this intellectual elite was discussed above in some detail (pp. 257ff) because, so ay contention, the sociology of the derivative middle class provides the key to understanding the developments in Nigeria during the $1950 \mathrm{~s}$ and beyond. Its first goal was to replace the British at every level of the adninistration, particularly however, at the comanding heights of government. Nkrumah's often quoted credo "Seek ye first the political kingdom, and all shall be added unto you" concisely captures the sentivents of a intensely frustrated westernized elite which hitherto had been relegated to the political off-side. The slow pace of econonic development, from their perspective, was not matter of hard choices under circunstances of scarce resources, but conclusive proof of a racist conspiracy. The solution, entirely voluntaristically, lay in gaining control. They, "the enlightened few, were not only destined by right to rule, but by an act of will they could create an independent Nigerian nation which would allow thea, in the words of their prophet Nnandi Azikiwe, to walk 'majestically with the other races of mankind'" (Colenan:1965,410).

Yet it soon ewerged that their nationalisn had less been based on a sense of Nigerian unity than on a profoundly suspicious distrust of 
the British and a passionate belief in tue idea of progress, especially economic progress which, so they were convinced, had been withheld by the colonial government. Once it became incontrovertible that the days of colonialism were numb, red, the nationalists' front, whose unity had been fragile at the best of tines, began to dissolve. There was still agreement on the principles of self-government and independence, yet apprehension mouited when the possibility crystallized that this aight mean - in the case of the North - trading Southern donination for British dorination, or - in the case of the West or the East - donination by the other. In the end, the nationalists sacrificed their earlier ohjective, national unity, for the nore easily obtainable goal of regional self-government (cf. Cole:1962,45ff). Indeed, the educated elite which had spearheaded the anti-colonial struggle now turned out to be nationalist only in the zense of an abstract dichotony setting Nigerian nationalism agains: British colonialige. As soon as that battle seemed won, Nigerian unity acquired the quality of a British conspiracy.

Since the amalganation all the efforts of the British Government have been devoted to developing the country into a unitary state. This is patently impossible; and it is astonishing that a nation with wide political experience like Great Britain fell into such a palpable error. ... Nigeria is not a nation. It is a nere geographical expression. There are no "Nigerians" in the sane sense as there are "English", "Welsh", or "French". The word "Nigerian" is merely a distinctive appellation to distinguish those who live within the boundaries of Nigeria fron those who do not (Awolowo: 1947, 47-48).

Chief Awolowo's sentiments were expressed sinilarly by his colleagues turned opponents, the Easterner Azikiwe and the Northerner 
Tafawa Balewa. The great Nigcrian novelist Chinua Achebe traces nany of Nigeria's contenporary problens to the wanton and selfish recourse to tribalisn and regionalise of the intellectual elite in the preindependence era (Ache: :1983). Regionalise was, as the colonial government learned to appreciate quickly in the innediate post-war period, attractive for its very own reasons: in the classical divide-and-rule tradition it promised to prevent the possible seizure of central power by the educated elite.

Regionalization and Nigerianization increasingly becane the doninant themes of three consecutive constitutional revisions between 1946 and 1954 (Crowder:1980,224-236). The Richards constitution of 1946 (named after the Governor of the day, Sir Arthur Richards) atill ained at maintaining Nigeria's unitary character which, pararoxically but realistically, necessitated decentralization only because of the North's apprehension regarding Southern domination (Hanilton:1962,37). It did not yet entail any provision for policy co-deteraination by Nigerians, but only their greater participation in the discussion of policies. The fora were the existing national Legislative Council and three newly created regional assemblies which were to consider and advise on natters referred to them by the Governor. An extraordinary insensitivity set the stage for virulent confrontation in the Legislative Council: no change had been made in the number - established in 1923 - of directl. elected nembers (see above, p. 373) while vested European interests (banking, shipping, industry and aining) continued to be represented (Blitz:1965,3-4). The unofficial Nigerian majority reacted by naking extensive use of the new constitution's financial provisions which gave 
the Legislative Council dilatory powers over government spending.

Withholding agreement on spending authorizations was thus the only lever available to Nigerian representatives.

Divorced fron executive responsibility, this was nerely a power to oppose, delay, and obstruct official proposa18 , and to deny officials the men, money, and naterials needed for the officially prepared ten-year prograne of development. The elenent in the legislature hostile as a natter of course and of principle to officialdon was the NCNC. ... There was a good deal of exasperation and frustration on both sides. For the officials, with nemories of the days befo:e the war when progress had been linited chiefly by lack of mey rather than by lack of men to fill the establishment ... it was a strange turn of events, now that more noney was available, to find the progress of development held up by shortage of wen and of materiais, and by unofficials' disagreenent with them over their propused allocation of funds. ... For the unofficials, with bitter feelings about the inadequacy of services by officialdom in the past, and with deeply ingrained suspicions that Nigeria was being run by officials for their own benefit, it was anathea to be associated with neasures to increase the nuabers and to improve the conditions of British officials (Nicolson: 1969,250 ff).

One result was that at the end of 1953 , of the 5,000 established senior service positions approxinately 3,300 were held by expatriates, 800 by Nigerians, and 900 were vacant (World Bank:1955,23). This stalewate was tackled with the 1951 Macpherson constitution and, nore pronouncedly still, in its 1954 revision, the Lyttleton constitution (named after the then Colonial Secretary) which fornally recreated Nigeria as a Federation. In practice, the State structure was alnost confederal which, arguably, was intended as a safeguard against the nore substantial power-sharing arrangenents the constitution also entailed, In a Westainster-style parliamentary system, quasi responsible 
federal and regional asseablies had legislative authority while sone executive powers rested with Nigerian ainisters at the federal level and in the three regions (Adanolekun:1986,52). Until 1957, the Governor-General at the Federation's centre and the Lieutenant-Governors in the regions still possessed veto-power over policy; thereafter their role becane ceremonial and advisory. With the effective shift of legislative and executive powers to Nigerian politicians, antagonisns shifted away, temporarily, from the "inperialist oppressor" towards competition for resources between regions. Also by 1957 a robust, ethnically based party had won elections in each of the regions. The Nigerian Federation, lacking a strong centre, now revealed itself as a balance of power system in which the colonial government, albeit with decreasing effectiveness, served as a stabilizing force.

Regionalization meanwhile was conpleted by breaking up the fornerly unitary civil service and by replacing it with four civil services, one federal and three regional (cf, Kirk-Greene:1965,221). This atomization further eroded British hegenony and accelerated the politicization of the public bureaucracy. While the colonial adninistration had been an instrument of British interests, the civil service now became an instrument of internal political forces whose interests were less directed towards national developnent than towards regional preeminence. With political power-gharing between the Britigh colonial government and Nigerian politicians acconplished, the renaining irritant, namely the "expatriate" conposition of the civil service, was being speedily addressed. Earlier pressures had, in 1945, resulted in the abolition of the distinction between "European" and "African" posts 
and their replacenent by the categories of "Senior Service" and "Junior Service" (Fletcher:1970,143). Continued agitation on the part of the educated elite led in 1948 to the creation of conission (Nnandi Azikiwe was a prominent aeaber) which was to advise the Governor about the recruitment and training of Nigerians for senior posts in the Government. Its recomendation that no non-Nigerian should be recruited for any Government post except where no suitable and qualified Nigerian was available, was accepted and inplenented forthwith (Colenan:1965,313). A further and equally decisive step in consolidating the aaterial base of the emerging state class was taken in 1951 when the Harragin Salaries Comission (consisting of British officials) established the conditions for the Nigerian Civil Service. These were essentially the gaintenance of the privileges, such as salaries and car and education allowances, which had been enjoyed by expatriate officials (Nafziger: 1977,45). The macroecononic side-effects of this egalitarian measure were aentioned earlier (see pp. $115 \mathrm{ff}$ ). Since pressures to reduce the income disparities could be accomodated more easily by raising the pay scales at the botton, intra-bureaucratic pay differentials were narrowed considerably, if at a high price for the econony: not only did general administrative costs increase substantially but, equally if not more importantly, the income differential between the econony's formal and informal sectors widened.

Government discrisination against farmers in favour of urban workers weant that the gap had been widened by reducing fa: a incones as well as by raising urban wages. "If we take the average of 1950-52 as a base, the prices paid to southern farners by the Marketing Boards 
went down from 100 to 73 in 1961-63, while the ainiaun wage paid by the Federal government to unskilled labourers over the sane period went up from 100 to 297" (Lewis:1967,42). Put differently, "real wages in the organized sector [between 1953 and 1965] have increased at more than twice the rate of per capita GDP" (Kilby:1969,281). Cospared with the great aajority of Nigeria's population, fornal sector workers whose incones and benefits moved (and move) in convoy at the pace set by government for its own staff, becane a highly privileged ninority. The bureacratic state is instrumental in fuelling and perpetuating this disparity. Like in other African countries, salaries for top civil servants (and because public pay scales are staggered, for all public employees and, by extension, for the modern econony's private sector) in Nigeria were/are extraordinarily high in relation to per capita incone. For example, in 1963-1964 the ratio was 130:1 in Nigeria, while in the United States it was/is about 7:1 (Duignan:1986,18). By 1982, this ratio in Nigeria had dropped to $35: 1$ (World Bank:1982, i; Nigeria: 1982a,720; my calculation).34

In 1948, the senior service numbered 2,035 expatriates and 172 Nigerians, i.e. about 8x; by 1954 the senior service had, nostly because of the creation of three regions, nore than doubled to 5,137 posts, of which 824 (16x) were held by Nigerians (Kirk-Greene:1965,220-

34 Unfortunately, this says nore about the statistical increase of GDP than about its distribution. After 1970, per capita GDP figures are grossly nisleading because the oil revenue accruing to the federal sovernment nade thea a mere statistical measure without significance for mean incones. Also, published pay scales renain silent about legal perquisites (noninal rent, car education allowances etc) and illicit opportunitles. Even 80 , the ratio between a statistically inflated per capita GDP and public service pay has been since pre-independence days, and reasins today, hugely inbalanced. 
221). By 1955, because of unattractive reauneration and the prevailing uncertainties, the colonial governoent was hard pressed to find British officers; between 1954 and 1956 not "one single adninistrative recruit had been obtained for Nigeria" (Jeffries:1972,92) and the vacancy rate for adninistrative officers in the whole Nest African region stood at staggering $83 x$ (ibid.,82). By 1958, there were 31,777 Nigerian and other West African officers on the payroll of the federal governnent; the number of British officers, all of whon senior, had dropped to 1,514 (Kimble:1960a,356). At independence in 1960, Nigerians held 62x of all senior service posts: $80 x$ in the Eastern Region, $82 x$ in the Western Region, $28 x$ in the Northern Region, and $57 x$ in the Federal Government (Nwanwene:1970a,201). Anti-colonial resentment led to sose synbolically gratifying but ultimately self-defeating nanoeuvres. For example, on the first day of independence, the Western Region Government announced that "the retention of overseas officers in key posts in the Public Services would be inconsistent with the dignity and interests of an independent Nigeria" and inediately replaced the nine overgeas Permanent Secretaries then in office by Nigerians (Cole:1962,51). However, this unceremonious swap remained the exception in effecting the desired cast change in the Public Service; the nornal process ras to increase its size. In the six years prior to independence, the public service "had been doubled, and the nubber of Nigerians in senior posts had been increased almost tenfold. Sone of this increase was due to planned expansion ... But nuch of it was haphazard growth due to the weakness of financial control over establishments. A part of the increase was due to panic measures to create scores of supernunerary su- 
perscale posts for Nigerians ..." (Nicolson:1969,297). After independence the growth of the civil services continued unabated. The federal senior civil service which had conprised 1,711 officers in 1954, wore than doubled to 4,403 in 1962 , and grew by another $40 \%$ to 6,108 in 1965 (Dean: 1972,284$)$.

In the Northern Region, Nigerianization or, as it was called there, Northernization, proceeded at a slower pace. As was pointed out before, British colonial policy had consistently ained at preserving the Muslim North and at limiting its exposure to nodernity. This accounts for the absence of an aggrieved westernized elite and of nationalist groupings before the 1950s. "Few educated northerners were taught, or felt inclined, to ape the white man; hence the psychology of revolt sieming from frustration over the denial of equal social status which was such a significant factor anong educated southerners did not develop in the North" (Coleman:1965,355). To the contrary, Northern nationalists, even some conservative ones, were enlightened or generous enough to realize that the British conquest of the North in the early 20 th century had triggered modernizing developnents which, instead of subduing their culture had enriched it. The first pre- as well as post-independence Preaier of Northern Nigeria argued that the attainment of self-government concluded a period of both robust continuity and propitious change:

It night be called the restoration of the pre-1900 era, nodernized, polished, denocratised, refined, but not out of recognition; reconstructed, but still within the sene framework and on the same foundation; conprehensible by all and appreciated by all. The train, the car, the lorry, the aeroplane, the telephone, the hospital, the dispensary, the school, the college, the fertilizer, the hypoderaic syringe 
have transformed Othman dan Fodio's world, but the basis is still there (Be110:1962,227).

This absence of resentment vis-z-vis British colonialisa was also rooted in the nature of the Northern elite. A substantial number of Northerners who had received Western education in the interwar period were sons of titled fanilies or of high-ranking officials in the native administrations. There was no dearth of career openings, and strong social and political forces compelled them to acconnodate themselves to the status quo. Also, with one exception, no northerner went abroad for higher studies until 1945 (Coleman:1965,355). Little aggrieved, the Northern elite in the 1950s had more to fear from independence than to gain from it.

The region's general unpreparedness and the perceived hazard of Southern domination accounted for both the North's insistence on regionalization, that is, the split of the formerly unitary Civil Service, and its reluctarice concerning national independence, the emphasis being on both "national" (in its reference to Nigeria as a whole) and on "independence." The confrontation between the North and the South became openly hostile after the Premier of the Northern Region, the Sardauna of Sokoto's, historic statenent in the Federal House of Representatives. Referring to Lugard's amalgamation of the Northern and Southern Regions (see p. 350 above), he contended that the "mistake of 1914 has come to light" (Bello:1962,133).

In 1956, a Yoruba backbencher in the House of Representatives introduced a private nember's bill denanding inmediate self-governnent. The Northern representatives substituted ailder notion asking for 
self-government as soon as practicable. This led to a walk-out of Eastern and Western nebbers and to Northern neabers being booed in the streets of Lagos. The Northern Presier reports in his autobiography that secession fron the Federation was seriously contenplated ( $c$. Bello:1962,110 ff). A compromise was reached at a conference in London at which the regional parties negotiated with the British government about the nature of Nigeria's regionalisa, resource sharing and a tinetable for independence (cf. Crowder:1980,234ff). It was deterained that self government was to be offered to those regions that wanted it, but not to the federation as a whole, thus leaving it open for the North to decide for itself when it was ready. In the event, the Eastern and Western Regions becane internally self-governing in 1957, the Northern Region in March 1959 (cf. Dudley:1982,35).

The North's apprehension had extended beyond early regional selfgovernment and encompassed national independence. In 1957, just after Ghana's release into independence, imnediate independence also for $\mathrm{Ni}$ geria had once more been demanded in a motion passed by the Federal House of Representatives. After the North's objection, a compronise was reached and the date postponed by two years. The North's hesitation rested to a large extent on its inability to provide numbers of indigenous staff, commensurate with her size for regionsl and federal office (cf. Kings?ey:1963,304): in 1960 less than $1 x$ of aiddle-ranking and senior officials, 29 out of 4,398 officers were Northerners (Cole$: 1962,57)$. Thus in "Northernization" the replacement of Southerners in all posts took priority over the replacenent of expatriates in higher posts. In his aenoirs the Northern Preaier explains: 
This natter of a separate Public Service was inportant for us. As you see, it nade it possible for us to select whon we wished for our jobs here, and aade it inpossible for the Federal Government to flood us with Southern staff to the exclusion of our own people (Bello:1962,153).

Expatriates were considered haraless and disinterested workers, a transient phenomenon, while Southern Nigerians "appointed to the civil service in the North [tended] to bring wives, children, and relations and settle there, taking leases of land ... and using their official influence to infiltrate their brothers and cousins into jobs previously held by Northerners" (Nicolson:1969,292). Southern Nigerians felt doubly discriminated against because, in the Northern Region's public gervice, expatriates where given preference ${ }^{35}$ while, at the federal level, $:=$ rtherners were favoured in recruitnent. Nevertheless, nany Southern Nigerians continued to work in the North for federal parastatals because of the dearth of qualified Northerners. Their presence was deeply resented among the indigenous population and their expulsion was often threatened by Northern politicians (Ofiaja:1979,43). Within years of independence, the hostilities caused (and experienced) by Southerners ultinately led to pogroms and civil war. Before, however, the future antagonists entered into a balance-of-power alliance at the national level. In the interest of national unity - and againgt ideological and arithmetic logic - the two strongest parties, that is, the conservative (Northern) NPC and the radical (Southern) NCNC, forned a

35 The nationality distribution of officers recruited on contract basis by the Northern Region in 1961 is indicative: 67\% were British, 13\% Pakistani and 1.5x respectively Lebanese, Danish and Nigerian, i.e. non-Northerners (Kirk-Greene: 1965,232 ). 
coalition against the sallest party, the Western Action Group whose credentials were even nore radical than the NCNC's (cf. Anglin:1965, 175). Without the need for discipline isposed by a narrow nargin of seats, or by a strong opposition, the NPC/NCNC coalition was inherently unworkable since it united the two strongest parties against the weakest, rather than the two weakest against the strongest, as connon sense would have indicated.

A last constitutional conference held in London in 1958 agreed on federal elections for 1959 and for independence in 1960, provided the newly constituted Federal Parlianent would be able to pass a respective resolution; this the votes of the NPC/NCNC coalition ensured. After independence on 1 October 1960, Alhaji Abubakar Tafawa Balewa retained the office of Prime Minister which he had held since 1957 and Nnandi Azikiwe becane Governor-General of the Federation of Nigeria; in 1963, the state form was changed to a Federal Republic and Dr. Azikiwe becane its first President. Within six years of independence, the frailty of the balance of power system between the regions had been exposed. The 1962 census, upon which state representation was to be based, gave the North an absolute majority of the 53 million population and 80 was rejected by the East and West. A careful re-run the following year confirned the results and replicated the rejection (2artan with Schatz: $1983,3 \mathrm{ff})$. The events which followed led to the collapse of the nultiparty system, to the first ailitary coup d'etat and to civil war. 


\section{e) Bcononics mefore Independence}

In the post-war and pre-independence era, econonic matters were less in the liselight than political or constitutional issues. Nonetheless, they, as nuch as conflicts between the regions and the strugsle for control, are an integral elenent of the post-colonial state's foundation. The intense politicization which was typical for the contentious issues of Regionalization, Nigerianization, Northernization and national independence also affected official econonic policies. Conflicts arose over distributional questions, not over the fundamentals of econonic policy where, once sore, the concerns of the British government coincided with the interests of the energing indigenous state class. In derisive break with past policy, the colonial selffinancing imperative was given up in favour of what has been called the "developaental ethos". This reinterpretation of British trusteeship led to direct financial transfers from Britain to the colonies in the form of grants, to a pronounced welfare orientation of policy and to the assumption by governnent of responsibilities for planning, inplementing and financing of econouic change (Rimer:1978,146ff).

It was the experience during the $1930 \mathrm{~s}$ which had convinced nost Europeans, particularly however the Labour Party now governing Britain, that economic progress would require the state to take a more active role in the econony, to conprehensively plan econonic and social development and to directly engage in productive ventures (Hargreaves: $1988,86(\mathrm{f})$. Circunstances throughout the world pointed to the same conclusions. For Africans no less than for Europeans, the Soviet Union 
seened to have denonstrated that centralized econonic planning represented rationality's triunph over the anarchic narket (cf. Colenan: $1965,248 \mathrm{f})$. In Western capitalist countries, faith in the selfequilibrating economic forces had been seriously underained and state interventionist policies according to Keynesian theory were seen as a necessary conplement to the sarket, if not as its substitute (Wilson: 1977,212). Of more direct relevance to developing countries was the research conducted within the Keynesian franework in the 1940s (proninently the Harrod-Donar equation) seeking to pos culate capital-output ratios in the sense of deterwinate relationships between savings translated into increases in the capital stock and the ensuing econowic growth (Hirschman: 1981a,61; Rimer:1984,217; Stern:1989,622). Such reasoning informed even the World Bank which, in its first report on an African country, asserted that the state-led capital formation through the medium of marketing board operations "have benefited the producers of the controlled crops in seneral and the Nigerian economy in general. ... in our opinion the arketing board systee is well suited to Nigerian conditions" (World Bank:1955,86-87).

Rewarkable as such statements are from today's vantage point, then the consensus was near universal that assertive governaent intervention in the economy was both politically opportune and theoretically justified. Consequently, Nigeria's colonial government inmediately after the war began to accept - and later to clain - overall responsibility both for the delivery of material welfare and for the managenent of economic change. In an unprecedented developnent, government expenditures doubled between 1950 and 1955 , and doubled again between 1955 
and 1960 (see table 6). This trend accelerated well before indepen'ence and very much so thereafter. The idea of state intervention, like any idea, was not powerful in itself. Only because it coincided with political interests did it acquire the tremendous power it exercised in the post-independence era. In the intensely conflict-ridden situation of decolonization, regionalization and Nigerianization, investment driven development policies by necessity becane politicised because they exacerbated competition for scarce resources. Allocative decisions could no longer be taken with nationally defined, technicaleconomic optimization in aind. Instead, politicians' and parties' fortunes now depended on their skills to acquire their fair share, or more, of the available total for their clientele. ${ }^{36}$ Distributional considerations won over growth objectives which is why, despite - or arguably because of - co..siderable State involvement in the economy, success remained elusive. One of the main areas of state activity was industrialization. This thrust was entirely in line with developaent

36 In Aluko's novel, an African District Engineer, in desperation, requests a meeting with his British Director of Public Works: "I'm going to be frank with you, sir. I's rather worried about what's been going on in the last thu months. Orders from headquarters about petty contracts in the ..eld. Orders to stop vital work of maintenance of government roads and buildings because we have no funds. Now we are to embark upon the construction of Local Authority roads with government funds. Just what are we going to put forward as the economic justification for this rost? I really can't understand why we are doing it.' The Englishman's eyes were red. 'You want to know why we do what we do, young man? You want to know the econosic justification for the little village roads that we now do, Mr. George? Do not ask me. Ask him, the Honourable Alade Moses, Minister of Works. And I suppose you want to know the cost/benefit ratio too? Ask Chief Franco-John, Attorney-General and Minister of Agriculture, the real power behind the throne of your government. ... They are the reasons for doing what $I$ do. They are the econonic justification, the cost/benefit ratio. And don't ask me about the moral, young man. The pending by-election of your precious Minister - that's the noral'" (Aluko:1977,146). 
orthodoxies then as now.

For Nigerian nationalists, the argueents for industrialization tied in neatly with the general thrust for self-government. During the war when many traditional supplies of manufactured goods dried up, a whole range of small industries was created to provide building aterials, concrete, furniture, leather goods and processed foodstuffs (Crowder:1981,495). Their technical and comercial success seemed to substantiate the nationalists' charge that colonialige generally and the collusion between government and the large European trading firas specifically, had been obstructive for both developent and political independence (Ekundare:1973,358; Lawal:1987,118-119). While not sharing this diagnosis, the colonial government's prescribed therapy closely matched the demands articulated, namely heavy government involvenent in social and industrial development. In 1946, the first development plan - emphasizing social services such as health, education and water supplies - was drawn up at the request of the Colonial office. It was not an integrated progranme that assessed the needs of the country or the economy as a whole and then assigned priorities. Rather, it was an aggregation of every government department's pet projects without regard for their individual cost-benefit ratios or their cumulative effects (Okigbo:1989,31-32). Nevertheless, there were two principles enbodied in this plan, namely the direct provision of welfare by the State, and the State's responsibility for accelerating the pace of economic change through the creation of nodern industries. The industrialization strategy pursued was two-pronged: in addition to dire-tly investing in anufacturing (and in the service sector), the governments, 
federal and regional, sought to nurture private enterprise, predoninantly Nigerian and, with fluctuating emphasis, also foreign.

The Nigerian nationalists' attitude towards foreign capital oscillated between two extrenes. The noderate end was occupied by pragmatists like the Northern Preaier Alhaji Sir Ahnadu Bello who declared that Nigeria's future prosperity "will largely depend upon the confidence which the world at large places in the probity of our institutions... If there is any lack of confidence the result will inevitably be that we shall fail to obtain the foreign capital and investment which we need in order to expand our economy and develop our social services" (Bello:1962,218), or by the federal Minister of Finance, Okotie-Eboh, who, in the Fall of 1961, successfully countered Chief Awolowo's nationalization call with the motion that the House "deplores irresponsible statements on nationalisation which have recently been made in Nigeria and overseas" (Hansard:1961,351). The radical end of the spectrum was taken up by politicians like Waziri Ibrahim, the Minister for Economic Development, who lamented that Nigerians would "continue to be under the control of the imperialists and capitalists who have taken the lead in this world in econonic development" (Hansard: 1961,76$)$, who expressed doubt whether "in view of the fact that the expatriate firms and individuals who ... virtually control the economy of our country, ... we Nigerians have the necessary courage, unity, real understanding of the issue, deteraination, real desire to free our country from foreign exploitation" (Hansard:1961,201), and who declared that it was "sinply a matter of British firas exploiting the country left and right" (Hansard:1961,463). Sinilarly Chief Awolowo 
who reainded his colleagues that "last week on the floor of this honourable House, the Government, by the nouth of the hon. Minister of Economic Development, declared, without equivocation that Nigeria is under imperialist economic bondage. And so say all of us" (Hansard: 1961,347; eaphasis in original; see also above, p. 402). Even the Federal Prime Minister, Sir Abubakar Tafawa Balewa, stated that it "must be obvious that no Nigerian can be content so long as any aajor sector of the econony is controlled by foreigners" (cited in Proehl: 1965,159). Torn between suspicions of foreigners and recognition of their worth, and unable to bridge tle gap between the rhetoric of state support for industrialization and actual iaplenentation, the potential for the development of an industrial sector was only aarginally tapped. Policies took two forms: direct investment by the state and promotion of private investment.

As was mentioned earlier, the immediate postwar years were the period of Nigeria's greates prosperity which, on the one hand, raised hopes for imediate welfare gains and, on the other, inflamed rather than doused the particularist competition over distributional advantages; wore was at stake. The naterial basis of expanded governnent activity was provided by grants from Britain's newly created Colonial Development and Welfare Act (Kanarck:1967,198) as well as, nore inportantly, by the substantial increase in export volune and value which accrued to the centralized Marketing Boards or directly to the governments, federal and state, through increased taxes. The Marketing Boards for the country's export crops which, as temporary war-tine arrangements, had been established against the fierce opposition of the 
Nationalist movement, were not now abolished. The intellectual elite, its goal of self-government within sight, recognized their value as revenue generators. They concurred with the colonial governnent not only to maintain them but to convert then fron price-stabilizing agencies - which they arguably never really were (cf. Bauer:1963) - to ir.struments of fiscal policy (Ehrlich:1973,662ff; Idachaba and Ayoola: 1991,285) as well as, inportantly, financiers of political agendas and parties. 37

The Action Group had won the Western Nigeria Regional election of 1954 on a platform of lavish development expenditures, notably for health and education. Upon assuming office, the government headed by Chief Awolowo realized that existing resources could cover less than half of the promises made. "Where would the required money come from? That was the question. And it was a question which had to be tackled with speed and success, if we were to redeen our pronises to the electorate" (Awolowo:1960,273). Even though the anti-tax NCNC and independent candidates won $65 x$ (23 seats) in the Novenber 1954 federal elections and the Action Group only $35 \%$ (19 seats), "the NCNC's renewed demand that we should resign because of the results was ignored, and we pressed on with our schenes. We also inposed a purchase tax on cocoa, and on oil palm produce" (ibid.,276). Then, in a fine exercise of po-

37 Most notorious was the National Investnent and Properties Conpany founded and controlled by Chief Awolowo and other Action Group (AG) politicians in 1958. An official connission of Inquiry established that its wain function was to act as front for the AG. In 1960 it $801 d$, for 4850,000 , alnost worthless land to the AG controlled Western Region government, and between 1958 and 1962 , it served as a conduit for over 84 villion fros the Western Region Marketing Board into the AG treasury (Nigeria:1962, vol4,1-2). 
litical nanoeuvering, the Eastern and Western Preniers managed to wrest control of the marketing boards from the Federal Government. The previously national boards, organized along comodity lines, were transformed into multi-connodity boards under the control of the three regions. Their reserves and revenues were shared according to the principle of derivation: "an accunulated reserve of over 234 million was transferred to the Western Region, and as a result of the latter our revenue rose from 26.39 million in $1953-1954$ to 13.20 aillion in 19541953. ... Since the introduction of these financial neasures, our revenue has been on a steady increase" (ibid.,276). ${ }^{38}$

Until that time, 1954, the national boards had acquired enormous reserves because since 1939 for cocoa (or since 1942 for all other crops) direct producers had "received barely more than one-half of the net sales proceeds. The difference was taken up in part by the surpluses of the marketing boards and in part by export duties" (Baver: $1971,373)$. The Marketing Boards profits of $\$ 87$ million, realized since 1947 (Annual Reports of Marketing Boards), were sore than the principal source of government revenue (export/import duties) had earned, which meant that the cost of the state-engineered development neasures were downloaded on the producers of export crops. After their regionaliza-

${ }^{38}$ A radical critic laments that, against all the evidence, the concept of narketing boards (i.e. the need for the state to promote "orderly narketing" and to protect the peasantry from exploitative middlemen and noneylenders), "maintains a strong appeal for bureavcrats, technocrats and, regrettably, many socialists. Socialists have no business defending or reforming such exploitative institutions. De jure state nonopolies ... create de facto monopolies for favoured and protected traders and the opportunities for profitable collusion between businesseen and officials, civil, police and ailitary. Against such corrupt institutions and nonopolist arrangenents, oocialists should support free trade" (Willians:1985,13; enphasis in original). 
tion, the boards matured into important econosic actors in their own right and, lying outside the civil service and its procedural roles, they became conspicuous focal points for patronage and spoils. Had they previously passed on the bulk of their profits to the Developnent Corporations, the government agencies charged with development policies, they now entered into direct competition with then by beginning to supply funds in the forn of grants and loans to the regional governments, by acquiring equity in and offering loans to private companies and by purchasing government securities, Nigerian and British (Helleiner: 1970,133$)$.

Rather than concentrating resources and harmonizing strategies, in addition to the Marketing Boards other State branches began to invest heavily in private companies. Between 1955 and 1959 , each of the regions had established Development or Finance Corporations whose official mandate was to pursue vigorous industrialization projects, in lieu as it were of the as yet unable or unwilling private sector. All investments, so the claim, were held "'as a public trust,' until such time as their citizens can purchase the equity shares. Actually, the decision to transfer the interests to the public eventually does not appear to have been made, even though the government officials pay lip service to the stated policy" (Sokolski:1965,175-176). Equally deplorable, the Development Corporations' investments proved pari passu unprofitable and not particularly catalytic for wider developaental purposes. After a scrupulous account of the business practices of these parastatals, such as investments in real estate concerns and banks, all with connections to either the Action Party in the Western Region or 
the NCNC in the Eastern Region - even the sympathetic Helleiner adnits the institutions' gross inproprieties and carelessness in these investments (cf. Helleiner: 1970,138 ). The operating terns of reference of these parastatals were, perhaps intentionally, vague. ${ }^{30}$ Helleiner's tendency to imply an unlikely degree of governnental rationality leads him to suggest that fron "a developnental point of view it is less a matter for concern that ethical standards were not maintained in these instances than that these funds aight have been allocated wore rationally" (Helleiner:1970,135). Such a rather narrowly technocratic perspective obstructs the view on the long-tern and structural debilities (social, political and economic ${ }^{40}$ ) which result froa centralization and politicization of economic decision-making in the absence of effective countervailing pressures.

39 Under Western Region Law 9 of 1955, as anended by Law No 4 of 1956, the Finance Corporation was authorised to aake "advances [i.e. both loans and investments] to any person [including corporate bodies] ... for the pronotion of projects which appear to it calculated to further the econonic developnent of the Region and in particular the development of agricultural, industrial or commercial enterprises in the Region" Western Region of Nigeria, Legislation of the Western Region of Nigeria, 1955 and 1956 (Ibadan: 1955 \& 1956), cited in Baratz: 1964,60 ).

10 It could thus happen that a regional government, blindly pursuing its interests, actively frustrated econonic developaent. A case in point was the vigorous obstruction during the 1950 s of local groundnut processing plants which "have had their peanut purchases restricted by the Northern Regional Government anxious to retain its pre-eninent place in the world peanut markets, upon which so large a part of the country's revenue depends" (R.J. Harrison, cited in Kimble: 1960,377 ). Ironically, by the late 1970s, no longer dependent on the revenues of agricultural exports, governent priorities had changed, not however its interventionist reflexes. The export of groundnuts was now banned "in an effort to secure adequate supplies of raw naterials for the local crushing industry at prices the industrialists could afford" (Bates:1981, 26). 
An empirical investigation of the investment decisions taken by the Western Region Finance Corporation in the late $1950 \mathrm{~s}$ and early $1960 \mathrm{~s}$ concluded that four of the five companies invested in were neither profitable at the tine of their acquisition, nor did they pronise to be so in future. The fifth, a hotel, was profitable but its acquigition at inflated cost was undertaken with undue haste to preenpt private investors. ${ }^{41}$ The developmental value of funding the specific projects (two car dealerships, a boatyard, a hotel and an insurance conpany) was also questionable (Nigeria:1962,passiv; Baratz:1964,60ff). An official investigation of the Northern Nigeria Developaent Organization's investment decisions found that between 1964 and 1966 \&2.4 million had been spent to acquire assets in a number of firas. Only seven out of the thirty-nine projects analyzed were judged successful or potentially successful (Northern Nigeria:1966,2 47). In both cases, scarce public funds were used to finance activities which could just as well have been, and in fact were, performed by efficient private enterprises. Also, by confusing profitability (even without achieving it) with developmental merit, it was overlooked that one of the ostensible reasons for governmental involvement in development was to invest in

41 W. A. Lewis in his report on industrialization in the Gold Coast warned against public investme.t in productive enterprise as a profound misuse of scarce resources. Governments "need all the money that they can raise ... for the more urgent purpose of expanding the public services. This purpose is more urgent in a double sense. It is more urgent because the expansion of the public services is necessary if other econonic activities are to be developed, so that a government is likely to contribute nore to development if it expands the public services generally than if it uses the sane noney to build a factory. And it is more urgent also in the sense that no one but the governnent can expand the public services, whereas if the governeent does not build factories, others will" (Lewis:1953,9). 
comercially unprofitable (and therefore unattractive for private capital) but socially or developmentally beneficial projects, especially in the realn of public and of capital soods. 12 That scarce funds - 896 aillion ( $\$ 170$ ailion) or $14 x$ of the first national Developnent Plan's public investment prograsne (Asiodu:1967,162) - were invested in light consumer goods industries and earning negative returns (Kilby:1969,168) was more than sad irony, given that their ostensible purpose was development; it was an indictment. What makes the actions of these corporations noteworthy was not at all their singularity nor the incidence of mismanagement, but the depressing circunstance that they were representative for the whole spectrue of the Nigerian State's direct involvement in the econony's productive sector. 43 "Por reasons having to do with political abuse of the corporations, their rather narrow profitability orientation, and Nigeria's liaited managerial capacity, virtually none of the undertakings were profitable and few could be called successful by any econonic standard" (Schatz:1977,6; see also Stolper: 1966,284-294; Nigeria:1962,passin; Nigeria:1970,76).

Confiraing this analysis, a comission of inquiry blaned the problems on political interference combined with low degrees of ac-

42 My argument, of course, follows Keynes' advice, viz. that the "nost important Agenda of the State relates not to those activities which private individuals are already fulfilling, but to those functions which fall outside the sphere of the individual, to those decisions which are aade by no one if the State does not nake thea" (Keynes:1972,291; enphases in original).

13 A World Bank mission concluded that in 1967 publicly owned enterprises accounted for $18 x$ of total paid-up capital, alwost $6 \%$ of total eaploynent yet only for $0.7 \%$ of large-scale value-added in 1967, "indicating the linited success of the public sector anufacturing ventures. Few of these ventures are prof itable, largely because of misnanagenent" (World Bank:1974,82). 
countability and poor managenent (Nigeria: 1967). Regarding aanagerial inadequacies in state enterprises, these have been described in draantic terms by several Nigerian acadenic observers, one of whon wrote that the reasons for the poor perforance of the state-owned sector could be seen "in the over centralization of authority ... inspired by sheer love of power" (Nigerian Econonic Society:1974,125). Another located the dilemma "in unwise policy decisions; in day to day ineptness in running the enterprises; in illicit government transfer paynents in construction and purchase contracts and through every other inaginable channel; in the use of contractor finance and suppliers' credits to finance the venality of state officials; and in overburdened and unrealistic capital structures" (ibid.,30). Yet nismanagenent was but an epiphenomenon of the emerging bureaucratic node of production, the foundation for which was thus being laid in the waning days of colonialism.

It is with the benefit of hindsight that we can view Nigerian parastatals as a developmental cul-de-sac. The reasons for this rejection are found in the very same fundanental impasse which parastatals were intended to overcone, nanely the absence of atructures capable of generating and supporting economic growth or even developnent. Bureaucratically organized parastatals established when and as they were in Nigeria almost by necessity had weak internal controls, yet the possibility for misuse of funds was only the nost obvious hazard. Their most serious pitfall was their generally dislocating effect on socioeconomic development. By strengthening unaccountable state apparatuses, the naterial basis was created for the energence of a state class 
which, unsurprisingly, began to view econonic, especially industrial activity as a sinecure instead as a way to create seneral wealth. Moreover, for econonic actors outside the state, aspiring entrepreneurs for instance, it becane a natural reflex to show atrong distaste for assuming risks as well as to avold setting up those enterprises necessary for a productive locsl econony, as lons as they could depend on the State for contracts or protection. An iaportant plank of the colonial State's development strategy, thus, perversely underained the emergence of entrepreneurship, that is, "the perception of investment opportunities and transforeation into actual investeents" (Hirschnan: 1961,44 ) or the willingness to risk available surplus by investing it in productive activities. What was encouraged instead, was rent-seeking.

The colonial government's investment promotion policy began in 1946 with the establishment of a Department of Comerce and Industry. Its mandate was to accelerate industrial developnent with a two-pronged strategy: to assist existing local industries and attract new ones, but also to "participate in such econonic improvenents and developents as may be decided upon" (Nicolson:1969,265). Between 1952 and 1958, a whole series of fiscal incentives was enployed. The first was the "Aid to Pioneer Industries Act" which afforded anong other benefits, relief from the payment of incone tax on profits for conpanies which were engaged in "pioneer industries" for up to five years. To obtain pioneer status, a conpany had to apply to the government and successfully argue that the proposed industry would be beneficial to the Nigerian econony, that it did not yet exist in Nigeria or if 80 only on an inadequate 
scale (cf. Adedeji:1969,203-204; Munnery:1968,6-8; Phillips:1967;

Sokolski:1965,196-198; Stolper:1966,305). Cognizant of the pitfalis of overregulation, a World Bank aission to Nigeria had sugsested in 1953

that government should exercise its restrictive powers

in the nost liberal nanner [because] if industrialization through private enterprise is desired as a matter of policy, then unless it clearly appears that a particular industry would be harnful to the country, we susgest that is "expedient in the public interest" [as required by the legislation] to encourage every new industry and every existing industry not yet sufficiently active in Nigeria for which private capital is available (World Bank:1955,359).

This advice was not heeded. After two years, only three certificates had been awarded and until 1966 not more than 140 (Asiodu:1967, 163). Approvals, on occasion took well over a year to be granted, not at least because of the governnent machinery's unwieldiness: although application had to be ade to the Ministry of Commerce and Industry, the decision to grant pioneer status was taken at the Cabinet level. The ambiguity of the approval criteria together with the slow pace of actual processing pointed to a disturbing tendency on the part of the State - in both its bureaucratic and in its political branch which amplified the paralysis - to jealously guard its role in the econony, rather than to actively accelerate its growth. ${ }^{14}$ This syndrone was

14 One otherwise nost synathetic observer connented despairingly that "while there are any able Nigerians in posts connected with 'processing' would-be investors, the number of knowledgeable, responsible, hard-working, and clear-thinking officials is all too few. There is sill too auch preoccupation with status and perquisites in the Nigerian Civil Service ... and the of ficers concerned with econonic development are no exception. ... One has the iupression in visiting office after office, in both federal and regional sovernments, of officials who have "arrived" and are quite content with being, rather than doing. ... All too often the inpression is one of a haphazard operation, where the compass of conpetence and knowledge of individual officials 
significant firstly as an indication of the indiscrininate controlorientation of already the enbryonic bureaucratic Nigerian state, secondly for the inplied hazards of abuse this entailed and thirdly for the resulting developental inpediments. Even years later, the governaent still found reason to deplore "unnecessary restriction and adninistrative bottlenecks ... in particular the multiplicity of authorities frov whom various peraits, licences, etc. have to be asseabled and the lack of strealined procedure for getting thea" (Nigeria:1975, vol 1,150$)$

In sum and given what could have been, Nigeria's industrialization policies until the 1966 civil war proved to be a non-starter. Manufacturing, usually the most dynamic part of the industrial sector, remained limited to light consumer goods whose inport substitution value was low as foreign rather than donestic raw aterials were predoninantly processed, which accounted also for the very low rate of valueadded. Extensive tariff protection - 120x of value-added for textiles, 1437 for metal goods and over $200 x$ in the furniture, glass products, radio and television industries (World Bank:1974,83) - allowed inefficient production to remain profitable and dependent on foreign inputs, obviously at high opportunity $\operatorname{costs}^{45}$ and at the expense of self-sus-

is very narrow, self-criticisa is rare, co-ordination of individuals is sparse, records are unevenly naintained (conplaints of lost files are nunerous), and the presuaption is against initiative and action. Frequently, one can find greater concern and enthusiasn for noving ahead with Nigerian industrial developwent anong expatriates than anong Nigerians" (Proehl:1965,132-133).

45 The World Bank mission concluded diplonatically that, "since many products only survive behind tariffs of 50 percent or more on value-added, Nigeria, by manufacturing instead of inporting sone itens, is probably losing foreign exchange" (World Bank:1974,84). Losses were also incurred in several instances in which the establishment of processing operations was subsidized 
taineci development. The latter, as far as industry is concerned, requirus a bias towards capital goods which alone entail the potential to increase societa: productivity, and against consuner goods industries which do not. This is prinarily because plants established to neet consuaer demands depend on imported equipment and, thus, entail little scope to mature. They rarely ever make the qualitative jump from consumption to investment goods. Also, their profitability, level of capacity utilization and of employment creation depend on consunption, all of which creates pressures to consume, rather than to invest.

Nigeria's present industrial structure lof the highly protected, passive, consumer goods and import-substitution varietyl goes back to the groundwork laid in the 1950s and 1960s. Even then, because of the high import content and low value added locally, the econonic linkage effects were less than impressive, as was the sector's contribution to GDP: in 1950 it accounted for about $0.5 x$ of GDP and in 1965 for about $6 \%$ - in 1987 it would be $8 \%$ (see table 8). Statistically this reveals a phenomenal growth rate, whose real reason, however, lies in a very low base at the beginning. In 1963 , about 70,000 workers were enployed in the Nigerian manufacturing sector and its paid up capital was $\$ 56.8$ million (about $\$ 159$ million), of which about $10 x$ were held by private Nigerians, $68 x$ by foreigners and $22 x$ by the central and federal governments (FOS, Industrial Survey:1966,35). By 1965 enployment had risen

\footnotetext{
through the provision of export crops at prices below the world arket level. "In the case of cocoa butter, this arrangement pronoted not only an otherwige unprofitable activity but also an activity that actually decreased the value of Nigeria's output" (Schatz:1977,125; enphasis in original); it was sold on the world market at a $5 x$ discount because of inferior quality.
} 
slightly as had the paid up capital: 264 ailion (about $\$ 180$ million) shared among 291 firms: 110 of these were privately owned by expatriates, 52 privately o' wed by Nigerians, 14 by governeent and 115 of aixed structure (Schätzl:1973,42ff). Government investment did not appear to be developmentally focused, unless this is defined widely to include the vanufacturing sector as a whole and disregarding its integration into the national econony. It spanned a wide spectrua, as can be seen from the list of wajor projects for which governments, regional and federal, have provided $90 x$ or nore of the capital, over $\$ 35$ nillion in total: a fruit cannery, four cenent wills, two large sack factories, a paper mill, two breweries, an integrated textile aill, two soft drink bottling plants, a ceramics factory, a nint, a glass factory and four oil-seed crushing plants (Kilby:1969,24). Given the scope and variety of government undertakings, and their inefficiency - in 1967 these accounted for $18 \%$ of the total paid-up capital in manufacturing, but for only $0.7 x$ of value added; World Bank:1974,82) - it is plausible to assume that government as an institution (as well as individual neabers of the bureaucracy and the political stratual were preoccupied nore with controlling the anufacturing sector - and sharing in its expected fortune - than by a disinterested desire to accelerate econonic development.

The reasons for the manufacturing sector's less than auspicious performance were several: the unfriendly business clinate for private investment, the inefficiency of state-owned companies, imbunity against foreign competition provided by nassive tariff protection, but also the lack of effective denand. Sadly but ironically, developnent policies 
were partly responsible for all three. The policy of withholding revenue frow export producers - 20 to 33 percent of potential earnings between 1947 and 1960/61 (cP. Rimer:1981,38) - and channelling then into public coffers, peraitted the raising of public spending while depressing the consunption expenditure of private households. Between 1950/ 51 and 1960/61 both governaent current spending and gross investnent in fixed assets increased at an annual rate of about $12 x$, contrasted with consumer spending of only 3x (Stolper:1966,96-97). However, because wuch of the public investment in productive enterprises was perforning poorly (Nigeria:1962), and much of the subsidized investment in private industries not doing much better (Schatz:1977,66-75), the redistribution of income from agriculture to industry had doubly negative consequences: depressing the level of effective demand without appreciably raising the economy's productivity or creating the respective preconditions. The combination of money-loosing public corporations engaged in directly productive activities and the bureaucratic inpedinents preventing the full potential of Nigeria as a production site to be realized through private capital, indigenous and foreign, neant that the deck was stacked too heavily against effective industrialization.

To add to the emerging picture of State policies in the period shortly before and after independence, two core policy areas will be considered: agriculture and education. Sinilar deficiencies to those observed in the industrialization arred the conduct of these policies. Before the second World War, the colonial government had confined its agricultural activities to a linited anount of research and extension work. These schemes were concerned only with the technical drawbacks 
of peasant-type production such as low yields per acre or crop diseases. In accordance with the dual nandate's conservationist tenets, the colonial government's agricultural policy had been to develop the country's resources through the local pessants. Atteapts by expatriate business interests to improve efficiency through plantations had steadfastly been rebuffed, nostly because of an anticipated conflict with the government's primary objective of preserving law and order. However, after the war the government abandoned its longstanding hands-off policy and began to promote the fornation of large-scale agricultural enterprises, plantations and farn settlenents, priaarily for export crop production. This change of policy was as nuch an outgrowth of the new developmental activism as the result of agitations by local politicians who accused the government of having systematically obstructed development through its anti-plantation policy (cf. Udo:1964,301ff). In the North, one large undertaking, the Niger Agricultural Project, was established; in the South, several tree crop plantations and fara settlement schemes were launched (Berry and Liedholm:1970,72). Although increased government participation in agriculture coincided with the rapid growth of Nigeria's agricultural exports, there is little evidence that government schenes contributed to the growth of output. Production of food staples such as cassava, yan, sorghue or aillet received no attention. The country was largely gelf-gufficient and its vast potential of land and labour was still underutilized, which is why food crops held out no hope to either earn or aave foreign exchange and thus remained outside the state-led nodernization drive (cf. Sano:1983, 15). 
The Niger Agricultural Project was conceived as an experiment in land settlevent which sought to conbine nodern and traditional nethods of farming with the existing syster of peasant land holding. It failed spectacularly. Not enough settlers could be attracted to demonstrate the superiority of modern over traditional methods of farming; nechanization, although highly capital intensive, could replace only a snall proportion of the necessary farning operations; finally, with one exception, yields per acre never exceeded those obtained by local faraers, and revenue per acre was actually lower than the local average (Baldwin:1970,163ff). Governoent-owned plantations in Southern Nigeria were not abandoned, as was the Niger Agricultural Project in 1954 but, despite massive investment (over $\mathbf{x 7}$ million - $\$ 20$ million - by 1962 , cf. Helleiner: 1966,303$)$, they contributed little to agricultural output; in 1961 the plantations accounted for $5 x$ of rubber and $3.5 x$ of palm oil exports (Udo:1967,313). This disappointing perforaance was the result of fundamental weaknesses in design and inplementation: often they were located in response to political pressures, rather than in areas where the soil and rainfall were best suited to the proposed crops; planting proceeded slowly and was often ill-tined or improperly executed. As a result, the nortality rate of trees was high and their average yields low (Helleiner: $1964,98 \mathrm{f}$ ).

The third approach, farm settlements, was equally disappointing. Begun in both the Eastern and Western Regions in 1960, farm settlesents were attempts to raise agricultural productivity (and acreage) through the resettlement of farmers, their training in new techniques, their close supervision and easy access to assistance. The settlers norally 
were primary and secondary school leavers about eighteen years of age. After receiving sone formal training they were allocated 20 to 25 acres and had access to machinery and arketing facilities which were part of a cooperative pool. The scheme was hoped to sten rural-urban nigration by showing that farming was both profitable and honourable (Helleiner: 1966,303ff). In practice, the settlenents by 1967 appeared "to be turning in a worse performance than the arginal one predicted. Settler turnover had been high, costs were considerably higher than the original amount predicted, and the schenes had absorbed considerable numbers of agricultural staff fron other activities. Their net iapact on the economy ... appeared to be limited to providing opportunities to increase the government labor rolls" (Wells:1970,256). Interventions of this nature were not even necessary because the linits of the ventfor-surplus economy had not yet been reached. In the 1950s and until the civil war, food production increased twice as fast as the population grew (Ekundare:1973,279-280; see also table 11) while agricultural exports, responding to favourable prices, were still expanding across the board (except for paln products which were holding steady).

Unfortunately, sub-optinal performance by the state bureaucracy was not limited to its direct participation in the production process nor to specific policy areas such as industrialization and agriculture, all of which were at the tive rather recent additions to the arsenal of state functions. Education, in contrast, had in eost parts of the world long been a proninent field of government policy. In Nigeria, it was here where, once nore, political passion exceeded technical ability. The absence of widely accessible educational facilities had been 
one of nost serious grievances of the nationalist opposition. After the $1930 \mathrm{~s}$, the call for education - and its persisting unavallability rallied Nigerians around the nationalist cause while, after the war, it shaned the new British government into action. With the cclonial government's policy of Regionalization, the responsibility for education was also devolved to the regions. For the nationalist politicians this was a welcome high-profile policy area, especially since they acquired at the same time the control over narketing board resources. These provided then with the financial neans for supporting education and other popular policy conmitments without having to rely on new taxes. Naturally, the education campaign was eninently political, intended in no small measure as proof that self government would benefit the population at large.

Universal free primary education was established in 1955 in the Western Region (where it was also compulsory) and in 1957 in the Eastern Region (Nixon:1970b,159). However, the results of these bold schemes vere dramatic, unexpected, and, to some extent, disastrous. They were a classic case of what has been called the "notivation-outrunsunderstanding" syndrome (Hirschman:1963,236-237). To begin with, the number of children reporting for school greatly exceeded the planners' expectations. In the Western Region, 170,000 pupils were anticipated for first-year registration but 390,000 turned up ( $0^{\prime}$ Connell:1964,119). Within five years, total prinary school enrollaent had more than quadrupled, exceeding $2.6 \mathrm{million}$ pupils at independence (Ekundare:1973, 358). Expansion on this scale caused immediate and severe problens. Shortage of teachers resulted in schools to be staffed by "prinary 
school leavers, ... by untrained teachers who included alcontents and discards from the voluntary agency schools, and by people who were alleged to have obtained posts through the corrupt influence of local councillors" (O'Connell:1964,122). Even though the regional governments spent about $50 x$ of their total current and capital expenditures on education, adequate school facilities could not be paid for and teachers' salaries remained too low to attract competent and notivated aspirants (Helleiner:1966,307). Unfortunately, these were not just inevitable start-up problems, and even by African standards, Nigeria's education system has been less than propitious. In the mid-1960s, the number of children in priaary school was more than 500,000 below the goal set, and the percentage of children aged six to eleven attending primary school was about thirty per cent (Callaway:1971,686). In terms of primary school enrollment, five per cent of the population, the country occupied twenty-ninth place, while in the case of secondary education, 0.5 per cent, it ranked nineteenth. By 1980 , at the height of the boom in oil revenues and despite massive increases in absolute figures, universal primary education remained an elusive goal; Nigeria's position compared with other African countries had inproved by one notch to twenty-eighth place (Zartman with Schatz:1983,9ff; see also table 19).

The obvious failures of the inediate pre and post independence governments in areas accorded critical importance by these governuents thenselves, nanely in industrialization, agriculture and even in education, can be viewed as the results of scarcity in hunan and naterial resources or of executive inexperience, in short in the striking asyo- 
metry between problens and neans available for their solution. This inference is probahly correct, but cannot be the whole answer. A more persuasive explanation ought to look further and deeper, nostly because a quarter century later, the problens have not inproved much, if at all. Nigeria has been blessed with the windfall of oil revenues and has an abundance of university graduates, in fact gore than can be enployed. Yet its industry's share in GDP has hardly inproved over the 1960 level or, rather, it is rapidly dropping back to that level. The country, once an exporter of agricultural produce, in the 1970s resorted to importing food on a massive scale (see table 11), and in the 1980 s had to purchase abroad even its traditional export crops palnoil, cotton and groundnuts to neet local denand (see tables 1 and 2). It bears repeating that in the early 1960 s Nigeria was still the world's largest exporter of groundnuts and paln oil as well as the second largest exporter of cocoa. It is easy to forget that Nigeria's independence was welcomed optiaistically, at hone as nuch as abroad and it was not a merick who wrote in 1965: "Few of the new nations that have energed in the postwar era, and certainly none in sub-Saharan Africa, have so clearly made their mark for stability and sophistication as has Nigeria. Indeed, nations both old and new aight well stand in wonder of the achievements of Nigeria" (Proeh1:1965,4-5). What went sour, and why, will be addressed in the subsequent chapter. 


\section{1) Concluding Sunnary}

An investigation of the roots of the bureaucratic state cannot be divorced from an assessment of British colonialisn in Nigeria. The general thrust of argunent is that colonialisa had a trenendous inpact on Nigeria, more specifically that

- colonial rule, at least until the watershed of World War II, was overwhelmingly positive in the sense of creating and maintaining circunstances conducive for econonic growth; but that

- some of the colonial government's policies - conservationism, indirect rule, the westernized elite's exclusion first and its exaggerated inclusion second, economic interventionisa - influenced change in a counterproductive direction.

Colonial rule thus implied change, but it also inhibited further change. If economic development were to be visualized as the arduous process of rowing a boat over a long distance against the river's flow, colonialism had the effect of a lock: it greatly reduced the time and effort to scale a significant height, yet it also locked the econony in at that level of attainment and fostered the illusion that the process necessitated less popular effort and nore political steering than was in fact the case. Such an interpretation of events goes against the grain of a widely shaled sentiment in Nigeria. A Nigerian scholar, to illustrate, contends that

a major cause of the difference in the pace of development between present-day, ex-colonial dependencies such as Nige- 
ria and 19th century Japan enanates essentially from the servile [sic] incursion of external influences iniaical to the retention and fusion of traditional attributes with known growth deterninants. Such attributes as discipline, co-operation, dedication, organisational conpetence and, above all, patriotisn (for which various pre-colonial Nigerian comaunities were renowned) were, in Meiji Japan, fostered and effectively harnessed for econonic srowth objectives. But, in Nigeria, the afternath of colonial dependency has stifled these attributes enough to engender a relatively low performance of the econony during the two decades of political independence (Usoro: 1982, 209-210).

The correlation between colonialisa and poor developnental performance does not carry the weight put on it here. For one, how would it explain the stunning performance of singapore, ${ }^{46}$ another arbitrarily created, ethnically mixed former British colony, highly dependent on foreign trade, resource-poor and inundated by foreignowned companies? To offer a somewhat broader explanatory base, the purpose of the present chapter was to sketch out the dramatic developments of the past century or so and to suggest that the record of colonialism in Nigeria is a fair bit nore conplex than can be acconnodated by all kinds of reductionisns. In certain respects, Nigeria was greatly transformed, arguably for the better, under colonialisa: the slave trade and slave holding were abolished, a reasonably egalitarian, regionally balanced and hugely successful agricultural econony developed whose welfare effects were widely distributed, the traditional elites were cut down to size (but subsequently propped up), and a new, west-

16 Without the benefit, or burden, of exportable nineral resources, Singapore's GDP between 1965 and 1988 grew by alnost $1,800 x$ fron US\$0.994 bn to $\$ 418.848 \mathrm{bn}$; per capita GDP grew by over 1,200 \% fron $\$ 533$ to $\$ 7,113$ (IMF, International Financial Statistics 11, Novenber 1970, pp. 278-281, and 7, July 1991, pp. 470-473). Nigeria's oil-based econony grew in the same period by under $600 x$ from $\$ 4,715$ bn [\$71 per capita] to $\$ 32,389$ bn [\$303] (see table 8 ). 
ernized elite energed whose influence was based on acadeaic achievenent and political organizing skills, rather than on custon, wealth or power. The Ghanaian scholar Adu Boahen sunarized the inpact and legacy of colonialism as follows:

The first and nost obvious, though destined to be one of the indelible positive narks, is the very physical appearance of the independent states of Africa. Virtually all the states of Africa owe their national boundaries to the activities of the colonial powers in the nineteenth century. These boundaries have not undergone any change with the overthrow of colonialisa, nor are they likely to in the foreseeable future. The second positive legacy has been the infrastructure of roads, railways, harbours and airports. In many independent African states, a large nuaber of roads have been widened, resurfaced or tarred, or straightened; but not nany alles of new roads or railways have been added since independence. A third positive inpact is urbanization. There is no doubt that wany urban centres in Africa, and even the very capitals of some of the independent African states, owe their foration or rapid growth to the colonial iapact. Fourthly, we have seen the emergence of two classes unknown in traditional African society: a literate middle class and a predoninantly illiterate working class. A fifth peraanent feature has been the transfer of power within the African society itself. The process of decolonization has aeant not only the overthrow of colonial rule, but also the transfer of power from the traditional ruling ariatocracy to the new middle and lower classes. ... Still another significant contribution has been the introduction of cash crops and cash economy, and the consequent entry of African econony into the orbit of world econony (Boahen:1970,520-521; see also Cookey : $1979,22-23$ ).

While these changes were indisputably positive in constituting the pre-requisites for econonic developnent, they were obviously not sufficient. What I have tried to show is that the cunulative inpact of colonialisa was not only revolutionary but, despite all positive aspects, engendered and nurtured the developnental obstacles of the bureaucratic state. My argunent takes tack very different fron the 
simple "colonialisn = exploitation" school. In order to prepare the ground for an analysis of Nigeria's conteaporary development dileana, I have conplenented the earlier theoretical discussion (pp. 114ff) with a review of the various historical stages and aspects of Nigeria's integration into the international econony and the flexible, inaginative and extraordinarily successful adaptation to its econonic signals and opportunities by Nigerian peasant farmers.

With the formal imposition of colonialisa, the open econony was successively being closed through the colonial state's increasingly interventionist econovic policies. Constrained by the self-financing imperative, the State's initial role was confined to an enabling one, that is, to the maintenance of law and order as well as to the provision of infrastructure. This minimalism reconended indirect rule and prevented the developwentally essential comercialization of land. During World War II, state control was inposed over the export sector and in the decade preceding independence, the reversal culminated in a complete redefinition of the State's role in the econony. The state now was not only responsible for the country's physical infrastructure or for directly supplying welfare in the form of health care or education. It assumed the management of the entire econony which entailed the retention of state trading monopolies as well as of any state-owned and operated enterprises; it also eant the introduction of extensive 1icencing of industrial and comercial enterprises as well as of inports and exports. Even before independence, thus, the state had arrogated to itself the power to directly control the livelihood of the najority of the population, the agricultural producers, and to condition the 
evolution of a saall entrepreneurial class. The State to be inherited by the derivative niddle class also becane a powerful source of patronage and finance. Both the earlier laissez faire policy and the later interventionism cannot be explained by considering either only material or only ideological factors.

Ideology fed on material reality and, in turn, contributed to changing it. Colonialisa, especially its conservstionist ethos which translated into sluggish education policies and indirect rule, was found particularly oppressive by the professional aiddle class, itself the product of colonialism. Being directly in line to inherit the reins of power from the British colonial administration, the aiddle class was existentially conmitted to conquering the State in its entirety. For its struggle, it could gain the support of other disaffected groups such as farmers, traders, teachers or junior clerks. After the war, with Britain se: on aithdrawal course, the derivative aiddle class took over the colonial State, the civil service aore gradually, and the legislatures and political executive positions in toto after 1951. Nationalism was certainly nore than an ideology cynically appropriated by frustrated intellectuals lusting for power. It provided a coherent organizing franework for the struggle against British colonialism. All grievances, whether real or inaginary, could be blaned on the foreign occupation. In this perspective, any redress lay in conquering the colonial State's apparatuses, in gaining political sovereignty and in achieving econonic control. Nationalisa as a xenophobic or chauvinistic ideology, often enployed to nobilize public sentinent has been, even after independence, a recurrent thene in Nigeria's poli- 
tical discourse. Depending on the economic fortunes of the nonent, it was at times more muted and at others more vocal; its targets shifted frow expatriate capital to labourers from neighbouring countries and to the industrialized North in toto. Policies of indigenization, Nigerianization or nationalization, not to forget the wholesale extradition of aliens or the recent reparations clain for the slave trade, all under a banner of nationalism even if transpareatly in the interest of identifiable class or group interests, have alternated with attempts to attract expatriate enterprises, capital and know-how.

For reasons largely external to Nigeria, the colonial State's functions changed after the second World War from its traditional enabling role to economic and developmental activism. Thus, not out of their total experience in Nigeria but because of a last-ninute (and therefore badly thought out) change of heart, the colonialists bequeathed to their successors the ruinous belief that not only should but a: 30 could the state run every detail of a national economy. The nationalists welcomed this mutation, even more so as it coincided with their long-sought inclusion into the State. An active and expansive State was very much in their interest as a class and as individuals. It meant jobs and programe funds, both of which were importani to validate their claim that self-government wou id accelerate the pace of development and benefit the nopulation at large. An obvious, if from the colonial government's point of view unintended consequence of the State's economic activism was i.s politicization. Development policies, especially of the investment-oriented kind undertaken in Nigeria, were first and foremost distributional in effect: they were evaluated, 
and therefore shaped, by how and where and to whow they delivered welfare. The post-war colonial state, as an état actif, becane an ever more attractive and important prize; controlling it permitted, even demanded, extensive government investment in the economy. Investment could then be used to repay political debts, to underine political opposition, and generally to maintain political control. Of course, it could also be used to serve the state class's property interest direct$1 \mathbf{y}$.

With independence no longer an elusive goal but nerely a matter of time, nationalist unity of purpose gave way to intense jockeying for position. Azikiwe's support was much stronger in the East than in the West; Awolowo's was the reverse, and neither had any in the North where there was little inclination to exchange Southern domination for British domination. This stalemate led each of the anti-colonial champions to the development and consolidation of their regional power bases; from these the erstwhile nationalists intended to launch their campaigns to capture the centre. It is a sad irony that regionalisa or tribalism was, in effect, a feature not so much of colonialisa but of de-colonization with the colonial government as a witting acconplice. Having created an almost confederal state structure, it had concocted a fragile balance of power systen which, to the extent that it was easier to manage in the immediate pre-independence period, nade the country ungovernable thereafter.

The process of change initiated by colonial rule did not cone to a halt at independence. Conspiratorial clains to the opposite effect, more interested in condeaning than understanding, are transparently 
gelf-serving. So for example the Nigerian scholar's charge that "the country failed to develop because it did not undergo, and has not undergone [what is the difference?], structural change. The social, political, and econonic character of the society has not been transformed, but continues to resemble its colonial forn" (0layiwola:1987, 10; see also Nigeria:1987). While empathizing with this attitude of disappointment so widespread among Nigerian intellectuals, I view it more as rationalizing ideology put in the service of reflexive selfdefence than as the result of detached analysis.

I have argued a contrary thesis, nanely that there was, of course, tremendous change in the short time of colonialisa - barely more than fifty years - and just as much in the past thirty years of independence. Colonialism, in my view, did not create Nigeria's contemporary developmental quagmire. What it did was to found structures and initiate policies which had the effect to nurture those forces whose interest position was and is developmentally counterproductive. In other words, Nigeria's conteaporary problens are indeed homenade, even if the hone itself has major foreign conponents.

After independence, the centre was extrenely weak, bereft of powerful centripetal forces. The state largely served the interests of regional elites and their clients. The unitary civil service having been regionalized in 1954 , ever, the federal civil service becane, at the end of British suzerainty, simultaneously an arena for and a trophy in the rampant struggle for political power. The ailitury intervened in 1966, like it did again in 1983, essentially to prevent the State's disintegration into conflicting sub-units, that is, to aaintain its 
unity and to restore its governability. Not to be discounted is the possibility that the military segment of the state class desired to partake in the ongoing bonanza. Econonic policies changed little which meant that peasant farmers, as usual responding with alacrity to the prevailing warket opportunities, quit producing. At the eve of the civil war, Nigeria was still the world's leading supplier of groundnuts and palm products, and second only to Ghana as a cocoa exporter. With petroleum coming on strean, the State depended less and less on extracting agricultural surplus, that is, on keeping eacroecononic conditions conducive for the large agricultural sector which consequently began to decline. Trade streans reversed and soon Nigeria iaported not only food, but also its traditional export products palm oil. groundnuts and cotton to weet local demand. The State's aaterial basis shifting from a regionally balanced agricultural economy to a geographically centralized (in the South) aining enclave, political incentives also shifted from regionalization (except for the south-east where the oil was pumped) to centralization. The arbitrariness of the country's borders, for which the British had been severely criticized in the run up to independence, was no longer contentious. Now the issue becane the regionally balanced allocation of the centrally appropriated oil-rent and, therefore, the conquest of the federal government or, conversely, the prevention of its being hijacked by sectarian, that is, regional forces. 


\section{The Bureaucratic Nigerian state in Action}

The 1970, like the $1950 \mathrm{~s}$, were a period of dramatically increasing trade revenues and, once more, of resulting illusions of iminent prosperity which, again, translated into tangible policy inplications. A significant difference, however, was the fact that this time round the honanza accrued directly to the state. Surplus did not have to be withheld from the direct producers through enforced monopsony arrangements, nor was the State, a ailitary regime, compelled by a democratic process to share it with the public. This is not to suggest that the Statc's privileged position was the result of any manipulation; it was much rather one aspect of an unalterable feature of the new Nigerian economy: the accrual of very substantial, albeit unstable, oil revenues to the federal government. This feature was also intractable because there was no immediately apparent alternative way in which the economic rent derived from export sales of oil could have been captured. There were, naturally, a number of possibilities to spend this manna from heaven, for example to jump-start a development process, or to increase the welfare of ligerians at large. As it happened, development and mass relfare were but slogans employed by the burequcratic state to cover policies which were either inept or plainly in the sectional interests of the state class directly or of its clients.

The pattern of economic and political dislocations which are likely to follow from the bureaucratic mode of production has been outlined in Part I. In the Nigerian variant of this economic system, developmental disturbances were rooted not so much in the instability 
of revenues but, much more importantly, in their nature as rents and, at least through the 1970s, in their extraordinary agnitude which amplified the government's propensity to extensively intervene in the economy and which strengthened its considerable powers of patronage. The bureaucratic Nigerian State's enormous (in teros of even optimistic expectations of previous decades) econonic prowess was used to engage in macro-economically counterproductive policies, to waste econonic resources and to reward the state class and its clients. In a very tangible and sinister sense, the concentration of power in the state became a marketable commodity which was instrumentalized with the result not simply to delay necessary and possible developaent processes, but to create particularist interests constituting serious obstacles to derelopment. The state class and its business class appendix should, by nature of their nembers' education, influence and relative affluence, have been the dynamic core of a developmental push. As it turned out, their efforts were primarily spend in attempts to obtain special privileges for thenselves, an activity which did not generate any wider social surplus. To the contrary, their unrestrained rent-seeking undermined and all but demolished agriculture which until the 1970s had been the economy's productive centre.

In the present chapter, the macro-econowic scenario of the $1970 \mathrm{~s}$ and early 1980s will be outlined at first by surveying the decline of agriculture, the sluggish growth of an overprotected and underperforaing manufacturing sector, and the inpact of oil which peraitted the funding of an ever escalating system of subsidies, interventions and controls by the state, none of which was successful in achieving its 
stated goal, yet all of which were successful in generating rents. In subsequent sections, the state policies of the decade will be reviewed to show how, precisely, they served the state class's interests in legitinacy, autonony and property, or to suggest why they, rather than alternative causes of action, were chosen. A caveat is in order about the following inquiry. There can be no question that a comprehensive and detailed analysis of Nigeria's econonic environment and of the extent to which it was shaped by state policies would obviously desirab1e. However, it would also be inpractical in the present context. Paucity of data and limitations of space are inportant constraints, as is the specific scope of the present study. Since, at bottom, it deals with the motivation of political actors and since it is, even in principle, impossible to account in a rigorous, testable and verifiable fashion for the motives of an actor, let alone for those of changing groups of actors, any causal links identified can only be suggestive. What is attempted here is not the presentation of any conclusive proof but of some plausible evidence, selected in good faith, that the Nigerian State, following its patrimonial-bureaucratic logic, not only failed to make the most of an admittedly difficult situation, but that it actually made matters worse, all the while it furthered its own interests. The guiding question when reviewing state policies, and their results, is "qui bono?" 
a) The Macroecononic Setting in the 1970 and early 1980

Mineral oil had a truly revolutionary inpact on Nigeria's economy, mainly by displacing agriculture as the source of foreign exchange and state revenue. Agricultural comodities in 1960 accounted for about $90 x$ of exports and oil for 3x. By 1980 exactly the reverse was the case: agricultural exports (i.e. cocoa since the exportation of palm products, groundnuts, cotton and rubber had ceased al together) were a mere $2 x$ of the total while crude petroleum accounted for a staggering 97\% (see table 3). Given that Nigeria was and is an agricultural country, the systematic ruin of this once flourishing sector has to be considered the saddest consequence of the arrogance sponsored by oil, especially since no viable alternative, such as manufacturing industry or services, was created to serve as the basis for broadly based and self-sustained economic development. It is neither a secret. nor a recent revelation that economic development or/and industrialization in all historic cases went together with rising mass income, increased agricultural productivity and higher agricultural prices. ${ }^{1}$ The

1 cf. Elsenhans: 1983,9-10; Hart:1982,160; Hobsbawn: 1990,97-100; Lewis: 1954,173; Marx:1969a,703. For an interpretation which subscribes to this dynamic but emphasizes the stimulating influence of low food prices, see Brenner and Jones who contend that developments on the production side of agriculture were instrumental in bringing the earliest advanced countries to the brink of industrialization. Brenner argues that "continuing improvenents in agricultural productivity combined with low food prices [gavel an extra margin of spending power to significant elements throughout the aiddle and even perhaps the lower class so as to expand the home market and fuel the steady growth of industry in the period of the industrial revolution" (Brenner:1976,68). Similarly Jones who suggests that "agricultural surpluses, arising at a fortunate demographic juncture, played a large part in generating rural industrialization in England, several European countries, Anerica and Japan. ... although agricultural prices were low, the extension of both urban and rural-industrial arkets for food had prevented then frov being fatally depressed, the faraing 
latter two factors

- permitted an increase in and the diversification of farm output while at the same time releasing workers for urban employnent;

- created surpluses which could be taxed away to finance infrastructural investment or industrial capital formation; and which

- established an important market for both capital goods and consumer goods.

The argument runs as follows. Industrialization to be selfsustaining must be demand-driven which, to obtain the critical mass necessary for take-off, requires a market of a certain size, affluence and taste-homogeneity. In an agricultural economy with a majority of the population engaged in farming, these conditions are, if at all, given only if manufacturing can satisfy the demands of the rural population. To translate their unlimited wants into effective demand, agricultural production must either be more productive, more profitable, or both. There is no other way to increase, in a self-sustaining fashion, the disposable income of agriculturalists. The growth of a

commity was able to acquire tastes for purchased goods" (Jones:1968,70). Whatever the controversy over the precise level of prices, and their role, there seems to be consensus that a "high standard of living cannot be build upon an econony in which half the people are scratching the ground for food with a hoe" (Lewis:1953,2). 
manufacturing sector both stimulates and depends on more efficient agriculture. It produces agricultural inplenents which increase the sector's productivity and output, it absorbs the increased production as well as the released workers, and it creates the incentive goods which stimulate agricultural development. Conversely, an inefficient manufacturing sector can act as a brake on agricultural developaent. If, because of state protection and subsidies, it can afford to pay relatively high wages and charge high prices for substandard goods, the rural sector is doubly penalized, its output will stagnate or even fall and thus feed back to undermine the growth also of the anufacturing sector. In short,

industrialisation is dependent upon agricultural iaprovement; it is not profitable to produce a growing volume of manufactures unless agricultural production is growing simultaneously. This is also why industrial and agrarian revolutions always go together, and why economies in which agriculture is stagnant do not show industrial development (Lewis:1954,173; see also Murphy, Shleifer and Vishny:1989, $537-540$ and $1989 a, 1006-1007)$.

In Nigeria, oil rents supported the illusion that a shortcut was viable, that is, that an urban industrial and service sector could be created while effectively delinking agriculture from general economic progress. This deliberate neglect, or worse, assuned various forms, such as the heavy taxation of agricultural exports, the depression of food prices through the iaportation of large quantities of staples, and lok investment in rural infrastructures. In 1960, Nigeria's agriculture generated over $60 \%$ of GDP and eaployed over $70 \%$ of the country's workforce; in 1980 , the latter category had not narkedly changed while 
the former had declined steeply to about $20 x$ (see table 8). This was not only because oil-driven GDP underwent a quantum leap (growing by over $600 x$ in nominal terms between 1970 and 1980 , see table 8 ), but because agriculture regressed: with the area under cultivation falling, ${ }^{2}$ with accelerated rural-urban agration mainly due to considerable rural-urban wage and welfare differentials, and with hardly any productivity gains achieved, crop exports collapsed and food production stagnated or even declined.

Absolute food output in 1965 was almost $50 x$ higher than in 1960 and 100\% higher than in 1955. By 1973 it had fallen back to the level of 1960 and after 1975 remained considerably below the base of 1960 , even though population between 1960 and 1975 had grown by 50x, and more than doubled between 1960 and 1986 (see tables 9 and 11). The shortfalls led to declining food production per capita - in 1988 it was $25 x$ belon the 1961-1965 average (see table 11) - and to reduced caloric intakes per capita, ${ }^{3}$ despite considerable food imports. Already before independence, Nigeria imported food stuffs (mostly processed kinds), even if their value remained well below $20 x$ of agricultural exports.

2 According to the Nigerian Federal Ministry of Agriculture, 20.4 million hectares here cultivated in 1965, 14.9 illion in 1974 and only 9.6 aillion in 1980 (reported in Iyegha: 1988,50 ). It bears repeating that the Nigerian government estimates the cultivable land area to be 71.2 million hectares (Nigeria:1981,98). As can be seen fron table 13, the area under cultivation for the rood staples cassava, sorghum and yams in 1988 was only marginally larger than in 1948-1956, despite the fact that the population had almost tripled. Unfortunately, the productivity gains in teras of yield per hectare were entirely insufficient to feed everybody without using sore or the available aralil. 'and.

${ }^{3} 2,166$ calories per day in 1965 versus 2,039 calories in 1988 (World Bank: 1991,258$)$. The 1965 intake was $95 x$ of daily requirements; in 1985 it had dropped to $90 x$ (UNDP: 1991,27 ). 
By 1980, however, food inports cost alwost four times as wuch as agricultural exports earned, a trend which e:en accelerated in the following years (see tables 2 and 11). Imported foods, since the 1970s predominantly staples such as rice or aize (but also wheat, a luxury aiaed at an upscale urban market), directly competed with local produce. ${ }^{4}$ In $1960,2,400$ tons of rice, 900 tons of wheat but no naize had been imported. The figures for 1981 were 600,000 tons of rice, 1.6 million tons of wheat and 293,000 tons of naize (see table 12). Thus, in 1981 , rice imports were over $40 x$ of domestic production, maize imports nearly 20\%, while wheat imports exceeded domestic output by a stunning factor 60 (see table 13). The importation of food was an invaluable political tool, keeping food prices low and providing opportunities for the state to reward clients and meabers of the state class alike. In 1980 , for instance, a $50 \mathrm{~kg}$ bag of rice cost $\$ 40$ to import, but sold for $\$ 150$ in Lagos (NYT, 18 January 1981, 9). Such government sponsored scams - the official in charge of the rice taskforce, laaro Dikko, transport minister and the President's brother in law, was charged with squirreling away $\$ 2$ billion before absconding to London - were wentioned by General Buhari in an interview to justify his coup d'état. (WA No 3471,27 February 1984,424 ). 5

- A number of examples concerning aize have been wentioned earlier. Highly instructive is also the case of rice: "Following the recomendation of the anti-inflation task force set up following the displacenent of the Gowon regime, the Nigerian government reduced the duty on rice fron 20 percent to 10 percent; with rising domestic prices, demand shifted to foreign sources, and given the overvaluation of Nigerian currency, inports rose over 700 percent" (Bates: $1981,36-37$ ).

5 The importation of rice by the Presidential Taskforce and its local resale at a considerable mark-up becave an important source of patronage. "As the [1983] general elections approached, the governnent imported unliaited 
Food imports were ainly consumed in the urban areas which expanded by a rate of $5.7 x$ between 1965 and 1980 and by $6.2 x$ between 1980 and 1989 (World Bank:1991,264),6 while rural Nigerians continued subsistence farming or reverted to it. The rural-urban terms of trade deteriorated markedly since the oil-driven expansion of urban activities in commerce, construction, industry and services increased wage levels throughout the econony and thus ade smallholder farming ever more unattractive and uncompetitive. In the late 1960s, ninimum pay for urban workers ranged from 1.5 to 2.5 times the average farmer income. "Annual earnings of paid agricultural workers have been estimated for 1967 at less than 45 percent of average earning for workers in wage and salary employment, a decline from about 58 percent in 1960" (World Bank: 1974,28-29). In the 1970s, the differential grew wider. Were urban incomes double that of rural incomes early in the decade, after 1974

quantities of rice, ostensibly to satisfy consumers' demands, but also quite apparently to raise money for its supporters to fight the election. The high prices consumers paid was quite clearly due to the latter consideration rather than to actual scarcity" (WA No. 3474, 19 March 1984, 605). One of President Shagari's advisers, Prof. Odenigwe, was sentenced to 21 years in jail for illegally enriching himself by over N800,000 (> \$1mn). He had arranged for 20,000 bags of rice to be declared unfit for human consunption and subsequently to be sold for his own benefit (ARBp:5/1984,7654).

6 Nigeria's urban population grew by $6.3 \%$ between 1960 and 1990 (UNDP: 1991,158). Between 1986 and 1990 it had slowed to 6x, which, however, was still nearly three times the rate of rural growth (United Nations:1990,206). In $1965,17 x$ of the total population lived in urban areas, by 1989, this share had increased to $35 \%$ (World Bank:1991,264). Lagos grew particularly rapidly. Its population grew from 25,000 in 1866 when the first census was carried out to $+2,000$ in $1901,100,000(1921), 267,000(1952), 364,000(1960), 875,417$ $(1970), 2,064,000(1975), 4$ aillion $(1980)$ and to 4.5 aillion in 1985 (Ekundare:1973,351; I yegha: 1988,159; Schätzl:1973,115-116). 
they were four times as high. ${ }^{9}$ Rural per capita product (share of GDP) was about $40 x$ of urban product in $1962 / 63$ but fell to about $10 x$ in 1975/76. In other words, urban per capita product grew froe three times its rural equivalent to nearly ten times within 15 years (Diejomaoh and Anusionwu: 1981,99). Agricultural incoves, therefore, were low ainly if not exclusively because of the State's preferential treatment of urban activities and because of extortionate export taxes on cash crops. ${ }^{8}$ That aside, agricultural work, especially in food production, was unprofitable because of the low productivity of cultivating marginal land esgentially with hand-tools.

Agriculture, since the state-led efforts to modernize, that is, industrialize the Nigerian economy began in the 1950s, was considered backward and useful to the development effort only insofar as it generated the funds for the state and its projects. For the state class, the advent of oil obviated also this final attraction and the rural majority was relegated into oblivion. Attention and resources were directed towards the few urban centers. Thus, it was not only the wage

7 Okowa $(1985,76)$ measured the average annual income of agricultural workers (IAW) and of non-9gricultural workers (NIAW). The multiplier URM indicates urban-rural income differential. Despite some problems with datareliability and methodology, his findings are instructive. His figures (converted into \$) are:

$\begin{array}{rrrlrrrrrrrr}\text { Year } & \text { IAW } & \text { NIAW } & \text { URM } & \text { Year } & \text { IAW } & \text { NIAW } & \text { URM } & \text { Year } & \text { IAW } & \text { NIAW } & \text { URM } \\ 1950 & 83 & 185 & 2.0 & 1970 & 239 & 510 & 2.1 & 1974 & 493 & 2,189 & 4.4 \\ 1955 & 122 & 207 & 1.7 & 1971 & 300 & 693 & 2.3 & 1975 & 592 & 2,354 & 4.0 \\ 1960 & 153 & 220 & 1.4 & 1972 & 304 & 742 & 2.4 & 1976 & 628 & 2,922 & 4.5 \\ 1965 & 169 & 317 & 1.7 & 1973 & 327 & 1,243 & 3.8 & 1977 & \mathbf{7 2 5} & 3,145 & 4.3\end{array}$

8 It is important to note that these trends were reversed in the aid1980s. Austerity measures first and structural adjustment later, both necessitated by falling oil prices and rising foreign debt, had the effect to erode urban incomes and, to a smaller extent, to raise rural incones. 
cifferentials, but also the patterns of state investment and the provision of social services which were overwhelmingly biased in favour of urban areas and hence contributed to the erosion of the countryside's i iability. ${ }^{9}$ In the mid-1980s, $100 x$ of urban dwellers had access to safe water, but only $20 \%$ in rural areas; access to health services was $75 \%$ compared with $30 \%$ (UNDP: 1991,137 ). Keeping food prices low dispayed the same urban bias and was a major factor in preventing domestic fond production to effectively tap the existing potential.

The production of the staples cassava, yams, sorghum and maize in 1988 wis alout double the 1948-1956 average, while the area planted with these crops had increased by less than 25\% (see table 13). Considerable increases in output and in area under cultivation was achieved for the luxur: staples rice and wheat, if from a very small base and with limited impact on the country's overal utritional situation. Thi' ('umlined rice and wheat harvest (in terms of weight) in 1988 was umitr th of the combined cassava, yam, sorghum and maize harvest (see (aill, 1.3). The positive correlation between high food imports and low dom.utic production is obvious. In 1981, that is, after the second oil

9 The wanned rural-urban distribution (percentages) of investment and semices is instructive, especially since actual implementation was consistelltly lower still for ruri? expenditure (Source: Okowa:1985,83-85):

\begin{tabular}{|c|c|c|c|c|c|}
\hline Actitity & $\begin{array}{l}\text { First } \\
1962- \\
\text { rural }\end{array}$ & $\begin{array}{l}\text { Plan } \\
1968 \\
\text { urban }\end{array}$ & $\begin{array}{l}\text { Second Plan } \\
1970-1974 \\
\text { rural urban }\end{array}$ & $\begin{array}{l}\text { Third } \\
1975- \\
\text { rural }\end{array}$ & $\begin{array}{l}\text { Plan } \\
1980 \\
\text { urban }\end{array}$ \\
\hline Electricity & 0.6 & 97.9 & $11.0 \quad 89.0$ & 21.9 & 78.1 \\
\hline Communications & 0.0 & 91.4 & 0.0100 .0 & 0.1 & 97.5 \\
\hline$H \cdot .4]$ th & 3.9 & 76.2 & $6.6 \quad 43.1$ & 13.3 & 50.0 \\
\hline Social helfare & 9.2 & 90.8 & 66.1 & 0.4 & 68.3 \\
\hline hater supply & 39.6 & 58.5 & 60.8 & 23.6 & 68.2 \\
\hline Total & 5.8 & 89.6 & $9.3 \quad 73.7$ & 4.1 & 78.4 \\
\hline
\end{tabular}


price explosion, ${ }^{10}$ food imports reached a high with nearly $\$ 3$ billion and domestic production (except for rice) stagnated (see tables 11 and 13). By 1986, oil prices had fallen to $\$ 14.3$ per barrel, oil revenues to $\$ 6.3$ billion and food imports to under $\$ 700$ million (see tables 4,2 and 11 ), while food production was picking up. 1985 saw the highest ever recorded output for maize, 1985 for cassava and sorghum, 1987 for rice, and 1988 for yams and wheat (see table 13). Prior to the oilprice crisis of the 1980s, the induced bans on food imports and the inesitable uprard-adjustment of food prices, rural Nigeria had been much more vulnerable to inflation than were the cities.

The consumer price index $(1970=$ base level of 100$)$ stood at 186 in 1975 , at 568 in 1980 , at 1,413 in 1985 and at 2,584 in 1989 (see table 7 ). While urban incomes were not entirely immune to this ranpant inflation, several minimum-wage decrees as well as massive public sector wage increases, radiating throughout the manufacturing, construction and service sectors also, went some way towards defending the purchasing porer of the salariat; since productivity and production did not also increase, inflation was further fired on. Rural Nigeria was hurt in several respects, that is, in all three of its markets: in the market for manufactured inputs and incentive goods, in the market for labour, and in the market for its products. Prices in the first tho markets went up in tandem with inflation, whereas the state-fixed producer prices for the agricultural export commodities sank to all-time

10 the 1978 price of crude oil, \$14.9, had more than doubled to $\$ 35.4$ in 1980. The respective revenues rose from under $\$ 9$ billion in 1978 to over $\$ 24$ billion in 1980; see tables 4 and 2 . 
lows in real terms (see table 5), and the prices for food crops were undermined by cheap imports and state support to selected large-scale farms. Exports of the traditional staples palm products, groundnuts and cotton virtually collapsed ieven necessitating the importation of these commodities in the 1980 s for domestic consumption) except for cocoa which fared less badly, exporting in 1987 the same amount as in 1950 , or in 1988 as wuch as in 1960 (see table 1).

The reason for this decline, it should be emphasized, was not the unfavourable development of worldmarket prices - these had increased considerably in the 1970s, for cocoa and cotton by over 200\%, for grrundnuts by over $100 \%$ and for palm products by $40 \%$ - but how little of it trickled down to the direct producers. 11 No longer needed to gentrate resources for the state, export agriculture received little at tention. The case was somewhat different for food crops, an imporlant item in the basket determining the urban consumer price index. Insufficient supplies exerted upward pressures on prices, and necessitaled remedial action. The State chose to import and to promote production in selected enclaves.

1 Ser tables 4 and 5 for the gaps in absolute terms between world market and government-ficed producer prices. Brian Pinto's index of real producer prices ( = government-fixed producer prices divided by the rural CPI) is an equally insightful measurement of the deterioration of the rural terms of trade. It shows that, by 1985, the purchasing power of a given amount of export commodity, had dropped to half its 1975 level (Pinto:1987,433):

$\begin{array}{lcccc}\text { Yea" } & \text { Cocoa } & \text { Palm Oil } & \text { Groundnuts } & \text { Cotton } \\ 1975 & 100 & 100 & 100 & 100 \\ 1978-79 & 90 & 81 & 76 & 65 \\ 1980-81 & 93 & 92 & 90 & 64 \\ 1981-82 & 77 & 76 & 80 & 62 \\ 1983-84 & 62 & 57 & 60 & 52 \\ 1984-85 & 48 & 50 & 62 & 50\end{array}$


The Nigerian State's second remedial action after food imports, namely capital intensive high-technology enclave agriculture (irrigation schemes, huge integrated agricultural development projects (ADPs) and subsidized inputs of imported fertilizer and achinery), failed to appreciably increase food production, even if in some isolated cases, the horld Bank assisted ADPs proved successful (cf. World Bank:1981, 53). What seemed possible in the 1970s, namely "plowing part of the oil wealth back to the rural areas and [not needing] to attach great. importance to cost recovery and a financially self-sustaining agricultural sector" (loc. cit.), could not be upheld thereafter. The horld Bank had cautioned in 1974 that even if 2 million hectares of agricultural land could be irrigated as the government's unrealistically ambitious development plans envisaged, output would be raised by a mere 3\%. It concluded that the "same result can be achieved wish much less investment by extending the area cropped under rain fed cultuvation currently only 30 million acres out of a possible 80 million acres of arable land" (World Bank:1974,79\&130). Not heeding this advice, the Third National Development Plan allocated N290,276 willion, the greatest single share of agricultural expenditure, to River Basin Development Authorities (RBDAs) and thus to irrigation projects (Nigeria: 1975,9-78; see alsu AfBe:6/1974,3175-3176 and ARBe:7/1974,3209). Because of cost-overruns, this figure had risen to over N1 billion by 1979 (Sano:1983,36) and an estimate put the cost of one hectare at $\$ 8,000$ or over $\$ 12,000$ (Wallace:1981,241).12 Nevertheless, in 1982

12 A "Ministerial Committee on the Causes of the Excessively High Cost of Government Contracts in Nigeria" noted that in the Bakalori Irrigation Scheme, "the total cost of irrigated land per hectare reached the staggering figure of 
only 48,000 hectares were irrigated, and the plan target of 243,000 hectares was as remote as ever (Synge:1982,21). By 1988, the total reached 70,400 hectares (EIU:1990,21), an achievement rendered inauspicious by the high costs involved. For instance, in the Hadejia-Jamaara RBDA just south of Kano, only 12,000 hectares (instead of 22,000) were developed by 1990 , at costs of $\$ 20,000$ per hectare "naking returns on investment wholly unviable" (FT, 19 March 1990, XIII). The RBDAs, whose number reached eighteen by 1984, received N2 billion in government support between 1982 and 1985 (Hackett:1989,777) and a further 1290 million between 1986 and 1988 (EIU:1990,21); they continue to account for the largest part of state expenditure on agriculture. Integrated agricultural development projects (ADPs) were the alternative to irrigation favoured by the World Bank and supported with loans. Between 1974 and 1985 , thirteen ADPs were established, some of which (notably those in Gusau, Funtua and Gombe, all in Northern Nigeria) were financially supported and managed by the World Bank which, hetween 1975 and 1988 allocated nearly $\$ 1.4$ billion of its total sectoral loans to these and similar projects (FT, 8 March 1988, XI). To increase food production, "progressive" farmers were targeted and provided with subsidized fertilizers, ${ }^{13}$ machinery and credit; in addition,

$\$ i, 540$ as compared with the normal cost of $N 2,740^{\prime \prime}$ (Nigeria:1981a,13). It then noted that the "normal" cost of $N 2,740$ (or $\$ 4,250$ ) was already more than twice the hectare cost in Ghana $(\$ 1,650)$, more than five times that of Côte d'lvoire (\$775) and more than ten times that of Liberia (\$390) (loc. cit.).

13 Even on purely technical grounds, fertilizers are of only limited use as a pield-raising input in much of Africa because of the continent's semiaridness. For instance, between 1960 and 1975, yields for Maize, Millet and Sorghum in Nigeria increased from about $500 \mathrm{~kg} / \mathrm{ha}$ to about $1,000 \mathrm{~kg} / \mathrm{ha}$, while those for cassava (about $9,000 \mathrm{~kg} / \mathrm{ha}$ ), cocoyams $(4,000 \mathrm{~kg} / \mathrm{ha}$ ) yams $(10,000 \mathrm{~kg} / \mathrm{ha})$ and cohpeas $(300 \mathrm{~kg} / \mathrm{ha})$ remained largely unchanged (cf. 0jo:1977,17). Compa- 
local roads and storage facilities were constructed. Necessary as some of these measures were, they were obviously not sufficient for selfsustaining rural development. The State's inputism which increased output only moderately because of its failure to reach the great ajority of smallholder farmers and to improve their living conditions, had precursors in the late 1950 s but wore particularly in the 1970s. For instance, in the context of its "Operation Feed the Nation," the Federal Government in 1976 purchased 32 heavy-duty feed mills (cost N3.9 millionl and contracted the construction of 70 grain storage depots (N5.3 million) (ACR:1978,B689-690), even though the problem then as later was lacking price-incentives for farmers to produce for the market, rather than solely for their own consumption. In the same veit, Plateau State in 1981 purchased 528 tractors, combine harvesters, bulldozers and trucks from International Harvester (Sano: 1983,fi7). Also, in December 1981, the Nigerian Ambassador in London told a business conference that $\$ 1,000$ ( $\$ 1.6$ billion) had been budgeted by the Federal government for the acquisition of fertilizers and N790 (about $\$ 1.3$ billion) for the procurement of tractors and other farm equipment (hit No. 3361, 4 January 1982, 17). Apart from its unfavourable costbenefit ratio in terms of agricultural production, the state's inputoriented food strateg: had other serious disadvantages. Most importantly, it failed to raise rural living standards on a broad scale and

rable climatic constraints account for the equally limited yjeld increases of grains in Australja (from $1,000 \mathrm{~kg} / \mathrm{ha}$ in $1950-52$ to $1,301 \mathrm{~kg} / \mathrm{ha}$ in 1981-83), compared with more generously rain-fed East Asia $(1,419 \mathrm{~kg} / \mathrm{ha}-2,973 \mathrm{~kg} / \mathrm{ha})$, Western Europe $(1,733 \mathrm{~kg} / \mathrm{ha}-3,843 \mathrm{~kg} / \mathrm{ha})$ or North America $(1,646 \mathrm{~kg} / \mathrm{ha}$ $3,757 \mathrm{~kg} / \mathrm{ha}$ ) (Brown and holf: $1985,55-57$ ). 
thus prebated the emergence of a viable market for the outputs of dom«stle manufacturing. As a result, agriculture for most parts remained mired in a subsistence mode, and manufacturing confined to a narrow urhan market.

State-led import substitution industrialization in the 1950 s and 1960 s has possible only through the heavy taxation of agriculture which, among other things, had the disadvantage of depriving it of a marbet. Since it remained dependent on state protection and economicrll! unville, earning negative returns in most cases, also the emergerces of a completitive private sector was effectively preempted. Pribite culsumption was reduced - dropping from 87\% of GDP in 1960 to 62\% in 1980 (horld Bank:1982a,118), and with it the space for private business, just as public consumption and gross domestic investment increasw (from 19\% in 1960 to $34 \%$ in 1980; loc. cit.) without proportionately 'hilanding the econom?'s self-sustained growth putential. The withdranal of agriculture into a subsistence mode left the modern sector murkers, that is, around five per cent of the population, as a potenlal mirhet for manufactured products. But even this small portion of lir. pumlation was internally segmented into a high-income stratum orituted tohardsi imports, a widdle-income stratum of potential customers, and the large majority of minimum wage earners with little disposahle income. Of course, urban incomes were also highly segmented. Although no reliable data for the $1970 \mathrm{~s}^{14}$ and $1980 \mathrm{~s}$ exist, the patterns

It In 1968, a skilled or semi-skijled worker earned $50 x$ more than an unskilled horker; clerical staff earned $150 x$ more and professional, administrative and managerial personnel nearly 800x more (Schätzl:1973,150). The unpublished National liban Consumer Suryey of $1974 / 75$ showed that the avarage incomes of the highest income group of wage earners were five times those of the 
of the 1960 s are highly instructive since no dramatic change seens to have taken place until the mid-1980 structural adjustent programme. A 1963 survey established that the highest quintile of wage earners took $54 x$ compared with the lowest quintile's share of $4 x$; the top $5 x$ earned 26\% (Diejomaoh and Anusionwu: 1981,110). Once this small market was saturated, manufacturing output had reached a plateau.

After 1970, the performance of the tiny manufacturing sector (it never exceeded 2,000 establishwents, 450,000 workers or $\$ 50$ of per capita value added) ras, like agriculture, closely tied to the level of oil revenues (see tables $16 \& 17$ ). It differed significantly, and predictatly, in that its relationship to oil revenues was inverse. Highl! dependent on imported tools, raw materials and intermediate inputs, the shortage of foreign exchange of the 1980 s led to extremely low levels of capacity utilization. For instance, in Nigerian manufacturing's largest subsector (food, beverages and tobacco), capacity utilization declined from $44.6 \%$ in 1986 to $33.6 x$ in 1987 (UNIDO:1988,37); in textiles, the second largest sub-sector, capacity utilization declined from $90 \%$ in 1982 to 46.5 in 1988 (ibid, 44 ), and in the automotive industry, capacity utilization stood at under $20 x$ in 1987 (ibid.,46). 15 The rea-

lowest group and nearly three times those of the aiddle group (cf.Ayeni:1981, 2461 .

15 Overall industrial capacity utilization in early 1989 [1991], according to the su. vey roncucted regularly by the Manufacturer's Association of Nigeria, stn. . .9x [29.6x] (EIU:3/1990,17, [WA No. 3871, 25 November 1991, 1972]). In .ition to the industry's structural deficiencies, it was further hampered in the late 1980 s by the State's inability to contain its budget deficit (which fuelled inflation) and to maintain the Naira's external value (at whatever level). Both these failings, in an already difficult environment, made it so much more difficult for businesses to plan ahead. 
sons for thas degtaraicion are to be found in the structure of the arIufucturing sector (its consumer goods orientation and import dependen(*), in its international uncompetitiveness which foreclosed exports as a vent for excess capacity, and in its vulnerability to falling effective demand in the wake of declining oil revenues.

All three reasons were decisively shaped by the public policies of the bureaucratic state as outlined in chapter 3: an overvalued exchange rate which cheapened imports of machinery and other inputs, high protective tariffs which kept out foreign competition but also obviated the need to increase the efficiency of domestic manufacturing, and finally, inflationary policies which pushed up domestic production costs and added pressures for further protective measures. In toto, these wlicies militated against the emergence of a capital goods sector and thus against one of the most effective weasures to increase societal froductivity. Instead, the classical flaws of consumer goods importsubst itution materialized:

- Fffective subsidies of foreign-made machinery and inputs (primary and intermediate) meant that industrial investment translated into higher level of imports. This not only implied obvious resource-leakage abroad but also prevented the emergence of backiard and forward linkages as well as of a national capacity for technology-creation or adaptation.

- High profits and wages (in relation to value-added) were guaranteed by a domestic market held captive through high effecti- 
ve protection against foreign competition. Systemic imperatives to innovate, improve productivity, lower prices or rely on domestic sourcing were consequently absent.

- The national manufacturing sector, consisting mostly of importdependent assembly type operations with low value added, was incapable to adapt to new consumer demands which, then, could only be met through imports of either the product or the machines with which to assemble it locally. In either case, much of the multiplier effect of demand seeped out.

- Employment and capacity utilization levels were a function of consumption. These biases against savings and investments solidified the sector's dependence on oil revenues and undermined the bases for self-sustained growth, not to speak of development.

Initially, the Nigerian State's consumption-oriented import-substitution policies were, on their own terms, quite successful, especially as long as the high import contents could be regarded as a temporary phenomenon which, unsurprisingly, it was not however. ${ }^{16} \mathrm{By}$

16 Thus, even in 1987, the share of imports in industrial inputs was:

Wood and wood products Non-metallic minerals Food, beverages, tobacco Textile and wearing apparel Basic metal and fabricated metal products Chemicals and pharmaceuticals Paper products
$22.4 x$

$23.5 \%$

$34.8 \%$

$47.6 \%$

$50.3 x$

$55.8 \%$

$60.1 \%$ 
1973, domestic sources had largely replaced imports for a number of light consumer goods. "Ratios of domestic production to total supply were over $90 x$ for cotton textiles, beer, soft drinks, soap and detergents, and roofing sheets and, over $80 x$ for paints and footwear" (Stevens: $1990,262-263$ ). Manufacturing's share of GDP rose from $0.5 x$ in 1950 to $5 x$ in 1960 , to $7 x$ in 1970 and to a high of $12 x$ in 1981,1982 and $1985 \%$ (see table 8). However, once the market for traditional light consumer goods was saturated with domestic products, the manufacturing sector did not go anywhere. Because of its lack of competitiveness, it could not begin exporting, ${ }^{17}$ and because of its narrow technological base, it did not engender a capital goods subsector. Even in the Federal office of Nigeria's somewhat dubious classification schemo - cars are considered capital goods, rather than consumer durables consumer goods in 1984 still accounted for $79 x$ of manufacturing value added (see table 15 ).

The structure of manufacturing value added, in fact, changed little in the post-independence period. Food, beverages and tobacco remained (and remain today) the largest subsector with over $30 \%$ of va-

lehicles

Industrial plastic and rubber

Electrical machinery
$78.2 \pi$

79.47

$80.7 \%$

(Source: Manufacturers' Association of Nigeria, Sample Survey of the Manufacturing Sector, June 1987; cited in UNIDO: 1988,25).

17 Even though the exportation of manufactures had been one of the original aims of the Nigerian government's industrial policy (cf. Asiodu:1967,161) important elements of economic policy militated against this objective. In addition to the ones referred to earlier, high export taxes were an important factor. These, intended to shore up government income, applied not only to raw materials but also to processed goods (Schätzl:1973,32). 
lue added, followed by textiles (15x) and, increasingly inportant, petroleum products (13x). Technologically sophisticated products, or capital goods, were/are still of only aarginal importance. Moreover, manufacturing value added, in per capita teras, peaked in 1985 at under $\$ 100$ (see table 15). More critical than this low level is the fact that it is generated in the production of $1 \mathrm{ight}$ consuner goods. This bias in manufacturing structure necessitates high consumption levels to utilize production capacity, a particularly wasteful impetus at Nigeria's stage of development. Obviously, consumption is the ultimate goal of development, but an important trade-off is to forego some consumption today in favour of investments in facilities, infrastructures or other assets which produce incomparably greater future wealth. ${ }^{18}$ The incentive structures created by the Nigerian State in the $1950 \mathrm{~s}$ and maintained through the mid-1980s favoured short-term consumption at the expense of secure long-term consumption. The damage thus inflicted is serious, in particular because known oil reserves will be depleted in the next twenty to thirty years (International oil Encyclopedia: 1989, 79). Even if new discoveries will stretch this deadline out, the need

18 Technological change in the development experience of 19 th century North America or Europe was spearheaded by capital goods manufacturers wh ise skills grew by adapting and improving their products in response to the specific needs of their customers. "The importance of the machine tool industry to the process of technical change is that it came to constitute pool or reservoir of the skills and technical knowledge which were essential to the generation of technical change throughout the machine-using sectors of the economy. Precisely because it came to deal with processes and problems which were common to an increasing number of industries, it played the role of a transmission center in the diffusion of the new technology. The pool of skill and technical knowledge was added to as a result of problens which arose in particular industries. ... the existence of a well-developed nachine tool industry induced a higher rate of technological change by lowering the cost of innovation throughout the metal-using sectors of the economy" (Rosenberg:1972,102). 
to develop alternatives to oil as an earner or saver of foreign exchange is critical, if only because of the extraordinary rate of population growth.

An important economic reason for the aanufacturing sector's stagnation is the income inelasticity of demand for basic consumer goods the consumption of beer, soap or writing paper does not increase proportionately to income, but slower. Given a shallow if extensive domestic market, fidening the import-substitution base proved difficult once the "easy" initial phase of import-substitution was completed but export markets remained closed. Consumption oriented import-substitution turned out to be a failure even on its own terms. Nevertheless, the situation looked rather auspicious in the late 1960s. Industrial production had considerably increased as a result of wartime import restrictions, of the direct needs to sustain the war effort, and of the war-related unmet consumer demands - on joth sides. The end of the (ivil war, like the attainment of independence a decade earlier, heralded a new beginning. The Second National Development Plan struck a most optimistic tone, inter alia because of the government's confidence regarding

the quantity and quality of [Nigeria's] manpower, the innate ability of its people and their determination to transform their country politically, economically and socially. The Nigerian economy has emerged from the war as probably the most promising in Tropical Africa" (Nigeria:1970,29).

The war, indeed, had provided golden learning opportunities to improve on existing technologies, to use locally available raw materials and skills, and to adapt, adjust and modify processes to redress 
the non-availability of imports. However, the end of war which coincided with exploding oil revenues, obviated the necessity to build on this learning process. Understandably if regrettably, the briming self-confidence engendered by the war experience went to seed, taking the portentous turn towards overbearing nationalism and misplaced illusions, not only concerning the economy's potential but also the State's omnipotence. The Second National Development Plan contended that "a truly independent nation cannot allow its objectives and priorities to be distorted or frustrated by the manipulations of powerful foreigh investors" (Nigeria:1970,289). What happened instead was that. the development of the manufacturing sector, like agriculture, was distorted and stunted by the manipulations of powerful indigenous actors, especially the State. Sharing the pie became more important than its size or quality, not to speak of the question how the creation of new and different pies would be stimulated. The ownership structure of industries and the nationality of executives became a priority while the productive structure of industries and the quality of management received little attention. Scarce capital and talent was atracted to existing enterprises and hence diverted from investment into new intures.

Not surprisingly, the hopes regarding the sector's potential for employment creation were not borne out in fact. Employment in manufacturing increased from 16,000 in 1950 (around $0.01 \%$ of the labour force) to 450,000 in 1980 (around 1.4\%), but fell to under 300,000 in the 1980s (well below 1x; see table 9). Yet, even the staggering growth in absolute terms of manufacturing employment in the $1960 \mathrm{~s}$ can- 


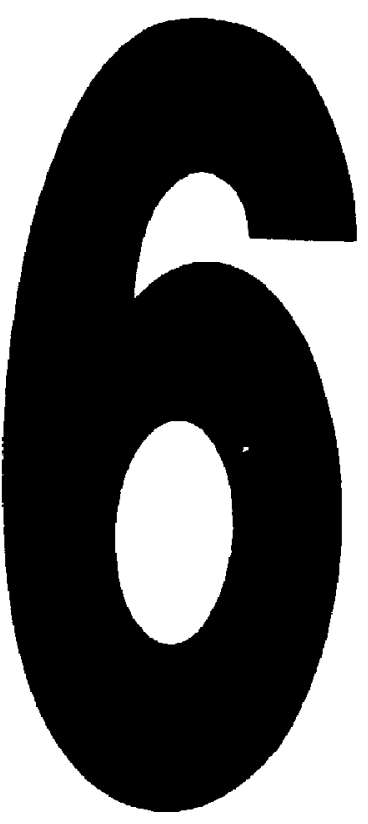

$\therefore 1$

PM-1 3\%"x4" PHOTOGRAPHIC MICROCOPY TARGET NOS 1010a ANSI/ISO w2 EOUIVALENT

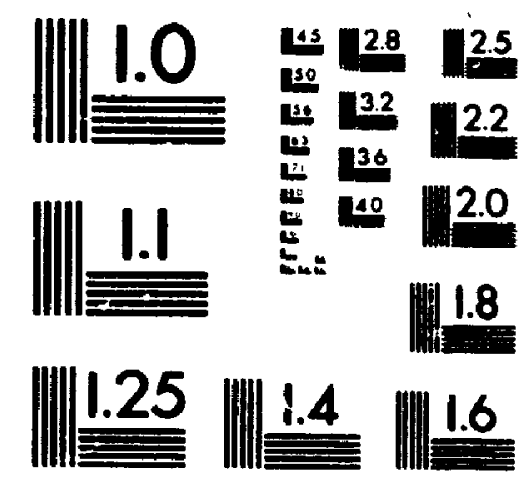

PRECISION ${ }^{2 M}$ RESOLUTION TARGETS

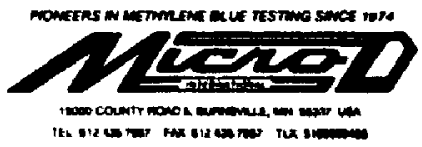

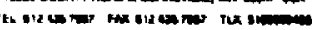


not hide the fact that manufacturing has never been a viable alternative to agriculture as an employment generator. Population growth added more people to Nigeria each vear - about twice as any in fact than the total number of manufacturing employees. Being, as it is, concentrated in a few big cities, ${ }^{19}$ manufacturing was far more successful at pulling people out of rural areas than at actually providing a livelihood to more than a minute fraction of them.

High relative wages have added to this pull, and to the excessive production costs. They were not necessarily high in relation to prevailing consumer prices, only in relation to labour productivity and to the rages in comparable Third World countries. In the late 1970s, wages in Nigerian textile wills, for instance, were three to four times higher than in other African countries (World Bank: 1982,102), while the general wage level in Thailand was less than half of Nigeria's official minimum wage. The comparative disadvantage of Nigerian manufacturing was exacerbated by the fact that experienced Nigerian workers were able "to earn double the minimum with allowances and fringe benefits possibly adding another 60x (Stevens:1990,277). It is noteworthy that private sector wages were oriented not at market conditions or productivity, but used the public service as conparator. In the 1960s they were about $20 x$ higher while, after oil came on stream, they nere significantly lower (World Bank:1982,126). Oil ren!s, which fuel-

19 Lagos's share in industrial production (in terms of value added and employment) rose from $24 x$ in 1963 to $66 \%$ in 1975 (FOS, Industrial Survey 1963 pp. 28 \& 38 and Industrial Survey 1975-1978, pp. 6 \& 10). Interestingly, the Federal office of Statistics has discontinued presenting figures on the regional distribution of manufacturing production in its surveys after 1977. 
led the growth and cost of the public sector, thus spilled over into the private sector, not in the sense of increasing productivity but of increasing production costs. ${ }^{20}$ They anplified :he tendency towards capital-intensive investments (created by effective subsidies of imported machinery), dampened the prospects of labour-intensive production and, typically, operated far below capacity. Despite these glaring debilities the State's protective regime (overvalued exchange rate, restricted access to foreign exchange, high tariff walls and quantitative import restrictions) permitted companies to increase wages and profits while letting productivity stagnate.

Import controls involved cumbersome procedures as well as frequently changing rules and tariff rates. Even in the expansive phase of the early 1970s when imports were relatively unrestricted, prospective importers had to scale the hurdle of gaining access to foreign exchange which, because of its subsidization, was allocated not automatically but administratively. The distortions and temptations entailed in such discretionary wethods have been referred to before. With the depletion of foreign exchange reserves in the late 1970 s (see table 10), the earlier liberalization was reversed and imports subjected to extensive State regulation. The Nigerian Central Bank's Annual reports

20 In fact, the misman-ement of oil rents increased production costs and lowered industrial produc...vity in other tangible ways: essential physical infrastructures such as reliable electricity and water, and adequate comunications and transportation facilities were never provided. Most firms, even though connected to the public phone, power and water systens, require their own radio networks, boreholes and generators (World Bank: 1989,28). Morgover, because of the unreliability or unavailability of public transport, many employers operate their own buses to ferry staff to and from work. Such deficiencies increase capital-intensity and production costs without, however, adding anything to productivity. 
show that consumer good imports grew more than seventeenfold between 1970 and 1980 . Because of falling oil revenues and dramatically rising foreign debts (see tables 2 and 10 ), this pattern was no longer supportable in the $1980 \mathrm{~s}$. Rather than devaluing the naira in an atteapt to equilibrate the supply and demand for foreign exchange, a comprehensive and cumbersome inport supervision scheme was introduced in 1979. All imports over $N 20,000(\$ 33,000)$ had to undergo pre-shipment inspection by the Swiss company Societé Générale de Surveillance (SGS) to ensure that items were of the correct quantity, quality and price. However, the outward pressure of an overvalued naira could not be checked by such police methods and

Nigeria appears to have been no exception to the rule operating in many developing countries that whenever controls on foreign exchange become tight, imports are overinvoiced. In order to divert part of the foreign exchange obtained at the official rate with the use of their import licenses, traders sometimes present the government with invoices that overstate the actual expenditure of foreign exchange (Salehi-Isfahani:1989,500).

According to the managing director of the International Bank for West Africa, the real value of Nigerian imports in 1981 was only N3 billion, despite outlays of N11.5 billion (Ohiorhenuan: 1989,199; see also Galloway: 1989,326$)$.

Duties were raised, ${ }^{21}$ many commodities were added to the list of those requiring a specific licence, ${ }^{22}$ and others to the 1 ist of those

21 Tariff rates varied between $10 x$ (e.g. for cigarette paper) and $500 x$ (for vehicles over $2,500 \mathrm{cc}$ and costing over $\mathrm{N15,000}$ ).

22 For example (in alphabetıral order): asbestos cenent pipes; assembled road and agricultural tractors; auto-cycles and cycles; cement; ceramic products, including ceramic sinks, water basins, bidets, water closets, pans 
banned altogether. ${ }^{23}$ If import restrictions were inevitable to counteract the outward pull resulting from the overvalued exchange rate, their pattern showed that the protection of domestic anufacturing was also an important concern. ${ }^{24}$ The total subsidy to industry arising from this trade regime was estimated at $23 x$ of value added at dosestic prices or $30 x$ of value added at world prices (Forrest:1982, 333). The burden on the Nigerian consumers was considerably, if unquantifiably, higher than these figures would suggest. What has to be reckoned in addition to the subsidies to manufacturers are the scarcity rents accruing to licence holders, the transaction costs of administering the unvieldy import regime and covering illicit payments to multifarious gatekeepers, and outlays involved in enforcement actions to prevent

baths, wall tiles etc. and sanitary fixtures; cereal flours; concentrated malt extract; cotton yarn; fishing nets; furniture fabrics; jute and other vegetable fibre; manufactured articles of wood of all types; nails, bolts and nuts; passenger cars of all types; pick-up delivery vans; plastic pipes; pre-printed papers and forms with or without carbon paper; rice; sugar; tea; tires for cars; umbrella handles; yarn of man-made fibre. A licence was also required for components of the above goods imported unassembled or disassembled, unless they were imported under an 'approved user's licence' (Nigeria: An AED Special Report, May 1982, 6). The Approved Users' Schene, created in 1964, went back to the Customs Duties Act of 1958. It allowed an "approved" aanufacturer to pay duty at a concessionary rate (sometimes zero) on materials inported for use in manufacturing (cf. Phillips:1967; Schatz:1977,122-123). It was finally abolished by the 1986 SAP.

23 For example (in alphabetical order): beer, bicycle tires tubes in of specific sizes, concentrated aalt extract, ganing machines, fabrics for furniture, frozen chicken, jute bags or U2 batteries (Nigeria: An AED Special Report, May 1982,6; Price Waterhouse: 1982,95).

24 It would be difficult to marshal fiscal arguments for the restrictions on lampshades, paper napkins, brass bed ornaments or wheel-barrows and the like (Frice Waterhouse: 1982,96). 
smuggling. ${ }^{25}$ The Nigerian State simply lacked the adainistrative apacity to implement efficiently the discretionary treatment of the wide range and huge quantity of merchandise which its inport-addicted economy required. Nevertheless, as porous and expensive as the shield against foreign competition was, it was successful enough to hold the Nigerian market captive to the domestic manufacturing sector, and to obviate the latter's need to increase its productivity.

Rising productivity is the key aspect of economic development. It implies a reduction of factor inputs - labour, capital and materials - for any given output and thus releases resources to either increase output or for alternative uses. In Nigeria, manufacturing productivity growth in the 1973-1983 period was recorded for only thirteen of twenty-six branches and "in the case of three of these sectors (electrical machinery, other chemicals and leather products) was not significantly greater than zero. The productivity growth performance of the intermediate and capital goods industries was particularly disappointing" (UNIDO: 1988,18 ). Nonetheless, the "most striking aspect of the pre-

25 For example, throughout the 1970s, the Nigerian Oil and Chemical Marketing Company (NOLCHEM) was the sole importer and supplier of bitumen, a key construction material. A review connittee argued that, because "of the company's monopoly position it has been in a unique position to dictate an increase in price from $N 45.90$ [\$70] per ton in 1973 to $N 120$ [\$190] per ton in 1978. The price in Algeria, in 1979, for instance was N76.80 [\$127] per ton" (Nigeria: 1981a,25). The granting of import licences was a rather murky process which lead one analyst to conclude that "the distribution of quota has depended largely on arbitrary decisions of the ILA and IQAC. ... The paucity of published information on the mode of operation of Nigeria's import licensing does not permit a definitive and detailed assessment of its administrative efficiency. Such evidence as is available tends to suggest some inefficiency in the administration. ... import licensing decisions are based largely on guesswork" (Fajana:1977,514 \&517). The scope for patronage and corruption is evident. 
recession period (1970-1978) was the relatively high level of the gross profit to value added ratio. The wean gross profit to value added ratio was as high as $80 x$ during this period [... and] declined to 75 per cent during the recession of the 1980s. Profit levels have risen even in years when industrial output has fallen drastically (such as 1983)" (UNIDO:1988,19). The intimate relationship between the state and the manufacturing sector has made this possible. ${ }^{26}$

With population growing, agriculture stagnating, anufacturing performing sluggishly and imports soaring, the question arises how these diseconomies could be sustained. The answer, of course, is the State and oil. Oil obviated the need for the Nigerian State to finance itself through surplus extracted from the agricultural sector, and it also permitted the funding of imports, the subsidization of domestic ranufacturing and the payments of rents to traders, contractors and to the state class.

The 1970 s began nost auspiciously for the Nigerian State. Mineral oil, the income from which accrued directly to the state, had become the economy's most prominent factor - in 1960 it had accounted for just 3\% in value terms of Nigeria's exports, in 1970 its share had increased to a staggering $63 x$; it culminated in 1981 at $98 x$ before falling back slightly (see table 3 ). Income from oil was virtually no factor in

26 For instance, Peugeot and Volkswagen, effectively operating in a sellers' market can charge considerably oore for their locally assembled products than they can in Canada for imports. For example, in 1991, a $\mathrm{WW}$ Santana cost $\mathrm{N} 255,100$ (about $\$ C D N 30,000$ ) in Nigeria and a Peugeot 505 GR N214,000 (about SCDN 25,000 (WA No 3858, 19 August 1991, 1380). While these models are not, or no longer, available in Canada the prices of a comparable lolkswagen were about \$CDN20,000; a Peugeot 505, before it was taken of the Canadian market in 1988, sold for about \$CDN 18,000 (dealer information). 
1960 , yet by 1970 it accounted for about a quarter of federal revenues, by 1975 for over 80x, a margin it would waintain nore or less throughout the 1980s (see table 17). Just as stupefying as the process of switching the sources of state revenue were its growth. Within one year (1970-1971), it more than doubled; within another three (19711974) it tripled its higher base which, in further six years (19741980), it nearly quadrupled again (see table 6). Two of the almost inevitable drawbacks of such a windfall were that

- it accrued to the state, rather than to a myr: of private producers. This entailed the danger of being spent unproductivels, either as recurrent expenditure for an inflated state apparatus in the form of salaries and perquisites, or as hastily planned, badly coordinated and haphazardly executed capital investments; and that

- it was not the result of domestic productive activity as, for instance, income or producer taxes would have been. Normally, a State taxes a portion of wealth already created by its citizens' labour, capital and ingenuity. Subsequently, a major portion of these tax revenues are funnelled back into the economy with the effect of employing and improving its productive base. Oil rents, if spent massively in a protected donestic market, will deluge an unprepared econoey and lead to hyperinflation. Only if the government underspends and, instead, increases its foreign-exchange reserves, can the pressure on 
domestic resources be minimized and these built up to enable them to meet higher denand.

The Nigerian State was unable or, nore likely, unwilling to husband these gratuitous resources and to eaploy them in systematic and constructive fashion. The State's size and weight increased dranatically, as did canital investments in overwhelmingly dubious schenes. 27 Very quickly, even these unexpected windfall gains were insufficient and had to be complemented by external borrowing. Returns on investment were considerably lower than would have been necessary to ignite self-sustaining economic growth, and inflation galloped. State expenditures were under $8 x$ of GDP in 1955 , but grew to $18 \%$ in 1960 , to $30 x$ in 1975 and to $36 x$ in 1979 before settling down in the $20 x$ range in the 1980s (sre tables $6,8 \& 16$ ). Naturally, these figures alone are not. instructive, since the money could have been well spent. However, as has been argued in the foregoing, this was not the case. Perhaps with the lone exception of a modern highway system - prompting the Economist to the caption "Let them eat flyovers" (Nigeria Survey in No. 7444,3 May 1986, p. 18) - Nigeria has done worse in all respects, actually much worse in most cases, than its comparators, that is, other low-

27 Data on the number of state employees are notoriously hard to cone by, especially those of local governeents and of the proliferating states of the federation. Nonetheless, the total payroll seens to have increased fron 213,000 in 1960 to well over 3 aillion in the 1980 s (see table 9). The federal civil service grew from 35,000 in 1960 to over 100,000 in 1973, to over 225,000 in 1980 and to over 300,000 in 1984 before declining (see table 14). The growth of state expenditure in the $1970 \mathrm{~s}$ was nothing but breathtaking. By 1976 the federal government alone spent more than the country's entire GDP of 1970 (see tables 6 and 8 ). 
income economies. Table 19 represents a danning indictaent, showing that in such social areas as education, health care or sanitation, but equally in such economic fields as food production, industrialization, per capita GNP and per capita GNP growth rates, Nigeria's perforance is well below average. In fact, there is not a single meaningful domain in which Nigeria does better than its conparators (see also Nigeria: 1987,35$)$.

This disastrous balance appears even gloomier if it is considered that state spending was not confined to current revenues from oil, but exceeded those by a considerable margin. External debt by far outstripped external reserves since 1978, except for the fluke year 1980 when oil prices soared to their historic level of over $\$ 35 /$ barrel. By 1981, net external obligations had risen to over $\$ 8$ billion, a figure which nearly quadrupled until 1988 (see table 10). During the 1970s when oil revenues first accrued on a masive scale, their monetization in an unprepared domestic economy resulted in enormous inflationary jolts (see table 7 ). Government pay increases and spending on construction projects brought money into circulation which was not natched by corresponding supply capacities. The governisnt atteapted to contain these inflationary pressures by liberalizing imports, by creating the National Supply Company and by instituting price controls. ${ }^{28}$ These

28 The National Supply Company was established in 1970 with the nandate to enter the distribution business directly. Its first task was to inport 50,000 tonnes of flour and 150,000 tonnes of cement (World Bank:1974,52). It was abolished in 1986 in the context of SAP. It will, as one comentator remarled, "go down in history as the only trading company in Nigeria to fold up in the red despite huge financial investment by its proprietors, unliaited inport licences, access to foreign exchange at the official rate and a virtual monopoly on importation of essential comodities at a time when the country was a seller's market" (Odunfa:1986,2300). A Price Control Board was estab- 
measures, whether state spending, trade controls, or food, wage and industrialization policies, while econonically dubious, developentally counterproductive and socially disastrous, all followed an identifiable logic. They either served to increase state autonony and legitinacy, or they coincided with the state class's property interests, or all three.

\section{b) Increasing state Autonor and naintaining state lesitinacr}

State autonomy, economic and political, is both a prerequisite for and a consequence of state legitimacy. Only a State with a secure resource base has the means to carry out policies which prowise to enhunce its legitimacy and by implication its political autonomy. Control oriented, that is, interventionist policies, as was argued earlifr, are more useful than conceivable alternatives to fortify state autonom: and legitimacy, not to mention their usefulness for the pursuit of the state class's property interests. They are the policy instruments of choice for a patrimonial-bureaucratic state. The diri-

\footnotetext{
lished also in 1970 and charged with controlling the prices of a wide range of commodities, whether imported or locally manufactured: beer, stout and soft drinks, flour, wilk, salt, sugar, tinned fish, watches, tobacco, pharnaceuticals, textiles, tires and inner tubes, bicycles and spare parts, kerosene, petrol, diesel oil, fuel oil, notor vehicles and spare parts, building naterials, cement and roofing-sheets (ARBe:5/1970,1702). Proving highly ineffective, this board was abolished in 1980. Before that, however, in January 1977, the federal military government promulgated the Price Control Act to conbat galloping inflation and hoarding. The prices of a range of conmodities very similar to the one of 1970 were controlled and atiff penalties fixed for disobeying the law (Price Waterhouse:1982,13). It was equally ineffective. Throughout the $1970 \mathrm{~s}$ and 1980s, inflation soared: prices in 1980 were four $t$ imes their 1970 level; they more than doubled again until 1984 and doubled once more until 1989 (see table 7).
} 
giste State becomes the sole dispenser of gignificant econosic opportunities which in turn relegates non-state actors to positions of subaltern dependence. The bureaucratic Nigerian State's autonomy-preserving and legitimacy-enhancing strategy consists of three distinct components, all of which are positively related also to the state class's property interest.

The first refers to securing the state's econonic base which is a necessary, not however a sufficient condition to further the state class's autonomy and property interests. Under the circumstances this means capturing a maximud share of the oil rent or increasing its own weight in the relationship with foreign oil companies. The second conpollent of the bureaucratic State's autonomy-sustaining strategy ains at utilizing the oil rent in a manner congenial to the bureaucratic temperament, if not directly for the state class's own benefit. To erect innumerable gates which require keeping is the instinctively logical course. The thus possible regulation of economic life permits, anong other things, the preferential treatment of those individuals and groups which could become threatening to the state class's monopoly positior. To let them partake in the bonanza to a liaited degree is a worthwile investment for the state class. Its clients, thus domesticated and with their own economic well-being at stake, becone valuable defenders of the bureaucratic mode of production. The business class, additionally, is a particularly precious instrunent for bureaucrats to translate their position into aterial benefits. The third conponent of the State's autonony and legitinacy enhancing strategy is to crean off the politically discontented, who can well be nembers of the state 
class, by creating economic or political structures which, then, absorb many who could otherwise becone a threat to the state class. Establishing parastatals or creating new states serves this purpose. It strengthens the center because these subsidiary bodies are both financially dependent and in direct conpetition anong thenselves for access to and resources fros the state.

By far the nost significant of these autonomy-enhancing measures was the nationalization of the country's oil industry. Undertaken with dispatch in the 1970s, it provided the state with a secure and independent resource base, thus effectively delinking it from agriculture, the economy's traditional surplus-generating sector. The State's hegemony was established in one fell swoop and all econonic or social actors realized that their fortune depended on the quality of their rela: ionship to the State. The State, as a military regime not subject to a periodic renewal of its andate through elections, could be threatened only frow within, or rather, each ruling clique, having itse]f hijacked the state in a coup, had to face the prospect of being custed in the same manner.

while oil exploration in Nigeria dates back to the late 1930s, commercial production, entirely by nultinational companies, began in the late 1950s. As stipulated in the Petroleun Profits Tax Ordinance of 1959 , they nere obliged to share their profits, based on realized prices, 50x-50x with the Nigerian State (Munnery:1968,12). This arrangement was altered in favour of the Nigerian State through the Petroleum Profits Tax (amendment) Decree No. 1 of 1967. The actually realized price as a calculating basis for profit-sharing was replaced 
by the "posted price" which, negotiated between the government and the oil companies, is normally higher (Kemp:1987,49-50). A number of decrees issued in subsequent years strengthened the Nigerian State's position vis-a-vis international oil companies. In 1971 , the government resolved to vest the ownership and control of petroleum found under or upon Nigerian land, territorial water or within Nigeria's continental shelf with the Nigerian government (ARBe:3/1971,1989). In 1969, the government served notice to the foreign oil companies of its intention to directly participate in the industry. A Petroleum Decree reduced concession leases fron 99 to a maximum of 20 years, included the option of government participation in the lease and stipulated that within ten years Nigerians would have to hold $75 x$ of all managerial, professional and supervisory positions, that only Nigerians could be employed as workers, and that detailed training and recruitment programmes for Nigerians had to be submitted upon application for a lease (ARBe:11/1969,1536; Pearson:1970,187-188; Edogun:1985,92).

In 1971, the Nigerian National Oil Corporation (NNOC) was established as a functional complement to the regulatory mandate of the Ministry of Petroleum Resources. The NNOC was to manage the government's equity in foreign oil companies as well as to engage, either independently or in cooperation with these foreign companies, in all technical activities of the oil sector, such as in exploration, production, refining, marketing, transportation and research. This move was in connection of the country's accession to OPEC which, in 1968, had decided that all its members were to acquire $51 x$ of the equity interests of foreign oil companies operating in their countries and to 
participate actively in all aspects of oil operations (Amu:1983,7).

In the aftermath of the Yom Kippur war of September 1973, the balance of power shifted decisively in favour of OPEC governments and away from oil companies. The oil price was unilaterally doubled in October (from $\$ 4.3$ to $\$ 8.3$ per barrel in the Nigerian case), and nearly doubled gaain in January 1974 (to $\$ 14.7$ ). Also increased was the petroleum profits $\operatorname{tax} a \cdot f$ the oyalty rate so that "the tax-take per barrel at the end of 1974 wust have been about $\$ 10$, while in 1970 it had been about 90 cents" (Rimmer: 1981,85-86; seo also Meyer and Pearson: $1974,155) .29$ The Nigerian government in addicion moved aggressively to increase the share of Nigerians working in the industry and to exercise a veto if the appointment of "a senior Nigerian official above the grade of skilled worker" was to be terminated (ARBe:2/1972,2304).30 The nevt move was to increase the state's equity shares in oil compallies as spelled out in the Second National Development Plan:

29 Since 1979 , the petroleum profit tax is $85 \%$ of the posted price minus the sum of the royalty and a notional production cost allowance (Kemp: 1987, 501 .

$30 \mathrm{By} 1976$ the staff of the oil industry had been Nigerianized to a very large extent (Source: Nigerian National Petroleum Company, 1975-1976 Annual :eiort on the Nigerian Oil Industry (Lagos: NNPC, undated):

Oil Exploration Conpanies Nigerians non-Nigerians

Management Professional Supervisory Clerical/secretaries Skilled labour Unshilled labour others Totals

63
1,047
840
1,492
1,666
487
26
5,855

63 840 1,492 1,666 487 26 5,855
79 403

1
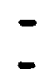

$-$

$-$

483
Service Companies Nigerians non-Nig

$\begin{array}{rc}23 & 57 \\ 109 & 131 \\ 265 & 226 \\ 343 & - \\ 1,788 & 12 \\ 1,317 & - \\ 231 & - \\ 4,076 & 426\end{array}$


The exploration of strategic natural resources will be undertaken by the government singly or in technical partnership with private concerns provided that in all cases, the Government remains the dominant partner (Nigeria:1970,289).

The 1962 agreement with the Nigerian Agip Oil Company (NAOC) had included the option of a $33 x$ government participation in the company's equity; this option was exercised in April 1971 (NNPC:1983,4). On the same date the Federal Government acquired $35 \%$ equity interest in Safrap (later Elf), a subsidiary of the French, partially state-owned, company Elf-Erap, in retaliation for political and wilitary support given to Biafra during the Civil war (Meyer and Pearson:1974,157; Onoh:1983,23; ARBe : 4/1971,2022).

In the early 1970s, eleven international petroleum companies with a combined investment volume of nearly $\$ 170$ million operated in Nigeria. The most important was Shell-BP which accounted for about $60 x$ of the oil wining leases, $65 x$ of the proved reserves and for over $70 x$ of the total production (cf. Pearson:1970,16-17, Schätzl:1973, ${ }_{-}$). The other companies, listed according to production volume, were: Gulf 0 il, Mobil Oil, Agip/Phillips, Safrap and Texaco. Effective 1 April 1973, the Nigerian government acquired $35 x$ equity of Shell-BP, Gulf and Mobil. One year later, the Nigerian State's equity in most companies was enlarged to 55x. To cope with increased responsibilities and revenues, the NNOC was merged with the Ministry of Petroleum Resources to form the Nigerian National Petroleum Corporation (NNPC). It, too, was charged with the production of crude oil and all related upstream and downstream activities, directly alone or through joint ventures or service contracts with foreign oil companies. In 1979, oil prices in- 
creased f - $\$ 15 / b$ to $\$ 22 / b$, that, is by nearly $50 x$ compared with the previous year; in 1980 they peaked at over $\$ 40 / \mathrm{b}$ and averaged $\$ 35 / \mathrm{b}$ for the year as a whole (see table 4). Thus buoyed, the Nigerian government took over $60 x$ of all remaining foreign oil companies - $80 x$ in the case of Shell-BP to underline its displeasure with Britain's announcement to sell oil to South Africa and/or her failure to dislodge Ian Smith's illegal Rhodesian regime (Amu:1983,10; Holman:1989,A22; see a] so table 18 ).

Whereas the State's share of realized oil revenues stood at $16 x$ in 1965, it increased decisively in the 1970s, reaching $98 \%$ in 1975 and remaining well above $80 \%$ thereafter (see table 17). The small residual rent to the multinational oil companies. As was shown earlier, the State's success in capturing the lion-share of the oil rent was, unfortunately, not mirrored in its similarly successful management. The latter, following the logic of the bureaucratic mode of production, was concerned more with state autonomy, state legitimacy and with the selfaggrandizement of the state class, than with economic or human development. Before examining examples of predominantly legitimacy-enhancing policies, two pertinent cases of autonomy-augmenting measures will be considered: exchange rate policies and the proliferation of federal states. Both of these had, from the interest position of the bureaucratic State, the advantage of furthering all three central objectivea, that is, autonomy, legitimacy and property.

Among the instruments available to any State to affect domestic production and welfare, taxes, trade policies (such as quantitative import restrictions, exchange controls as well as import duties and 
export levies) and exchange rate policies are anong the most powerful. They are interesting for the bureaucratic state because they permit, indeed necessitate, considerable administrative and/or political discretion, and because they allow the precise targeting of costs and benefits. Tax and trade policies have been discussed previously. Their significance for state revenue as well as to support the State's gatekeeper role is fairly obvious. Domestic manufacturing can be protected, urban consumers subsidized, and the business class tied to the State through the ariard of lucrative import licences. Exchange rate policies, even if somewhat. more diffuse in their impact, are equally worthwile to strengthen the State's autonomy and legitimacy. An appreciation of the exchange rate immediately cuts import prices and consumers' prices and, therefore, immediately boosts real income of those involved in the cash economy, which means, broadly speaking, urban consumers. Urban consumers, in a situation such as Nigeria's, constitute a segment of society which, for the State's legitimacy, is of crucial importance. Exchange rate policies are, additionally, of singular economic and developmental relevance because they create an incentive or disincentive system to which producers adjust.

Any country's goods-producing sectors, such as agriculture, construction or industry, are extremely sensitive to exchange rates. A relatively undervalued domestic currency favours domestic producers because any given world market price in US $\$$ or \& Sterling translates into more domestic currency units. Domestic products are then comparatively cheap in relation to foreign products and thus have a competitive advantage, not only in the home-market but also abroad. Converse- 
$1 y$, a relatively overvalued currency reduces both the competitiveness of local products vis-à-yis imports and the internally realized price of export comodities. Domestic products are in this case comparatively expensive in relation to foreign products and thus have a comparative disadvantage. 31 An overvalued currency pre ipitates an importpull and, therefore, implies a bias in favour of consumption and against production: importers are subsidized while producers and exporters are penalized.

The Nigerian state, rather than controlling and containing these effects, as for example its Indonesian counterpart did in very similar circumstances, 32 amplified them. Anticipating even higher revenue flaks in future, fiscal deficits were allowed to widen and the foreign drbt grew even while oil prices and production were high. Since most of the State's spending went either directly into consumption or into

31 During the 1970s, Nigeria's rate of inflation exceeded world inflation b) oner 5\% annually while the Naira's nominal value appreciated at an annual rate of over $2 \%$. This caused imports to be $44 x$ cheaper than domestic goods in 1981 as compared to 1972 (cf. Salehi-Isfahani:1989,496; see also table 7 ).

32 Indonesia is roughly comparable to Nigeria in that it is a populous former colony with an economy which in the past was dominated by agricultural exports (tea, coffee, palm oil products, rubber), and which in recent years has become a major exporter of mineral oil. While the share of oil production in GN during the 1970 s and 1980 s was roughly similar in both countries, government policies differed considerably. The upward pressure on the domestic currency which results from wineral export booms was resisted in Indonesia and reversed much earlier than in Nigeria. The Indonesian State increased domestic taxes during the $1980 \mathrm{~s}$ oil boom and was also much less profligate in its expenditures (Bery:1990,1126). Both measures kept the State's internal and external debt lower while, through attractive producer prices and governmentprovided infrastructures, agricultural imports could be held steady and agricultural production, even exports, could be boosted (cf. Gelb:1986; Gelb: 1986a; Pinto:1987; horld Bank:1986b,72). 
nonproductive, inefficient and predominantly imported investment, ${ }^{33}$ it had no appreciable developmental effect but, to the contrary, dislocated even existing production, as has been shown earlier for manufacturing and agriculture. It bears emphasizing that the anti-production effects of an overvalued exchange rate were particularly pronounced in export agriculture.

What matters in the case of exports is the effective exchange rate, which is the number of local currency units actually received by producers for, say a dollar's worth of their commodities, adjusted for inflation. ${ }^{34}$ In Nigeria during the 1970 s and the first half of the 1980 s, not only was inflation rampant but the official exchange rate appreciated considerably, thus dramatically widening the gap between the administratively established official exchange rate and the effective exchange rate (see table 6 ). The result, compounded by the fact that the government-fixed producer prices were by a wide margin below

33 The State's proclivity to import was not only a reaction to the limited domestic supply capacity but exacerbated by the fact that, until the structural adjustment measures of the mid-1980s, imports by government organizations were duty-free (cf. Stevens:1990,286).

34 If the internal rate of inflation is higher than the external, and if the nominal exchange rate remains unchanged, the domestic currency appreciates de facto as can be scen from the following hypothetical exanple. if a ton of groundnuts sells for $\$ 200$ in the world market and if the naira/dollar exchange rate is 2.8 , the Nigerian farmer receives N71 (abstracting from export duties, transportation costs or actual prices paid by Marketing Boards). If, then, Nigerian inflation is $20 x$, US inflation only $5 \%$ and the world aarket groundnut price increases parallel to the US inflation rate, next year's price will be \$210. To maintain this year's real price, i.e. next year's adjusted for inflation, the Nigerian farmer needs to receive N86, while a constant exchange rate of $2.8 \$ / N$ provides only $N 75$. The farmer's income would remain stable only if the exchange rate would be depreciated fron $2.8 \mathrm{~N} / \$$ to $2.4 \mathrm{~N} / \$$, i.e. by the inflation differential of 15x. For actual world arket and producer prices see table 5 . 
world market prices (see table 5), was the steady decline of quantities of agricultural comodities produced and exported (see table 1). A shift to food production for sale was precluded because the prices obtained in urban markets were low, artificially so in fact, because of the State's food import policies.

To provide cheap food in urban areas is an important legitimacyenhancing measure, not only for the Nigerian state, but also for its cour:terparts in many other developing countries. Since wost of the wage earners are poor, even if they are better off than saallholder peasant farmers, food figures prominently in their budget. To prevent food riots or even only pressures for salary increases and thus to keep the wage bill low for the public service, but also for the small industrial sector, ${ }^{35}$ food consumption will be subsidized which, because of the relatively lower prices of imports, will further damage domestic agriculture. In Nigeria, as for example also in Venezuela or Zambia, mineral exports supported an artificially strong currency and with it the illusion of "cheap" imports which prevented not only the emergence of a dinamic manufacturing sector, but which were also instrumental in the decline of agriculture. Paradoxically perhaps, but certainly at enormous costs in terms of developmental prospects, this decline enhanced the state's political autonomy so lons as the oil rent was available. No longer dependent on revenues from export agriculture,

35 Nigerian industry has another interest in low food prices. Since it is internationally uncompetitive, it does not export its products which make it dependent on the dumestic market which is anyhow rather shallow and would become only more so, if spending power were diverted from consumer goods to food. 
and also not dependent on domestic agriculture to feed the urban centers, the state was free to ignore and neglect the overwhelaing aajority of its citizens. Instead, it could concentrate its attention and resources on those sections of society which could muster significant conflict potential. These were parts of the state class itgelf and the business class. The fcrmer's aspirations were addressed, inter alia, through the expansion of state apparatuses, the latter's through the indigenization of foreign owned enterprises.

State autonomy requires that potential opponents are either neutralized or coopted. Neutralization works only if the targets of such measures cannot mobilize significant popular support for their cause and thus resist their relegation into obscurity. The intimate if subsidiar relationship between state autonomy and state legitimacy comes into sharp relief here. Because only if the victims of autononyenhan:ing measures are unable too thwart their legitimacy, will these measures be sustainable.

This is why the crude attempt to augment state autonomy by way of abolishing the regions failed so utterly in 1966. In May of that year, the first military regime declared a unitary State in a short-lived attempt to contain centrifugal forces and to strengthen the center. Northern fears of domination by Southerners, especially by Ibos, together with the related anxieties of many non-Ibo officials prepared the ground for a counter-coup and the restoration of a federal structure barely two months later. It also launched the East into secession and the country into an acrimonious civil war (cf. O'Connell:1967,173184). The lesson drawn from the events of the second half of the $1960 \mathrm{~s}$ 
was that the abolition of regions, since it lacked legitimacy, would not strengthen the center but, on the contrary, weaken it. Consequent$1 y$, in the past twenty years, state legitimacy and autonony have been pursued also by means of establishing wore and nore federal states. Creating alternative fora for political abitions and new business opportunities, the proliferation of states was useful to divide the center's political opponents and to deflect some patronage-seekers. New states provided new addresses for non-state actors to pressure, but, because they were ultiately dependent on the center, the balance of power shifted in favour of the center. There was thus a congruence between the political interests of the central state and the political cum commercial interests of regional elites. Focussing on tlif latter, one recent comentator contended that state creation in contemporary Nigeria was a function

of economic benefits that accrue to politicians (including some technocrats in agbada and khaki). Apart from recouping what has been expended, lobbyists, including some influential personalities, generally capitalise on the vacuum for job opportunities, presidential and state appointments, ahards of contracts, hiring out of residential and office accommodation to the governments of the newly-created regions (Musa: 1991, 1846).36

As is typical for clientelist arrangements, loyalty to the patron

36 In 1979, the outgoing Obasanjo government attempted, unsuccessfully, to rule that state legislators should not be provided with accomodation at public expense and that all states should be linited to nine ninistries. However, in the Second Republic, legislators "quickly coerced governors to provide them with quarters. The governors themselves were busy creating unnecessary posts, and filling thea with their friends; state administrations which all had nine ministries in 1979, quickly expanded, sone to as many as 20 ministries with over 40 permanent secretaries" (WA No 3468, 8 February 1984 ). 
commands a certain price. ${ }^{37}$ The viability of this divide-and-rule strategy critically hinges on a secure resource base controlled by the center which permits it to fund the otherwise non-viable states, but also to keep them dependent. ${ }^{38}$ As has been demonstrated above, the center's control of mineral oil - since 1973 generating over $70 x$, in some years over 95\%, of public revenue (see table 17) - provided it with the necessary wherewithal.

Nigeria's atomization began shortly after independence. The former liestern Region, dominated by the oppositional Action Group was split and the new Mid-Western Region created in 1963. After the 1966 interlude, the four regions were replaced by twelve states. In 1977 the twelve states rere succeeded by 19 states, two more were added in 1987 and $a$ further nine in 1991 , bringing the total to 30 . Further subdivisions cannot be excluded. ${ }^{39}$ Since fer of these states were/are

3i To enable the states meet their expenditure obligations, the federal government made special loans available on three occasions alone between 1979 and 1984. During his re-election campaign in the sumer of 1983, President Shagari announced a $N 460 \mathrm{mn}$ ( $\$ 644 \mathrm{mn}$ ) rescue loan to all 19 states while the Buhari regime lent $\mathrm{N} 600 \mathrm{mn}(\$ 840 \mathrm{mn})$ to 13 of the 19 states (ARBe:3/1984,72307231). Also, immediately after their creation in 1991, the federal government approved a grant of N30 million for each of the nine new states towards their immediate infrastructural needs. The 47 new local governments, established at the same time, got N5 million apiece (WA No 3861, 9 September 1991, 1506).

35 The share of internal revenue in the federal states' total recurrent revenues is a good measure of their viability. In 1984, this share was $37 x$ for all states, with only Borno, Lagos and Ogun over 50x and with Anambra, Kivara, Ondo, Plateau and Sokoto under 25x (WA, No. 3493, $30 \mathrm{July} \mathrm{1984,} 1523$ ). In 1985 the share of internally generated revenue dropped to $24 \times$ (ARBe:2/ 1985,7643 , also for detailed figures on individual states).

39 In the run-up to the 1983 elections, a veritable scramble for new states took place. The House of Representatives voted for 21 new states (i.e. for a total of 40 ) and the Senate for 26 new states (i.e. for a total of 45) (ACR: 1984,B537). After the establishment of Akwa Ibon and Katsina states in 1987, President Babangida publicly announced that no further requests for the creation of new states would be entertained or tolerated during his adminis- 
financially self-sufficient, various revenue-sharing fornulae were tried and discarded, invariably however strengthening the center's preeninence and fortifying the federal states' dependency.

Before independence, revenue allocation evolved around the two principles of regional autonony and derivation with population added as a factor in 1958 (Onoh:1983,109-110). The regions' financial autonomy, confirmed in the 1963 constitution, were weakened by subsequent regimes, but also by the collapse of agriculture as a revenue generator. Deriration as a principle was more or less given up and the present distribution formula, worked out under the Shagari regime and slightly adjusted in 1990, gives the federal government 50x of revenues, the state governments $35 x$ and the remaining $15 x$ to local governments (ARBe:2/1985,7643; ARBe:1/1991,10259). By maintaining the center's share and sub-dividing the residual among a larger number of federal states in a zero-sum fashion, it is difficult to see how "the principle of development" could be served, as President Babangida clained (WA No. $3860,2$ September 1991,1446$)$. A sore plausible if speculative sotive conld be that the military regime, unwilling to surrender power to

tration (AC No 19, 27 September 1991, 4). Barely two years later, another nine states were established (ARBp:8/1991, 10253). One connentator guggested that President Babangida, when raising the number of states to 30 , hoped to "end future agitation for new states. But the expectation proved wide of the mark. ... ardent state agitators clained that the struggle for aore states still continues. ... For some agitators it was the triunph of a drean. For others, who got neither a new state nor a new capital, it was a nightnare. But the really lucky ones got not only a new state but the surprising gift of a capita] as well - a clear case of manna fron IBB [Ibrahie Badamasi Babangida]" (Ayeni:1991,1533). Rioting broke out in various parts of the country, for example in Delta state because Asaba and not Warri had been chosen as the capital, and in Kwara state because the carving out of the new Kogi state had left kiara "barren and bereft of federal presence" (WA No. 3861, 9 September $1991,1506)$. 
civilians as promised by 1992, will use the creation of states as justification to stretch out the timetable once are (AC No 19, 27 September 1991, 4). Having won considerable legitinacy with aspiring politicians and bureaucrats through this ostensible act of generosity, the center benefitted even more in terms of autonony, not at least in light of the realistic prospect that the present military regine will be able to enjoy it even beyond 1992 .

If the creation of states can shore up state legitinacy in inportant respects and thus neutralize the specific threat to the state's autonom: emanating from aspiring politicians and anbitious bureaucrats, it does little to mollify a second significant pressure group, namely businessmen. Various ways in which the state co-opts the business class - and their momentous costs in developmental and general welfare terms - have been discussed earlier: import licencing, contract awards and the protection of manufacturing industries. A final and equally telling example of the State's effort to engage the business class and thus to enhance its own legitiary were the indigenization policies of the $1970 \mathrm{~s}$.

Indigenization is one of the most thoroughly researched aspects of the post-independence Nigerian political econony. 40 It will not be necessary to retrace these analyses in the present context and I will limit myself to highlighting how indigenization gerved the legitimacy interests of the Nigerian State. How it served the property interest.s of the state class will becone apparent by inplication. Indigeniza- 
tion, unlike the partial nationalization of the oil industry, addressed the foreign ownership of manufacturing, construction and service industry establishments and sought to reduce and complement or replace it by Nigerian ownership.

Nigeria was and is a predoninantly agricultural country whose tentative first steps towards industrialization were taken only in the decade before independence. Her export trade during pre-colonial and colonial times, as was outlined before, was doainated by expatriate trading houses which, in the context of the import-substitution policies of the 1950 s and after, reluctantly turned their attention to local production. Endowed with considerable advantages, financial, technological and managerial, they dominated the small nanufacturing sector even after independence. In 1963 [1972] it consisted of 649 [1,952] firms with a paid-up capital of EN58.8 million or $\$ 160$ million [\{Y382.0 or $\$ 1.2$ bn], 10x [11x] of which was held by private Nigerian investors, 20x [16x] by Nigerian governeents (federal and state) and 6BX [58x] by private foreign investors (Nigeria, FOS, Industrial Survey 1963:35 (1972:43]). This preponderance of expatriate capital caused considerable resentment, borne out of envy, within the Nigerian elite. Rather than viewing foreign companies as an asset as W.A. Lewis had advised the similarly placed Gold Coast government (Lewis:1953) in that it freed domestic capital for other ventures and thus enlarged the economy's potential, it was taken for granted that they haraed the economy. Excessive profit-taking as well as racist hiring practices were charged and the (counterfactual) clain was aade that their presence preempted Nigerians fron entering the nodern sector (cf. Akeredolu- 
Ale:1971,215-219 and idea:1976). Indigenization, the mandatory transfer of property from foreign owners to nationals, promised to change matters. Buoyantly emerging from civil war, the federal government resolved to transform Nigeria into

a united, strong and self-reliant nation; a great and dynaaic economy [which called for the] progressive eliaination of the foreign dominance in the national econony, not merely in terms of nominal financial ownership but really in terms of the level of managerial and technological control. ... It is vital, therefore, for Government to acquire and control on behalf of the Nigerian society, the greater proportion of the productive assets of the country. [To this end the] government will seek to acquire, by law of necessity [sic] equity participation in numer of strategic industries that will be specified from time to time. In order to ensure that the economic destiny of Nigeria is determined by Nigerians themselves, the Government will seek to widen and intensify its positive participation in industrial development (Nigeria:1970,32-33 289).

This statement of will, clearly establishing redistributive rather than growth or developmental objectives, was operationalized in the Indigenization Decree of 1972 and its subsequent revision in 1977 . These decrees, outlawing any entirely foreign owned comercial venture, identified three distinct categories of enterprises: ${ }^{1}$

11 The 1972 Decree stipulated that by April 1974 only Nigerian citizens could own, even partially, an enterprise in 22 selected types of industries (schedule I). Foreigners could also not participate in any of the 33 schedule II industries whose paid-up share capital was under $\& N 200,000(\$ 600,000)$ or whose turnover was less than $2 N 500,000$. Decisions were at the discretion of the Nigerian Enterprises Prowotion Board (NEPB). Other schedule Il enterprises had to make $40 x$ of their share capital available to Nigerians (ARBe:2/ 1972,2303). There were 357 enterprises in schedule I and 593 in schedule II (Collins:1977,129). The Obasanjo government revised the decree in 1976 and 1977, adding third schedule (40x Nigerian ownership), including 20 new industries to schedule I and 33 to schedule II as well as raising the winimum Nigerian participation in Schedule II to 60x. A detailed list of the 1977 schedules is reproduced in Appendix $C$. 
- private and public (joint. stock) companies in the fields of manufacturing, construction, engineering and wholesale and retail trade which required $40 x$ Nigerian ownership;

- small-scale private enterprises, many owned by resident expatriates (predominantly Greek, Lebanese, Indian and Syrians), which had to be passed over to Nigerians in their entirety;

- the "commanding heights" industries (comprising banking, insurance, oil as well as iron and steel enterprises in which the federal government acquired a $60 x$ equity share).

In total some 1,800 firms were affected by these decrees (Bierstekc.r:198ia,263). Just like in the campaign for independence of the $1910 s$ and 1950 s the nationalist agitation was spearheaded by those groups with the most to gain, so also in the case of indigenization. Small businessmen resented the commercial success of the few but visible Lebanese or Indian enterprises, and rather than founding their onn, say, cinemas, laundries or passenger bus services, it was much more convenient to take over thriving operations and to prevent their previous owners from re-establishing themselves as competitors. Educated Nigerians working in subaltern positions welcomed the higher echelon employment opportunities created by the indigenization programme. Middle and upper income Nigerians were delighted to snap up the shares which successful companies were obliged to sell, and they also savoured the opportunities implied in sitting on boards of direc- 
tors. Finally the state, i, itated about the fence-sitting of foreign companies during the civil war and, also because of its successful intervention in the economy during the war, was intent on pursuing its activist and nationalist drive thereafter. In sum, the "central objectives of the 1972 [Enterprise Promotion] decree reflected the dual sources of support for indigenization from the government and local business community" (Biersteker:1987a,259).

The benefits from indigenization were tightly focussed on a small group of fortunate Nigerians with senior civil servants and military officers reaturing particularly prominently (cf. Dudley:1982,118-119; Koehn: 1983,15; idem:1990,274-276). The federal and state governments also acquired shares. In a not untypical case of flight forward, the giant lnited Africa Company set aside blocks of one million shares for each stat? government (Collins:1974,498). The valuation of shares, private and public, was done by the Capital Issues Commission which established their price considerably, in some cases by as much as $30 \%$, belok par (Hoogvelt:1979,58; Inanga:1978, 326-327).

By October 1974 the average share price of the thirteen manufacturing companies rose 50.7 percent above the transfer price set ... six months earlier; for the eight companies in commerce, appreciation was 29.6 percent; and for the service companies, appreciation was 33.9 percent. Moreover, dividend rates in the neighbourhood of 50 percent were common soon after indigenization. ... The indigenization windfall went mainly to strategically placed or wealthy Nikerians (Schatz:1977,61).

"For the tens of thousands middle class Nigerians able to obtain shares, heaven had descended to earth: they had procured a guaranteed income and substantial financial assets with negligible risks and ef- 
fort. ... The only real struggle being that of obtaining application forms from the banks using personal contacts and prestige (Joseph:1978, 229). The redistributive character of the indigenization exercise is illustrated by the fact that almost $70 \%$ of all shares consisted of nominal transfers. "That is, no money changed hands at all. The foreign partner, forced to sell a portion or ail of his business to a Nigerian subscriber, constructed a nominal credit system under which a share of the enterprise would be transferred to his new join-venture partner to be paid for eventually out of future dividends or profits" (Biersteker: 1987,104). The remaining financial resources in support of this transfer of wealth came, for the most part, from the State. On the one hand through credits from the Bank of Commerce and Industry, a government institution established expressly with the mandate to assist in financing indigenization and, on the other, through massive pay increases in the public sector which, de facto, also applied in the other parts of the modern economy. The latter measure, in itself an interesting example of attempts by the State to enhance its legitimacy, will be discussed below.

While thus well over half of the Nigerian economy's equity capital changed hands, it did nothing to improve economic performance. Quite the opposite. It froze the status quo in manufacturing and deterred new foreign capital and new technology from entering. The level of foreign assets throughout the 1970 s and the 1980 s remained practically constant in nominal terms, which means it actually decreased (see table 10). Outside the oil sector, foreign investment "has been writta. down to a nominal amount" (Holman:1989,A22) and, according to the 
Manufacturers' Association of Nigeria and the National Association of Chambers of Commerce, "inflows of foreign investment [are] virtually non-existent [... because of] the country's poor infrastructure, high production costs and a burdensome tax regime" (cited in EIU:1/1991,23). What little capital inflow there was in the 1980 s consisted predominantly of unremitted profits (cf. Central Bank of Nigeria, Economic \& Financial Review $3(1987), 38)$. Multinational companies present in Nigeria in the $1970 \mathrm{~s}$, after some initial resistance, soon recognized that indigenization did not undermine the viability of existing enterprises. In fact, Nigerian managers and board members proved useful in negotiations with the State to obtain contracts, import licences, land, expatriate quota exemptions, lifting of export duties or price control provisions, and to generally influence government policies. Rather than getting unduly involved in "their" companies, empirical research found that "there was a tendency amongst the foreign community to think that now that the Nigerians had such a large stake in the firm it was time they did something to earn a living" (Hoogvelt:1979,65).

Indigenization, to summarize, was an exercise in redistribution. Oil rents were employed by the state in favour of the urban middle class, the business class and the state class. The expatriate companies' ostensible loss of control over their operations was compensated by the enhanced security resulting from the incorporation of puissant ind:genous groups; this was obviously appealing for existing enterprises, not however conducive to attract new ones to Nigeria. Interests were thus realigned and a quasi corporatist structure created with local and foreign business concerns becowing more tightly affiliated 
with the state, whose goodwill and resources, in the prevailing compactly regulated economy, was indispensable. The state, serving as a hub on wich the varic is economic interests were focussed, gained in legitimacy to the extent that it managed to accomodate these interests. Similar mechanisms, and motives, were at play in the final example to be considered briefly, namely in the public sector pay policies.

Public sector wage-hikes benefit the state class directly and indirectly. They increase the legitimate income of its members and they enhance the State's legitimacy vis-à-vis an important pressure group. An underpaid and therefore demoralized workforce reduces the State's effectiveness, whereas public sector wages which are high in relation to alternative employment opportunities go a long way to ensure staff loyalty to the state, or at least acquiescence to state policies which otherwise might engender opposition. The preferred medium to determine salaries in the Nigerian public service have been wage commissions. In the 1970 s and early 1980 s there were half a dozen of such commissions, ${ }^{42}$ either addressing the public serica as a whole (Nigeria:1970c \& 1971 = Adebo commissions; Nigeria: $1974=$ Udoji commission) or specific segments which, claiming extraordinary merit, de-

42 Between 1946 and 1966 there had also been six commissions, all dealing with the conditions of service and/or the structure of the public service, oscillating between integration and differentiation, yet all consolidating and expanding the bureaucracy's privileged position: the Harragin conmission (1946), the Gorsuch commission (1955), the Newns commission (1959), the Muanefo commission (1959), the Morgan commission (1964) and the Elwood commission (1966) (Nigeria:1974,212-213). 
manded - and received - special considerations. ${ }^{43}$ A ratchet system was set in motion which created privileges for a branch of the public sector, employees of parastatals, university teachers and the staff of technical learning institutions, which in turn led to further demands for upward adjustments in the conditions of other segments (Nigeria: 1981b = Onosode commission; Nigeria: $1981 \mathrm{c}=$ Cookey comission; Nigeria: 1986 = Adamolekun commission). This modus operandi, oiling the squeaking wheel and ignoring the mute ones, illustrates the legitimacy enhancing function of the State's wage policy. An egregious example were the recommendations of the Public Service Revier [Udoji] Commission - salary increases of $30 x$ to $120 x$ (Nigeria:1974,166) - and, even more so, their revision upward (74x to 130\%), generous backdating and partial tax exemption by the government (Nigeria:1974a, 36; ARBe:12/1974,3356). The belief that t?.ese increases

43 The Presidential Commission on Parastatals, for instance, managed to demand a square circle in its recommendation that the "pay of pilots of $\mathrm{Niger-}$ ia Airways Limited should continue to be $f$ ixed by reference to prevailing international rates, taking due account of local conditions" (Nigeria:1981b,44). The unified salary structure recommended by the Udoji commission provoked the fjercest opposition. Doctors and nurses went on strike until they were promised "an interim $40 x$ pay rise pending examination" (WA No. 3010, 3 March 1975, 249). University teachers felt downgraded and charged a conspiracy by "the administrative class in the public services [who had unduly influenced the commission] with intent to maintain its privileged position" (loc. cit.). The university teachers then got their own conmission and promptly were removed from the unified salary structure (Nigeria: 1981c). According to a collaborator on the Adamolekun Commission on polytechnics, advanced technical and teacher's colleges, these institutions' staff petitioned to be given salaries cqual to or higher than those of university staff. "Some of the arguments advanced, particularly from the polytechnics, sought to establish the greater relevance and importance of their courses to the envisaged 'technological revolution,' and hence that their status and galaries should be higher than those of university staff" (Otobo:1986,120). 
were designed to 'buy' the support of the middle class, whose support is essential for the stability of the Government ... was strengthened by the fact that the Government paid nine months' arrears of salaries and wages and implemented the new salary acales in one blow in contravention of the recommendation of the Public Service Review Conmission. The latter had recomended that no arrears should be paid and that salary increases should be implemented in tro phases: $60 x$ of the increase in the first instence and $40 x$ one year later (Oyediran and Gboyega: 1978,5).

The context in which these generous awards were made was, of course, the explosion of oil prices and the spectacular increases in government revenues of the early 1970 s which made General Gowon, in October 1974, retract his earlier assurance to hand over the reigns of power to a popularly elected civilian government by 1976. State revenues in 1974 were seven times larger than they had been in 1970 (see table 6) and pressures mounted on the government to share this bonanza, especially after the Winter of $1973 / 74$ which saw the oil price rise from $\$ 4.3$ per barrel in October to $\$ 14.7$ in January. The State embarked upon a wide range of measures intended to engender popular support. General Gowon, broadcasting to the nation on 31 March 1974, announced that, to ieduce inflation, imports were liberalized and import duties lonered oll items such as building materials, consumer goods, passenger cars and "on essential food items such as rice and maize ... but without endangering the healthy development of local agriculture" (ARBe:3/ $1974,3074)$; the introduction in 1975 of universal, compulsory primary education had been promised some weeks earlier (ARBp:2/1974,3155). In the Independence Day Broadcast of 1 October 1974, in which General Gowion disclosed the postponement of a return to civilian rule, he also announced the creation of more states, the doubling of the police 
force, and the allocation of $\mathrm{N} 2,200 \mathrm{million}(\$ 3,500 \mathrm{million})$ for the improvement of army and police facilities such as barracks, hospitals and schools (ARBp:10/1974,3392-3394 3401). The civil service wage hikes rounded out the picture. Two astute observers posed, and answered, the rhetorical question:

\begin{abstract}
How does one explain this 'manna from Gowon'? ... There is no doubt that the [government's] recommendation of backdating the payment of the monetary reward was tied to the desire of the Government to buy public support. ... This betrayal [of not returning power to civilians] made the Government very unpopular, and with all other unpopular actions and inactions, it was thought that the pumping of millions of naira from the public fund into the pockets of 650,000 public servants would go a long way to redeem the image of government (Oyediran and Ajibola:1978,123; see also Joseph: 1978,237 ).
\end{abstract}

While this exercise in legitimacy generation failed - Gowon was forcibly removed from power in July 1976 - its macroeconomic consequences rere devastating. Inflation soared (see table 7) because the public sector pay awards spilled over into the private sector, for instance doubling construction prices (Nigeria:1981a,25-26), and because the spring-tide of liquidity overwhelmed Nigeria's narrow productive base which could not, over night, increase the output of goods to match the higher level of money in circulation. Income inequities between the urban salariat and the rural population were exacerbated since agriculturalists had no one to protect them against the raging inflation. One commentator denounced it as "an act of unpardonable injustice that senior civil servants earn, in addition to their high salaries, between N600 and N960 per annum as basic allowance on cars they purchased with government loans in a country where the per capita income is about N205 
per annum" (Olugbeni: 1979,107).

The selective distribution of largesse to "buy" the acquiescence, if not the loyalty, of important social groups, was not the unattractive but necessary means to an ulterior end. Undertaken by the Nigerian patrimonial-bureaucratic State, it developed a dynamic of its own. Developmental objectives, because of the inherent necessity of sustained policy support over the long haul in spite of doubtful prospects for eventual success, were being crowded out by short-terw measures promising immediate returns. While these might have ensured the state's legitimary and thus autonomy to pursue its very own goals for some time, they had an addictive and ultimately self-defeating quality. Each concession, contract or differential benefit created not only winners but also losers, even if only relative losers, and hence new pressures for more distributive state action.

During the 1970s, the bureaucratic Nigerian State was eminently successful in capturing the overwhelming proportion of the oil rent from the expatriate production companies. Having secured a solid material base independent from society's productive foundation, the state not only could afford ever more intrusive regulatory interventions in the economy, it also became the main dispenser of monetary resources. This economic centrality, prerequisite and consequence alike of state autonomy, raised the costs of state legitimacy. As a rule, state actions, and inactions, reflected the property interests of the state class, and/or the accomodation of pressures to eaploy the State's porers, material and regulatory, in the interest of individual or group appropriation. The oil windfall permitted the state to indulge a wide 
range of particularist. interests which, as it happened, were all urban based and consumption oriented. Little was done to raise production and productivity in general, and in agriculture specifically. With no effective mechanisms to either limit state spending or to focus it in a developmentally worthuhile fashion, a syndrome exacerbated during the Second Republic, economic disaster became inevitable. Equally inevitably, the State had to react. The next section addresses the question whether this reaction was a resolute transformation of the bureaucratic mode of production, or whether the latter was merely adjusted to meet the requirements of a changed reality.

\section{c) The Bureaucratic State Transforned or Reforned?}

This section concludes the empirical survey of the bureaucratic Nigerian State. Mostly for reasons of data availability, the year 1988 has been chosen as the cut-off point, even though in some instances the coverage has been extended somewhat further. ${ }^{44}$ Since serious structural adjustment policies began only in 1986, and since their very nature implies a multi-year incubation period before definitive results emerge, the tentative nature of the following analysis and conclusions should be borne in mind.

44 For instance, 1987 is the most recent year for which the IMF's International Financial Statistics of Februar 1992 (Vol. 45 No. 2, p. 400) provides data on Nigerian government finances. 
In the early 1980 s it became clear that the profligate and interventionist policies of the previous decade were no longer sustainable. In 1980, external reserves still exceeded external debt by sowe 15x. In 1981, the latter was under one third of the former, and by 1983 under 6x (see table 10). With oil exports and oil prices falling (see tables 1 and 4 ), with public spending by far exceeding revenues (see table 6), with public sector staffing and food inports at unprecedentedly high levels and food production at unprecedentedly low levels (see tables 11-14), and with the government of President Shehu Shagari attempting bv all means to win the 1983 elections, the country was on a dangerous collision course with economic reality. It appeared as if the State had begun to disregard the cybernetic imperative of a zerosum situation, namely that the pursuance of property by the state class has to be tempered by measures to maintain state legitinacy and state autonomy. In the early 1980s, the state class helped itself freely to the treasury, both stealing for its immediate benefit and to buy public support. The price, of course, was that the State's financial autonomy was mortgaged in the process with foreign debt rising by a stunning $50 x$ to over $\$ 18,000,000,000$ in 1960 alone.

On Ner Year's eve 1983, the military struck for the fifth time. In an effort to prevent the state frow self-destructing and to restore its lost political and financial autonomy, a group of senior officers removed the civilian regime and embarked on a tough austerity course. In his broadcast to the nation after assuring power, the coup leader, Major-General Buhari, claimed that with prudent management and an end to raste his regine would be able to overcome the economic crisis that 
had prompted the coup. As a result of the civilian adainistration's "inability to cultivate financial discipline, and through bad anagement of the economy," Nigeria had cone to depend on internal and external borrowing to finance government projects (ARBe: $12 / 1984,7117$ ).

The Buhari regime, entirely disregarding structural aspects, perceived the country's predicament in strictly behavioural teras. The politicians' venality, their lack of competence, discipline and probity was seen to have poisoned purlic life, squandered the country's riches and jeopardized the State's capacity to govern. To restore the State's financial and political autonomy, the Buhari regime set out to imannize itself agairst any dependence on particular interest groups. Consequently it refused to entertain questions regarding its eventual handing over of power to civilians and sought to remedy the situation through tough action. Within weeks of taking over, the Buhari regime

- declared "War Against Indiscipline," a re-education campaign which aimed to make Nigerians work harder, resist corruption and learn how to queue (ACR: 1986, B545);

- purged civil servants, like the Murtala Mohamaed regime, its avowed role model, had done nine years earlier. Over 300 members of the civil service, police and customs were removed immediately (Diamond: 1987,201). Between February and July 1984 a total of 54,000 officials were "either sacked, retrenched, retired or dismissed" (WA No. 3490, 9 July 1984, 1418);

- created special, i.e. extra-judicial tribunals whose decisions could not be appealed, and prescribed the death penalty for a variety of offences including arson, currency counterfeiting, oil smuggling and drug trafficking. Cheating in examinations, unlawful exportation of food stuffs, selling of prohibited goods, tampering with electric and telephone cables was nade punishable with 21 years' imprisonment (WA No. 3493, 30 July $1984,1551-1552$ );

- staged public executions at times averaging three per week, according to reports submitted to Amesty International. Death sentences could also be imposed retroactively, that is for 
crimes for which it was not prescribed when they were connitted (ARBp: 11/84, 7444);

- gave alitary rulers new detention powers. Under a special decree (No. 2), people could be detained for up to three nonths without formal charges on suspicion of violation of state security or of consitting econonic crimes (WA No. 3467, 30 January $1984,242)$;

- threatened freedon of expression and of the press by making it a punishable offence to publish "false information," to bring the government into disrepute or to ridicule a sovernment officer. It arrogated to itself the power to shut down for twelve months those newspapers or radio stations it deened "detriental to the interest of the Federation." Trials against which no appeals were allowed were by a special tribunal chaired by a High Court judge with three ailitary officers as nembers (WA No. 3479, 23 April 1984, 900 and No. 3481, 7 May 1984, 968-969; ARBp: $4 / 1984,7220) ; 45$

- closed the country's borders to prevent gnuggling and to curb the inflow of "illegal aliens." To enforce these measures, border officials were trained in the use of firearms (ACR:1986, B553);

- outlawed any payments by Nigerian residents to recipients abroad (ARBe:4/1984,7263), reduced the basic travel allowance to N100 (except for Hajj pilgrims whose allowance remained unchanged at N800), suspended business travel allowances (ARBe: $3 / 19+4,7229)$, discontinued fees and allowances for students wishing to study abroad, placed imports under specific licence (WA No. 3482, 14 May 1984, 1010), and required foreign visitors to pay their bills in foreign exchange, all in an attenpt to stem the resource outflow (WA No. 3480,30 April 1984, 936);

45 Two famous publicists, Tai Solarin and Haroun Amadou, were detained immediately after the coup and held without charge (ARBp:11/1984,7442). Two journalists of the Guardian (Lagos) were sentenced to a one year jail term for a factual error: in an article on the changes in Nigerian missions abroad, they correctly indicated the number of missions to be closed and naned eight military officers to be naned ambassadors. They incorrectly identified the candidate for the London ambassadorship (WA No. 3490,9 July 1984). Duro Onabule, the editor of the National Concord (Lagos) criticized the Information Minister in a personal column for alleging that the whole Nigerian press had a "bring-down-the government-syndrone." The Minister, Capt. Emeka Omeruah, in a letter to the paper, objected to the tone of the editor's coments, suggesting they were "lacking refinement." The editor was rounded up by plainclothes agents of the notorious NSO and held for two weeks. After his release, an official statement said he had been "guest" at NSO headquarters (ARBp:12/85, 7479). 
- changed the banknote design overnight and inposed severe restrictions on swapping old bills in an attenpt to dry up illgotten funds (ARBe:4/1984,7263; WA No. 3480, 30 April 1984, 936);

- attempted to curb irflation by means of soldiers going into markets and forcing traders at gunpoint to reduce prices (WA No 3465, 16 January 1984,126$)$. After this policy, predictably, failed because traders simply refused to open their stores, a campaign against "unpatriotic hoarders" was started in the course of which warehouses were broken into and their contents auctioned on the spot; also, various adinistrative price control measures were, unsuccessfully, tried (WA No 3469,13 February 1984, 312);

- vowed that no new states would be created and dissolved all local governments created after 1979 (WA No. 3475, 26 March $1984,660)$.

While the sentiments informing these measures were understandable given the circumstances - the economic malaise and the Shagari government's, even for Nigeria's casual standards, striking levels of corruption and mismanagement - the single-minded pursuit of discipline and austerity did nothing to transform either the state or the economy. Buhari's populism as exemplified by his vow "to pursue a policy of the greatest good of the greatest number, without wasting time on such economic fancy words as gross domestic product (GDP), growth rates, etc." (cited in HA No 3465,16 January 1984, 126) proved very quickly inadequate since they did nothing to tackle the structural flaws of the $\mathrm{Ni}$ gerian economy: a trade policy, centered around an overvalued domestic currency, which encouraged imports, consumption and rent-seeking while discouraging exports, investment and production; a trade policy, moreover, which required far-reaching administrative controls, resource allocations and sectoral subsidies, all in an attempt to duplicate (unsuccessfully) what the market does automatically (and successfully), 
namely to equilibrate resource imbalances. The overvaluation of the naira continued to suck imports into the country, and the administrative capacities throughout the government and the Central Bank were still inadequate to either ensure that import comitments were in line with what could be afforded, or that the imports reaching Nigeria bore any relation tc what had been paid for. Comparisons of Nigeria's import data with those of her trading partners gave credence to the suspicion that "exporters colluded with Nigerians to ship with forged documents, or to make claims for $\delta$,ods not actually delivered, or to over-invoice, in order to transfer foreign exchange from Nigeria" (WA No. 3468,6 February 1984, 256).

Negotiations with the IMF over a balance-of-payment loan stalled, as they had done during the last year of the Shagari regime, because of the Nigerian side's refusal to consider the IMF's conditions: cutting of petroleum subsidies to Nigerian consumers who enjoyed among the lowest gas prices in the world, a devaluation of the naira and the relaxation of import controls. Selling petrol below production costs might hue helped to pacify the urban middle class heavily dependent on cheap transportation, while the over-administered import regime, as earlier discussed, entailed most attractive opportunities for rent-seekers inside and outside the state. Failure to see the merits of the IMF's conditions, namely to make real costs a price-determinant and to let supply and demand regulate trade, suggested either the inability to appreciate economic relationships or the unvillingness to sacrifice the material benefits associated with state regulation. As it happened, the naira was even revalued vis-à-vis the us currency on February 29 
1984 and a devaluation ruled out categorically (WA No. 3475, 19 March 1984, 619 and No. 3475, 26 March 1984, 674), import restrictions were tightened (WA No. 3470,20 February 1984, 395) and a reduction of petroleum subsidies was rejected (ARBe:4/1984,7270). The IMF was depicted as an imperialist agency, intent on lowering the living standards of ordinary Nigerians. This ploy helped the Buhari regime to avoid squarely confronting the cause for the country's economic malaise, namely the misplaced policies of the previous decade or so which it chose to leave substantially intact.

The Buhari regime ran out of steam rather quickly. It seemed to werlook that austerity and discipline were viable onls as elements of a larger adjustment programme not, however, as substitutes for having one. Publicly preaching water while secretly drinking wine did not enhance the regime's legitimacy: in November 1984, thirteen members of the putschists' inner circle, including the Chief of Staff and suspected strongman behind Buhari, Brigadier Tunde Idiagbon, were promoted to the rank of Major-General (WA No. 3509, 19 November 1984, 2356). At the same i ime, the first batch of 36 British Aerospace "Jaguar" jets, at cost of over $\$ 440 \mathrm{million}$ representing the country's largest military acquisition ever, arrived in Nigeria (ACR:1986, B548-549). To prevent the outflow of foreign exchange, the government tightened the import-licencing regime in a manner which imposed severe burdens on the 
manufacturing sector. ${ }^{46}$ Owing to its failure to come to an agreement with the IMF and hence to reschedule its massive foreign debt, Nigeria's creditworthiness sank, and with it the her ability to procure essential inputs from abroad. Countertrade deals, directly swapping oil for goods, offered a seemingly elegant way out of this quandary. 47 The resulting concentration of decisional authority in the hands of the State lead, as was later revealed, to massive fraud (ARBe:8/1985,7882; see also Galloway: 1989,329$)$. Finally, suspicions regarding even General Buhari's personal probity emerged - it was surmised that he personally benefitted from countertrade deals and during the campaign to substitute redesigned naira notes for old ones (ACR:1987,B124-125).48

46 Thoroughly disregarding the needs of enterprises, especially the flevibility to quickly adjust production to changing market situations, the Buhari government demanded that all requests for imports planned for 1985 had to be submitted by 31 August 1984. Later applications or adjustments were not entertained (hit No. 3493, 30 July 1984, 1543).

47 Countertrading permitted the Buhari government to avoid dealing with the IMF, and to circumvent those foreign suppliers who were disinclined to provide further credits to Nigeria in light of the huge backlog of unsettled debts. The major deals, involving mainly machine tools, manufacturing inputs and spare parts, were with Cotia of Brazil (September 1984; $\$ 500 \mathrm{mn}$ to $\$ 1 \mathrm{bn}$ ), Peugeot, SCOA and Elf Aquitaine of France (May 1985; $\$ 500 \mathrm{mn}$ ), Voest Alpine of Austria (May 1985; $\$ 200 \mathrm{mn}$ ) and Fiat and ENI of Italy (May 1985; $\$ 400 \mathrm{mn}$ ) (ARBe:4/1985,7714; ARBe:8/1988,7882); a smaller transaction was to barter $\$ 77 \mathrm{mn}$ kortr of oil for 90,000 tons of palm oil, Nigeria's cwn traditional export prociuct (ARBe:5/1985,7750).

4s Because of their inefficiency and scope for abuse, Babangida at first voried to discontinue countertrading. After a change of heart on his part, "an agreement involving $\$ 1.6 \mathrm{~b}$ with $\mathrm{BCCI}$ was rumoured to have been signed" (WA 3595, $28 \mathrm{Jul} \div 1986,1571)$. One cannot but help noticing that the President's wife in 1990 was a recipient of $\$ 25,000$ "Africa Price for the sustainable End of Hunger" (ARBp:9/1991,10288), awarded by the "Hunger Project" whose close links with BCCI have been rumoured. Also, when the spiritual leader of Nigeria's muslims, Sir Siddiq Abubakar III, 16th Sultan of Sokoto died in Noveaber 1988 , the Babangida regime overruled the convent of royal kingmakers and named Mr. Ibrahim Dasuki the new Sultan. Dasuki, a close financial associate of President Babangida and a near relative of Finance Minister Alhaji Abubakar Alhaji, was the former chairman of BCCI (Nig.) (ARBp:11/1988,9081-9082; 
The Buhari regime's bloodless ouster on 27 August 1985 was, once again, greeted with widespread relief, even euphoria (WA No. 3809,17 September 1990, 2350). Major-General Ibrahia Babangida, the new leader, assumed the title of President which was the first time that a military Head of State had done so. To underline his determination to break with the old ways, and to bolster his authority the Armed Forces Ruling Council (AFRC) gave the president exclusive and wide-ranging powers to deal with the economic crisis (ARBe:11/1985,8000). Babangida distanced himself immediately from his predecessor's stern authoritarianism. The death sentences prescribed by decree No. 20 of 1984 were abolished (ARBp:4/1986,8473), decree No 4 which had limited press freedom was repealed and the six journalists who had been imprisoned for violating it were released. Also set free were a number of Second Republic politicians who had been detained for well over a year without

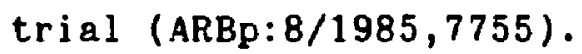

While the Buhari regime might have been able to slow the economy's decline, it failed to halt, let alone reverse, it. The massive external debt could not be reduced in 1984, even though oil revenues were over $16 \%$ higher than in 1983, and remained at over $20 \%$ of GDP. GDP in 1984 was $5 \%$ below that of 1983 and dropped by another $3 \%$ in 1985 (see table 8). Government expenditures continued to far exceed revenues and the already rampant inflation accelerated, not at least becauge of the draconian import control measures whish, on their own narrow terms, were quite successful (see tables 6 and 7 ). However, because of 
the manufacturing sector's import dependence, the previously discussed low capacity utilization ratios resulted. Especially because of Buhari's stubborn refusal to devalue the naira, he deprived the economy of any chance to adjust to leaner times and to recover. President babangida introduced an "economic state of emergency" which was to run from Ortober 1985 to December 1986 (it was later extended by two years to December 1988). To set the tone, public service and military salaries were reduced by $2-20 x$ (ARBe:10/1985,7956; ACR:1987,B125), the military leave-allowance was cut by half ( $A C$ No. 20, 1 October 1986,5 ), and the "war against indiscipline" was revived. ${ }^{49}$ Apart from such publicity sturits, an economic reform programme, unprecedented in its scope, was set in motion.

In his first address to the nation, President Babangida perceptively attributed the causes of the country's economic problems to declining production but increasing population, the economy's import dependence, glaring income disparities, and to the "large role played by the public sector in economic activities with hardly any concrete result.s to justify such a role" (cited in ARBe:8/1985,7881). A sweeping programme to tackle these issues was developed and, after much controversy, in July 1986 a Structural Adjustment Programme (SAP) was launch-

49 It ras made an offence for any public or private organization to fly a torn national flag - or not to hoist one at all (WA No. 3581, 21 April 1986, 851). The last Saturday of each month was declared National Sanitation Day. "On that day, all Nigerians will clean their homes, offices and work places, and there $\mathrm{will}$ be no movement of vehicles between $7.00 \mathrm{a} . \mathrm{m}$. an 12.00 noon except ambulances or vehicles conveying critically ill people to hospitals, vehicles engaged in refuse collection and disposal, vehicles of the Nigerian fire services, security forces on duty and other vehicles strictly used for essential services" (WA No. 3593, 14 July 1986, 1495). 
ed, intended to remain in operation for two years. Its main objectives were the attainment of a "realistic" exchange rate, rationalization of the customs tariff, privatization of public enterprises, and elimination of subsidies. A foreign exchange auction scheme was to be introduced, foreign trade liberalized and an "appropriate" pricing policy instituted for domestic petroleum products; public expenditures were to be curtailed, administrative controls dismantled, import tariffs restructured and lowered, and marketing boards abolished; parastatals which hitherto had been heavily subsidized were scheduled for privatization (ARBe: 12/1986,8043-8044).

To cushion the invariably arduous short-term effects of retrenchment, structural adjustment loans from the IMF and the World Bank had been sought by the Shagari adwinistration shortly before its overthrow (hit No. 3465, 16 January 1984, 135). The Buhari government found the IMF's conditions unacceptable and let negotiations fizzle. The new regime inherited the emotionally charged debate which, in Nigeria, was more conducted in mythological than in economic terms. Babangida, while clearly appreciating the merits of the IMF/World Bank's arguments was caught in this irrational nationalistic fervor. In December 1985 he announced that Nigeria rould not accept the IMF loan of about $\$ 2.4$ bn because "the path of honour and the essence of democratic patriotigm lies in discontinuing the negotiations with the IMF for a support loan" (cited in ARBe:11/1985,8000). At the same tive he set out to fulfill the loan conditions.

The 1986 budget, published in late 1985, reduced petroleum subsi- 
dies by $50 \%$ and led to a doubling of gas prices on 1 January 1986.50 A general levy on imports of 30x, except for production inputs, increased consumer prices and a surcharge on incomes decreased salaries (ARBe:12/ 1986,8043 ; WA No. $3595,28 \mathrm{July} 1986,1567$ ). Because the revenues thus raised were earmarked for investment in rural infrastructures, these measures constituted an important incentive shift away from, largely urbari, consumption and towards, largely rural, production. This shift was significantly boosted in September 1986 when the administrative determination of the naira's exchange rate was ended, and its value was henceforth established through a weekly auction system in which a given amount of dollars were sold to the highest bidders (ARBe:6/1986,8277). The naira's value dropped immedictely by 60x; its 1985 annual average had been $\$ 1.121$, that of 1987 was only $\$ 0.250$ (see table 7 ). Because inport licencing, in President Babangida's words, was "not only cumbersome but also liable to corrupt and/or invite arbitrary administrative practices," it was equally abolished - except for some items which remained banned (ARBe:6/1986,8278; WA No. 3605, 6 October 1986, 2132 ). Both the naira's value and the flow of imports was no longer to be determined by government fiat, but by the forces of supply and demand. The theory's clarity suffered somewhat in the process of implementa-

50 As will be argued below, SAP ran out of steam rather quickly and old habits began to reassert theaselves. In the 1989 budget, fuel prices were raised by $43 x$ for private motorists but left untouched for taxis, motorcycles, buses and transport vehicles. This differential pricing policy, obviously, created manipulations, shortages and rents which could not be deterred by the threat of life imprisonment for "economic sabotage" as stipulated in the miscellaneous offences decree, promulgated by Buhari regime but left intact after hjs werthrow (ARBe:1/1989,9437). By 1991 petrol was still heavily subsidized: one liter sold for $\$ 0.07$, compared with $\$ 0.5 / 1$ in neighbouring $N i g e r$ or $\$ 0.58 / 1$ in Chad (WA No. 3875, 16 December 1991, 2101). 
tion.

Initially, the foreign exchange market was split into two tiers, one for official government transactions such as debt repayments and another for commercial transactions such as the importation of goods. Only in the second tier was the naira's value to be determined by market forces, in the first the price-fixing authority continued to be the Central Bank which, invariably, set the naira's value high so as to minimize the costs (in naira terms) of the State's external comaitments. "According to a Central Bank of Nigeria source, only the Ministry of Defence which is vital to the nation's security was being considered for exemption from the SFEM at the moment, although the government might. exempt other vital government organs from going through the market" (ARBe:8/1986,8362). Various other interest groups, unsurprising$1 y$, lobbied to transact their imports at the "official" exchange rate rather than the market-determined rates (WA No. 3598, 18 August 1986, 1743 ; WA No 3602,15 September 1986, 1914; WA No 3604,29 September 1986, 2032) or to be compensated for the "inevitable assault" on workers' income resulting from a freed exchange rate. Unions demanded that the government should "'increase adequately all fringe benefits and promotion prospects [sic] of workers' to reduce the burdens that might be imposed on them as a result of the proposed SFEM" (WA No. 3602, 15 September 1986, 1953). Since the system was underwritten by loan from the World Bank which insisted on the abolition of the first tier exchange rate, it remained a temporary phenomenon and was indeed merged with the second tier in July 1987 (ARBe:6/1987,8742).

The devaluation of the naira through the auction system, together 
with the abolition of the marketing boards, had an imediate impact on the profitability of agriculture and thus encouraged its revival, while also increasing incentives to substitute locally grown crops for agricultural imports. In 1988 , despite extremely depressed world market prices, more cocoa was exported than during any year since 1978 lexcepting the bumper crop of 1982); it was no longer necessary to import palm products, as it had been in 1985,1986 and 1987 , but a considerable amount was being exported; rubber exports reached their highest level since 1975 (see table 1). Food production also picked up, albeit more slowly than export crops. This is attributable not only to adverse climatic conditions and to the lead-time required for new seeds to reach their operating potential, but also to some reluctance on the farmers' part to embark on production expansion before it was clear whether reforms would stick and whether prices remained attractive. Nevertheless, food production increased dramatically in the late 1980s, giving cause for cautious optimism. The Babangida government banned imports of hey agricultural commodities, including maize, rice, vegetable oil and wheat (WA No. 3605, 6 October 1986, 2132). This policy was extended in the 1988 and 1989 budgets to oblige manufacturing industries to seek ways of substituting locally produced agricultural inputs for imports (ARBe:12/1987,8962; ARBe:1/1989,9436).

In 1986 the government lifted bans on exports of agricultural commodities and introduced export incentives, including the right to retain 25 per cent of foreign exchange earned from all non-oil exports (ARBe: $12 / 1986,8043$ ). This was raised to 100 per cent under the SAP (WA No 3604,29 September 1986,2040$)$. After some dithering the agricult- 
ural commodity boards were dissolved while several agro-industrial parastatals were targeted for privatisation. 51 In addition, plans were made to devolve responsibility for fertilizer procurement and distribution from the agriculture ministry to the private sector with effect from 1990/91 cropping season (EIU:1990,21). Still, the government found it difficult to comprehensively kick its étatiste habits. 52 The newly created Directorate of Food, Roads and Rural Infrastructure in early 1987 began a major programe to cultivate 50 million fruit trees as fiell as large quantities of vegetables (ARBe:1/1987,8565). In light. of previous instances of state-run plantations, doubts remain concerning the wisdon of investing scarce resources in such a venture.

The problems facing manufacturers have been severe since 1982 . Unt il then, as illustrated in table 16 and outlined above (pp. $467 \mathrm{ff}$ ), growth had been greatest in vehicle assemhly, synthetic fabrics, soft drinks, brewing as well as paints and related products. In 1988 only synthetic fabrics showed a decisively stronger performance than in 1982, four sub-sectors (soft drinks, beer stout, petroleum products and soap \& detergents) held roughly steady, while the others teetered

51 In April first 1986 the abolition of the six commodity boards was announced (ARBe:5/1986,8199). In January 1987 this decision was reversed in favour of the boards' privatization, mainly to protect about 5,000 jobs(ARBe: $1 / 1987,8548)$; another and final change of heart led to their dissolution in April 1987 (ARBe: 1987,8587 ).

52 For instance, when all airlines raised their domestic fares by 50x, in December 1991, the Aviation Ministry described the increase as "illegal" and decreed the reinstatement of the old fares. The ainistry contended that there were procedures for raising fares - an individual formal application - and that government "had acted as it did because none of the airlines had complied with that requirement, let alone obtained formal approval" (WA No. 3875, 16 December 1991, 2111 ). 
on the verge of collapse, especially shoe production and the assembly of vehicles and of radio and tv sets (see table 16). Manufacturing capacity utilization after 1982 has remained under $50 \%$. In 1988 , as a rule, manufacturers using locally sourced inputs were the most successful in achieving higher rates, notably beer and stout (67x), basic industrial chemicals $(65 x)$, textiles $(57 x)$, tires and tubes (56x) and printing and publishing (52x). Predictably, those industries relying hearily on imported inputs did much worse with capacity a utilization of 22x (EIL:1990,31). Since 1988 manufacturing growth has continued, although capacity utilization has rewained low, owing to deptessed demand and persisting import dependence. Whether the manufacturing sector can be revived, and restructured away from consumer goods, remains to be seen and much will depend on conducive incentive structures and a secure business climate which only the state can create.

Structural adjustment, in liberalizing trade and clearing away injurious distortions, was the necessary and unavoidable first step. The Babangida government undertook it against the massive opposition of powerful interest groups, but obviously appreciative of the fact that the gravity of Nigeria's economic plight was such that there simply was no viable alternative. The economy's import-dependence and anti-export and anti-production biases had created serious disequilibria between relatively privileged urban areas and largely neglected rural areas. More serious than these differentials per se was that they were, contrary to some variants of development economics, growth-retarding rather than growth-inducing. With falling oil revenues, mounting debts and a fast growing population it became inescapable that, in order to 
avoid economic collapse and the resulting political chaos, any growth let alone development prospects necessitated a fundanental change of course.

Implicitly recognized by President Babangida was the arginal executive capacity of the Nigerian state which, in the past, had led to the private appropriation of advantages inherent in the state's interventionist policies and thus to their subversion. Freeing the exchange rate and abolishing marketing boards and import licences could be implemented by presidential fiat. It neither required the consent nor the cooperation of those negatively affected: the bureaucrats awarding import licences and the businessmen receiving them, the Central Bank officials allocating foreign exchange and their clients, and the customs' officers whose notorious delinquency in enforcing import restrictions had been a lucrative endeavour. Since there was hardly any choice - the economy on its knees and the IMF and World Bank jointly breathing down President Babangida's neck - and since these measures promised to create not only losers but also winners, the plunge was taken and the erosion of the State's autonomy halted. However, the other shoe dropped only haltingly, thus jeopardizing the hard-won gains of austerity and adjustment. Moving considerably less forcefully, the government specifically failed to avoid substantial budget deficits, to determinedly advance the commercialization and privatization of parastatals, the deregulation of business activity and civil service reform.

The success of the 1986 austerity budget was severely undermined by the collapse of oil prices from $\$ 27$ in 1985 to $\$ 14$ in 1986 (table 
4). Counting on a barrel price of around $\$ 20$, the government was unable to service its foreign debt to the extent it had planned and a projected balance of payments surplus of N1,100 million (\$820mn) was turned into a deficit of $N 763$ aillion (8566m) (ARBe:1/1987,8510). Hovever, because oil revenues, earned in US\$ and monetized in the devalued naira, government incowe in local currency increased sharply which permitted, for instance, paying federal and state employees who had received their salaries only sporadically in the early 1980s; it also allowed reducing the arrears owed to internal creditors. On the other hand, weaning an economy addicted to imports proved more acrimonious because the reduction was instantaneous - imports in 1986 were lialf the level of 1985 and $20 x$ of 1981 (table 6) - while the provision of domestic substitutes was by its very nature a long term process. The shortage of foreign exchange, inevitable because of the lon oil price and the heavy foreign debt, put further pressure on the naira, fuelled inflation, depressed manufacturing activity and thus undermined the effect of the adjustment weasures.

With the reflationary 1988 budget, the Babangida government sought to address these symptoms but, unsurprisingly, made them much horse and seriously jeopardized the hard-won gains of the previous two years. N2.5bn out of a total budgeted expenditure of N24.5bn (in naira terms the highest ever, up to that year) was earmarked as special reflation expenditure and, in a shrewd attempt at legitimacy creation, administered directly by the Office of the President. This process of reining in outlying branches of the state and concentrating allocative poner directly in the President's hands was reinforced by the transfer 
of the Budget Department from the Finance and Development Ministry to the Presidency, and by the removal of the Central Bank from the control of the Finance Minister and its likewse subordination under the office of the President (AC No 4, 19 February 1988, 7). The wage-freeze, in effect since 1984 was ended and private credits were permitted to increase by $50 x$ compared with 1987 (ARBe:12/1987,8960-8963). The result was leapfrogging inflation, further depreciation of the naira (table 7 ) and the re-emergence of black market for foreign currencies because the extra liquidity injected in the economy was not matched by either increased domestic production or foreign exchange earnings. Even though subsequent budgets sought to undo the damage, much of the original steam of SAP had irrevocably evaporated.

In an effort to shed more of the State's dead weight, and willing to sacrifice the increasingly insupportable interests of some peripheral members of the state class and its clients, President Babangida in January 1989 modified the country's industrial policy. The indigenization decrees of the 1970 s (see above, p. 498) were essentially cancelled, yet not for existing ventures but only for new investment wich, to the extent that it protected existing interests failed to reinvigorate the modern sector (ARBe:1/1989,9127; ARBe:2/1990,9880). A year earlier, but seventeen months after launching SAP, the President had revealed a list of ninety-six state-owned companies, many of which in the manufacturing sector, which were to be privatized or commercialized (see Appendix B). In July 1988 the decree enabling the government to proceed with its divestiture plan was promulgated and the Technical Committee on Privatization and Comercialization (TCPC) established. 
Insurance companies, textile firms, breweries and agro-industrial businessi's featuren prominently among the forty-nine companies in which the state intended to sell its entire equity interest. The second category of thenty companies for partial privatization included all cement companies, two important newspaper groups, Nigeria Airways and the Nigerian atiollal Shipping Line. The NNPC headed the third category of nine companies for full commercialization. A further eighteen companies (including Ajaokuta Steel Company, the Delta Steel Company, federal hospitals, the National Electric Power Authority and the Nigerian Railhay Corporation) were scheduled to be partly commercialized (ARBe:2/ 1388,9033 ; WA NO. 3574,25 January 1988,142 ).

There were seventeen successful but small privatizations during 1989 and thirty-seven in 1990 (IMF information), even "though here, too, the administration is dragging its heels and expectations have, yet again, run ahead of performance" (ARBe:2/1988,9032). In particular the withdraval of the lucrative banks from the privatization list deflated the programme but also shed light on the motives informing it: "Perhaps the plausible excuse for the decision is [the government's fisli] to retain the power base and the avenues for patronage" (Business Concord (Lagos), cited in ARBe:7/1988,9219). As with the liberalization of trade controls, it appeared that the Babangida regime decided to cut its losses but salvage from the ruins whatever could be. Since most of the parastatils were unprofitable, the economic and politica? costs of hanging on to them rlearly outweighed the benefit of casting them off. Their comercial viability necessitated profound management reforms and significant increases in product prices, both highly un- 
popular with the beneficiaries of the status quo: employees and customers. A major attraction of commercialization and privatization was the resulting depoliticization of these inevitable but unpalatable decisions.

While undoubtedly putting Nigeria's economy on a sounder footing, the benefits of SAP failed to translate into immediate, widely distributed welfare gains. Implementation weaknesses, caused by an inefficient and demoralized public service, were exacerbated by low oil prices, a heavy foreign debt burden and a rising population. In 1985 the Nigerian State's oil revenue was nearly $\$ 12$ billion, in 1988 it was under $\$ 5.5$ bn (table 17). External debt in the same period soared from about $\$ 19$ billion to nearly $\$ 32$ billion (table 10), while population increased by about 10 million (table 9), a figure which would have tested the facilities of even a much better equipped society than Nigeria's. Popular discontent mounted, as did the State's repressiveness. Lnable to inspire popular confidence in the soundness of its policies, or in the probity of its dealings, any sign of dissent was met with increasing intolerance. Decree No. 2, inherited from the Buhari regime, (see above, p. 511), had not been rescinded and, instead, the initial period of detention without formal charges on suspicion of violation of state security or of committing economic crimes, was even extended to six months (WA No. 3585, 19 May 1986, 1082). After a wave of vocal protests by an emerging human rights movement and in the media, this period was again reduced to three nonths (WA No. $3596,4$ August 1986,1646$)$. 
Nevertheless, the honeymoon President Babangida enjoyed with the public after replacing the brutal Buhari regime, proved short-lived. Media reports about corruption and abuse of office wet with harsh retribution. After publishing an article on large-scale fraud involving wheat imports, Dele Giwa, the editor-in-chief of Newswatch magazine was killed by a letterbomb apparently bearing the presidential seal (ARBp: 10/1986,8271; AC No. 14, $13 \mathrm{Ju} 1 \mathrm{y} 1990,5) .53$ Giwa's friend and lawyer, the civil rights activist Gane Faweninmi, accused the director of military intelligence and the deputy director of the state security service of involvement in the killing. After protracted legal battles, losing at both the High Court and the Court of Appeal, the Supreme Court endorsed Fawehinmi's murder charges against the two (ARBp:1/1988,8757); these, however, were subsequently quashed by a Lagos Court, even though serious doubts remained (ARBp:2/1988,8789). Other journalists got of $f$ more Jightly. An editor whose paper reported that the Armed Forces Ruling Council was split over whether to give clemency to the coup plotters of December 1985 "was detained and released apparently only on an understanding not to repeat his 'mistake"" (AC No. 6, 12 March 1986, i). After publishing a cover story on the key personalities around President Babangida in June 1988, the publisher, three senior editors and a reporter of This Week magazine were interrogated first by the Directorate of Military Intelligence and subsequently by the State

53 Another twist in Giwa's murder was his alleged uncovering of highlevel drug dealing. In 1985, a suspezted drug smuggier ostensibly died in police detention but, in fact, "was removed to the United States where Giwa managed to interview her, and she implicated top people in the drug trade" (AC io. $14,13 \mathrm{Ju}$ y 1990,5$)$. 
Security Service, to which they then had to report daily, only to be held for around 14 hours (AC No. 14, $15 \mathrm{July} 1988$ ). After the coup attempt of April 1990, the daily Punch was closed and the deputy editor of the Vanguerd detained (ARBp:5/1990,9701). Finally, the correspondent of the Financial Times (London) was detained and expelled in June 1991 after a writing a article, critical of the way in which the Gulf Kar oil rindfall of about $\$ 5$ bn had been spent (ARBp:6/1991, 1044010441). He argued in particular that the foreign currency stabilization fund, created after Iraq's invasion of Kuwait in September 1990, contained only about $\$ 2 b n$ in March 1991 . The shortfall had, so his contention, been spent on Nigeria's expedition corps in Liberia, on a lavish OAC summit in Abuja, and on an \$810mn aluminum smelter whose cost was between $60 \%$ and $100 \%$ higher than similar plants elsewhere in the world (AC No. 25, 20 December 1991, 2; Keeling:1991,4; idem 1991a, 5).

After some time in office, and true to the patrimonial model, a serious breakdown of financial discipline occurred, mounting repression was counterbalanced with attempts at cooptation, and corruption reasserted itself forcefully as the prevailing style of conducting public business. The creation of eleven new states and forty-seven new local governments by the Babangida regiae has been mentioned above (p. 493 ), as has its disastrous reflationary budget of 1988 (p. 525). In the same line of legitimacy generation through the distribution of public largesse belongs the order to the national directorate of employnent and the ministry of works and housing to create over 70,000 jobs (WA No. 3809,27 August 1990, 2350), and the raising by $100 x$ of the nation- 
al minimum pension - and its backdating by ten months (WA No. 3867,21 October 1991, 1776). Despite the muzaling of the media, accounts of corruption do get published occasionally and visitors to the country report that it is as rampant and all-pervasive as ever since the Civil War, having reached even "the highest echelons of government" (AC No. 25, 20 December 1991,2$) .54$ Like others before him, and probably with the same justification, Major Gideon Oguaza Oka, one of the leaders of the unsuccessful coup against President Babangida of April 1990 announced in his radio address the "ousting of the dictatorial, corrupt, drug-baronish, inhumane ... administration of General Ibrahim Badamasi Babangida" (cited in ARBp:4/1990,9666).

54 While substantiated accounts of the embezzlement of public resources might have to arait a regime change - the former governor of Oyo state, Bola Ig*, is reported to be compiling a comprehensive list of the ill-gotten assets of the military establishment with a view to confronting them in 1992 (AC No. 19, 27 September 1991, 5) - embarrassingly much has come out already about the closelless of important figures to the drug trade (AC No. 14, 13 July 1990, 5). Early 1991 the head of the National Drug Law Enforcement Agency was suspended for having accepted bribes to release drug dealers. The Vice-President absolved him from any wrong-doing before the case was settled in court, which as seen "as an attempt to cover up by an administration that has already lost the battle to maintain a clean image" (AC No. 6, 27 March 1991,5). There is no dulbting that promises "to end corruption have not been fulfilled, and senior offjcers are among the worst offenders" (ARBp:4/1990,9667). Especially within the militar!, the "godfather - who is able to buy the loyalty and personal support of junior ranks - has become a key factor. Those officers without godfathers are left to watch while their colleagues grow spectacularly rich frow contract awards and political appointments. Allegations of mind-boggling corruption are rife within the military establishment" (AC No. 19, 27 September 1991,4$)$. If the style of public conduct is used to judge an incumbent's concept of his/her office, Mrs. Babangida only very poorly its the role of a representative of a least developed country engaged in a serious austerity programme. Addressing the EC-ACP Assembly on the role of women in development, she arrived by private jet, missed several scheduled appointments without explanation and, instead, was rumoured to have been attending to her privat business affairs (AC No. 20, 12 October 1990). 
Still, there is some difficulty in assessing the Babangida regime's tenure, mainly of course because it is still ongoing but also of the considerable incubation period required by many of the reforms undertaken. On the positive side there can be no doubt that the economic environment has been changed for the better in the past five years. The abolition of exchange, $+t_{1}$; and price controls have shifted ti:e balance of economic incentives in favour of agriculture and those nariufacturing activities which utilize local inputs, and the promised commercialization of most parastatals, if indeed carried through, will make them more cost-effective. Truly remarkable was the courage of President Babangida with which he, in his first year or so, took on thase powerful interest groups on whose support his predecessors critically depended: bureaucrats whose gatekeeper positions were abolished, businessmen whose fortunes depended on state patronage, and the urban salariat which had benefitted from artificially cheapened imported consumer goods, from the protection of domestic industries and and from the subsidization of food and energy. Before long, however, the regime fell bach oll traditional patrimonial ways in pursuit of its legitimacy, autonomy and property objectives: deficit spending, accommodation of potential opponents, tolerance of corruption, and selective repression. The bureaucratic State was not transformed, at best reformed at the margins. Sadly, it appears that the present military regime will not hand over the country to elected civilian politicians in the Fall of 1992 - if indeed it will do so at all - any better prepared than in 1979. 


\section{d) Concluding Sumary}

Having dislodged the civilian politicians, the first military regimes (1966-1979) were a coalition between the civilian and military branches of the state bureaucracy. Unlike in the standard model of Lat in American military regimes, the Nigerian ilitary's intervention was not to suppress, vicariously in the interest of the bourgeoisie, the lower classes. In Nigeria it was not social pressures which, as a result of some variety of derailed capitalist development, threatened to overwhelm the State. Here the conflict was almost entirely within the State itself. To be sure, regional sentiments, and ressentiments, were appealed to by various elite factions. But ethnic egotisms were not so much mediated through the political process as instrumentalized by politicians for their very ow advantage. The virulence of the conflicts was heightened by the advent of oil in the 1960s, because now, even more su than before, a state office became a virtual warranty for prosperity. ${ }^{55}$

In rescuing the State from itself, as it were, the military decisively re-created Nigeria's unity after three years of acrimonious civil war; it also re-established and consolidated the State's autonomy vis-à-ris society, economy and foreign interests (economic and politi(ai): the four regions were replaced by twelve states; various revenue distribution formulae increased the central government's share at the

55 Inlike in some authoritarian Latin American States where political power, for much of the recent past, was a function of economic success, in post-independence Nigeria this causation has been the exact reverse: economic success here typically was/is a function of political power. 
expense of state and local governments; expatriate oil companies were nationalized in order for the state to capture the oil rent itself; the banking, construction, manufacturing and service sectors were indigenized and Nigerianized to pacify the potentially threatening business stratum and also to permit the members of the state class to pursue their property interests. Since nothing could have stopped it, the state class apparently realized that its interests were better served by using its position to participate in private enterprises, rather than by nationalizing them outright. The management of the oil rent also followed the triple imperatives of State legitimacy, State autonomy and state class property which meant that much of the financial windfall, disbursed rithout an element of public accountability, was wasted. It was the inability to use its autonomy productively in the interest of national development, that is, to live up to the public trust and to responsibly administer national assets, which caused considerable frustration among ordinary Nigerians. The former Governor of Imo State, Sam Mbakwe, expressed this widespread apprehension by publicly wondering whether a return to colonial rule should be considered a Viable option by Nigerians (reported in Ayoade: 1988,110).

The State's overregulation of and heavy intervention in the economy failed to ignite economic development and more likely retarded it. The small import-substitution manufacturing sector remained, paradoxically but predictably, onerously dependent on imported inputs of machinery, technology and raw materials. Its profitability was a function of the heavy protection against foreign competition accorded it by the State. It is moot to speculate whether this particular industrializa- 
tion policy was the result of

- reasonable errors: for instance the unreflected application of the historic lesson that infant industries have to be protected initially with little thought given to the equally historic lesson that this protection has to be time-limited; or the vistaken concentration on light consumer goods which, although promising initially dramatic results, entails little developmental potential and, eventually, fails even on its own terms, namely to reduce the national economy's import dependence;

- a failure to resist the instinctive equation of industrialization and development: the Nigerian colony's relationship with the British metropole was characterized by the exchange of unprocessed agricultural goods for consumer goods, predominantly light consumer goods. Given the severe power imbalance between colony and imperial country, the emotive equation of consumer gonds manufacturing with progress, prosperity and prowess, and of agriculture with backiardness, penury and weakness, is understandable, as is the deduction that it was an imperialist conspiracy which preempted the creation of a viable manufacturing sector also in the colony. Industrialization at whatever cost, ideologically impregnated as it was, saw populace and leadership in unison - with Western economics providing the rationalizing script; 
- the inherent potential for rents: an industry, dependent on imported inputs but protected against imported competition is a rentier's dream scenario. On the one hand, the captive narket inplies sonopoly rents, on the other, factor inports entail the possibility to over-invoice and thus to transfer foreign exchange out of the country.

Whatever ultimately accounts for the overprotection of manufacturing industry, it was, disastrously, airrored by the anti-protection of agriculture. Firstly, in the 1950 s and 1960s, the State, by neans of the monopsonic marketing boards, withheld from direct producers a significant share of their crops' world market prices. Secondly, the purchasing power of agricultural incomes was reduced by inflation and by higher than necessary prices for domestic manufactures. Thirdly, the relatively high modern sector wages further deteriorated rura]urban terms of trade. Fourthly, public sector investment in education, sanitation, health and transportation was heavily biased in favour of urban centers. Finally, the importation of food depressed agricultural prices. In combination, these policies undermined the viability of agriculture and induced its regression frow a vibrant, exchange-oriented to a subsistence sector, unable to aintain per-capita food production at pre-independence levels.

The mindless monetization of oil revenues, especially in the for of public sector consumption, sparked inflation which was countered by generous wage awards and massive deficit-financing; this, in turn fired on inflation even more. The State established an elaborate regulatory 
framework, far ahead of its executive capacity, to counter the negative effects of other policies it had decided on for narrowly self-interest reasons. An overvalued exchange rate appeared to cheapen inports, yet required an extensive administrative achinery to allocate the subsidized foreign exchange. The resulting temptations were hard to resist for public officials, as was unproductive rent-seeking by the business class. To prevent the country from being flooded by inports and to protect domestic manufacturing, an intricate import licencing and tariff system, permitting the precise targeting of benefits, was operated. Declining food production was countered by capital-intensive large-scale agricultural projects and by food imports. All three measures, again made attractive by subsidized foreign exchange, entailed lucrative opportunities for the state class and its clients. The indigenization of domestic industry or the creation of additional federal states enhanced state legitimacy and autonomy and benefitted the state class directly. However, the former did not enhance domestic productivity, nor did the latter bring governmert closer to the people in the sense of making it more responsive.

The State during the Second Republic (1979-1983), as a civilian regime popularly elected and subject to periodic reconfirmation by the populace at large, hed a more diffuse clientele to serve than a wilitary regime. It resealsled the First Republic in its clientelism gone wild, its incoherence and lack of coordination between different centers of policy-making. The State's unity and ruling capacity again began to dissolve while, at the same time, unprecedented financial profligacy threatened to mortgage the country's revenue base with nothing 
to show for it. The Buhari coup, carried out to reclain the state for the military-bureaucratic elite (the state class proper) and to save its managerial capacity, removed the ineffective and, even by the casual Nigerian standards, exceedingly corrupt civilian regine. Blatant clientelisa was replaced by single-ninded authoritarianisa and perspectiveless austerity measures, Since nisnanagenent had been only one of the previous regine's failures, and since Buhari proved unable to constructively address the econony's structural deforation, his regime quickly ran out of ideals, money and public support.

The present Babangida regime started out in a sonewhat aellower style. Forced by dire economic straights it embarked on a reversal of policies which had remained sacrosanct for almost four decades, irrespective of the regime of the moment: it sought to liberalize trade, withdraw from its involvement in the economy, turn control over to private groups and force new private economic activity. Unfortunately, progress stalled as soon as it became clear that economic recovery, let alone capitalist development, required more than a first painful cut. The privatization of parastatals and the closure of unprofitable projects proceeded only haltingly. Maintaining budgetary discipline proved elusive, as did the professionalization of the state apparatuses and their $r$ orientation to be facilitating rather than controlling agencies and avenues for bureaucrats' self-aggrandizenent. What, in 1985-86 might have looked like a veritable transformation of the bureaucratic State, was by 1988 revealed as a nere adaptation to a changed macroeconomic reality, characterized by falling income and mounting debt. 
The Nigerian experience of the $1980 \mathrm{~s}$ seems to entail an inportant lesson about structural adjusteent policies in general: while macroeconomic streaslining in the sense of eliminating anti-production incentives and rent-seeking opportunities is absolutely essential, it is not sufficient. If the state continues in its patrimonial ways, albeit on a nurh narrower resource base, it will reaain unstable, coup prone and persistent in its failure to fulfill its historic nission as a developmental catalyst. Since it seens unable, frov within, to sustain meaningful reforms, it may well fall to external agencies such as the World Bank to provide respective stimuli. What is needed as an indispensable complement to sound macroeconomic policies are measures to significantly improve the quality of governance. Guided by the axims of accountability, competence, transparency and rule-bound operation, the State's institutions need improvenent to ensure that they truly merit the denotation "public service," instead of evoking, as in the past and present, the connotation "self service." 


\section{General Conclusion}

The foregoing description and analysis of Nigeria's econonic development has been organized around the ideal type of the bureaucratic State and, derived therefrom, the bureaucratic mode of production. Both are premised on the proposition that economic development, that is, the process of transforming the economy's structure with a view to raising societal productivity, is for the bureaucratic Nigerian State at best a residual objective. Of far greater importance is the pursuance of state legitimacy, state autonomy and of the state class's property interests. Politically, the latter set of priorities recommends the development of clientelist relations to the country's relatively powerful, and therefore potentially threatening, groups, such as the small business class, modern sector workers and public sector employees. Economically, clear preference is given to input-oriented guick fixes, such as assembly type operations for the local manufacture of consumer goods or capital-intensive faraing to provide food, which promise the result of development without the pain. This particular if elusive version of a "shortcut to progress" (Hyden) requires ample financial resources at the disposal of an activist state to secure the availability of imported inputs, to protect domestic producers against foreign competition and to satisfy the demand of possibly menacing individuals, groups and classes.

Each intervention is costly, creates beneficiaries (usually precisely targetable ones) and victims (usually more diffuse), causes distortions and necessitates further interventions. For instance, the 
marimization of the national currency's purchasing power recommends a high exchange rate which cheapens imports but threatens domestic pioducers as well as the leakage abroad of valuable resources. To prevent both, imports are restricted and access to foreig.l exchange is regulated administratively. Thus protected, industry produces inefficiently whic!. raises the prices of consumer goods. Agriculture is discriminated against in three complementary ways. An overvalued exchange rate undermines its competitiveness in the world market whose prices transJate into fewer naira. The subsidization of the urban sector drives up both the prices for the manufactured products used in rural areas and the labour costs there, while imported foods have a dampening effect on food prices. Falling agricultural production is countered by huge irrigation project; or the importation of machinery and fertilizers. All threr are heavily subsidized and passed on to selected "progressive" farmurs with the intention to raise food output. What these measures have in common is not only that they are circuitous and cumbersome rays to achipve goals which could be reached much more cheaply and elegant$1 y$, but that all feature the stato as the provider, protector or gatekeeper. As long the resources keep flowing in, they permit the state to create the illusion of a rools' paradise and to sustain the mechanisms on which state autonomy and the pro.jerty interests of the state class depend. If resource inflows plummet, adjustments become inevitalle. These take the form of load shedding: of trimming the sails and perhaps of tacking, not however, of changing course fundamentally. Like all ideal types, the model of the bureaucratic State, too, entails a great deal of oversimplification but, so my hope, not too 
much falsification. It is neither a passe-partout nor a monocausal explanation of Nigeria's recent history, but a useful template to crystallize the issues, in particular to focus on the logic behind the control-oriented and interventionist public policies since pre-independence days, and even more so thereafter. The bureaucratic Nigerian State is a specific order of domination and a concrete organization. It is not an arena for class struggle nor an impartial processor of sociptal demands. Its poner base and its ruling element is the bureaucracs. Inlike the institutional form of legal-rational bureaucracy which is strictly rule-oriented, the bureaucratic Nigerian state is thoroughl: pratrimonialized and driven by power. Because of the State's ctintrality, the organizing logic of the Nigerian social order is the bureaucratic mode of production. The latter is a generic economic system just as the bureaucratic state is generic order of domination. Nigria's non-capitalist nature is corroborated also by the facts that commodity production and the antagonistic classes of accumulating capitalists on the one hand and of formally free labourers on the other are, if not marginal, then by no means dominant phenomena. Given, then, that Nigeria is a non-capitalist social formation, attempts to analyze the Nigerian State as a capitalist one must be aisplaced. Better leads are provided by the framework of atrimonial-bureaucratic order which suggests that State legitinacy and State autonomy are the immediate objectives in the service of the state class's overall goal, namely the pursuance of its property interests. These assumptions prove more incisive than alternative hypotheses for sifting and interpreting the historical material of the past thirty years. 
Development as State goal has to be excluded, not because it has not been achieved, but because even with the keenest sense of appreciation for the formidable obstacles involved, no case can be made that the actual policies pursued entailed much developmental aerit. During the 1970s, the Nigerian State attained considerable autonony vis-à-vis the previously dominant foreign companies, most meaningfully in the oil sector. The State's revenues not only soared to unprecedented levels, but their base became detached from agriculture, the country's traditional productive sector, which enhanced the State's autonomy tc an extraordinary degree. Yet, and this is a paradox which seems to refute any putative claim concerning the Nigerian State's developmental orientation, the greater the State's financial and economic autonomy were, the lorer its sense of urgency regarding econonic development.

External determination, scarcities or unfavourable terms of trade fyuall! have to be rejected as too facile to be useful explanatory avenues for Nigeria's lackluster developmental performance. Instead, What has been argued is that the State, staffed by officials modelled neitler in the image of Platonic philosopher kings nor of Fabian administrators but by bureaucrats with their own interests, is developmentally counterproductive if left to its own devices. What has been emphasized, therefore, is the necessity to complement the sts:e-oriented perspective of neo-classical development economics which points to ubiquitous market-imperfections or market-failures, with the equally likely syndrome of state-failure. Especially in a context of state autonomy - as a military regime, the Nigerian government for over twenty of its thirty years, did not need to have its mandate periodi- 
cally renewed in popular elections - there were few constraints to arrest the wastage of scarce resources. Of equal or greater importance is that nothing prevented the bureaucratic Nigerian state from pursuing regulatory policies which preempted the mobilization of those potentialities which lay largely ungarnered in civil society.

To provide historical depth and with the obvious benefit of hindsight, the origins of the bureaucratic Nigerian state have been traced to the colonial government's omissions and conmissions as well as to the specific forms of nationalist opposition these gave rise to. The colonial state failed, on the one hand, to create private land-ownership, to open the civil service to qualified Nigerians and to abolish produce marketing boards after the emergency situation of World War II. On the other hand, it used traditional chiefs as its extension agents which did ensure stability, yet at the expense of development. By the same totien it prevented the emergence of a manufacturing sector and of a productive bourgeoisie. Then, in the twilight of its existence and as if to make up for prior dereliction, it directly participated in the economy's productive sector through the acquisition of assets of private enterprises and through the creation of wholly state-owned companies. The nationalist opposition to colonialisw was a movement of mostly westernized intellectuals, such as lawyers, doctors and teachers who were both a product of colonialism and dependent on the colonial economy for their livelihood, yet who were also intensely frustrated because of the colonial government's haughty disinclination to accurd them a voice and role in political matters. The State became a trophy as important as national sovereignty, or more, and dirigiste policies 
the natural reflex of this étatiste fixation. With the advent of oil, and in the absence of puissant groups or classes, political power became the key to economic success. The struggle for power intensified. I have argued that the post-independence Nigerian State uncannily rits the model of the bureaucratic State, a direct descendant of Max heber's model of the patrimonial state. By applying this ideal type to the 1970 s and $1980 \mathrm{~s}$, the discrete logic of the Nigerian State's interventionist policies cawe into sharp relief. Even though prescription goes beyond my topic, the model of the patrimonial-bureaucratic State points to the desirability of greater market-reliance, to a shift from a predominantly vertical organization of society to one with equally strong horizontal links. This is not a plea for a minimalist or laissez-faire state, yet it does suggest a reduction and a reorientation of the State's role in the economy. Rather than directly participating in production, except as interim or last resort measures, and rather than overregulating or overtaxing and thus stifling production, the State's role should be to create and guarantee a market econony. This implies sound macro-economic and trade policies which stimulate production rather than rent-seeking, which facilitate market exchanges rather than the exploitation of monopolies, economic and political, and which provides public goods efficiently, reliably and non-arbitrarily. As to the practicability of such a metamorphosis, it aight well require some catalytic action from abroad in support of the nascent domestic forces of competitive capitalism: developwent agencies playing the role of loyal opposition to the weak but autonomous, omipresent but irrational, and poor but wasteful state. 
1776

1787

1794

1802

1807

1815

1833

1861

1863

1885

1886

1887

1893

1900

1906
British House of Commons rejects notion declaring the slave trade "contrary to the laws of God and the rights of man."

Formation of the Society for the Abolition of the Slave Trade.

France abolishes slavery in her colonial possessions.

Napoleon restores slavery in France. Slave trading declared illegal for British subjects.

The Congress of Vienna prohibits slave trade; under pressure fron Britain, the restored French monarchy abolishes slavery. Slavery and slave trade finally abolished in Britain and her inperial possessions.

The Yoruba ruler Deceno cedes Lagos Island which is declared a British Crown Colony. lagos receives its own Colonial Government (however, between 1866 and 1874 it is administered from Sierra Leone and between 1874 and 1886 from the Gold Coast).

Berlin Conference acknowledges British claims to the Niger basin.

Niger Delta proclained "Oil Rivers Protectorate".

The Colony and Protectorate of Lagos receives an independent British Colonial Government; first census carried out; the Royal Niger Company obtains Charter.

After cocoa had been introduced into Nigeria frow Fernando Po in the early 1870s, seedlings are made available to peasant farmers by the government botanical gardens in Lagos.

Custons duties inposed in Lagos.

"Niger Coast Protectorate" proclaimed. Authority over all three Nigerian territories transferred to the Colonial Office; Royal Niger Company's charter revoked; "Protectorate of Northern Nigeria" proclaimed.

Native Lands Acquisition Proclanation (reserved land for Nigerians and required interested aliens to obtain High Commissioner's written consent). Colony of Lagos nerged with the Niger Coast Protestorate and renamed "Colony and 
Protectorate of Southern Nigeria".

Establishment of governeent Department of Agriculture.

The "Colony and Protectorate of Southern Nigeria" verged with the "Protectorate of Northern Nigeria" to form a colony called "Nigeria".

Land and Native Rights Ordinance issued. Anti-glavery laws $f$ inally being enforced in Nigeria; direct taxes introduced in the Southwest.

Clifford Constitution; establishment of a constitutional Legislative Council in Lagos. Direct taxes introduced in the East. Establishment of the first institution of higher learning, Yaba College, with a andate to provide well trained assistants for various departments of government and private enterprise. Creation of the Eastern and Western Regions; statutory narketing introduced for cocoa. West African Produce Control Board established.

Abolition in the civil service of "European" and "African" posts.

"Ten Year Plan of Development and Welfare" becomes operative.

Richards Constitution; creation of three regional Houses of Asseably and a central Legislative Council.

Nigerianization of Public Service begins; expatriates can be recruited only if no qualified Nigerian can be found;

Lagos Chamber of Conmerce admits Africans; University College Ibadan, Nigeria's first university, inaugurated.

Macpherson Constitution; appointment of Nigerian Ministers with executive powers in the regions and at the federal level; Aid to Pioneer Industries Ordinance (entails incentives to companies enploying Nigerians). Lyttleton Constitution; Nigeria formally constituted into a federation; leaders of ajority parties in the regional assemblies designated preaiers; they head cabinets of ministers who are responsible to the assemblies; National Marketing Boards regionalized. Universal, free and compulsory primary education introduced in the Western Region. 
1956

1957

1958

1959

1960 October 1

196:1 February 11-12

1962 April 1

May

May $13-31$

1963 July 13

October 1

November 5-8

1964

May 31

December

1965 October-December

1966 January 15
Industrial estates established.

British Governor anci Lieutenant-Governors cease to have veto-power over policy; strong, ethnically based parties win elections in all three regions; the Eastern and Western Regions becone self governing: Alhaji Abubakar Tafawa Balewa (NPC) naned Prime Minister; universal, free (not compulsory) prinary education introduced in the Eastern Region.

Constitutional Conference in London agrees to hold federal elections in 1959 and sets date for independence in 1960;

Tax Relief Act (offers tax concessions to companies employing Nigerians in managerial positions). Northern Region becones self governing; Elections for federal House of Representatives; NPC forms coalition with NCNC; Central Bank of Nigeria becomes sole authority for the issue of currency in Nigeria; a Petroleum Profits Tax Ordinance establishes a 50\%-50x profit sharing arrangement (based on realized prices) between oil companies and the Nigerian State. Independence Day; NPC/NCNC Coalition; Tafawa Balewa remains Prine Minister; Nnandi Azikiwe naned Governor-General. Second Caneroons Plebiscite.

First National Development Plan inaugurated. State of Emergency in Western Nigeria. Abortive Population Census (North gets absolute majority of the 53 million counted).

Plebiscite in favour of creating a Mid-West Region.

Nigeria becomes a Republic; Nramdi Azikiwe becomes President.

Population re-count results in total of 55.67 allion and is again rejected;

Inaigration Act (quota system for expatriates in newly establighed foreignowned coopanies; government approval required to eaploy foreign professionals. Approved Users Scheme introduced;

Joint Action Conmittee of trade unions calls a general strike. General Election crisis. Crisis deepens after Western Region elections. Violent coup d'état, end of First Republic; Prine Minister Sir Abubakar Tafana Balewa 
May 24

July 29

August 8

September-October

1967 January 5

May 27

May 30

July 6

August

November

1968-1969

1969 April

Noverber

1970 January 12

April 1

May 27

October 1

1971 March 31

April 24

May:

July

August 6

1972 February 29

1973 January 1

February

April 1 killed, also federal Finance Minister Chief Festus Okotie-Eboh, Northern Previer Sir Ahnadu Bello and Western Presier Chief S.L. Akintola; I ronsi regime;

Federal system abolished in favour of unitary State (Decree 34 );

Second coup d'état, Gowon regine;

Federal systen restored;

Ad Hoc Constitutional Conference.

Petroleum Profits Tax (anendment) Decree No.1 promulgated which, retroactively to January 1966, placed the 50x-50\% sharing arrengenent on the basis of "posted prices; Abolition of four regions in favour of twelve states;

Eastern Region secedes and is proclaimed "Republic of Biafra;"

Start of Civil War (lasts until 12 Jan.'70);

Secessionist invasion of Mid-West;

OPEC terms effective in petroleum industry. Agbekoya riots in Western State.

Report of (Dina) Interin Revenue Allocation Comaittee rejected;

Petroleum Decree signals a new, decidedly participatory role for government in the oil industry;

Surrender of Biafra, end of civil war;

Second National Development Plan inaugurated;

Price Control Board and National Supply

Conpany established to combat inflation;

Gowon announces 9-point plan for return to

civilian rule.

By decree, the ownership and control of petroleu found in Nigeria is vested in the federal government;

Government acquires $40 \%$ of three largest

commercial banks as well as $35 \%$ equity of

the Nigerian Agip Oil Company (later Agip/

Phillips) and of Safrap (later Elf);

Nigerian National Oil Corporation (NNOC)

established;

Nigeria joins OPEC;

Final report of (Adebo) Nages and Salaries

Review Connission.

Nigerian Enterprises Pronotion Decree (first indigenisation decree).

Naira currency (equivalent to $0.5 \mathrm{NE}$ ) introduced;

Reform of Marketing Boards announced;

Government acquires $35 \%$ equity of Shell-BP, Gulf and Mobil; 
October

December

1974

January

May

September 25

October 1

1975

April 1

July 29

October 1

Ortober 18

1976 January 1

February 13

April

September

September 14

Sept. - Dec.

October 1

1977 January 1

January 12

April 1

August 31

October 6

1978 January

January

February

March 29

April 6-24

June 5

July 14
OPEC unilaterally doubles oil prices; Nigerian crude increases fron $\$ 4.3$ to $\$ 8.3$ per barrel;

Population census conpleted after 20 months. Government acquires $55 x$ of petroleue industry; Nigerian crude raised to $\$ 14.7 / \mathrm{b}$; Gowon announces the census results: 79.76 aillion. After the coup, Gen. Mohanned annuls these figures as unacceptable; fixed relationship between the naira and the US\$ terminated; the naira's value vis-à-vis the US and Sterling is increased by $6.5 \%$;

Report of (Udoji) Public Service Review Connission:

Gowon postpones return to civilian rule. Congestion acute at Lagos port;

Third National Developnent Plan;

Third coup d'état, Murtala Mohamed regine; Murtala Mohaned announces 5-stage progranme for return to civilian rule;

Inaugural meeting of (Rotini Williams)

Constitution Drafting Comattee.

Wartime inhibitions on right to strike maintained in new Trade Disputes Decree; Murtala Mohammed assassinated, Obasanjo regime;

12 States replaced by 19 ;

Progranme of universal primary education launched;

Constitution Drafting Comittee reports; Local government reforms;

Appointment of Federal Electoral Comission. Price Control Act pronulgated

Second Indigenisation Decree;

Marketing Boards reconstituted as national boards; Nigerian National Petroleun Corporation (NNPC) established to replace NNOC;

Elections to Constituent Assembly;

Constituent Assembly begins sittings.

Nigeria begins borrowing heavily in eurocurrency market;

Report of (Aboyade) Technical Conaitee on revenue allocation;

Trade union reform; Nigerian Labour Congress establ ished;

Land Use Decree (trusteeship of all land vested in the government);

Constituent Asseably proceedings held up by boycott;

Constituent Assembly adjourns indefinitely;

Reposting of state ailitary governors to nilitary duties; 
August 29

September 21

1979 January

July 7

July 14

July 21

July 28

August

August 11

October 1

October 2

1980

Jurie 30

1981 January

1983 January-

February

April

October 1

December 31

1984 February

March

March 28

April 17

April 20

April 23

Constitution presented to Head of state. Constitution pronulgated, ban on political parties lifted.

Further rapid increases in oil prices begin following Iranian revolution;

Elections to the Senate;

Elections to the House of Representatives;

Elections to the State Houses of Assembly;

Elections of State governors;

BP' $\mathrm{g} 20 \%$ share in Shell-BP (Nigeria) nationalized in reaction to the British governant's decision to sell oil to South Africa; Presidential elections;

Inauguration of Second Republic, withdrawal of the military from government, installation of Alhaji Shehu Shagari as President; Coalition formed between northern based NPN (207 seats) and eastern NPP (93 seats).

Fourth National Developnent Plan;

Report of the (Okigbo) Conaission on Revenue Allocation; Report of the (Irikefe) Tribunal of Inquiry into Crude Oil Sales.

Price for Nigerian crude oil peaks at $\$ 40 / \mathrm{b}$; about 2 aillion "illegal aliens" expelled (bostly fron Ghana, but also fron Caneroun, Mali, Niger and Burkina Faso);

Having exhausted its drawing rights on the IMF, government begine negotiations with the IMF for an extended credit of at least $\$ 2 \mathrm{bn}$; Installation for second tere of Shehu Shagari ;

Coup d'état, end of Second Republic; Buhari regime.

Religious riots throughout the North, over 1,000 die in Yola alone;

har Against Indiscipline declared;

Decree No. 3 (Recovery of Public Property Special Military Tribunals Decree) imposes aininum sentences of 21 years for former public officers found guilty of corruption or theft;

Decree No. 4 (Protection against False Accusation Decree) aakes it an offence to publish false infornation or ridicule a government officer;

"Anti-Sabotage" Decree tightens exchange controls: any paynent by a Nigerian resident to a person outside $\mathrm{Ni}$ - geria declared illegal - retroactive to October 1979; Nigerian borders closed to prevent smuggling (Niger and Benin appeal to France for help to compensate for losses); 
April/May

April 23

May

July 5

July 24

1985 February

August 27

October 1

December 12

December 20

1986 January

February

March 1

March
Change of banknote design as part of anticorruption drive;

Closure of all borders, ostensibly to prevent currency trafficking and smuggling of essential connodities;

Trials in ailitary courts begin against Second Republic politicians (15 of 19 former governors sentenced to $15-23$ years of ioprisonment; these terms were reduced to between 2 and 10 years for $8 i x$ of the accused); expulsion of another 700,000 foreigners announced;

Kidnapping in London and aborted abduction to Nigeria of former (under Shagari)

Minister of Transport, Unaro Dikko;

"Special Tribunal (Miscellaneous offences) Decree (No.20) establishes special tribunals and iaposes death penalty for a variety of offences (e.8. for drug dealing, ieporting/ exporting aineral oil, tampering with electric telephone cables etc.) and aininue 21 years iaprisonment for others (e.g. cheating at examinations, unlawful exportation of foodstuffs etc.);

Diplonatic relations at anbassadorial level established with PLO;

Palace coup, Babangida regine; as first military ruler Babangida assumes title President;

Government declares economic emergency and announces austerity neasures, e. B. postponeaent by one year of 5 th National Development Plan (1986-'90) and downward revision of spending estinates; importation of aize and rice banned; salary cuts for vilitary fron 2x -20x; NNPC re-organized to increase accountability;

President Babangida decides not to accept a $\$ 2.4$ bn loan from the IMF; Inportation of stockfish vegetable oil banned;

Over dozen senior officers arrested and accused of planning coup.

Return to elected civilian regine pledged for October 1990 (in July 1987 this deadline is extended to 1992): Meabership in Islanic Conference Organization announced;

Political Bureau established; it is charged with aking reconnendations re future political systen;

Borders reopened (they had been closed since April 1984);

Ten plotters of the 20 Decenber 1985 coup 
April 18

April-May

June 28

June 30

July

Septenber 26

October 21

October 23

October 16

1987 January

February

March

May 7

July 2

July

1988 January

February 23

July: attenpt executed;

Presidential announcement re abolition of conoodity boards, central price fixing for agricultural connodities, and the privatization of over 100 (federal) parastatals; second nass expulsion of foreigners; President Babangida announces Structural Adjustment Progranne (SAP) intended to run frow July 1986 to June 1988;

Marketing boards seize trading;

Forner President (Shagari) and VicePresident (Ekwuene) released fron detention; Inport Regulations abolished and connenceent of Second-tier Foreign Exchange Market (SFEM);

Dele Giwa, editor-in-chief of Newswatch nagazine killed by letterbonb; senior nembers of the government inplicated; World Bank approves a crucial loan over $\$ 452$ aillion to support SAP;

Wole Soyinka awarded Nobel Prize for Literature; to break the colonial legacy, the academic year for prinary and secondary schools switched fron Septeaber-July to January-December.

President Babangida announces extension of state of economic energency from July to Decenber 1988; the inportation of wheat, barley and nalt is banned;

IMF approves stand-by arrangement for SAP over SDR 650 until January 1988; aarketing boards foraally abolished;

During religious riots in the North, Muslims attack Christians; over 100 people killed and about 100 churches razed to the ground; Chief Obafemi Awolowo dies aged 78;

First-tier (government-fixed) exchange rate of the naira merged with second-tier

(narket-deternined);

President Babangida announces new date for return to civilian rule: 1992 instead of 1990; creation of Akwa Ibom and Katsina brings number of states to 21 . President Babagngida reveals a list of 96 state owned companies, nany in the manufacturing sector, to be privatized or fully or partially connercialized;

A Lagos Court quashes charges of Newswatch editor Giwa's aurder against director of Military Intelligence and deputy director of the State Security Service;

Privatization Decree promulgated. 
November 1

1989

January 9

January 16

September

December 29

1990 April 22

September 19

November

December 8

December 17

1991 August 17

August 27

October 11

November 27-28

December 12

December 14

1992 January 1

January 2
Sir Siddiq Abubakar III, the 16th Sultan of Sokoto and spiritual leader of Nigeria's nuslins dies aged 85 ; overruling the decjsion of the royal kingmakers, the Babangida names Mr. Ibrahim Dasuki, forner chairnan of BCCI (Nig.) as successor; riots break out claining hundreds of casualties;

Foreign exchange auction systen abandoned and replaced by a unified systee with arket-deternined rates;

Presidential announcenent that indigenization policy of the 1970 s will be reversed and foreigners allowed to hold $100 x$ (up from a maximum of 40\%) equity in Nigerian businesses;

Opening of bureaux de change authorized;

Chief Emeka Anyaoku elected Secretary-

General of the Commonwealth;

Decree No. 54 revises 1972/1977 Enterprises Promotion Decrees and allows $100 x$ foreign ownership of newly created companies. Second coup attempt against the Babangida regine; 27 plotters executed; Mrs. Myriam Babangida awarded the "1991 Africa Prize for Leadership for the sustainable End of Hunger;"

World Bank cancels $\$ 500$ allion loan because of disagreements over public expenditure, especially in respect of the multi-billion Ajaokuta steel plant;

Local governaent elections;

President Babangida in a public speech calls for reparations from Europe and the United States for the danage inflicted by the slave trade.

Nigeria suspends membership in Islamic

Conference Organization;

President Babangida announces the creation of nine new states (Abia, Delta, Enugu, Jigawa, Kebbi, Kogi, Oshun, Taraba, Yobel for a total of thirty, as well as of 47 new local government councils for a total of 500 ; government raises minivum pension by $100 \%$; Census, the fourth since independence; Abuja declared capital of Nigeria; Elections for state governors and state assemblies. Number of federal anistries reduced from twenty-six to sixteen; Thirty elected civilian state governors take over from ailitary predecessors. 


\title{
Appendix A: Statistical Tables
}

\author{
Comments on Tables
}

\begin{abstract}
There are two problems with Nigerian date: availability and reliability. In many crucial areas such as population, workforce, agricultural production, or state spending and employeent, data (in any event of dubious qualityl are published only sporadically, if at all. For instance, the ILO's Bulletin of Labour Statistics or the United Nations Monthly Bulletin of Statistics, although global in range, do not cover Nigeria for precisely this reason. Power, rather than being based on knowledge as common sense suggests, is of ten derived from nescience. Statistics as power instruments are thus highly political and, in the volatile disposition of post-independence Nigeria, unlikely an dispassicnate representation of reality. To illustrate: fears of an increased tax burden wight well have deflated the national 1952 census, while the need for ethnic balance as well as hopes for more political clout and greater share in resource allocation might well have inflated the results of the regionally organized $1962 / 63$ counts. Hence, even whif-re datia are published, one does well to remember the caveat that "[a]ny number anybody puts on anything $\mathrm{Nigerian}$ is pretty certainly wrong" (Harman: 1986,4).1 In addition to the scarcity of data and their doubtful reliability, the lack of compatibility betwi : sources throws up a further obstacle to consciencious analysis.
\end{abstract}

To contain the resulting fall-out, I have consulted as many sourcess as ava, lable and selected the data which appeared the most plausible, or thost on which the majority of sources agreed. Another major problem witl. data spanning almost a century is the incommensurability

] Discrepancies between national and international sources are not all that surprising, if still puzzling. For instance, the Central Bank of Nigerir's Anmual Report and Statement of Accounts $(1986,19)$ gives the cocoa production for 1983 and 1984 as 100,000 tons and 101,000 tons respectively, while the FAO Trade Yearbook $(1985,187)$ indicates that 206,024 tons and 130,808 tons nert exported, that is, over $100 \%$ or nearly $30 x$ more than were ostensibly produced. Concerning the quality of Nigerian sources, two of a virtually unlimited population of examples should suffice. In one of the Nigerian Federal Office of Statistics' major publications, the Digest of Statistics, data are being changed by a margin of over $50 \%$ without acknowledgment, let alone explanation. In the issue of December 1984 the figures marked * are given; in the issue of June 1987 those marked $\$$.

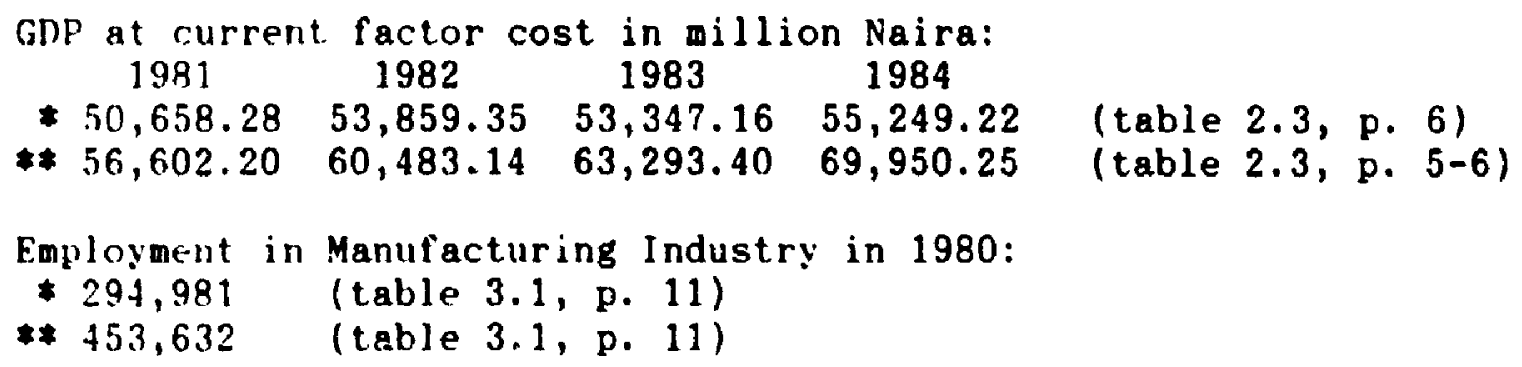


and thus the lack of comparability between the different units of account (surface measures, weights, volumes and currencies). To provide for basic compatibility, all raw data have been converted to a decimal system. It should be emphasized that the value of these data - especially those of monetary values - cannot be to provide hard information but, at best, to indicate trends and orders of magnitude.

\section{Weights, Measures and Sybbols}

Regarding surface measures, acres have been converted to hectares (1) ha $=10,000 \mathrm{~m}^{2} \approx 2.5$ acres). Regarding weights, long tons $(=1.016$ metric tons) or hundredweights $(=50.8 \mathrm{kgs})$ have been converted to metric tons and the volume indication for mineral oil to barrels. One barrel equals 158.984 liter (or 36 imperial or 42 uS gallons). The equivalent of barrels in metric tons depends on the specific gravity of petroleum, which varies considerably. For example, the number of barrels per metric ton is in the USA 7.39 , in the USSR 7.29 , in Mexico 6.74, in Venezuela 6.77 (League of Nations:1936,14), in Canada 7.56, in Angola and in Nigeria 7.5 (United Nations, Statistical Yearbook 1979/ $\underline{80}, 201)$. Where the original sources used metric tons, these have been converted into barrels at a ratio of 7.5 barrels/ton.

The following symbols are used in the tables:

$$
\begin{aligned}
\overline{0} & =\text { nil } \\
0 & =\text { negligible quantity }(\text { i.e. }<0.5) \\
i 1 & =\text { marginal quantity (i.e. } 0.5-0.99) \\
\ddot{j} & =\text { data not available } \\
\text { bn } & =\text { estimate } \\
\mathrm{mn} & =\text { million } \\
\mathrm{n} \cdot \mathrm{a} . & =\text { not applicable } \\
\mathrm{b} / \mathrm{day} & =\text { barrels per day } \\
\mathrm{p} / \mathrm{c} & =\text { per capita } \\
* & =\text { pointer to category or source as defined } \\
& \text { in each context } \\
& =\text { data from previous or subsequent year }
\end{aligned}
$$

\section{Currency}

To allow comparability over time, and especially since petroleum in Nigeria as elsewhere has always been traded in US\$, all original data have been converted to current USS at the rates indicated in table 7. The obvious problem with this conversion and non-adjustoent for inflation is that the thus derived costs, prices, revenues and expenditures are of ten unable to reflect "true" values. it bears emphasizing, therefore, that the purpose of the following tables is confined to highlighting tendencies. 
P.ior to 1959, the four West African Colonies (Sierra Leone, the Gambia, Gold Coast and Nigerial had maintained a common currency, at par with Sterling (Sokolski:1965,159). In 1958, the Nigerian colonial government pasged an ordinance establishing a Central Bank which, in JuJy 1959, began to issue Nigerian $\Sigma$ (NE), also at par with Sterling. After the latter's devaluation in 1967 the $N \varepsilon^{\prime}$ 's par value was aintained in gold and, for a time, in US\$. The devaluation of the US\$ in December 1971 was countered by a re-valuation of the $N \&$ from $\$ 2.8$ to $\$ 3.04$ to defend the gold parity of 2.4884 grans of gold per NE (ARBe: 12/1971,2239. In June 1972, the N乏 was revalued by $5.1 \times$ vis-a-vis Sterling because, as the Governor of Nigeria's Central Bank contended, the Nigerian currency was stronger than that of Britain and because imports into Nigeria from the United Kingdon (still her ain supplier) would now be cheaper (ARBe:6/1972,2409.

On 1 January 1973, the naira (N), equivalent to $0.5 \mathrm{NE}$, was introduced (United Nations, Yearbook of International Trade Statistics, 1976, Vol.1, 666).2 In May 1974, the fixed relationship between the naira and the US\$ was ended and the naira's value vis-à-vis the US\$ and Sterling increased by 6.5\% (ARBe:7/1974,3199-3200), "the Central Bank's intention being to make more frequent adjustwents" (EIU, Quarterly Econumic Revieh of Nigeria: Annual Supplement 1975, p. 4$)$.

Lntil 1986, the naira was a non-convertible currency whose rate was set by the government. This led not only to a black market (the naira's real effective exchange rate is indicated as $Y$ in table 7 ) but to a dramatic devaluation after its rate was no longer established administratively. $Y$ denotes the real effective exchange rate which is measured as the number of US\$ per naira, aultiplied with the ratio of the ('S consumer price index (CPI) to the Nigerian CPI (cf. Edwards: 1990,268; Markandya \& Pemberton:1988,28-29; Mosley \& Smith:1989,325; horld Bank:1986b,67). The difference between $X$ and $Y$ indicates the proximate extent of the naira's overvaluation. The werely suggestive quality of $Y$ cannot be overemphasized. For one, there is no such thing as an objectively definable "proper" or "appropriate" rate; every rate,

2 This conversion causes some confusion. In order to ensure the comensurability of post-and pre-1973 prices, some sources, such as the World Bank or the IMF, contert pre-1973 data into Naira (at half their sN value). The seeming contradiction between the Nigerian currency's \$ values between 1960 and 1972 indicated in Table 7 and those given in World Bank publications (see belon) is dissolved, once it is realized that the former reflect the actual rates of the time while the latter are based on this ex-post conversion to Naira.

horld Tables 1976* (pp. 178-179); 1989-90** (pp. 426-427):

\begin{tabular}{|c|c|c|c|c|c|c|c|}
\hline * & $\$ / N$ & ** & $\$ / N$ & $* *$ & $\$ / N$ & $* *$ & $\$ / N$ \\
\hline $\begin{array}{l}1960- \\
1970\end{array}$ & 1.40 & $\begin{array}{l}1968- \\
1971\end{array}$ & 1.41 & $\begin{array}{l}1972- \\
1973\end{array}$ & 1.515 & $\begin{array}{l}1974 \\
1975\end{array}$ & $\begin{array}{l}1.587 \\
1.613\end{array}$ \\
\hline
\end{tabular}


whether high or low, always benefits sone econonic sectors or activities and causes hardship to others. Secondly the relationship between Nigeria's and the US's CPI can be questioned because Nigeria inports very little from there (it buys mostly from Britain, Geraany, France and Japan) which seens to call for a different conparator. Thirdly, there are many more measures of the "real effective exchange rate" (i.e. various kinds of trade- and import-weighted concepts; cf. Pinto: 1987,425 ). Yet, whichever combination of paraneters is chosen ultimately remains a subjective choice. If the extent of the naira's overvaluation thus remains contentious, there is near universal consensus that it was significantly overvalued in the $1970 \mathrm{~s}$ and early 1980s; a vibrant parallel market bore testimony to the distorted official value of the naira.

\section{Population}

The 1952 census results ( 30.4 aillion) were not contested but probably 20\%-30\% belon the actual total. Although probably above the actual total, the 1962 census results (53 million) were rejected as were those of 1963 (55.7 million) and of 1973 (79.8 million). Despite their non-recognition, official Nigerian statistics until today are projections of the 1963 result. Because of the political premiun of inflated numbers expected by the various Regions, these yield higher totals than those arrived at by the World Bank or the IMF. Here, the horld Bank's figures are used (except 1935-1945 which are from United Nations: 1949,98-99). To illustrate the considerab!e discrepancies between sources:

$\begin{array}{lrrrrrr}\text { Source } & 1983 & 1984 & 1985 & 1986 & 1987 & 1988 \\ \text { lN * } & 86.3 & 93.3 & 95.7 & 98.2 & 101.4 & 105.0 \\ \text { IMF ** } & 89.0 & 93.3 & 95.7 & 98.2 & 101.4 & 105.0 \\ \text { FAO *** } & 89.0 & 92.0 & 95.2 & 98.6 & 101.9 & 105.4 \\ \text { WB **** } & 93.2 & 96.3 & 99.7 & 103.1 & 106.6 & 110.1 \\ \text { FOS ***** } & 95.4 & 98.6 & 101.8 & 105.2 & 108.6 & \ldots\end{array}$

* UN, Monthly Bulletin of Statistics 6 (June 1991), p. 4 . ** IMF, International Financial Statistics 3 ('90), p. 398.

*** FAO, Production Yearbook 1984, 65; 1986, 1; 1988, p. 66 .

**** horld Bank, World Tables 1989-90 ed (1990), pp. 424-425. ***** FOS, Digest of Statistics June 1987 edition, p. 1 .

Sources (where applicable, issues of various years have been used):

1) Africa Research Limited, Africa Research Bulletin, economic series (Oxford: Africa Research Ltd., monthly). 
2) Central Bank of Nigeria, Annual Report and Statement of Accounts (Lagos: CBN, annually).

3) Central Bank of Nigeria, Economic and Financial Review (Lagos: CBN, quarterly).

4) Economist Intelligence Unit (EIU), Nigeria Country Profile: Annual Survey of Political and Economic Background (London: EIU, annually).

5) FAO, Production Yearbook (Rome: FAO, annually).

6) FAO, Trade Yearbook (Rome: FAO, annually).

7) ILO, Bulletin of Labour Statistics (Geneva: ILO, quarterly).

8) International Petroleun Encyclopedia, Vol. 22 (Tulsa: Penwell, 1989).

9) IMF, Government Finance Statistics Yearbook

(Washington: IMF, annually).

10) IMF, International Financial Statistics

(washington: IMF, annually).

11) League of Nations, International Trade Statistics

(Geneva: League of Nations, various years).

12) League of Nations, Statistical Year-Book

(Geneva: League of Nations, various years).

13) Nigeria, [or "Federation of" or "Federal Republic of"],

Trade Reports (Lagos: Government Printer or

Department of Statistics, annually).

11) Nigeria, Department of Labour, Annual Report

(Lagos: Government Printer, various years).

15) Nigeria, Federal office of statistics (FOS),

Annual Abstract of Statistics (Lagos: FOS, annually).

16) Nigeria, FOS, Digest of Statistics (Lagos: FOS, periodically).

1i) Nigeria, FOS, Economic and Social Indicators (Lagos: FOS, period.).

18) Nigeria, FOS, Economic and Social Statistics Bulletin

(Lagos: FOS, periodically).

19) Nigeria, FOS, Industrial Survey of Nigeria [1963, 1975-1978, 1980-1983, 1984] (Lagos: FOS, various years).

20) Nigeria, FOS, Irade Summary (Lagos: FOS, annually). 
21) Nigeria, Federal Republic of, Third National Developent Plan 1975-1980 (Lagos: Federal Ministry of Econonic Development, $1975)$.

22) Nigeria, Federal Republic of, Fourth National Developnent Plan 1981-85 (Lagos: Federal Ministry of National Planning, 1981).

23) Nigeria, Federal Republic of, Federal Civil Service Manpower Statistics (Lagos: Federal Ministry of Establishments, various years).

24) Nigerian National Petroleum Corporation (NNPC).

Progress of Public Sector Participation in the Nigerian Oil Industry (Lagos: NNPC, 1982).

25) United Nations, Demographic Yearbook 1948

(Lake Success: United Nations, 1949).

26) United Nations, Monthly Bulletin of Statistics

(New York: United Nations, monthly).

27) UN, Yearbook of International Trade Statistics

(New York: United Nations, annually).

28) UN, Yearbook of National Accounts Statistics

(New York: United Nations, annually).

29) UN Economic Commission for Africa, African Statistical

Yearbook (Addis Ababa: UNECA, various years).

30) LNDP, Human Development Report 1991 (New York: Oxford University Press, 1991 ).

31) LNIDO, Handbook of Industrial Statistics (Vienna: UNIDO various years).

32) S.H. Frankel, Capjtal Investment in Africa: Its Course and Effects (London: Oxiord University Press, 1938), p. 317.

33) B.R. Mitche11, British Historical Statistics (Cambridge: Cambridge University Press, 1990 [1988]), pp. 702-703.

34) World Bank, World Tables, 1988-89 edition (Baltimore: Johns Hopkins University, 1989), pp. 436-439.

35) World Bank, World Tables, 1989-90 edition (Baltimore: Johns Hopkins University, 1990), pp. 424-427.

36) World Bank, World Development Report 1991: The Challenge of Development (New York: Oxford University Press, 1991). 
Table 1

Quantity of Principal Export Products (1900-1988)

(1,000 tons for non-oil commodities; 1m barrels for oil)

$\begin{array}{rrrrrrrr}\text { Year } & \text { Cocoa } & \begin{array}{c}\text { Pale } \\ \text { Products }\end{array} & \begin{array}{c}\text { Ground- } \\ \text { nuts }\end{array} & \text { Cotton } & \text { Rubber } & \text { Tin } \begin{array}{c}\text { Mineral } \\ \text { Oil }\end{array} \\ 1900 & 0.2 & 133.3 & 0.6 & - & 1.3 & - & - \\ 1905 & 0.5 & 162.0 & 0.8 & 0.6 & 1.4 & - & - \\ 1910 & 3.0 & 253.8 & 1.0 & 1.1 & 1.2 & 0.8 & - \\ 1915 & 9.3 & 230.0 & 9.1 & 1.2 & 0.3 & 6.7 & - \\ 1920 & 17.4 & 296.6 & 46.2 & 3.3 & 0.5 & 8.0 & - \\ 1925 & 45.4 & 407.6 & 129.3 & 6.7 & 1.0 & 9.4 & - \\ 1930 & 53.2 & 402.3 & 148.8 & 8.1 & 2.2 & 8.5 & - \\ 1935 & 89.6 & 462.8 & 186.0 & 11.0 & 2.1 & 6.0 & - \\ 1940 & 91.1 & 374.2 & 172.2 & 9.5 & 3.0 & 15.1 & - \\ 1945 & 78.3 & 413.4 & 179.1 & 1.1 & 10.7 & 15.4 & - \\ 1950 & 101.6 & 598.5 & 316.3 & 12.8 & 13.8 & 11.6 & - \\ 1955 & 89.8 & 625.4 & 403.4 & 33.7 & 30.9 & 11.6 & - \\ 1960 & 156.7 & 611.3 & 338.3 & 27.4 & 58.2 & 10.8 & 6.2 \\ 1965 & 225.6 & 579.5 & 520.0 & 24.9 & 69.0 & 10.7 & 97.0\end{array}$

(exports other than oil now regress)

$\begin{array}{rrrrrrrr}1970 & 195.9 & 255.8 & 291.2 & 28.3 & 59.3 & 10.9 & 383.5 \\ 1971 & 221.7 & 291.9 & 136.5 & 22.0 & 50.2 & 8.0 & 542.5 \\ 1972 & 227.5 & 245.6 & 106.2 & 1.0 & 41.1 & 3.0 & 651.0 \\ 1973 & 213.9 & 166.1 & 198.7 & 8.2 & 49.4 & 5.4 & 723.3 \\ 1974 & 197.1 & 233.5 & 30.4 & - & 61.3 & 5.7 & 795.7 \\ 1375 & 241.2 & 247.3 & - & - & 47.8 & 4.7 & 627.6 \\ 1976 & 223.0 & 316.0 & 1.6 & 0.0 & 27.4 & 3.2 & 736.8 \\ 1977 & 165.0 & 208.1 & 0.8 & 9.2 & 35.4 & 3.0 & 744.4 \\ 1978 & 192.7 & 198.9 & - & 3.2 & 29.4 & 3.1 & 667.4 \\ 1979 & 113.0 & 199.7 & - & 24.9 & 21.8 & 0.9 & 818.7 \\ 1980 & 133.9 & 113.5 & - & - & 24.0 & 1.0 & 698.2 \\ 1981 & 111.2 & 52.4 & - & 1.8 & 24.4 & - & 458.9 \\ 1982 & 206.0 & 102.5 & 0 & 0.8 & 26.7 & - & 368.3 \\ 1983 & 130.8 & 98.0 & - & 2.2 & 26.8 & - & 335.8 \\ 1984 & 100.0 & 15.5 & \mathbf{0 . 2 *} & - & 28.8 & - & 394.6 \\ 1985 & 92.9 & \mathbf{7 2 . 4 *} & \mathbf{3 8 . 8 *} & \mathbf{2 5 . 0 *} & 29.1 & 0.4 & \mathbf{4 4 4 . 2} \\ 1986 & 148.4 & \mathbf{9 8 . 3 *} & \mathbf{2 9 . 0 *} & \mathbf{1 0 . 0 *} & \mathbf{3 3 . 8} & \mathbf{0 . 1} & \mathbf{5 1 0 . 3} \\ 1987 & 101.0 & \mathbf{1 8 5 . 6 *} & - & \mathbf{1 4 . 5 *} & 36.5 & 1.6 & \mathbf{4 3 1 . 9} \\ 1988 & 155.0 & \mathbf{8 3 . 8} & - & 10.0 * & \mathbf{4 7 . 4} & 0.5 & \mathbf{4 2 6 . 4}\end{array}$

Sources: ${ }^{4} 1,10,12,13,27$.

denotes imports

3 composite category consisting of palm oil, palm kernel, palm kernel oil, palm kernel cake and palm kernel meal.

4 These numbers refer to the publications listed above, pp. $558 \mathrm{ff}$. 
Table 2

Value of Principal Export Products (1900-1988)

$(\$ 1,000,000)$

\begin{tabular}{|c|c|c|c|c|c|c|c|}
\hline Year & Cocos & $\begin{array}{l}\text { Palo } \\
\text { Products }\end{array}$ & $\begin{array}{l}\text { Ground- } \\
\text { nuts }\end{array}$ & Cotton & Rubber & Tin & $\begin{array}{c}\text { Mineral } \\
\text { Oil }\end{array}$ \\
\hline 1900 & 0.04 & 7.4 & 0.02 & - & 0.1 & - & - \\
\hline 1905 & 0.08 & 9.5 & 0.03 & 0.1 & 1.2 & - & - \\
\hline 1910 & 0.5 & 20.4 & 0.04 & 0.4 & 1.5 & 0.4 & - \\
\hline 1915 & 1.5 & 15.0 & 0.34 & 0.3 & 0.2 & 3.4 & - \\
\hline 1920 & 4.5 & 38.1 & 1.1 & 2.6 & 0.2 & 6.5 & - \\
\hline 1925 & 7.2 & 44.0 & 11.6 & 3.9 & 0.5 & 8.4 & - \\
\hline 1930 & 8.5 & 33.7 & 10.7 & 3.0 & 0.7 & 6.7 & - \\
\hline 1935 & 7.8 & 19.1 & 10.3 & 2.8 & 0.3 & 7.1 & - \\
\hline 1940 & 6.4 & 10.5 & 6.0 & 2.5 & 1.1 & 11.0 & - \\
\hline 1945 & 8.7 & 21.7 & 10.9 & 0.3 & 4.9 & 12.6 & - \\
\hline 1950 & 53.2 & 80.1 & 42.7 & 8.3 & 7.9 & 16.9 & - \\
\hline 1955 & 73.3 & 90.6 & 64.8 & 26.3 & 15.6 & 16.4 & - \\
\hline 1960 & 103.3 & 110.4 & 64.3 & 17.4 & 40.0 & 17.0 & $i 2.4$ \\
\hline 1965 & 112.5 & 112.0 & 105.4 & 9.5 & 30.7 & 41.7 & 190.6 \\
\hline 1970 & 186.3 & 89.8 & 60.9 & 18.5 & 24.6 & 47.7 & 712.4 \\
\hline 1971 & 201.8 & 43.3 & 34.0 & 15.7 & 17.5 & 34.7 & $1,343.7$ \\
\hline 1972 & 153.7 & 29.1 & 32.5 & 1.0 & 12.5 & 29.1 & $1,793.6$ \\
\hline 1973 & 170.8 & 31.2 & 69.2 & 7.2 & 29.5 & 23.5 & $2,889.9$ \\
\hline 1974 & 252.4 & 35.4 & 10.8 & - & 52.7 & 42.0 & $8,537.6$ \\
\hline 1975 & 294.1 & 51.4 & 0.8 & - & 17.7 & 28.1 & $7,448.9$ \\
\hline 1976 & $3+9.3$ & 52.1 & 26.7 & - & 18.5 & 21.4 & $9,885.8$ \\
\hline 1977 & 482.6 & 60.5 & 12.7 & 15.7 & 25.0 & 25.0 & $10,983.0$ \\
\hline 1978 & 638.3 & 55.8 & - & 8.1 & 19.9 & 28.9 & $8,961.1$ \\
\hline 1979 & 372.0 & 74.3 & - & 37.0 & 20.0 & 15.2 & $15,516.5$ \\
\hline 1980 & 243.4 & 36.2 & - & - & 25.0 & 48.5 & $24,306.4$ \\
\hline 1981 & 149.7 & 24.3 & - & 0.5 & 29.2 & - & $17,451.6$ \\
\hline 1982 & 244.9 & 44.1 & 1.2 & 0.2 & 41.6 & - & $13,260.5$ \\
\hline 1983 & 321.2 & 35.1 & - & 0.6 & 34.2 & - & $9,952.1$ \\
\hline 1984 & 251.9 & 8.4 & $0.1 *$ & - & 31.3 & - & $11,563.5$ \\
\hline 1985 & 258.0 & $45.0 *$ & $17.5 *$ & $40.0 *$ & 22.0 & 4.2 & $12,639.3$ \\
\hline 1986 & 275.1 & $58.7 *$ & $12.8 *$ & $14.5 *$ & 22.1 & 0.6 & $6,385.9$ \\
\hline 1987 & 375.0 & $126.7 *$ & - & $23.0 *$ & 26.6 & 10.1 & $7,052.2$ \\
\hline 1988 & 325.0 & 11.5 & - & $18.0 *$ & 47.0 & 3.3 & $6,341.0$ \\
\hline
\end{tabular}

Sources: $5,1 . .3,17,27,29$.

* denotes imports

5 These numbers refer to the publications ligted above, pp. $558 \mathrm{ff}$. 
Table 3

Percentage Share (Value) of Principal Export Products (1900-1988)

$(x)$

\begin{tabular}{|c|c|c|c|c|c|c|c|}
\hline Year & Cocos & $\begin{array}{l}\text { Pala } \\
\text { Products }\end{array}$ & $\begin{array}{l}\text { Ground- } \\
\text { nuts }\end{array}$ & Cotton & Rubber & Tin & $\begin{array}{c}\text { Miner: } \\
\text { Oil }\end{array}$ \\
\hline 1900 & $<1$ & 82 & 0 & - & 10 & - & - \\
\hline 1905 & $<1$ & 77 & $<1$ & $<1$ & 11 & - & - \\
\hline 1910 & 2 & 85 & $<1$ & 2 & 7 & 2 & - \\
\hline 1915 & 6 & 65 & 2 & 1 & 1 & 12 & - \\
\hline 1920 & 7 & 63 & 7 & 5 & $<1$ & 11 & - \\
\hline 1925 & 9 & 54 & 14 & 5 & $<1$ & 10 & - \\
\hline 1930 & 12 & 47 & 15 & 4 & 1 & 9 & - \\
\hline 1935 & 14 & 35 & 18 & 5 & $<1$ & 13 & - \\
\hline 1940 & 18 & 28 & 16 & 7 & 3 & 29 & - \\
\hline 1945 & 15 & 37 & 18 & $<1$ & 8 & 21 & - \\
\hline 1950 & 25 & 38 & 20 & 4 & 4 & 8 & - \\
\hline 1955 & 26 & 32 & 23 & 9 & 6 & 6 & - \\
\hline 1960 & 28 & 30 & 18 & 5 & 11 & 5 & 3 \\
\hline 1965 & 15 & 15 & 14 & 1 & 4 & 6 & 26 \\
\hline 1970 & 16 & 8 & 5 & 2 & 2 & 4 & 58 \\
\hline 1971 & 12 & 2 & 2 & 1 & 1 & 2 & 74 \\
\hline 1972 & 7 & 1 & 1 & 0 & $<1$ & 1 & 83 \\
\hline 1973 & 5 & $<1$ & 2 & 0 & $<1$ & $<1$ & 84 \\
\hline 1974 & 3 & $<1$ & 0 & - & $<1$ & $<1$ & 93 \\
\hline 1975 & 4 & $<1$ & 0 & - & 0 & 0 & 93 \\
\hline 1976 & 3 & $<1$ & 0 & - & 0 & 0 & 94 \\
\hline 1977 & 4 & $<1$ & 0 & 0 & 0 & 0 & 93 \\
\hline 1978 & 6 & $<1$ & - & 0 & 0 & 0 & 90 \\
\hline 1979 & 2 & 0 & - & 0 & 0 & 0 & 88 \\
\hline 1980 & 1 & 0 & - & - & 0 & 0 & 96 \\
\hline 1981 & 0 & 0 & - & - & 0 & - & 98 \\
\hline $198:=$ & 1 & 0 & 0 & - & 0 & - & 97 \\
\hline 1983 & 3 & 0 & - & - & 0 & - & 95 \\
\hline 198.4 & 2 & 0 & 0 & - & 0 & - & 97 \\
\hline $198 \%$ & 2 & imp.* & imp.* & i mp. * & 0 & 0 & 96 \\
\hline 1986 & 5 & $\operatorname{img} *$ & imp.* & imp.* & 0 & 0 & 93 \\
\hline 1987 & 5 & imp.* & - & i mp. * & 0 & 0 & 96 \\
\hline 1988 & 4 & 0 & - & $\mathrm{imp} . *$ & 0 & 0 & $8 E$ \\
\hline
\end{tabular}

Sources: data derived from tables 2 and 6 ; computation is my own.

imp* indicates the importation of these traditional export comodities 
Table 4

Unit Value (World Market) of Principal Export Products (1900-1988)6

(\$/metric ton for non-oil commodities, \$/barrel for oil)

\begin{tabular}{|c|c|c|c|c|c|c|c|}
\hline ear & Cocoa & $\begin{array}{l}\text { Paln } \\
\text { Products }\end{array}$ & $\begin{array}{l}\text { Ground- } \\
\text { nuts }\end{array}$ & Cotton & Rubber & Tin & $\begin{array}{c}\text { Minera } \\
\text { Oil }\end{array}$ \\
\hline $\begin{array}{l}978 \\
979 \\
980 \\
981 \\
982 \\
983 \\
984 \\
985 \\
986\end{array}$ & $\begin{array}{r}220.7 \\
179.1 \\
170.4 \\
166.2 \\
268.7 \\
157.9 \\
165.8 \\
90.2 \\
72.1 \\
114.5 \\
540.4 \\
842.8 \\
681.1 \\
391.0 \\
951.0 \\
756.3 \\
645.2 \\
648.0 \\
873.4 \\
1,510.0 \\
1,566.0 \\
2,925.0 \\
3,105.0 \\
2,904.0 \\
3,011.1 \\
2,072.0 \\
1,710.8 \\
2,032.4 \\
2,321.4 \\
2,587.6 \\
2,695.8 \\
1,991.5 \\
1,598.6\end{array}$ & $\begin{array}{r}122.3 \\
133.3 \\
182.6 \\
150.0 \\
308.0 \\
248.2 \\
187.7 \\
93.6 \\
60.0 \\
116.9 \\
314.4 \\
331.5 \\
395.4 \\
247.3 \\
242.7 \\
173.1 \\
137.8 \\
208.5 \\
400.7 \\
269.0 \\
262.7 \\
356.3 \\
367.7 \\
554.5 \\
339.7 \\
423.9 \\
347.8 \\
417.4 \\
607.2 \\
394.3 \\
288.2 \\
253.3 \\
360.3\end{array}$ & $\begin{array}{r}33.1 \\
38.4 \\
44.3 \\
39.0 \\
91.9 \\
92.2 \\
73.9 \\
56.9 \\
35.5 \\
62.5 \\
136.9 \\
190.1 \\
198.0 \\
206.6 \\
228.2 \\
250.1 \\
254.0 \\
391.3 \\
739.1 \\
433.0 \\
423.0 \\
546.9 \\
630.9 \\
562.8 \\
485.6 \\
622.7 \\
383.2 \\
349.4 \\
349.8 \\
349.9 \\
963.9 \\
933.3 \\
-9\end{array}$ & $\begin{array}{r}- \\
128.5 \\
349.0 \\
225.0 \\
819.0 \\
589.1 \\
372.6 \\
258.5 \\
272.8 \\
250.5 \\
672.0 \\
804.7 \\
656.4 \\
673.0 \\
650.0 \\
705.0 \\
725.2 \\
1,241.8 \\
1,302.6 \\
1,431.4 \\
1,251.2 \\
1,703.0 \\
2,036.0 \\
1,888.0 \\
2,027.2 \\
2,612.4 \\
1,424.6 \\
1,392.8 \\
1,363.0 \\
1,938.8 \\
1,556.0 \\
-0\end{array}$ & $\begin{array}{r}148.7 \\
882.2 \\
1,312.4 \\
739.3 \\
431.3 \\
562.0 \\
340.3 \\
150.0 \\
373.6 \\
466.3 \\
594.7 \\
522.2 \\
710.6 \\
446.0 \\
415.0 \\
349.7 \\
362.0 \\
704.0 \\
796.0 \\
370.0 \\
675.0 \\
706.0 \\
675.0 \\
917.0 \\
1,372.2 \\
1,140.0 \\
905.6 \\
1,123.6 \\
991.6 \\
802.2 \\
1,425.0 \\
972.0 \\
1,202.3\end{array}$ & $\begin{array}{r}- \\
- \\
515.0 \\
839.8 \\
917.5 \\
562.0 \\
811.0 \\
752.4 \\
844.7 \\
1,501.1 \\
1,464.7 \\
1,620.8 \\
3,897.0 \\
4,266.0 \\
4,371.0 \\
3,414.8 \\
4,368.0 \\
7,426.2 \\
5,979.0 \\
6,688.0 \\
8,333.0 \\
9,313.0 \\
13,990.0 \\
15,220.0 \\
12,854.0 \\
11,639.0 \\
11,782.2 \\
11,095.2 \\
10,463.2 \\
5,886.2 \\
6,312.0 \\
6,618.0\end{array}$ & $\begin{array}{r}- \\
- \\
- \\
- \\
- \\
- \\
- \\
- \\
- \\
- \\
- \\
- \\
2.3 \\
2.2 \\
2.3 \\
3.1 \\
3.4 \\
4.8 \\
14.7 \\
12.9 \\
13.8 \\
14.6 \\
14.9 \\
21.9 \\
35.4 \\
34.8 \\
33.7 \\
29.4 \\
28.6 \\
26.9 \\
14.3 \\
17.2 \\
14.9\end{array}$ \\
\hline
\end{tabular}

Sources: $^{i} 6,8,10,11,13,18,20,26$.

6 From 1942 (for cocoa since 1939) until 1986 when the central price fixing authority vas abolished, the prices paid to Nigerian producers did not correspond to world market prices, but were established politically, as a rule considerably lower, except during the 1970 s and early 1980s when the over-valued exchange rate of the Naira induced considerable subsidies (see table 5 ; see lso World Bank:1982,16). The price-elasticity of supply can, therefore, not be directly deduced from world market prices.

7 These numbers refer to the publications listed above, pp. 558ff. 
Table 5 Producer Prices of Agricultural Export Products $(1950-1986)^{8}$
(\$/netric ton)

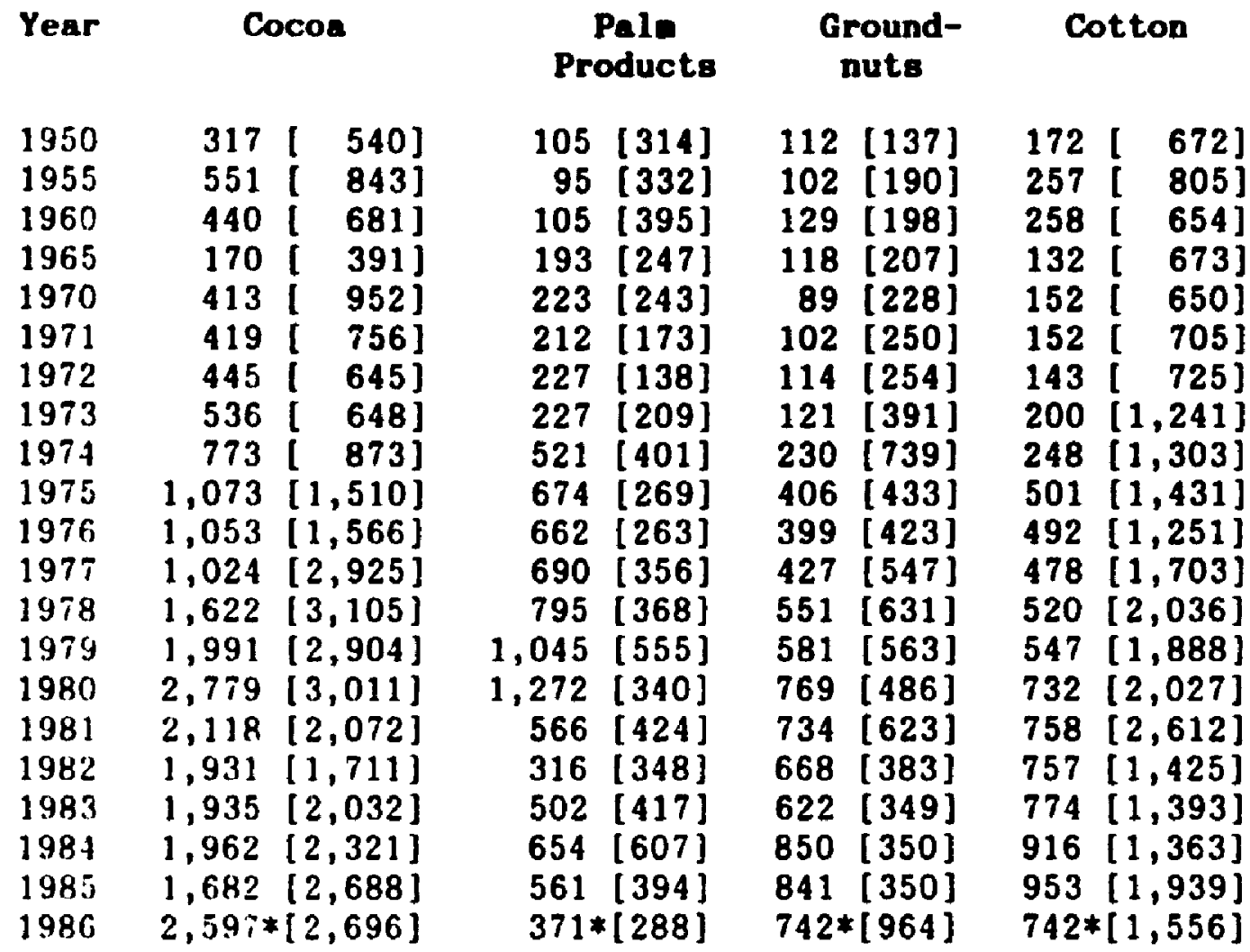

Sources: ${ }^{9} 3$ (No. $3 / 1987,111-112$ ), 10, 15, 21, 22,

* Irices suggested by the Technical Comittee on Produce Prices yet not implemented because of the abolition of central price fixing

- Intil 1986 prices of the main agricultural commodities were administratively established. Norld market prices as supplied in table 4 are reproduced here [in square brackets] for ease of comparison. Cautich Is harranted in the interpretation of these data, however, since the dollar values, calculated at the nominal rate of exchange, fail to reflect the artual domestic purchasing power which was increasingly eroded hy rampant inflation. A more accurate iapression, if still only All impression, of the producers' underpayeent is gained if the governmint-fixed producer prices are converted into uSs at the "real effective exchange rate" (coluan $Y$ in table 7 ). For the years 1975-1980, to illustrate, the thus obtained prices would be (indicated in boldface):

\begin{tabular}{llllr} 
& Cocoa & Palm Prods & \multicolumn{1}{c}{ Groundnuts } & Cotton \\
1975 & $330[1,510]$ & $207[269]$ & $125[433]$ & $154[1,431]$ \\
1976 & $283[1,566]$ & $178[263]$ & $107[423]$ & $132[1,251]$ \\
1977 & $242[2,925]$ & $176[356]$ & $109[547]$ & $122[1,703]$ \\
1978 & $367[3,105]$ & $180[368]$ & $125[631]$ & $118[2,036]$ \\
1979 & $302[2,904]$ & $159[555]$ & $88[563]$ & $83[1,888]$ \\
1980 & $475[3,011]$ & $217[340]$ & $131[486]$ & $125[2,027]$
\end{tabular}

9 These numbers refer to the publications listed above, pp. $558 \mathrm{ff}$. 
Table 6

Value of Trade and Government Pinances (1900-1988)

\begin{tabular}{|c|c|c|c|c|c|c|}
\hline Year & Inports & Exports & $\begin{array}{c}1,000, \\
\text { Gov't } \\
\text { Revenue }\end{array}$ & $\begin{array}{l}00 \text { ) } \\
\text { Indi rect } \\
\text { Taxes }\end{array}$ & $\begin{array}{l}\text { Direct } \\
\text { Taxes }\end{array}$ & $\begin{array}{l}\text { Government } \\
\text { Bxpend. } 12\end{array}$ \\
\hline $\begin{array}{l}1900 \\
1905 \\
1910 \\
1915 \\
1920 \\
1925 \\
1930 \\
1935 \\
1940 \\
1945 \\
1950 \\
1955 \\
1960 \\
1965 \\
1970 \\
1971 \\
1972 \\
1973 \\
1974 \\
1975 \\
1976 \\
1977 \\
1978 \\
1979 \\
1980 \\
1981 \\
1982 \\
1983 \\
1984 \\
1985 \\
1986 \\
1987 \\
1988\end{array}$ & $\begin{array}{r}8.5 \\
13.2 \\
24.9 \\
23.6 \\
75.9 \\
71.4 \\
61.3 \\
38.3 \\
30.1 \\
54.7 \\
173.2 \\
381.1 \\
606.7 \\
701.6 \\
1,059.0 \\
1,510.5 \\
1,504,9 \\
1,861.7 \\
2,780.6 \\
6,041.2 \\
8,194.6 \\
11,020.2 \\
12,762.8 \\
10,274.3 \\
16,642.0 \\
20,877.0 \\
16,060.0 \\
12,254.0 \\
9,364.0 \\
8,890.0 \\
6,744.0 \\
5,774.0 \\
5,776.0\end{array}$ & $\begin{array}{r}9.2 \\
13.0 \\
25.6 \\
23.5 \\
62.1 \\
81.9 \\
73.1 \\
55.6 \\
46.8 \\
72.5 \\
252.6 \\
371.1 \\
475.2 \\
736.3 \\
1,227.9 \\
1,793.2 \\
2,161.0 \\
3,448.0 \\
9,195.0 \\
7,992.0 \\
10,568.7 \\
11,848.4 \\
10,560.0 \\
17,712.6 \\
25,968.0 \\
17,864.0 \\
13,656.7 \\
10,370.0 \\
11,891.0 \\
12,566.0 \\
6,784.0 \\
7,532.0 \\
7,053.0\end{array}$ & $\begin{array}{r}3.1 \\
5.0 \\
11.1 \\
12.4 \\
25.0 \\
39.9 \\
27.3 \\
29.4 \\
24.6 \\
46.1 \\
97.4 \\
218.7 \\
175.1 \\
837.6 \\
1,062.7 \\
2,304.5 \\
2,112.6 \\
2,576.9 \\
7,204.8 \\
8,961.4 \\
10,798.4 \\
11,869.0 \\
10,733.9 \\
19,969.7 \\
27,878.2 \\
19,513.6 \\
17,447.0 \\
11,823.1 \\
14,562.9 \\
16,373.4 \\
13,574.1 \\
6,495.8 \\
6,531.0\end{array}$ & $\begin{array}{r}2.9 \\
3.9 \\
7.0 \\
6.5 \\
11.4 \\
16.7 \\
16.0 \\
12.9 \\
10.5 \\
20.9 \\
48.1 \\
123.1 \\
109.9 \\
624.9 \\
777.6 \\
1,534.2 \\
1,783.0 \\
2,329.2 \\
6,709.1 \\
8,176.4 \\
9,971.2 \\
7,012.7 \\
7,701.0 \\
18,907.0 \\
26,071.1 \\
18,066.8 \\
15,074.1 \\
11,122.4 \\
10,171.1 \\
12,428.5 \\
10,526.0 \\
5,571.8 \\
5,640.6\end{array}$ & $\begin{array}{r}0.2 \\
1.1 \\
3.6 \\
5.8 \\
13.6 \\
22.5 \\
10.8 \\
15.1 \\
13.6 \\
25.2 \\
38.0 \\
18.8 \\
22.9 \\
45.8 \\
169.5 \\
575.6 \\
255.1 \\
127.2 \\
253.4 \\
459.4 \\
363.1 \\
620.9 \\
698.2 \\
898.2 \\
1,092.0 \\
874.9 \\
1,131.0 \\
582.6 \\
838.2 \\
330.1 \\
1,363.8 \\
308.8 \\
350.6\end{array}$ & $\begin{array}{r}3.6 \\
6.7 \\
10.5 \\
16.3 \\
23.8 \\
31.8 \\
30.8 \\
28.2 \\
26.2 \\
40.8 \\
58.8 \\
159.0 \\
252.0 \\
799.6 \\
1,876.9 \\
3,089.9 \\
4,449.6 \\
2,324.4 \\
4,869.6 \\
10,161.3 \\
12,859.5 \\
14,364.3 \\
15,266.3 \\
25,207.8 \\
25,878.4 \\
25,456.8 \\
24,705.8 \\
19,172.8 \\
17,983.4 \\
20,386.8 \\
10,876,2 \\
6,770.8 \\
7,643.3\end{array}$ \\
\hline
\end{tabular}

Sources: $^{13} 2,6,9,10,13,15,17,27,32,35$.

10 Indirect taxes include import duties, export duties, excise duties (introduced in 1939), mining taxes (rent, royalties, petroleum profit tax and, for the year 1984 the one-time company supertax). To include the petroleum profit tax is admittedly against standard accounting practice; it is done so as not to obscure the lor proportion of tax revenue derived frow directly productive activity.

11 direct taxes include poll tax, personal and company income tax (exclucing petroleum profit tax; see previous footnote), capital gains tax and fees.

12 includes federal recurrent and capital expenditure as well as transfers to the states of the Federation (when applicablei. $558 \mathrm{ff}$.

13 These numbers refer to the publications listed above, pp. 
Table 7

Exchange Rates (1900-1989)

(1) Sterling [1900-1959], 1 EN [1959-1973], or $1 \mathrm{~N}$ [1973-1989]

equal $X$ sUS)

$\begin{array}{llllll}\text { Year } & \boldsymbol{X} & \text { Year } & \boldsymbol{X} & \mathbf{Y}^{14} & \mathbf{C P I}^{15} \\ 1900 & 4.872 & 1970 & 2.800 & 1.5873 & 100 \\ 1905 & 4.866 & 1971 & 2.800 & 1.4286 & 114 \\ 1910 & 4.868 & 1972 & 3.040 & 1.3158 & 117 \\ 1915 & 4.748 & 1973 & 1.520 & 0.6623 & 121 \\ 1920 & 3.661 & 1974 & 1.588 & 0.6225 & 141 \\ 1925 & 4.829 & 1975 & 1.625 & 0.5000 & 186 \\ 1930 & 4.862 & 1976 & 1.596 & 0.4292 & 227 \\ 1935 & 4.903 & 1977 & 1.551 & 0.3967 & 275 \\ 1940 & 4.03 & 1978 & 1.575 & 0.3559 & 310 \\ 1945 & 4.03 & 1979 & 1.659 & 0.2519 & 347 \\ 1950 & 2.80 & 1980 & 1.830 & 0.3125 & 568 \\ 1955 & 2.80 & 1981 & 1.629 & 0.2226 & 647 \\ 1960 & 2.81 & 1982 & 1.485 & 0.2564 & 779 \\ 1961 & 2.802 & 1983 & 1.382 & 0.3106 & 910 \\ 1962 & 2.808 & 1984 & 1.308 & 0.2481 & 1,270 \\ 1963 & 2.800 & 1985 & 1.121 & 0.2464 & 1,413 \\ 1964 & 2.793 & 1986 & 0.742 & 0.2475 & 1,505 \\ 1965- & 2.800 & 1987 & 0.250 & 0.2326 & 1,556 \\ 1970 & & 1988 & 0.223 & 0.2130 & 1.696 \\ & & 1989 & 0.136 & 0.1418 & 2,584\end{array}$

Sources: ${ }^{16}$ fi, $7,10,33$

14 $Y$ denotes the real effective exchange rate which is measured as the number of USS per naira, autiplied with the ratio of the US consumer price index. The difference between $X$ and $Y$ indicates the proximate extent of the naira's overvaluation, the emphasis being on "proximate." For more detailed comments see above, p. 557.

15 CPI denotes the Nigerian Consumer Price Index (urban-rural composite), base year 1970 . Indices cover all the main items of expenditure: food and drink; fuel and light; clothing, rent and mischllaneous. $558 \mathrm{ff}$.

16 These numbers refer to the publications listed above, pp. 
Table 8

Sectoral Origins of GDP* and Share of Beployent** (1950-1988)

\begin{tabular}{|c|c|c|c|c|c|c|c|}
\hline \multirow[t]{2}{*}{ Year } & \multirow{2}{*}{$\begin{array}{l}\text { GDP } \\
(\$ \mathrm{mn})\end{array}$} & \multicolumn{2}{|c|}{ Agriculture ${ }^{17}$} & \multicolumn{2}{|c|}{ Manufacturing ${ }^{18}$} & \multicolumn{2}{|c|}{ Mining ${ }^{19}$} \\
\hline & & & ** & * & $* *$ & * & \\
\hline 1950 & $1,467.2$ & $67 x$ & $78 x(e)$ & $<1 x$ & $<0.1 x$ & $<1 x$ & $0.4 x$ \\
\hline 1955 & $2,167.8$ & $64 x$ & $78 \times(e)$ & $1 x$ & $0.1 x$ & $<12$ & $0.3 x$ \\
\hline 1960 & $2,582.4$ & $63 x$ & $71 x$ & $5 x$ & $0.2 x$ & $<1 x$ & $0.2 x$ \\
\hline 1965 & $4,715.2$ & $58 x$ & $71 x$ & $6 x$ & $0.3 x$ & $4 x$ & $0.3 x$ \\
\hline 1970 & $11,725.3$ & $48 x$ & $71 x$ & $7 x$ & $0.5 x$ & $6 x$ & $0.2 x$ \\
\hline 1971 & $13,124.3$ & $48 x$ & $71 x$ & $6 x$ & $0.6 \%$ & $14 x$ & $0.2 x$ \\
\hline 1972 & $14,997.5$ & $45 x$ & $70 x$ & $7 x$ & $0.7 x$ & $16 x$ & $\ldots$ \\
\hline 1973 & $16,705.9$ & $43 x$ & $70 x$ & $5 x$ & $0.6 \%$ & $18 x$ & $\ldots$ \\
\hline 1974 & $29,057.7$ & $28 x$ & $70 x$ & $4 x$ & $0.7 x$ & $33 x$ & $\ldots$ \\
\hline 1975 & $34,056.2$ & $24 x$ & $70 x$ & $6 x$ & $0.9 x$ & $22 x$ & $\ldots x$ \\
\hline 1976 & $42,542,4$ & $24 x$ & $70 x$ & $5 x$ & $1.0 x$ & $25 x$ & $\ldots x$ \\
\hline 1977 & $48,520.6$ & $21 x$ & $69 x$ & $7 x$ & $1.1 \%$ & $25 x$ & $\ldots x$ \\
\hline 1978 & $53,553.5$ & $19 x$ & $69 x$ & $5 \%$ & $1.0 \%$ & $25 x$ & $\ldots x$ \\
\hline 1979 & $69,636.0$ & $20 x$ & $68 \%$ & $5 x$ & $0.9 x$ & $24 x$ & $0.2 x$ \\
\hline 1980 & $88,825.6$ & $21 x$ & $68 x$ & $9 \%$ & $1.4 x$ & $28 x$ & $\ldots x$ \\
\hline 1981 & $92,205.0$ & $26 \%$ & $68 \%$ & $12 x$ & $1.4 x$ & $22 x$ & $\ldots x$ \\
\hline 1982 & $89,817.5$ & $28 x$ & $67 x$ & $12 x$ & $1.0 x$ & $18 x$ & $\ldots x$ \\
\hline 1983 & $87,471.5$ & $32 x$ & $67 x$ & $10 x$ & $0.9 x$ & $16 \%$ & $0.1 x$ \\
\hline 1984 & $83,199.3$ & $39 x$ & $67 x$ & $10 x$ & $0.9 \%$ & $16 x$ & $\ldots x$ \\
\hline 1985 & $81,109.9$ & $35 x$ & $66 \%$ & $12 x$ & $\ldots$ & $16 x$ & $\ldots x$ \\
\hline 1986 & $54,211.3$ & $40 x$ & $66 \%$ & $9 x$ & $\ldots$ & $15 x$ & $\ldots x$ \\
\hline 1987 & $27,221,0$ & $40 x$ & $66 x$ & $10 x$ & $\ldots$ & $14 x$ & $\ldots x$ \\
\hline 1988 & $32,389.0$ & $39 \%$ & $66 x$ & $10 x$ & $\ldots$ & $14 \%$ & $\ldots x$ \\
\hline
\end{tabular}

Sources: ${ }^{20} 9,10,16,28,34$.

17 includes livestock, forestry and fishing.

18 manufacturing denotes the mechanical or chemical transformation of inorganic or organic materials into new products, irrespective of the kind of tools used or of the size of the establishment in which this takes place (cf. United Nations: 1968,28). Here only enumerated establishments are reflected. The informal sector is surely sizeable, especially as an employer, yet no data exist.

19 Before the exploitation of petroleum reserves, this category comprised mainly the extraction of coal and $t$ in.

20 These numbers refer to the publications listed above, pp. $558 \mathrm{ff}$. 


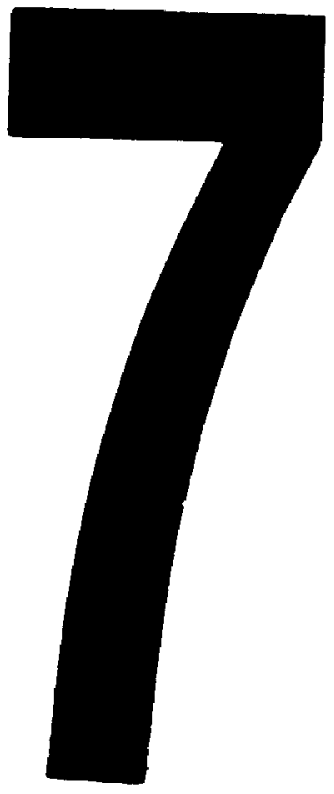

PM-1 3Y" "X4" PHOTOGRAPHIC MICROCOPY TARGET NAS to10a ANSI/ISO *2 EOUIVALENT

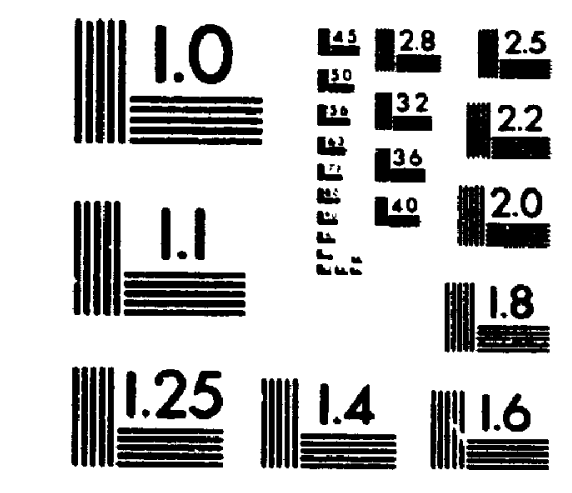

\section{PRECISIONEM RESOLUTION TARGETS}

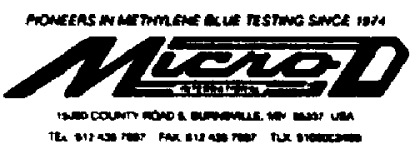


Table 9

Eeployent by Sector (1935-1988)

$(1,000)$

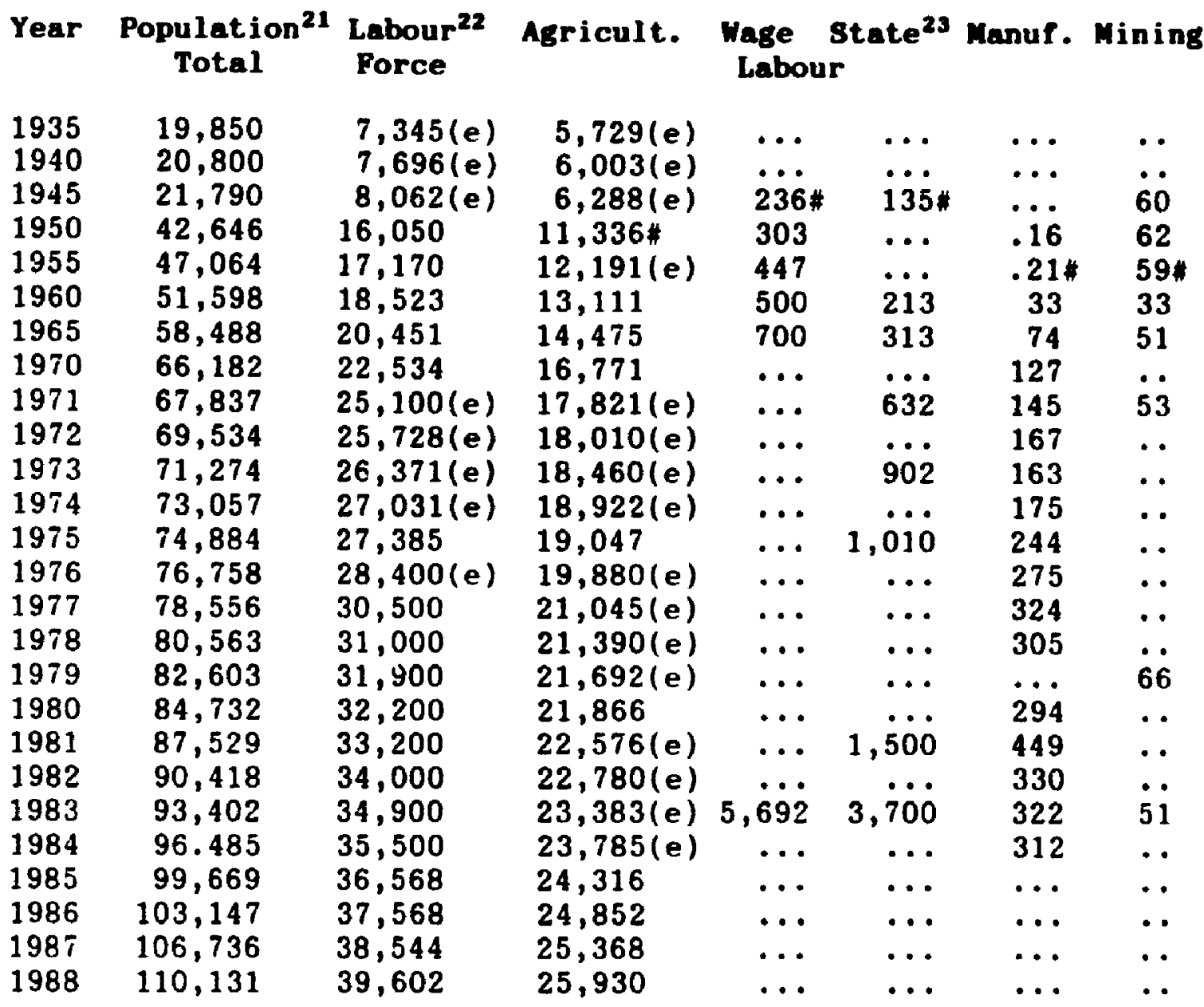

Sources: ${ }^{24} 5,14,15,18,19,21,25,34,35$; Nigeria:1974, 169; Lindauer: 1991,832 ; Olowu: 1987,29 .

21 For comments on data problems and sources see above, p. 558 .

22 The great uncertainty regarding the share of the labour force in the total population is not alleviated much by some isolated surveys or official figures. I have therefore filled in the blanks - denoted (e) - with my own calculation, assuming the labour force to be $37 x$ of the total population. This ratio is suggested by the published figures. It is also a compromise between the Labour Force Sample ". rvey 1966/67 which assumed $40 x$ (cf. Schätzl:1973,128) and another in-depth study which considered $35 \%$ more appropriate (Comittee on Education and Human Resource Development:1967,18). The agricultural workfore estinates are based on column 3 of table 8 .

23 includes employees of federal, state and local governaents as well as parastatals (where applicable); excludes ailitary conscripts (where applicable).

24 These numbers refer to the publications listed above, pp. $558 \mathrm{ff}$. 
Poreign Investeent (total assets), Poreign (public) debt (1960-88)

\begin{tabular}{|c|c|c|c|c|}
\hline Year & $\begin{array}{l}\text { Poreign } \\
\text { owned } \\
\text { asgetg27 } \\
(\$ \mathrm{mn})\end{array}$ & $\begin{array}{l}\text { Plow of Long } \\
\text { Tero Capital } \\
\text { plus direct } \\
\text { investnent } \\
\text { (\$ mn) }\end{array}$ & $\begin{array}{l}\text { External } \\
\text { debt } 25 \\
(\$ \otimes n)\end{array}$ & $\begin{array}{l}\text { External } \\
\text { Reserves } \\
\text { (s mn) }\end{array}$ \\
\hline $\begin{array}{l}1950 \\
1955 \\
1960 \\
1965 \\
1970 \\
1971 \\
1972 \\
1973 \\
1974 \\
1975 \\
1976 \\
1977 \\
1978 \\
1979 \\
1980 \\
1981 \\
1982 \\
1983 \\
1984 \\
1985 \\
1986 \\
1987 \\
1988\end{array}$ & $\begin{array}{l}\ldots \\
\ldots \\
1,056 \\
1,405 \\
1,852 \\
2,388 \\
2,681 \\
2,878 \\
3,717 \\
3,728 \\
3,926 \\
4,510 \\
\ddot{3}, 792 \\
3,703 \\
4,089 \\
4,245 \\
4,519 \\
4,294 \\
\ldots \\
\ldots \\
\ldots\end{array}$ & $\begin{array}{r}8 \\
19 \\
23 \\
155 \\
192 \\
247 \\
280 \\
405 \\
211 \\
300 \\
202 \\
363 \\
2,333 \\
2,894 \\
5,084 \\
5,275 \\
1,330 \\
1,277 \\
(-1,350) \\
(-1,818) \\
(-1,241) \\
(-3,549) \\
(-2,611)\end{array}$ & $\begin{array}{r}\ldots . \\
214 \\
544 \\
1,924 \\
651 \\
732 \\
1,205 \\
1,274 \\
1,144 \\
906 \\
3,146 \\
5,091 \\
6,216 \\
8,855 \\
12,018 \\
12,815 \\
18,586 \\
18,422 \\
19,324 \\
24,164 \\
30,039 \\
31,950\end{array}$ & $\begin{array}{r}310 \\
656 \\
554 \\
276 \\
202 \\
408 \\
356 \\
559 \\
5,603 \\
5,586 \\
5,180 \\
4,232 \\
1,887 \\
5,548 \\
10,235 \\
3,895 \\
1,613 \\
990 \\
1,462 \\
1,667 \\
1,081 \\
1,165 \\
651\end{array}$ \\
\hline
\end{tabular}

Sources $^{25}: 3$ (No. 3/1987), 10, 35, Stolper:1966,99.

25 includes public and publicly guaranteed and private long-term debt, short term debt and monev wed to official creditors; amounts outstanding at year's end.

26 excluding gold reserves. The Market price of Nigeria's gold holdings went up from $\$ 23.9$ aillion in 1968 to $\$ 281.8$ million in 1988 (World Bank: 1990, 426-427).

27 Cumulative paid-up capital holdings (plus reserves) of foreigners.

28 These numbers refer to the publications listed above, pp. $558 \mathrm{ff}$. 
Table 11

Performance Indicators for Agriculture (1955-1988)

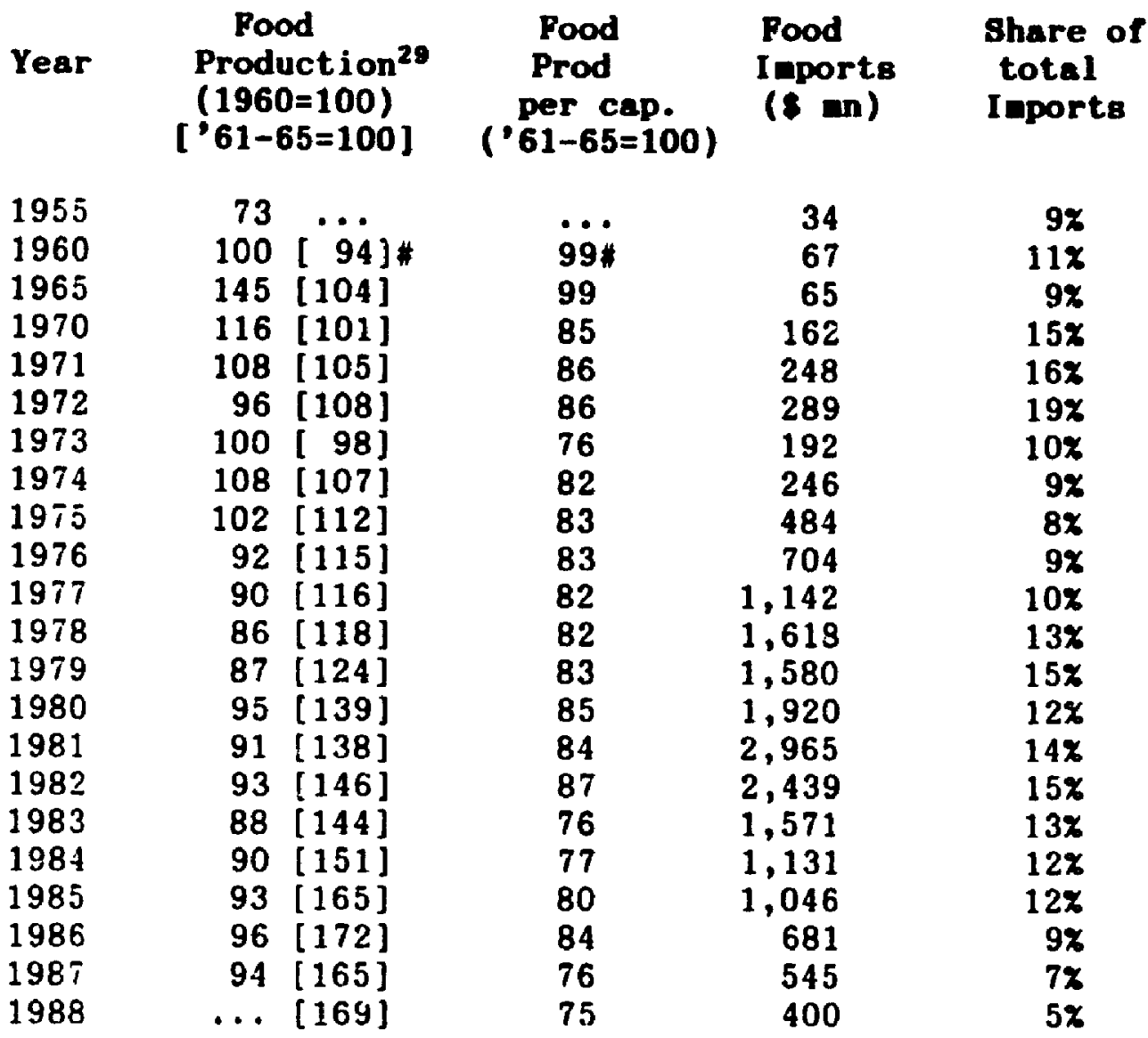

Sources: ${ }^{30} 2,5,6,15$

29 In column 1, the data on the left are based on information from the Central Bank of Nigeria Annual Report and Statement of Accounts (various issues) while the data in square brackets are from the FAO (Production Yearbook - 1972 vol 26, pp. 27 61-72; 1983 vol 37, pp. $72-83 \& 85 ; 1988$ vol $42, p, 83-88)$. The discrepancies underline the frailty of all statistics dealing with Nigeria. Also, column 2 (per capita food production), based on FAO data, would perforce paint an over optimistic picture if the Central Bank's figures are correct.

Some statistical data are available for the period 1950-57 and again from 1960/61-1965/66, yet not for the 1957-1960 interlude. It is therefore not possible to directly extend the food production index backwards. Using Okigbo's pioneering data compilation as a base (Okigbo: 1962,47 ), an annual gruwth rate of $6 \%$ for food production between 1950 and 1957 can be conputed. Extrapolating this growth rate from 1957 to 1960, an index figure of 73 results for 1955. Even if the data are less hard than desirable, it seems clear that both food production and exportable cash crop production grew at a phenomenal rate between 1950 and 1965 when both began to decline equally drastically. $558 \mathrm{ff}$.

30 These numbers refer to the publications listed above, pp. 
Table 12

Pood Inports (1960-1988)

(weight: 1,000 metric tons; cost: 1 million US\$)

\begin{tabular}{|c|c|c|c|c|c|c|}
\hline Year & wht & $\begin{array}{l}\text { Rice } \\
\text { cost }\end{array}$ & wght & $\begin{array}{l}\text { Wheat } \\
\text { cost }\end{array}$ & wght & $\begin{array}{l}\text { Maize } \\
\text { cost }\end{array}$ \\
\hline $\begin{array}{l}1960 \\
1965 \\
1970 \\
1971 \\
1972 \\
1973 \\
1974 \\
1975 \\
1976 \\
1977 \\
1978 \\
1979 \\
1980 \\
1981 \\
1982 \\
1983 \\
1984 \\
1985 \\
1986 \\
1987^{3} 1 \\
1988\end{array}$ & $\begin{array}{r}2.4 \\
1.4 \\
1.8 \\
0.3 \\
5.9 \\
1.1 \\
\ldots .7 \\
6.7 \\
65.4 \\
450.0 \\
564.0 \\
245.0 \\
400.0 \\
600.0 \\
530.0 \\
543.5 \\
212.5 \\
345.0 \\
320.0 \\
400.0 \\
200.0\end{array}$ & $\begin{array}{r}0.4 \\
0.3 \\
0.2 \\
0.1 \\
1.7 \\
0.4 \\
1.0 \\
3.9 \\
32.2 \\
165.0 \\
306.6 \\
140.0 \\
224.0 \\
360.0 \\
239.0 \\
237.8 \\
96.6 \\
147.0 \\
80.0 \\
92.0 \\
55.0\end{array}$ & $\begin{array}{r}0.9 \\
54.1 \\
267.1 \\
405.1 \\
316.9 \\
454.7 \\
331.0 \\
407.6 \\
735.5 \\
807.2 \\
879.0 \\
900.0 \\
1,176.4 \\
1,516.7 \\
1,375.0 \\
870.3 \\
1,070.9 \\
1,678.7 \\
996.1 \\
141.3 \\
25.0\end{array}$ & $\begin{array}{c}0.02 \\
9.6 \\
22.3 \\
33.6 \\
35.4 \\
59.4 \\
81.7 \\
89.4 \\
156.8 \\
162.2 \\
121.1 \\
150.0 \\
240.0 \\
297.0 \\
244.0 \\
364.2 \\
325.9 \\
417.7 \\
211.8 \\
20.0 \\
4.0\end{array}$ & $\begin{array}{r}- \\
0.1 \\
8.9 \\
3.8 \\
2.3 \\
1.7 \\
2.0 \\
2.2 \\
9.9 \\
90.0 \\
47.0 \\
111.0 \\
168.0 \\
293.0 \\
345.0 \\
49.9 \\
40.4 \\
97.0 \\
49.8 \\
0.3 \\
0.3\end{array}$ & $\begin{array}{c}- \\
0.002 \\
1.2 \\
0.5 \\
0.6 \\
0.3 \\
0.5 \\
0.7 \\
2.3 \\
18.0 \\
22.8 \\
26.0 \\
60.0 \\
95.0 \\
107.0 \\
17.6 \\
18.2 \\
35.7 \\
8.8 \\
0.02 \\
0.02\end{array}$ \\
\hline
\end{tabular}

Source: FAO, Trade Yearbook (various issues)

31 The importation of rice, wheat and waize (as well as of barley \& malt) was banned in January 1987. The $1987 / 88$ figures therefore represent estimates of smuggled conmodities. 
Table 13

Pood Production (1948-1988)

Production of major staples (1,000 metric tons)

Area of land cultivated $(/ 1,000$ hectares $)$

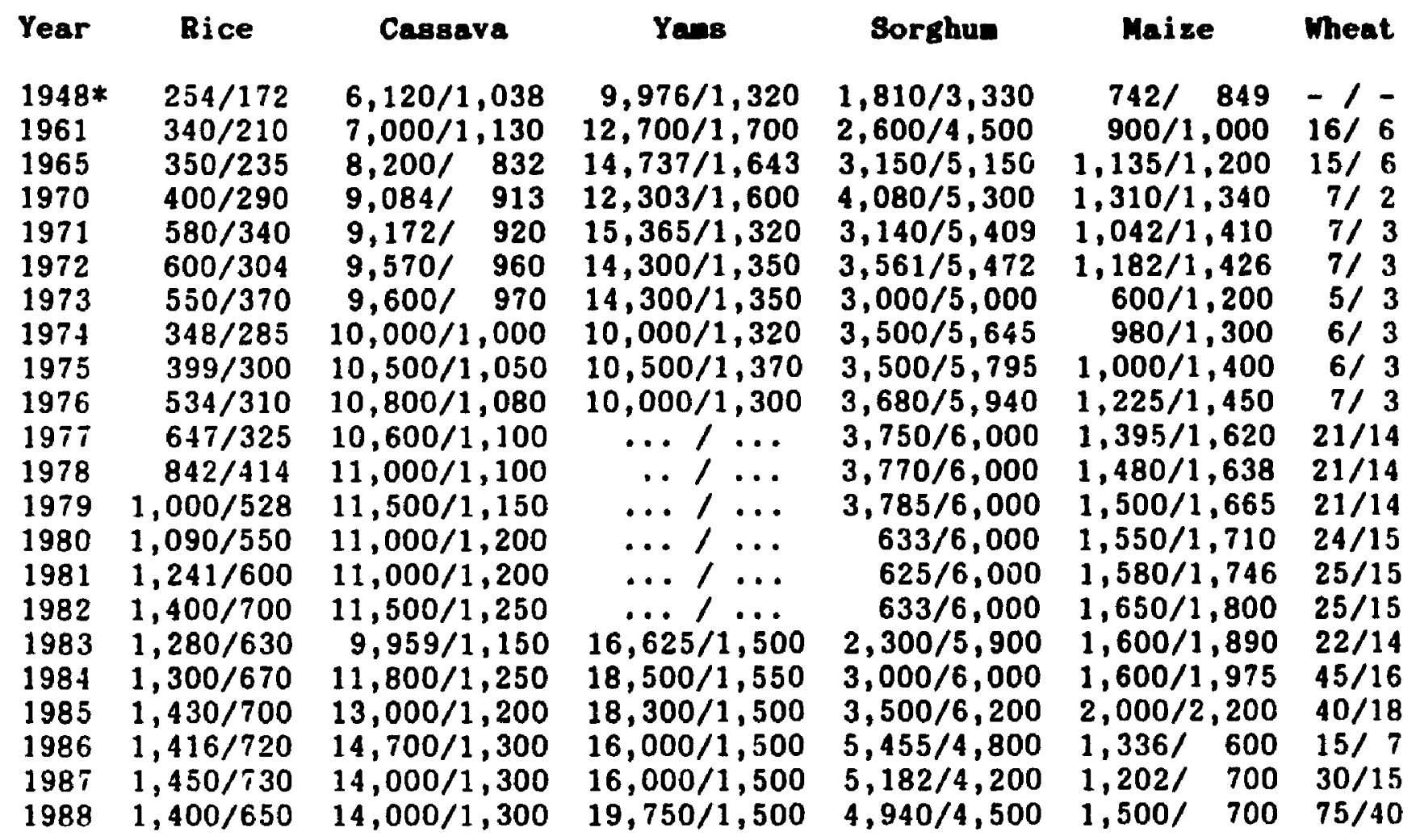

Source:

FAO Production Yearbook (various issues). 
Table 14

Federal Civil Service (1960-1988) ${ }^{32}$

$\begin{array}{cc}\text { Year } & \text { Nunber } \\ & \\ 1960 & 35,000 ? \\ 1965 & 47,404 \\ 1970 & 58,157 \\ 1971 & 67,476 \\ 1972 & 77,843 \\ 1973 & 100,672 \\ 1974 & 121,020 \\ 1975 & 133,906 \\ 1976 & 154,593 \\ 1977 & 159,600 \\ 1978 & 187,672 \\ 1979 & 195,919 \\ 1980 & 225,624 \\ 1981 & 256,334 \\ 1982 & 266,345 \\ 1983 & 292,985 \\ 1984 & 302,424 \\ 1985 & 255,892 \\ 1986 & 254,456 \\ 1987 & \cdots \ldots \\ 1988 & \ldots .\end{array}$

Sources: ${ }^{33} 15,16,23$.

32 Established staff or pensionable staff, i.e. eaployees whose personal emoluments count for pension purposes. $558 \mathrm{ff}$.

33 These numbers refer to the publications listed above, pp. 
Table 15: Structure of Manufacturing Value Added (MVA) ${ }^{34}$ (Percent.age)

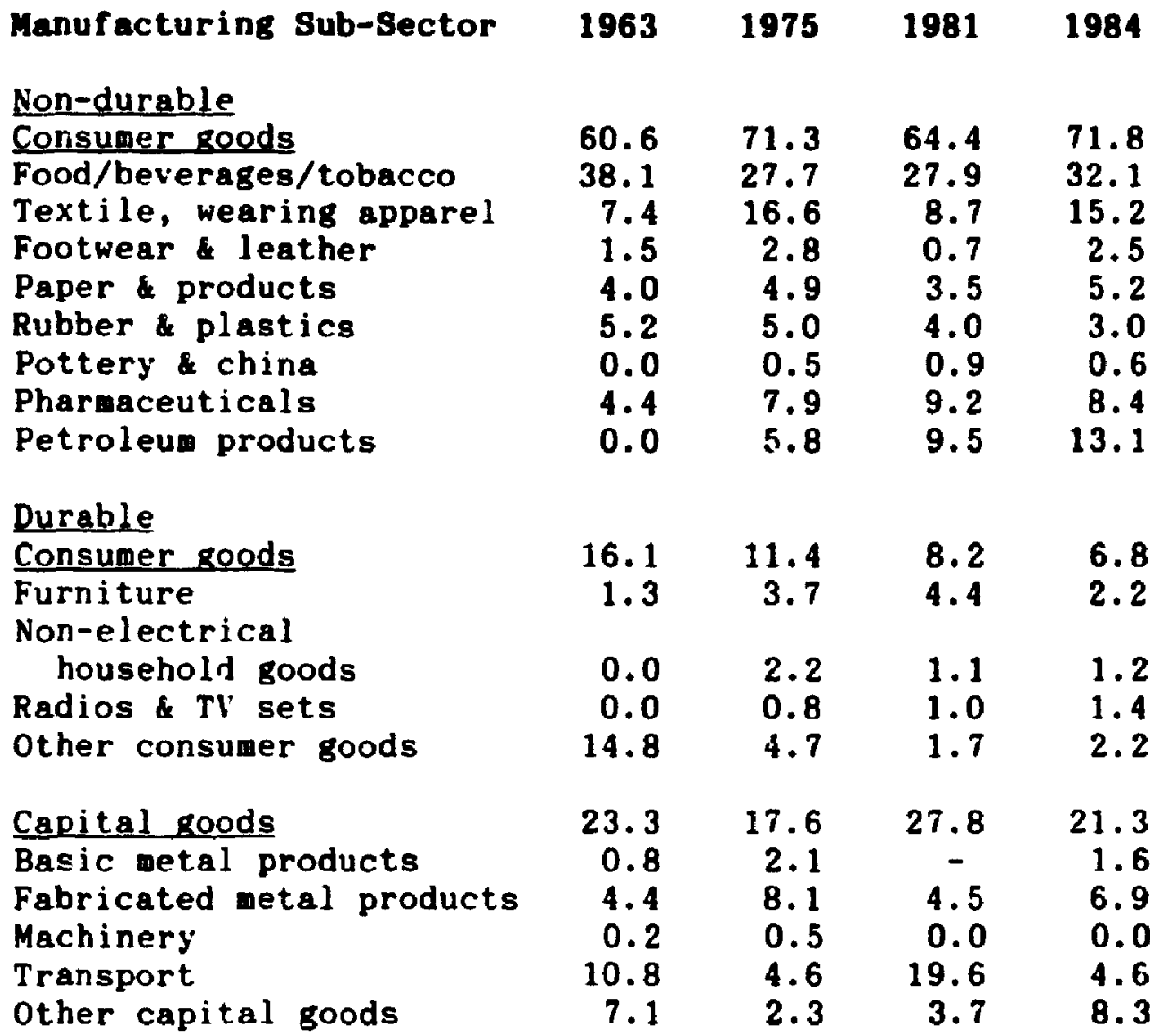

Computation based on:

Fos, Industrial Survey of Nigeria 1963, 1975-1978, 1980-1983, 1984.

34 It is not just the sectoral composition of manufacturing value added (MVA = difference between gross output and factor inputs) which reveals the developmentally moot nature of Nigeria's manufacturing sector. Equally instructive is its small size, in absolute terms and even more in per capita terms:

\begin{tabular}{|c|c|c|c|c|c|c|c|c|}
\hline Year & $\begin{array}{c}\text { MVA } \\
(\$ m n)\end{array}$ & $\begin{array}{l}\text { MVA } \\
(\$ p / c)\end{array}$ & Year & $\begin{array}{c}\text { MVA } \\
(\$ \pm n)\end{array}$ & $\begin{array}{l}\text { MVA } \\
(\$ p / c)\end{array}$ & Year & $\underset{(\$ m n)}{\text { MVA }}$ & $\begin{array}{l}\text { MVA } \\
(\$ p / c)\end{array}$ \\
\hline $\begin{array}{l}1950 \\
1955 \\
1962 \\
1965 \\
1970 \\
1971 \\
1972 \\
1973\end{array}$ & $\begin{array}{r}8 \\
20 \\
98 \\
136 \\
543 \\
512 \\
824 \\
882\end{array}$ & $\begin{array}{l}0.18 \\
2.3 \\
2 \\
4 \\
8 \\
8 \\
12 \\
12\end{array}$ & $\begin{array}{l}1974 \\
1975 \\
1976 \\
1977 \\
1978 \\
1979 \\
1980 \\
1981\end{array}$ & $\begin{array}{l}1,304 \\
2,852 \\
3,011 \\
3,196 \\
3,715 \\
3,425 \\
4,364 \\
4,399\end{array}$ & $\begin{array}{l}18 \\
38 \\
39 \\
41 \\
46 \\
46 \\
57 \\
55\end{array}$ & $\begin{array}{l}1982 \\
1983 \\
1984 \\
1985 \\
1986 \\
1987 \\
1988 \\
1989\end{array}$ & $\begin{array}{l}4,008 \\
4,483 \\
\ddot{9}, \ddot{927} \\
\ldots \ldots \\
\ddot{2}, \ldots \\
\ldots,\end{array}$ & $\begin{array}{c}48 \\
52 \\
\ddot{96} \\
\ldots \\
\ddot{27} \\
\ldots\end{array}$ \\
\hline
\end{tabular}

Sources: UNIDO, Handbook of Industriel Statistics 1979-83; $1986 \mathrm{ed.,p} p$ 23); World Developaent Report 1991,214 (1970/88 MVA); World Bank: 1982 , 125 (1972/75 MVA); Olaoye: 1985,321 (1962 MVA) Okigbo:1962,78 (1950/55). 
Table 16

Index of Manufacturing Production (1970-1988)

$$
(1972=100)
$$

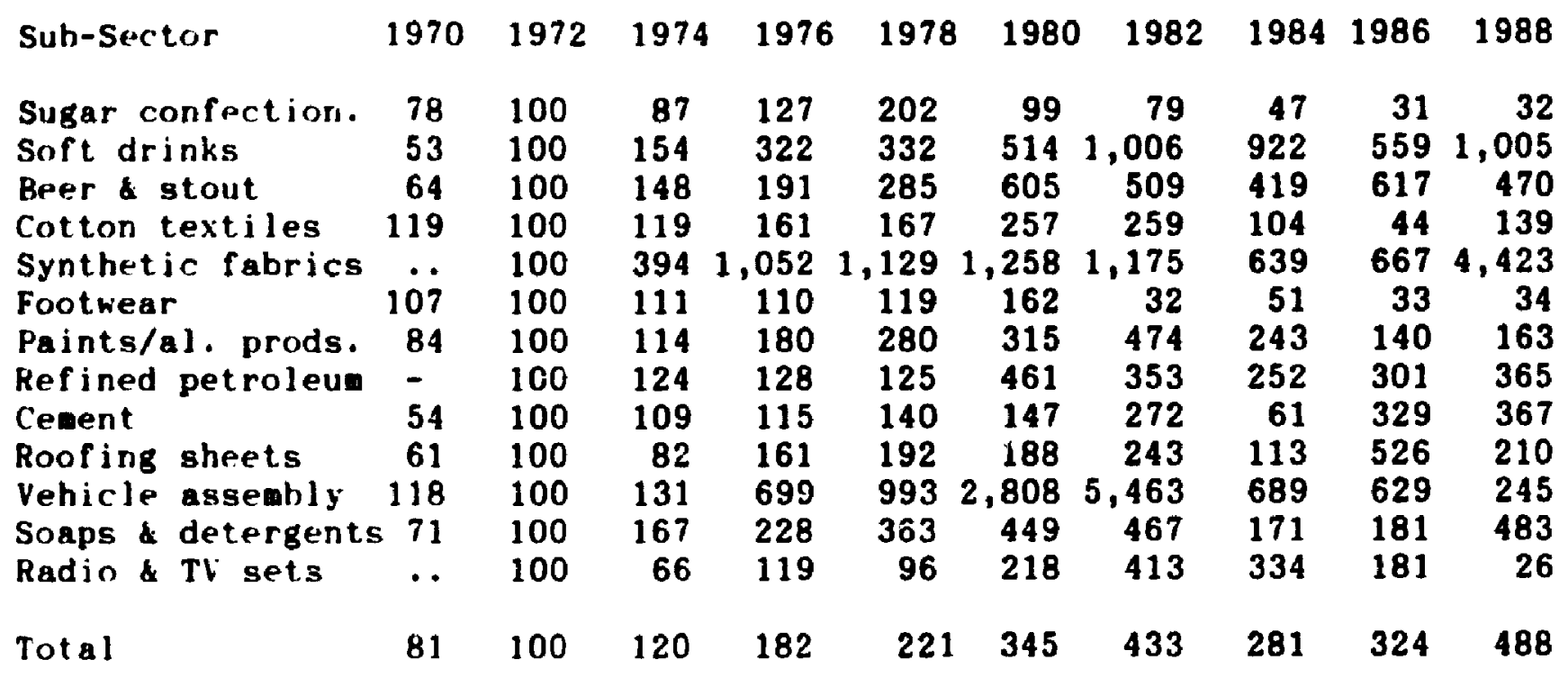

Source: Central Bank of Nigeria, Annual Report and Statenent of Accounts, various issues. 
Table 17

The Significance of Oil for State and Bconony (1960-1988)

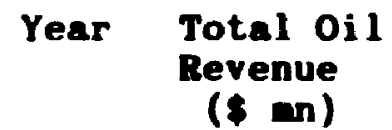

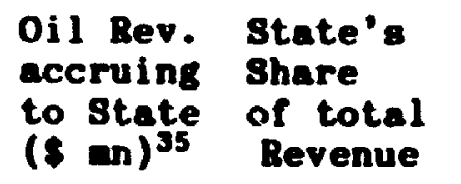

$\begin{array}{rr}1960 & 12 \\ 1965 & 191 \\ 1970 & 712 \\ 1971 & 1,344 \\ 1972 & 1,794 \\ 1973 & 2,890 \\ 1974 & 8,538 \\ 1975 & 7,449 \\ 1976 & 9,886 \\ 1977 & 10,983 \\ 1978 & 8,961 \\ 1979 & 15,517 \\ 1980 & 24,306 \\ 1981 & 17,452 \\ 1982 & 13,261 \\ 1983 & 9,952 \\ 1984 & 11,564 \\ 1985 & 12,639 \\ 1986 & 6,252 \\ 1987 & 7,052 \\ 1988 & 6,341\end{array}$

$\begin{array}{rr}3 & 25 x \\ 31 & 16 x \\ 227 & 32 x \\ 766 & 57 x \\ 1,162 & 65 x \\ 2,226 & 77 x \\ 6,653 & 78 x \\ 7,291 & 98 x \\ 8,493 & 86 x \\ 8,554 & 78 x \\ 7,280 & 81 x \\ 14,733 & 95 x \\ 23,405 & 96 x \\ 16,713 & 96 x \\ 13,086 & 99 x \\ 10,155 & 102 x \\ 11,453 & 99 x \\ 11,942 & 95 x \\ 8,762 & 140 x \\ 6,233 & 88 x \\ 5,276 & 83 x\end{array}$

Oil Rev. as $x$ of state Rev.

\author{
State Exp. \\ as $x$ of \\ GDP
}

$\begin{array}{rr}<1 x & 10 x \\ 4 x & 17 x \\ 6 x & 16 x \\ 10 x & 24 x \\ 12 x & 30 x \\ 17 x & 27 x \\ 29 x & 17 x \\ 22 x & 30 x \\ 23 x & 30 x \\ 23 x & 30 x \\ 17 x & 29 x \\ 22 x & 36 x \\ 27 x & 29 x \\ 19 x & 28 x \\ 15 x & 28 x \\ 11 x & 22 x \\ 14 x & 22 x \\ 16 x & 25 x \\ 12 x & 23 x \\ 26 x & 25 x \\ 20 x & 23 x\end{array}$

Sources:

column 1: table 2

column 2: Horld Bank:1974,248-249 (1960-70); Rimer:1981,52

(1970-72); IMF Government Finance Statistjcs Yearbook vol 13 (1989), pp. 466-467 (1973-76); Graf: 1988,219

(1977-1979); West Africa No 3811 of 10 September 1990, $2431(1980-1988)$.

column 3: ratio of columns 2 and 1

columr A: ratio of column 2 (table 17) and coluan 3 (table 6)

column 5: ratio of coluan 1 (table 17) and coluan 1 (table 8)

column 6: ratio of column 6 (table 6) and coluan 1 (Lable 8)

35 oil revenues accruing to the state consist of returns on equity capital, royalties, profit taxes, rentals for oil exploration and aining leases, premia paid for the acquisition of concessions, and aiscellaneous fees, such as for the use of pipelines and ports (Meyer and Pearson: 1974,164 ). 
Table 18: Nigerian Government Interests in Oil Conpanies (1988)

\begin{tabular}{|c|c|c|c|c|}
\hline Company & $\begin{array}{l}\text { Partici- } \\
\text { pation }\end{array}$ & $\begin{array}{l}\text { Date } \\
\text { acquired }\end{array}$ & $\begin{array}{c}\text { Consideration } \\
\text { (s an 1982) }\end{array}$ & $\begin{array}{l}\text { Production } \\
\text { Nov.' } 88 \mathrm{~b} / \mathrm{day}\end{array}$ \\
\hline $\begin{array}{l}\text { She l 1-BP } \\
\text { She } 11^{36}\end{array}$ & $\begin{array}{l}35 x \\
55 x \\
60 x \\
80 x\end{array}$ & $\begin{array}{l}1.4 .1973 \\
1.1 .1974 \\
1.7 .1979 \\
1.8 .1979\end{array}$ & 301.6 & 700,000 \\
\hline $\begin{array}{l}\text { Gulf } \\
\text { (Chevron) }\end{array}$ & $\begin{array}{l}35 x \\
55 x \\
60 x\end{array}$ & $\begin{array}{l}1.4 .1973 \\
1.1 .1974 \\
1.7 .1979\end{array}$ & 101.9 & 220,000 \\
\hline Mobil & $\begin{array}{l}35 x \\
55 x \\
60 x\end{array}$ & $\begin{array}{l}1.4 .1973 \\
1.4 .1974 \\
1.7 .1979\end{array}$ & 150.6 & 170,000 \\
\hline $\begin{array}{l}\text { Agip/ } \\
\text { Phillips }\end{array}$ & $\begin{array}{l}33 x \\
55 x \\
60 x\end{array}$ & $\begin{array}{l}1.4 .1971 \\
1.4 .1974 \\
1.7 .1979\end{array}$ & $\begin{array}{l}21.5 \\
58.0\end{array}$ & 100,000 \\
\hline $\begin{array}{l}\text { Elf } \\
\text { (Safrap) }\end{array}$ & $\begin{array}{l}35 x \\
55 x \\
60 x\end{array}$ & $\begin{array}{r}24.4 .1971 \\
1.4 .1974 \\
1.7 .1979\end{array}$ & $\begin{array}{l}6.6 \\
7.5\end{array}$ & 90,000 \\
\hline $\begin{array}{l}\text { Tevaco } \\
\text { (Chevron) }\end{array}$ & $\begin{array}{l}55 x \\
60 x\end{array}$ & $\begin{array}{l}1.5 .1975 \\
1.7 .1979\end{array}$ & 68.8 & 65,000 \\
\hline Pan Ocean & $\begin{array}{l}55 x \\
60 x\end{array}$ & $\begin{array}{l}1.1 .1978 \\
1.7 .1979\end{array}$ & 22.7 & 5,000 \\
\hline $\begin{array}{r}\text { Produ } \\
\text { Sha }\end{array}$ & $\begin{array}{l}\text { luction } \\
\text { laring }\end{array}$ & June $: 73$ & n.a. & 40,000 \\
\hline $\begin{array}{ll}\text { Mobil } & (50 x) \\
\text { Tenneco } & \left(37 \frac{1}{2}\right) \\
\text { Sun } & \left(12 \frac{1}{2}\right)\end{array}$ & $\begin{array}{l}\text { n.a. } \\
\text { n.a. } \\
\text { n.a. }\end{array}$ & n.a. & n.a. & 9,000 \\
\hline Phillips $(100 x)$ & n.a. & n.a. & n.a. & 1,000 \\
\hline $\begin{array}{l}\text { Agip/Africa } \\
\text { Elf Aquitaine Co } \\
\text { Nigus } \\
\text { Sources: NNPC: } 19\end{array}$ & $\begin{array}{l}\text { Service } \\
\text { ontracts } \\
982,7 ; \mathrm{Pe}\end{array}$ & Sept ' 79 & ist, cited in & $10: 1990,26$ \\
\hline
\end{tabular}

36 BP's $20 x$ were nationalized in 1979 to penalize Britain for the British government's decision to supply oil to South Africa (A=u: $1983,10)$ and/or for its ostensible failure to revoke Rhodesia's unilateral declaration of independence (Holnan:1989, A22). In its desperate effort to attract foreign investeent, the Babangida government in late 1991 ended the ban on BP's activities and granted it peraission to resume oil prospecting and production (WA No. 3871, 25 Noveaber 1991, 1973). In June 1989, NNPC sold $20 \%$ of its holdings in shell, thus reducing its stake to $60 \%$. The shares were bought by shell (10x), Agip (5X) and EIf (5x) (EIU: 1990,25). 
Table 19

Nigeris's Perforance conpared with other poor Countries ${ }^{37}$

Life expectancy at birth (1989)

Population per physician (1984)

with access to

health services (1986)

Rural population with access to:

- Health services (1985-1988)

- Water (1985-1988)

- Sanitation (1985-1988)

Public health expenditure ( $x$ of GNP, 1986)

Birth rate per 1,000 population (1989)

Infant nortality rate (1989)

- crude, per 1,000 live births

- under age five per 1,000 live births

Maternal mortality rate (1980-1987)

per 100,000 live births

One-year-olds immunized (1988-1989)
Nigeria

51 years

6,440

$46 x$

$30 x$

$20 x$

$5 x$

$0.2 x$

47

100

170

800

$62 x$
Low-incone econonies

62 years

5,890 Population

56\%*

40x*

40x*

20x*

$1 \times *$

31

70

155*

430*

67x*

37 In 1991 the World Bank classified those countries as "low income" in which per capita GDP was $\$ 560$ or less (World Bank:1991, 199). The 41 countries in this category were in ascending order: Mozambique (\$80), Ethiopia (\$120), Tanzania (\$130), Sonal ia (\$170), Bangladesh $(\$ 180)$, Laos $(\$ 180)$, Malawi $(\$ 180)$, Nepal $(\$ 180)$, Chad $(\$ 190)$, Burundi $(\$ 220)$, Sierra Leone (\$220), Madagascar $(\$ 230)$, Nigeria $(\$ 250)$, Uganda $(\$ 250)$, Zaire $(\$ 260)$, Mali $(\$ 270)$, Niger $(\$ 290)$, Burkina Faso (\$320), Rwanda (\$320), India (\$340), China (\$350), Hait i $(\$ 360)$, Kenya $(\$ 360)$, Pakistan $(\$ 370)$, Benin $(\$ 380)$, Central African Republic $(\$ 390)$, Ghana $(\$ 390)$, Togo $(\$ 390)$, Zanbia $(\$ 390)$, Guinea $(\$ 430)$, Sri Lanka $(\$ 430)$, Lesotho $(\$ 470)$, Indonesia $(\$ 500)$, Mauritania $(\$ 500)$, Afghanistan (n.a), Bhutan (n.a.), Canbodia (n.a.), Liberia (n.a.), Myanmar (n.a.), Sudan (n.a.), Vietnan (n.a.) (ibid.,204). In its pioneering atteapt to include the hunan dieension into aeasures of developaent, the UNDP's Hunan Developnent Report groups countries into three categories: high (53 countries), nediun ( 44 countries) and low human development ( 63 countries). Nigeria is in 129 th place, i.e. right in the middle of the "low hunan developnent" category (UNDP: 1991$, 120)$. Since the latter is not identical with, if very siailar to, the World Bank's "low incone" group, it is marked (*) if it is used as a conparator for Nigeria. 
Daily calorie supply (per capita; 1988)

Daily calorie supply as $x$ of requirenent

$-1965$

$-1985$

Index of food production (1987-89)

$(1979-81=100)$

2,039

2,331

$95 x$

$90 \%$

88x*

99x*

Adult literacy (total; 1985)

96

116

Fenale literacy (1985)

Mean years of schooling (1980)

- Male

- Fenale

School enrolment (prie. second. 1986-88)

Scientists technicians per 1,000 inhabitants (1980-88)

$42 x$

$56 x$

$31 x$

$42 x$

1.6

2.1*

1.6

$3.0 *$

0.4

$1.2 *$

47

59

1.2

$3.7 *$

$1.4 x$

$3.5 x *$

Public expend. on education ( $X$ of GNP; 1986)

GNP per capita (1989)

GNP annual growth rate (average 1965-1989)

$\$ 250$

$0.2 x$

$\$ 330$

Gross dow. investment as $x$ of GDP (1988)

Total external debt in relation to

- exports of goods and services (1989)

$13 x$

$2.9 x$

21x*

- GNP (1989)

$389.6 x$

$214.1 x$

$119.3 x$

$32.3 x$

Interest payaents in relation to exports of goods and services (1989)

$15.6 x$

$9.8 x$

8.0x

Annual industrial growth rate (average 1965-89) $7.0 x$

3.18

$\begin{array}{llr}\text { Annual agricultural growth rate (av.1965-89) } & 1.5 x \\ \text { Annual rate of inflation (average } 1965-1989 \text { ) } & 14.5 \%\end{array}$

$8.4 x$

Sources:

World Bank: 1991 (World Development Report).

Pp. 204-205: Life expectancy, literacy, per capita GNP, GNP growth rate, inflation.

P. 258: Pop per Physician; Infant nortality, calorie supply.

P. 256: Birth rat 2 . Yage 206: agriculture, industrial growth rates. P. 210:

food prod index.

P. 250: External debt ratios.

(UNDP: 1991 (Human Developnent Report),

Pp. 120-121 129: Mean years of schooling.

P. 127: calorie supply.

P. 129: scientists.

P. 137: access to water, sanitation health.

P. 141: X indunization; under five nortality rate.

F. 143: aternal nortality rate; public health expenditure population with access to health services.

P. 149: expenditure on educ as $X$ of GNP; prin sec enrolment.

P. 165: Gross donestic investment 88 of GDP. 


\section{Appendix B: Pederal Paregtatale in Fiseris ${ }^{38}$}

\section{Non-Commercial Parastatals:}

- Administrative Staff College (ASCON)

- Ahmadu Bello University Teaching Hospital

- Centre for Black and African Arts and Civilization

- Centre for Managenent Development

- Citizenship and Leadership Training Centre

- Cocoa Research Institute of Nigeria

- Council of Legal Education

- Export Promotion Council of Nigeria

- Federal Electoral Connission

- Federal Government-owned Universities

- Forestry Research Institute of Nigeria

- Industrial Training Fund

- Joint Admission and Matriculation Board (JAMB)

- Kainji Lake Research Institute

- Kainji Lake National Park * (pc)

- Lagos University Training Hospital (pc)

- Lake Chad Research Institute of Nigeria

- Law Reform Conmission

- Leather Research Institute of Nigeria

- National Board for Technical Education

- National Cereals Research Institute

- National Commission for Museums and Monuments

- National Council for Arts and Culture

- National Dock Labour Board

- National Eye Centre

- National Fertilizer Board

- National Horticultural Research Institute

- National Institute for Oceanography and Marine Research

- National Institute for Policy and Strategic Studies

- National Library of Nigeria

- National Population Bureau

- National Provident Fund (pc)

- National Root Crops Research Institute

- National Steel Council

- National Teachers Institute

38 Source: Federal Republic of Nigeria, Report of the Pregidential Commission on Parastatals (Lagos: Government Press, 1981b; chairman: G.0. Onosode), pp. 68-72. The number of ataff enployed by these parastatals - no exact figures exist which is a telling conentary on their efficiency - is estinated to have been about 165,000 (Otobo:1986,102). In January 1988 President Babangida revealed a privatization programe involving 96 companies to be either fully privatized (fp), partially privatized ( $p p)$, fully connercialized ( $f c)$ or partially connercialized (pc) (ARBe:2/1988,9033). Those parastatals included in the privatization list but not. in the 1981 report are denoted with an asterisk. 
- National Universities Comaission

- National Water Resources Institute *

- Natjonal Youth Service Corps (NYSC) Directorate

- Nautical College of Nigeria

- Nigeria Building and Road Research Institute

- Nigeria Civil Aviation Training Centre

- Nigeria Institute for Oil Pal- Research (pc)

- Nigeria Institute for Trypanosomiasis Research

- Nigeria Institute of Medical Research

- Nigeria Pilgrims Board

- Nigeria Stored Products Institute

- Nigerian Enterprises Pronotion Board

- Nigerian Institute for International Affairs

- Nigerian Institute of Med1. 2l Teth sratory Technology

- Nigerian Press Council

- Nigerian Securities and Exchange Commission

- Nigerian Shippers Council

- Petroleum Technology Development Fund

- Petroleum Training Institute

- Projects Development Institute (PRODA) (Pc)

- Rubber Research Institute of Nigeria

- Lniversity College Hospital, Ibadan (pc)

- University of Benin Teaching Hospital (pc)

- Unjversity of Ife Teaching Hospital (pc)

- Universit! of Nigeria Teaching Hospital, Enugu (pc)

- Veterinary Research Institute of Nigeria

Commercial Parastatals (either fully government funded or with government holding controlling interest)

- Aba Textile Mills Ltd. (fp)

- African Petroleum Ltd.

- Agip (Nigeria) Ltd.

- Ajaokuta Steel Company Ltd. (pc)

- Allied Bank of Nigeria Ltd. (pp)

- American International Insurance Company * (fp)

- Anambra/Imo River Basin Authority (pc)

- Ashaka Cement Company Ltd. (pp)

- Arsociated Ores Mining Company Ltd. (fc)

- '.cita Sugar Company * (pp)

- Berin/Owena River Basin Authority (pc)

- Bonny Liquified Natural Gas Ltd.

- British-American Insurance * (fp)

- Central Bank of Nigeria

- Central Water Transportation Company Ltd. (fp)

- Chad Basin Development Authority (pc)

- Chase Merchant Bank (Nigeria) Ltd. (pp)

- Cross River Basin Development Authority (pc)

- Crusader Insurance * (fp)

- Daily Times of Nigeria * (pp)

- Defence Industries Corporation 
- Delta Steel Company Ltd. (pc)

- Durbar Hotels (Nigeria) Ltd. (fp)

- Electricity Meters Company Ltd. (pc)

- Elf (Nigeria) Ltd.

- Federal Capital Development Authority

- Federal Housing Authority (pc)

- Federal Mortgage Bank of Nigeria (pp)

- Federal Radio Corporation of Nigeria (pc)

- Federal Savings Bank (pp)

- Grains Production Company Ltd. * (fp)

- Guinea Insurance * (fp)

- Gulf Oil Company of Nigeria Ltd.

- Hadeja Jama'are River Basin Development Authority (pc)

- Impresit Bakalori Nigeria Ltd. (fp)

- International Bank for West Africa Ltd. (pp)

- International Merchant Bank of Nigeria Ltd. (pp)

- Jos Steel Rolling Mills Ltd. (pp)

- Katsina Steel Rolling Mills Ltd. (pp)

- Lafiagi Sugar Company Ltd. (pc)

- Law Union and Rock * (fp)

- Lower Benue River Basin Development Authority (pc)

- Madara Dairy Company * (fp)

- Mercury Assurance * (fp)

- Mifergun Nimba Company Ltd.

- National Animal Feed Company * (fp)

- National Cargo Handling Company Ltd. (fp)

- National Electric Power Authority * (pc)

- National Freight Company * (fp)

- National Fruit Company Ltd. * (fp)

- National Grain Production Company Ltd. (fp)

- National Insurance Corporation of Nigeria ( $f c)$

- National Livestock Production Ltd. * (fp)

- National Oil and Chemical Marketing Company Ltd.

- National Properties Ltd * (fc)

- National Root Crops Production Company Ltd. (fp)

- National Salt Company Ltd. (fp)

- National Shrimp Company Ltd. (fp)

- National Steel Council (Exploration and Metallurgical Research Division)

- NEM Insurance * (fp)

- New Nigerian Newspapers Ltd. (pp)

- New Nigerian Salt Company Ltd. (fp)

- New Agency of Nigeria * (pp)

- Niger Insurance * ( $f p)$

- Nigeria-Arab Bank Ltd. (pp)

- Nigeria Engineering Construction Ltd. (pp)

- Nigeria Film Corporation (fp)

- Nigeria Hotels Ltd. (fp)

- Nigeria Industrial Development Bank Ltd. (pp)

- Nigeria Machine Tools Company Ltd. (fc)

- Nigeria Mining Corporation * (fc)

- Nigeria Ranches * (fp) 
- Nigeria-Rumanian Wood Industries Ltd. * (fp)

- Nigerian Agricultur,l and Co-operative Bank Ltd. (pp)

- Nigerian Airportr chority

- Nigerian Airways std. (pp)

- Nigerian Bank for Comerce and Industry (pp)

- Nigerian Beverages Company Ltd. (fp)

- Nigerian Coal Corporation ( $f c$ )

- Nigerian Cocoa Board

- Nigerian Cotton Board

- Nigerian Dairies Company Ltd. (fp)

- Nigerian External Telecomunications Ltd. (fc)

- Nigerian Fertilizer Company * (pp)

- Nigerian Film Corporation * (fp)

- Nigerian Food Company Ltd.

- Nigerian Grains Board

- Nigerian Groundnuts Board

- Nigerian Merchant Bank Ltd. (pp)

- Nigerian National Fishing Company Ltd. (fp)

- Nigerian National Paper Manufacturing Conpany Ltd. (pp)

- Nigeriar National Petroleum Company Ltd. (fc)

- Nigeriar, National Shipping Line Ltd. (pp)

- Nigerian National Supply Company Ltd. (fp)

- Nigerian Newsprint Manufacturing Ltd. (pp)

- Nigerian Oil Palm Board

- Nigerian Paper Mills Ltd. (pp)

- Nigerian Ports Authority (pc)

- Nigerian Poultry Production Company Ltd. (fp)

- Nigerian Railways Corporation (pc)

- Nigerian Re-Insurance Corporation ( $f c$ )

- Nigerian Root Crops Board

- Nigerian Rubber Board

- Nigerian Security Printing and Minting Company Ltd. (pc)

- Nigerian Superphosphate and Fertilizer Company Ltd. (pp)

- Nigerian Telecommunications * (pc)

- Nigerian Television Authority (pc)

- Nigerian Transport Ltd. * (fp)

- Nigerian Yeast and Alcohol Company Ltd. * (fp)

- North Breweries Nigeria Ltd. * (fp)

- Ogun/Oshun River Basin Authority (pc)

- Okomu Dil Palm Company Ltd. * (fp)

- Opobo Boatyard Ltd. (fp)

- Ore/Irele Oil Palm Company Ltd. * (fp)

- Oshogbo Steel Rolling Mills Ltd. (pp)

- Posts and Telecommunications

- Prestige Assurance * (fp)

- Road Construction Company of Nigeria Ltd. (fp)

- Royal Exchange Company * (fp)

- Sapele Gas Plant

- Savannah Bank of Nigeria Ltd. (pp)

- Savannah Sugar Company Ltd. (pp)

- Shell Petroleum Development Nigeria Ltd.

- Sokoto Rima Basin Development Authority (pc) 
- South-East Rumania Wood Industries, Ltd. * (fp)

- Specomills Textile Ltd. (fp)

- Sun Insurance * (fp)

- Sunti Sugar Company Ltd. (fp)

- Tafawa Balewa Square Management Committee $*$ (fc)

- Tourist Company of Nigeria Ltd. (pp)

- Union Bank of Nigeria Ltd. (pp)

- Unipetrol Nigeria Ltd. (pp)

- United Nigerian Insurance * ( $f p)$

- Upper Benue River Basin Authority (pc)

- West African Distilleries Ltd. (fp)

- West African Prudent;al Insurance * (fp) 


\section{Appendix C: Indigenization Schedules ${ }^{39}$}

Foreign Investnent - Nigerian Enterprises Pronotion Act 1977

Schedule 1 - Enterprises exclusively regerved for Nigerians

- Advertising and public relations business

- All aspezts of pool betting business and lotteries

- Assembly of radios, radiograms, record players, television sets, tape recorders and other electric domestic appliances not combined with manufacture of components

- Blending and bottling of alcoholic drinks

- Blocks and ordinary tile manufacture for building and construction works

- Bread and cake making

- Candle manufacture

- Casinos and gaming centers

- Cinemas and other places of entertainment

- Commercial transportation (wet and dry cargo and fuel)

- Commission agents

- Departmental stores and supermarkets having an annual turnover (sales) of less than N2,000,000

- Distribution agencies excluding motor vehicles, wachinery, equipment, spare parts

- Electricai repair shops other than repair shops associated with distribution of electrical goods

- Estate agencies

- Film distribution (including cinema films)

- Hairdressing

- Icecream making when not associated with manufacture of other dairy products

- Indenting and confiraing

- Laundry and dry-cleaning

- Manufacturers' represenatitives

- Manufacture of suitcases, briefcases, handbags, purses, wallets, portfolios and shopping bags

- Municipal bus services and taxis

- Newspaper publishing and printing

- Office cleaning

- Passenger bus services and taxis

- Poultry farming

- Printing of stationery (when not associated with printing of books)

- Protective agencies

- Radio and television broadcasting

- Retail trade (except by or within departmental stores and

39 Source: Price Waterhouse, Doing Business in Nigeria (Lagos Price Waterhouse, 1982), pp. 97-100. 
supermarkets)

- Singlet manufacture

- Stevedoring and shorehandling

- Tire retreading

- Travel agencies

- Wholesale distribution of local anufacturers and other locally produced goods

Schedule 2 - Enterprises in which Nigerians aust have eajority interest (i.e. $60 x$ or more of equity participation)

- Banking - commercial, merchant and development banking

- Basic iron and steel manufacture

- Beer brewing

- Boat building

- Bottling and soft drinks

- Business services (other than machinery and equipment rental and leasing) such as business management and counseling services, fashion designing

- Cleaning and forwarding agencies

- Canning and preserving of fruits and vegetables

- Coastal and inland waterways shipping

- Construction industry

- Departmental stores and supermarkets having annual turnover (sales) of not less than N2,000,000

- Distribution and servicing of motor vehicles, tractors and spare parts thereof or similar objects

- Establishments specializing in the repair of watches and clocks

- Fish and shrimp trawling and processing

- Garment manufacture

- Grain mill products except rice willing

- Industrial cleaning

- Insecticides, pesticides and fungicides

- Internal air transport (scheduled and charter services)

- Insurance (all classes)

- Lighterage

- Manufacture of bicycles

- Manufacture of cosmetics and perfumery

- Manufacture of cocoa, chocolate and high-grade confectionery

- Manufacture of dairy products, butter, cheese, ailk and other wilk products

- Manufacture of food products like yeast, starch, baking powder, coffee roasting; processing of tea leaves into black tea

- Manufacture of jewelry and related articles including initation jewelry

- Manufacture of furniture and interior decoration; manufacture of metal fixtures for household, office and public building

- Manufacture of leather footwear

- Manufacture of matches 
- Manufacture of paints, varnishes or other similar articles

- Manufacture of plastic products such as plastic dinner ware, tableware, kitchenware, plastic mats, plastic achinery parts, bottles, tubes and cabinets

- Manufacture of rubber products, rubber footwear, industrial and mechanical rubber specialties such as gloves, nats, sponges and form

- Manufacture of tires and rubber bicycles and Dotorcycles; of tires and tubes for notor vehicles

- Manufacture of soap and detergents

- Manufacture of wire, nails, washers, bolts, nuts, rivets and similar articles

- Other anufacturing industries such as nonrubber and nonplastic trays, pens, pencils, umbrellas, canes, buttons, brooms and brushes, lampshades, tobacco pipes and cigarette holders

- Mining and quarrying

- Oil milling, cotton ginning and crushing industries

- Paper conversion industries

- Printing of books

- Production of sawn timber, plywood, veneers and other rood conversion industries

- Petrochemical feedstock industries

- Publishing of books, periodicals and such like

- Pulp and paper mills

- Rice milling

- Restaurants, cafes and other eating and drinking places

- Salt refinery and packaging

- Screen printing on cloth, dyeing

- Inland and coastal shipping

- Slaughtering, storage associated with industrial processing and distribution of meat

- Tanneries and leather finishing

- Tin smelting and processing

- Wholesale distribution of imported goods

- Photographic studios, including commercial and aerial photography

Schedule 3 - Enterprises in which Nigerians must have at least $40 x$ equity

- Cement manufacture

- Distilling, rectifying and blending of spirits such as ethyl alcohol, whisky, brandy, gin and the like

- Fertilizer production

- Manufacture of basic industrial chemicals (organic and inorganic) except fertilizers

- Manufacture of synthetic resins, plastic aterials and man-made fibers except glass

- Manufacture of drugs and eedicines

- Manufacture of metal containers

- Manufacture of pottery, china and earthenware

- Manufacture of $\mathbf{g l a s s}$ and glass products 
- Manufacture of miscellaneous nonmetallic mineral products such as concrete, gypsum and plastering products, including ready-aixed concrete; aineral wool, abrasive; asbestos products; graphite products

- Manufacture of primary nonferrous netal products such as ingots, bars and billets; sheets, strips, cirales, cecrous, rods, tubes, pipes and wire rods; casting and extrusions

- Manufacture of (fabricated aetal) cutlery, hand tools and general hardware

- Manufacture of structural netal products such as components of bridges, tanks, metal doors and screens, window frames

- Manufacture of miscellaneous fabricated metal products, except achinery and equipment, such as safes and vaults; steel springs and furnaces; stoves, and the like

- Manufacture of engines and turbines

- Manufacture of agricultural machinery and equipment

- Manufacture of metal and wood working machinery

- Manufacture of special industrial machinery and equipment, such as textile and food machinery, paper industry machinery, oil refining machinery and equipment and the like

- Manufacture of office, computing and accounting machinery

- Manufacture of other machinery and equipment except electrical equipment, pumps, air and gas compressors; blowers, air-conditioning and ventilating machinery; refrigerators, and the like

- Manufacture of electrical industrial machinery and apparatus

- Manufacture of radio, television and communication equipment. and apparatus

- Manufacture of electrical apparatus and supplies not elsewhere classified, su h as insulated wires and cables, batteries, electric lamps and tubes, fixtures and lamp switches, sockets, switches, insulators, and the like

- Manufacture of electric appliances and houseware

- Shipbuilding and repairing (excluding boat building)

- Manufacture of railroad equipment

- Manufacture of motor vehicles and motorcycles

- Manufacture of aircraft

- Manufacture of professional and scientific and measuring and controlling equipment, such as laboratory and scientific instruments, surgical, medical and dental equipment, instruments and supplies and orthopaedic and prosthetic appliances

- Manufacture of photographic and optical goods

- Manufacture of watches and clocks

- Jcean transport/shipping

- Oil servicing companies

- Storage and warehousing, the operation of storage facilities and warehouses (including bonded and refrigerated warehouses) for hire by the general public

- Tobacco manufacture

- Textile manufacturing industries

- Hotels, rooming houses, canps and lodging places

- Data processing and tabulating services (on a fee or contract basis)

- Production of cinena and television filas (or notion picture 
production)

- Machinery and equipment rental and leasing

- Sugar plantation and processing

- Agricultural plantation for tree crops, grains and other cash crops

- All other enterprises not included in Schedule 1 or 2 not being public sector enterprises 


\title{
Appendix D: The General Theors of Not-Gardening
}

\author{
A Major Contribution to Social Anthropology, \\ Ontology, Moral Philosophy, Sociology, Political \\ Theory, and Many Other Fields of Scientific Investigation. \\ by Leszek Kolakowski 40
}

Those who hate gardening need a theory. Not to garden without a theory is a shallow, unworthy way of life. A theory wust be convincing and scientific. Yet to various people, various theories are scientific. Tharefore we need a number of theories. The alternative to notgardeung without a theory is to garden. However, it is much easier to have a theory than actually to garden.

Marxist Theory

Capitalists try to corrupt the minds of the toiling asses and to poison them with their reactionary "values." They want to "convince" workers that gardening is a great "pleasure" and thereby keep them busy in their leisure time and prevent them from carrying out the proletarian revolution. Besides, they want to make them believe that with their miserable plot of land they are really "owners" and not wage earners and in this way win them over to the side of the owners ins the class struggle. To garden is therefore to participate in the great plot aiming at the ideological deception of the masses. Do not garden! Q.E.D.

Psychoanalytical Theory

Fondness for gardening is a typically English quality. It is easy to see why this is so. England was the first country to take part in the Industrial Revolution. The Industrial Revolution killed the natural environment. Nature is the symbol of Mother. By killing Nature, the English people comaitted matricide. They are unconsciougly haunted by feelings of guilt, and they try to expiate their crive by cultivating and worshipping their sall, pseudonatural gardens. To garden is to take part in this gigantic self-deception. You nust not garden. Q.E.D.

10 Reprinted (peraission not requested) from: Modernity on Endless Trial, (Chicago and London: University of Chicago Press, 1990), pp. 240-241. 
Existentialist Theory

People garden in order to aake Nature huan, to "civilize" it. This, however, is a desperate and futile atteapt to transfore being-initself into being-for-itself. This is not only ontologically impossible; it is a deceptive, norally inaduissible escape fron reality, as the distinction between being-in-itself and being-for-itself cannot be abolished. To garden, or to inagine that one can "humanize" Nature, is to try to efface this distinction and hopelessly to deny one's own irreducibly human ontological status. To garden is to live in bad faith. Gardening is wrong. Q.E.D.

\section{Structuralist Theory}

In primitive societies life was divided into the pair of opposites work/leisure, which corresponded to the distinction field/house. Prople worked in the field and rested at hose. In nodern societies the axis of opposition has been reversed: People work in houses (factories, offices) and rest in the open (gardens, parks, forests, rivers, etc.) Such distinctions are crucial in mintaining the conceptual framework whereby people structure their lives. To garden is to confuse the distinction between house and field, between leisure and work; it is to blur, indeed to destroy, the oppositional structure that is the basis of thinking. Gardening is blunder. Q.E.D.

\section{Analytical Philosophy}

In spite of many attempts, no satisfactory definition of garden and of gardening have been found; all existing definitions leave a large area of uncertainty about what belongs where. We siaply do not know what exactly a garden and gardening are. To use these concepts is therefore intellectually irresponsible, and actually to garden would be even more so. Thou shalt not garden. Q.E.D. 


\section{Biblionrengy}

Abernethy, David B. "Bureaucracy and Econonic Developeent in Africa." The Africen Review 1 (1971), pp. 83-197.

Abernethy, D. "Bureaucratic Growth and Bcononic starmation in Sub-Saharan Africa." In S.K. Connina, ed. Africn's Developent Challenres ind the World Bank: Herd Ouentions. Costly Choices, pp. 179-214. Boulder: Lynne Rienner, 1988.

Abernethy, D. "European Colonialise and Postcolonial Crises in Africa." In H. Glickean, ed. The Crialend Challenre of African Developnent, pp. 3-23. Weatport: Greenwood Preas, 1988a.

Aboyade, 0 . Foundations of an African Econonv: a study of Investment and Growth in Nigeria. New York: Praeger, 1966.

Aboyade, O. "The Econony of Nigeria." In P. Robson and D.A. Lury, eds. The Econonies of Africs, pp. 127-193. London: Allen Unwin, 1969.

Acharya, S.N. "Perspectives and Probleas of Developeent in SubSaharan Africa." World Deyelopent 2 (1981). pp. 109-147.

Achebe, C. Man of the People. London: Heinesann, 1966.

Achebe, C. The Trouble with Nigeris. London: Heinemann, 1983.

Achebe, C. Anthills of the Savannah. New York: Doubleday, 1987.

Adamolekun, L. Public Adninistration: A Niderian and Conparative Perspective. London: Longan, 1983.

Adamolekun, L. Nigerian Public Adninigtration 1960-1980: Perspectives and Prospects. Lagos: Heineann, 1985.

Adanolekun, L. The Fall of the Second Republic. I badan: Spectrun Books, 1985a.

Adanolekun, L. Politics and Adninistration in Nigeris. Ibadan: Spectrum Books, 1986.

Adamolekun, L. and V. Ayeni. "Nigeria." In V. Subrananian, ed. Public Adninistration in the Third Horld: An International Handbook, pp. 258-288. Westport: Greenwood, 1990.

Adebayo, A. "Policy-Making in Nigerian Public Adniniatration." Journal of Adninistration Overseas 1 (1979), pp. 4-14.

Adebayo, A. Princioles and Practice of Public Adniniatration in 
Niseris. Chicheater: Wiley, 1981.

Adedeji, A. Nirerien Adninlatration and its Political setting. London: Hutchinson, 1968.

Adedeji, A. Nigerien Federel Finence: it Develonent. Problens and Proupecte. New York: Africans, 1969.

Adedeji, A., ed. Indisenisation of African Tconontes. New York: Africana, 1981.

Adejugbo, M. "The Myths and Bealities of Migerian Business Indigenization." Developnent and Chance 4(1984), pp. 577-592.

Adelean, I. and C.T. Morris. "Perforeance Criteria for Evaluating Economic Development." Quarterly Journal of Dcononica 2 (1968), pp. 260-280.

Adelnan, I. and C.T. Morris. "An Econonetric Model of SocioEcononic and Political Change in Underdeveloped Countries." Anerican Fcononic Review 3 (1968), pp. 1184-1218.

Adelean, I. and C.T. Morris. Bcononic Growth and Socinl Fauity in Developing Countries. Stanford: Stanford University Press, 1973.

Adenoyi, E.O. "National Developnent Planning and Plan Adeinistration in Nigeria." Journal of Adninistration Overseas 3 (1980), pp. 160-174.

Addo, H. Inperialisn: The Pernanent stage of Capitalisn. Tokyo: The United Nations University, 1986.

Agiri, B.A. "Slavery in Yoruba Society in the 19th Century." In P.E. Lovejoy, ed. The Ideoloty of Slavery in Africe, pp. 123-148. Beverly Hills and London: Sage, 1981.

Ahiauzu, A.I. "Methods of Job Regulation in Nigerian Workplaces: A Study of Cultural Influences in Industrial Relations." Genève-Afrique 1 (1984), pp. 107-122.

Aigbokhan, B.E. "Changes in Financial Markets and their Effects on Agriculture with particular Reference to Nigeria." Indian Journal of Dcononice 277 (1989), pp. 235-244.

Aina, S. "Bureaucratic Corruption in Nigeria: Continuing Search for Cause and Cures." International Review of Adninintrative Sciences 1 (1982), pp. 70-76.

Ajayi, J.F.A. Milestones in Nigerian History. Ibadan: Ibadan University Press, 1962.

Ajayi, J.F.A. and M. Crowder, ede. Hietory of Went Africa. 
New York: Columbia University Press, 1976.

Ajuogu, M.A. "Ethical Dileamas of Public Sector Executives in a Developing Econony." International Review of Adninistrative Science 4 (1983), pp. 386-392.

Aké, C. "The Future of the State." International Political Science Review 1 (1985), pp. 105-114.

Aké, C. "Indigenization: Probleas of Transformation in a Neocolonial Econony." In C. Ake, ed. Political Econony of Nigerie, pp. 173-200. London: Longnan, 1985a.

Akeredolu-Ale, E.O. "Values, Motivation and History in the Developaent of Private Indigenous Entrepreneurship: Lessons fros Nigeria's Experience, 1946-1966." The Niserian Journal of Econonic and Social Studies 2 (1971), pp. 195-219.

Akeredolu-Ale, E.O. "The 'Conpetitive Threshold' Hypothesis and Nigeria's Industrialization Process - a Review Article." The Nigerian Journal of Econonic and Sociel Studies 1 (1972), pp. 109-120.

Akeredolu-Ale, E. The Underdevelopent of Indigenous Entrepreneurship in Nigeria. Ibadan: Ibadan University Press, 1975.

Akeredolu-Ale, E. "Private Foreign Investment and the Underdevelopnent of Indigenous Entrepreneurship in Nigeria." In G. Willians, ed. Nigeria: Econony and Society, pp. 106-122. London: Rex Collins, 1976:

Akinsanya, A. "The Military Regine, Top Bureaucrats and what Next? The Nigerian Case." Genève-Afriaue, 1 (1976), pp. 57-77.

Akinsanya, A. "Reforning a Public Enterprise through a Managenent Audit: Any Lessons fron the Forner Western Nigeria Development Corporation." Indian Journal of Public Adninistration \& (1978), pp. 1016-1031.

Akinsanya, A. "Bureaucratic 'Politics': A Study of the Forner Western Nigerian Ministry of Agriculture and Natural Resources." Indian Journal of Public Adninistration (1983), pp. 865-893.

Akinyele, T.A. "On Being a Higher Civil Servant." Quarterly Journal of Adninistration 3-4 (1979), pp. 231-242.

Akpan, N.U. Elitaph to Indirect Rule: A Dircourse on Local Governnent in Africs. London: Cassell, 1956.

Alavi, H. "The State in Post-Colonial Societies." New Left Review 74 (1972), pp. 59-81.

Alnond, G. "The Return of the State." Anerican Political Science 
Review 3 (1988), pp. 853-874.

Almond, G. and J. Colenan, eds. The Politics of the Developins Areas. Princeton: Princeton University Press, 1960.

Alter, R. "Fron Myth to Murder." The New Republic 20 (20 May 1991), pp. 34-42.

Aluko, O. Egsays in Nigerian Foreign Policy. London; Allen Unwin, 1981 .

Aluko, T.M. Chief the Honourable Minister. London: Heinenann, 1977 $[1970]$.

Alter, R. "Frod Myth to Murder." The New Republic 20 (20 May 1991), pp. 34-42.

Amin, 3. "Underdevelopment and Dependence in Black Africa - Origins and Contenporary Fores." The Journal of Modern African Studies $4(1972)$, pp. 503-524.

Amin, S. Accumulation on a World Scale: A Critique of the Theory of Underdevelopment. New York: Monthly Review Press, 1973.

Amin, S. Neo-Colonialigm in West Africa. Harmondsworth: Penguin, $1973 a$.

Amin, S. "Underdevelopment and Dependence in Black Africa - their historical Origins and contemporary Forns." Social and Econonic Studjes 1 (1973b), pp. 177-196.

Amin, S. Unequal Development: An Essay on the Social Fornations of Perioheral Capitalisa. Sussex: Harvester Press, 1976.

Amin, S. Imperialise and Unequal Development. Sussex: Harvester Press, 1977.

Amin, S. "Preface: The State and the Question of Developnent." In P.A. Nyong'o, ed. Popular Strutgles for Denocracy in Africa, pp. 1-13. London: Zed Books, 1987.

Amsden, A.H. "The State and Taiwan's Econonic Developnent." In P. Evans, D. Rueschemeyer and T. Skocpol, eds. Bringing the State Back In, pp. 78-109. New York: Canbridge University Pres8, 1985.

Amsden, A.H. "Taiwan's Econonic History: A Case of Etatisne and a Challenge to Dependency Theory." In R.H. Bates, ed. Toward a Political Econony of Developent: A Rational Choice Perapective, pp. 142-175. Berkeley and Los Angeles: University of California Press, 1988.

Anu, L. A Review of Nigeris's 0il Industry. Lagos: NNPC, undated, probably :983. 
Andersen, P. Lineages of the Ab-plutist state. London: New Left Books, 1974.

Anglin, D.G. "Nigeria: Political Non-Alignnent and Econonic Alignment." The Journal of Modern African Studies 2 (1964), pp. 247-263.

Anglin, D.G. "Brinknanship in Nigeria: The Federal Elections of 1964-65." International Journal 2 (1965), pp. 173-188.

Anise, L. "Desubsidization: An Alternative Approach to Governmental Cost Containment and Incone Redistribution Policy in Nigeria." African Studieg Review 2 (1980), pp. 17-37.

Antonio, R.J. "Weber vs. Parsons: Donination or Technocratic Models of Social Organization." In R.M. Glassman and V. Murvar, eds. Max Weber's Political Sociology: A Pessinistic Vision of a Rationalized World, pp. 155-174. Westport: Greenwood Press, 1984.

Arndt, H.W. Economic Development: The History of an Idea. Chicago: University of Chicago Press, 1987.

Arndt, H.W. "'Market Failure' and Underdevelopment." World Development 2 (1988), pp. 219-229.

Arnold, G. Modern Nigeria. London: Longman, 1977.

Asechenne, D. "Financial Reporting by State Governments in Nigeria." International Journal of Adninistrative Science 1 (1985), pp. 54-60.

Asiegbu, J.U.J. Nigeria and its British Invaderg, 1851-1920. New York: Nok Publishers International, 1984.

Asiodu, P.C. "Industrial Policies and Incentives in Nigeria." The Nigerian Journal of Econonic and Social Studies 2 (1967), Fp. 161-174.

Asiodu, P.C. The Future of the Federal and state Civil Services in the Context of the Twelve States' Structures. Benin City: Midwest Newspapers Conpany, 1971.

Asiodu, P.C. "The Civil Service: an Insider's View." In O. Oyediran, ed. Nigerian Government and Politics under Military Rule, 196679, pp. 73-95. London and Basingstoke: Macnillan Press, 1979.

Askari, H. and J. Cunnings. Agricultural Supoly Regponse; A Survey of the Econonetric Evidence. New York: Praeger, 1976.

Austin, D. "Elenental, ay dear Watson." Vest Africh No 3160 , (6 February 1978), pp. 246-247. 
Awa, E.0. "High Level Adniniatration in the Public Services of Nigeria." The Nigerian. Journal of Econonic and Social Studies 1 (1964a), pp. 43-50.

Awa, E.0. Dederal Government in Nigerie. Berkeley and Los Angeles: University of California Press, $1964 b$.

Awolowo, O. Path to Niserian Freedon. London: Faber and Faber, 1947.

Awolowo, 0. Awo: The Autobiography of Chief obafeni Awolowo. Cambridge: Canbridge University Press, 1960.

Ayeni, B. "Spatial Aspects of Urbanization and Effects on the Distribution of Incone in Nigeria." In H. Bienen and V.P. Diejonaoh, eds. The Political Econony of Incone Distribution in Niferia, pp. 237-268. New York: Holt Meier,1981.

Ayeni, 0. "Balancing the Federation: Reactions to the Creation of States." West Africa 3862 (16 Septenber 1991), p. 1533.

Ayida, A.A. "The Federal Civil Service and Nation Building." Quarterly Journal of Adninistration 3-4 (1979), pp. 217-229.

Ayo, S.B. "The Evolution of the Nigerian Federal Adninistration System." Publius 1 (1989), pp. 157-176.

Ayoade, J.A.A. "States without Citizens: an energing African Phenomenon." In D. Rothchild and N. Chazan, eds. The Precarious Balance: State and Society in Africa, pp. 100-118. Boulder: Westview, 1988.

Ayuni, V. "Nigeria's bureaucratized Obbudsaan Systea: An Insight into the Problem of Bureaucratization in a Developing Country."

Public Adainistration and Developent 3 (1987), pp. 309-324.

Baaklini, A. "Conparative Public Adninistration: The Persistence of an Ideology." Journal of Comparative Adninistration 1 (1973), pp. 109-124.

Babai, D. "The World Bank and the IMF: Rolling Back the State or Backing its Role?" In R. Vernon, ed. The Propise of Privatization: a Challenge for U.S. Policy, pp. 254-285. New York: Council on Foreign Relations, 1988.

Bach, D. "Managing a Plural Society: The Boonerang Effects of Nigerian Federalisa." The Journal of Connonuealth and Comparative Politicg 2 (1989), pp. 218-245.

Bachrach, P. and M.S. Baratz. "Two Faces of Power." Anerican Political Science Review 4 (1962), pp. 947-952.

Baker, D.G. "Developnent Models and Stratesies: The Probles of Hunan Mot, ation." Journal of Contenporary Africen studies 3 (1982), 
pp. 211-240.

Baldwin, R.E. "Patterns of Developnent in newly settled Regions." Manchester School of Econonics and Social Studies 2 (May 1956), pp. 161-179.

Baldwin, K.D.S. "The Mokwa Land Settlewent Schene." In C.K. Eicher and C. Liedholn, eds. Growth and Developnent of the Nigerian Econony, pp. 163-178. East Lansing: Michigan State University, 1970.

Balogun, M.J., ed. Managerial Efficiency in the Public Sector: Patterns and Problens in Nigeria. Ile Ife: University of Ife Press, 1980 .

Balogun, M.J. Public Adninistration in Nigeria: A Develonent Approach. Lagos: Macnillan Press Nigeria, 1983.

Bangura, Y. "The Nigerian Econosic Crisis." In P. Lawrence, ed. Norld Recession and the Food Crisis in Africa, pp. 40-58. London: James Currey, 1986a.

Bangura, Y. "Structural Adjustment and the Political Question." Review of African Political Econogy 37 (1986b), pp. 24-37.

Baran, P.A. "On the Political Econumy of Backwardness." The Manchester School of Fcononic and Social Studies $1(1952)$, pp. 66-84.

Baran, P.A. The Political Econogy of Growth. New York: Monthly Review Press, 1962.

Baratz, M.S. "Public Investnent in Private Enterprige: A Western Nigeria Case Study." The Nigerian Journal of Econonic and Social Studies 1 (1964), pp. 60-71.

Barker, J. Rural Comunities under Stress: Peagant Farners and the State in Africa. Cambridge: Cambridge University Press, 1989.

Barnett, S.A. and N. Engel. "Effective Institution Building." A.I.D. Progras Evaluation Digcuggion Paper 11. Washington: USAID, 1982.

Barratt-Brown, M. After Inperialign. New York: Hunanities Press, 1970.

Barrows, R. and M. Roth. "Land Tenure and Investment in African Agriculture: Theory and Evidence." The Journal of Modern African Studies 2 (1990), pp. 265-297.

Barry, B. "Review Article: Crisis, Choice, and Change." Britigh Journal of Political Science 1 (1977), pp. 99-113; and 2 (1977), pp. 217-253. 
Bassey, C.0. "Retrospects and Prospects of Political stability in Nigeria." African Studies Review 1 (1989), pp. 97-114.

Bates, R.H. Markets and States in Tropical Africai The Political Basis of Asricultural Policies. Berkeley and Los Angeles: University of California Press, 1981.

Bates, R.H. Esgays on the Political Econony of Rural Africs. Berkeley and Los Angeles: University of California Press, $1987 a$.

Bates, R.H. "The Politics of Agricultural Pricing in Sub-Saharan Africa." In Z. Ergas, ed. The African State in Transition, pp. 237-261. London: Macailian, 1987b.

Bates, R.H., ed. Toward a Political Econony of Developnent: A Rational Choice Perspective. Berkeley \& Los Angeles: University of California Press, 1988.

Baver, P.T. West African Trade. A Study of Conpetition, Oligopoly and Monopoly in a Changing Econony. New York: Kelley, 1963 [1954].

Bauer, P.T. Dissent on Developent: Studies and Debates in Developent Economics. London: Weidenfeld and Nicolson, 1971.

Bauer, P.T. Equality, the Third World and Econonic Delusion. London: Weidenfeld and Nicolson, 1981.

Baver, P.T. Reality and Rhetoric: Studies in the Econonics of Development. Cambridge: Harvard University Press, 1984.

Baumann, F. "Wie weit half der Marshall Plan?" Darals 5 (1976), p. 419-438.

Beckett, P. and J. O'Connel1. Education and Power in Nigeris. London: Hodder and Stoughton, 1977.

Beckman, B. "Inperialise and the 'National Bourgeoisie'." Review of African Political Econony 22 (1981), pp. E-19.

Beckman, B. "Whose state? State and Capitalist Development in Nigeria." Review of African Political Econony 23 (1982), pp. 37-51.

Beckman, B. "Neo-Colonialisn, Capitalise, and the State in Nigeria." In H. Bernstein and B. Campell, eds. Contradictions of Accunulation in Africa: Studies in Econon and state, pp. 71-113. Beverly Hills: Sage, 1985.

Beethaw, D. Bureaucracy. Milton Keynes: Open University Press, 1987.

Bello, Sir Ahaadu, Sardauna of Sokoto. My life. Canbridge: Canbridge University Press, 1962.

Belloc, H. The Modern Traveller. London: Edward Arnold, 1898. 
Bello-Iaan, I.B. "Civil Service Training in Africa: the Case of Nigeria." Indian Journal of Public Adniniatration 3 (1988), pp. 755-774.

Bendix, R. and S.M. Lipset. "Karl Marx's Theory of Social Clasees." In R. Bendix and S.M. Lipset, eds. Clage, status, and Power: Social Stratification in Comparative Perspective, pp. 6-11. New York: The Pree Press, 1966 [1953].

Bendix, R. "What is Modernization?" In W.A. Beling and G.0. Totten, eds. Developing Nations: Quest for sodel, pp. 3-20. New York: van Nostrand Reinhold, 1970.

Bendix, R. "What Max Weber Means to Me?" In R.M. Glassean and v. Murvar, eds. Max Neber's Political Sociology: a Pessigistic Vigion of a Rationalized World, pp. 13-24. Westport: Greenwood Press, 1984.

Bennell, P. "British Industrial Investment in Sub-Saharan Africa: Corporate Responses to Econonic Crisis in the 1980s." Developnent Policy Review 2 (1990), pp. 155-177.

Bennett, V. and A.H.M. Kirk-Greene. "Back to the Barracks: A Decade of Marking Tine." In K. Panter-Brick, ed. Soldiers and 0il: the Political Transfornation of Nigeria, pp. 13-26. London: Frank Cass, 1978.

Berg, E.J. "Real Income Trends in West Africa, 1939-1960." In M.J. Herskovits, and M. Harwitz, eds. Econonic Transition in Africa, pp. 199-238. Evanston: Northwestern University Press, 1964.

Berg, R. and J.S. Whitaker, eds, Strategies for African Developelezt. Berkeley and Los Angeles: University of California Press, 1936.

Berger, M. Industrialization Policies in Nigerie. Müchen: Weltforun Verlag, 1975.

Berger, P.L. The Capitsliat Revolution: fifty Propositions about Prosperity, Equality and Liberty. New York: Basic Books, 1986.

Berlin, I. The Crooked Tiber of Hunanity: Chapters in the History of Ideas. H. Hardy, ed. London: Murray, 1990.

Berman, B. "Structures and Progress in the Bureaucratic states of Colonial Africa." Developent and Change 2 (1984), pp. 161-202.

Berry, S.S. "Christianity and the Rise of Cocoa-Growing in Ibadan and Ondo." Journal of the Historical Society of Niseris 3 (1968), pp. $439-451$.

Berry, S,S. "Cocos and Econonic Developent in Western Nigeria." In C.K. Eicher and C. Liedholn, eds. Growth and Developent 
of the Nigerian Econony, pp. 16-29. East Lansing: Michigan State University, 1970.

Berry, S.S. and C. Liedhole. "Perforance of the Nigerian Economy, 1950-1962." In C.K. Eicher and C. Liedholn, eds. Growth and Developnent of the Nigerian Fconony, pp. 67-85. East Lansing: Michigan State University, 1970.

Bery, S.K. "Econosic Policy Reform in Developing Countries: The Role and Managenent of Political Factors." World Developent 8 (1990), pp. 1123-1131.

Bhagwati, J.N. "Directly Unproductive, Profit-Seeking (DUP) Activities." Journal of Political Econony 5 (1982), pp. 988-1002.

Bhagwati, J.N. "DuP Activities and Rent-Seeking." Kyklos 4 (1983), pp. 634-637.

Bhagwati, J.N., R.A. Brecher and T.N. Srinivasan. "DUP Activities and Economic Theory." In D.C. Colander, ed. Neoclsssical Political Economy, pp. 17-32. Cambridge: Ballinger, 1984.

Bhatnagar, P.S. "Planning and Adainistrative Development." Indian Journal of Public Administration 2 (1985), pp. 308-320.

Bialer, S. "The Death of Soviet Conunism." Foreign Affairs 5 (1991), pp. 166-181.

Bienefeld, M. "The International Context for National Development Strategies: Constraints and Opportunities in a Changing World." In $M$. Bienefeld and $M$. Godfrey, eds. The Strughle for Development: National Strategies in an International Context, pp. 25-64. Chichester: Wiley, 1982.

Bienen, H. and V.P. Diejomaoh, eds. The Political Economy of Income Distribution in Nigeria. New York: Holt \& Meier, 1981.

Biersteker, T.J, Distortion or Developent: Contending Perspectives on the Multinational Corporation. Cambridge: Massachusetts Institute of Technology Press, 1978.

Biersteker, T.J, Multinationals, the State, and Control of the Nigerian Economy. Princeton: Princeton University Press, 1987.

Biersteker, T.J. "Indigenization and the Nigerian Bourgeoisie: Dependent Developeent in an African Context." In P.M. Lubeck, ed. The African Bourgeoisie: Capitalist Developent in Nizeria. Kenve and the Ivory Coast, pp. 249-279. Boulder: Lynne Rienner, 1987a.

Biersteker, T.J. "Reducing the Role of the State in the Econony: A Conceptual Exploration of IMF and World Bank Prescriptions." International Studies Puarterly 4 (1990), pp. 477-492. 
Black, J.E., J.S. Colenan and L. 3tifel, eds, Education and Training for Public sector Mansenent in Developins Countries. New York: Rockefeller Foundation, 1977.

Blaisdel1, W. "Defining 'National Developaent': A Proposal." International Developent Review 2 (1970), pp. 39-40.

Blitz, L.F., ed. The Politics and Adninistration of Niserian Governgent. London: Sweet and Maxwell, 1965.

Bloch, E. Das Prinzip Hoffnung. Frankfurt: Suhrkanp Verlag, 1979 [1959; written 1938-1947].

Blonström, M. and B. Hettne. Developnent Theory in Transition. London: Zed Books, 1984.

Blumenthal, W.M. "The World Econony and Technological Change." Foreign Affairs 3 (1988), pp. 529-550.

Blunt, P. Organizational Theory and Behaviour: An African Perspective. London and New York: Longman, 1983.

Boahen, A.A. "The Colonial Era: Conquest to Independence." In L.H. Gann and P. Duignan, eds. Colonialign in Africa 1870-1960, Vol. 2: The History and Politics of Colonialian 1914-1960, pp. 503-524 Canbridge: Cambridge University Press, 1970.

Boahen, A.A. "Politics and Nationalism in West Africa." In A.A Boahen, ed. General History of Africa, Vol. VII: Africa under Colonial Domination, pp. 624-647. Paris: UNESCO, 1985.

Bolsover, A. "Nigeria: The Way ahead for Agriculture." Africa Report 1 (1982), pp. 17-19.

Booth, D. "Marxism and Development Sociology: Interpreting the Impasse." World Development 7 (1985), pp. 761-787.

Bovill, E.W. The Gold Trade of the Moors. London: Oxford University Press, 1968.

Bower, B. "The Mining Industry." In M. Perhan, ed. The Native Econonies of Nizeria: the Econonics of a Tropical Dependency, Vol. 2, pp. 1-42. London: Faber \& Faber, 1948.

Braibanti, R. "Transnational Inducenent of Adninistrative Refurm." In J.D. Montgonery and W.J. Siffin, eds. Approachen to Develapment: Politics, Adninistration and Chanse, pp. 133-183. New York: McGraw-Hill, 1966.

Braibanti, R. "External Inducement of Political-Adninistrative Developnent: An Institutional Strategy." In R. Braibanti, ed. Political and Adninintrative Developnent, pp. 3-106. Durhan: Duke University Press, 1969. 
Brandt Comeission. North-South: A Progranne for Survival. London: Pan Books, 1980.

Brandt Comission. Conen Crisis - North-South: Co-operation for World Recovery. London: Pan Books, 1983.

Bratton, M. "Patterns of Developnent and Underdevelopaent." International studieg Quarterly 3 (1982), pp. 333-372.

Bratton, M. "Beyond the State: Civil Society and Associational Life in Africa." World Politicg 3 (1989), pp.407-430.

Braudel, F. Afterthoughts on Material Civilization and Capitalign. Baltinore: Johns Hopkins University Press, 1977.

Braudel, F. Civilization and Capitalise 15th-18th Century, Vol. 2: The Wheels of Conmerce. New York: Harper Row, 1982 [1979].

Braudel, F. Civilization and Capitalige 15th-18th Century, Vol. 3: The Perspective of the World. New York: Harper Row, 1984 [1979].

Brecht, A. Politische Theorie. Tübingen: Mohr Verlag, 1976 [1959].

Brenner, R. "Agrarian Class Structure and Econonic Developnent in Preindustrial Europe." Past and Present 70 (February 1976), pp. 30-75.

Brenner, R. "The Origins of Capitalist Development: a Critique of Neo-Smithian Marxism." New Left Review 104 (1977), pp. 25-92.

Brent, R.S. "Aiding Africa." Foreign Policy 80 (1990), pp. 121-141.

Bretton, H.L. Bower and Stability in Nigeria: the Politics of Decolonization. New York: Praeger, 1962.

Bretton, H.L. Power and Politics in Africs. Chicago: Aldine Publishing Company, 1973.

Brown, D. "Bureaucracy as an lssue in Third World Managenent: An African Case Study." Public Adninistration and Developnent 4 (1989), pp. 369-380.

Brown, L.R. and E.C. Wolf. "Reversing Africa's Decline." Worldwatch Paper 65. Washington: Worldwatch Institute, 1985.

Browne, R.S. "Evaluating the World Bank's Major Reports: A Review Essay." Issue 2 (1988), pp. 5-10.

Brownsberger, $W$. "Development and Governmental Corruption Materialise and Political Fragmentation in Nigeria." The Journsl of Modern African Studies 2 (1983), pp. 215-233. 
Bruton, H. "Inport Substitution." In H.B. Chenery and T.N. Srinivasan, eds. Handbook of Developnent Bcononica, Vol. 2, pp. 1601-1644. Ansterdan: Elsevier Sciences Publishers, 1989.

Burnhan, J. The Manaterial Revolution. Bloonington: Indiana University Press, 1960 [1941].

Burns, A. History of Niseris. London: Allen Unwin, 1972 [1929].

Bylinsky, G. "The Race to the Autonated Factory." Fortune 4 (21 February 1983), pp. 52-64.

Caiden, G.E. "International Consultants and Developent Adninistration." International Review of Adninistrative Sciences 1 (1976), pp. 1-7.

Caiden, G.E. "Developeent, Administrative Capacity and Adainistrative Reform." International Review of Adninistrative Sciences 4 (1973), pp. 327-344.

Caiden, N. and Wildavsky, A. Planning and Budgeting in Poor Countries. New York: Wiley, 1974.

Callaghy, T.M. "The State as Lame Leviathan: The Patrimonial State in Africa." In 2. Ergas, ed. The African State in Transition. pp. 87-116. London: Macaillan, 1987.

Callaghy, T.M. "The State and the Developnent of Capitalisn in Africa: Theoretical, Historical and Conparative Reflections." In D. Rothchild and N. Chazan, eds. The Precarious Balance: State and Society in Africa, pp. 67-99. Boulder: Westview, 1988a.

Callaghy, T.M. "Debt and Structural Adjustment in Africa: Realities and Possibilities." Issue 2 (1988b), pp. 11-18.

Callaghy, T.M. "Lost Between State and Market: The Politics of Economic Adjustment in Ghana, Zambia, and Nigeria." In J.M. Nelson, ed. Econopic Crjais and Policy Choice: The Politics of Econonic Adjustnent in the Third Vorld, pp. 257-319.

Princeton: Princeton University Press, 1990.

Callaghy, T.M. and E.J. Wilson III. "Africa: Policy, Reality, or Ritual?" In R. Vernon, ed. The Pronise of Privatisation: a Challenge for U.S. Policy, pp. 179-230. New York: Council on Foreign Relations, 1988.

Callaway, A.A. "Connents on Professor Ogunsheye's Paper." In A.A. Ayida and H.M.A. Onitiri, eds. Reconstruction end Developent in Nigeria: Proceedings of Netional Conference, pp. 685-690. Ibadan: Oxford University Press, 1971. 
Campbell, A.K. "Aray Reorganization and Military Withdrawal." In K. Panter-Brick, ed. Soldiers and 0il: the Political Transfornation of Nizerie, pp. 58-100. London: Frank Cass, 1978.

Caneron, D. "1934: Caneron's Policy of Indirect Adninistration." In A.H.M. Kirk-Greene, ed. The Principle of Native Adninistration in Niseria: Selected Docunents 1900-1947, pp. 193-225. London: Oxford University Prese, 1961.

Caporaso, J. "Dependency Theory: Continuities and Discontinuities in Development Studies." International studies Puarterly \& (1980), pp. 605-628.

Caporaso, J. "The State's Role in Third World Econonic Growth." Annals of the Anerican Academy of Political and Social Science 459 (1982), pp. 103-111.

Cardoso, F.H. "Dependency and Developent in Latin Anerica." New left Review, 74 (1972), pp. 83-95.

Cardoso, F.H. "Associated-Dependent Developnent: Theoretical and Practical Inplications." In A. Stepan, ed. Authoritarian Brazil: Origins, Policies and Futures, pp. 142-176. New Haven: Yale University Press, 1976 [1973].

Cardoso, F.H. and E. Faletto. Dependency and Developnent in Latin Aperica. Berkeley and Los Angeles: University of California Press, 1978 [1971].

Carnoy, M. The State and Political Theory. Princeton: Princeton University Press, 1984.

Carter, G.M. and P. O'Meara, eds. African Independence; The First Twenty-Five Year. Bloonington: Indiana University Press, 1985

Cassen, R. and Associates. Does Aid work? Report to an Intergovernmental Tagkforce. Oxford: Clarendon, 1986.

Castellino, G. "Une analyse organisationelle de la corruption dans la fonction publique en Afrique sub-saharienne." Cahiers africaing d'adpinistration publique 25 (1985), pp. 27-63.

Central Bank of Nigeria. Annual Reports and Statenent of Accounts. Lagos: Central Bank of Nigeria, various years.

Central Bank of Nigeria. Econonic and Financisl Review. Lagos: Central Bank of Nigeria, various years.

Chabal, P., ed. Political Donination in Africs: Reflections on the Linits of Power. New York: Canbridge University Press, 1986.

Chazan, N. "The New Politics of Participation in Tropical Africa." 
Conparative Politics 2 (1982), pp. 169-189.

Chazan, N. "Planning denocracy in Africa: a conparative perapective on Nigeria and Ghana." Pelicy Sciences 3-4 (1989), pp. 325-358.

Chenery, H.B. Structural Chante and Developnent Policy. New York: Oxford University Press, 1979.

Chenery, H., S. Robinson, and M. Syrquin. Induatrialisation and Growth: A Conparative Study. New York: Oxford University Press for the World Bank, 1986.

Chenery, H.B. and T.N. Srinivasan, eds. Handbook of Developnent Econonics, 2 vols, Ansterdan: Elsevier Sciences Publishers, 1988 \& 1989 .

Chirot, D. "The Rise of the West." Anerican Socielogical Review 50 (1985), pp. 181-195.

Chosky, A.M. "state Intervention in the Industrialization of Developing Countries: Selected I s8ues." World Bank Staff Working Paper 341 (1979).

Chwala, R.L. "Oil and Economic Development of Nigeria." India Quarterly 3-4 (1987), pp. 247-266.

Claphan, C., ed. Private Patronage and Public Power: Political Clientelise in the Modern State. London: Frances Pinter, 1982.

Clark, P.B. "Economic Planning for a Country in Transition: Nigeria." In E. E. Hagen, ed. Planning Econonic Develepant, pp. 255-258. Homewood: Irwin, 1963.

Cliffe, L. "The Debate on African Peasantries." Develoonent and Change (1987), pp. 625-635.

Clough, P. and G. Willians. "Decoding Berg> the World Bank in Northern Nigeria." In M. Watts, ed. State, Oil and Axriculture in Nigeria, pp. 168-201. Berkeley: Institute of International Studies, 1987.

Coase, R.H. "The Lighthouse in Econonics." In T. Cowen, ed. The Theory of Market Failure: A Critical Exanination, pp. 255-277. Fairfax: George Mason University Press, 1988.

Cockcroft, L. Africs's Way: A Journey fron the Past. London: I. B. Tauris, 1990.

Coe, R. and C. Wilber, eds. Capitalian and Denocracy: Schunpeter Revisited. Notre Dane: University of Notre Dane Press, 1985.

Cohen, G.A. Karl Marx's Theory of Hiatory: a Defence. Princeton: Princeton University Press, 1978. 
Cohen, J.M. "Land Tenure and Rural Developnent in Africa." In R. Bates and $M$. Lofchie, eds. Asricultural Develonent in Africe: Issues of Public Policy, pp. 349-400. New York: Praeger, 1980.

Cohen, R. "Conflict and Change in a Northern Nigerian Eairate." In G. 2011schan and W. Hirsch, eds. Explorations in Social Chanse, pp. 109-124. Boston: Houghton Mifflin, 1964.

Cole, T. "Bureaucracy in Transition: Independent Nigeria" Public Adninietration Vol. 37 (Winter 1960), pp.321-337.

Cole, T. "Energent Federalian in Nigeria." In The Nicerian Political Scene, pp.45-62. R.0. Tilman and T. Cole, eds. Durham: Duke University Press, 1962

Coleman, J.S. Nigeria: a Backround to Nationalisn. Berkeley \& Los Angeles: University of California Press, 1965 [1958].

Coleman, J.S. and C. Halisi. "Anerican Political Science and Tropical Africa: Universalisn v8. Relativisn." African Studieg Review 3-4 (1983), pp. 25-62.

Collier, P. "Oil and Inequality in Rural Nigeria." In D. Ghai and S. Radwan, eds. Asrarian Policies and Rural Poverty in Africa, pp. 191-217. Geneva: ILO, 1983.

Collier, P. "Oil Shocks and Food Security in Nigeria." International Labour Review 6 (1988), pp. 761-782.

Collier, P. "Africa's External Econonic Relations: 1960-90." African Affairs 330 (1991), pp. 339-356.

Collins, P. "The Political Econony of Indigenization: The Case of the Nigerian Enterprises Pronotion Degree." The African Review (1974), pp. 491-508.

Collins, P. "Public Policy and the Development of Indigenous Capitalisa." The Journal of Connonwealth and Conparative Politics 2 (1977), pp. 127-150.

Collins, P. "The State and Industrial Capitalise in West Africa." Development and Change 3 (1983), pp. 403-429.

Collins, R. "Weber's last Theory of Capitalise: A Systenatization." Anerican Sociological Review 6 (1980), pp. 925-942.

Collins, R.0., ed. Problens in the History of Colonis Africa: 1860-1960. Englewood Cliffs: Prentice Hall, 1970.

Colson, E. "African Society at the Tibe of the Scramble." In L.H. Gann and P. Duignan, eds. Colonialian in Africa 1870-1960, Vol. 1: The History and Politics of Colonielis 1870-1914, 
pp. 27-65. Canbridge: Cambidge University Press, 1969.

Cook, P. and C. Kirkpatrick, eds. Privatisation in Lese Developed

Countries. New York: St. Martin's Press, 1988.

Cookey, S.J.S. "Colonialism and the Process of Underdevelopment in Nigeria: A Review." Journal of Astan and African Studies 1-2 (1979), pp. 19-31.

Cooper, F. "Africa and the World Econony." Africen Studieg Review 2-3 (1981), pp. 1-86.

Comeittee on Education and Hunan Resource Developnent, Nigeria Project Task Force. Nigerien Hunan Resource Developnent and Utilization. New York: Education and World Affairs, 1967.

Corbridge, S. "Post-Marxism and Developnent Studies: Beyond the Inpasse." World Development 5 (1990), pp. 623-639.

Corden, W.M. Inflation. Exchanse Rates, and the World Econony. Chicago: University of Chicago Press, 1981 [1977].

Corden, W.M. and P.J. Neary. "Booning Sector and De-industrialisation in a snall open Econony." The Econonic Journal Vol. 92 (December 1982), pp. 825-848.

Cortes, F., A. Przeworski and J. Sprague. Systeng Anslysis for Social Scientists. New York: Wiley, 1974.

Cowen, T. The Theory of Market Failure: A Critical Exanination. Fairfax: George Mason University Press, 1988.

Crocker, W.R. Niferis: A Critique of British Colonial Adninistration. London: Allen and Unwin, 1936.

Crowder, M. "The White Chiefs of Tropical Africa." In L.H. Gann and $P$. Duignan, eds, Colonialign in Africe 1870-1960, Vol. 2: The History and Politics of Colonialisn 1914-1960, pp. 320-350. Canbridge: Cambridge Univeraity Press, 1970.

Crowder, M. The Story of Nigeria. London: Faber \&aber, 1980 [1962].

Crowder, M. West Africs under Colonisl Rule. London: Hutchinson University Library for Africa, 1981 [1968].

Crozier, M. The Buresucratic Phenonenon. Chicago: University of Chicago Press, 1964.

Cruise O'Brien, C. "Paradise Lost." The New York Review of Books 8 (25 April 1991), pp. 52-60.

Dahrendorf, R. The Modern Socisl Conflict. London: Weidenfeld and Nicolson, 1988 . 
Danachi, U.G. Nigerian Modernization: The Colonial Legecy. New York: The Third Press, 1972.

Davidson, B. Africa in Modern Hietory: the Search for a New Society. Harmondsworth: Penguin, 1981 [1978].

iaan, E. "Nonecononic Barriers t, Effective Planning in Nigeria, 1962-66." Econoric Developent and Cultural Change 4 (1971), pp. 560-579.

Dean, E. Plan Inc'enentation in Nigeria: 1962-1966. Ibadan: Oxford University Press, 1972.

Decraene, P. "La corruption en Afrique noire." Pouvoirg 31 (1984), pp. 95-104.

De Gregori, T. Technolog: and the Econonic Developnent of the Tropical African Frontier. Cleveland: Case Western Reserve University Press, 1969 [1965].

Dent, M. and D. Austin, eds. Operation of the Nigerian Political System under the Second Republic. Manchester: Munchester University Press, 1981.

Diakosavvas, D. and P.L. Scandizzo. "Trends in the Teras of Trade of Primary Commodities, 1900-1982: The Controversy and Its Origins." Economic Developent and Cultural Change 2 (1991), pp. 231-264.

Devisse, J. with S. Labib. "Africa in inter-continental Exchanges." In D.T. Niane, ed. General History of Africa, Vol. IV: Africs from the Trelfth to the sixteenth Century, pp. 635-672. Paris: UNESCO, 1984.

Diamond, L. "Cleavage, Conflict, and Anxiety in the Second Nigerian Republic." The Journal of Modern African Stildies 4 (1982), p. 629-668.

Diamond, L. "Nigeria in Search of Democracy." Fol gign Affairs 4 (1984), pp. 905-927.

Diamond, L. "Nigeria Update." Eoreign Affairs 2 (1985), pp. 326-336.

Diamond, L. "Nigeria Between Dictatorship and Dewocracy." Current History 520 (1987a), pp. 201-204 and 222-224.

Diamond, L, "Class Fornation in the Swollen African State." The Journal of Modern African Studies 4 (1987b), pp. 567-596.

Diamond, L. "Nigeria: Pluralism, Statisn and the Struggle for Denocracy." In L. Diamond, J.J. Linz and S.M. Lipset, eds. Democracy in Developing Countries, Vol. II: Africa, pp. 33-91. Boulder: Lynne Rienner, 1988. 
Diamond, L. "Fiction as Political Thought." (Review Essay of Chinua Achebe's novel Anthills of the Savannah) African Afrairs 352 (1989), pp. 435-445.

Dichter, T.W. "Development managenent: plain or fancy? Sorting out some nuddles." Public Adninistration and Development 4 (1989), pp. 381-393.

Diejomaoh, V.P. and E.C. Anusionwu. "The Structure of Incone Inequality in Nigeria: A Macro Analysis." In H. Bienen and V.P. Diejonaoh, eds. The Political Econony of Incone Distribution in Nigeria, pp. 89-125. New York: Holt \& Meier, 1981.

Diké, K.0. Trade and Politics in the Niger Delta 1830-1885. Oxford: Clarendon Press, 1956.

Dillard, D. "Capitalism." In C. Wilber, ed. The Political Econony of Development and Underdevelopeent, pp. 87-95. New York: Randon House, 1988 [1973].

Djilas, M. The New Class: An Analysis of the Connunist Systen. New York: Praeger, 1962 [1957].

Dobb, M. Studies in the Development of Capitalign. New York: International Publisher, 1981 [1947].

Doob, L.W. "Facilitating Rapid Change in Africa." In A. Rivkin, ed. Nations by Design: Institution Building in Africa, pp. 333-386. New York: Doubleday, 1968.

Doornbos, M. "The African State in Acadenic Debate: Retrospect and Prospect." The Journal of Modern African Studies 2 (1990), pp. 179-198.

Dorner, P. Land Reform and Economic Developyent. Kingsport: Kingsport Press, 1972.

Dos Santos, T. "The Structure of Dependence." Anerican Econonic Review 2 (1970), pp. 231-236.

Drucker, P.F. "The Emerging Theory of Manufacturing." Harvard Business Review 3 (1990), pp. 94-102.

Dudley, B.J. An Introduction to Nigerian Government and Politics. Bloomington: Indiana University Press, 1982.

Duignan, P. and R.H. Jackson, eds. Rolitics and Governnent in African States 1960-1985. London: Croon Hela, 1986.

Dunleavy P. and B. O'Leary. Theories of the state: The Practice of Liberal Denocracieg. Houndnills: Macnillan Education, 1987. 
Dunn, J., ed. West African stateg: Failure and Pronige. Cabridge: Cambridge University Press, 1978.

Durotoye, $Y$. "The Civil Service in the Nigerian Presidential Systee of Government." Indian Journal of Public Adninistration 4 (1982), pp. 802-813.

Duvall, R., S. Jackson, B.M. Russett, D. Snidal and D. Sylvan. "A Foreal Model of 'Dependencia Theory': Structure and Measureaent." In R.L. Merritt and B.M. Russett, eds. Fron National Developnent to Global Conunity: Essays in Honor of Karl W. Deutsch, pp. 312350. London: Allen \& Unwin, 1981.

Duvall, R. and J. Freenan. "The State in Dependent Capitalisa." International Studies Puarterly 1 (1981), pp. 99-118.

Duvall, R. and J. Freenan. "The Techno-Bureaucratic Elite and the Entrepreneurial State in Dependent Industrialization." American Political Science Review 3 (1983), pp. 569-587.

Easton, D. "An Approach to the Analysis of Political Systens." World Politicg 3 (1957), pp. 383-400.

Easton, D. A Framework for Political Analysis. Englewood Cliffs: Prentice Hall, 1965.

Easton, D. "The Political Systen besieged by the State." Political Theory 3 (1981), pp. 303-325.

Economist Intelligence Unit. Nigeria Country Report: Analysis of Economic \& Political Trends every Quarter. London: EIU, quarterly.

Economist Intelligence Unit. Nigeria Country Profile: Annual Survey of Political and Economic Background. London: EIU, annually.

Edogun, E.E. "The Structure of State Capitalisn in the Nigerian Petroleum Industry." In C.Ake, ed. Political Econony of Nigeria, pp.89-112. London and Lagos: Longman, 1985.

Echerua, M.J. Victorian Lagos: Aspects of nineteenth Century Lagos L1fe. London: Macnillan Press, 1977.

Edozien, E.C. "The Development Decade in Africa: A Prelininary Appraisal." The Nizerian Journal of Econonic and Social Studies 1 (1972), pp. 77-92.

Edwards, S. "Equilibriun Real Exchange Rate." In G.M Meier and W.F. Steel, eds. Industrial Adiustnent in Sub-Saharan Afric日, pp. 266-270. New York: Oxford University Press, 1989.

Ehrlich, C. "Building and Caretaking: Econonic Policy in British Tropical Africa, 1890-1960." Econonic History Review 4 (1973), pp. 649-667. 
Eicher, C.K. "The Dynanics of Long-Tern Agricultural Developnent in Nigeria." In C.K. Eicher and C. Liedhola, eds. Growth and Developnent of the Nigerian Econony, pp. 6-15. East Lansing: Michigan State University Press, 1970.

Eisen, A. "The Meanings and Confusions of Neberian 'Rationality."" British Journal of Sociology 1 (1978), pp. 57-70.

Eisenstadt, S.N. "Bureaucracy and Political Development." In J. LaPalonbara, ed. Bureaucracy and Political Developent, pp. 96-119. Princeton: Princeton University Pres8, 1963.

Eisenstadt, S.N. "Reflections on a Theory of Modernization." In A. Rivkin, ed. Nations by Design: Institution Building in Africa, pp.35-61. New York: Doubleday, 1968.

Ekeh, P. "Colonialise and the two publics in Africa: a theoretical statement." Conparative Studies in Society and History, 1 (1975), pp. 91-112.

Ekekwe, E.N. "State and Econonic Development in Nigeria." In C. Aké, ed. Political Econony of Nigerie, pp. 53-70. London: Longman, 1985.

Eker, V. "On the Origins of Corruption: Irregular Incentives in Nigeria." The Journal of Modern African Studies 1 (1981), pp. 173-182.

Ekundare, R.O. An Econonic History of Nigeria 1860-1960. New York: Africana, 1973 .

Elliott, C. The Pains of Ungrowth in Africa. Unpublished manuscript. February 1983.

Elsenhans, H. Abhängizer Kapitalisnus oder bürokratische Entwicklungsgesellschaft: Versuch über den stast in der Dritten Welt. Frankfurt 2 New York: Canpus Verlag, 1981.

Elsenhans, H. "Rising Mass Incoses as a Condition of Capitalist Growth: Implications for the World Econony." International Organization 1 (1983), pp. 1-34.

Elsenhans, H. "Der periphere Stant: Zun Stand der entwicklungstheoretischen Diskussion." Politische Vierteliahresschrift Sonderheft 16 (1985), pp. 135-156.

Elsenhans, H. "Dependencia, Unterentwicklung und der Staat in der Dritten Welt." Rolitische Vierteliahresschrift 2 (1986), pp. 133-158.

Elster, J. "Clearing the Decks." Ethics (July 1981), pp. 634-644. 
Emerson, R.M. "Power-Dependence Relations." Anerican Sociological Review 1 (1962), pp. 31-41.

Eamanuel, A. Unequal Exchange: A Study of the Inperialign of Trade. New York: Monthly Review Press, 1971 [1969].

Engels, F. "Herrn Eugen Dihrings Unwälzung der Wissenschaft (Anti Dühring)." In Karl Marx - Friedrich Ensels Weri-i, Vol. 20, pp. 5-292. Berlin: Dietz Verlag, 1968 [1878].

Engels, F. "Entwicklung des Sozialisnus von der Utopie zur Wissenschaft." In Karl Yarx - Friedrich Engels: Ausgewählte Schriften in zwei Bänden, Vol, 2, pp. 80-140. Berlin: Dietz Verlag, 1977 [1880].

English, M.C. An Outline of Nigerian History. Ikeja: Longman, 1959.

Ergas, Z., ed. The African State in Transition. London: Macmillan, 1987.

Esman, M.J. "Foreign Aid: Not by Bread Alone." Public Adninistration Review 1 (1971), pp. 92-100.

Esman, M.J. "The Politics of Developnent Adninistration." In J.D. Montgomery and W.J. Siffin, eds. Approsches to Developrent: Politics, Adninistration and Change, pp. 59-112. New York: McGraw-Hill, 1966.

Etuk, E.J. "Middle Managers in Cross River State of Nigeria Public Service: A Study of their Job Attitude and Work Role Involvement." Indian Journal of Public Adninistration 4 (1981), pp. 993-1005.

Evans, D. "Alternative Perspectives on Trade and Developaent." In H.B. Chenery and T.N. Srinivasan, eds. Handbook of Development Econonics, Vol. 2, pp. 1241-1304. Ansterdan: Elsevier Sciences Publishers, 1989.

Evans, P. Dependent Developent: The Alliance of Nultinational. State, and Local Capital in Braril. Princeton: Princeton University Press, 1970.

Evans, P.B. "Predatory, Developnental, and Other Apparatuses: A Comparative Political Econony Perspective of the Third World State." Sociolosical Forun 4 (1989), pp. 561-587.

Evans, P., D. Ruescheneyer and T. Skocpol. "On the Road toward a More Adequate Understanding of the State." In P. Evans, D. Rueschemeyer and T. Skocpol, eds. Bringing the state Back In, pp. 347-366. New York: Cambridge University Press, '85.

Faal and, J. and J.R. Parkinson. Political Econony of Developnent. London: Frances Pinter, 1986. 
Fabbrini, S. "The Return of the State: Critiques." Anerican Politiral Science Review 3 (1988), pp. 891-901.

Fajana, O. "Inport Licensing in Nigeria." Developent and Change $4(1977)$, pp. 509-522.

Fallers, L.A. "Social Stratification and Econonic Processes in Africa." In R. Bendix and S.M. Lipset, eds. Clags, Status. and Power: Social Stratification in Conparative Perspective, pp. 141-149. New York: The Free Pres8, 1966 [1964].

Falola, T. and J.O. Ihonvbere. The Rise and Fall of Nigeria's Second Republic: 1979-1984. London: Zed Books, 1985.

Falola, T. and J.0. Ihonvbere, eds. Nigeria and the International Capitalist Syster. Boulder: Lynne Rienner, 1988.

Famoriyo, S. "Land Ownership and Control in Nigeria: Inplications of the Land Use Act for Nigeria's Political Econony." In Nigerian Economic Society. The Nigerian Econony: a Political Econony Approach, pp. 126-141. London: Longnan, 1986.

Fanon, F. The Wretched of the Earth. New York: Grove Press, 1968 [1961].

FAO (Food and Agriculture Organization of the United Nations). FAO Production Yearbook. Rone: FAO, various years.

FAO (Food and Agriculture Organization of the United Nations). FAO Trade Yearbook. Rone: FAO, various years.

Farid, S.M. "Public Enterprises in Nigeria." Journal of Administration Overgeas 1 (1980), pp. 47-51.

Feder, G. and D. Feeny. "Land Tenure and Property Rights Rights: Theory and Implications for Development Policy." The World Bank Economic Review 1 (1991), pp. 135-153.

Federal office of Statistics [Nigeria]. Annual Abatract of Statisticg. Lagos: Federal office of Statistics, various years.

Federa] of $f$ ice of statistics [Nigeria]. Digest of Statistics. Lagos: Federal Office of Statistics, various years.

Federal office of Statistics [Nigeria]. Econonic and Sociel Indicators, Lagos: Federal office of Statistics, various years.

Federal office of Statistics [Nigeria]. Econonic and Social Statigtics Bulletin. Lagos: Federal office of statistics, various years.

Federal office of Statistics [Nigeria]. Industrial Survey of Nizeris 1963. Lagos: Federal office of Statistics, 1966. 
Federal Office of Statistics [Nigeria]. Industrial survey of Nigerie 1975-1978. Lagos: Federal Office of Statistics, 1982.

Federal office of Statistics [Nigeria]. Trade Sunnary. Lagos: Federal office of statistics, various years.

Feit, E. "Military Coups and Political Development: Sone Lessons Iron Ghana and Nigeria." World Politics 2 (1968), pp. 179-193.

Feit, E. The Arned Bureaucrats: Military-Adninistrative Resines and Political Developent. Boston: Houghton Mifflin, 1973.

Fitzpatrick, J.F.J. "Nigeria's Curse: Indirect Rule." In R.O. Collins, ed. Problens in the History of Colonial Africa: 18601960, pp.118-124. Englewood Cliffs: Prentice Hall, 1970.

Fletcher, F.J. "The Executive Class in Nigeria: Introduction, Problems, Prospects." In D.J. Murray, ed. Studieg in Nigerian Administration, pp. 140-176. London: Hutchinson, 1970.

Flint, J.E. Sir George Goldie and the Making of Nigeria. London: Oxford University Press, 1960.

Flint, J.E. "Nigeria: the Colonial E:perience fron 1880-1914." In L.H. Gann and P. Duignan, eds. Colonialign in Africa 1870-1960, Vol. 1: The History and Politics of Colonialise 1870-1914, pp. 220-260. Canbridge: Canbridge University Press, 1969.

Forde, D. "The Rural Econonies." In M. Perhan, ed. The Native Econonies of Nigeria: the Dcononics of a Tropical Dependency, Vol. 1, pp. 29-215. London: Faber \& Faber, 1946.

Forrest, T. "Recent Developnents in Nigerian Industrialization." In M. Fransman, ed. Industry and Accunulation in Africa, pp. 324-344. London: Heinemann, 1982.

Forrest, T. "The Political Econony of Civil Rule and the Econonic Crisis in Nigeria (1979-84)." Review of African Political Economy 35 (1986), pp. 4-26.

Forrest, T. "State Capital, Capitalist Developent and Class Formation in Nigeria." In P.M. Lubeck, ed. The African Bourgeoisie: Capitalist Develonent in Nizerias Kenvs and the Ivory Coast, pp. 307-342. Boulder: Lynne Rienner, 1987.

Francis, P. "'For the Use and Conmon Benefit of all Nigerians': Consequences of 1978 Land Nationaliration." Africa 3 (1984, pp. 5-28.

Frank, A.G. Capitalisn and Underdevelopnent in Latin Anerica: Higtorical Studies of Chile and Braril. New York: Monthly Review Press, 1967 . 
Frank, A.G. Lunpenbourseoisie: Lunpen Developnent. Dependence, Class and Politics in Latin Anerics. New York: Monthly Review Press, 1972a.

Frank, A.G. "The Development of Underdevelopment." In J.D. Cockcroft, A.G. Frank and D.L. Johnson. Dependence and Underdevelopnent: Latin Anerice's Political Econony, pp. 3-17. Garden City: Anchor Books, $1972 b$.

Frankel, S.H. Capital Investnent in Africa: Its Course and Effects. London: Oxford University Press, 1938.

Franks, T. "Bureaucracy, Organization, Culture and Development." Public Administration and Developnent 4 (1989), pp. 357-368.

Frbayo, J.A. "Swall-scale Enterprise Development Strategy: A critical Option for long-term Econonic Progress in Nigeria." Indian Journal of Econonics 277 (1989), pp. 159-175.

Freeman, J.R. "State Entrepreneurship and Dependent Developnent." Anerican Journal of Political Science 1 (1982), pp. 90-112.

Friedrich, C.J. "Political Decision-Making, Public Policy and Planning." Canadian Public Adninistration 1 (1971), pp. 1-15.

Freyhold, M.v. "The post-colonial State and its Tanzanian version." Review of African Political Econony 8 (1976), pp. 75-89.

Fromm, E. Haben oder Sein: Die seelischen Grundlagen einer neuen Gesellschaft. Stuttgart: DVA, 1976.

Galenson, W. and H. Leibenstein. "Investment Criteria, Productivity and Economic Development." Quarterly Journal of Economics 3 (1955), pp. 343-370.

Gall, L. Bismarck: Der weiBe Revolutionär. Frankfurt: Ullstein, 1980.

Galletti, R, K.D.S. Baldwin and 1.O. Dina. Nigerian Cocos Farners: An Economic Survey of Yoruba Cocoa Faraing Fanilies. Westport: Greenwood Press, 1972 [1956].

Galloway, C. "The Dikko Affair and British-Nigerian Relations." The Round Table 311 (1989), pp. 323-336.

Gana, A.T. "The State in Africa: Yesterday, Today, and Tomorrow." International Political Science Review 1 (1985), pp. 115-132.

Gann, L.H. and P. Duignan, eds. Colonialign in Africe, 1870-1960, Vol. 1: The History and Politics of Colonialisn 1870-1914. Cambridge: Cambridge University Press, 1969.

Gann, L.H. and P. Duignan, eds. Colonialign in Africe, 1870-1960, Vol. 2: The History and Politics of colonialien 1914-1960. 
Cambidge: Cambridge University Press, 1970.

Gann, L.H. and P. Duignan. "Exploitation or Developnent." In R.O. Collins, ed. Problens in the Histery of Colonial Africa: 18601960, pp.300-315. Englewood Cliffs: Prentice Hall, 1970a.

Garcia-zanor, J.C. "Micro-Bureaucracies and Development Adninistration." International Review of Adninistrative Sciences $4(1973)$, pp. 417-423.

Gboyega, A. "The Federal Character of the Attenpt to Create Representative Bureaucracy in Nigeria." International Review of Adninistrative Sciences 1 (1984), pp. 17-24.

Geary, W.N.M. Nigeria under Britigh Rule. London: Frank Cas8, 1965.

Geertz, C. Negara: The Thestre state in Nineteenth Century Bali. Princeton: Princeton University Press, 1980.

Gelb, A.H. "The Oil Syndrone: Adjustent to Windfall Gains in OilExporting Countries." In D. Lal and $M$. Wolf, eds. Stagflation, Savings, and the State: Perspectives on the Global Econony, pp. 115-130. New York: Oxford University Press, 1986.

Gelb, A.H. "Adjustment to Windfall Gains: A Conparative Analysis of Oil Exporting Countries." In J.P. Neary and S. van Wijnbergen, eds. Natural Resources and the Macroeconony, pp. $54-93$. Cambridge: The MIT Press, 1986a.

Gerschenkron, A. Economic Backwardnegs in Higtorical Perspective. Cambridge: Cambridge University Press, 1963.

Gerschenkron, A. "The Modernization of Entrepreneurship." In M. Weiner, ed. Modernigation: The Dynanics of Growth, pp. 246-257. New York: Basic Books, 1966.

Gerth, H.H. and C.W. Mills, eds. Fron Max Heber: Esgays in Sociology. New York: Oxford University Press, 1946.

Ghadar, F. "Oil: The Power of an Industry." In R. Vernon, ed. The Pronise of Privatization: a Challenge for U.S. Policy, pp. 231-253. New York: Council on Foreign Relations, 1988.

Giddens, A. "Marx, Weber, and the Development of Capitalisa." Sociology $3(1970)$, pp. 289-310.

Gide, A. Untitled essay in The God That Foiled: Six studies in Comanisp, pp. 179-198. London: Hanish Hamilton, 1950 $[1937 / 1938]$.

Gilder, G. Microcosn: The Ouantun Revolution in Econonics and Technology. New York: Sinon and Schuster, 1989. 
Gillis, M. "The Role of State Enterpriees in Econonic Developaent." Social Regearch 2 (1980), pp. 248-289.

Glickman, H. "Reflections on State-Centrise as Ideology in Africa." In 2. Ergas, ed. The African state in Transition, pp. 25-60. London: Macnillan, 1987.

Glickman, H. "The Present and Future of the African state." In H. Glickman, ed. The Crisis and Challense of African Development, pp. 23-43. Westport: Greenwood Press, 1988.

Godfrey, M. "The International Market in Skills and the Transaission of Inequality." Developnent and Change 4 (1975), pp. 5-23.

Gold, D.A., C. Lo, and E.O. Wright. "Recent Developeents in Marxist Theories of the Capitalist State." Nonthly Review 5 (1975), pp. 29-43.

Goldsworthy, D. "Civilian Control of the Military in Black Africa." African Affairs 318 (1981), pp. 49-74.

Goodse11, C.T. "The Developnent Planning Mythos and the Real World." Public Administration Review 4 (1970), pp. 454-458.

Goody, J. Technology, Tradition and the state in Africa. London: Oxford University Press, 1971.

Goody, J. Production and Reproduction: a Conparative Study of the Domestic Domain. Cambridge: Cambridge University Press, 1976.

Gordenker, L. "International Organizations and Developaent Aid," In R.S. Jordan, ed. Multinational Cooperation: Econonic, Social and Scientific Developgent, pp. 20-49. New York: Oxford, 1972.

Graf, W.D, The Nigerian State: Political Bconony, State Class and the Post-colonial Era. London: Janes Currey, 1988.

Green, R.H. and S.H. Hyner. "Cocos in the Gold Coast: A Study in the Relations between African Farners and Agricultural Experts." Journal of Economic Higtory 3 (1966), pp. 299-319.

Green, R.H. "The Role of the State as an Agent of Econonic and Social Developwent." Journal of Develophent Planning 6 (1974), pp.1-40.

Grey, Earl. The Colonial Policy of Lord John Rugsell's Adninistration. 2 vols. London: Richard Bentley, 1853.

Grindle, M.S. and J.W. Thomas. "Policy nakers, policy choices, and policy outcones: the political econony of reforn in developing countries." Policy Sciences 3-4 (1989), pp. 213-248.

Gunn, G. "Contracting Procedures: Clearing the Obstacles." Nigeria: An Africa Bcononic Dizest Special Report (May 1982), pp. 55-56. 
Gunn, G. "Investsent: A Bureaucratic Odyssey.". Nireria: An Africe Econonic Disest Special Report (May 1982), pp. 56-58.

Guyer, J. "Household and Connunity in African Studies." African Studies Review 2-3 (1981), pp. 87-137.

Hackett, P. "Nigeria: Econony." In: Africe South of the Sahara, 19th edition, pp. 775-783. London: Europa Publications, 1989.

Hailey, W.M. An African Survey: Study of Problens arising in Africe South of the Sshars. London: Oxford University Press, 1938.

Hailey, W.M. An African Survey (revised in 1956): A Study of Probleng arising in Africa South of the Sahara. London: Oxford University Press, 1957.

Hall, J.A. "Capstones and Organisas: Political Foras and the Triunph of Capitalism." Sociolosy 2 (1985), pp. 173-192.

Hallett, R. Africa to 1875: A Modern History. Ann Arbor: University of Michigan Press, 1970.

Hallett, R. Africa since 1875: A Modern History. Ann Arbor: University of Michigan Press, 1974.

Hamilton, A., J. Madison and J. Jay. The Federaligt Papers. New York: New Anerican Library, 1961 [1786-1787].

Hamilton, W.B. "The Evolution of British Policy Toward Nigeria." In R.O. Tilman and T. Cole, eds. The Nigerian Political Scene, pp. 17-41. Durhan: Duke University Press, 1962

Hance, W.A. The Geography of Modern Africa. New York: Colunbia University Press, 1975 [1964].

Handy, C. Gods of Manasement. London: Pan Books, 1979

Hansard [Nigeria, Federation of]. Parlianentary Debateg. Lagos: Government Printers, various years.

Hargreaves, J.D. Prelude to the Partition of West Africa. London: Macmillan Press, 1963.

Hargreaves, J.D. Decolonisation in Africs. London and New York: Longan, 1988.

Hargrove, E.C. The Missing Link: The Study of the Inplenentation of Socist Policy. Washington: Urban Institute, 1975.

Harnan, N. "Survey Nigeria: After the Ball." The Econonist 7444 (3 May 1986), pp. 1-35. 
Harris, R.L. "The Role of Higher Public Servants in Nigeria: As Perceived by the Western-educated Elite." In D.J. Murray, ed. Studies in Nigerian Adninietration, pp. 283-309. London: Hutchinson, 1970.

Harrison, D. The Sociolozy of Modernization and Developnent. London: Unwin Hyaan, 1988.

Hart, $K$. The Political Econony of West African Arriculture. Cambridge: Canbridge University Press, 1982.

Hawkins, E.K. "The Growth of a Money Econony in Nigeria and Ghana." Oxford Econonic Papers 3 (1958), pp. 339-354.

Hawthorn, G. "The Logic of Pessinism." The New Republic 20 (20 May 1991), Pp. 42-44.

Hay, A.M. "The Developent of Road Transportation in Nigeria." Journal of Transport History 2 (1971), pp. 95-107.

Hazzeltine, G.D. White Man in Nigeria. New York: Negro University Press, 1969.

Headrick, D.R. The Tools of Fnoire: Technology and Furopenn

Imperialism in the Nineteenth Century. New York and Oxford: Oxford University Press, 1981.

Heckscher, E.F. Mercantilige. London: Allen \& Unwin, 1955 [1931].

Hegel, G.W.F. Grundlinien der Philosophie des Rechts oder Naturrecht und Staatswissenschaft in Grundrisge. Berlin: Akadenie Verlag, 1981 [first published 1833, written 1820].

Heilbroner, R.L. Between Capitalign and Socialism: Dosays in Political Econonics. New York: Randon House, 1970.

Heilbroner, R.L. Marxigm For and Against. New York: Norton, 1980.

Helleiner, G. "The Eastern Nigeria Developaent Corporation: A Study in Sources and Uses of Public Developnent Funds 1949-1962." The Nigerian Journal of Econonic and Social studies 1 (1964), pp. 98-123.

Helleiner, G. Pessant Asriculture, Government, and Bcononic Growth in Nigeria. Honewood: Irwin, 1966.

Helleiner, G. "The Fiscal Role of the Marketing Boards in Nigerian Economic Development, 1947-1961." In C.R. Eicher and C. Liedholn, eds. Growth and Developnent of the Nirerian Econony, pp. 119-155. East Lansing: Michigan State University, 1970.

Helleiner, G. "Beyond Growth Rates and Plan Volunes - Planning in Africa in the 19708." The Journal of Modern African studien 
3 (1972), pp. 333-355.

Helleiner, G. "External Resource Flows to Sub-Saharan Africa." Background Paper for Ottawa Roundtable on "The Challenge of Africa in the 1990s," held in Ottawa on June 16-18, 1991.

Heper, M., C.L. Kin and L.-T. Pai. "The Role of Bureaucracy and Regine Types: a Conparative Study of Turkish and South Korean Civil Servants." Adninigtration and Society 2 (1980), pp. 137-157.

Herbst, J. "Political Inpedinents to Econonic Rationality: Explaining Zinbabwe's Failure to Reform its Public Sector." The Journoi of Modern African Studies 1 (1989), pp. 67-84.

Hettne, B. Development Theory and the Three Worldg. London: Longaan, 1990.

Hill, P. The Migrant Cocoa-Farnerg of Southern Ghana: a Study of Rural Capitalign. Cambridge: Cambridge University Press, 1963.

Hill, P. Studies in Rural Capitalian in West Africa. Canbridge: Cambridge University Press, 1970.

Hindess, B. and P.Q. Hirst. Precapitalist Modes of Production. London: Routledge and Kegan Paul, 1975.

Hinderink, J. and J.J. Sterkenburg. Agricultural Connercialization and Government Policy in Africs. London: KPI, 1987.

Hirsch, F. The Social Linits of Growth. London: Routledge and Kegan Paul, 1977.

Hirschman, A.0. The Strategy of Econonic Developnent. New Haven: Yale University Press, 1961 [1958].

Hirschman, A.0. Jourreys Toward Progress: Studies of Scononic PolicyMaking in Latin Anerics. New York: Twentieth Century Fund, 1963.

Hirschwan, A.O. "The Search for Paradigns as a Hindrance to Understanding." Vorld Politics 3 (1970), pp. 329-343.

Hirschman, A.0. A Bias for Hope: Bsangs on Developnent and Latin Americs. New Haven: Yale University Press, 1971.

Hirschman, A.0. "A Generalized Linkage Approsch to Development, with Special Reference to Staples." Bcononic Developnent and Cultural Change Vol. 25, Supplenent, (1977a), pp. 67-98.

Hirschman, A.O. The Passions and the Interests: Political Arrunents for Capitalise before its Triunph. Princeton: Princeton University Press, 1977b.

Hirschana, A.0. "Exit, Voice, and the State." Norld Politics 1 
(1978), pp. 90-107.

Hirschnan, A.O. Esgays in Trespasging: Econonics to Politics and Beyond. New York: Cambridge University Press, 1981a.

Hirschaan, A.O. "The Rise and Decline of Development Econonics." In A.0. Hirschman. Esgavs in Trespassing: Bcononice to Politics and Beyond, pp. 1-24. New York: Canbridge University Press, 1981b.

Hirschnan, A.O. Rival Views of Market Society and Other Recent Bsaayg. New York: Viking, 1986a.

Hirschaan, A.O. "A Dissenter's Confession: The Strategy of Economic Development Revisited." In A.O. Hirschman. Rival Views of Market Socjety and Other Recent Essays, pp. 3-34. New York: Viking, $1986 \mathrm{~b}$.

Hirschman, A.O. "Linkages in Econonic Development Revisited." In A.O. Hirschman. Rival Views of Market Society and Other Recent Essays, pp. 56-76. New York: Viking, 1986c.

Hirschman, A.O. The Rhetoric of Reaction: Perversity Futility, Jeopardy. Cambridge: Harvard University Press, 1991.

Hirschman, A.O. and M. Rothschild. "The Changing Tolerance for Economic Inequality in the Course of Econonic Developnent." Quarterly Journal of Econonics 1 (1973), pp. 544-566.

Hirschmann, D. "Development or Underdevelopment Adninistration? a further 'Deadlock."' Develeonent and Change 3 (1981), pp. 459-479.

Hobsbawm, E.J. The Age of Enpire 1875 - 1914. New York: Vintage Books, 1989 [1987].

Hobsbawm, E.J. Industry and Enpire: Fron 1750 to the Present Day. Harwondsworth: Penguin, 1990 [1968].

Hof fmann, S. "Letter to the Editors." International Security 2 (1990), pp. 191-192.

Hogendorn, J.S. "The Origins of Groundnut Trade in Northern Nigeria." In C.K. Eicher and C. Liedholn, eds. Growth and Developnent of the Nigerian Econony, pp. 30-51. East Lansing: Michigan State University, 1970.

Holnan, M. "The Strains on an enfeebled Giant." Einancial Tines (London), Wednesday, 1 March 1989, p. 22.

Holt, R.T., and J.E. Turner. The Political Basis of Econonic Development: An Exploration in Conparative Political Analygis. Princeton: van Nostrand, 1966.

Home, R.K. "Urban Growth and Urban Governnent: Contradictions in the 
Colonial Political Econowy." In G. Williass, ed. Nigeria: Economy and Society, pp. 55-75. London: Rex Collins, 1976.

Honadle, G. "Develnpment Administration in the Eighties: New Agendas or Cid Perspe:tives?" Public Administration Review 2 (1982), pp. 174-179.

Hoogvelt, A. "Indigenisation and Foreign Capital: Industrialization in Nigeria." Review of African Political Economy 14 (1979), pp. 56-68.

Hope, K.R: "Politics, Bureaucratic Corruption and ealadministration in the Third World." International Review of Administrative Sciences 1 (1985), pp. 1-6.

Hopkins, A.G. "Economic Aspects of Political Movements in Nigeria and in the Gold Coast." Journal of African History 1 (1966), pp. 133-152.

Hopkins, A.G. An Economic History of West Africa. London: Longman, 1973.

Horohitz, D. The Abolition of Poverty. New York: Praeger, 1969.

Horowitz, D.L. "Is there a Third-World Policy Process?" Policy Sciences 3-4 (1989), pp. 197-212.

Hoselitz, B.F. "Levels of Economic Performance and Bureaceratic Structures." In J. LaPalombara, ed. Bureaucracy and Political Development, pp. 168-198. Princeton: Princeton University Press, 1963.

Hoslett, S.D. Plan for the Development of the Nigerian Institute of Management and Administration. Lagos: Ford Foundation, 1961.

Hunter, G. Untitled Review of Colin Ley's 'Underdevelopment in Kenya.' IDS Bulletin 3 (1975), pp. 40-47.

Huntington, S. Political Order in Changing Societies. New Haven: Yale University Press, 1968.

Hunt ington, S. "The Change to Change: Modernization, Developwent and Politics." Comparative Politics 3 (1971), pp. 283-322.

Huntington, S. American Politics: the Pronise of Disharmony. Cambridge: Harvard University Press, 1981.

Hyden, G. "Administration and Public Policy." In J.D. Barkan with J.J. Okumu, eds. Politics and Public Policy in Kenva and Tanzania, pp. 93-113. New York: Praeger, 1979.

Hyden, G. Beyond Ujamas in Tanzania: Underdevelopment and an Uncaptured Peasantry. London: Heinemann, 1980. 
Hyden, G. No Shortcuts to Progress: Auricen Developnent Managenent in Perspective. Berkeley and Los Angeles: University of California Press, 1983.

Hyden, G. "The Anonaly of the African Peasantry." Develonent and Change 4 (1986), pp. 677-705.

Hyden, G. "Fiual Rejoinder." Developnent and Change 4 (1987), pp. 661-667.

Hyden, G, and A.H. Rweyemanu, eds. A Decade of Public Adninistration in Africa. Nairobi: East African Literature Bureau, 1975.

Idachaba, F.S. "Commodity Boards in Nigeria: A Crisis of Identity." In K. Arhin, P. Hesp and L. v.d. Laan, eds. Marketing Boards in Tropical Africa, pp. 149-168. London: Routledge and Kegan Paul, 1985.

Idachaba, F.S. and G.B. Ayoola. "Market Intervention Policy in Nigerian Agriculture: An ex-post Evaluation of the Technical Committee on Produce Prices." Developnent Policy Review 3 (1991), pp. 285299.

Ihimodu, I.I. "Managing Public Commercial Enterprises in Nigeria: The Case of Kwara State Commercial Parastatals."

Public Admir.istration and Developnent 3 (1986), pp. 223-238.

Ihonvbere, J.0. "The Foreign Policy of Developing States: The Impact of Oil on Nigerian Foreign Policy 1960-1982."

International Political Science Review 1 (1984), pp. 81-106.

Ike, D.N. "The Evolution and Operation of the Second-tier foreign exchange market (SFEM) in Nigeria: an appraisal." Indian Journal of Econonics 276 (1989), pp. 93-108.

Ikein, A.A. The Impact of Oil on a Developing Country: the Case of Nigeria. New York: Praeger, 1990.

Ikime, 0. "Reconsidering Indirect Rule: the Nigerian Exanple." Journal of the Historical Society of Nigeria 3 (1968), pp. 421-438.

Ikenberry, G.J. "The State and Strategies of International Adjustment." World Politics 1 (1986), pp. 53-77.

Ikoiwak, E.A. "Trends in Attitudinal and Structural Developnent of the Nigerian Civil Service." Indian Journal of Public Administration 1 (1984), pp. 137-156.

Ikoiwak, E.A. "Public Officials and Corruption in Nigeria 1960-1979." Indian Journal of Public Adninistration 1 (1987), pp. 62-73. 
Ilchman, W. "Decision Rules and Decision Roles." The African Review $2(1972)$, pp. 219-246.

Il iffe, J. The Energence of African Capitalign. London: Macmillan, 1983

Inanga, E.L. "The First 'Indigenization Decree' and the Dividend Policy of Nigerian Quoted Companies." The Journal of Modern African Studies 2 (1978), pp. 319-328.

Inanga, E.L. and C.I. Ojo. "Portfolio Selection in the Nigerian Stock Market." Indian Journal of Econonics 277 (1989), pp. 177-202.

International Institute for Strategic Studies. The Military Balance. London: IISS, various years.

International Labour office (ILO). Bul?etin of Labour statistics Geneva: ILO, quarterly.

International Monetary Fund. Government Finance Statistics Yearbook. Washington: IMF, annually.

International Monetary Fund. International Financial Statistics Washington: IMF, annually.

International Petroleun Encyclopedia, Vol. 22. Tulsa: PenWell, 1989.

Iwayemi, A. "An Investment Planning Model for the Electricity Sector in Nigeria." Socio-Economic Planning Scienceg 5 (1978), pp. $285-292$.

Iwayemi, A. "The military and the econony." In 0 . Oyediran, ed. Nigerian Government and Politics under Military Rulr, $1966-79$, pp. 47-72. London \& Basingstoke: Macnillan Press, 1979.

Iyayi, F. "The Primitive Accumulation of Capital in a Neo-Colony: The Nigerian Case." Review of African Political Econony 35 (1986), pp. 27-39

Iyegha, D.A. Asricultural Crisis in Africa: The Nigerian Experience. Lanham: University Press of Anerica, 1988.

Jackson, R.H. "Political Stratification in Tropical Africa." Canadian Journal of African Studieg 3 (1973), pp. 381-400.

Jackson, R.H. "Conclusion." In P. Duignan and R.H. Jackson, eds. Politics and Government in African States 1960-1985, pp. 408-429. London: Croos Hele, 1986.

Jackson, R.H, and C. Rosberg. Personal Rule in Black Africa: Prince, Autocrat, Prophet, Turant. Berkeley and Los Angeles: University of California Press, 1982. 
Jackson, R.H. and C. Rosberg. "Popular Legitinacy in African MultiEthnic States." The Journal of Modern African Studies 2 (1984a), pp. 177-198.

Jackson, R.H. and C. Rosberg. "Personal Rule: Theory and Practice in Africa." Comparative Politicg 4 (July 1984b), pp. 421-442.

Jackson, R.H. and C. Rosberg. "Denocracy in Tropical Africa: Democracy versus Autocracy in African Politics." Journal of International Affairs 2 (Winter 1985), pp. 293-305.

Jackson, R.H. and C. Rosberg. "Sovereignty and Underdevelopment: Juridical Statehood in the African Crisis." The Journal of Modern African Studies 1 (1986), pp. 1-31.

Jacobs, J. Cities and the Wealth of Nations: Principles of Economic Life. New York: Randon House, 1984.

Jeffries, C.J. The Colonial Eapire and its Civil Service. Cambridge: Cambridge University Press, 1938.

Jeffries, C.J. Whitehall and the Colonial Service: An Adninistrative Memoir. 1939-1956. London: Athlone Press, 1972.

Jeffries, R. "Rawlings and the Political Econony of Underdevelopnent in Ghana." African Affairs 324 (1982), pp. 307-317.

Jenkins, R. "The Political Econony of Industrialization: A Comparison of Latin American and East Asian Newly Industrializing Countries." Development and Change 1 (1991), pp. 197-231.

Johnson, B. and P. Kilby. Agriculture and Structural Transforation: Econonic Strategies in Late Developing Countries. New York: Oxford University Press, 1975.

Johnson, C. Revolutionary Change, Boston: Little, Brown, 1966.

Johnson, M. "The Cowrie Currencies of West Africa." Journal of African History 3 (1970, pp. 331-353.

Johnson, O.E.G. "Political Leadership and the Econonic Development Process." The Nigerian Journal of Econonic and Socisl Studies 2 (1986), pp. 213-228.

Johnston, $B$ and J. Mellor. "The Role of Agriculture in Econonic Developaent." Anerican Econonic Review 4 (1961), pp. 556-593.

Jones, E. "Politics, bureaucratic corruption and aaladninistration in the Third World: some Connonwealth considerations." International Review of Adninistrative Sciences 1 (1985), pp. 19-23.

Jones, E.L. "Agricultural Origins of Industry." Pagt and Pregent 40 (July 1968), Pp. 58-71. 
Jones, E.L. The European Miracle: Environents, Econonics and Geopolitics in the History of Furope and Asia. Canbridge: Cambridge University Press, 1981.

Jones, G.I. "Native and Trade Currencies in Southern Nigeria During the Eighteenth and Nineteenth Centuries." Africa 1 (1958), pp. 43-54.

Jones, R.W. and W.M. Corden. "Devaluation, Non-Flexible Prices, and the Trade Balance for a Saall Country." Canadian Journal of Econonics 1 (February 1976), pp. 150-161.

Jordan, B. The State: Authority and Autonony. Oxford: Basil Blackwell, 1985.

Joseph, R.A. "Affluence and Underdevelopment: the Nigerian Experience." Journal of Modern African Studies 2 (1978), pp. 221-239.

Joseph, R.A. "Class, State, and Prebendal Politics in Nigeria." The Journal of Comnonwealth and Conparative Studies 3 (1983), pp. 21-38.

Joseph, R.A. "The Overthrow of Nigeria's Second Republic." Current History 491 (March 1984), pp. 122-138.

Joseph, R.A. Denocracy and Prebendal Politics in Nigeria. New York: Cambridge University Press, 1987.

July, R.W. A History of the African People. New York: Scribner's, 1970.

Kalberg, S. "Max Weber's Types of Rationality: Cornerstones for the Analysis of Rationalization Processes." Anerican Journal of Sociology 5 (1980), pp.1145-1179.

Kaldor, N. "The Irrelevance of Equilibrium Econonics." The Economic Journal 328 (1972), pp, 1237-1255.

Kamarck, A.M. The Economics of African Developnent. New York: Praeger, 1967.

Kaniki, M.H.Y. "The Colonial Econony." In A.A Boahen, ed. General Histors of Africa, Vol. VII: Africa under Colonial Domination, pp. 382-419. Paris: UNESCO, 1985.

Kaplan, M. "The Theory of the State and the Third World." In $A$. Kazancigil, ed. The State in Global Perspective, pp. 276-292. Aldershot: Gower for UNESCO, 1986.

Kaplow, S.B. "The Mudfish and the Crocodile: Underdevelopment of a West African Bourgeoisie." Science and Society 3 (1977), pp. $317-333$. 
Kasfir, N. "Relating Class to State in Africa." The Journal of Connonwealth and Conparative Politics 3 (1983), pp. 1-20.

Kasfir, N. "Are African Peasants Self-Sufficient?" Development and Change 2 (1986), pp. 335-357.

Kautsky, K. Bolshevism at a Deadlock. New York: Rand School Press, 1931 [1930].

Kay, J.A. and D.J. Thompson. "Privatisation: A Policy in Search of a Rationale." Econonic Journal Vol. 96 (March 1986), pp. 18-32.

Kazancigil, A. "Paradigms of Modern State Fornation in the Periphery." In A. Kazancigil, ed. The State in Global Perspective, pp. 119-142. Aldershot: Gower for UNESCO, 1986.

Keeling, W. "Nigeria's Windfall Hardens Hearts of Creditors." Financial Times (London), 12 September 1990, p. 24.

Keeling, W. "Concern at Use of Lagos Oil Windfall." Financial Tines (London), 27 June 1991, p. 4.

Keeling, W. "Nigeria may prove World Bank's acid Test." Financial Tines (London), 1 July 1991a, p. 16.

Kemp, A.G. Petroleun Rent Collection Around the World. Hal if ax: Institute for Research on Public Policy, 1987.

Kennedy, P. African Capitalism: the Strugsle for Ascendancy. Cambridge: Cambridge University Press, 1988.

Kevnes, J.M. "The End of Laissez-Faire." In The Collected Writings of John Maynard Keynes, Vol. IX: Essays in Persuasion, pp. 272-294. New York, St. Martin's Press, 1972, [1926].

Kilby, P. Industrialization in an Open Econony: Nigeria 1945-1966. Cambridge: Cambridge University Press, 1969.

Killick, T. "The Possibilities of Developnent Planning." Oxford Economic Papers 2 (1976), pp. 161-184.

Killick, T. "Trends in Developnent Economics and their Relevance to Africa." The Journal of Modern African Studies 3 (1980), pp. 367-386.

Killick, T. Policy Econonics: A Textbook of Applied Econonics on Developing Countries, London: Heineaann, 1981.

Killick, T. "Twenty-five Years in Development: The Rise and Inpending Decline of Market Solutions." Developnent Policy Review 2 (1986), pp. 99-116. 
Kimble, G.H.T. Tropical Africa, Vol, 1: Land and Livelihood. New York: Twentieth Century Fund, 1960.

Kimble, G.H.T. Tropical Africa, Vol, 2: Society and Politics. New York: Twentieth Century Fund, 1960a.

Kingsley, J.D. "Bureaucracy and Political Developnent, with Particular Reference to Nigeria." In J. LaPalombara, ed. Bureaucracy and Political Developnent, pp. 301-317. Princeton: Princeton University Press, 1963.

Kirk-Greene, A.H.M., ed. The Principle of Native Adninistration in Nigeria: Selected Docunents 1900-1947. London: Oxford University Press, 1961.

Kirk-Greene, A.H.M. "The Higher Public Service." In L.F. Blitz, ed. The Politics and Adninistration of Nigerian Governnent, pp. 213-248. London: Sweet and Maxwell, 1965.

Kirk-Greene, A.H.M. "The Merit Principle in an African Bureaucracy: Northern Nigeria." In A. Rivkin, ed. Nations by Design: Institution Building in Africa, pp. 253-332. New York: Doubleday, 1968.

Kirk-Greene, A.H.M. Lugard and the Analganation of Nigeria: A Documentary Record. London: Frank Crss, 1968a

Kirk-Greene, A.H.M. "The Thin White Line: the Size of the British colonial Service in Africa." African Affairs 314 (1980), pp. 25-44.

Kirk-Greene, A.H.M. and D. Rimer. Nigeris since 1970: A Political and Econonic Qutline. New York: Africana, 1981.

Kirk-Greene, A.H.M. "West Africa: Nigeria and Ghana." In P. Duignan and R.H. Jackson, eds. Politics and Government in African States 1960-1985, pp. 30-77. London: Croom Helm, 1986.

Kitching, G. Class and Econonic Change in Kenya: The Kaking of an African Petite Bourgeoisie. New Haven: Yale University Press, 1980.

Kitching, G. "The Role of a National Bourgeoisie in the Current Phase of Capitalist Development: some Reflections." In P.M. Lubeck, ed. The African Bourzeoisie: Capitalist Developent in Nigeria. Kenya and the I vory coast, pp. 27-55. Boulder: Lynne Rienner, 1987 .

Klitgaard, R. "Managing the fight against corruption: a case study." Public Adainistration and Developnent 1 (1984), pp. 77-98.

Klitgaard, R. Tropical Gangsters. New York: Basic Books, 1990. 
Koehn, P. "The Role of Public Aduinistrators in Public Policy Making: Practice and Prospects in Nigeria." Public Adninistration and Developent 1 (1983), pp. 1-26.

Koehn, P. "State Land Allocation and Class Fornation in Nigeria." The Journal of Modern African Studies 3 (1983a), pp. 461-481.

Koehn, P. "Local Government Involvenent in National Development Planning: Guidelines for Project Selection based upon Nigeria's Fourth Plan Experience." Public Adninistration and Develoonent 4 (1989), pp. 417-436.

Koehn, P.H. Public Policy and Adninistration in Africe: Lessons from Nigeria. Boulder: Westview, 1990.

Koestler, A. "The Intelligentsia." In A. Koestler. The Yogi and the Comissar, pp. 61-76. New York: Macmillan, 1946 [1944].

Koestler, A. "Soviet Myth and Reality." In A. Koestler. The Yogi and the Commissar, pp. 131-192. New York: Macmillan, 1946a [1944].

Koestler, A. Untitled essay in The God That Failed: Six Studies in Communism, pp. 25-82. London: Hamish Hamilton, 1950.

Koestler, A. Darkness at Noon. Harmondsworth: Penguin, 1968 [1940].

Koestler, A. The Call-Girls: A tragi-comedy with Prologue and Epilogue. London: Hutchinson, 1972.

Kolakowski, L. Main Currents of Marxism: its Origins, Growth and Dissolution. Oxford: Oxford University Press, [1978]. Vol. 1 The Founders (1988). Vol. 2 The Golden Age (1987). Vol. 3 The Breakdown $(1987 \mathrm{a})$.

Kolakowski, L. Modernity on Endless Trial. Chicago and London: University of Chicago Press, 1990.

Korten, D.C. and F.B. Alfonso, eds. Bureaucracy and the Poor: Closing the Gap. Singapore: McGraw-Hill, 1981.

Krasner, S.D. "Approaches to the State: Alternative Conceptions and Historical Dynanics." Conparative Politics 2 (1984), pp. 223246.

Kraus, J. "Economic Adjustment and Regine Creation in Nigeria." Current History 538 (1989), pp. 233-250.

Krieger, M. "Education and Developnent in Western Nigeria: the Legacy of S.0. Awokoya, 1952-1985." The International Journal of African Historical Studies 4 (1987), pp, 647-667.

Krugman, P.R. "Debt Relief is Cheap." Foreltn Policy 80 (1990), pp. 141-152. 
Krueger, A.O. "The Political Econony of the Rent-Seeking Society." American Economic Review 3 (1974), pp. 291-303.

Kubr, M. and J. Wallace. "Success and Failures in neeting the Management Challenge: Strategies and their Inplications." World Bank Staff Working Paper 685 (1983).

Kuznets, S. Modern Economic Growth. New Haven: Yale University Press, 1966.

Lal, D. The Poverty of "Developient Econonics". London: The Institute of Economic Affairs, 1983.

Lal, D. "The Political Econowy of Liberalization." The World Bank Economic Review 2 (1987), pp. 273-299.

Lal, D. "The Misconception of 'Development Econowics'." In C. Wilber, ed. The Political Econony of Developnent and Underdevelopnent, pp. 28-36. New York: Randon House, 1988

Lancaster, c. "Policy Reform in Africa: How effective?" Issue $2(1988)$, pp. 30-35.

Lancaster, C. "Economic Reform in Africa: is it working?" Washington Quarterly 1 (1990), pp. 115-128.

Landau, M. "Redundancy, Rationality, and the Problen of Duplication and Overlap." Public Adninistration Review 4 (1969), pp. 346358 .

Lane, J.-E. and S. Ersson. "State or Market? Politics Does Matter." International Political Science Review 1 (1986), pp. 91-104.

Langmuir, G.1. History, Religion and Antigenitige. Berkeley and Los Angeles: University of California Press, 1990.

LaPalombara, J. "An Overview of Bureaucracy and Political Developnent." In J. LaPalombara, ed. Bureaucracy and Political Developnent, pp. 3-33. Princeton: Princeton University Press, 1963.

LaPalombara, J. "Bureaucracy and Political Developnent: Notes, Queries, and Dilemas." In J. LaPalombara, ed. Bureaucracy and Political Developgent, pp. 34-61. Princeton: Princeton University Press, 1963.

Law, R. The Oyo Eapire c. $1600-c$ 1836: A Wegt African Inperialign in the Era of the Atlantic Slave Trade. Oxford: Oxford University Press, 1977.

Lawal, A.A. "Industrialization as Tokenisa." In T. Falola, ed. Britain and Nigeria: Exploitation or Developent? pp. 114123. London: Zed Books, 1987. 
Lawrence, P. ed. World Recession and the Food Crisis in Africa. London: Janes Currey, 1986.

League of Nations. International Trade Statistics. Geneva: League of Nations, various years.

League of Nations. Statigtical Year-Book. Geneva: League of Nations, various years.

Lee, J.M. Colonial Developrent and Good Government: a Study of the Ideas expressed by the British official Classes in planning Decolonization. Oxford: Clarendon Press, 1967.

Lee, J.M. and M. Petter. The Colonial office, War, and Development Policy. London: Maurice Tenple Saith, 1982.

Lee, S. -H. State-Building in the Contenporary Third World. Boulder: Westview, 1988.

Leff, N.H. "Entrepreneurship and Econonic Development: The Problem Revisited." Journal of Economic Literature 1 (1979), pp. 46-64.

Legum C., ed. Africa Contemporary Record, 1971-1972. New York: Africana Publishing, 1972.

Leibenstein, H. Econonic Backwardness and Econonic Growth. New York: Wiley, 1957.

Lemarchand, R. "Political Clientelisa and Ethnicity in Tropical Africa: Competing Solidarities in Nation-Building." American Political Science Review 1 (1972), pp. 68-90.

Lemarchand, R. "The State, the Parallel Economy, and the Changing Structure of Patronage Systeas." In D. Rothchild and N. Chazan, eds. The Precarious Balance: State and Society in Africa, pp. 149-170. Boulder: Westview, 1988.

Lenin, V.I. The Development of Capitalisn in Russia. Moscow: Foreign Languages Publishing House, 1956 [1919].

Lenin, V.I. "Inperialign, the highest Stage of Capitalisa." In V.I. Lenin, Collected Works, Vol. 22, pp. 185-304. Moscow: Progress Publishers, 1964 [1917].

Lenin, V.I. "The Proletarian Revolution and the Renegade Kautsky." In V.I. Lenin, Collected Works, Vol. 28, pp. 225-325. Moscow: Progress Publishers, 1965 [1918].

Lenin, V.I. "A Great Beginning." In. V.I. Lenin. Selected Workg, Vol. III, pp. 201-225. Moscow: Progress Publishers, 1967 [1919].

Leonard, D.K. Resching the Pesasant Farner: Organization Theory and 
Practice in Kenya. Chicago and London: University of Chicago Pres8, 1977.

Leonard, D.K. "Putting the Farner in Control: Building Agricultural Institutions." In R.J. Bers and J.S. Whitaker, eds. Stratexies for African Developent, pp. 185-214. Berkeley and LOB Angeles: University of California Press, 1986.

Leonard, D.K. "The Political Realities of African Managenent." World Developnent 7 (1987), pp. 899-910.

Levin, D.P. "Experts doubt Cutbacks alone will save GM: Managenent Problens were not addressed." The New York Tines, 23 Decenber 1991, pp. A1 D5.

Levine, A. "The Marxisn that Failed." Ethics (July 1981), pp. 645650.

Lewis, S.R. "Primary Exporting Countries." In H.B. Chenery and T.N. Srinivasan, eds. Handbook of Developaent Econonics, Vol. 2, pp. 1541-1600. Ansterdan: Elsevier Sciences Publishers, 1989.

Lewis, W.A. "World Production, Prices and Trade, 1870-1960." Manchester School of Econonic and Social Studies 2 (1952), pp. 105-138.

Lewis, W.A. Report on Industrialization and the Gold Cosat. Accra: Government Printing Department, 1953.

Lewis, W.A. "Econonic Development with Unlinited Supply of Manpower." The Manchester School of Econonic and Social Studies 2 (1954), pp. 139-191.

Lewis, W.A. Politics in West Africa. London: Allen Unwin, 1965.

Lewis, W.A. The Theory of Econonic Growth. London: Allen \& Unwin, 1965a [1955].

Lewis, W.A. Developnent Planning: The Essentials of Econonic Policy. New York: Harper \& Row, 1966.

Lewis, W.A. Reflections on Nizeria's Econonic Growth. Paris: Development Institute of the OECD, 1967.

Lewis, W.A. The Evolution of the International Econonic Order. Princeton: Princeton University Press, 1978.

Leys, C. "New States and the Concept of Corruption." In A.J. Heidenheiner, ed. Political Corruption": Readings in Comparative Analysis, pp. 341-345. New Brunswick: Transaction Books, 1978 [1965].

Leys, C., ed. Politics and Change in Developins Countries. 
London: Canbridge University Press, 1969.

Leys, c. Underdevelopent in Kenva: The Political Econony of Neo-Colonialise. London: Heinenann, 1975.

Leys, C. "The 'Overdeveloped' Post Colonial State: a Reevaluation." Review of African Political Econony 5 (1976), pp. 39-48.

Leys, C. "Underdevelopment and Dependency: Critical Notes." Journal of Contenporary Asis 1 (1977), pp. 92-107.

Leys, C. "Kenya: What does 'Dependency' explain?" Review of African Political Econony 17 (1980), pp. 108-113.

Leys, C. "African Econonic Developnent in Theory and Practice." Daedalus 2 (1982), pp. 95-124.

Liedholm, C. "The Influence of Colonial Policy on the Growth of Nigeria's Industrial Sector." In C.K. Eicher and C. Liedhoim, eds. Growth and Developnent of the Nigerian Econony, pp. 52-61. East Lansing: Michigan State University, 1970.

Lindauer, D.L. "Parastatal Pay Policy in Africa." World Developent 7 (1991), pp. 831-838.

Lindblon, C.E. "The Science of 'nuddling-through'." Public Administration Review 2 (Spring 1959), pp. 79-88.

Lindblom, C.E. Politics and Markets: The World's PoliticalEconomic Systems. New York: Basic Books, 1977.

Lindenberg, M. "Making econonic adjustment work: the politics of policy implementation." Policy Sciences, 3-4 (1989), pp. 359-394.

Lipton, M. "Linits of Price Policy for Agriculture: Which way for the World Bank." Development Policy Review 2 (1987), pp. 197-215.

Lloyd, P.C. "The Traditional Political Systen of the Yoruba." Southwestern Journal of Anthropology Vol. 10 (1954), pp. 366-384.

Lovejoy, P.E. Transfornation in Slavery: A History of Slavery in Africa. Cambridge: Cambridge University Press, 1983.

Lowi, T.J. "The Return of the State: Critiques." Anerican Political Science Review 3 (1988), pp. 885-891.

Loxley, J. "IMF and World Bank Conditionality and Sub-Saharan Africa." In P. Lawrence, ed. World Recession and the Food Crisis in Africs, pp. 96-103. London: James Currey, 1986.

Lubeck, P.M. "Nigeria: A Political Econony." Africe Today (Denver) 4 (1977), pp. 5-10. 
Lubeck, P.M. "The African Bourgeoisle: Debates, Methods, and Units of Analysis." In P.M. Lubeck, ed. The African Bourgeoisie: Capitaliet Developent in Nigerial Kenva and the Ivory Cosst, Pp. 3-26. Boulder: Lynne Rienner, 1987.

Luckhan, $R$. The Niserian Military: A Sociolorical Anslyais of Authority and Revolt 1966-67. London: Canbridge University Pres8, 1971.

Lugard, F.J.D. The Dual Mandate in Britiah Tropical Africa. London: Frank Cas8, 1965 [1923].

Lugard, F.J.D. Report on the Analgenntion of Northern and Southern Nigeria and Adninistration, 1912-1919. London: Frank Cass, 1968 [1919].

Lugard, F.J.D. Political Menoranda: Revigion of Instructions to Political officers on subjects chiefly Political and Adninistrative, 1913-1918. London: Frank Cass, 1970 [1919].

Luke, D.F. "Trends in Developent Adninistration." Public Administration and Developent 1 (1986), pp. 73-85.

Luxemburg, R. The Accunulation of Capital. London: Routledge and Kegan Paul, 1963 [1913].

Machiavelli, N. The Prince. Haraondsworth: Penguin, 1978 [1513].

Main, J. "Manufacturing the Right Way." Fortune 11 (21 May 1990), pp. 54-64.

March, J.G. and J.P. Olsen. "Organizing Political Life: What Adwinistrative Reorganization Tells Us about Government." Anerican Political Science Review 1 (1983), pp. 281-296.

March, J.G. and J.P. Olsen. "The New Institutionalism: Organizational Factors in Political Life." Anerican Political Science Review 3 (1984), pp. 734-749.

Marcuse, H. Der Eindinensionale Mensch: Studien gur Ideologie der fortgeschrittenen Industriesesellschaft. Neuwied: Luchterhand, 1970 [1964].

Marcuse, H. "Industrialisaus und Kapitalisnus is Werk Max Neber's." In H. Marcuse. Kultur und Gesellschaft, Vol. 2, pp.107-129. Frankfurt: Suhrkanp, 1977 [1965].

Marcuse, L. Pessinignus ein Stadiun der Reife: Unverlorene Lllusionen. München: Szczesny Verlag, 1966 [1953].

Marenin, 0. "The Nigerian State as Process and Manager: a Conceptualization." Conparative Politica 2 (1988), pp. 215-232. 
Marenin, 0. "Resolving the Epistenological Contradictions in Marxist African Studies." The Journal of Modern African Studies 4 (1989), pp. 641-669.

Markandya, A. and M. Penberton. "Econonic Pollcy with Fluctuating Oil Revenues." OPEC Review 1 (1988), pp. 17-33).

Mars, J. "Extra-Territorial Enterprises." In M. Perhan, ed. The Native Econonies of Nixeris: the Econonics of a Tropical Dependency, Vol. 2, pp. 43-136. London: Faber Faber, 1948.

Marx, K. "Brief an Joseph Weydeneyer in New York." In Karl Marx - Eriedrich Entels Werke, Vol. 28, pp. 503-509. Berlin: Dietz Verlag, 1963 [written 5 March 1852].

Marx, K. "Brief an Ferdinand Donela Nieuwenhuis in Den Haag." In Karl Marx - Friedrich Entels Werke, Vol. 35, pp. 159-161. Berlin: Dietz Verlag, 1967 [written 22 February 1881].

Marx, K. "Das Kapital: Kritik der politischen Okononie; Dritter Band, Buch III; Der GesantprozeB der kapitalistischen Produktion." In Karl Marx - Friedrich Engels Werke, Vol. 25. Berlin: Dietz Verlag, 1968 [1894].

Marx, K. "Okonomisch-philosophische Manuskripte aus den Jahre 1844." In Karl Marx - Friedrich Engels Werke, Ergänzungsband: SchriftenManuskripte-Briefe bis 1844, erster Teil, pp. 465-588. Berlin: Dietz Verlag, 1968a [written in 1844, first published in 1932].

Marx, K. "Lohn, Preis und Profit." In Karl Marx - Friedrich Engels Werke, Vol. 16, pp. 101-152. Berlin: Dietz Verlag, 1968 b [written in 1865 , first published in 1898].

Marx, K. "Das Elend der Philosophie: Antwort auf Proudhons 'Philosophie des Elends'." In Karl Marx - Friedrich Engels Werke, Vol. 4, pp. 63-182. Berlin: Dietz Verlag, 1969 [1847].

Marx, K. "Das Kapital: Kritik der politischen Okononie; Erater Band, Buch I; Der ProduktionsprozeB des Kapitals." In Karl Marx Friedrich Engels Verke, Vol, 23. Berlin: Dietz Verlag, 1969a [1867].

Marx, K. "Zur Kritik der Hegelschen Rechcsphilosophie." In Karl Marx - Friedrich Engels Werke, Vol. 1, pp. 201-333. Ber]in: Dietz Verlag, 1969b [1843].

Marx, K. "Zur Kritik der Politischen Okononie." In Karl Marx Friedrich Engels Werke, Vol. 13, pp. 3-160. Berlin: Dietz Verlag, 1969c [1859].

Marx, K. "Zur Judenfrage." In Karl Marx - Friedrich Enzels Werke, Vol. 1, pp. 347-377. Berlin: Dietz Verlag, 1969d [1844]. 
Marx, K. "Kritik des Gothaer Progranms." In Karl Marx - Friedrich Engels Werke, Vol. 19. pp. 11-32. Berlin: Dietz Verlag, 1969e [written 1875, first published 1891].

Marx, K. "Das Kapital: Kritik der politischen Okononie; 2weiter Band, Buch II; Der 2 irkulationsprozeB des Kapitals." In Karl Marx Friedrich Engels Werke, Vol. 24. Berlin: Dietz Verlag, 1970 [1885].

Marx, K. "Der achtzehnte Brunaire des Louis Bonaparte." In Karl Marx - Friedrich Engels: Ausgewählte Schriften in Zwei Bärden, Vr! 1, pp. 222-316. Berlin: Dietz Verlag, 1975 [1852].

Marx, K. "Grundrisse der Kritik der politischen Okononie." In Karl Marx - Friedrich Engels Werke, Vol. 42, pp. 15-768. Berlin: Dietz Verlag, 1983 [written 1857-1858; first published 1939-1941].

Marx, K. and F. Engels. "Die deutsche Ideologie. Kritik der neuesten deutschen Philosophie in ihren Repräsentanten Feuerbach, B. Bauer und Stirner, und des deutschen Sozialiswus in seinen verschiedenen Propheten." In Karl Marx - Friedrich Ensels Werke, Vol. 3, pp. 9-521. Berlin: Dietz Verlag, 1969 [written 1845-1846, first published 1932].

Marג, K. and F. Engels. "Manifest der Kommunistischen Partei." In Karl Marx - Friedrich Engels: Ausgewählte Schriften in Zwei Bärțen, Vol. :, pp. 17-57, Berlin: Dietz Verlag, 1975 [1848].

Mazrui, A. "Lumpen Proletariat and Lumpen Militariat." In R.C. Macridis and B.E. Brown, eds. Comparative Politics: Notes and Readings, pp. 467-483. Homewood: Dorsey, 1977 [1973].

Mazruj, A. and M. Tidy. Nationalisa and New States in Africa from about 1935 to the Present. Nairobi: Heinemann, 1984.

McCle'land, D.C. The Achieving Society. New York: The Free Press, 1967 [1961].

"cGraw, T.K. "Schumpeter Ascending." The American Scholar (Summer 1991), pp. 371-^32.

McGowan, P.J. "Econonic Dependence and Econonic Perforaance in Black Africa." The Journal of Modern African Studies 1 (1976), pp. 2540 .

McGowan, P.J. and D.L. Smith. "Econowic Dependency in Black Africa: an Analysis of competing theories." International Orsanization 1 (1978), pp. 179-235.

McGrath, J. "Mengistu's Agricultural Reforms start to pay off." Financial Times (London), Thursday, 20 December 1990, p. 9.

McMullan, M. "Corruption in the Public Services of British Colonies 
and Ex-Colonies in Wesi Africa." In A.J. Heidenheiner, ed. Political Corruption": Readings in Conparative Analysis, pp. 317-340. New Brunswick: Transaction Books, 1978 [1961].

McPhee, A. The Econonic Revolution in British West Africa. London: Frank Cass, 1971 [1926].

Medard, J.-F. "The Underdeveloped State in Tropical Africa: Political Clientelisa or Neo-Patrieonialisa?" In C. Clapham, ed. Private Patronase and Public Power: Political Clientelism in the Modern State, pp. 162-192. London: Frances Pinter, 1982.

Meier, G.M. "Direct Controls and Rent Seeking." In G.M Meier * W.F. Steel, eds. Industrial Adjustnent in Sub-Saharan Africa, pp. 272-274. New York: Oxford University Press, 1989.

Meillassoux, C. "A Class Analysis of the Bureaucratic Process in Mali." The Journal of Developnent Studies 2 (1969), pp. 97-110.

Melson, R. and H. Wolpe, eds. Nigeria: Modernization and the Politics of Communalism. Ann Arbor: Michigan State University, 1971.

Merleau-Ponty, M. Humanism and Terror: An Essay on the Communist Problem. Boston: Beacon Press, 1969 [1947].

Meyer, J.W. and M.T. Hannan, eds. National Development and the World System: Educational, Economic and Political Change. Chicago: University of Chicago Press, 1979.

Meyer, R.K. and S.R. Pearson, "Contributions of Petroleun to Niserian Economic Development. In S.R. Pearson and J. Cownie, eds. Commodity Expnrts and African Economic Development, pp. 155-178. London: D.C. Heath, 1974.

Michels, R. Political Parties: A Sociological Study of the oligarchical Tendencies of Modern Denocracy. London: Collier-Macmillan, 1962 [1911].

Migdal, J. Peasants, Politics and Revolution. Princeton: Princeton University Press, 1974.

Migdal, J. "studying the Politics of Development and Change: The State of the Art." In A.W. Finifter, ed. Political Science: The State of the Discipline, pp. 309-338. Washington: American Political Science Association, 1983.

Migdal, J. "Strong States, Weak States: Power and Acconnodation." In $M$. Weiner and $S$. Huntington, eds, Understanding Political Development, pp. 391-434. Boston: Little, Brown, 1987.

Migdal, J. Strong Societies and Weak States: State-Society Relations and State Capabilities in the Third World. 
Princeton: Princeton University Press, 1988.

Migot-Adholla, S., P. Hazell, B. Blarel and F. Place. "Indigenous Land Rights Systems in Sub-Saharan Africa: A Constraint on Productivity?" The World Bank Econonic Review 1 (1991), pp. 155-175.

Milewski, J.J. "Capitalisn in Nigeria and Problems of Dependence: sone Historical Conments." In D. Seers, ed. Dependency Theors: A Critical Reassessent, pp. 109-118. London: Frances Pinter, 1981.

Miliband, R. The State in Capitalist Society. New York: Basic Books, 1969.

Mill, J.S. "Of Interference of Government Grounded on Erroneous Theories." Book V, chapter 10 of "Principles of Political Econowy." In Collected Works of John Stuart Mill, Vol. 3, pp. 913-935. Toronto: University of Toronto Press, 1965 [written 1845-1847; first published 1848].

Mitchell, B.R. British Historical Statistics. Cabridge: Cambridge University Press, 1990 [1988].

Mockler-Ferryman, A.F. British Nigeria. London: Cassell, 1902.

Mommsen, W. "ȟapitalisnus und Sozialiseus. Die Auseinandersetzung mit Karl Marx." In W. Momasen. Max Weber: Gesellschaft, Politik und Geschichte, 144-181. Frankfurt: Suhrkanp, 1974._

Moore, B. Social Origins of Dictatorship and Denocracy: Lord and Peasant in the Making of the Modern World. Boston: Beacon Press, 1966.

Moore, B. "Reply to Rothman" Anerican Political Science Review 1 $(1970)$, pp. 83-85.

Morgan, W.B. and J.C. Pugh. West Africa. London: Methuen 1973 [1969].

Moris, J. "The transferability of the western managenent tradition to the non-western public service sectors," Phjlippine Journal of Public Adninistration 4 (1976) pp. 401-427.

Moris, J. Managenent Education in Africa: Prospectus and Appraisals. Arusha: East African Management Institute, 1977.

Moris, J. Managing Induced Rural Developnent. Bloonington: International Developaent Institute, Indiana University, 1981.

Moris, J. "The Transferability of Western Managenent Concepts: a Fourth World Perspective." Developnent Disest 1 (1981a), pp. 56-65.

Morss, E.R. "Institutional Destruction Resulting fron Donor and Project Proliferation in Sub-Saharan African Countries." 
World Developnent 4 (1984), pp. 465-470.

Mosca, G. The Ruling Class: Elenenti di Scienre Politica. New York: McGraw-Hill, 1939 [1895].

Mosley, P. and L. Snith. "Structural Adjustment and Agricultural Perforance in Sub-Saharan Africa 1980-87." Journal of International Developnent 3 (1989), pp. 321-355.

Mowery, D.C. and N. Rosenberg. Technology and the Pursuit of Econopic Growth. Cambridge: Cabridge University Press, 1989.

Mumery, D.R. The Protection of International Private Invegtment: Nigeria and the World Connunity. New York: Praeger, 1968

Munro, J.F. Africa and the International Econony, 1800-1960. London: Dent \& Sons, 1976.

Munro, J.F. Britain in Tropical Africa, 1880-1960: Econonic Relationships and Inpact. London: Macaillan Press, 1984.

Murphy, K.M., A. Shleifer and R. Vishny. "Incone Distribution, Market Size, and Industrialization." Quarterly Journal of Econonics 2 (1989), pp. 537-564.

Murphy, K.M., A. Shleifer and R. Vishny. "Industrialization and the Big Push." Journal of Political Econony 5 (1989a), pp. 10031026 .

Murray, D.J. The Work of Administration in Nigeria. Lendon: Hutchinson, 1969.

Murray, D.J, ed. Studies in Nigerian Adninistration. London: Hutchinson, 1970.

Murray, D.J. "The World Bank's Perspect, ve on How to I oprove Adninistration." Public Adeinistration and Development 4 (1983), pp. 291-297.

Musa, N.D. "Balancing Interest Groups." West Africa 3869 (4 Novenber 1991), p. 1846.

Myint, H. Economic Theory and the Underdeveloped Countries. New York: Oxford University Press, 1971.

Myint, H. The Econonics of the Developing Countries. New York: Praeger, 1973 [1964].

Myrdal, G. Econonic Theory and Under-Developed Rexions. London: Duckworth, 1959 [1957].

Myrdal, G. Asian Drana: An Inquiry into the Poverty of Nations, Vol. 2. New York: 20th Century Fund \& Pantheon Books, 1968. 
Nafziger, E.W. African Capitalisn: a Case Study in Nigerian Entrepreneurship. Stanford: Hoover, 1977.

Nafziger, E.W. "Sayre Schatz: Nigerian Capitalism." Econonic Development and Cultural Change 3 (1980), pp. 650-654.

Nasar, S. "Good News Ahead for Profuctivity." Fortune 12 (10 December 1984), pp. 40-50.

Nash, M. Unfinished Asenda: The Dynarics of Modernization in Developing Countries. Boulder: Westview, 1984.

Nayar, B.R. "Political Mainsprings of Econonic Planning in the New Nations: The Modernization Imperative versus Social Mobilization." Copparative Politics 3 (1974), pp. 341366.

Ndegwa, P. "Africa and the World: Africa on its own." Background Paper for Ottawa Roundtable on "The Challenge of Africa in the 1990s," held in Ottawa on June 16-18, 1991.

Nduka, 0. "Colonial Education and Nigerian Society." In G. Willians, ed. Nigeria: Econony and Society, pp. 90-106. London: Rex Collins, 1976.

Nef, J. "Lat in America: The Southern Cone." In V. Subramaniam, ed. Public Adainistration in the Third World: An International Handbook, pp. 352-384. Westport: Greenwood, 1990.

Nellis, J. Maladministration: Cause or Result of Underdevelopment: The Algerian Example." Canadian Journal of African Studies 3 (1979), pp. 407-422.

Nelson, J.M. "The Political Economy of Stabilization: Comnitment, Capacity, and Public Response." World Developnent 10 (1984), Pp. 983-1006.

Nettl, J.P. "The State as a Conceptual Variable." World Politics 4 (1968), pp. 559-592.

Niane, D.T. "Relationships and Exchanges anong the different Regions." In D.T. Niane, ed. General History of Africa, Vol. IV: Africa from the Twelfth to the Sixteenth Century, pp. 614-634. Paris: UNESCO, 1984.

Nicolson, I.F. The Adninistration of Nigeris 1900-1960: Men, Methodes and Myths. Oxford: Clarendon Press, 1969.

Nigeria, Colony and Protectorate. Annual Reports on the Governnent Railway and Colliery of Nigeria. Lagos: Nigerian Railway Corporation, various years. 
Nigeria, Colony and Protectorate [later: Federation of]. Trade Report for the Year.... Lagos: Government Printer, various years.

Nigeria, Federation of. Report of the Coker Connission of Inouiry into the Affairs of Certain Statutory Corporations in Western Niseria. 1962, 4 vols. Lagos: Federal Ministry of Inforation, Printing Division, 1962.

Nigeria, Federal office of Statistics [FOS]. Econonic and Social Statistics Bulletin. Lagos: Federal office of Statistics, various years.

Nigeria, FOS. Digest of Statistics. Lagos: Federal office of Statistics, various years.

Nigeria, FOS. Industrial Survey. Lagos: Federal office of Statistics, various years.

Nigeria, Federal Republic of. Report of the Working Party on Statutory Corporations and State-owned Conpanies. Lagos: Federal Ministry of Information, 1967.

Nigeria, Federal Republic of. Second National Developnent Plan 1970-1974. Lagos: Federal Ministry of Information, 1970.

Nigeria, Federal Republic of. Progress Report on the Second National Developnent Plan 1970-1974. Lagos: Federal Ministry of Information, 1970a.

Nigeria, Federal Republic of. Second and Final Report of the Wages and Salaries Review Connission, 1970-71. Lagos: Federal Ministry of Information, 1971 (chairman: S.0. Adebo).

Nigeria, Federal Republic of. Public Service Review Conaission: Main Report. Lagos: Federal Ministry of Inforation, 1974 (chairman: J. 0. Udoji).

Nigeria, Federal Republic of. The Public Service of Nigeria: Government Views on the Report of the Public Service Review Commission. Lagos: Federal Ministry of Inforation, 1974a.

Nigeria, Federal Republic of. Third National Developent Plan 19751980. Lagos: Federal Ministry of Econonic Developnent, 1975.

Nigeria, Federal Republic of. Report of the Conittee on the Location of the Federal Capital of Nigeria. No place and publisher, $1975 a$.

Nigeria, Federal Republic of. First Report of the Anti Inflation Taskforce. Lagos: Federal Ministry of Inforaation, 1975b.

Nigeria, Federal Republic of. Federal Military Governnent Views on the Report of the Panel on Creation of States. Lagos: 
Federal Ministry of Information, 1976.

Nigeria, Federal Republic of. Report of the Tribunal of Inauiry into the Inportation of Cenent. Lagos: Federal Ministry of Information, $1976 a$.

Nigeria, Federal Republic of. Federal Military Governnent Vjews on the Report of the Tribunal of Inquiry into the Inportation of Cenent. Lagos: Federal Ministry of Inforation, 1976b.

Nigeria, Federal Republic of Government Views on the Report of the Location of the Federal Capital of Nigeria. Lagos: Federal Ministry of Infornation, 1976c.

Nigeria, Federal Republic of. Federal Military Government Views on the Report of the Tribunal of Inquiry into the Finances of the Second World Black and African Festival of Arts and Culture. Lagos: Federal Ministry of Information, 1976d.

Nigeria, Federal Republic of. Federal Military Government Views on the Report of the Federal Assetg Investigation Panel 1975. Lagos: Federal Ministry of Information, 1976e.

Nigeria, Federal Ministry of National Planning. Guidelines for the Fourth National Development Plan 1981-1985. Lagos: Federal Ministry of national Planning, undated, probably 1979.

Nigeria, Federal Republic of. Report of the Tribunal of Inquiry into Crude Oil Sales. Apapa: Federal Governnent Press, 1980.

Nigeria, Federal Republic of. Fourth National Developnent Plan 198185. Lagos: Federal Ministry of National Planning, 1981.

Nigeria, Federal Republic of. Report of the Ministerial Conittee on the Causes of the Excessively Hith Cost of Goveinnent Contracts in Nigeria. Apapa: The Federal Government Press, 1981a.

Nigeria, Federal Republic of. Report of the Presidential Connission on Parastatals. Lagos: Federal Government Press, 1981b (chairnan: G.0. Onosode).

Nigeria, Federal Republic of. Report of the Presidential Conission on Salary and Conditions of Service of University Staff. Lagos:

National Assembly Press, 1981c (chairman: S.J. Cookey).

Nigeria, Federal Republic of. Revenue, Recurrent and Capital Estinates of the Government of the Federal Republic of Nigeria 1982.

Lagos: Government Press, 1982.

Nigeria, Political Bureau. Report of the Political Bureau. Lagos: Government Printer, 1987.

Nigeria, Federal Republic of. Inplenentation Guidelines on the Civil 
Service Reforms. Lagos: Federal Government. Printer, 1988.

Nigeria, Western Region. Report of the Coker Connigsion of Enquiry into the Affairs of Certain Statutory Corporations in Western Nigeria, 4 vols.. Ibadan: Government Printer, 1962.

Nigerian Econouic Society. Proceedings of the 1973 Annual Conference of the Nigerian Econonic Society. Ibadan: Ibadan University Press, 1974.

Nigerian National Petroleun Company (NNPC). Prosress of the Public Sector Participation in the Nigerian Dil Industry. Lagos: NNPC, undated, probably 1983.

Nixon, C.R. "An Analysis of Nigerian Governnent Expenditure Patterns, 1950-1962." In C.K. Eicher and C. Liedholl, eds. Growth and Development of the Nigerian Econony, pp. 86-118. East Lansing: Michigan State University, 1970a.

Nixon, C.R. "The Role of Marketing Boards in the Political Evolution of Nigeria." In C.K. Eicher and C. Liedholw, eds. Growth and Development of the Nigerian Economy, pp. 156-162. East Lansing: Michigan State University, 1970b.

Nnoli, 0. Path to Nigerian Developent. Dakar: Codesia, 1981.

Nolutshungu, S.C. "Fragments of a Denocracy: Reflections on Class and Politics in Nigeria." Third World Quarterly 1 (1990), pp. 86 115 .

Nordlinger, E.A. On the Autonony of the Denocratic State. Cambridge: Harvard University Press, 1981.

Nordlinger, E.A. "Taking the State Seriously." In M. Weiner and S.P. Huntington, eds. Understanding Political Developent, pp. 875-885. Boston: I.ittle, Brown, 1987.

Nordlinger, E.A. "The Return of the State: Critiques." Anerican Political Science Review 3 (1988), pp. 875-885.

Northern Nigeria. A White Paper on the Military Government Policy for the Reorganisation of the Northern Nigeria Developnent Corporation. Kaduna: Government Printer, 1966.

Northrup, D. "The Ideological Context of Slavery in Southeastern Nigeria in the 19th Century." In P.E. Lovejoy, ed. The Ideolosy of Slavery in Africa, pp. 101-122. Beverly Hills and London: Sage, 1981.

Nurske, R. Problens of Capital Fornation in Underdeveloped Countries. Oxford: Blackwell, 1953.

Nwabuzor, E.J., ed. State and Society in Nigeria: Edited 
Proceedings of the Eleventh Annual Conference of the Niserian Political Science Association. Benin City: Nigerian Political Science Association, 1985.

Nwankwo, G.0. "Legislative Supervision of the Adainistration The Nigerian Experience in a Presidential Systen of Government." Journal of Constitutional and Parlianentary Studies 1-2 (January-June 1983), pp. 53-65.

Nwanwene, 0. "The Nigerian Public Service Comnissions." In D.J. Murray, ed. Studies in Nigerian Adninistration, pp. 177-208. London: Hutchinson, 1970.

Nwanwene, 0 . and E.O. Kowe. The Progress of Nigerian Public A.lministration: Report on Research. Ife: Institute of Administration, University of Ife, 1970.

Nwosu, N.N. "The Political Policies of Nigeria." Journal of Social, Political and Economic Studies 1 (1983), pp. 101-114.

Nyang'oro, J.E. The State and Capitaligt Developnent in Africa: Declining Political Economies. New York: Praeger, 1989.

Nyang'oro, J.E. and T.M. Shaw, eds. Corporatisn in Africa: Comparative Analysis and Practice. Boulder: Westview, 1989.

Nye, J.S. "Corruption and Political Development, A Cost-Benefit Analysis." American Political Science Review 2 (1967), pp. 417-427.

Nyong'o, P.A., ed. Popular Struggles for Democracy in Africa. London: Zed Books, 1987.

Obadan, M. "Direct Foreign Investment in Nigeria: an Empirical Analysis." African Studies Review 1 (1982), pp. 67-81.

Obadan, M.I. and B.U. Ekuerhare. "The Theoretical Bases of Structural Adjustment Programmes in Nigeria: An Appraisal." International Social Science Journal 2 (1989), pp. 211-222.

Obasanjo, O. "Eastern Promises." West Africa 3793 (7 May 1990), pp. $762-763$.

O'Brien, P.J. "A Critique of Latin American Theories of Dependency." In I. Oxaal, T. Barnett and D. Booth, eds. Beyond the Sociolory of Development: Economy and Society in Latin Anerica and Africa, pp. 7-27. London: Routledge and Kegan Paul, 1975.

0 'Connell, J. "The State and the Organisation of Elenentary Education in Nigeria: 1945-1960." In H.N. Weiler, ed. Education and Politics in Nigeria, pp. 112-131. Freiburg: Rombach, 1964.

o'Connell, J. "The Political Class and Econonic Growth." The Nigerian Journal of Econonics and Social Studies 1 (1966), pp. 129-140. 
O'Connell, J. "Political Integration: the Nigerian Case." In A. Hazlewood, ed. African Intesration and Disintesration: Case Studies in Econonic and Political Union, pp. 129-184. London: Oxford University Press, 1967.

Oculi, 0. "Green Capitalisn in Nigeria." In P.M. Lubeck, ed. The African Bourgeoisie: Capital ist Developent in Nizeria. Kenva and the Ivory Coast, pp. 167-184. Boulder: Lynne Rienner, 1987.

Odetola, T. The Military Politics in Nigeria: Econonic Developent and Political Stability. New Brunswick: Transaction Pres8, 1978.

O'Donnell, G. "Corporatism and the Question of the state." In J. Malloy, ed. Authoritarianise and Corporatisn in Latin Anerica, pp. 41-87. Pittsburgh: Pittsburgh University Press, 1977.

O'Donnell, G. Modernization and Bureaucratic-Authoritarianisn: Studies in South-American Politics. Berkeley: Institute of International Studies, University of California, 1979 [1973].

O'Donnell, G. Bureaucratic Authoritarianisn: Argentina, 1966-1973 in Comparative Perspective. Berkeley and Los Angeles: University of California Press, 1988.

Odunfa, S. "The new, improved NEPA." West Africa 3609 (3 November 1986), pp. 2300-2303.

OECD. Positive Adjustment Policy: Managing Structural Change. Paris: OECD, 1982.

Offe, C. "Theses on the Theory of the State." In J. Keane, ed. Contradictions of the Welfare State, pp. 119-129. Cambridge: MIT Press, 1984.

Offiong, D. "The Prevalence and Repercussions of Corruption in Nigeria." Indian Political Science Review 1 (1984), pp. 59-72.

Ofiaj2, N.D. Stability and Instability in Politics: The Case of Nigeria and Caneroun. New York: Vantage Press, 1979.

Ofonagoro, W. I. The Currency Revolution in Southern Nizeria 1880-1948. Occasional Paper No. 14, African Studies Center, University of California, Los Angeles, 1976.

Ogundana, B. "Infrastructural Problens of Development in Nigeria: Port Congestion." In 0 . Oyediran, ed. Survey of Nigerian Affairs, 1975, pp. 71-88. Ibadan: Oxford University Press, 1978.

Ohiorhenuan, J.F.E. Capital and the State in Nigeria. Westport: Greenwood, 1989.

0jo, M.O. "Food Supply in Nigeria, 1960-1975." Econonic and Financial 
Review 2 (1977), pp. 12-18.

OH:igbo, P.N.C. Nigerian National Accounts 1950-1957. Enugu: Federal Ministry of National Development, 1962.

Okigbo, P.N.C. Nigerian Public Finance. Evanston: Northwestern University Press, 1965.

Okigbo, P.N.C. National Developnent Planning in Nigeria, 19001992. London: Janes Currey, 1989.

Okoli, F.C. "The Dilenna of Prenature Bureaucratization in the new States of Africa: the Case of Nigeria," African Studies Review 2 (Septenber 1980), pp. 1-16.

Okonjo, I.M. British Adninistration in Nigeria, 1900-1950: a Nigerian Viek. New York: NOK, 1974.

Okowa, h. "Public Policy and rural-urban Distribution in Incone in Nigeria." In C.Aké, ed. Political Economy of Nigeria, pp.71-88. London and Lagos: Longean, 1985.

Olaloku, F.A. Structure of the Nigerian Economy. London: Macmillan Press, 1979.

Olayne, A.0. "Total Factor Productivity Trends in Nigerian Manufacturing." The Nigerian Journal of Social and Econonic Studies 3 (1985), pp. 317-329.

Olayiwola, P.0. Petroleum and Structural Chante in a Develoning Country: the Case of Nigeria. New York: Praeger, 1984.

Olorunsola, V.A. Soldiers and Power: the Developnent Perfornance of the Nigerian Military Regine. Stanford: Hoover Institution, 1977.

Olowu, D. "The Nature of Bureaucratic Corruption in Nigeria." International Review of Adninistrative Scienceg 3 (1983), pp. 291-296.

Olowu, D. "Bureaucratic Corruption and Public Accountability in Nigeria: An Assessment of recent Developnents." International Review of Adninistrative Sciences 1 (1985), pp. 7-12.

Olowu, D. "The Environeent of Nigerian Public Administration in a Period of Uncertainty." Philipoine Journal of Public Administration 1 (1987), pp. 24-35.

Olugbemi, S.0. "The Civil Service: an Outsider's View." In 0. Oyediran, ed. Nigerian Government and Politics under Military Rule, 1966-79, pp. 96-109. London \& Basingstoke: Macnillan Press, 1979.

Olukoshi, A, and T. Abdyulraheen. "Nigeria: Crisis Managenent under 
the Buhari Administration." Review of African Political Econony 34 (1985), pp. 95-101.

Omolehinwa, E. "PPBS in Nigeria: Its Origins, Progress and Problens." Public Adninistration and Development 4 (1989), pp. 395-404.

Onimode, B. "Planning for Underdevelopnent in Nigeria." In O. Nnoli, ed. Path to Nigerian Development, pp. 137-150. Dakar: Codesia, 1981 .

Onimode, B. Imperial iss and Underdevelopnent in Nizeria: The Dialectics of Mass Poverty. London: Zed Press, 1983.

Oppermann, C. "Krieg an laufenden Band." Stern 20 (8 May 1991), pp. 56-71.

Organization of African Unity, Lagos Plan of Action for Econonic Development of Africa 1980-2000. Addis Ababa: OAU, 1980.

Oshikoya, T.W. The Nigerian Econony: A Macroecononetric and Input-Output Model. New York: Praeger, 1990.

Osoba, S. "The deepening Crisis of the Nigerian National Bourgeoisie." Reviek of African Political Econony 13 (1978), pp. 63-77.

Ostheimer, J.M. Nigerian Politicg. New York: Harper Row, 1973.

Othman, S. "Nigeria: Power for Profit - Class, Corporatisa, and Factionalism in the Military." In D.B. Cruise $0^{\prime}$ Brien, J. Dunn and R. Rathbone, eds. Contemporary West African States, pp. 113144. Cambridge: Cambridge University Press, 1989.

Otobo, D. "Bureaucratic Elites and Public-Sector Wage Bargaining in Nigeria." The Journal of Modern African Studies 1 (1986), pp. 101-126.

Ouchi, H.G. "Markets, Bureaucracies, and Clans." Administrative Science Quarterly 1 (1980), pp. 129-141.

Ouchi, W.G. and A.L. Wilkins. "Organizational Culture." Annual Revier of Sociology Vol, 11 (1985), pp, 457-483.

Onoh, J.K. The Nigerian Oil Econony: Fron Prosperity to Glut. London: Croom Helm, 1983.

Owen, E.R.J, and R.B. Sutcliffe, eds. Studies in the Theory of Imperialise. London: Longaan, 1972.

Oxaal, I., T. Barnett and D. Booth, eds. Bevond the Sociology of Developent: Econony and Society in Latin Anerica and Africa. London and Boston: Routledge and Kegan Paul, 1975. Oyediran, O. and W.A. Ajibola. "Nigerian Public Service in 1975." 
In O. Oyediran, ed. Survey of Nigerian Affairs, 1975, pp. 115-131. Ibadan: Oxford University Press, 1978.

Oyediran, 0 . and A. Gboyega. "The Nigerian Political Scene in 1975." In O. Oyediran, ed. Survey of Nigerian Affairs, 1975, pp. 3-18. Ibadan: Oxford University Press, 1978.

Oyediran, 0 . and 0 . Olagunji. "The Military and the Politics of Revenue Allocation." In O. Oyediran, ed. Niserian Government and Politics under Military Rule, 1966-79, pp. 192-211. London \& Basingstoke: Macmillan Press, 1979.

Oyejide, T.A. Tariff Policy and Industrialisation in Nigeria. Ibadan: Ibadan University Press, 1975.

Oyejide, T.A. The Effects of Trade and Exchange Rate Policies on Agriculture in Nigeria. Research Report No. 55. Washington: International Food Policy Research Institute, 1986.

Oyinloye, 0 . Changing Role of the District Officer in Northern Nigeria, 1945-1965. Zaria: Ahaadu Bello University, 1966.

Oyoubaire, S.E. "The Politics of Revenue Allocation." In K. PanterBrick, ed. Soldiers and Qil: The Political Trans formation of Nigeris, pp. 224-249. London: Frank Cass, 1978.

Oyovbaire, S.E. "Structural Change and Political Processes in Nigeria." African Affairs 326 (1983), pp.3-28.

Oyovhaire, S.E. Federal ism in Nigeria: A Study in the Development of the Nigerian State. New York: St. Martin's Press, 1985.

Oyugi, W.O. "The African public services: challenges and prospects." Indian Journal of Public Adrinistration 3 (1980), pp. 792-813.

Ozgediz, S. "Managing the Public Service in Developing Countries: I ssues and Prospects." World Bank Staff Working Paper 583 (1983).

Pacey, A. Technology in World Civilization: A Thousand-Year History. Cambridge: The MIT Press, 1990.

Palma, G. "Dependency: A Formal Theory of Underdevelopment or a Methodology for the Analysis of Concrete Situations of Underdevelopment?" World Developnent 7/8 (1978), pp. 881-924.

Papanek, G.F. "Ecrnonic Developnent Theory: The Earnest Search for a Mirage." Economic Developnent and Cultural Change Vol. 25, Supplement, (1977), pp. 270-287.

Parsons, T. Structure and Process in Modern Societies. Glencoe: The Free Press, 1960. 
Parsons, T. "Max Weber" Review Article of Reinhard Bendix' "Max Weber: An Intellectual Portrait." Anerican Socjological Review 5 (1960a), pp. 750-752.

Pearson, L.B. et al. Partners in Developnent: Report of the Connission on International Development. New York: Prasger, 1969.

Pearson, S.R. Petroleun and the Nigerian Dconomy. Stanford: Stanford University Press, 1970.

Pearson, S.R. and J. Cownie, eds. Connodity Exports and African Econonic Development. London: D.C. Heath, 1974.

Peel, Q. "Nigeria: Economic Options and Political Constraints." The World Todey 6 (1984), pp. 226-233.

Perham, M. ed. The Native Economies of Migeria: the Econonics of a Tropical Dependency, 2 vols. London: Faber \& Faber, 19461948.

Perham, M. "General Introduction: The Country. Outline of political and economic development." In M. Perhan, ed. The Native Economies of Nigeria: the Econonics of a Tropical Dependency, Vol. 1, pp. 1-22. London: Faber \&aber, 1946.

Perham, M. Lugard: The Years of Authority 1898-1945. London: Collins, 1960.

Perham, M. The Colonial Reckoning: the End of Inperial Rule in Africa in the Light of British Experience. New York: Knopf, 1962.

Petras, J. "State Capitalism and the Third World." Development and Change 1 (1977), pp. 1-17.

Phillips, A. "The Concept of Development." Review of African Political Economy 8 (1977), pp. 7-20.

Phillips, A. The Enigma of Colonialigm: Britigh Policy in West Africa. London: Janes Currey, 1989.

Phillips, A.0. "Nigerian Industrial Tax Incentives: Inport Duties Relief and the Approved User Scheme." The Nigerian Journal of Economic and Social Studies 3 (1967), pp. 315-327.

Phillips, A.0. "Nigeria's Experience with Incone Tax Exenption: A Preliwinary Assessnent." The Nizerian Journal of Econonic and Social Studies 1 (1968), pp. 33-62.

Phillips, C.S. "Political versus Adninistration Developaent: What the Nigerian Experience Contributes." Adninistration and Society 4 (1989), pp, 423-445.

Pin, A,W. "Public Finance." In M. Perham, ed. The Native Econonies 
of Nigeria: the Econumics of a Tropical Dependency, Vol. 2, pp. 225-279. London: Faber \& Faber, 1948.

Pinto, B. "Nigeria During and After the 0il Boom: A Policy Conparison with Indonesja." The World Bank Economic Review 3 (1987), pp. 419-445.

Polanyi, $k$. The Great Transformation. Naw York and Toronto: Rinehart, 1957 [1944].

Polanyi, K. Dahomey and the Slave Trade. Seattle: University of Washington Press, 1966.

Popper, K.R. The Open Society and Its Enemies. Vol. 2 The High Tide of Prophecy: Hegel, Marx and the Aftermath. Princeton: Princeton University Press, 1971 [1962].

Poptin, S.L. The Rational Peasant: The Political Economy of Rural Soriety in Vietnam. Berkeley and Los Angeles: University of California Press, 1979.

Poulantzas, N. Classes in Contemporary Capitalism. London: New Left Books, 1975 .

Prebisch, R. "The Economic Development of Latin America and its Principal Problems." Economic Bulletir for Latin America 1 (1962), pp. 1-22.

Probisch, R. "A Critique of Peripheral Capitalism." Cepal Review (First Semester 1976), pp. 9-76.

Preston, P.h. New Trends in Development Theory: Essays in Development and Social Theory. London: Routledge and Kegan Paul, 1985.

Price, R.M. Society and Bureaucracy in Contemporary Ghana. Berkeley and Los Angeles: Unjversity of California Press, 1975.

Price haterhouse. Doing Business in Nigeria. Lagos: Price Waterhouse, $1982 \& 1987$.

Proehl, P.O. Foreign Enterprise in Nigeria: Laws and Politics. Chapel Hill: University of North Carolina Press, 1965.

Frosser, G, and W.R. Louis. The Transfer of Power in Africa: Decolonization, 1940-1960. New Haven: Yile University Press, 1982.

Pye, I.. H. Aspects of Political Development. Boston: Little, Brown, 1966.

Raghaviah, Y. "Post-Positivist Bureaucratic Theory and the Third World Predicament." Indian Journal of Public Administration 1 (1984), pp. 1-19. 
Ranis, G., ed. Government and Economic Development. New Haven: Yale University Press, 1971.

Ranis, G. "Developwent Theory at Three-Quarters Century." Economic Development and Cultural Change Vol. 25, Supplement, (1977), pp. 254-269.

Ravenhill, J. "Reversing Africa's Econonic Decline: No Easy Answers." World Policy Journal 4 (1990), pp. 703-732.

Reilly, W. "Management and Training for Developnent: the Hombe Thesis." Public Adniristration and Developent 1 (1987), pp. 25-42.

Revel, J.-F. The Flight from the Truth: The Reign of Deceit in the Age of Information. New York: Random House, 1991 [1988].

Riddell, R.C. Foreign Aid reconsidered. London: James Currey for Overseas Development Institute, 1987.

Riddell, R.C. "A Forgotten Dimension? The Manufacturing Sector in African Development." Development Policy Review 1 (1990), pp. 5-27.

Riedel, J. Muths and Reality of External Constraints on Development. Aldershot: Gower for Trade Policy Research Centre, 1987.

Riggs, F.W. Administration in Developing Countries: The Theory of Prismatic Society. Boston: Houghton Mifflin, 1964 .

Riggs, F.W. "The Structures of Government and Administrative Reform." In R. Braibanti, ed. Political and Administrative Development, pp. 220-324. Durham: Duke University Press, 1969.

Riggs, F, h. Administrative Reform and Political Responsiveness. Beverly Hills: Sage, 1970.

Riggs, F.W. "Modernization and Political Problems: Some Developmental Prerequisites." In W.A. Beling and G.O. Totten, eds. Developing Nations: Quest for a Model, pp. 60-82. New York: van Nostrand Reinhold, 1970 .

Riggs, F.W., ed. Frontiers of Development Administration. Durham: Duke University Press, 1971.

Rimmer, D. "Schumpeter and the Underdeveloped Countries." Quarterly Journal of Economics 3 (1961), pp. 422-450.

Rimmer, D. "The Abstraction froe Politics: a Critique of Economic Theory and Design with Reference to West Africa." The Journal of Development Studies 3 (1969), pp. 190-204. 
Rimmer, D. "Elements of the Political Economy." In K. PanterBrick, ed. Soldiers and 0il: The Political Transforation of Nigeria, pp. 141-165. London: Frank Cass, 1978.

Rimmer, D. "Development In Nigeria." In H. Bienen and V.P. Diejonaoh, eds. The Political Econony of Incone Distribution in Nigeria,

pp. 29-87. New York: Holt Meier, 1981.

Rimmer, D. The Economies of West Africa. New York: St. Martin's Press, 1984.

Rimmer, D. "The over-valued Currency and Over-Adninistered Economy of Nigeria." African Affairs 336 (1985), pp. 435-446.

Rimmer, D. "External Debt and Structural Adjustnent in Tropical Africa." African Affairs 356 (1990), pp. 283-291.

Rimmer, D. and A.H.M. Kirk-Greene. Nigeria since 1970: A Political and Economic Outline. New York: Africana, 1981.

Rivkin, A., ed. Nations by Design: Institution Building in Africa. New York: Doubleday, 1968.

Rizzi, B. The Bureaucratization of the World. New York: The Free Press, 1985 [1939].

Ruberts, J. "Liberalizing Foreign Exchange Rates in Sub-Saharan Africa." Development Policy Review 2 (1989), pp. 115-142.

Robertson, J. Transition in Africa: From Direct Rule to Independence: A Memoir. London: C. Hurst \& Co, 1971.

Robiuson, J. Economic Philosophy, Chicago: Aldine, 1962.

Robinson, R. and J. Gallagher with A. Denny. Africa and the Victorians: The Climax of Imperialism. Garden City: Anchor Books, 1968.

Robinson, R. "Non European Foundations of European Imperialism: A Sketch for a Theory of Collaboration." In E.R.J. Owen and R.B. Sutcliffe, eds. Studies in the Theory of Inperialism, pp. 117-142. London: Longman, 1972.

Robson, P. and D.A. Lury, eds. The Economies of Africa. London: Allen \& Unwin, 1969.

Rodney, W. How Europe Underdeveloped Africa. Washington: Howard University Press, 1981 [1972].

Roemer, M. "Economic Development in Africa: Performance since Independence, and a Strategy for the Future." Daedalus 2 (1982), pp. 125-148. 
Rondinelli, D.A. "The Dilema of Developnent Administration: Complexity and Uncertainty in Control-oriented Bureaucracies." Vorld Politics 1 (1982), pp. 43-72.

Rondinelli, D.A. "Decentralization, Territorial Power and the State: A Critical Response." Developpent and Change 3 (1990), pp. 491-500.

Rondinelli, D.A. and J.D. Montgonery. "Managing Econonic Reform: An Alternative Perspective on Structural Adjusteent Policies." Policy Sciences 1 (1990), pp. 73-93.

Rood, L.L. "Nationalisation and Indigenisation in Africa." The Journal of Modern African Studies 3 (1976), pp. 427-447.

Rose, P.L. Revolutionary Antisemitism in Germany from Kant to hagner. Princeton: Princeton University Press, 1990.

Rosenberg, N. "The Direction of Technological Change: Inducement. Mechanisms and Focusing Devices." Economic Development and Cultural Change 1 (1969), pp. 1-24.

Rosenberg, N. Technology and American Economic Growth. New York: Harper and Row, 1972.

Rosenberg, N. and L.E. Birdzell. How the West grew rich: the economic Transformation of the Industrial World. New York: Basic Books, 1986.

Rosenstein-Rodan, P.N. "Problems of Industrialisation of Eastern and South-eastern Europe." The Economic Journa] Vol. 53 (1943), pp. 202-211.

Rosenstein-Rodan, P.N. "The Modernization of Industry." In M. Weiner, ed. Modernization: The Dynamics of Growth, pp. 270-280. New York: Basic Books, 1966.

Rostow, K.W. "The Take-Off into Self-Sustained Growth." The Economic Journal Vol. 66 (March 1956), pp. 25-48.

Rostow, W.W. The Stages of Economic Growth: A Non-Conmunist Manifesto. Cambridge: Cambridge University Press, 1968 [1960].

Roth, G. "Introduction." In G. Roth and C. Wittich, eds, Max Weber = Economy and Society, Vol. 1, pp. XXXIII-CX. Berkeley Los Angeles: University of California Press, 1978 [1968].

Rothchild, D. and R.L. Curry, Scarcity, Choice and Public Policy in Middle Africa. Berkeley and Los Angeles: University of California Press, 1978.

Rothchild, D. "Hegemony and State Softness: Some Variations in Elite Responses." In $Z$. Ergas, ed. The African State in 
Transition, pp. 117-148. London: Macmillan, 1987.

Rothchild, D. and N. Chazan, eds. The Precarious Balance:

State and Society in Africa. Boulder: Westview, 1988.

Rothchild, D. and M. Foley. "The Inplication of Scarcity for Governance in Africa." International Political Science Review 3 (1983), pp. 311-326.

Rothman, S. "Barrington Moore and the Dialectics of Revolution: An Essay Review." Anerican Political Science Review 1 (1970), pp. 61-82.

Rourke, F.E. Bureaucracy, Politics, and Public Policy. Boston: Little, Brown, 1976.

Rokiley, C.K., R.D. Tollison and G. Tullock, eds. The Political Economy of Rent Seeking. Boston: Kluwer Academic, 1988.

Royal Institute of International Affairs. Nigeria: the political and Economic Background. London: Oxford University Press, 1960.

Rudolph, L.I. and S. Hoeber Rudolph. "Authority and Power in Bureaucratic and Patrimonial Administration: A Revisionist Interpretation of Weber on Bureaucracy." World Politics 2 (1979), pp. 195-227.

Rueschemeyer, D. and P. Evans. "The State and Economic Transformation: Toward and Analysis of the Conditions Underlying Effective Intervention." In P. Evans, D. Rueschemeyer and T. Skocpol, eds. Bringing the State Back In, pp. 44-77. New York: Cambridge University Press, 1985.

Ruthenberg, H. "Some Characteristics of Saallholder Farming in Tanzania." In H. Ruthenberg, ed. Smallholder Farming and Smallholder Development in Tanzania, pp. 325-355. München: Weltforum Verlag, 1968.

Salehi-Isfahani, D. "Oil Exports, Real Exchange Rate Appreciation and Demand for Imports in Nigeria." Economic Development and Cultural Change 3 (1989), pp. 495-512.

Sandbrook, R. "The State and Economic Stagnation in Tropical Africa." World Development 3 (1986), pp. 319-332.

Sandbrook, R. "Taming the African Leviathan." World Policy Journal 4 (1990), pp. 673-701.

Sandbrook, R, with J. Barker. The Politics of Africa's Economic Stagnation. Cambridge: Cambridge University Press, 1985.

Sano, H. -0. The Political Economy of Food in Nigeria 1960-1982: A Discussion on Peasants, State, and World Econony. Research 
Report No. 65. Uppsala: Scandinavian Institute of African Studies, 1983.

Saul, J. "The State in Post-Colonial Societies: Tanzania."

In R. Miliband and J. Saville, eds. The Socialist Register 1974, pp. 349-372. London: The Merlin Press, 1974.

Scaff, L.A. Fleeing the Iron Cage: Culture, Politics, and Modernity in the Thought of Max Weber. Berkeley and Los Angeles: University of California Press, 1989.

Schaffer, B.B. "The Deadlock in Developaent Adninistration." In C. Leys, ed. Politics and Change in Developing Countries: Studies in the Theory and Practice of Developent, pp. 177211. Cambridge: Canbridge University Press, 1969.

Schaffer, B.B. "Administrative legacies and links in the postcolonial state: preparation, training and adainistrative reform." Development and Change 2 (1978), pp. 175-200.

Schatz, S.P. "The Influence of Planning on Development: The Nigerian Experience." Social Research 4 (1960), pp. 451-468.

Schatz, S.P. "Nigeria's First National Development Plan (1962-1968): An Appraisal." The Nigerian Journal of Econonic and Social Studies 2 (1963), pp. 221-235.

Schatz, S.P. "The Capital Shortage Illusion: Government Lending in Nigeria." Oxford Economic Papers 2 (1965), pp. 309-316.

Schatz, S.P. Economics, Politics and Administration in Government. Lending: the Regional Loan Boards of Nigeria. Ibadan: Oxford University Press, 1970.

Schatz, S.P. Nigerian Capitalism. Berkeley and Los Angeles: University of California Press, 1977.

Schatz, S.P. "Pirate Capitalisw and the Inert Econowy of Nigeria." The Journal of Modern African Studies 1 (1984), pp. 45-57.

Schatz, S.P. "Laissez-Faireisa for Africa?" The Journal of Modern African Studies 1 (1987), pp. 129-138.

Schatz, S.P. "African Capitalisn and African Econoeic Perforance." In $H$. Glickman, ed. The Crisis and Challenge of African

Development, pp. 62-85. Pestport: Greenwood Press, 1988.

Schätzl, L. Industrialization in Nigeria: A Spatial Analysis. München: Weltforum Verlag, 1973.

Schmitz, H. and R.Q. Carvalho. "Autonation and Labour in the Brazilian Car Industry." The Journal of Develoment Studies 1 (1989), pp. 81-119. 
Schoenholtz, A.I. "The I.M.F. in Africa: Unnecessary and Undesirable Western Restraints on Development." The Journal of Modern African Studies $3(1987)$, pp. 403-433.

Schultz, T. Transforaing Traditional Azriculture. New Haven: Yale University Press, 1967 [1964].

Schumpeter, J.A. Theory of Econonic Development. Cambridge: Harvard University Press, 1934.

Schumpeter, J.A. Capitalism, Socialism and Democracy. New York: Harper \& Row, 1962 [1942].

Schumpeter, J.A. Imperialism, Social Classes. Two Essays. Cleveland: The World Publishing Company, 1969 [1919].

Scott, R. "Production for Trade." In M. Perham, ed. The Native Economies of Nigeria: the Econonics of a Tropical Dependency, Vol. 1, pp. 216-291. London: Faber Faber, 1946.

Seers, D. "The Stages of Econonic Development of a Primary Producer in the Middle of the Twentieth Century." Economic Bullet in of Ghana 7 (1963), pp. 57-69.

Seers, D. "The Meaning of Development." In H.T. Uphoff and W.F. Ilchman, eds. The Political Econony of Development: Theoretical and Empirical Contributions, pp. 123-129. Berkeley and Los Angeles: University of California Press, 1972.

Sell, A. "Development: Which Way Now?" In C. Wilber, ed. The Political Economy of Development and Underdevelopeent, pp. 37-58. New York: Random House, 1988 [1982].

Sender, J. and S. Smith. The Development of Capitalism in Africa. London: Methuen, 1986 .

Sengupta, A. "Two Contrasting Western Academic Attitudes to Planning and Policy-Making in the Third World." Indian Journal of Public Administration 2 (1985), pp. 321-330.

Shafer, D.M. "Undermined: the implications of mineral export dependency for state formation in Africa." Third World Quarterly 3 (1986), pp. 916-952.

Sharwood-Smith, B. Recollections of British Administration in the Cameroons and Northern Nigeria 1921-1957: But Always As Friends: Northern Nigeria and the Cameroons 1921-1957. London: Allen and Intiin, 1969.

Shenion, R.W. The Development of Capitalisn in Northern Nigeria. Toronta: University of Toronto Press, 1986. 
Shirley, M.M. "Managing State-Owned Enterprises." World Bank Staff Working Paper 577 (1983).

Shivji, I.G. "Tanzania: The Silent Clasg Struggle." In The Silent Class Struggle, pp. 1-60. Dar es Salaan: Tanzania Publishing House, 1976 [1970].

Shivji, I.G. Class Struggle in Tanzania. London: Heinemann, 1976a.

Siddle, D. and $K$. Swindell. Rural Change in Tropical Africa: from Colonies to Nation-Stateg. Oxford: Basil Blackwell, 1990.

Sigelman, L. "Do modern Bureaucracies dominate underdeveloped Polities? A Test of the Imbalance Thesis." Anerican Political Science Review 2 (1972), pp. 525-528.

Silberman, B. State Bureaucratization: A Comparative Analysis. Chicago: University of Chicago, 1982.

Singer, H.K. "US Foreign Investment in Underdeveloped Areas: The Distribution of Gains between Investing and Borrowing Countries." American Economic Review 2 (1950), pp. 473-485.

Sklar, R.L. "The Nature of Class Domination in Africa." The Journal of Modern African Studies 4 (1979), pp. 531-552.

Sklar, R.L. "Democracy in Africa." African Studies Review 3/4 (1983), pp. 11-24.

Skocpol, T. "A critical Review of Barrington Moore's Social Origins of Dictatorship and Democracy." Politics and Society 1 (1973), pp. 1-34.

Skocpol, T. "Wallerstein's World Capitalist System: A Theoretical and Historical Critique." American Journal of Sociology 5 (March 1977), pp. 1075-1090.

Skocpol, T. "Political Response to Capitalist Crisis: Neo-Marxist Theories of the State and the Case of the New Deal." Politics and Society 2 (1980), pp. 155-201.

Skocpol, T. "Bringing the State Back In: Strategies of Analysis in Current Reseal - $h$." In P. Evans, D. Ruescheweyer and T. Skocpol, eds. Ar ?ing the State Back In, pp. 3-43. Nen York: Camb. = University Press, 1985.

Skowronek, S. Building New American State: The Expansion of National Administrative Capacities. New York: Cambridge University Press, 1982.

Smith, A, An Inquiry into the Nature and Causes of the Wealth of Nations. Harmondsworth: Penguin, 1974 [1776]. 
Smith, A. "The History of Astronony." In W.P.D. Wightman and I.C. Bryce, eds. Adam Snith: Essays on Philogophical Subjects, pp. 33-105. Oxford: Oxford University Press, 1980【1795; written before 1758 ].

Smith, B.C. Bureaucracy and Political Power. Brighton: Wheatsheaf, 1988 .

Swith, J.H. Colonial Cadet in Nigeria. Durham: Duke University Press, 1968.

Smith, L.D. "Structural Adjustment, Price Reform and the Agricultural Sector in Sub-Saharan Africa." Journal of Agricultural Econonics 1 (1989), pp. 21-31.

Smith, S. "Colonialism in Economic Theory: the Experience of Nigeria." The Journal of Development Studies 3 (1979), pp. 38-59.

Smith, S. "The Ideas of Samir Anin: Theory or Tautology? The Journal of Development Studies 1 (1980), pp. 5-21.

Smith, T. "The Underdevelopment of Development Literature: The Case of Dependency Theory." World Politics 2 (1979), pp. 247-288.

Smithies, A. "Memorial: Joseph Alois Schumpeter, 1883-1950." The Anerican Economic Review 4 (1950), pp. 628-648.

Smock, N.R. "Cultural and Attitudinal Factors Affecting Agricultural Development in Eastern Nigeria." Econonic Development and Cultural Change 1 (1969), pp. 110-124.

Sobhar, R. "Public Enterprises and the Nature of the State." Development and Change 1 (1979), pp. 23-40.

Sokolsti, A. The Establishment of Manufacturing in Nigeria. New York: Praeger, 1965.

Sonaike 0. and B. Olowoporoku. "Econonic Dependence: The Problew of Definition." Journal of Asian and African Studies 1-2 (1979), pp. 33-43.

Soto, H. de. The Other Path: The Invisible Revolution in the Third World. New York: Harper Row, 1989.

Spengler, J.J. "Bureaucracy and Economic Development." In J. LaPalombara, ed. Bureaucracy and Political Development, pp. 199-232. Princeton: Princeton University Press, 1963.

Staley, E. "The Role of the State in Economic Development." In M. Weiner, ed. Modernizgtion: The Dynanics of Growth, pp. 294-306. New York: Basic Books, 1966.

Stark, F.M. "Theories of Contemporary State Formation in Africa: 
a Reassessment." The Journal of Modern African Studies 2 (1986), pp. 335-347.

Stepan, A. The State and Society: Peru in Conparative Perspective. Princeton: Princeton University Press, 1978.

Stephens, H.W. "Administration in African Development: A Continuing Neglect." Journal of Comparative Adninistration 3 (1973), pp. 381-391.

Stern, N.H. "The Economics of Developwent: A Survey." The Econonic Journal Vol. 99 (1989), pp. 597-685.

Sternhell, Z. "The Fascist Temptation." The Jerusalen Journal of International Relations 2 (1991), pp. 69-94.

Stevens, C. "Nigeria." In R. Riddell. Manufacturing in Nigeria: Performance and Prospects of Seven Countries in Sub-Saharan Africa, pp. 257-296. London: James Currey, 1990.

Stolper, W. "The Development of Nigeria." Scientific American 3 (1963), pp. 169-184.

Stolper, W. Planning Without Facts: Lessons in Resource Allocation from Nigeria's Development. Cambridge: Harvard University Press, 1966.

Stolper, w. "Economic Growth and Political Instability in Nigeria: On Growing Together Again." In C.K. Eicher and C. Liedholm, eds. Growth and Development of the Nigerian Economy, pp. 328-351. East Lansing: Michigan State University, 1970.

Streeten, P. Development Perspectives. London: Macmillan, 1981.

Streeten, P. "Development Dichotomies." World Development 10 (1983), pp. 875-889.

Streeten, P. "Structural Adjustment: A Survey of the Issues and Options." World Development 12 (1987), pp. 1469-1482.

Streeten, P. Review of Tony Killick's book "A Reaction Too Far: Economic Theory and the Role of the State in Developing Countries." Economic Development and Cultural Change 2 (1991), pp. 421-429.

Stren, R.E. "Urban Services in Africa: Public Management or Privatisation?" In P. Cook and C. Kirkpatrick, eds. Privatisation in Less Developed Countries, pp. 217-247. New York: St. Martin's Press, 1988.

Subramaniam, V. "Politicized Administration in Africa and Elsewhere: A socio-historical Analysis." International Review of Administrative Sciences 4 (1977), pp. 297-308. 
Subramanian, V. "Western Marxist Approaches to Managenent and Organization Theory." Indian Journal of Public Adainistration 4 (1982), pp. 747-765.

Subramaniam, V. "Administrative Elites and Development in India: Some Comparisons and Reflections." Paper presented to the Conference on the Role of Elites in Development at the International Acadeny for Development in Freedon, Sintra/ Portugal, July 1989 .

Subramaniam, V. "Appendix: The Derivative Middle Class." in V. Subramaniam, ed. Public Adninistration in the Third World: An International Handbook, pp. 403-411. Westport: Greenwood Press, 1990.

Sullivan, B.C. "Structural Dependency: The Nigerian Economy as a Case Study." Journal of Asian and African Studies 1-2 (1979), pp. 44-55.

Sutcliffe, B. "Inperialism and Industrialisation in the Third World." In R. Owen and R.B. Sutcliffe, eds. Studies in the Theory of Imperialism, pp. 171-192. London. Longaan, 1972.

Swindell, K. and A.B. Mamman. "Land Expropriation and Accumulation in the Sokoto Periphery, Northwest Nigeria." Africa 2 (1990), pp. 173-187.

Synge, R. "Green Revolution Fails to Meet Targets." Nigeria: An Africa Econonic Digest Special Report (May 1982), pp. 18-21.

Tamuno, T.N. Evolution of the Nigerian State: The Southern Phase 1898-1914. London: Lorigman, 1972.

Taylor, W.H. "Missionary Education in Africa Reconsidered: The Presbyterian Educational Impact in Eastern Nigeria 1846-1974." African Affairs 331 (1984), pp. 189-205.

Teal, F. "The Supply of Agricultural Output in Nigeria 1950-1974." Journal of Development Studies 2 (1983), pp. 191-206.

Teal, F. "Domestic Policies, External Constraints, and Economic Development in Nigeria since 1950." African Affairs 346 (1988), pp. 69-81.

Temin, P. Iron and Steel in Nineteenth Century Anerica: An Economic Inquiry. Cambridge: Cambridge University Press, 1964.

Teriba, O. and M.O. Kayode, eds. Industrial Develonent in Nigeria. Ibadan: I badan University Press, 1977.

Theobald, R. "Patrimonialism." World Politics 4 (1982), pp. 548-559.

Therborn, G. What does the Ruling Class do when it rules? 
London: Verso, 1980.

Tibenderona, P.K. "British Adninistration and the Decline of the Patronage-Clientage Systen in Northwestern Nigeria, 1900-1934." African Studies Review 1 (1989), pp. 71-96.

Tilman, R.O. and T. Cole, eds. The Nigerian Political Scene. Durham: Duke University Press, 1962

Timer, C.P. "The Agricultural Transfornation." In H.B. Chenery and T.N. Srinivasan, eds Handbook of Development Economics, Vol. 1, pp. 275-331. Ansterdan: Elsevier Sciences Publishers, 1988.

Tinbergen, J. "Towards a Better International Econonic Order." LNITAR Lecture Series. New York: UNITAR, 1971.

Tinbergen, J. "Reshaping the International Order." Public lecture No 6. Geneva: International Institute for Labour studies, 1976.

Tinbergen, J., A.J. Dolman and J. van Ettinger. Reshaping the International Order: A Report to the Club of Rose. New York: Dutton, 1976 .

Tomori, S. "Agriculture, Forestry and Fishing." In F. Olakolu, ed. Structure of the Nigerian Economy, pp. 10-33. London: Macmillan, 1979.

Toyo, E. "Food and Hunger in a Petroleum Neocolony: A Study of the Food Crisis in Nigeria." In P. Lawrence, ed. World Recession and the Food Crisis in Africa, pp. 231-248. London: James Currey, 1986.

Trimberger, E.K. Revolution from Above: Military Bureaucrats and Development in Japan, Turkey, Egypt and Peru. New Brunswick: Transaction Books, 1978.

Tullock, G. "Rents and Rent-Seeking." In C.K. Rowley, R.D. Tollison and G. Tullock, eds. The Political Econory of Rent Seeking, pp. 51-62. Boston: Kluwer Academic, 1988.

Turner, S.P. "Explaining Capitalism: Weber on and against Marx." In R.J. Antonio and R.M. Glassman, eds. A Weber-Marx Dialogue, pp. 167-188. Lawrence: University of Kansas Press, 1985.

Turner, T. "Multinational Corporations and the Instability of the Nigerian State." Review of African Political Economy 5 (1976), pp. 63-79.

Turner, T. "Commercial Capitalism and the 1975 Coup." In K. PanterBrick, ed. Soldiers and Oil: The Political Transformation of Nigeria, pp. 166-197, London: Frank Cass, 1978.

Turner, T. "Oil Workers and Oil Bust in Nigeria" Africe Today 
(Denver) 4 (1986), pp. 30-50.

Uchendu, V.C. "State, Land and Society in Nigeria: A Critical Assessaent of Land Use Decree (1978)." Journal of African Studies 2 (1979), pp. 62-74.

Uchendu, V.C. "Dependency and the Developnent Process: An Introduction." Journal of Asian and African Studies 1-2 (1979), pp. 3-16.

Udo, R.K. "British Policy and the Development of Export Crops in Nigeria." The Nigerian Journal of Econonic and Social Studies 3 (1967), pp. 299-314.

Ukpolo, v. "Currency Devaluation in Developing Countries: some Lessons for Nigeria from recent Experience." The Nigerian Journal of Economic and Social Studies 3 (1987), pp. 257-268.

United Nations. Demographic Yearbook 1948. Lake Success: Statistical of fice of the United Nations, 1949.

United Nations. International Standard Industrial Classification of all Economic Activities, Statistical Papers, Series M, No. 4, Rev.2. New York: United Nations, 1968.

Lnited Nations. Monthly Bulletin of Statistics. New York: United Nations, various years.

United Nations. World Economic Survey 1990: Current Trends and Policies in the World Economy. New York: United Nations, 1990.

United Nations. Yearbook of International Trade Statistics. New York: United Nations, various years.

United Nations. Yearbook of National Accounts Statistics. New York: United Nations, various years.

United Nations Centre on Transnational Corporations (UNCTC). World Investment Report 1991: The Triad in Foreign Direct Investment. New York: United Nations, 1991.

Inited Nations Development Programme (UNDP). Human Development Report 1991. Nek York: Oxford University Press for UNDP, 1991.

United Nations Economic Commission for Africa. African Statistical Yearbook. UNECA: Addis Ababa, various years.

United Nations Economic Comission for Latin America. "General Administrative Aspects of Planning." Adninistrative Aspects of Planning. New York: United Nations, 1969.

UNIDO (United Nations Industrial Development Organization). Handbook of Industrial Statistics. Vienna: UNIDO, various 
years.

UNIDO. Industry and Development: Global Report 1989/90.

Vienna: UNIDO, 1990.

UNIDO. Industrial Development Review Series: Nigeria. Is.557. Vienna: UNIDO, 1985.

UNIDO. Nigeria: Industrial Restructuring through Policy Reform. Industrial Development Review Series, PPD.100. Vienna: UNIDO, 1988.

Uphoff, N.T. and W.F. Ilchman, eds. Political Economy of Development: Theoretical and Empirical Contributions. Berkeley and Los Angeles: University of California Press, 1972.

Usher, D. The Econon ic Prerequisite to Democracy. New York: Columbia University Press, 1981.

Usoro, E.J. "Economic Transition from Colonial Dependency to National Development: The Case of Nigeria." The Nigerian Journal of Economic and Social Studies 2 (1982), pp. 209-230.

Vaillant, J.G. Black, French, and African: A Life of Léopold Sédar Senghor. Cambridge: Harvard University Press: 1990.

Valenzuela, J.S. and A. Valenzuela. "Modernization and Dependency: Alternative Perspectives in the Study of Latin American Underdevelopment." Comparative Politics 4 (1978), pp 535-557.

Valpy, M. "Tanzania's Aid Donors wield growing Influence in Economy." Globe and Mail (Toronto), Friday, 27 September 1985, pp. 1 \& 13.

Vernon, R., ed. The Promise of Privatization: a Challenge for U.S. Policy. New York: Council on Foreign Relations, 1988.

Wade, R. Governing the Market: Economic Theory and the Role of Government in East Asian Industrialization. Princeton: Princeton University Press, 1990.

Wallace, T. "Agricultural Projects and Land in Northern Nigeria." Review of African Political Economy 17 (1980), pp. 60-70.

Wallace, T. "The Challenge of Food: Nigeria's Approach to Agriculture 1975-80." Canadian Journal of African Studies 2 (1981), pp. 239258.

Wallerstein, I. "Class and Class-Conflict in Contemporary Africa." Canadian Journal of African Studies 3 (1973), pp. 375-380.

Wallerstein, 1. "Modernization: Requiescat in Pace." In L.A. Coser and O.N. Larsen, eds. The Uses of Controversy in Sociology, pp. 131-135. New York: The Free Press, 1976. 

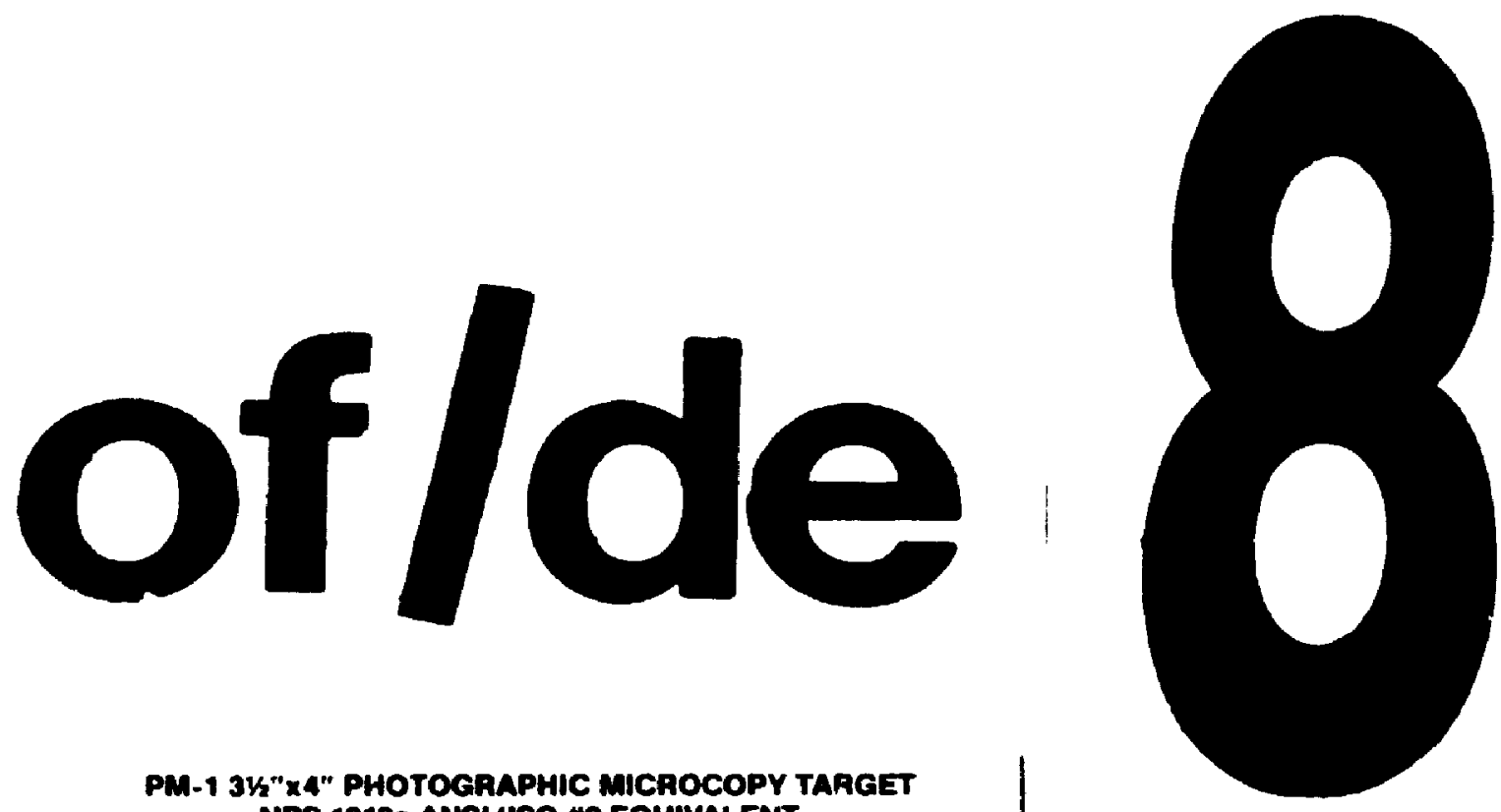

PM-1 3Y" $\times 4$ " PHOTOGRAPHIC MICROCOPY TARGET MBS 1010a ANSI/ISO 22 EQUIVALENT

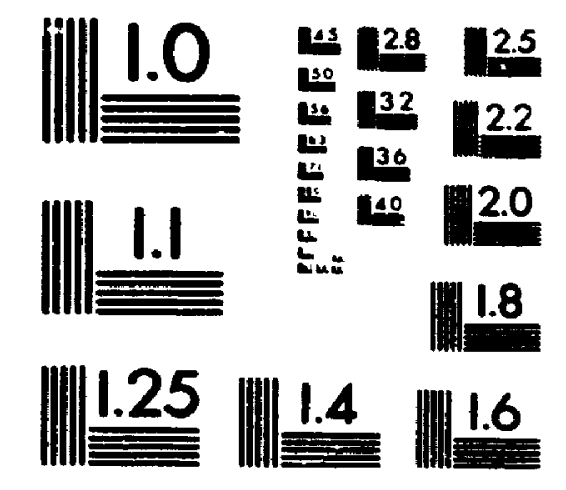

\section{PRECISION"M RESOLUTION TARGETS}

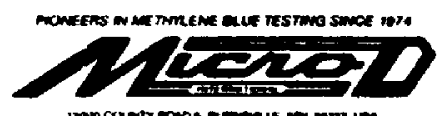

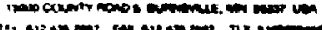


Wallerstein, I. "The States in the Institutional Vortex of the Capitalist World-Economy." In A. Kazancigil, ed. The State in Global Perspective, pp. 145-154. Aldershot: Gower for UNESCO, 1986.

Wallis, M. Bureaucracy: its Role in Third World Development. London and Basingstoke: Macwillan, 1989.

Warren, B. "Imperialism and Capitalist Industrialization." New Left Review 81 (1973), pp. 3-44.

Warrer, B. Inperialism: Pioneer of Capitalism. London: New Left Books, 1981.

Waterston, A. Development Planning. Baltimore: Johns Hopkins University Press, 1979.

Watkins, M.H. "A Staple Theory of Economic Growth." Canadian Journal of Economics and Political Science 2 (1963), pp. 141-158.

Watts, M. Silent Violence: Food, Famine and Peasantry in Northern Nigeria. Berkeley and Los Angeles: University of California Press, 1983.

Keber, M. "Politics as a Vocation." In H.H. Gerth and C.W. Mills, eds. From Max Weber: Essays in Sociology, pp. 77-128.

New York: Oxford University Press, 1946 [1919].

Weber, M. The Theory of Social and Economic Organization.

T. Parsons, ed. New York: Oxford University Press, 1947 [1913].

Weber, M. The Protestant Ethic and the Spirit of Capitalism. New York: Scribner's, 1958 [1904-1905].

Weber, M. "'Objectivity' in Social Science and Social Policy." In M. Weber. The Methodology of the Social Sciences, pp. 50-112. E.A. Shils and H.A. Finch, eds. Glencoe: The Free Press, 1964 [1949/1904].

Weber, M. General Econonic History. New York: Collier, 1966 [1919].

Weber, M. "Class, Status, Party." In H.H. Gerth and C.W. Mills, eds. From Max Weber: Essays in Sociology, pp. 180-195. New York: Oxford University Press, 1946 [1919].

Weber, M. Econony and Society. 2 vols. G. Roth and C. Wittich, eds. Berkeley and Los Angeles: University of California Press, 1978 [1968/1922].

Webster, J.B. "The Bible and the Plough." Journal of the Historical Society of Nigeris 4 (1963), pp. 418-434. 
Weiner, M. Modernization: The Dynanics of Growth. New York: Basic Books, 1966.

Wells, H.G. Qutline of History. London: Macmillan, 1973 [1920].

Wells, J.C. "Issues in Agricultural Policy During the 1962-68 Nigerian Development Plan." In C.K. Eicher and C. Liedholm, eds. Growth and Developent of the Nigerian Econony,

pp. 240-267. East Lansing: Michigan State University, 1970.

Wells, J.C. Agricultural Policy and Econonic Growth in Nigeria, 1962-1968. London: Oxford University Press, 1974.

Wheeler, D. "Sources of Stagnation in Sub-Saharan Africa." World Development 1 (1984), pp. 1-23.

White, J. Central Administration in Nigeria 1914-1948. Dublin: Irish Academic Press, 1981.

Wilber, C., ed. The Political Economy of Development and Underdevelopment. New York: Random House, 1988 [1973].

Wiles, P.J.D. Economii:Institutions Compared. Oxford: Basil Blackwel1, 1977.

Williams, E.E. Capitailsm and Slavery. New York: Russell and Russell, 1941.

Williams, G. "Nigerin: a Political Economy." In G. Williams, ed. Nigeria: Economy and Society, pp. 11-54. London: Rex Collins, $1 \subseteq 76$.

Willians, G. "Marketing Boards in Nigeria." Review of African Political Economy 34 (1985), pp. 4-15.

Williams, G. "Primitive Accumulation: the Way to Progress?" Development and Change 4 (1987), pp. 637-659.

Williams, G. and T. Turner. "Nigeria." In J. Dunn, ed. hest African States: Failure and Promise, pp. 132-172. Cambridge: Cambridge University Press, 1978.

Williams, R. Political Corrupt; in Africa. Aldershot: Gower, 1987.

Wilson, C. "Economy and Society in Late Victorian Britain." Economic History Review 1 (1965), pp. 183-198.

Wilson, E.J. "Contested Terrain: A Comparative and Theoretical Reassessment of State-Owned Enterprises in Africa." The Journal of Componwealth and Copparative Studies 1 (1984), pp. 4-27.

Wilson, E.J. "Privatization in Africa: Donestic Origins, Current 
Status and Future Scenarios." Issue 2 (1988), pp. 24-29.

Wilson, E.J. "Strategies of State Control of the Econony: Nationalization and Indigenization in Africa." Conparative Politics 4 (1990), pp. 401-419.

Wilson, H.S. The Inperial Experience in Sub-Saharan Africa since 1870. Minneapolis: University of Minnesota Press, 1977.

Wilson, J.Q. Bureaucracy: What Government Agencies do and why they do it. New York: Basic Books 1989.

Wittfogel, K.A. Oriental Despotisn: A Conparative Study of Total Power. New Haven: Yale University Press, 1967 [1957].

Holf, C. "A Theory of Nonmarket Failure: Framework for Inplementation Analysis." Journal of Law and Economics 1 (1979), pp. 107-139.

Wolin, s. "Max Weber: Legitimation, Method, and the Politics of Theory." Political Theory 3 (1981), pp. 401-424.

Woodstiorth, N. "Biggest Test yet for Agriculture." Financial Times (London), Tuesday, 1 March 1988, p. XI.

World Bank. The Economic Development of Nigeria. Baltimore: Johns Hopkins Press, 1955.

Forld Bank. Nigeria: Options for Long Term Development. Baltimore and London: Johns Hopkins University Press, 1974.

World Bank. "State Intervention in the Industrialization of Developing Countries: Selected Issues." World Bank Staff Working Paper 341 (1979).

World Bank. Accelerated Development in Sub-Saharan Africa: An Agenda for Action. Washington: IBRD/World Bank, 1981.

World Eank. Nigeria: Non-Oil Export Prospects, Report No. 3771UNI. Washington: IBRD/World Bank, 1982.

World Bank. World Development Report 1982. New York: Oxford University Press, 1982a.

world Bank. Toward Sustained Development in Sub-Saharan Africa. hashington: IBRD/World Bank, 1984a.

World Bank. Institutional Development in Africa: A Review of World Bank Project Experience. Washington: IBRD/World Bank, $1984 \mathrm{~b}$.

World Bank. Financing Adjustment with Growth in Sub-Saharan Africa. 1986-90. Washington: IBRD/World Bank, 1986.

World Bank. Population Growth and Pollcies in Sub-Saharan Africs. 
Washington: IBRD/World Bank, 1986a.

Horld Bank. World Devalopnent Report 1986. New York: Oxford University Press for IBRD/World Bank, $1986 \mathrm{~b}$.

World Bank. Sub-Saharan Africa: Fron Crisis to Sustainable Growth. Washington: IBRD/World Bank, 1989.

World Bank. World Tables, 1988-89 edition. Baltimore: Johns Hopkins University Press, 1989a.

World Bank, World Tables, 1989-90 edition. Baltieore: Johns Hopkins University, 1990.

World Bank. World Development Report 1991: The Challense of Development. New York: Oxford University Press, 1991.

Wriggins, H.W. The Ruler's Imperative: Strategies for Political Survival in Asia and Africa. New York: Columbia University Press, 1969.

Wright, S. "Nigeria: The 1983 Elections." Round Table 289 (1984), pp. 69-75.

Yahaya, A.D. "The Creation of States." In K. Panter-Brick, ed. Soldiers and $0 i 1$ : The Political Transformation of Nigeria, pp. 201-223. London: Frank Cass, 1978.

Young, C. "Patterns of Social Conflict: State, Class and Ethnicity." Daedalus 2 (Spring 1982), pp. 71-98.

Young, C. Ideology and Development in Africa. New Haven and London: Yale Iniversity Press, 1982a.

Zartman, I.W. with S. Schatz. "Introduction." In I.W. Zartman, ed. The Political Economy of Nigeria, pp. 1-24. New York: Praeger, 1983.

Ziemann, W, and $M$. Lanzendörfer. "The State in Peripheral Societies." In R. Miliband and J. Saville, eds. The Socialist Register 1977, pp. 143-177. London: The Merlin Press, 1977.

Zolberg, A. Cresting Political Order: The Party States of West Africa. Chicazo: Rand McNally, 1966.

Zolberg, A. "The Structure of Political Conflict in the New States of Tropical Africa." In N.T. Uphoff W.F.Ilchman, eds. The Political Econony of Developrent: Theoretical and Enpirical Consider ations, pp, 155-165. Berkeley and Los Angeles: University of California Press, 1972.

Zolberg, A. "Tribalism through Corrective Lenses." Foreign Affairs 4 (1973), pp. 728-739. 

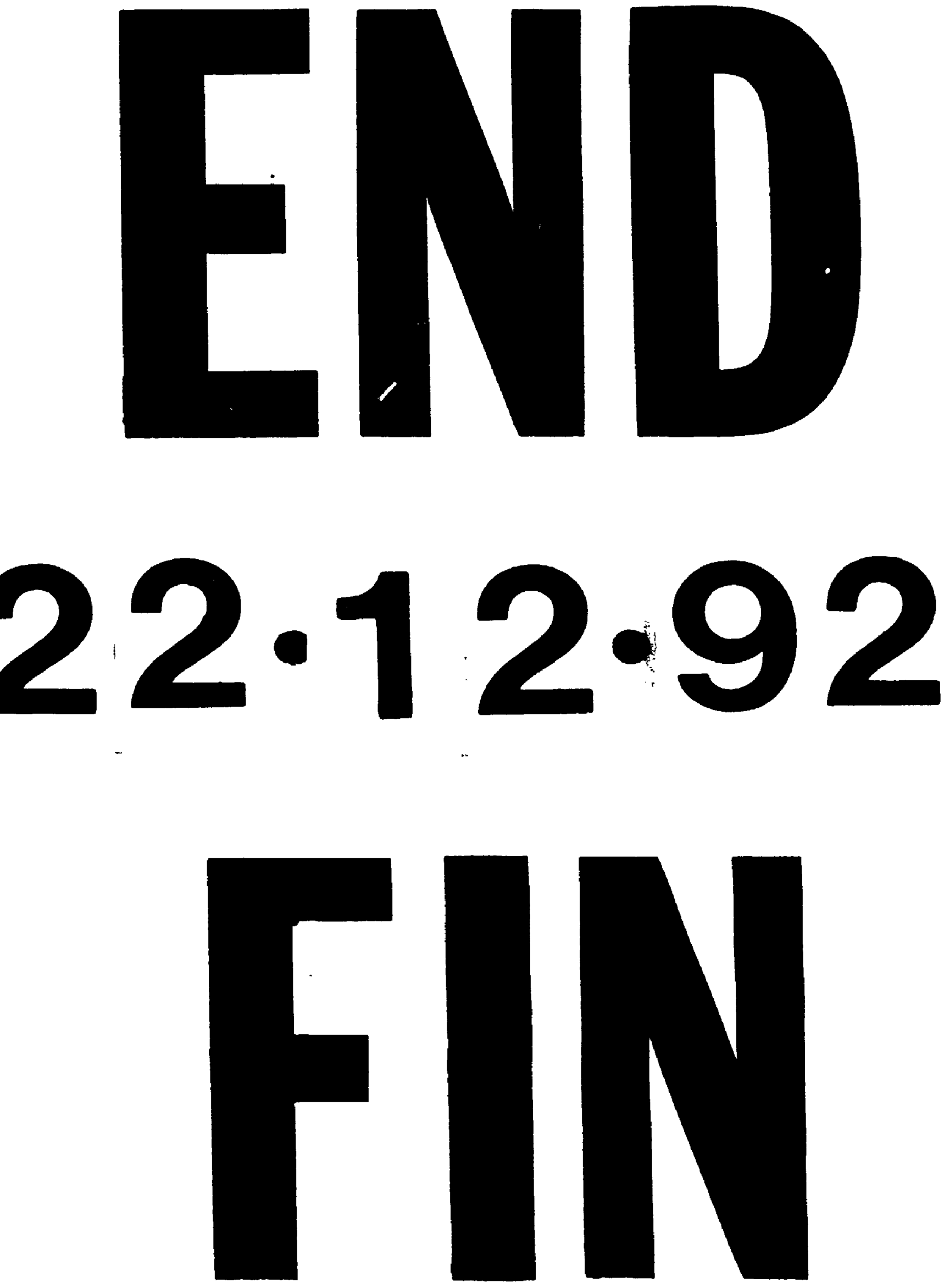